

\section{URBANISTYKA ODDOLNA}





\section{Łukasz Drozda}

\section{URBANISTYKA ODDOLNA}

Koszmar partycypacji

a wytwarzanie przestrzeni

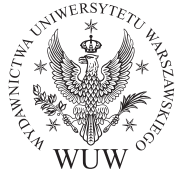


Recenzenci

dr hab. inż. Beata Joanna Gawryszewska

dr hab. Katarzyna Kajdanek, prof. UWr

Redaktor prowadzący

Urszula Gogol

Redakcja

Elwira Wyszyńska

Korekta

Magdalena Orczykowska

Projekt okładki i stron tytułowych

Elżbieta Chojna

Ilustracja na okładce

Łukasz Drozda

Skład i łamanie

Beata Stelegowska

Projekt finansowany w ramach programu Ministra Nauki i Szkolnictwa Wyższego pod nazwą „Strategia Doskonałości - Uczelnia Badawcza” w latach 2018-2019, nr projektu 0009/SDU/2018/18.

Publikacja dofinansowana przez Instytut Profilaktyki Społecznej i Resocjalizacji UW

(C) Copyright by Wydawnictwa Uniwersytetu Warszawskiego, Warszawa 2019

ISBN 978-83-235-3931-5 (druk)

ISBN 978-83-235-3947-6 (e-pub)
ISBN 978-83-235-3939-1 (pdf online)

ISBN 978-83-235-3955-1 (mobi)

Wydawnictwa Uniwersytetu Warszawskiego

00-497 Warszawa, ul. Nowy Świat 4

e-mail:wuw@uw.edu.pl

księgarnia internetowa: www.wuw.pl

Wydanie 1, Warszawa 2019 
Mojej Oli, mojemu Stambułowi, stambulczykom i stambulskim psom. Żeby wytrwali. 



\section{Spis treści}

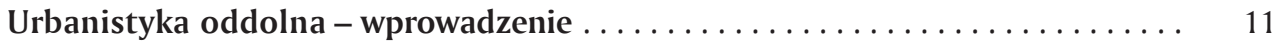

1. Między oddolnością i koszmarem partycypacji ................ 11

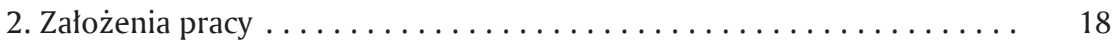

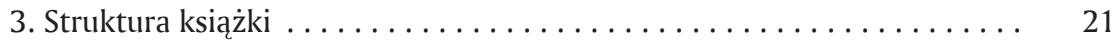

CZĘŚĆ I. PRZESTRZEŃ ZURBANIZOWANA - WYTWARZANIE I ANALIZA ..... 23

ROZDZIAL 1. Przestrzeń zurbanizowana i jej uwarunkowania ............. 25

1.1. Interdyscyplinarność i polityczność przestrzeni zurbanizowanej .... 25

1.1.1. Interdyscyplinarność badań nad przestrzenią ........... 25

1.1.2. Przestrzeń a polityka publiczna $\ldots \ldots \ldots \ldots \ldots \ldots \ldots \ldots . \quad 39$

1.1.3. Polityka miejska a znaczenie urbanistyki oddolnej ........ 43

1.2. Waloryzacja przestrzeni i jej związki z badaniami jakości życia .... 47

1.2.1. Waloryzacja a percepcja przestrzeni $\ldots \ldots \ldots \ldots \ldots \ldots \ldots .47$

1.2.2. Rozumienie jakości życia $\ldots \ldots \ldots \ldots \ldots \ldots \ldots \ldots \ldots \ldots \ldots$

1.2.3. Jakość życia w środowisku zurbanizowanym ........... 60

1.3. Społeczne wytwarzanie przestrzeni miasta .............. 63

1.3.1. Proces społecznego wytwarzania przestrzeni .......... 63

1.3.2. Aktorzy wytwarzający przestrzeń $\ldots \ldots \ldots \ldots \ldots \ldots \ldots \ldots . \quad 70$

1.3.3. Formalne i nieformalne sposoby wytwarzania przestrzeni .... 74

1.3.4. Metody społecznego wytwarzania przestrzeni miasta ...... 82

ROZDZIAL 2. Metoda wieloczynnikowej waloryzacji przestrzeni ............ 85

2.1. Zasady waloryzacji przestrzeni zurbanizowanej $\ldots \ldots \ldots \ldots \ldots \ldots .65$

2.2. Struktura zastosowanej metody i jej techniki badawcze ......... 89

2.2.1. Ogólna charakterystyka metody i źródeł danych .......... 89

2.2.2. Badanie rynku nieruchomości $\ldots \ldots \ldots \ldots \ldots \ldots \ldots \ldots . . \ldots 4$

2.2.3. Analiza infrastruktury osadniczej $\ldots \ldots \ldots \ldots \ldots \ldots \ldots . \quad 96$

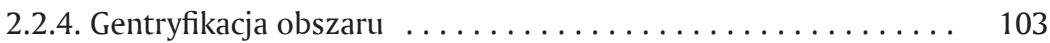

2.2.5. Ocena estetyki przestrzeni $\ldots \ldots \ldots \ldots \ldots \ldots \ldots \ldots \ldots . \ldots \ldots$ 
2.2.6. Mapowanie poznawcze $\ldots \ldots \ldots \ldots \ldots \ldots \ldots \ldots \ldots \ldots \ldots . \ldots \ldots$

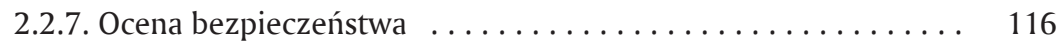

2.2.8. Monitoring internetu . . . . . . . . . . . . . . . . 118

CZĘŚĆ II. MIĘDZY ODDOLNOŚCIĄ I DEWITALIZACJĄ - STUDIA PRZYPADKU . . 127

ROZDZıAŁ 3. Sztuka publiczna. Plac Grzybowski ........................ 129

3.1. Interwencja artystyczna jako impuls działań społecznych . . . . . . . 129

3.2. Właściwości rynku nieruchomości ................... 135

3.3. Ocena funkcji z zakresu infrastruktury osadniczej ............ 137

3.4. Zaawansowanie gentryfikacji obszaru . ................ 139

3.5. Wartości estetyczne przestrzeni $\ldots \ldots \ldots \ldots \ldots \ldots \ldots \ldots \ldots . \ldots \ldots . \ldots \ldots$

3.6. Sposoby mapowania poznawczego $\ldots \ldots \ldots \ldots \ldots \ldots \ldots \ldots . \ldots \ldots$

3.7. Poziom i poczucie bezpieczeństwa $\ldots \ldots \ldots \ldots \ldots \ldots \ldots \ldots \ldots \ldots \ldots \ldots$

3.8. Wyniki monitoringu internetu $\ldots \ldots \ldots \ldots \ldots \ldots \ldots \ldots \ldots . \ldots \ldots$

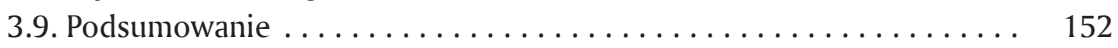

ROZDZIAt 4. Zielona gentryfikacja. High Line Park ................... 154

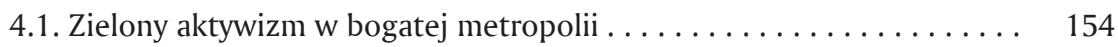

4.2. Właściwości rynku nieruchomości $\ldots \ldots \ldots \ldots \ldots \ldots \ldots \ldots \ldots . \ldots \ldots$

4.3. Ocena funkcji z zakresu infrastruktury osadniczej ............ 165

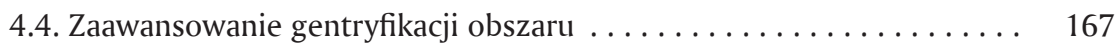

4.5. Wartości estetyczne przestrzeni $\ldots \ldots \ldots \ldots \ldots \ldots \ldots \ldots \ldots . \ldots \ldots$

4.6. Sposoby mapowania poznawczego $\ldots \ldots \ldots \ldots \ldots \ldots \ldots \ldots . \quad 174$

4.7. Poziom i poczucie bezpieczeństwa $\ldots \ldots \ldots \ldots \ldots \ldots \ldots \ldots \ldots . \ldots \ldots$

4.8. Wyniki monitoringu internetu $\ldots \ldots \ldots \ldots \ldots \ldots \ldots \ldots \ldots . \ldots \ldots$

4.9. Podsumowanie .............................. 183

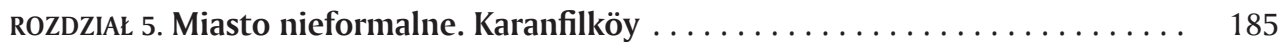

5.1. Spontaniczna urbanizacja w modelu gecekondu ............. 185

5.2. Właściwości rynku nieruchomości - powód zaniechania badań ..... 191

5.3. Ocena funkcji z zakresu infrastruktury osadniczej ........... 192

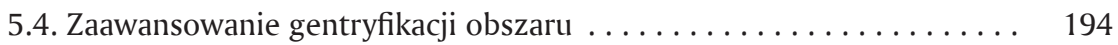

5.5. Wartości estetyczne przestrzeni _.................... 198

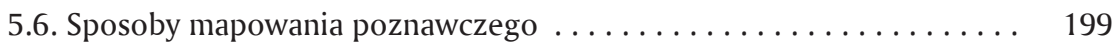

5.7. Poziom i poczucie bezpieczeństwa $\ldots \ldots \ldots \ldots \ldots \ldots \ldots \ldots \ldots . \ldots \ldots 202$

5.8. Wyniki monitoringu internetu $\ldots \ldots \ldots \ldots \ldots \ldots \ldots \ldots \ldots .204$

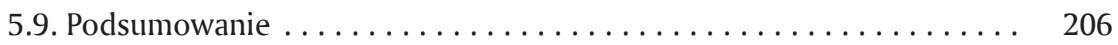

Bilans oddolności - zakończenie ........................ 208

1. Urbanistyka oddolna w społecznym wytwarzaniu przestrzeni - wnioski . 208

2. Perspektywy dla dalszych badań $\ldots \ldots \ldots \ldots \ldots \ldots \ldots \ldots \ldots \ldots .222$

Podziękowania ....................................... 225 
1. Kwestionariusz wywiadu częściowo ustrukturyzowanego . . . . . . . . 227

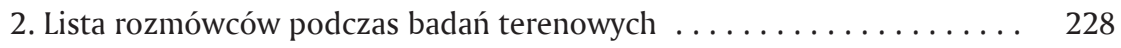

3. Mapy poznawcze autorstwa respondentów zebrane podczas badań

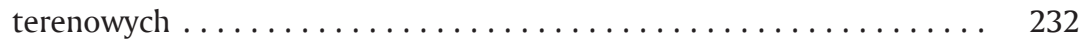

4. Zdjęcia stanowiące podstawę analiz SBE i ich średnie oceny . . . . . . 238

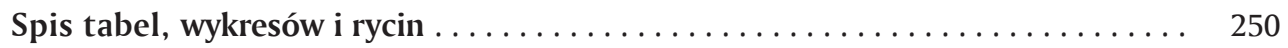

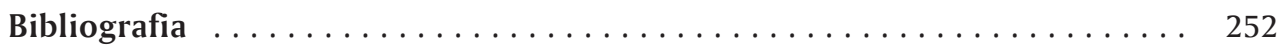

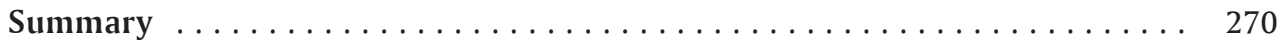



Podczas gdy [McCartyzm] mógł przerażać nowojorskich intelektualistów, to miejska odnowa była tym, co najbardziej przerażało ubogich i ludzi pracy.

R. Fitch, The Assassination of New York, Verso, London-New York 1993, s. 98.

\section{Urbanistyka oddolna - wprowadzenie}

\section{Między oddolnością i koszmarem partycypacji}

W XX wieku oblicze przestrzeni zurbanizowanej odmieniło się w nieodwracalny sposób i na niespotykaną nigdy wcześniej skalę. Przemiany objęły nie tylko dominujący typ osadnictwa, czego wyrazem było odejście od modelu cywilizacyjnego, w ramach którego większość ludności mieszkała na wsi. Równie istotny stał się kontekst zmian dotykających poszczególne rodzaje przestrzeni zurbanizowanej. Współczesne miasto i wieś coraz mniej przypominają swoje historyczne odpowiedniki. Na ich transformację oddziałuje wiele uwarunkowań o podłożu ekonomicznym, politycznym i społecznym. Niezwykle istotny okazuje się też wpływ zachodzącej w miastach rewolucji technologicznej. W tym ostatnim zakresie rozumieć należy nie tylko refleksję nad najbardziej innowacyjnymi i skomplikowanymi przemianami tak zwanego miasta inteligentnego (smart city) ${ }^{1}$, ale przede wszystkim rozwój infrastruktury komunalnej, informacyjnej i szczególnie transportowej. Zwłaszcza pojawienie się motoryzacji z pierwszoplanową rolą samochodów osobowych przemieniło kształt przestrzeni publicznej oraz strukturę i charakter całej przestrzeni zamieszkiwania ${ }^{2}$.

Procesy te wpływają również na sposoby projektowania urbanistycznego i zarządzania przestrzenią zurbanizowaną. Jakkolwiek upowszechnienie się elektryfikacji czy usług wodociągowo-kanalizacyjnych można traktować jako ważne osiągnięcia rozwojowe XX wieku, pełny obraz jego dziedzictwa jest bardziej złożony

${ }^{1}$ E. Almirall, J. Wareham, C. Ratti, P. Conesa, F. Bria, A. Gaviria, A. Edmondson, Smart Cities at the Crossroads: New Tensions in City Transformation, „California Management Review”, nr 59/2016, passim.

${ }^{2}$ L. Mumford, The City in History. Its Origins, Its Transformations, and Its Prospects, Hartcour Brace Jovanovich, New York 1961, s. 408. 
i dyskusyjny. Dystrybucja osiągnięć cywilizacyjnych nie ma równomiernego charakteru. Niektórzy mieszkańcy współczesnych miast i wsi do dzisiaj nie są w stanie odczuć tego postępu. Z kolei wiele osiągnięć uznawanych za ambitne doprowadziło do dystopijnych przekształceń osadnictwa. Najczęściej zresztą wbrew towarzyszącym im szlachetnym intencjom. Jak pisze światowej sławy duński urbanista Jan Gehl, obecnie

[w]spólną cechą niemal wszystkich miast - niezależnie od ich położenia geograficznego, potencjału gospodarczego i poziomu rozwoju - jest to, że ich mieszkańcy [...] są coraz gorzej traktowani. Żyją w skandalicznych wręcz warunkach; w coraz bardziej ograniczanej przestrzeni, w skażonym środowisku i hałasie, napotykają liczne bariery architektoniczne, rosnące ryzyko wypadków itp. ${ }^{3}$

Tego typu licznie występujące problemy inspirują rozmaite koncepcje naprawcze i projekty mające na celu przekształcenie współczesnych jednostek osadniczych oraz poprawę jakości życia w środowisku zurbanizowanym. Wyrazem działań prowadzonych na rzecz przeciwdziałania dysfunkcjom urbanizacji jest między innymi pomysł na wykorzystywanie potencjału społecznych aktywności o oddolnym charakterze. Odgórne programy publiczne z jednej strony, a z drugiej komercjalizacja i prywatyzacja przestrzeni zurbanizowanej jako metody właściwe urynkowionemu modelowi zarządzania zyskują alternatywę. Stają się nią działania mające na celu włączanie w proces społecznego wytwarzania przestrzeni jej mieszkańców i różnego rodzaju podmiotów reprezentujących stronę społeczną. Wzrost znaczenia obywatelskiej partycypacji ma w założeniu zwiększyć legitymizację i akceptację dla dokonywanych taką drogą przekształceń, ale też przynieść korzyści związane z pozyskiwaniem od bezpośrednich użytkowników przestrzeni zurbanizowanej wiedzy nie zawsze dostępnej dla urzędników i zewnętrznych ekspertów.

Wyrazem tego typu działań jest upowszechnianie się zjawisk, które w niniejszej pracy określam mianem urbanistyki oddolnej. Pod nazwą tą kryją się takie sposoby organizowania, adaptowania i projektowania przestrzeni zurbanizowanej, które wykorzystują zaawansowany udział wszelkich reprezentantów strony społecznej. Tymi ostatnimi są zwłaszcza nieformalne grupy mieszkańców i bardziej zorganizowane ruchy miejskie. Urbanistyka oddolna wykracza więc poza dychotomię zdefiniowanego już przez innych autorów podziału na formalne i nieformalne wytwarzanie przestrzeni. Tym samym, jak staram się przekonać w tej pracy, właściwe wydaje się wprowadzenie tego nowego terminu jako wspólnego mianownika dla opisanych w tej pracy działań podejmowanych przez aktorów społecznego wytwarzania przestrzeni. Dokładniejszą operacjonalizację pojęcia, które rozumiem

\footnotetext{
${ }^{3}$ J. Gehl, Miasta dla ludzi, tłum. S. Nogalski, Wydawnictwo RAM, Kraków 2014, s. 3.
} 
jako przeciwieństwo odgórnego wytwarzania przestrzeni, przedstawiam w dalszej części książki.

Zgodnie z jednym z ulubionych aforyzmów przedstawicieli nauk politycznych, nie istnieje w ogóle coś takiego jak nie-polityka. Przenika ona bowiem wszystkie dziedziny życia społecznego. Parafrazując ten cytat z Czarodziejskiej góry Thomasa Manna, moglibyśmy podobnie stwierdzić, że nie ma też i nie-polityki publicznej. Istnieć mogą jedynie zaniechania w tej kwestii, których przejaw stanowi na przykład dysfunkcyjna polityka miejska. Właśnie z takową mamy do czynienia w kontekście polskiej przestrzeni zurbanizowanej, czego dowodzą zaniedbania w obszarze planowania przestrzennego. Planowanie to stało się w ostatnich latach ofiarą generalnej krytyki idei planowania w jakimkolwiek wymiarze. Jest to zresztą charakterystyczne dla transformacji kapitalizmu z przełomu XX i XXI wieku. David Harvey postrzega to zjawisko jako immanentną cechę myślenia entuzjastów ideologii wolnorynkowej. I to pomimo tego, że stoi to jego zdaniem w jawnej sprzeczności z działaniami beneficjentów wychwalanego przez nich modelu społeczno-ekonomicznego. Jak zauważa ów teoretyk,

[w]iele mówiące jest to ideologiczne narzekanie, że planowanie jest złe - w szczególności dla kapitalistów - mające na celu jedynie zaatakowanie tej idei z powodu tego, że przekształciłaby ona świat na podobieństwo ich własnych straszliwych fabryk. Potępienie planowania nie zazębia się w żaden sposób z tym, co zachodzi w strukturach Toyoty czy Wal-Martu. Odnoszące sukcesy korporacje rozwijają zawiłe techniki planowania w ramach kompleksowego zarządzania jakością, analiz nakładów-wyników [...], optymalnego ustalania harmonogramów czy projektowania, planując wszystko po najdrobniejsze szczegóły

Po 1989 roku w państwach dawnego realnego socjalizmu zaznacza się odwrót od przestrzeni kreowanej odgórnie przez państwo na rzecz jej prywatyzacji. Niekiedy przyjmuje to pośrednią formę związaną z mechanizmami partnerstwa publiczno-prywatnego. W innych przypadkach dochodzi do praktycznego przejmowania roli przestrzeni publicznej przez już w pełni komercyjne przedsięwzięcia biznesowe. Szczególnie dobitnymi przykładami tego zjawiska okazały się wielkie centra handlowe. Równolegle poparcie zyskał opisany przez Richarda Floridę model transformacji przestrzeni miejskich oparty na inwestycjach mających pobudzać tak zwaną klasę kreatywną5. Osoby zatrudnione we właściwych tej grupie

${ }^{4}$ D. Harvey, Przewodnik po Kapitale Karola Marksa, tłum. K. Szadkowski, Wydawnictwo Ekonomiczne Heterodox, Poznań 2017, s. 221. Harvey nawiązuje w tym miejscu do szczególnie pomijanej we współczesnym polskim dyskursie akademickim Marksowskiej krytyki kapitalizmu. Zob. K. Marks, Kapitat. Krytyka ekonomii politycznej, t. 1, Proces wytwarzania kapitału, [w:] K. Marks, F. Engels, Dzieła, t. 23, Książka i Wiedza, Warszawa 1968, s. 421-422.

${ }^{5}$ R. Florida, Narodziny klasy kreatywnej oraz jej wptyw na przeobrażenia w charakterze pracy, wypoczynku, społeczeństwa i życia codziennego, tłum. T. Krzyżanowski, M. Penkala, Narodowe Centrum Kultury, Warszawa 2010, s. 31-38. 
zawodach branży kreatywnej mają w myśl przywołanej teorii wzmacniać innowacyjny potencjał miast. W opinii wspomnianego autora branżę tę stymulują punkty węzłowe życia kulturalnego. Przykładami tego rodzaju miejskiej akupunktury mogą być pokazowe inwestycje realizowane po upadku PRL. Muzea historyczne i sztuki współczesnej, budowane w całej Polsce porty lotnicze, aquaparki, filharmonie czy stadiony. Społeczny oddźwięk przywołanych inwestycji jest różny, wiele charakteryzuje jednak ograniczona dostępność. Charakterystyczne jest, że najwięcej inwestycji kreatywnych przyciągają ośrodki miejskie, będące najbardziej uprzywilejowanymi miejscami największych przepływów finansowych. Szczególnie zaś ich najbogatsze dzielnice. Jak podaje Krzysztof Nawratek, wbrew obiegowej opinii, innowacyjność wcale nie musi być jednak związana z intensywną urbanizacją ${ }^{6}$ Inwestycje na rzecz klasy kreatywnej dla neoliberalnego kapitalizmu do pewnego stopnia pełnią więc funkcję analogiczną do peerelowskich obiektów oddawanych do użytku na 22 lipca. $\mathrm{Na}$ ironię zakrawa zresztą fakt, że właśnie tego dnia oddano do użytku naczelny symbol rodzimej modernizacji ostatnich lat - Stadion Narodowy.

Sam Florida dzięki wspomnianej koncepcji stał się prawdopodobnie najbardziej popularnym na świecie doradcą w obszarze polityki miejskiej. Sprzedaż pierwszego wydania jego przywoływanej książki osiągnęła rzadko spotykany w przypadku opracowań urbanistycznych poziom 300 tysięcy egzemplarzy. Zawarte w niej, niekoniecznie zresztą ugruntowane empirycznie twierdzenia, stały się z biegiem czasu obiektami zaostrzającej się krytyki. W czasie niektórych wystąpień publicznych autor ten określał na przykład Detroit jako odradzającą się metropolię, chociaż powszechnie kojarzy się to miasto jako archetypiczny wręcz przykład urbanistycznej degradacji. W rzeczywistości rewitalizacja dotyka zaledwie części powierzchni tego w dalszym ciągu wyludniającego się i skrajnie nieegalitarnego ośrodka miejskiego. Jego oficjalne bankructwo ogłoszone w 2013 roku umożliwiło masową prywatyzację usług i dóbr publicznych. O zorientowaniu rewitalizacji Detroit na potrzeby najzamożniejszych grup ludności świadczyć może, że beneficjentami aż 69 procent środków przeznaczonych na programy miejskiej odnowy stają się reprezentanci najzamożniejszej, białej części ludności. Tymczasem to Afroamerykanie stanowią 83 procent populacji ${ }^{7}$. Krytyka tego typu skłoniła do autorefleksji

${ }^{6}$ Pokazuje to przykład Doliny Krzemowej, niezbyt zwartego przestrzennie obszaru grupującego siedziby największych koncernów przemysłu informatycznego, włącznie z Google, Apple i Microsoftem. Zob. K. Nawratek, Miasta - maszyny produkujące niezwykłość, „Znak”, nr 673/2011, http://www.miesiecznik.znak.com.pl/2754/miasta-maszyny-produkujace-niezwyklosc, dostęp: 2.05.2015.

7 P. Moskowitz, How To Kill a City. Gentrification. Inequality, and the Fight for the Neighborhood, Nation Books, New York 2017, ebook. W opracowaniu w charakterze pełnoprawnych źródeł wykorzystywałem wydania elektroniczne (ebooki), chociaż jak do tej pory badacze rzadko sięgają po 
również samego Floridę. W ostatniej książce pisze on już o dotkliwościach, jakie wywołują

nowe podziały opisujące rosnące nierówności i ekonomiczną segregację, które są fundamentalnymi kwestiami dla nowej geografii klasowej. Są to [dlań] fenomeny leżące w środku Nowego Kryzysu Miejskiego [New Urban Crisis $]^{8}$.

W innym fragmencie autor ten wskazuje różnice w cenach nieruchomości w poszczególnych miastach. Za pieniądze równe wartości jednego domu w nowojorskim sąsiedztwie SoHo kupić można we wspomnianym Detroit aż 29 takich nieruchomości ${ }^{9}$.

Ponieważ skrajne wizje kreowania przestrzeni za pomocą planowania odgórnego oraz jej zupełnej prywatyzacji ujawniły liczne wady, współcześnie postuluje się niekiedy wariant pośredni, związany z tworzeniem przestrzeni w sposób „społeczny". To swego rodzaju truizm, albowiem każdy rodzaj przestrzeni jest w istocie wytwarzany przez jej użytkowników. Przedmiot zainteresowania moich rozważań obejmuje jednak określony rodzaj podmiotów właściwych dla modelu partycypacyjnego, który jest związany z rosnącą popularnością mechanizmów demokracji bezpośredniej. Dobre wyniki w tym zakresie pozwala też osiągać wspieranie rozwoju miasta nieformalnego. Jak pokazuje przykład Ameryki Łacińskiej ${ }^{10}$, niektóre przypadki tego typu charakteryzują większą spójność społeczną niż odgórnie zaplanowane miasta formalne. Takie jak choćby z jednej strony ortogonalne blokowiska z czasów realnego socjalizmu, a z drugiej suburbanizujące Polskę grodzone osiedla deweloperskie ${ }^{11}$ czy inne wielkie, publiczne osiedla socjalne ${ }^{12}$.

Jak konstatuje Andrzej Zybała, badacz z obszaru nauk o polityce publicznej, „urbanizacja zrodziła konieczność regulowania, budowania infrastruktury umożliwiającej funkcjonowanie jednostkom w coraz bardziej współzależnym

nie we w pełni otwarty sposób. Ebooki nie posiadają tradycyjnej paginacji, co znalazło odzwierciedlenie w dotyczących ich przypisach.

${ }^{8}$ R. Florida, New Urban Crisis. How Our Cities Are Increasing Inequality, Deepening Segregation, and Failing the Middle Class - and What We Can Do About It, Basic Books, New York 2017, ebook.

${ }^{9}$ Ibidem.

${ }^{10} \mathrm{~J}$. McGuirk, Radykalne miasta. Przez Amerykę Łacińską w poszukiwaniu nowej architektury, tłum. M. Wawrzyńczak, Fundacja Bęc Zmiana, Res Publica, Warszawa 2015, passim.

${ }^{11} \mathrm{~J}$. Gądecki, Za murami. Osiedla grodzone w Polsce - analiza dyskursu, Wydawnictwo Uniwersytetu Wrocławskiego, Wrocław 2009, s. 128-223.

${ }^{12}$ A. Przymeński, Zarzq̨dzanie socjalnq pomocq mieszkaniowq̨, [w:] A. Przymeński, M. Oliwa-Ciesielska, Publiczna pomoc mieszkaniowa a demarginalizacja społeczna ludności ubogiej, Wydawnictwo Uniwersytetu Ekonomicznego w Poznaniu, Poznań 2014, s. 170; idem, Socjalny najem mieszkań jako instrument demarginalizacji mieszkaniowej w Polsce, „Problemy Polityki Społecznej. Studia i Dyskusje”, nr 1/2016, s. 27. 
środowisku”13. Nie ulega zatem wątpliwości, że problem przestrzeni urbanizowanej, sposobów jej projektowania i zarządzania nią, stanowić powinien przedmiot zainteresowania polityki publicznej. Związana z nią nauka ma zresztą na celu, jak zauważył jej założyciel - Harold Lasswell - między innymi wynajdywanie praktycznych rozwiązań dla problemów związanych z podejmowaniem decyzji publicznych ${ }^{14}$. To w ramach perspektywy charakterystycznej dla tej właśnie dyscypliny podjąłem problem społecznie wytwarzanej przestrzeni w ramach urbanistyki oddolnej. Przedmiotem zainteresowania nauk o polityce publicznej jest wszakże jednoczesna analiza dotycząca celów, rezultatów, instrumentów i aktorów działań publicznych. Z tego punktu widzenia bardzo interesujące zdaje się pytanie o motywacje przyświecające działaniom interesariuszy polityki publicznej, dotykającej przestrzeni zurbanizowanej.

Przedmiot urbanistyki oddolnej niesie za sobą ryzyko autoteliczności prowadzonych działań. Polega to na tym, że techniki włączające oddolnych aktorów mogą stawać się potencjalnie celami takich przedsięwzięć samymi w sobie. Prowokuje to pytania o przesłanki, jakie towarzyszą w rzeczywistości stosowaniu technik partycypacyjnego wytwarzania przestrzeni. Jak również o to, na ile te rozwiązania okazują się korzystne oraz którzy użytkownicy przestrzeni zurbanizowanej są ich rzeczywistymi beneficjentami.

Polityka publiczna jest w tym aspekcie podobna do ekonomii rozumianej jako

nauk[a] o dokonywaniu wyborów[, która b]ada, w jaki sposób ludzie dobierają rzadkie albo ograniczone zasoby wytwórcze $[\ldots]$ aby produkować z nich różne dobra [...] i jak decydują o rozdziale tych dóbr między konsumujących je członków społeczeństwa ${ }^{15}$.

Badanie urbanistyki oddolnej jest zakorzenione również w perspektywie socjologicznej. Nauka ta nie tylko bada struktury społeczne, ale i przyczynia się do „oceny skutków działania”. Jak opisuje to Anthony Giddens,

badania socjologiczne pomagają w ocenie efektów praktycznych inicjatyw społecznych. Każdy program reformy społecznej może się nie powieść lub wywołać zgoła niepożądane skutki. [...] Socjologia nie ogranicza się do abstrakcyjnych dywagacji intelektualnych. Znajduje $[. .$.$] wiele znaczących zastosowań praktycznych { }^{16}$.

${ }^{13}$ A. Zybała, Polityki publiczne. Doświadczenia w tworzeniu $i$ wykonywaniu programów publicznych w Polsce i innych krajach, Krajowa Szkoła Administracji Publicznej, Warszawa 2012, s. 14.

${ }^{14}$ H.D. Lasswell, A Pre-View of Policy Sciences, American Elsevier Publishing, Cambridge 1971, s. $40-48$.

15 P.A. Samuelson, W.H. Nordhaus, Ekonomia 1, tłum. H. Hagemejer, K. Hagemejer, J. Czekaj, Wydawnictwo Naukowe PWN, Warszawa 2000, s. 26.

${ }^{16}$ A. Giddens, Socjologia, tłum. A. Szulżycka, Wydawnictwo Naukowe PWN, Warszawa 2007, s. $30-42$. 
Opinię tę podzielał też Stefan Nowak. Według niego socjologowie

na podstawie swej wiedzy teoretycznej i znajomości konkretnych sytuacji [mogą wskazywać] jakie środki powinny być zastosowane, aby osiągnąć stan pożądany [lub] zmniejszyć (jeśli nie wyeliminować) problem społeczny ${ }^{17}$.

Socjologia, co szczególnie istotne w świetle moich dalszych rozważań, ma też silny wymiar krytyczny. W ramach tej dyscypliny wyodrębnia się wiele badań poświęconych przestrzeni zurbanizowanej. To, jak użyteczne może być wzbogacenie o socjologiczną perspektywę książki osadzonej w nurcie dyscypliny nauk o polityce publicznej, poświadcza dorobek takich badaczy jak William H. Whyte, czyli autor przełomowej dla badań z zakresu waloryzacji przestrzeni pracy o sposobach użytkowania środowiska zbudowanego ${ }^{18}$. To właśnie perspektywa socjologiczna, czerpiąca w przypadku tej pracy również z technik badań właściwych dla urbanistyki, wydaje się tym samym najlepiej przystosowana do ilościowo i jakościowo zorientowanych analiz charakterystycznych dla rozważań zawartych w tej książce.

Metodą wykorzystaną przy okazji moich rozważań jest opracowana przeze mnie wieloczynnikowa waloryzacja przestrzeni (WWP), stanowiąca równocześnie ramę konceptualną całej pracy. Jej założenia przedstawiam w rozdziale drugim. Już teraz zaznaczmy jednak, że chodzi w tym kontekście o waloryzację w rozumieniu urbanistycznym. Jest on odmienny od najpowszechniej kojarzonego wariantu ekonomicznego, który określa samo zwiększanie wartości pieniężnej. Waloryzacja urbanistyczna to, generalnie rzecz ujmując, szacowanie jakości przestrzeni, które odgrywa kluczową rolę dla planowania i zagospodarowania przestrzennego. Umożliwia identyfikację walorów danej przestrzeni. Pozwala określać jej atuty i główne problemy wymagające odpowiednich interwencji rozumianych jako ingerencje w tę przestrzeń. Dążenie do możliwie rzetelnej oceny przestrzeni zamieszkanej wydaje się tymczasem niezbędne dla wysiłków podejmowanych na rzecz harmonijnego rozwoju przestrzennego. Waloryzacja przestrzeni jest tym samym związana z badaniami jakości życia, a zwłaszcza jakości życia w środowisku zurbanizowanym, jakkolwiek zakres obu tych podejść nie jest w pełni tożsamy. W przypadku waloryzacji przedmiotem jest sama przestrzeń, w jej wszystkich wymiarach, także tych niematerialnych. W badaniu jakości życia są to natomiast egzystujące jednostki bądź zbiorowości ludzkie. Waloryzacja stanowi technikę przede wszystkim urbanistyczną, chętnie wykorzystywaną przez socjologów i badaczy z obszaru interdyscyplinarnych studiów miejskich. Badania nad jakością życia,

17 S. Nowak, Metodologia badań społecznych, Wydawnictwo Naukowe PWN, Warszawa 2010, s. 456 .

18 W.H. Whyte, The Social Life of Small Urban Spaces, Project for Public Spaces, New York 2001, passim. 
prowadzone w różnych wymiarach przez przedstawicieli takich dyscyplin, jak „,filozofia, socjologia, psychologia, aksjologia, ekonomia i statystyka" ${ }^{19}$, nie bez przyczyny nie są jednak kojarzone z profesją urbanistów. W zależności od towarzyszącego im celu badania waloryzacji i jakości życia mogą się przenikać. Waloryzacja może i powinna stanowić element badania jakości życia w środowisku zurbanizowanym. Badanie jakości życia jest natomiast istotną częścią składową wieloczynnikowej waloryzacji przestrzeni.

Skuteczne planowanie przestrzenne i kształtowanie zrównoważonej przestrzeni zamieszkiwania są kluczowe dla rozwoju (development) stawianego w opozycji do najważniejszej dla neoliberalizmu kategorii wzrostu (growth). O ile ten drugi opiera się na „wolności” rynków finansowych, to przez rozwój rozumieć należy splot sprawnego sektora publicznego, uwzględniającego mechanizmy rynkowe, oraz społeczeństwa obywatelskiego. Przestrzeń wytwarzana przez podmioty społeczne może być zatem rozumiana jako prorozwojowy czynnik stymulacyjny, modelujący zrównoważoną, odpowiedzialną społecznie urbanizację. To, czy rzeczywiście się nim okazuje w praktyce, stanowi przedmiot moich dalszych rozważań i wyprowadzanych na ich podstawie konkluzji. Niektórzy obserwatorzy taki sposób wytwarzania przestrzeni postrzegają bowiem w sposób dokładnie przeciwny. Krytycy mechanizmów partycypacyjnych określają je jako zrzucanie odpowiedzialności przez władze publiczne na mieszkańców. Służyć temu ma zwiększenie odpowiedzialności obywateli przy jednoczesnym dalszym ograniczonym stopniu decyzyjności społeczeństwa. To właśnie tytułowy koszmar partycypacji, pojęcie zapożyczone przeze mnie od Markusa Miessena ${ }^{20}$. W tej pracy sprawdzam, na ile praktyczne okazuje się to założenie niemieckiego teoretyka architektury w odniesieniu do różnych wycinków rzeczywistej przestrzeni zurbanizowanej.

\section{Założenia pracy}

Podstawowy cel tej książki stanowi waloryzacja następstw interwencji aktorów społecznych, prowadzona na przykładzie wybranych fragmentów metropolii położonych na różnych kontynentach. Analiza skutków tych działań służy do poszukiwania wniosków formułowanych w odniesieniu do kształtu polityki miejskiej możliwej do prowadzenia w Polsce. Zastosowanie kategorii waloryzacji przestrzeni w ujęciu interdyscyplinarnym pozwala zidentyfikować zróżnicowane wartości przestrzenne reprezentatywne dla poszczególnych badanych studiów przypadku.

19 T. Borys, P. Rogala, Jakość życia na poziomie lokalnym - ujęcie wskaźnikowe, UNDP, Warszawa 2008, s. 9.

${ }^{20}$ M. Miessen, Koszmar partycypacji, tłum. M. Choptiany, Fundacja Bęc Zmiana, Warszawa 2013, s. 65. 
Związane jest to z właściwą przestrzeni zurbanizowanej złożonością, której struktura i charakter stanowią jedne z głównych determinant jakości życia i stosunków społecznych. W wymiarze ekonomicznym przestrzeń tego rodzaju ma ulegającą zmianom wartość, umożliwiając osiąganie zysku ze sprzedaży bądź czerpanie innych korzyści z posiadania nieruchomości w postaci działek ziemi. W ujęciu socjologicznym przestrzeń zamieszkana kreuje relacje międzyludzkie. W psychologicznym natomiast oddziałuje na dobrostan psychofizyczny jednostek ${ }^{21}$.

Analizie i ocenie poddałem z tego względu trzy przykłady społecznych działań partycypacyjnych. Obejmują one fragmenty przestrzeni publicznej o charakterze punktowym (plac Grzybowski), liniowym (park High Line zbudowany na wyłączonym z użytku wiadukcie kolejowym), a także strefowym (osiedle mieszkaniowe typu nieformalnego o nazwie Karanfilköy). Wybrane przeze mnie przykładowe studia przypadków są zdecydowanie zróżnicowanymi geograficznie terenami na obszarach dużych metropolii. Jednocześnie metropolie te, odpowiednio Warszawa, Nowy Jork i Stambuł, wykazują pewne podobieństwa. Są głównymi ośrodkami miejskimi w swoich państwach, chociaż już niekoniecznie ich stolicami. Są za to najważniejszymi celami imigracji oraz centrami gospodarczymi o skali powiązań z innymi ośrodkami umożliwiającej ich klasyfikację jako metropolii globalnego zasięgu ${ }^{22}$. Cechuje je przy tym zróżnicowanie kulturowe oraz historyczne, co pozwala na ich przykładach ilustrować odmienne konteksty przestrzenne i społeczne. Wszystkie te przypadki są zarazem reprezentatywne dla różnych przykładów urbanistyki oddolnej.

Najwyższy poziom jakości życia, odnotowywany w stosunkowo najbardziej egalitarnych społeczeństwach zachodnich, wyraża się najwyższą jakością przestrzeni zurbanizowanej. Sama jej wartość nie wynika wyłącznie z wysokiej świadomości obywateli, władz różnego szczebla i osób odpowiedzialnych za planowanie przestrzenne, co da się określić zbiorczo jako wysoki poziom kapitału społecznego. Cechą tych miejsc jest przede wszystkim zasobny kapitał finansowy. Z punktu widzenia Polski, będącej państwem o zawiłych dziejach historycznych i gwałtownych przemianach ustroju społecznego i gospodarczego, inspirująca wydaje się analiza porównawcza także z innymi częściami świata. Chodzi przy tym o obszary bardziej różnorodne niż najczęściej analizowane przez polskich badaczy z obszaru studiów miejskich iście okcydentalne przykłady przestrzeni zurbanizowanej z państw Europy Zachodniej.

${ }^{21}$ I. Cieślak, Wybrane metody waloryzacji przestrzeni zurbanizowanej, [w:] eadem (red.), Wspótczesna waloryzacja przestrzeni zurbanizowanej, Wydawnictwo Uniwersytetu Warmińsko-Mazurskiego w Olsztynie, Olsztyn 2012, s. 76; E.T. Hall, Ukryty wymiar, tłum. T. Hołówka, Państwowy Instytut Wydawniczy, Warszawa 1976, passim.

${ }^{22}$ S. Sassen, The Global City: Introducing a Concept, „Brown Journal of World Affairs”, nr 2/2005, passim. 
Tym samym jako podejście badawcze ${ }^{23}$ zastosowałem zbiorowe studium przypadku wedle terminologii zaproponowanej przez Roberta E. Stake'a. Ten typ jakościowego badania jest dla przywołanego autora „instrumentalnym studium obejmującym kilka przypadków”. Ich dobór wynika z chęci „lepszego poznania i zrozumienia szerszego zjawiska", ale już niekoniecznie uchwycenia wszystkich aspektów analizowanych przykładów. W swojej pracy skupiam się zatem na współwystępowaniu opisywanych w niej zjawisk w różnych kontekstach geograficzno-społecznych, mimo że badane konteksty nie są ze sobą bezpośrednio związane. Wedle Stake’a różnorodność przypadków zaspokaja drugą kluczową, obok dostępności analizowanych przykładów, pożądaną cechę właściwie skonstruowanego jakościowego studium przypadku. Jest nią wielość oraz różnorodność informacji możliwych do zgromadzenia za pomocą przykładów wybranych do badania naukowego ${ }^{24}$.

W swoich rozważaniach poszukuję odpowiedzi na kilka pytań badawczych. Po pierwsze, zastanawiam się nad tym, czym różnią się w swoich skutkach działania oddolne w zakresie wytwarzania przestrzeni i sztywne programy „odgórnego” budownictwa. Po drugie, rozważam to, jaki wpływ wywierają mechanizmy partycypacji społecznej w zarządzaniu miastem. Po trzecie, przyglądam się temu, w jaki sposób partycypacja społeczna wpływa na lokalny rynek nieruchomości. Po czwarte, sprawdzam, na ile mierzalne są efekty działalności obywateli w kształtowaniu przestrzeni miejskiej. Przedmiotem piątego pytania jest natomiast refleksja nad tym, jakie skutki wywarły działania oparte na partycypacji społecznej w Polsce po 1989 roku. Zdecydowałem się zarazem zrezygnować z konstruowania tezy lub hipotez badawczych. Brałem w tym kontekście pod uwagę zastosowanie paradygmatu metod mieszanych - zgodnie z zasadą metodycznej elastyczności właściwej badaniom jakościowych studiów przypadku" ${ }^{25}$. Główny efekt poznawczy mojej książki stanowi ocena porównawcza skuteczności działań aktorów społecznych w wybranych kontekstach społeczno-geograficznych. Przyczyni się to, mam nadzieję, do zainteresowania tematyką książki praktyków będących interesariuszami w procesie gospodarowania przestrzenią miasta w warunkach demokracji uczestniczącej. Umożliwi to między innymi uporządkowanie i w konsekwencji tego uczytelnienie w tej pracy różnic między różnymi podejściami dotyczącymi przestrzeni zurbanizowanej.

${ }^{23}$ J.W. Creswell, Ch.N. Poth, Qualitative Inquiry and Research Design: Choosing Among Five Approaches, Sage Publications, Thousand Oaks 2018, s. 96-102.

${ }^{24}$ R.E. Stake, Jakościowe studium przypadku, [w:] N.K. Denzin, Y.S. Lincoln (red.), Metody badań jakościowych, t. 1, Wydawnictwo Naukowe PWN, Warszawa 2009, s. 628-636.

25 Ibidem, s. 623. 


\section{Struktura książki}

Odzwierciedleniem powyższych założeń jest przyjęta struktura książki, podzielonej na dwie główne części. W pierwszej tematem są teoretyczne aspekty towarzyszące analizowaniu przestrzeni zurbanizowanej. W otwierającym tę część rozdziale przedstawiłem przegląd obecnego stanu badań z zakresu waloryzacji przestrzeni zurbanizowanej, kwerendę literatury przedmiotu, stosowanej terminologii, związków urbanistyki oddolnej z polityką miejską i szerzej rozumianą polityką osadniczą, a także głównych zasad waloryzacji przestrzeni i jej powiązań z badaniami poziomu jakości życia w środowisku zurbanizowanym. W ostatnim fragmencie rozdziału pierwszego opisuję koncepcję procesu społecznego wytwarzania przestrzeni. Podejmuję w nim ponadto rozważania dotyczące opracowania typologii oddolnych działań podejmowanych w tym zakresie. Rozdział drugi poświęciłem przedstawieniu metodycznych założeń proponowanej przeze mnie metody WWP. Składa się na nią łącznie siedem metod szczegółowych służących kolejno: badaniu rynku nieruchomości (1), waloryzacji infrastruktury osadniczej (2), poziomu natężenia gentryfikacji (3), oceny estetycznej - analizy oceny piękna scenerii (4), mapowania poznawczego (5), oceny poziomu bezpieczeństwa (6) i behawioralnej analizy śladów internetowej aktywności użytkowników przestrzeni zurbanizowanej (7). Konsekwentnie piszę tu o metodach szczegółowych, a nie cechach zmiennych. W ten sposób większy nacisk kładę w przyjętej terminologii na sposób prowadzenia badań niż same pozyskane wartości cech zmiennych.

Grupa wskazanych metod szczegółowych czerpie z arsenału technik badawczych jeszcze dokładniej opisanych w drugiej części książki. Znalazły one w niej zastosowanie w postaci jednolitej matrycy badawczej przykładanej do każdego spośród wybranych przeze mnie studiów przypadku. Analizom tych kontekstów poświęciłem kolejne rozdziały, wzbogacone dodatkowo o szersze zarysowanie ich lokalnych uwarunkowań. Rozdział trzeci dotyczy zatem części badawczej realizowanej w Warszawie, czwarty - badań w Nowym Jorku, a piąty przedstawia te prowadzone w Stambule. Wnioski z rozważań opisanych w drugiej części posłużyły następnie do zarysowania aspektów teoretycznych urbanistyki oddolnej oraz zaprezentowania próby oceny takiego sposobu społecznego wytwarzania przestrzeni.

Tego rodzaju konkluzje zamieściłem w ostatniej części książki zawierającej jej podsumowanie. To właśnie tutaj znalazły się wnioski końcowe i synteza argumentów. Książkę zamyka propozycja kierunków dalszych badań. W zamieszczonych na końcu aneksach znalazły się ponadto: kwestionariusz przeprowadzonych wywiadów, lista moich rozmówców, a także zestawienia wykorzystywanych map poznawczych i materiałów wizualnych - zdjęć wykonanych w trakcie inwentaryzacji urbanistycznej - opracowane w ramach badań terenowych. 

CZĘŚĆ I

Przestrzeń zurbanizowana wytwarzanie $\mathrm{i}$ analiza 

ROZDZIAL 1

\section{Przestrzeń zurbanizowana i jej uwarunkowania}

\subsection{Interdyscyplinarność i polityczność przestrzeni zurbanizowanej}

\subsubsection{Interdyscyplinarność badań nad przestrzenią}

Wielość ujęć i publikacji dotyczących pojęcia przestrzeni przemawia za umieszczeniem na początku książki szerszego przeglądu literatury źródłowej. Ma to na celu wyjaśnienie kluczowych dla tej pracy zagadnień oraz uporządkowanie związanego $\mathrm{z}$ nimi interdyscyplinarnego zamieszania terminologicznego. Przyjęcie jako metody badawczej waloryzacji przestrzeni skłania natomiast do zdefiniowania w pierwszej kolejności samej przestrzeni oraz skonfrontowania tego terminu z innymi pojęciami bliskoznacznymi. Refleksję na jej temat podejmuje wiele dziedzin, wśród których znajdują się zarówno nauki społeczne, humanistyczne, jak i techniczne. Przestrzeń jest jednocześnie obiektem badań behawioralnych, analiz postaw wobec niej, refleksji filozoficznej, a także przedmiotem przekształceń w warstwie materialnej, dokonywanych przez człowieka i czynniki nieantropogeniczne. Jest pojęciem najbardziej ogólnym, najmniej konkretnie opisującym otoczenie i istotę życia człowieka. Ma charakter niepoliczalny i nieograniczony jako przestrzeń kosmiczna bądź ograniczony w sensie kuli ziemskiej, w tym jej części lub fragmentów. Zdaniem Jana M. Chmielewskiego

przestrzeń można $[\ldots]$ rozpatrywać jako nieskończoną rozciągłość, w której występuje świat ludzkich symboli zmaterializowanych lub tylko wyobrażonych, albo jako objętość zdefiniowaną przez elementy fizyczne i wizualną wyobraźnię człowieka ${ }^{1}$.

W myśl klasyfikacji wyprowadzonej przez tego autora przestrzeń może być obiektem obrazowania w sposób techniczny: planimetryczny - dwuwymiarowy, perspektywiczny - trójwymiarowy, czasoprzestrzenny - operujący czasem jako

${ }^{1}$ J.M. Chmielewski, Teoria urbanistyki w projektowaniu i planowaniu miast, Oficyna Wydawnicza Politechniki Warszawskiej, Warszawa 2001, s. 15-17. 
czwartym wymiarem, oraz intencjonalny - taki, który akcentuje wybraną cechę przestrzeni, jak też kulturowy ${ }^{2}$. W charakterystycznym dla kulturowego ujęcia przestrzeni opisie Yi-Fu Tuana „[i]stnieją trzy zasadnicze i nakładające się na siebie typy przestrzeni: mityczna, pragmatyczna i abstrakcyjna lub teoretyczna"3. Przestrzeń można zatem podzielić na: rzeczywistą, czyli dającą się obserwować, namacalną, współtworzoną przez człowieka, i symboliczną, czyli wytwór ludzkiej wyobraźni. Według Iwony Cieślak oba wspomniane typy przestrzeni są uwikłane we wzajemne relacje ${ }^{4}$. Przedmiotem mojego zainteresowania w tej pracy jest przede wszystkim miejska przestrzeń rzeczywista. Daje się ona opisać także jako przestrzeń zurbanizowana bądź środowisko zbudowane lub zurbanizowane. Określenia te w niniejszej książce stosuję wymiennie.

„»Przestrzeń« jest [przy tym] bardziej abstrakcyjna niż »miejsce«. To co na początku jest przestrzenią, staje się miejscem w miarę poznawania i nadawania wartości” ${ }^{5}$. Pojęcie miejsca służy konkretyzacji przestrzeni, w przeciwieństwie do abstrakcyjnej kategorii przestrzeni, wiąże się też z nim związek emocjonalny użytkownika miejsca. Zdaniem Marca Augé przestrzeń to nieokreślona materia rozciągająca się pomiędzy miejscamí ${ }^{6}$.

Kolejnym terminem odnoszącym się do pojęcia przestrzeni jest terytorium, które wedle Krzysztofa Nawratka dotyczy deskrypcji przestrzeni o określonych granicach ${ }^{7}$. Dla Bohdana Jałowieckiego terytorium to obszar czyjejś władzy ${ }^{8}$. Jest to zresztą zgodne z klasyczną, trójelementową definicją instytucji państwa. Rozumiane jest ono w jej ramach jako terytorium zamieszkiwane przez określoną ludność poddaną władzy zwierzchniej ${ }^{9}$. Za wyrazy bliskoznaczne względem terytorium uznać można też obszar i na ogół węziej rozumiany teren. Z tej samej terminologii czerpią też nauki o zagospodarowaniu przestrzennym. Na przykład programy rewitalizacji odnoszą się zwykle do obszarów zdegradowanych. Z kolei plany miejscowe decydują o przeznaczeniu funkcjonalnym poszczególnych terenów.

2 Ibidem.

3 Y.-F. Tuan, Przestrzeń i miejsce, tłum. A. Morawińska, Państwowy Instytut Wydawniczy, Warszawa 1987, s. 29.

${ }^{4}$ I. Cieślak, Wybrane metody waloryzacji..., s. 68.

5 Y.-F. Tuan, op. cit., s. 16.

${ }^{6}$ M. Augé, Nie-miejsca. Wprowadzenie do antropologii hipernowoczesności, tłum. R. Chymkowski, Wydawnictwo Naukowe PWN, Warszawa 2012, s. 56.

7 K. Nawratek, Total Urban Mobilisation. Ernst Jünger and the Post-Capitalist City, Palgrave Macmillan, Singapore 2019, s. 13.

${ }^{8}$ B. Jałowiecki, Społeczne wytwarzanie przestrzeni, Wydawnictwo Naukowe Scholar, Warszawa 2010, s. 27.

${ }^{9} \mathrm{~J}$. Oniszczuk, Termin, rozumienie i ujęcia państwa, [w:] idem (red.), Wspótczesne państwo w teorii i praktyce, Oficyna Wydawnicza SGH, Warszawa 2011, s. 37-38. 
W ujęciu Chmielewskiego trzecim, obok przestrzeni i miejsca, kluczowym pojęciem przestrzennym jest środowisko. Jego fundamentalnymi celami są według tego autora: „wspieranie procesów życiowych organizmów, dostarczanie im surowców i energii oraz pochłanianie ubocznych skutków i produktów wynikających z ich egzystencji" ${ }^{10}$. Środowisko ma konotacje ekologiczne raczej bez wyznaczonych granic przestrzennych.

Przestrzeń stanowi dobro podstawowe i warunek konieczny egzystencji człowieka, dlatego też stała się przedmiotem zainteresowań wielu dyscyplin nauki. Na przykład politologia rozpatruje różne aspekty rywalizacji o przestrzeń, zwłaszcza w ujęciu konfliktowym. Przestrzeń jest przedmiotem rywalizacji konkurencyjnych ideologii - żeby tylko przywołać niesławną, hitlerowską przestrzeń życiową (niem. lebensraum) - oraz polem współczesnych konfliktów społecznych. W równym stopniu dotyczą one sporów charakterystycznych dla miast, wsi, a nawet zasobów przyrodniczych. Przestrzeń politologiczna jest w swoim charakterze bardzo terytorialna.

W ujęciu ekonomicznym przestrzeń traktować należy jako zasób o charakterze dobra podstawowego. Umożliwia on prowadzenie działalności przez człowieka w sensie społecznego gospodarowania przestrzenią. Przestrzeń ekonomiczna charakteryzuje się wysoką wartością użytkową oraz zróżnicowaną wartością wymienną. Wartość ekonomiczna podlega też fluktuacjom wraz z upływem czasu. Jaskrawo dowodzi tego przykład wywołanego w Stanach Zjednoczonych kryzysu związanego z rynkiem kredytów hipotecznych ${ }^{11}$. Na podstawie tego ostatniego czynnika przestrzeń, rozumiana jako ziemia i jej fragmenty, staje się obiektem spekulacji i rywalizacji różnych podmiotów gospodarowania. Nie jest ona, jak twierdzi David Harvey, „towarem w zwykłym tego słowa znaczeniu. Jest [...] fikcyjną formą kapitału pochodzącą z oczekiwań otrzymania przyszłej renty"12.

Kapitalizm wzmacnia napięcia wokół przestrzeni w aspekcie prawno-własnościowym. Zarówno w wymiarze formalnym: notarialno-prawnym, jak i socjoekonomicznym ${ }^{13}$. Konflikty w zakresie własności zwiększają napięcia między różnymi typami aktorów uczestniczących w kształtowaniu przestrzeni i zarządzaniu nią. Różne aspekty tych konfliktów stają się następnie obiektami refleksji politologicznej

${ }^{10}$ J.M. Chmielewski, Teoria urbanistyki w projektowaniu..., s. 11.

11 T. Sowell, The Housing Boom and Bust, Basics Books, New York 2009, s. 57-89; M. Cesarski, Mieszkalnictwo społeczne a kryzysy gospodarcze XX i XXI w., [w:] J. Osiński (red.), Wymiary kryzysu - przyczyny, przejawy, prognozy i środki zaradcze, Oficyna Wydawnicza SGH, Warszawa 2009, s. $277-296$.

12 D. Harvey, Bunt miast. Prawo do miasta i miejska rewolucja, tłum. A. Kowalczyk et al., Fundacja Bęc Zmiana, Warszawa 2012, s. 52.

${ }_{13}$ M. Thompson, Between Boundaries: From Commoning and Guerrilla Gardening to Community Land Trust Development in Liverpool, „Antipode”, vol. 47, nr 4/2015, s. 7. 
i socjologicznej. Jeszcze inne dyscypliny badają z kolei przekształcenia przestrzeni w czasie czy też jej wymiar symboliczny. Z tego punktu widzenia przestrzeń jest obiektem zainteresowania historii, antropologii czy kulturoznawstwa. Różne perspektywy pokazują różnorodność kontekstów, w jakich możliwe jest analizowanie przestrzeni. Wpływ na nią mają czynniki (1) środowiskowe odnoszące się do warunków środowiska przyrodniczego, (2) społeczne związane z zachowaniem i wzajemnymi relacjami społeczności ludzkich oraz (3) techniczne - kojarzące się z infrastrukturą towarzyszącą określonej przestrzeni. Do najważniejszych nauk podejmujących refleksję na temat przestrzeni zamieszkanej zaliczyć należy zatem te badające relacje pomiędzy jednostkami a ich otoczeniem środowiskowym (psychologię środowiskową), podmiotami zbiorowymi i społecznościami (socjologię miasta i wsi, osadnictwa czy przestrzeni) oraz aspekty techniczne i praktyczne kształtowania przestrzeni zamieszkanej (nauki o zagospodarowaniu przestrzeni: urbanistykę i ruralistykę).

Na pograniczu tych obszarów lokują się interdyscyplinarne studia miejskie, jakkolwiek ich nazwa budzi zastrzeżenia ze względu na koncentrację uwagi na raptem jednej formie osadniczej. Mimo szybkiego wzrostu miast, nie tylko w Polsce, istotną rolę odgrywają bowiem w dalszym ciągu obszary wsi. Bernd Hamm twierdzi wręcz, że współczesnego „osadnictwa nie da się już opierać na takich pojęciach jak "miasto« czy "wieś«[, ponieważ] [...] forma osadnictwa jako zmienna objaśniająca coraz bardziej traci znaczenie"14. Zgodziłby się z tą opinią Harvey, dla którego „antagonizm między miastem i wsią został w końcu przezwyciężony” ${ }^{15}$, Sławomir Gzell piszący o zanikaniu (rozpraszaniu się) miasta tradycyjnego ${ }^{16}$ czy Maciej Czerwiński opisujący urbanizację jako proces ogólnospołeczny, który „nie zatrzymuje się na rogatkach miast"17. Wieś, pisał ostatni z przywołanych tu autorów, już w pierwszej połowie lat 70. XX wieku urbanizowała się nie tylko infrastrukturalnie ze względu na nadganianie technologicznych zaległości w stosunku do ośrodków miejskich, ale i społecznie. Świadczą o tym zwłaszcza przekształcenia rynku pracy zwiększające na wsi znaczenie innych zawodów niż rolnicze ${ }^{18}$. Bardziej precyzyjną koncepcję formułuje natomiast niemiecki urbanista Thomas Sieverts. Pisze on o międzymieściu (Zwischenstadt), rozumianym jako pośrednia forma między tradycyjnie rozumianym miastem i w pełni otwartym krajobrazem ruralistycz-

${ }^{14}$ B. Hamm, Wprowadzenie do socjologii osadnictwa, tłum. A. Rosłan, Książka i Wiedza, Warszawa 1990, s. 30.

${ }^{15}$ D. Harvey, Social Justice and the City, The University of Georgia Press, Athens 2009, s. 308.

16 S. Gzell, Wykłady o wspótczesnej urbanistyce, Oficyna Wydawnicza Politechniki Warszawskiej, Warszawa 2015, s. 20-22.

17 M. Czerwiński, Życie po miejsku, Państwowy Instytut Wydawniczy, Warszawa 1974, s. 6. Zob. też L. Wirth, Urbanism as a way of life, ,The American Journal of Sociology”, nr 1/1938, s. 8-24.

18 Ibidem, s. 185-190. 
nym ${ }^{19}$. Określenie studia miejskie, choć powszechnie stosowane, nie wydaje się zatem oddawać dobrze znaczenia anglojęzycznego urban studies. Odnosi się do bardziej ogólnej kategorii urbanizacji niż samej miejskości ${ }^{20}$. Przyjrzyjmy się jednak trzem ujęciom najbardziej istotnym z punktu widzenia moich rozważań nad urbanistyką oddolną jako fundamentalnych dla studiów miejskich.

Pierwsze odnosi się do zainteresowań psychologii środowiskowej, niekiedy nazywanej również psychologią ekologiczną ${ }^{21}$. Przedmiotem jej badań są relacje człowiek - środowisko. Zachodzą one między ludźmi a zamieszkiwanym przez nich otoczeniem, na przykład miastami i dzielnicami ${ }^{22}$. Cechą ujęcia psychologii środowiskowej, jak podają Maria Lewicka i Augustyn Bańka, jest jej przenikalność z innymi dziedzinami. Wśród prekursorów, takich jak psychologowie Kurt Lewin i Edward Tolman, wymienia się również urbanistów Kevina Lyncha i Christophera Alexandra, socjologa Roberta Sommera czy antropologa Edwarda T. Halla ${ }^{23}$.

Psychologia środowiskowa bada kształt przestrzeni, ponieważ ich zaprojektowanie wpływa na zachowania jej użytkowników ${ }^{24}$. Mówić można wręcz o przestrzeniach do- i odspołecznych, czyli takich, które sprzyjają zachowaniom społecznym lub je utrudniają. Psychologia środowiskowa analizuje fizjonomię przestrzeni oraz to, w jaki sposób jej kształt wpływa na użytkowników. W jej ujęciu przestrzeń daje się zatem opisać się za pomocą zestawu zmiennych, których wartości niełatwo poddają się pomiarom i klasyfikacji. Ich głównie opisowa identyfikacja pozwala jednak wyraźnie podkreślać atuty i wady przestrzeni kluczowe dla analizy służącej waloryzacji, będącej metodą badawczą stosowaną w tej pracy. Ważną zmienną określającą charakter przestrzeni jest zwłaszcza jej zag ę szczenie. Termin ten odnosi się do liczby użytkowników, a także ich rozkładu przestrzennego. Zbyt wielkie zagęszczenie prowadzi do patologii społecznych, a jego wzrost - do zwiększania społecznej stratyfikacji oraz natężenia zachowań patologicznych. Zbiorczo zdają

19 T. Sieverts, Zwischenschadt: zwischen Ort und Welt Raum und Zeit Stadt und Land, Springer Fachmedien Wiesbaden, Wiesbaden 1998, s. 7.

${ }^{20}$ W Polsce w zakres tak rozumianych studiów miejskich własny dorobek wpisała między innymi Katarzyna Kajdanek. Autorka ta zajmuje się badaniem suburbanizacji małych miast, czyli procesu zachodzącego w oderwaniu od tradycyjnie rozumianego podziału miasto-wieś. Zob. eadem, Suburbanizacja po polsku, Zakład Wydawniczy Nomos, Kraków 2012, s. 10; eadem, 0 potrzebie końca socjologii miasta, „Przestrzeń Społeczna”, nr 2/2012, passim.

${ }^{21}$ Np. A.M. Wicker, Ecological Psychology. Historical Contexts, Current Conception, Prospective Directions, [w:] R.B. Bechtel, A. Churchman (red.), Handbook of Enviromental Psychology, John Wiley \& Sons, New York 2002, passim.

${ }^{22}$ M. Lewicka, A. Bańka, Psychologia środowiskowa, [w:] J. Strelau, D. Doliński (red.), Psychologia. Podręcznik akademicki, t. 2, Gdańskie Wydawnictwo Psychologiczne, Gdańsk 2008, s. 498.

${ }^{23}$ Ibidem, s. 499.

${ }^{24}$ H. Shaftoe, Convivial Urban Spaces. Creating Effective Publice Spaces, Earthscan, London-Sterling 2008, s. 51. 
się one według Halla opisać jako tak zwane bagno behawioralne ${ }^{25}$. Przestrzeń o niskim zagęszczeniu nie buduje harmonijnego, wspólnotowego środowiska sąsiedzkiego zdolnego do samoregulacji, natomiast jego przeludnienie prowadzi do zwiększania liczby zachowań patologicznych. Klasyfikacja ta dotyczy środowiska miejskiego.

Ze zjawiskiem zagęszczenia związana jest skala, która zdaniem Halla jest „podstawowym czynnikiem w planowaniu miast, osiedli i dzielnic mieszkalnych"26. Ten twórca proksemiki, czyli nauki o relacjach przestrzennych, opracował najbardziej znaną skalę dystansów regulujących zachowanie na podstawie poziomu emisji głosu i aktywności społecznej. Skala ta wyróżnia dystanse: intymny, indywidualny, społeczny i publiczny ${ }^{27}$. Jest kluczowym pojęciem w architekturze, zwłaszcza w kontekście rozwoju techniki budowlanej, która umożliwiła tworzenie budynków wielokondygnacyjnych. Wpływa na pobudzanie zmysłów (zwłaszcza wzroku i słuchu), w konsekwencji zaś - na rodzaj zachowania i kształtujące się w jego toku relacje społeczne. Bazując na analizach Halla, urbanista Jan Gehl wskazał na wertykalny i horyzontalny charakter skali architektonicznej oraz ich środowiskowe następstwa. Szczególnie istotna jest ta wertykalna, mająca kluczowe znaczenie dla budownictwa mieszkaniowego. Jak wykazały analizy Gehla, ludzie mieszkający powyżej piątej kondygnacji tracą kontakt audiowizualny z powierzchnią ziemi ${ }^{28}$. Czwarta kondygnacja stanowi granicę podkreślaną również przez innych autorów. Christopher Alexander ze współpracownikami podaje, iż ,istnieje wiele dowodów wskazujących, że wysokie budynki doprowadzają ludzi do szaleństwa”, a budownictwo wyższe niż czterokondygnacyjne powinno być przeznaczone wyłącznie na budynki o celach innych niż mieszkaniowe ${ }^{29}$. Przeskalowane budownictwo stało się obiektem krytyki także ze strony jednego z najlepiej prosperujących współcześnie architektów, Rema Koolhaasa. Jego zdaniem

Wielka Skala komplikuje to, co architektura odkrywa[, a] [...] [r]ozmiar sprawia, że budynki wkraczają na amoralny obszar, poza kategoriami dobra i zła. [...] Wielka Skala przestaje być częścią tkanki architektonicznej. [...] Jej podtekst to: pieprzyć kontekst ${ }^{30}$.

${ }^{25}$ E.T. Hall, op. cit., s. 242-243.

26 Ibidem, s. 239.

${ }^{27}$ Ibidem, s. 166 i nast.

${ }^{28} \mathrm{~J}$. Gehl, Miasta dla ludzi..., s. 38-42.

${ }^{29} \mathrm{~Np}$. Ch. Alexander, S. Ishikawa, M. Silverstein, M. Jacobson, I. Fiksdahl-King, S. Angel, Język wzorców. Miasta, budynki, konstrukcja, tłum. A. Kaczanowska, K. Maliszewska, M. Trzebiatowska, przekł. przejrzał i popr. oraz wstępem opatrzył J.K. Lenartowicz, Gdańskie Wydawnictwo Psychologiczne, Gdańsk 2008, s. 115-119.

${ }^{30}$ R. Koolhaas, Wielka skala, czyli problem rozmiaru, [w:] Ch. Jencks, K. Kropf (red.), Teorie i manifesty architektury współczesnej, tłum. D. Szymczak, Grupa Sztuka Architektury, Warszawa 2013, s. 345. W późniejszym przekładzie dla Wielkiej Skali używany jest anglojęzyczny pierwowzór 
Wielkoskalowe założenia nie służą w rzeczywistości żadnej istotnej funkcjonalności. Na przykład wysokie bloki utrudniają nadzór nad dziećmi bawiącymi się w podwórzu, dobrze służą natomiast założeniom monumentalnym. Z wzorca wielkiej skali chętnie korzystają zatem reżimy autorytarne i totalitarne. Charakter wielkoskalowy (horyzontalnie) miał korytarz Kancelarii Trzeciej Rzeszy projektu Alberta Speera, budynku złożonego niemal wyłącznie z monumentalnego hallu. Miał on za zadanie przytłoczyć wizytujących swoim rozmiarem tak jak równie potężny gabinet Führera ${ }^{31}$. Znanym przykładem wykorzystania przez reżim polityczny skali wertykalnej było umiejscowienie w powojennej Warszawie Pałacu Kultury i Nauki. Przez całe dekady był on absolutną dominantą wysokościową polskiej stolicy. Operowanie skalą w kształtowaniu otoczenia pozwala zatem zarówno humanizować przestrzeń i przybliżać ją użytkownikom, jak i ją dehumanizować. Jak pisał Bolesław Szmidt, człowiek to „podstawowy miernik skalarny”32. Ważną skalą horyzontalną jest też skala ruchu. Inne odczucie przestrzeni wywołuje komunikacja piesza, do której skali dostosowane jest słynne „miasto piesze”33, Wenecja. Inne z kolei - Las Vegas, które wymusza na swojej głównej arterii przemieszczanie się samochodem $^{34}$.

Obiektem zainteresowań psychologii środowiskowej jest też badanie przestrzeni zamieszkanej w wymiarze terytorialnym, co wynika z osiadłego trybu życia większości ludzi. W kontekście terytorialnym badane są aspekty: geograficzno-fizyczny i emocjonalno-społeczny. Pierwszy jest bardziej uniwersalny dla wszystkich gatunków, drugi - przyporządkowany przeważnie społecznościom ludzkim. Z pojęciem terytorialności przestrzeni wiąże się jej podział na przestrzeń publiczną i prywatną oraz jej warianty pośrednie ${ }^{35}$.

Bigness. Idem, Śmieciowa przestrzeń, tłum. M. Wawrzyńczak, Centrum Architektury, Warszawa 2017, s. 50.

31 Zdaniem Dejana Sudjica założenie to było wyjątkowo skuteczne i prawdopodobnie odegrało istotną rolę w skruszeniu oporu czechosłowackiego prezydenta, Emila Háchy, przy okazji negocjacji toczonych przezeń z Adolfem Hitlerem na chwilę przed podbiciem tego środkowoeuropejskiego państwa przez III Rzeszę. Zob. D. Sudjic, Kompleks gmachu. Architektura władzy, tłum. A. Rasmus-Zgorzelska, Centrum Architektury, Warszawa 2015, s. 34-38.

32 B. Szmidt, Ład przestrzeni, Państwowy Instytut Wydawniczy, Warszawa 1981, s. 56. Zgodziłby się z nim Le Corbusier, który opracował własny model uniwersalnego użytkownika przestrzeni, Modulora, stanowiącego odpowiedź „papieża modernizmu” na klasycznego Człowieka Witruwiańskiego. Wysokość wyciągniętej ręki Modulora (226 centymetrów) stanowi wysokość mniejszych pokoi dziennych Jednostki Marsylskiej. Zob. S.E. Rasmussen, Odczuwanie architektury, tłum. B. Gadomska, Wydawnictwo Murator, Warszawa 1999, s. 116-118.

33 J. Gehl, Życie między budynkami. Użytkowanie przestrzeni publicznych, tłum. M.A. Urbańska, Wydawnictwo RAM, Kraków 2013, s. 109-110.

${ }^{34}$ R. Venturi, D. Scott-Brown, S. Izenour, Uczyć się od Las Vegas. Zapomniana symbolika formy architektonicznej, tłum. A. Porębska, Karakter, Kraków 2013, passim.

${ }^{35}$ M. Lewicka, A. Bańka, op. cit., s. 516-518. 
Drugą, po psychologii środowiskowej, kluczową z punktu widzenia moich rozważań perspektywą jest ta przynależna socjologii. Przestrzeń jest bowiem nie tylko genetycznym tworem materii fizycznej - środowiskiem i miejscem - oddziałującym psychologicznie na człowieka. Jest również „tworem ludzkim, antropogenicznym, kulturowym i społecznym, a więc wytworzonym przez jednostki, grupy i zbiorowości ludzkie (społeczna, kulturowa)"36. Przestrzeń, jak wskazują przedstawiciele socjologii miasta, jest wytwarzana społecznie, to znaczy różne podmioty społeczne uczestniczą w jej kreowaniu ${ }^{37}$.

Powstawanie przestrzeni w ramach procesu społecznego wytwarzania odbywa się zarówno w sposób czynny, jak i przez zaniechanie, prowadzące często do degradacji i dewitalizacji przestrzeni. Barierami w tworzeniu są wpływ środowiska przyrodniczego, rozwój techniki i technologii (sił wytwórczych) oraz stosunki panowania i podległości (własność, władza, ideologia) ${ }^{38}$. Tak rozumianą przestrzeń określić można jako społeczną, czyli stanowiącą miejsce zachodzenia relacji i reakcji społecznych. Aleksander Wallis pisał o podziale miasta na dwa autonomiczne, choć powiązane ze sobą podsystemy, obok społecznego wskazując na urbanistyczny. Ten drugi rozumiał jako

całokształt materialnych elementów miasta stworzonych przez człowieka, jak i elementów naturalnych, które składają się na jego strukturę przestrzenną. Podsystem społeczny to [z kolei] zbiorowość użytkowników miasta, których podstawową strukturę tworzą jego mieszkańcy. Każdy z podsystemów ma skomplikowaną budowę i strukturę, co prowadzi do znacznej złożoności ich wzajemnych relacji. Pierwszy podsystem będziemy niekiedy nazywali w skrócie „miasto”, drugi zaś - „społeczeństwo” ${ }^{39}$.

Do tego podziału nawiązał Hubert Izdebski. Łączy on ujęcie Wallisa z rzymskim dualizmem urbs - organizmu w sensie materialnym czy też dosłownie miasta za murami lub wałami, oraz civitas - miasta społeczności, z jakim można kojarzyć też pojęcie polis ${ }^{40}$. Podsystemy urbanistyczny i społeczny stają się zdaniem Wallisa podstawami dwóch procesów związanych z doświadczaniem miasta. Przebiegają na poziomie jednostki, małej grupy i wielkiej zbiorowości. Dotyczą poznawania i wartościowania poszczególnych przestrzeni miasta, wśród których

${ }^{36}$ B. Jałowiecki, Społeczne wytwarzanie przestrzeni..., s. 19.

${ }^{37}$ M. Gottdiener, The Social Production of Urban Space, University of Texas Press, Austin 1997, passim.

38 B. Jałowiecki, Społeczne wytwarzanie przestrzeni..., s. 39-41.

${ }^{39}$ A. Wallis, Socjologia przestrzeni, oprac. E. Grabska-Wallis, M. Oficerska, Niezależna Oficyna Wydawnicza, Warszawa 1990, s. 45.

${ }^{40} \mathrm{H}$. Izdebski, Ideologia i zagospodarowanie przestrzeni. Doktrynalne prawno-polityczne uwarunkowania urbanistyki i architektury, Wolters Kluwer Polska, Warszawa 2013, s. 22-23. 
wartościowanie [...] jest podstawą zachowań homeostatycznych całego systemu. Regulują one spontaniczne przestrzenne zachowania jednostek, rodzin i małych grup w zależności od stanu obu podsystemów, ich wzajemnej relacji, nieraz również w zależności od działania czynników zewnętrznych (na przykład zagrożenie systemu) ${ }^{41}$.

Przestrzeń społeczna do pewnego stopnia przenika tę urbanistyczną i nie jest tylko bierną ramą dla wydarzeń świata społecznego. Co więcej, stosunki przestrzenne mogą, jak podaje Harvey, kreować „moment procesu społecznego”42.

Ograniczoność przestrzeni w sensie fizycznym oraz naruszanie ekologicznej równowagi implikuje rosnącą liczbę konfliktów między jej użytkownikami. Jak zauważają urbaniści Yusnani Mohd Yusof i Marek Kozlowski ${ }^{43}$, występujący w przestrzeni interesariusze (stake-holders) i konsumenci (clients) dzielą się na różne grupy o odmiennych, często sprzecznych interesach. Finalni użytkownicy, czyli przede wszystkim mieszkańcy i państwo, są zainteresowani jej długoterminowym, pomyślnym rozwojem. Celem użytkowników początkowych, do których zaliczyć można planistów i deweloperów, jest użytkowanie krótkoterminowe. Zwłaszcza w przypadku deweloperów ma ono na celu uzyskanie jak największej wartości wymiennej, a zatem maksymalizację zysku ${ }^{44}$. Dostrzeżenie tej różnicy interesów także i mi wydaje się szczególnie istotne w kontekście prowadzenia wszelkich analiz środowiska zurbanizowanego.

Wśród procesów mających związek z użytkowaniem przestrzeni społecznej wymienić należy jej zamieszkiwanie, nadawanie znaczeń (symbolizację), kształtowanie i strukturalizację. Przestrzeń w wymiarze społecznym jest więc przestrzenią osadniczą, zamieszkaną, obrazującą społeczne dystanse i podziały klasowe. Rozumiana w tym wymiarze jest także przestrzenią ekologiczną, by posłużyć się określeniem charakterystycznym dla ekologii społecznej, nurtu w socjologii miasta zainspirowanego przez tak zwaną szkołę chicagowską ${ }^{45}$. Badania nad ekologią

${ }^{41}$ A. Wallis, Socjologia przestrzeni..., s. 47.

42 D. Harvey, Przestrzenie globalnego kapitalizmu. W stronę teorii rozwoju nierównego geograficznie, tłum. J.P. Listwan, Instytut Wydawniczy Książka i Prasa, Warszawa 2016, s. 112. Podobne uwagi H. Lefebvre, The Production of Space, Blackwell, Oxford 1991, s. 11.

${ }^{43}$ Y.M. Yusof, M. Kozlowski, Clients of Contemporary Urban Design. The Impact of Neoliberalism, [w:] K. Nawratek B. Huggins, M. Oxley, A. Horton-Howe (red.), Radical Inclusivity. Architecture and Urbanism, dpr-barcelona, Barcelona 2015, s. 82-103.

${ }^{44}$ Przykładu skrajnego dostarcza w tej materii kwestia samego ubóstwa, które bywa potencjalnym źródłem zysku dla niektórych aktorów rynku mieszkaniowego. Czerpią oni nieproporcjonalne korzyści z programów rewitalizacyjnych czy polityki publicznej prowadzonej z wykorzystaniem partnerstwa publiczno-prywatnego. Zob. M. Desmond, Evicted. Poverty and Profit in the American City, Crown Publishers, New York 2016, passim.

45 R.D. McKenzie, The Ecological Approach to the Study of the Human Community, [w:] R.E. Park, W. Burgess (red.), The City. Suggestions for Investigation of Human Behavior in the Urban Environment, 
przestrzeni doprowadziły do wyróżnienia układu stref koncentrycznych miasta. O ile dokładne podziały i charakterystyki zaproponowane przez reprezentantów szkoły chicagowskiej poddawano krytyce, o tyle sama strukturalizacja przestrzeni, czytelna zwłaszcza na obszarze miast, we współczesnych analizach ma status aksjomatu. Dość powszechnie wyróżnia się takie obszary, jak centrum, peryferia (suburbia), obszary pośrednie, dzielnice biznesowe, dzielnice rozrywki, sypialnie miejskie i inne typy przestrzeni o odmiennych sposobach użytkowania oraz wiążących się z nimi reprezentacjami statusów społeczno-ekonomicznych. Swoistą apoteozę strukturalizacji przestrzeni stanowiła idea urbanistyki modernistycznej. Wskazywała ona na potrzebę separacji odmiennych typów użytkowania w ramach strefowania przestrzeni miejskiej na ośrodki: usługowy, przemysłowy i mieszkaniowy. Podział ten, będący jedną z reakcji na żywiołowy rozwój wczesnokapitalistycznych miast, doprowadzał do nasilenia procesów segregacyjnych oraz ograniczenia witalności życia społecznego na wielu obszarach miasta. Z czasem stawał się przez to obiektem krytyki coraz większej liczby autorów ${ }^{46}$. W wariancie skrajnym segregacja przestrzenna prowadzi do gettoizacji, chociaż nie jest to związane wyłącznie z dziedzictwem modernizmu ${ }^{47}$.

W wyniku działalności człowieka przestrzeń zostaje poddana przekształceniom, począwszy od stanu pierwotnego, przechodzi się w środowisko zamieszkane, potem zurbanizowane. Produkt najbardziej zaawansowanego, społecznego wytwarzania stanowi miasto, najbardziej skomplikowany rodzaj organizacji ludności. Wytworzenie miasta nie jest jednak etapem finalnym. Jednym z wymiarów przestrzeni jest wszakże czas nieposiadający wyraźnego horyzontu granicznego. Taki charakter ma też miasto poddawane kolejnym przekształceniom. Włącznie z dezurbanizacją czy deindustrializacją, której wyraz stanowi wyraźnie obecny już w ubiegłym stuleciu proces suburbanizacji. Współcześnie coraz częściej zderza się on z procesami reurbanizacji i kluczową dla nich gentryfikacją, do której powrócę w dalszej części rozważań ${ }^{48}$.

Trzecią, po opisanych uprzednio socjologii i psychologii środowiskowej, szczególnie istotną perspektywą badawczą dla przestrzeni zdaje się refleksja charak-

The University of Chicago Press, Chicago-London 1984, s. 63-79; Z. Pióro, Główne nurty ekologii społecznej, [w:] idem (red.), Przestrzeń i społeczeństwo. Z badań ekologii społecznej, Książka i Wiedza, Warszawa 1982, s. 7-20; B. Jałowiecki, M.S. Szczepański, Miasto i przestrzeń w perspektywie socjologicznej, Wydawnictwo Naukowe Scholar, Warszawa 2002, s. 16-17.

${ }^{46}$ Np. J. Jacobs, Śmierć i życie wielkich miast Ameryki, tłum. Ł. Mojsak, Centrum Architektury, Warszawa 2014, s. 173-176.

47 B. Jałowiecki, Fragmentacja i prywatyzacja przestrzeni, [w:] B. Jałowiecki, W. Łukowski (red.), Gettoizacja polskiej przestrzeni miejskiej, SWPS Academica, Wydawnictwo Naukowe Scholar, Warszawa 2007, passim.

48 R. Atkinson, G. Bridge, Introduction, [w:] eidem (red.), Gentrification in a Global Context, Routledge, London-New York 2005, s. 3-6. 
terystyczna dla urbanistyki. Ta ostatnia jest dyscypliną techniczną, korzystającą z dorobku innych podejść związanych z badaniem i kształtowaniem przestrzeni. Mieszczą się w tym zakresie po pierwsze nauki techniczne, odpowiedzialne za bezpośrednie kształtowanie namacalnej przestrzeni fizycznej. Na przykład architektura, w obszarze której wyróżnić można budownictwo, ale i architekturę krajobrazu. Po drugie są to też nauki społeczne i humanistyczne, których celem jest badanie relacji między jednostkami i grupami społecznymi zamieszkującymi określoną przestrzeń. Termin urbanistyka odnosi się do kształtowania przestrzeni miast. Dziedziną pokrewną, odpowiedzialną za kształtowanie przestrzeni wiejskiej, jest ruralistyka. Zarówno urbanistykę, jak i ruralistykę przyporządkować można do dyscypliny nadrzędnej, jaką jest planowanie przestrzenne, wchodzące w zakres jeszcze szerzej rozumianej gospodarki przestrzennej ${ }^{49}$.

Rolę nauk o zagospodarowaniu przestrzeni stanowi planowanie rozmieszczania całych układów przestrzennych o różnej skali, które za Kazimierzem Wejchertem podzielić można na stopniowalne zespoły. Wejchert wskazuje w tym kontekście w pierwszej kolejności na te architektoniczne, czyli grupy budynków położonych w niewielkiej odległości, czytelnie wydzielone w przestrzeni - na przykład rynek miasta z otaczającymi go budynkami. Po drugie - zespoły urbanistyczne, tworzone przez kilka zespołów architektonicznych, wydzielone topograficznie lub krajobrazowo, takie jak niewielkie miasteczko, wieś czy osiedle. Po trzecie - zespoły krajobrazowe, czego emanacją jest „fragment krajobrazu dobrze widoczny z określonego punktu i posiadający elementy ograniczające spojrzenie, jak góry, wzgórza, wysokie drzewa, grupy zabudowań”, wyraźnie odróżnialny od środowisk sąsiednich, taki jak dolina czy założenie parkowe. Po czwarte, wreszcie, zespoły przestrzenne, takie jak „zbiorowisko zespołów urbanistycznych lub - najczęściej - urbanistycznych i krajobrazowych" ${ }^{50}$. Przykładem zespołu tego rodzaju jest miasto jako całość.

Urbaniści i architekci od dawna interesowali się kształtowaniem układów osadniczych, opracowując koncepcje nieraz bardzo radykalne. Wśród nich wymienić można takie jak - niezrealizowane z wyjątkiem krótkiego odcinka eksperymentalnego pod Madrytem - miasto linearne projektu hiszpańskiego urbanisty Artura Sorii y Maty ${ }^{51}$ czy jego późniejsza wariacja, koncepcja linearnego systemu

49 Ł. Drozda, Zagospodarowanie przestrzeni i jego znaczenie dla polityki publicznej, [w:] J. Luszniewicz, K. Obłąkowska-Kubiak (red.), Polityka publiczna - doświadczenia i wyzwania, Oficyna Wydawnicza SGH, Warszawa 2018, passim.

${ }^{50}$ K. Wejchert, Elementy kompozycji urbanistycznej, Warszawa, Arkady 1984, s. 23-25.

${ }^{51}$ Plany Ciudad lineal obejmowały ogromne odcinki „od Kadyksu do Petersburga i Kopenhagi do Neapolu”. Zob. J. Rykwert, Pokusa miejsca. Przeszłość i przyszłość miast, tłum. T. Bieroń, Międzynarodowe Centrum Kultury, Kraków 2013, s. 38. 
ciągłego Oskara Hansena. Zakładała ona utworzenie na obszarze Polski układu pasmowego obszarów zurbanizowanych wokół sieci rzek ${ }^{52}$. Na bardziej lokalnym i przez to mniej abstrakcyjnym poziomie planiści decydują o przestrzennym rozkładzie takich elementów, jak układ drogowy, rozmieszczenie budynków, elementów infrastruktury szarej (technicznej), zielonej (roślinności), społecznej czy małej architektury.

Elementy te wpływają na tworzenie odpowiednich wnętrz urbanistycznych. Są to relatywnie zamknięte (przede wszystkim widokowo), dające się identyfikować jako całość układy przestrzenne. Najbardziej spójne wnętrza uchodzą w opinii urbanistów za również najbardziej wartościowe. Spójność przestrzeni określana jest za pomocą jej czytelności, czyli możliwości identyfikowania elementów składowych. Zdaniem Lyncha ${ }^{53}$ elementami takimi są: wpływające na ułożenie elementów środowiskowych drogi (1); linearne przerwy w ciągłości poszczególnych elementów - krawędzie (2); strategiczne punkty miasta o charakterze punktowym, koncentrujące natężenie pewnych elementów węzły (3); dające się zidentyfikować obszary miasta cechujące się indywidualnymi cechami - rejo ny (4); oraz punkty orienta cyjne - punkty odniesienia, które obserwator widzi jedynie jako zewnętrze (5). Podobnie identyfikuje elementy przestrzeni Wejchert ${ }^{54}$. Wymienia on elementy krystalizujące miasta, drogi, rejony, linie i pasma graniczne, dominanty układu przestrzennego, wybitne elementy krajobrazu, punkty węzłowe i znaki szczególne. Typologię tego ostatniego odróżnia przede wszystkim większe rozróżnienie kategorii opisywanych przez Lyncha jako węzły i punkty orientacyjne ${ }^{55}$.

Z urbanistycznego punktu widzenia możliwe jest określenie kilku głównych typów przestrzeni ze względu na charakter użytkowania. Większość badaczy jest zgodna, wyróżniając przestrzeń publiczną, prywatną oraz stanowiące stadia pośrednie przestrzenie półpubliczną lub półprywatną. Niektórzy autorzy wskazują tylko jedną z dwóch ostatnich, jako kategorię opozycyjną względem wyraźnie zarysowanych przestrzeni publicznej i prywatnej, czyli tak zwaną prze-

52 F. Springer, Zaczyn. O Zofii i Oskarze Hansenach, Karakter, Muzeum Sztuki Nowoczesnej w Warszawie, Kraków-Warszawa 2013, s. 152.

${ }^{53}$ K. Lynch, Obraz miasta, tłum. T. Jeleński, Archivolta Michał Stępień, Kraków 2011, s. 54-98.

${ }^{54} \mathrm{~K}$. Wejchert, op. cit., s. 50-73.

55 Inną typologię urbanistyczną zaproponował Bolesław Malisz. Zob. idem, Gospodarka i polityka przestrzenna, [w:] J. Regulski (red.), Planowanie przestrzenne, Polskie Wydawnictwo Ekonomiczne, Warszawa 1985, s. 76-82. Strukturalizację układów przestrzennych stosują też architekci krajobrazu. Zob. B.J. Gawryszewska, Language of borders in the structure of everyday landscape, [w:] J. Plit, V. Andreychouk (red.), Methods of Landscape Research, Commision of Cultural Research of Polish Geographical Society, Sosnowiec 2008. 
strzeń sąsiedzką ${ }^{56}$. Podział przestrzenny tego rodzaju cechuje się różnym poziomem czytelności w zależności od opisywanej przestrzeni. Niektóre miejsca, jak harmonijnie zaplanowane osiedla mieszkaniowe powstałe w formie budownictwa małoskalowego, kreują sieć przestrzeni sąsiedzkich: przedsionków, półzamkniętych dziedzińców i wspólnych przestrzeni publicznych zorganizowanych na przykład wokół lokalnego ośrodka oświaty. Wskazuje to tym samym na wyraźną stopniowalność wyżej opisanych typów. Nie zawsze jednak udaje się je wyodrębnić. Albowiem, jak zauważa Gehl,

[s]kala pomiędzy tym, co publiczne, a tym, co prywatne może też być [...] znacznie mniej zdefiniowana, jak w przypadku wielokondygnacyjnych budynków mieszkalnych czy domu jednorodzinnego w niezdefiniowanej strukturze miejskiej. W wielu takich przypadkach nie istnieje niemal żaden grunt pośredni czy przejście pomiędzy terytorium prywatnym a bardzo publicznym ${ }^{57}$.

W opinii przywołanego autora czytelność struktury przestrzennej umożliwiająca wyraźną identyfikację tych typów przestrzeni jest kluczowa dla kształtowania się lokalnego życia społecznego. Dające się wyróżnić strefy przejścia umożliwiają wykształcanie sąsiedzkich wspólnot pozwalających na budowanie kapitału społecznego, bezpieczeństwa, szeroko rozumianej harmonii i spójności społecznej. Jednocześnie jednak muszą być do pewnego stopnia inkluzywne, aby nie wpływały na zupełną alienację od świata zewnętrznego, zarówno ze względów społecznych, jak i praktycznych. Gehl podaje w tym kontekście przykład kontaktu wizualnego. Ułatwia on dziecku, jako użytkownikowi przestrzeni, uzyskiwanie informacji na temat tego, czy rówieśnicy znajdują się na pobliskim placu zabaw ${ }^{58}$.

Takiego warunku z pewnością nie spełniają szczególnie często obecne w Polsce osiedla grodzone, kreujące zupełną separację w przestrzeni59 ${ }^{59}$ Innym przykładem są cechujące się brakiem wariantów pośrednich między przestrzenią publiczną i prywatną wytwory budownictwa wielkoskalowego, takie jak blokowiska konstruowane w okresie Polski Ludowej, zwłaszcza w stylu (soc)modernistycznym. Pierwotne założenie budownictwa tego rodzaju stanowiło rozrzedzenie zabudowy pod kątem większego skupienia ludności w budownictwie wysokościowym.

56 Szeroki przegląd typów przestrzeni można znaleźć w artykule: K. Kmicic, Struktura przestrzeni osiedli mieszkaniowych jako podstawa kształtowania ich zagospodarowania przestrzennego - wybrane koncepcje podziału przestrzeni osiedlowych, [w:] B. Szulczewska, R. Giedych (red.), Przestrzeń przyrodnicza i społeczna osiedli mieszkaniowych w XX i XXI wieku, Wydawnictwo SGGW, Warszawa 2011, s. 93-100. Zob. też O. Newman, Creating Defensible Space, U.S. Department of Housing and Urban Development Office of Policy Development and Research, Washington 1996, s. 14-19.

${ }^{57}$ J. Gehl, Życie między budynkami..., s. 59.

58 Ibidem, s. 61.

${ }^{59}$ J. Gądecki, Za murami. Osiedla..., passim. 
Wielkoskalowe założenia przyczyniły się wprawdzie do zwiększenia liczby przestrzeni publicznych, dając możliwość organizowania szeroko zakrojonych zielonych przestrzeni rekreacyjnych ${ }^{60}$, były one jednak pozbawione nawet ograniczonej intymności i przeznaczone dla tak licznych grup, że relacje sąsiedzkie w ich obrębie nawiązywano z dużym trudem lub wcale. Opozycję dla modernizmu stanowią pod tym względem takie prądy jak nowy urbanizm, którego nadrzędnym celem jest kreowanie lokalnej wspólnoty sąsiedzkiej ${ }^{61}$.

Ważnym zadaniem urbanistyki jest planowanie przestrzeni, oparte na rozkładzie różnych typów jej użytkowania. Obszarem zainteresowań urbanistów jest w związku z tym wymiarowanie przestrzeni ze względu na dobór jej właściwej skali. Do kluczowego arsenału decyzji planistów należy sposób alokacji sfer: usługowej, oświatowej, administracyjnej i rekreacyjnej. Wszystkie te typy użytkowania sprzyjają kreowaniu odmiennych rodzajów kontaktów między użytkownikami przestrzeni i wiążą się z codziennymi czynnościami w różnym stopniu wypełniającymi życie poszczególnych grup: dzieci, ich rodziców, osób aktywnych zawodowo czy seniorów. Skuteczne wymiarowanie przestrzeni czerpie z dokonań psychologii środowiskowej, czemu sprzyja na przykład analizowanie właściwości lokalnej komunikacji pieszej. Powszechnie uważa się, że przestrzenie sprzyjające integracji społecznej opierają się na założeniach o mniejszej skali, umożliwiającej komfortowy dostęp pieszy do lokalnego sklepu spożywczego, szkoły, placu zabaw czy ośrodka zdrowia. W sytuacji, w której organizacja przestrzeni wymaga dalekich dojazdów, zwłaszcza samochodami prywatnymi, kontakty między ludźmi są rzadsze, płytsze albo nie występują wcale. Przestrzenie pozbawione relacji sąsiedzkich nie wykształcają użytkowników zainteresowanych dbaniem o ich estetykę czy bezpieczeństwo. Można to zaobserwować w klasycznym przykładzie ulicy opisywanej przez Jane Jacobs. Lokalni sklepikarze, restauratorzy i mieszkańcy niewysokich domów, posiadających wyraźny audiowizualny kontakt z życiem ulicznym, dbali w jej

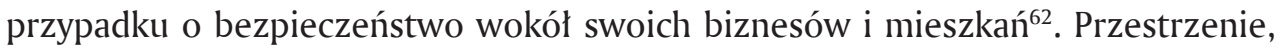
które są pozbawione wymiarowania w niewielkiej skali oraz komunikacji pieszej, stają się podobne do miasta neoliberalnego. Sprzyja ono anonimowości i segregacji społecznej. Wypełniają je zdehumanizowane oddziały punktów usługowych

${ }^{60}$ Le Corbusier, $W$ stronę architektury, tłum. T. Swoboda, Centrum Architektury, Warszawa 2012, s. 106-108. Le Corbusier, uważany za najważniejszego twórcę i teoretyka stylu modernistycznego i nieformalnego przywódcę Międzynarodowego Kongresu Architektury Nowoczesnej (Congrès international d'architecture moderne, CIAM), zwracał też w tym samym miejscu uwagę na znaczenie budownictwa wielkoskalowego dla względów higienicznych, dzięki poprawie jakości powietrza na obszarach zurbanizowanych.

${ }^{61}$ Np. L. Krier, Architektura wspólnoty, tłum. P. Choynowski, słowo/obraz terytoria, Gdańsk 2011, passim.

${ }^{62}$ J. Jacobs, Śmierć i życie wielkich..., s. 47-153. 
transnarodowych korporacji, sklepy franczyzowe czy rozwijające się dynamicznie usługi ochroniarskie ${ }^{63}$. Zaczynają tym samym przypominać opisane przez Marca Augé przestrzenie tranzytu, „nie-miejsca”, cechujące się niemal wyłącznie bezosobowymi relacjami ich sporadycznych użytkowników ${ }^{64}$.

Warto w tym miejscu wspomnieć również o domenach terytorialnych, konstytuujących się w procesie zamieszkiwania poprzez oddolne zagospodarowywanie przestrzeni miejskich w postaci rozmaitych form ogrodnictwa miejskiego. Badania tej sfery lokują się bowiem na pograniczu analiz z zakresu urbanistyki i architektury krajobrazu. W przypadku osiedli mieszkaniowych chodzi tu o ogródki podokienne i kształtowanie przestrzeni wspólnych z użyciem form ogrodowych, w skali miasta - ogrody społecznościowe i rodzinne ogrody działkowe, a także oddolne zagospodarowywanie miejskich nieużytków ${ }^{65}$.

\subsubsection{Przestrzeń a polityka publiczna}

Przestrzeń jest też przedmiotem silnego oddziaływania różnych wymiarów życia politycznego. W anglosaskiej terminologii nauk politycznych istnieje rozróżnienie między trzema znaczeniami, którym w języku polskim przyporządkowany jest wyłącznie jeden odpowiednik. Są to politics, polity oraz policy ${ }^{66}$. Politics to najczęściej kojarzone znaczenie potoczne, czyli polityka rozumiana jako rywalizacja oraz podejmowanie decyzji warunkujących ponoszenie kosztu politycznego. Rozumieć należy przez to utratę poparcia dla polityka podejmującego niepopularną, ale w jego przekonaniu konieczną decyzję. Polity określa porządek polityczny, co w polskich naukach o polityce opisuje się przeważnie jako ład bądź reżim - jest to pojęcie ustrojowe. Trzeci wariant to natomiast policy, czyli termin odnoszący się do efektów i kierunków politycznych decyzji. Odpowiada on znaczeniowo dziedzinie określanej w naukach społecznych jako polityka publiczna. Szczególnie wyraźna jest różnica właśnie między pierwszym i trzecim z wymiarów polityki. Prekursor nauk o polityce publicznej Harold Lasswell pisał, że

słowo policy jest powszechnie używane dla określenia najważniejszych decyzji podejmowanych zarówno w zbiorowym, jak i prywatnym życiu. Mówimy o „rządowej policy”, „biznesowej policy” albo „mojej własnej policy” odnośnie do inwestycji i innych spraw. Stąd policy

${ }^{63}$ S. Graham, Cities Under Siege. The New Military Urbanism, Verso, London-New York 2011, ebook.

${ }^{64}$ M. Augé, op. cit., s. 20.

${ }^{65}$ R. Nejman, M. Łepkowski, A. Wilczyńska, B.J. Gawryszewska, The right to wild. Green urban wasteland in the context of urban planning planning, „Urban Development Issues”, nr 3/2018, passim.

${ }^{66}$ K. von Beyme, Współczesne teorie polityczne, tłum. J. Łoziński, Wydawnictwo Naukowe Scholar, Warszawa 2010, s. 137-138. 
jest wolne od wielu niepożądanych znaczeń skupionych wokół wyrazu polityczny [political], który, jak się często wierzy, implikować ma „politykierstwo” [partisanship] lub „korupcję”67.

Wedle Jerzego Woźnickiego polityka publiczna stanowi „zbiór procesów, których realizację podejmuje administracja w ramach swej misji zaspokajania potrzeb publicznych”. Są to tym samym

podejmowane przez władzę publiczną powiązan[e] ze sobą decyzj[e] i działa[nia prowadzone] dla osiągnięcia określonych celów, w sytuacji gdy mechanizmy rynkowe nie mają zastosowania albo same nie mogłyby działać dostatecznie efektywnie.

Te decyzje i działania realizowane są zaś „przede wszystkim przez podmioty publiczne, rzadziej przez prywatne i pozarządowe, a także obejmuj[ą] to, czego władza publiczna postanawia nie realizować". Mówimy w tym miejscu oczywiście o praktyce stanowienia polityki publicznej (policy making), a nie dyscyplinie naukowej opartej na studiach teoretycznych prowadzonych nad tym zagadnieniem ${ }^{68}$. Po lityka miejska, zgodnie z typologią zaproponowaną przez Woźnickiego, stanowi jednakże również jedną ze specjalności (subdyscyplin) polityki gospodarczej rozumianej jako taka właśnie dyscyplina. W obrębie zainteresowań tej ostatniej znajdują się również inne publiczne polityki szczegółowe, dotykające między innymi transportu, rozwoju regionalnego i gospodarki przestrzennej ${ }^{69}$. Częścią polityki miejskiej jest też jej monitoring i ewaluacja efektywności. W zakresie tej polityki mieści się ponadto tematyka waloryzacji przestrzeni zurbanizowanej. Analizy dotyczące jej przekształceń dają się łatwo powiązać z optyką polityki publicznej ${ }^{70}$. Badania prowadzone w obszarze tej dyscypliny koncentrują się zarówno na aktorach, jak i instrumentach działania publicznego. Konfrontują też ich zamierzone cele (nie zawsze mające zresztą charakter jawny) z wynikami. Refleksja nad wpływem urbanistyki oddolnej na przestrzeń miejską jest zatem na dobrą sprawę pytaniem o wpływ polityki miejskiej rozumianej jako wycinek złożonej polityki publicznej.

W wyniku powojennego kryzysu legitymizacji, a także porażki wielu scentralizowanych reżimów politycznych, w wielu państwach rozpoczęto proces prze-

${ }^{67}$ H.D. Lasswell, The Policy Orientation, [w:] S. Braman (red.), Communication Researchers and Policy-making, The MIT Press, Cambridge 2003, s. 88.

${ }^{68}$ Odróżniać można na przykład nauki o polityce publicznej (teoria) od nauk dla polityki publicznej (praktyka). B.W. Hogwood, L.A. Gunn, Policy Analysis for the Real World, Oxford University Press, Oxford 1984, s. 29. Cyt. za: R. Szarfenberg, Miejsce polityki społecznej w polityce publicznejkontekst europejski, krajowy i lokalny, Mazowieckie Centrum Polityki Społecznej, Warszawa 2013, s. 36 .

${ }^{69} \mathrm{~J}$. Woźnicki, Nowa dyscyplina - „nauki o polityce publicznej” usytuowana $w$ dziedzinie nauk spotecznych, „Nauka”, nr 1/2012, s. 133-134, 143.

${ }^{70}$ W. Anioł, Kształtowanie przestrzeni miejskiej jako mikrokosmos polityki publicznej. Przypadek Warszawy, „Studia z Polityki Publicznej”, nr 2/2016, s. 14-15. 
kształceń systemu politycznego. Od tej pory miał być on oparty na stopniowej demokratyzacji procesu sprawowania władzy. W okresie tym poparcie uzyskały rozwiązania służące decentralizacji, czyli delegowaniu większej liczby zadań na szczebel samorządu terytorialnego ${ }^{71}$. Podobny wymiar miała także polska transformacja. W jej wyniku nastąpiła pluralizacja sfery publicznej, a przebudowie uległ nie tylko najczęściej kojarzony z tymi przemianami ustrój gospodarczy, ale i kościec administracji państwa. W 1990 roku odtworzono samorząd terytorialny wybierany w bezpośrednich wyborach powszechnych ${ }^{72}$. Jak podaje Paweł Swianiewicz, druga połowa XX wieku wiązała się z historyczną dekoncentracją władzy politycznej w wielu państwach Zachodu. Opierała się na zmianach w politycznych systemach wyborczych, zmianach terytorialnych (fragmentacja jednostek samorządu terytorialnego), modyfikacjach funkcjonalnych właściwych przekazywaniu większej liczby zadań instytucjom samorządowym oraz w zarządzaniu samym samorządem ${ }^{73}$. Proces ten można powiązać z tak zwaną trzecią falą demokratyzacji. Ta koncepcja autorstwa Samuela Huntingtona opisuje proces masowej demokratyzacji wielu państw, rozpoczęty symbolicznie rewolucją goździków w Portugalii w 1974 roku. Objął on także późniejszy upadek realnego socjalizmu w bloku skupionym wokół Związku Radzieckiego ${ }^{74}$.

Przełom XX i XXI wieku można z kolei określić już jako czas wzmocnienia lokalnego szczebla administracji. To zarazem okres przekierowania jego działalności z politics na rzecz policy - procesu decyzyjnego mającego na celu pragmatyczne zarządzanie społecznością lokalną. Jeszcze jednym jego aspektem jest większa inkluzja obywateli oraz częste dążenie do odchudzania aparatu administracyjnego, delegowania zadań na aktorów prywatnych i urynkowienia ${ }^{75}$. Decentralizacja w tym ujęciu spotyka się zarówno z opiniami krytycznymi, wskazującymi na niedostateczny stopień implementacji mechanizmów partycypacji obywatelskiej w zarządzaniu lokalnym $^{76}$, jak i entuzjazmem swoistych utopistów paradygmatu nowego zarządzania publicznego (new public management) czy też nieco nowszego zarządzania lokalnego (local governance). Przez ten ostatni termin należy rozumieć elastyczny proces decyzyjny oparty na luźnych powiązaniach poziomych między

${ }^{71}$ P. Swianiewicz, Nowe interpretacje teoretyczne polityki miejskiej, „Studia Regionalne i Lokalne", nr 4/2005, s. 6-8.

${ }^{72}$ A. Dudek, Historia polityczna Polski 1989-2012, Znak, Kraków 2013, ebook.

${ }^{73}$ P. Swianiewicz, op. cit., s. 6-8.

${ }^{74}$ S. Huntington, Trzecia fala demokratyzacji, tłum. A. Dziurdzik, Wydawnictwo Naukowe PWN, Warszawa 1995, s. 31.

75 P. Swianiewicz, op. cit., s. 9-11; D. Harvey, From Managerialism to Entrepreneurialism: The Transformation in Urban Governance in Late Capitalism, „Geografiska Annaler”, vol. 71, nr 1/1989, passim.

${ }^{76}$ Y.M. Yusof, M. Kozlowski, op. cit., s. 102. 
aktorami publicznymi i niepublicznymi. Jeszcze inni autorzy piszą z kolei o potrzebie przejścia do nowego paradygmatu responsive governance. Jego efektywność zapewniać ma już nie urynkowienie, lecz zwiększenie demokratycznego wymiaru opartego na partycypacji obywatelskiej ${ }^{77}$.

Pojęcie polityki miejskiej (urban policy) jest związane z upowszechnieniem się zarządzania lokalnego jako zastępującego klasyczny model samorządu (local government). Różnice między nimi opisuje Peter John. Pierwszy system opisuje on jako zhierarchizowany, zamknięty, zrutynizowany i oparty na modelu przywództwa czerpiącego z klientelizmu. System drugi służyć ma natomiast decentralizacji i fragmentacji struktury biurokratycznej, wzmacnianiu jej innowacyjności i samoedukacji. Model przywództwa jest tu bardziej charyzmatyczny ${ }^{78}$.

Oba podejścia należy traktować jako typy idealne, a nie dające się opisać w ramach dychotomii między sprawną i dysfunkcyjną praktyką w dziedzinie zarządzania publicznego. W tym ujęciu polityka miejska traktowana jest jako proces decyzyjny związany z zarządzaniem przestrzenią miejską. Polityka ta nie może zatem nie istnieć w ogóle. Tak samo jak proces wytwarzania przestrzeni, także i ona może być prowadzona poprzez zaniechanie, $\mathrm{w}$ takim kontekście niejednokrotnie powodując degradację przestrzeni. Patologiczny wymiar polityki miejskiej jest w dalszym ciągu sposobem realizowania tej polityki ${ }^{79}$. Politykę publiczną dotyczącą przestrzeni zurbanizowanej należy też rozumieć niekiedy szerzej - jako politykę osadniczą ${ }^{80}$. Zgodnie z przywołaną wcześniej wątpliwością na temat możliwości dychotomicznego podziału osadnictwa na linii miasto - wieś, urbanizacja i zainteresowania studiów miejskich oraz związanych z nimi polityk publicznych dalece wykraczają poza granice miast. Oprócz procesów suburbanizacji mówi się współcześnie niekiedy o eksurbanizacji, czyli przeniesieniu wszystkich funkcji miejskich na przedmieścia ${ }^{81}$. Rzadziej stosowany i mniej rozpoznawalny termin polityka osadnicza odróżnia od polityki miejskiej koncentracja na szerzej rozumianej przestrzeni zurbanizowanej, nie zawsze mającej miejski charakter. Sama polityka miejska, w myśl definicji ustawowej,

stanowi zespół działań prawnych, finansowych i planistycznych na rzecz zrównoważonego rozwoju miast i ich obszarów funkcjonalnych, mających na celu wykorzystanie poten-

77 L. Dowbor, Co to za gra? Nowe podejścia w ekonomii, Instytut Wydawniczy Książka i Prasa, Warszawa 2017, s. 52-53.

78 P. John, Local Governance in Western Europe, Sage Publications, London 2001, s. 17.

79 B. Jałowiecki, Polityka miejska a prawo do miasta, „Zoon Politikon”, nr 4/2013, s. 99.

${ }^{80}$ M. Cesarski, Polityka mieszkaniowa i osadnicza a wspótczesne problemy cywilizacji zachodniej, [w:] K. Żukrowska (red.), Nauki ekonomiczno-społeczne a rozwój, Oficyna Wydawnicza SGH, Warszawa 2008 , s. 561.

${ }^{81}$ Ch. Montgomery, Miasto szczęśliwe. Jak zmienić nasze życie, zmieniając nasze miasta, tłum. T. Tesznar, Wysoki Zamek, Kraków 2015, ebook. 
cjału miast i ich obszarów funkcjonalnych w procesach rozwoju kraju, wzmocnienie zdolności miast i ich obszarów funkcjonalnych do pobudzania wzrostu gospodarczego i tworzenia trwałych miejsc pracy oraz poprawy jakości życia mieszkańców ${ }^{82}$.

W ujęciu prawa stanowionego jest zatem procesem służącym rozwojowi obszarów zurbanizowanych. Stanowi zbiór określonych działań, służących osiągnięciu celów takich jak tworzenie warunków dla skutecznego i partnerskiego zarządzania rozwojem na obszarach miejskich, w szczególności na obszarach metropolitarnych; wspieranie zrównoważonego rozwoju ośrodków miejskich, w tym przeciwdziałanie negatywnym zjawiskom niekontrolowanej suburbanizacji; odbudowa zdolności do rozwoju poprzez rewitalizację zdegradowanych obszarów miejskich; poprawa konkurencyjności i zdolności głównych ośrodków miejskich do kreowania rozwoju, wzrostu i zatrudnienia; wspomaganie rozwoju subregionalnych i lokalnych ośrodków miejskich, przede wszystkim na obszarach problemowych polityki regionalnej (w tym na niektórych obszarach wiejskich) poprzez wzmacnianie ich funkcji oraz przeciwdziałanie ich upadkowi ekonomicznemu. Uogólniając to wyliczenie, wymieniający powyższe cele autorzy polskiego dokumentu strategicznego w zakresie polityki miejskiej wskazują na takie działania, które prowadzą do kształtowania miast dających się określić się jako sprawne, zwarte i zrównoważone, spójne, konkurencyjne i silne ${ }^{83}$.

\subsubsection{Polityka miejska a znaczenie urbanistyki oddolnej}

Naczelnym celem polityki miejskiej rozumianej jako strategia jest zatem określenie instrumentów służących poprawie jakości życia w przestrzeni zurbanizowanej. Istnieje bardzo wiele narzędzi tego rodzaju. Są to na przykład konsultacje społeczne i inne działania włączające obywateli; procedury związane z planowaniem i materialnym kształtowaniem przestrzeni zurbanizowanej; polityka społeczna i związana z nią polityka mieszkaniowa czy też wreszcie inne polityki sektorowe związane z transportem, kulturą i inwestycjami. Na polską politykę miejską oddziałują różne dokumenty o charakterze krajowym ${ }^{84}$ i międzynarodo-

${ }^{82}$ Ustawa z dnia 6 grudnia 2006 r. o zasadach prowadzenia polityki rozwoju, Dz. U. 2006 nr 227 poz. 1658.

${ }^{83}$ Krajowa Polityka Miejska 2023, dokument przyjęty uchwałą Rady Ministrów w dniu 20 października 2015 r., Ministerstwo Infrastruktury i Rozwoju, Warszawa 2015, s. 12.

${ }^{84}$ Np. Krajowa Polityka Miejska 2023...; Krajowa Strategia Rozwoju Regionalnego 2010-2020: Regiony, miasta, obszary wiejskie, Ministerstwo Rozwoju Regionalnego, Warszawa 2010, http://www. malopolskie.pl/Pliki/2015/KSRR_2020.pdf, dostęp: 20.09.2015; Koncepcja Przestrzennego zagospodarowania Kraju 2030, Kancelaria Prezesa Rady Ministrów, Warszawa 2011, http://rpo2020.lubuskie. pl/wp-content/uploads/2013/01/Koncepcja_Przestrzennego_Zagospodarowania_Kraju_203011. pdf, dostęp: 20.09.2015; Stowarzyszenie Architektów Polskich, Polska Polityka Architektoniczna, [w:] 
wym $^{85}$. Przeważnie kładą one nacisk na partycypację obywatelską i zróżnicowane sposoby angażowania organizacji społecznych. Wydatny wpływ na ten fakt ma prawdopodobnie udział przedstawicieli strony społecznej i aktywistów miejskich w opracowaniu treści większości z tych dokumentów. To istotny kontekst dla urbanistyki oddolnej jako tematu moich rozważań.

Istnieją jednak i istotne różnice między takimi strategiami. Wynikają one na przykład z odmienności wyzwań, przed jakimi stoi polityka miejska w różnych miejscach na świecie. Na całej Ziemi dynamicznie wzrasta bowiem nie tylko liczba miast, w tym wielkich aglomeracji znanych jako mega miasta, czyli ośrodki o populacji przekraczającej 10 milionów mieszkańców ${ }^{86}$. Niezwykle intensywny wzrost odnotowują także osiedla nieformalne (informal settlements). Jak podaje Murray Fraser, ponad połowa globalnej populacji będzie zamieszkiwać niedługo w takich właśnie formach zabudowy, pozostając do tego aktywną zawodowo wyłącznie w obszarze szarej strefy ${ }^{87}$. Osiedla nieformalne i megamiasta nie są jednak zasadniczo problemem europejskim, ale przede wszystkim państw rozwijających się położonych w Azji, Ameryce Południowej i Afryce. Jedynym europejskim megamiastem jest Stambuł, ulokowany zresztą na granicy kontynentu z Azją. Na dodatek tutejsze slumsy, znane pod nazwą gecekondu, rozwijają się przede wszystkim na azjatyckim brzegu Bosforu.

Polska z kolei uchodzi za państwo o niewielkich tradycjach miejskich ${ }^{88}$ i niskiej jak na Europę wartości współczynnika urbanizacji (61 procent). Plasuje ją to nawet poniżej poziomu właściwego dla Rosji (74 procent), będącej przecież największym obszarowo państwem świata ${ }^{89}$. W dodatku nie występują w Polsce wielkie ośrodki metropolitarne. Patrząc z globalnej perspektywy, rolę taką przypisać można właściwie wyłącznie Warszawie i ewentualnie konurbacji śląsko-zagłębiowskiej. Pomimo

B. Świątkowska (red.), Coś, które nadchodzi. Architektura XXI wieku, Fundacja Bęc Zmiana, Warszawa 2011; Kongres Ruchów Miejskich, Tezy o mieście, [w:] B. Świątkowska (red.), Coś, które nadchodzi...; Deklaracja Słupska - nowa, progresywna polityka miejska, http://antymatrix.blog.polityka. pl/2015/03/18/konfederacja-slupska-deklaracja-nowej-progresywnej-polityki-miejskiej/, dostęp: 19.09.2015.

${ }^{85}$ Karta lipska na rzecz zrównoważonego rozwoju miast europejskich, Lipsk 2007, http://www. sarp.org.pl/pliki/karta_lipska_pl.pdf, dostęp: 19.09.2015; Europejska Rada Urbanistów, Nowa karta Ateńska. Wizja miast XXI wieku, Lizbona 2013, http://www.zabytki-tonz.pl/pliki/karta\%20atenska\%20 2003_pl.pdf, dostęp: 19.09.2015; http://www.uia.archi/en/ressources\#.Vf1CCd_tmko, dostęp: 19.09.2015.

${ }^{86}$ Niektórzy autorzy definiują tę granicę na poziomie ośmiu milionów mieszkańców.

${ }^{87}$ M. Fraser, A Question of Infinite Exlusivity, [w:] K. Nawratek, B. Huggins, M. Oxley, A. Horton-Howe (red.), op. cit., s. 25.

${ }^{88}$ J. Gądecki, P. Kubicki, Polityki miejskie, „Politeja”, nr 1/2014, s. 136.

${ }^{89}$ Stan na 2014 rok. World Urbanization Prospects. Highlights, United Nations, New York 2014, s. 23. 
to większość populacji zamieszkuje miasta, które w dalszym ciągu pozostają celami migracji ludności wiejskiej. Nie tak dynamicznej jak w okresie Polski Ludowej, ale ciągle wzmacnianej dzięki wysokiemu odsetkowi osób kontynuujących kształcenie na poziomie szkolnictwa wyższego ${ }^{90}$. Mimo zaznaczającej się od 2000 roku zmiany salda migracji w miastach z dodatniego na ujemne ${ }^{91}$ Polska jest państwem o przewadze ludności miejskiej oraz postępującej urbanizacji. Wzrost ten nie jest w pełni odnotowywany w danych urzędowych, które nie oddają charakteru silnego w Polsce zjawiska suburbanizacji. Podmiejskie osiedla nadal bowiem „pozostają formalnie terenami wiejskimi”"92.

Polska polityka miejska zdaniem krytyków jej obecnego kształtu nie istnieje w sferze praktyki. Oddaje to już proces uchwalania jej głównego dokumentu strategicznego - Krajowej Polityki Miejskiej. Pomimo zobowiązania władz do jej uchwalenia w wyniku artykułu 21b ustawy o zasadach prowadzenia polityki rozwoju ${ }^{93}$ proces ten nastąpił z dużym opóźnieniem ${ }^{94}$. Zdaniem Bohdana Jałowieckiego polityka miejska opiera się też na zaniechaniu - w atrofii systemu planowania przestrzeni, prowadzącej do gettoizacji polskich miast; w preferowaniu handlu wielkopowierzchniowego; w chaosie wizualnym, na który składa się „kakofonia szyldów, reklam, bilbordów, banerów”; a „w zakresie zapewnienia mobilności mieszkańców polega na budowaniu dość chwiejnej równowagi między transportem zbiorowym a indywidualnym, samochodowym i rowerowym”. Niespójna jest w opinii tego autora także polityka mieszkaniowa, jako oparta na zaniechaniu i prywatyzacji zasobów mieszkaniowych ${ }^{95}$. Elementem polityki miejskiej budzącym szczególną krytykę jest natomiast planowanie przestrzenne ${ }^{96}$. Chociaż ma ono charakter procesu z definicji nastawionego na długoletni „cykl” strategiczny, przez minione trzy

90 W 2014 roku na 10 tysięcy osób w wieku 19-24 lata przypadało aż 4964 studentów. Bank Danych Lokalnych GUS, http://stat.gov.pl/bdl/, dostęp: 20.09.2015.

91 M. Cesarski, Sytuacja mieszkaniowa w Polsce lat 2002-2014 - światowy kryzys, niewiadome i szanse zamieszkiwania, Oficyna Wydawnicza SGH, Warszawa 2016, s. 85-86.

${ }^{92}$ J. Lewicki, Polityka miejska w polityce rozwoju państwa, [w:] D. Mikucka-Wójtowicz (red.), Przeszłość - Teraźniejszość - Przyszłość. Problemy badawcze politologów, Libron, Kraków 2010, s. 122.

${ }^{93}$ Ustawa z dnia 6 grudnia 2006 r. o zasadach prowadzenia polityki rozwoju...

94 B.a., Droga Krajowej Polityki Miejskiej, „Miasta”, nr 1/2014, s. 13-14.

${ }^{95}$ B. Jałowiecki, Polityka miejska a prawo..., s. 99-106. Zob. też M. Cesarski, Polityka mieszkaniowa w Polsce a wyniki Narodowego Spisu Powszechnego z lat 2002 i 2011, [w:] P. Grata (red.), Od kwestii robotniczej do nowoczesnej kwestii socjalnej. Studia z polskiej polityki społecznej XX i XXI wieku, t. 3, Wydawnictwo Uniwersytetu Rzeszowskiego, Rzeszów 2015, s. 191-209.

${ }^{96}$ H. Izdebski, op. cit., s. 139-164; Ł. Drozda, Koncepcja własności jako odpowiedzialności w planowaniu przestrzennym, [w:] J. Osiński, M. Pachocka, M. Ostrowska, M. Nawrot (red.), Rozwój we wspótczesnym świecie. Uwarunkowania, wyzwania, perspektywy, Oficyna Wydawnicza SGH, Warszawa 2016, passim. 
dekady uchwalono w Polsce aż trzy kolejne ustawy ${ }^{97}$. Każdorazowo reorganizowały one system regulacji przestrzeni, osłabiany dodatkowo rozmaitymi ustawami o specjalnych warunkach prowadzenia inwestycji, w tym głośną w ostatnim czasie ustawą, tak zwanym „lex deweloper”"98. Ogólnie rzecz biorąc, krytyka polskiej polityki miejskiej koncentruje się z jednej strony na braku podejmowania konkretnych działań, z drugiej - na powolnym i nieefektywnym procesie uchwalania związanych z tą dziedziną dokumentów strategicznych ${ }^{99}$.

Polityka miejska, jakkolwiek stanowi do pewnego stopnia obiekt zainteresowania władzy centralnej, nie jest też konsekwentnie realizowana przez władze szczebla lokalnego. Przy postępującej od 1990 roku decentralizacji polityk publicznych stanowi to duże wyzwanie dla realizacji zadań i celów polityki miejskiej rozumianej jako działanie o charakterze strategicznym. Zjawisko to budzi niepokój ze względu na stosunkowo długi okres jedności obozu politycznego znajdującego się u władzy, zwłaszcza w latach 2010-2015. Jedność ta obejmowała wówczas zarówno oba szczeble władzy wykonawczej całego państwa, jak i większość miast, włącznie z Warszawą. Następująca od 2015 roku dezintegracja monizmu obozu władzy - na szczeblu ogólnokrajowym włada kto inny niż w największych miastach - stanowi wyzwanie dla animowania polskiej polityki miejskiej, skoro była ona niedoskonała nawet w bardziej sprzyjających warunkach. Sugeruje to wręcz możliwość potencjalnego zakończenia się okresu dogodnego dla podjęcia w tym zakresie odpowiednich działań. Jest to tak zwane okno możliwości działania w polityce publicznej (policy window) ${ }^{100}$. Rozumieć przez to należy sytuację uwrażliwienia decydentów na doniosłość problemu, opracowania sposobu jego potencjalnego rozwiązania oraz pojawienia się woli politycznej potrzebnej dla podjęcia takiej aktywności.

Jednocześnie jednak wśród elementów polskiej polityki miejskiej warto zwrócić uwagę na pewne podjęte już działania. Ich przykłady stanowią wysiłki związane z poprawą jakości polskiej przestrzeni. Wywołane zostały one za pomocą takich działań, jak poprzedzona głośnym raportem ${ }^{101}$ inicjatywa byłego prezydenta, Bro-

97 Ustawa z dnia 12 lipca 1984 r. o planowaniu przestrzennym, Dz. U. 1984 nr 35 poz. 185; Ustawa z dnia 7 lipca 1994 r. o zagospodarowaniu przestrzennym, Dz. U. 1994 nr 89 poz. 415; Ustawa z dnia 27 marca 2003 r. o planowaniu i zagospodarowaniu przestrzennym, Dz. U. 2003 nr 80 poz. 717 .

${ }^{98}$ Ustawa z dnia 5 lipca 2018 r. o ułatwieniach w przygotowaniu i realizacji inwestycji mieszkaniowych oraz inwestycji towarzyszących, Dz. U. 2018 poz. 1496.

99 J. Kusiak, Chaos Warszawa. Porządki przestrzenne polskiego kapitalizmu, Fundacja Bęc Zmiana, Warszawa 2018, s. 68-71.

${ }^{100}$ J.W. Kingdon, Agendas, Alternatives, and Public Policies, Longman, New York 2003, s. 165195. Polskie tłumaczenie terminu za: W. Anioł, Pułapka ekonomizmu. U źródeł dominacji neoliberalnej narracji modernizacyjnej w Polsce, „Przegląd Socjologiczny”, nr 2/2015, s. 85.

${ }^{101}$ Raport o ekonomicznych stratach $i$ społecznych kosztach niekontrolowanej urbanizacji w Polsce, IGCZ PAN, Fundacja Rozwoju Demokracji Lokalnej, Warszawa 2013, passim. 
nisława Komorowskiego, której skutkiem stała się publikacja o polskiej przestrzeni zurbanizowanej ${ }^{102}$. Dyskusję wokół rewaloryzacji zdegradowanej przestrzeni poświadcza uchwalenie takich aktów jak ustawa o rewitalizacji ${ }^{103}$ i następnie licznych gminnych programów rewitalizacji ${ }^{104}$ czy analogicznego aktu poświęconego zagadnieniom ładu krajobrazowego ${ }^{105}$. Polska polityka miejska po raz pierwszy wykazuje też zainteresowanie tematyką urbanistyki oddolnej. Przestrzeń zurbanizowana wytwarzana społecznie pojawia się jako pochodna projektów zwyciężających w edycjach budżetów partycypacyjnych, programów rewitalizacji i innych mniej sformalizowanych inicjatyw obywatelskich.

Ocena prowadzonych w ten sposób działań wymagać będzie czasu związanego z długotrwałym charakterem zarówno samego dokonywania przekształceń przestrzeni zurbanizowanej, jak i ich społecznych następstw. Niedoskonałości oficjalnej polityki miejskiej wskazują na wagę działań oddolnych. W ten sposób zmagania z zakresu wytwarzania przestrzeni o mniejszym stopniu formalizacji, a zwłaszcza urbanistyki oddolnej stanowiącej przedmiot moich rozważań, stają się ważnym zagadnieniem w aspekcie waloryzacji przestrzeni. Urbanistyka oddolna stanowi wobec tego potencjalną alternatywę dla sztywnych i nieskutecznych działań prowadzonych w zakresie dotychczasowej polityki miejskiej.

\subsection{Waloryzacja przestrzeni i jej związki z badaniami jakości życia}

\subsubsection{Waloryzacja a percepcja przestrzeni}

Niezwykle istotnym pojęciem z punktu widzenia moich rozważań jest waloryzacja przestrzeni. Termin ten kojarzy się przeważnie z jego odmiennym, ekonomicznym znaczeniem. W jego ramach waloryzacja określana jest jako „zwiększenie wielkości nominalnej świadczeń finansowych, składek ubezpieczeniowych oraz wierzytelności, mające na celu zachowanie ich wartości realnej”"106. Ekonomia jest nauką badającą to, jak społeczeństwo wykorzystuje ograniczone zasoby w celu zaspokajania swoich potrzeb. Przestrzeń w swojej materialnej formie jest tymczasem

102 J. Sepioł (red.), Przestrzeń życia Polaków, Stowarzyszenie Architektów Polskich, Warszawa 2014, http://www.sarp.org.pl/pliki/1908_53fdc64bb3140-pzpspistresci1.pdf, dostęp: 2.05.2015, passim.

103 Ustawa z dnia 9 października 2015 r. o rewitalizacji, Dz. U. 2015 poz. 1777.

104 Ł. Drozda, Pułapka gentryfikacji? Zwiq̨zki „uszlachetniania” przestrzeni z programami rewitalizacji polskich miast, „Studia Regionalne i Lokalne”, nr 4/2017, passim.

105 Ustawa z dnia 24 kwietnia 2015 r. o zmianie niektórych ustaw w związku ze wzmocnieniem narzędzi ochrony krajobrazu, Dz. U. 2015 poz. 774.

${ }^{106}$ Encyklopedia PWN, Wydawnictwo Naukowe PWN, http://encyklopedia.pwn.pl/haslo/waloryzacja;3993682.html, dostęp: 12.07.2016. 
niezbędna do gospodarowania przez człowieka. Pod postacią ziemi stanowi zresztą jeden z trzech kluczowych (obok kapitału i pracy) czynników wytwórczych. Jakkolwiek czynniki te, jak wskazał Karl Polanyi ${ }^{107}$, nie mogą być zwykłymi towarami, przestrzeń jako zbiór nieruchomości poddawana jest obrotowi na poświęconym jej rynku. Z tego też powodu to właśnie ekonomiści odpowiedzialni są za opracowanie jednej z najbardziej zobiektywizowanych metod waloryzacji przestrzeni. Przez nich samych jest ona jednak nazywana inaczej - wyceną nieruchomości. W podejściu charakterystycznym dla pozostałych nauk zajmujących się przestrzenią definicja waloryzacji jest inna. Jest w takim kontekście procesem szacowania wartości (potencjału) przestrzeni na podstawie jej poszczególnych właściwości, możliwych do określania również jako wartości, cechy bądź walory przestrzenne.

Waloryzacja odnosić może się zarówno do przestrzeni zamieszkanej, jak i jej pozostałych typów. Przedmiotem są w tym kontekście obszary zurbanizowane, użytki rolne czy leśne oraz inne rodzaje użytków i nieużytków. Każdy z nich cechuje się innymi wartościami oraz odmiennymi podejściami metodycznymi mającymi na celu identyfikację tych wartości. Przykładowo wskaźnik bonitacji gleb jest kluczowy dla szacowania wartości gruntów rolnych, nie ma natomiast większego znaczenia przy wycenie działki budowlanej. Przedmiotem waloryzacji jest przestrzeń stanowiąca kontekst egzystencji człowieka. Istotnie powiązane z przedmiotem zainteresowania waloryzacji są tym samym badania nad poziomem jakości życia. Koncentrują one swoją uwagę nie tyle na przestrzeni, ile na jej użytkownikach i warunkach ich egzystencji. Przez to wykraczają poza węziej rozumiany poziom zależności ekonomicznych. W odniesieniu do tego, co stanowi obiekt badania, zarówno waloryzacja przestrzeni może służyć badaniu jakości życia, jak i badania jakości życia mogą zostać podporządkowane celom waloryzacji.

Tak rozumiana waloryzacja przestrzeni znajduje zastosowanie nie tylko w badaniach naukowych dyscyplin zajmujących się przestrzenią. Użyteczna staje się również przy praktycznych przedsięwzięciach związanych z kształtowaniem przestrzeni oraz maksymalizacją wykorzystania jej potencjału inwestycyjnego. W obu tych typach działań prowadzonych w przestrzeni zurbanizowanej wykonywana jest de facto inwentaryzacja przestrzeni, która wymaga identyfikacji możliwie największej liczby cech wraz z ich oceną jakościową. Prowadzi to następnie do bardziej kompleksowych ocen analizowanej przestrzeni. Waloryzacja stanowi zatem użyteczne narzędzie zarówno w przypadku inwestora pragnącego wykorzystać

${ }^{107}$ Wbrew założeniom Karla Polanyiego ziemia może być zresztą do pewnego stopnia wytwarzana. Wytwarzanie przestrzeni materialnej ogranicza się bowiem nie tylko do nowych budynków, ale i sztucznego tworzenia lądów. Zob. idem, Wielka transformacja. Polityczne i ekonomiczne źródła naszych czasów, tłum. M. Zawadzka, Wydawnictwo Naukowe PWN, Warszawa 2010, s. 88. 
potencjał nieruchomości, jak i badacza naukowego. Zdaniem Iwony Cieślak ujęta w tych kategoriach ,waloryzacja jest:

1. podstawowym narzędziem podejmowania decyzji planistycznych,

2. elementem szeroko pojmowanego zarządzania przestrzenią planistyczną,

3. źródłem wyboru najwłaściwszego wykorzystania elementów środowiska,

4. podstawą optymalizacji funkcji w przestrzeni,

5. instrumentem kontroli zgodności prowadzonej gospodarki przestrzennej z założeniami wynikającymi z miejscowych planów zagospodarowania przestrzennego oraz potrzebami społecznymi i gospodarczymi,

6. narzędziem realizacji polityki ochrony środowiska”108.

W konsekwencji, w opinii przywołanej autorki możliwe jest określenie struktury, organizacji, funkcjonowania oraz poziomu rozwoju danej przestrzeni. Waloryzacja prowadzona według powyższych wskazań odnosić może się do analiz środowiska przyrodniczego, różnych rodzajów krajobrazu, a także użytkowych, ekonomicznych i społecznych walorów przestrzeni ${ }^{109}$.

Podstawę procesu waloryzacji przestrzeni stanowi jej percepcja. Jak stwierdzają Ewa Szafrańska i Jacek Kaczmarek, jest ona „aktem spostrzegania, sposobem obserwacji, który prowadzi do utworzenia w umyśle podmiotu obrazu przestrzeni"110. Percepcja ta może być bezpośrednia (doświadczenie naturalne, zmysłowe, pochodzące z obserwacji) lub pośrednia (opinie oparte na ocenach innych obserwatorów - przekaz bezpośredni lub zapośredniczony na nośnikach informacji albo przez stereotypy) ${ }^{111}$. Sposoby percepcji przestrzeni są warunkowane względem zróżnicowanych czynników, odnoszących się do sytuacji, w jakiej znajdują się podmioty dokonujące tej percepcji. Bohdan Jałowiecki wymienia tutaj rodzaj trasy pokonywanej przez użytkownika przestrzeni (codzienna/niecodzienna); jego sytuację emocjonalną (nieszczęśliwy/szczęśliwy); sytuację społeczną i kulturową (co wiązać można z kapitałami społecznym i kulturowym ${ }^{112}$ ); czy sytuację materialną (pieszy/kierowca) ${ }^{113}$. Podobne czynniki wskazuje Marcjanna Nóżka. Dołącza ona do tej grupy takie elementy, jak sprawność fizyczna, emocjonalny stosunek do

108 I. Cieślak, Współczesne problemy oceny i waloryzacji przestrzeni, [w:] eadem (red.), Współczesna waloryzacja przestrzeni..., s. 8-9.

109 Ibidem, s. 9-10.

110 E. Szafrańska, J. Kaczmarek, Percepcja przestrzeni - pomiędzy prawdq a autentycznościq, [w:] M. Madurowicz (red.), Percepcja wspótczesnej przestrzeni miejskiej, Wydział Geografii i Studiów Regionalnych UW, Warszawa 2007, s. 48.

111 Ibidem, s. 55.

112 P. Bourdieu, The forms of capital, [w:] J. Richardson (red.), Handbook of Theory and Research for the Sociology of Education, Greenwood, New York 1986, passim.

113 B. Jałowiecki, Proces waloryzacji przestrzeni miejskiej, [w:] Z. Pióro (red.), Przestrzeń i społeczeństwo. Z badań ekologii społecznej, Książka i Wiedza, Warszawa 1982, s. 104. 
przedmiotu percepcji czy sama znajomość przestrzeni ${ }^{114}$. Wśród czynników emocjonalnych oprócz ogólnego nastroju podmiotu percepcji kluczową rolę zdaje się odgrywać także jego osobiste powiązanie z przestrzenią. Jak wykazały badania porównawcze Marii Lewickiej ${ }^{115}$ i Grażyny Prawelskiej-Skrzypek ${ }^{116}$, obok tych nasyconych wartościami historycznymi, najwyżej ocenianymi przestrzeniami są te związane z miejscem zamieszkania, nawet jeżeli w powszechnym odbiorze funkcjonują jako obszary zdegradowane, mało atrakcyjne czy wprost nielubiane przez mieszkańców innych części miasta. Co więcej, nawet zdegradowane przestrzenie, nabywające z upływem lat swoistej ciągłości historycznej, zaczynają być w końcu oceniane coraz lepiej. Pokazuje to na przykład wzrost ocen peerelowskich blokowisk w okresie oddzielającym badania obu przywołanych autorek. Dwie dekady odpowiadają zresztą demograficznemu ujęciu kategorii pokolenia. Osoby wychowane w środowisku dawniej postrzeganym jako nieprzyjazne nadają mu nowe znaczenia i pozytywniej waloryzują tak przetworzoną społecznie przestrzeń.

Według Szafrańskiej i Kaczmarka ${ }^{117}$ w badaniach percepcyjnych konieczne jest przyjęcie trzech założeń. Obejmują one istnienie obiektywnego świata realnego, zewnętrznego wobec jednostki (1), obiektywnego umysłu podmiotu (2) oraz możliwości poznania zmysłowo-umysłowego świata zewnętrznego przez podmiot percepcji przestrzeni (3). W konsekwencji możliwe jest wyprowadzenie hipotez badawczych pozwalających odnaleźć odpowiedzi na pytania o:

1. przedmiot percepcji przestrzeni (co nim jest?);

2. jej podmiot (kto spostrzega przedmiot percepcji?);

3. proces percepcji (w jaki sposób postrzegany jest jej przedmiot i jaką drogą?);

4. sytuację percepcji (w jakim kontekście, otoczeniu i środowisku jest postrzegany?);

5. rezultat percepcji (jaki jest jej wynik?).

Z punktu widzenia moich rozważań kontekstem szczególnie istotnym wydaje się sytuacja percepcji przestrzeni powiązana z jej kontekstem. Ten ostatni uzależniony jest od zróżnicowanych grup czynników wpływających na podmiot percepcji, począwszy od płci, przez sytuację klasową, po różnice kulturowe. Na przykład

${ }^{114}$ M. Nóżka, Społeczne zamykanie (się) przestrzeni. O wykluczeniu, waloryzacji miejsca zamieszkania i jego mentalnej reprezentacji, Wydawnictwo Naukowe Scholar, Warszawa 2016, s. 109.

115 M. Lewicka, Psychologia miejsca, Wydawnictwo Naukowe Scholar, Warszawa 2012, s. 50$54,63,68-69$.

116 G. Prawelska-Skrzypek, Waloryzacja przestrzeni polskich miast w opinii ich mieszkańców, [w:] B. Jałowiecki, H. Libura (red.), Percepcja i waloryzacja środowiska naturalnego i antropogenicznego, Wydawnictwa Uniwersytetu Warszawskiego, Warszawa 1992, s. 216-217.

117 E. Szafrańska, J. Kaczmarek, op. cit., s. 48. 
w wymiarze miasto - wieś: w zależności od prowadzonego stylu życia, wyznania religijnego, rasy bądź regionu świata ${ }^{118}$.

W najprostszym ujęciu w wyniku procesu waloryzacji możliwe jest przypisanie przestrzeni wartości związanych z wieloma dychotomicznymi typologiami, takimi jak: przestrzeń ładna - brzydka, pierwotna - wtórna, prywatna - publiczna, zamknięta - otwarta, odspołeczna - dospołeczna, swoja - obca, konkretna - abstrakcyjna, kompleksowa - selektywna, zwarta - rozczłonkowana, stabilna - zdestabilizowana, jednorodna - zróżnicowana, trwała - efemeryczna, nazwana - anonimowa, wirtualna - rzeczywista ${ }^{119}$. Ujęcia tego typu mogą być też poszerzone o kategorie pośrednie. Umożliwiają one lepszą identyfikację niuansów dotyczących przedmiotu analiz.

Waloryzacja przestrzeni, zgodnie z obowiązującymi przepisami, jest w Polsce działaniem obligatoryjnym, mimo że jej zasady nie zostały dookreślone przez ustawodawcę. Ustawa regulująca planowanie przestrzenne ${ }^{120}$ tylko pozornie podkreśla wagę inwentaryzacji przestrzeni. Już w artykule pierwszym akt ten uwzględnianie „walorów architektonicznych i krajobrazowych” wymienia jako drugi z kolei wśród najważniejszych wymogów dla procesu planowania i zagospodarowania przestrzeni. Ustawa tych walorów jednak nie definiuje, w przeciwieństwie do określonych jako warunek osobny „walorów ekonomicznych”. Zgodnie z treścią artykułu drugiego wskazanego aktu należy rozumieć je jako „wartość rynkową nieruchomości”. Sytuacji tej nie zmieniło nawet uchwalenie ustawy krajobrazowej ${ }^{121}$. Wprowadziła ona wprawdzie pojęcie audytu krajobrazowego, stanowiącego rodzaj metody waloryzacji przestrzeni mającej na celu identyfikację kluczowych krajobrazów oraz ich systematyczną aktualizację, wątpliwości wzbudza jednak ich rzetelność w wyniku interwałów wymaganych przez ustawodawcę - aż dwudziestoletnich. Brak uregulowania treści audytów sprzyja przygotowywaniu zróżnicowanych ocen przestrzeni za pomocą rozmaitych technik jej waloryzacji czy nawet niespójnemu identyfikowaniu wartości przestrzennych w różnych typach opracowań.

W ujęciu szerszym waloryzacja przestrzeni odnosi się do identyfikacji całego katalogu wartości przestrzennych. Składają się one na opisywany przez Kevina Lyncha „obraz miasta” ${ }^{22}$ czy tė̇ „duch miejsca” (genius loci), koncepcję powiązaną z nazwiskiem Christiana Norberga-Schulza ${ }^{123}$. Tak wytworzony w świadomości

118 E.T. Hall, op. cit., s. 188-241.

119 M. Nóżka, op. cit., s. 98.

120 Ustawa z dnia 27 marca 2003 r. o planowaniu i zagospodarowaniu przestrzennym Dz. U. 2003 nr 80 poz. 717.

121 Ustawa z dnia 24 kwietnia 2015 r. o zmianie...

${ }^{122}$ K. Lynch, op. cit., passim.

${ }^{123}$ Ch. Norberg-Schulz, Genius Loci. Towards a Phenomenology of Architecture, Rizzoli, New York 1979, passim. 
użytkowników wizerunek miasta ma charakter całościowy. Części składowe są doświadczane przez odbiorców przeważnie w połączeniu, analogicznie do wskazanego wcześniej, jednolitego odbioru tworzących miasto podsystemów: społecznego i urbanistycznego. Identyfikacja poszczególnych cech jest jednak istotna z punktu widzenia analiz przestrzeni, a także formułowania dotyczących jej ocen, tak aby były możliwie precyzyjne w procesie zaawansowanych analiz przestrzeni. W opinii Aleksandra Wallisa waloryzacja prowadzona w sposób całościowy, z zachowaniem dużej dozy obiektywizmu i precyzji oceny, jest jednak niezwykle trudna.

Zarówno dwa [właściwe dla niej] podsystemy[: urbanistyczny i społeczny], jak i cały system charakteryzujemy za pomocą wielkiej liczby szczegółowych wskaźników, które zawsze odnoszą się do któregoś z aspektów systemowej całości. Gdy pragniemy dojść do ocen ogólnych, trafiamy na zasadnicze trudności, nie dysponujemy bowiem wskaźnikami o charakterze syntetycznym. Możemy jedynie za pomocą wskaźników uznanych przez nas za najważniejsze charakteryzować wybraną dziedzinę życia lub gospodarki. W rezultacie oceny syntetyczne stanu podsystemów bądź całego systemu zwykle mają charakter opisowy, zilustrowany pewną liczbą wybranych wskaźników. Nie mają natomiast charakteru ogólnej, zmaterializowanej oceny ${ }^{124}$.

Podstawę procesu waloryzacji przestrzeni stanowi identyfikacja jej właściwości, czyli wartości przestrzennych, określanych także jako cechy lub walory przestrzeni. Pojęcie wartości przestrzennych wprowadził do polskiej nauki jeszcze w okresie międzywojennym Florian Znaniecki. Jako wartość przestrzenną definiował on przestrzeń wraz z towarzyszącym jej kontekstem. W tym ujęciu

[ż]adna z $[\ldots]$ wartości przestrzennych nie występuje $[\ldots]$ jako odosobniona $\mathrm{w}$ doświadczeniu ludzkim tak, by ją można było po prostu wydzielić i skojarzyć z innymi wartościami przestrzennymi w ramach wspólnego układu geometrycznego. Każda jest składnikiem jakiegoś nie przestrzennego systemu wartości, w odniesieniu do którego posiada swoistą treść i znaczenie. Może to być system religijny, estetyczny, techniczno-wytwórczy, ekonomiczny, społeczny ${ }^{125}$.

Dla Znanieckiego wartość przestrzenna jest bardziej przestrzenią o określonym znaczeniu niż samą cechą tej przestrzeni. Zdecydowanie niewłaściwe, zdaniem współautora Chłopa polskiego w Europie i Ameryce, byłoby też ekonomistyczne redukowanie tego terminu, albowiem „,[w]artości przestrzenne [...] nie dają się logicznie sprowadzić do wartości ekonomicznych, choć często te ostatnie są z nimi

${ }^{124}$ A. Wallis, Socjologia przestrzeni..., s. 75-76.

125 F. Znaniecki, Socjologiczne podstawy ekologii ludzkiej, „Ruch Prawniczy, Ekonomiczny i Socjologiczny”, z. 1/1938, s. 91. 
nierozerwalnie związane"126. Podejście to podzielali także autorzy późniejszych typologii wartości przestrzennych. Z drugiej strony ekonomiści traktujący wartość jako cechę określającą potencjał finansowy nieruchomości także wskazują na niuanse tego pojęcia. Rynek nieruchomości definiowany jest przez nich jako

wzajemne relacje, do jakich dochodzi w obrębie zbywania (nabywania) praw do nieruchomości oraz innych praw umożliwiających ich władanie zgodnie z prawem. Uczestnikami rynku nieruchomości są kupujący i sprzedający, będący osobami fizycznymi lub prawnymi [...] [oraz] notariusze, geodeci, wydziały ksiąg wieczystych sądów rejonowych, rzeczoznawcy majątkowi, instytucje finansujące, urzędnicy obsługujący rynek nieruchomości ${ }^{127}$.

Wszyscy wskazani tu aktorzy realizują w ramach rynku własne, częstokroć sprzeczne interesy. W celu obiektywizowania zasad regulujących transakcje dotyczące tych interesariuszy czy izolacji procesu wyceny nieruchomości od nacisków z ich strony dąży się do tworzenia powszechnych standardów wyceny. W ich myśl wyróżnia się dwie podstawowe wartości: rynkową oraz nierynkową. Wartość rynkowa odnosi się do najbardziej prawdopodobnej do uzyskania na rynku ceny za nieruchomość. Określonej na dany dzień, zbywanej w sytuacji niewymuszonej sprzedaży, w ramach transakcji niezależnych od siebie stron, które postępują rozważnie i bez przymusu ${ }^{128}$. Te nierynkowe to zaś wartości: inwestycyjna (szczególna dla konkretnego inwestora), godziwa (możliwa do uzyskania przy wyposażeniu stron transakcji w odpowiednie informacje wpływające na wielkość wartości) oraz synergiczna (odwzorowująca „dodatkowy element wartości powstały na skutek połączenia dwóch lub więcej praw, gdy wartość połączonych praw jest wyższa od sumy wartości poszczególnych praw”). Do grona tego zalicza się także stanowiąca przedmiot dyskusji wśród teoretyków wyceny wartość odtworzenio wa, czyli koszt odtworzenia wcześniejszego stanu nieruchomości ${ }^{129}$.

Współcześnie jako wartości tego rodzaju wymienia się przede wszystkim poszczególne cechy przestrzeni. Typologie tak rozumianych wartości są zróżnicowane i charakteryzuje je odmienny stopień szczegółowości. W ujęciu UNESCO ${ }^{130}$ identyfikowane są dwie główne grupy wartości: kulturowe i przyrodnicze. Ten

126 Ibidem, s. 94.

127 Rynek nieruchomości można podzielić ze względu na okres powstania nieruchomości poddawanych obrotowi (rynek pierwotny i wtórny) lub kategorię nieruchomości (rynki nieruchomości rolnych, mieszkalnych i usługowych). Zob. P. Wancke, Nieruchomości. Leksykon pojęć i definicji, Wolters Kluwer Polska, Warszawa 2007, s. 284.

128 E. Kucharska-Stasiak, Ekonomiczny wymiar nieruchomości, Wydawnictwo Naukowe PWN, Warszawa 2016, s. 176-177.

${ }^{129}$ Ibidem, s. 180.

130 UNESCO, Rekomendacje UNESCO w sprawie historycznego krajobrazu miejskiego, http://www. unesco.pl/fileadmin/user_upload/pdf/Rekomendacje/rekomenkrajobraz.pdf, dostęp: 13.07.2016. 
ogólny podział budzi jednak duże wątpliwości ze względu na fakt, iż przyroda także poddawana jest wpływom antropogenicznym, stając się elementem kultury człowieka. Do pewnego stopnia podobną, aczkolwiek zdecydowanie szerszą klasyfikację proponują Jan Rylke i Anna Długozima. Opierając się na ujęciu Jeremiego T. Królikowskiego, wymieniają „wartości zabytkowe, sakralne, symboliczne, poznawcze, psychologiczne, społeczne, indywidualne, historyczne, estetyczne, artystyczne, krajobrazowe, lokalne, narodowe, uniwersalne, energetyczne, finansowe, użytkowe. Do tego [w ich opinii] dochodzi cały wachlarz wartości przyrodniczych, stanowiących pierwotne wartości przestrzenne, na które dopiero nakładają się wartości kulturowe"131. Jeszcze inną typologię zaproponował Wallis, wedle którego ,jako najogólniejsze kryteria wartościowania przestrzeni społecznej [...] przyjąć [można] kryteria techniczne, przyrodnicze, ekonomiczne, społeczne, historyczne, estetyczne i sakralne. Każde z wymienionych pojęć można uznać za nazwę całej grupy kryteriów, które mogą podlegać dalszej klasyfikacyjnej rozbudowie”132. Dla waloryzacji przestrzeni wytwarzanej społecznie najbardziej interesującym podejściem wydaje się ostatnie z przywołanych ujęć. Po rozwinięciu pozwala na precyzyjne zidentyfikowanie w przestrzeni jej cech dystynktywnych odnoszących się do wartości w zróżnicowanych obszarach.

\subsubsection{Rozumienie jakości życia}

Innym istotnym podejściem, przydatnym w ocenie jakości przestrzeni zurbanizowanej i wykorzystanym przeze mnie samego, jest badanie jakości życia (quality of life). Zwłaszcza zaś - jakości życia w środowisku zurbanizowanym (quality of urban life). Kategoria jakości życia jest stosunkowo młoda i służy wartościowaniu warunków egzystencji, odgrywa jednak istotną rolę we współczesnych badaniach związanych z waloryzacją przestrzeni zamieszkanej. W połowie lat 70. XX wieku ukazał się artykuł Aleksandra Wallisa, w którym jakość życia opisana została jako ówczesne novum, mogące potencjalnie zastąpić w przyszłości koncepcję materialnego i kulturalnego poziomu (standardu) życia ${ }^{133}$. Jakość życia, pisał ten znany socjolog miasta,

polega na określonej strukturze wartości, czynności i sytuacji, jaką jednostka (rodzina) realizuje w swym życiu codziennym w ciągu dłuższych okresów [...]. Struktura ta łączy zatem

131 J. Rylke, A. Długozima, Ocena, wycena i kształtowanie zasobów kulturowych, [w:] J. Szyszko, B. Porter, J. Malczyk (red.), ABC gospodarki przestrzennej w aspekcie rozwoju regionalnego, Wydawnictwo SGGW, Warszawa 2009, s. 255.

132 A. Wallis, Socjologia przestrzeni..., s. 23.

133 Idem, Jakość życia - problemy i propozycje, „Ruch Prawniczy, Ekonomiczny i Socjologiczny”, z. 2/1976, s. 136 . 
standard życia, zespół uznawanych i realizowanych wartości, pożądane i pełnione role społeczne, wreszcie łańcuch życiowych sytuacji. Jakość życia jest w tym rozumieniu całością, obejmującą wszystkie podstawowe funkcje jednostki (rodziny) w sferze biologicznej, produkcyjnej i kulturowej ${ }^{134}$.

Zdaniem Wallisa koncepcja jakości życia była jednak trudna w operacjonalizacji. Wymaga bowiem zebrania tak ogromnej masy danych, że w praktyce pomiar tego rodzaju staje się nieosiągalny. Jednak autor ten zauważał, że zmienne tego rodzaju mogą być agregowane pod postacią łatwiejszych do opracowania wskaźników. Albowiem

charakteryzować jakieś zjawisko można [...] za pomocą kilku jego wybranych cech. Jeżeli wybór padł na rysy istotne, to taka charakterystyka może spełnić pewną rolę. Dlatego w stosunku do bardzo dużych zbiorowości - na przykład ludności wielkich miast lub zbiorowości zawodowych - można pokusić się o częściową charakterystykę ich jakości życia ${ }^{135}$.

Według niego liczba takich wskaźników jest jednak ograniczona. Wśród potencjalnych wymieniał te odnoszące się do: długości życia, samobójstw, wypadków komunikacyjnych, liczby osób przypadających na jedną izbę mieszkalną, stopy zatrudnienia oraz stopnia wykształcenia ludności w konkretnym roczniku urodzeń ${ }^{136}$. W opinii Moniki Mularskiej-Kucharek ${ }^{137}$ do lat 70. XX wieku badania nad tematyką jakości życia były prowadzone dość chaotycznie, a wcześniejszy ich etap daje się opisać jako „prototeoretyczny”. Przełom stanowiła publikacja Augusta Campbella, Philipa E. Converse'a oraz Willarda L. Rodgersa ${ }^{138}$. W 1976 roku, czyli nieomal równolegle z publikacją Wallisa, określili oni katalog piętnastu dziedzin życia, z których zadowolenie składać miało się na obraz jakości egzystencji. Techniki pomiaru jakości życia były następnie udoskonalane przez kolejnych badaczy, co prowadziło do coraz bardziej zaawansowanych metodycznie opracowań tego problemu.

Współcześnie w dalszym ciąu bardzo trudno znaleźć uniwersalną i powszechnie akceptowaną definicję jakości życia. Dowodzi tego już sam nieład pojęciowy, związany z wyróżnianiem przez poszczególnych autorów tak zróżnicowanych pojęć, jak poziom, warunki, sposób, styl, standard, znośność życia (livability), stopa życiowa, dobrobyt, jakość środowiskowa czy szanse

134 Ibidem, s. 140.

135 Ibidem, s. 142.

136 Ibidem.

${ }^{137}$ M. Mularska-Kucharek, Kapitał społeczny a jakość życia na przykładzie zbiorowości wielkomiejskiej, Wydawnictwo Uniwersytetu Łódzkiego, Łódź 2013, s. 43.

138 A. Campbell, P.E. Converse, W.L. Rodgers, The Quality of American Life. Recent Pattern and Trends, McGraw-Hill, New York 1976. 
na przetrwanie (sustainability). Ich definicje bywają wzajemnie sprzeczne, a poszczególne kategorie są też odmiennie klasyfikowane ze względu na kryterium ich obiektywności ${ }^{139}$. Dla Wallisa jakość życia

polega na zaspokajaniu $[\ldots]$ materialnych i duchowych potrzeb oraz na osiąganiu pożądanych $[\ldots]$ wartości w zakresie życia rodzinnego, zawodowego i osobistego ${ }^{140}$.

Monika Mularska-Kucharek przytacza definicje z perspektyw właściwych dla ujęć różnych nauk, podając, że

w definicjach eksplanacyjnych występuje różnorodność znaczeń pojęcia ,jakość życia”. Może być ono rozumiane jako brak obciążeń i dolegliwości, subiektywna ocena poziomu zadowolenia i satysfakcji płynącej z życia jako całości oraz jego sfer, posiadanie niezbędnych zasobów umożliwiających zaspokojenie indywidualnych potrzeb i pragnień, rozbieżność między sytuacją upragnioną a sytuacją aktualną, bilans emocjonalny, stopień ogólnego dobrostanu, stopień realizacji celów życiowych, optymalna dla jednostki relacja między stanem fizycznym i duchowym, satysfakcja i poczucie szczęścia w ważnych dla jednostki dziedzinach, bogactwo przeżyć, celów życiowych, wysoki poziom świadomości i aktywności, wyraz pozytywnej postawy względem życia. [...] W ramach ekonomii zwraca się uwagę na materialne warunki bytu człowieka, traktowane jako obiektywne parametry jakości życia. Samo pojęcie utożsamiane jest natomiast z ilością zużywanych dóbr i usług. [...] Na gruncie psychologii, podobnie jak w przypadku innych nauk, nie sformułowano jednoznacznego rozumienia terminu ${ }^{141}$.

Irene van Kamp z zespołem wskazuje na więcej możliwych sposobów definiowania. Autorzy ci podają aż osiem definicji jakości życia. Wymieniają one w różnych aspektach przeważnie takie elementy, jak poziom satysfakcji z życia połączony z subiektywnymi i obiektywnymi wskaźnikami poziomu życia; indywidualna percepcja swojej pozycji życiowej w kontekście kulturowym i systemu wartości w odniesieniu do swoich celów, oczekiwań, standardów i przekonań; czy poziom satysfakcji ze swojego życia ${ }^{142}$. Co więcej, wydaje się, że wybory te nie wyczerpują potencjalnej, pełnej liczby możliwych do opracowania wyznaczników jakości życia.

${ }^{139}$ A. Zborowski, Wybrane aspekty badań poziomu i jakości życia w dużym mieście, [w:] I. Jażdżewska (red.), Zróżnicowanie warunków życia ludności w mieście, Wydawnictwo Uniwersytetu Łódzkiego, Łódź 2004, s. 20-21; J. Piasny, Poziom i jakość życia ludności oraz źródta i mierniki ich określania, „Ruch Prawniczy, Ekonomiczny i Socjologiczny”, z. 2/1993, s. 77-78; T. Borys, P. Rogala, op. cit., s. 13; I. van Kamp, K. Leidelmeijer, G. Marsman, A. de Hollander, Urban environmental quality and human well-being. Towards a conceptual framework and demarcation of concepts; a literature study, „Landscape and Urban Planning", nr 65/2003, s. 7.

${ }^{140}$ A. Wallis, Jakość życia - problemy..., s. 143.

141 M. Mularska-Kucharek, op. cit., s. 43, 48, 51.

${ }^{142}$ I. van Kamp et al., op. cit., s. 7. 
W opinii Tadeusza Borysa i Piotra Rogali możliwe jest wskazanie aż siedmiu głównych typów klasyfikacji jakości życia, ,sugerują[cych] wyraźnie, że każde konkretne badanie powinna poprzedzić refleksja o tym, jaką - z punktu widzenia wyróżnionych typologii - jakość życia analizujemy"143.

Klasyfikacją opisywaną najczęściej jest podział ze względu na kryterium obiektywności. Według przywołanych autorów rozumiana w ten sposób „obiektywna” jakość życia dotyczy takich zagadnień, jak: aktywność ekonomiczna, sytuacja dochodowa i sposób gospodarowania dochodami, wyżywienie, zasobność materialna, warunki mieszkaniowe, korzystanie z pomocy społecznej, kształcenie dzieci, uczestnictwo w kulturze i wypoczynku, korzystanie z usług systemu ochrony zdrowia, ubezpieczenia i zabezpieczenia emerytalnego, postawy proekologiczne. „Subiektywna jakość życia to ocena stopnia zaspokojenia potrzeb”, określana przy użyciu wskaźników takich jak ogólna ocena życia fizycznego, zadowolenia z poszczególnych dziedzin i aspektów życia fizycznego, psychicznego, dobrostanu duchowego, wsparcia społecznego, ocena swojej sytuacji na rynku pracy i kariery zawodowej, stylu życia oraz indywidualnego zachowania i nawyków ${ }^{144}$. Na tej podstawie Andrzej Zborowski wyróżnia dwa podstawowe jego zdaniem ujęcia jakości życia, mówiąc o „1) węższym (sensu stricto) - jako ocena subiektywna poziomu życia, [oraz] 2) szerszym (sensu largo) - jako całokształt warunków życia ocenianych kategoriami obiektywnymi i subiektywnymi”"145.

Kluczowym problemem w przypadku badań nad jakością życia jest operacjonalizacja tej kategorii: liczba aspektów życia, które należy poddać badaniu odnoszącemu się do pomiaru jego jakości. Nawet w przypadku agregacji wskaźników do poziomu grup wyższego rzędu w dalszym ciągu odnosić się musi z konieczności do bardzo licznych zmiennych. Przekrojowa publikacja Borysa i Rogali opisuje zróżnicowane typy badań o odmiennych metodykach. Autorzy ci wyróżniają na szczeblu europejskim programy takie jak Urban Audit, czyli badanie obejmujące 286 wskaźników obiektywnych i 23 pytania o wskaźniki subiektywne, wykonywane dla kilkuset miast wszystkich państw członkowskich Unii Europejskiej i Turcji. Innymi typami programów są prowadzone już na mniejszą skalę Europejskie Badania Jakości Życia oraz Statystyka Dochodów i Warunków Życia Krajów Unii Europejskiej (EU-SILC). Na poziomie krajowym odnotować można prowadzony od początku lat 90. XX wieku Polski Generalny Sondaż Jakości Życia czy stanowiące swoistą kontynuację tego badania diagnozy społeczne nadzorowane przez Radę Monitoringu Społecznego, w ramach których opracowywane są cyklicznie raporty Diagnoza społeczna - warunki i jakość życia Polaków, czy wreszcie program Foresight

143 T. Borys, P. Rogala, op. cit., s. 10-16.

144 Ibidem, s. 13-14.

145 A. Zborowski, op. cit., s. 21. 
2020. Osobny nurt stanowią raporty publikowane przez organy statystyki publicznej. Do tej kategorii włączać należy nie tylko Główny Urząd Statystyczny, ale i na przykład Centrum Badania Opinii Społecznej. Z premedytacją nie omawiam w tym miejscu złożonej metodyki każdego z przytoczonych badań.

Jakość życia porównywana bywa też na większą skalę, czego dowodzą próby mierzenia jej przez Program Narodów Zjednoczonych do spraw Rozwoju (UNDP) poprzez wskaźnik rozwoju społecznego (HDI, Human Development Index) ${ }^{146}$. Indeks ten wydaje się wyjątkowo ciekawym miernikiem, tym bardziej że podstawą międzynarodowych badań porównawczych dotyczących zagadnień rozwojowych ciągle pozostaje przede wszystkim produkt krajowy brutto (PKB), dla celów porównawczych podawany zazwyczaj w formie per capita. PKB jako miara dotycząca przepływu strumieni pieniężnych tylko pośrednio i niedokładnie (ze względu na niedoszacowanie różnic cen czy szarej strefy), odnosi się do kwestii różnic rozwojowych. W rzeczywistości mierzy ekonomistyczną kategorię wzrostu (growth), mającą niewielkie przełożenie na realny byt przeciętnych ludzi, w przeciwieństwie do holistycznego rozwoju (development) ${ }^{147}$. Poziom jakości życia mierzony jest też na poziomie lokalnym przez poszczególne samorządy czy podmioty prywatne, w tym firmy konsultingowe konstruujące rankingi miast. Zestawienia tego rodzaju mają charakter zarówno krajowy, jak i międzynarodowy. W przypadku ich beneficjentów stanowią cenne narzędzie marketingowe, które wspiera starania miejskich włodarzy w konkurencyjnej walce o cenne zasoby. Jakość życia nie jest jednak jedyną podstawą rankingów, które najczęściej koncentrują się na takich zagadnieniach, jak poziom konkurencyjności czy „inteligencji” miasta. Obie te kategorie poddaje się krytyce, jako że podobnie jak PKB nie są to miary odnoszące się do egzystencji przeciętnego mieszczanina. Łatwo też można nimi manipulować. Teoretycznie wdrożenie rozwiązań informatycznych charakterystyczne dla smart city możliwe

146 T. Borys, P. Rogala, op. cit., s. 18-47.

147 O niedokładności i „obsesji wzrostu” PKB zob. G. Rist, Urojenia ekonomii, tłum. Ś.F. Nowicki, Instytut Wydawniczy Książka i Prasa, Warszawa 2016, s. 173-177. W kontekście kultu szybkiego wzrostu oraz niedoszacowania skumulowanego wzrostu uwagę zwraca także zdanie Thomasa Piketty'ego. Wskazuje on, że w ,horyzoncie roku wzrost o $1 \%$ może wydawać się bardzo słaby, prawie niezauważalny, i rzeczywiście zainteresowane osoby mogą go nie dostrzegać gołym okiem, odnosząc wrażenie kompletnej stagnacji i powtarzania się przeszłości z roku na rok. Wzrost wydaje się wówczas pojęciem abstrakcyjnym, czystą konstrukcją matematyczną i statystyczną. Ale w perspektywie pokolenia, czyli około trzydziestu lat, co [...] stanowi lepszą skalę czasu dla oceny zmian zachodzących w danym społeczeństwie, ten sam wzrost odpowiada progresji o ponad jedną trzecią, co oznacza zasadnicze przekształcenie. Jest to mniej spektakularne niż wzrost o 2-2,5\% rocznie, prowadzący do podwojenia w każdym pokoleniu, ale wystarczy do głębokiego, regularnego odnawiania społeczeństwa i przekształcenia go na dłuższą metę”. Zob. T. Piketty, Kapitat w XXI wieku, tłum. A. Bilik, Wydawnictwo Krytyki Politycznej, Warszawa 2015, ebook. 
jest w mieście, które nie rozwiązuje podstawowych problemów sanitarnych ${ }^{148}$. Co więcej, narzędzia technologiczne mogą też wzmacniać wykluczenie społeczne wybranych grup. „Kapitał często używa technologii jako broni w walce klas”, przekonuje w tym kontekście teoretyk David Harvey ${ }^{149}$. Z kolei w opinii Alessandra Vanola upowszechnienie inteligentnych technologii (smartness) ułatwia inwigilację życia prywatnego $^{150}$. Te rankingi, które tworzone są na podstawie badań jakości życia, wydają się zdecydowanie bardziej odporne na podobną krytykę.

Wskaźniki jakości życia można mnożyć i łączyć w grupy, zależnie od potrzeb badania i stosowanej metodyki. Z wielości ujęć przytoczyć można przykład najbardziej znanego polskiego badania jakości życia, opracowywanego cyklicznie w ramach Diagnozy społecznej ${ }^{151}$, czy podział dokonany przez Gordona Mitchella ${ }^{152}$. Kolejną typologię podają Linda Steg i Robert Gifford. Zwrócili oni też uwagę,

że prawdopodobnie nie wszystkie aspekty (domeny) życia są dla ludzi tak samo ważne. [...] Wśród 22 zasadnicz[ych] aspektów [...][, wyróżniono] w kolejności od najważniejszych do najmniej ważnych [takie wskaźniki jak]: zdrowie, związki, sprawiedliwość społeczna, swoboda, bezpieczeństwo, edukacja, tożsamość i duma, prywatność, jakość środowiska, relacje społeczne, praca, bezpieczeństwo, bioróżnorodność, rozrywka, finanse, komfort życia, estetyka, różnorodność życia, wyzwania, pozycja społeczna i jej rozpoznawalność, religia oraz piękno wokół domu (na przykład zadbane posesje) ${ }^{153}$.

148 Dietmar Offenhuber wskazuje, że „smart city umarło. [...] Chaotyczna infrastruktura miejska i jej historyczna spuścizna, specyfika instytucjonalna, krucha sieć czujników w surowym środowisku zewnętrznym oraz wynikające z umów ograniczenia pracowników sektora publicznego, a przede wszystkim niespełnione prognozy dotyczące dużej inicjatywy rządowej związanej z infrastrukturą po recesji w 2008 roku: wszystkie te czynniki sprawiają, że smart city wydaje się nieatrakcyjne. Zamiast borykać się ze złożonością materialnej infrastruktury miast oraz struktur organizacyjnych, firmy [...] skupiają się na tym, co potrafią robić najlepiej i co się bardziej opłaca: oferują usługi analityczne związane z ogromną ilością danych, którymi miasta już dysponują”. Zob. D. Offenhuber, Technologie obywatelskie. Narzędzia czy terapia?, [w:] K. Piekarski (red.), Metody badania i odkrywania miasta oparte na danych, Medialab Katowice, Katowice 2015, s. 39-40.

${ }^{149}$ D. Harvey, The Enigma of Capital and the Crises of Capitalism, Oxford University Press, New York 2010, s. 96.

150 A. Vanolo, Smartmentality. The Smart City as Disciplinary Strategy, „Urban Studies”, nr 5/2014, s. 894.

151 J. Czapiński, Jakość życia w Polsce - wygrani i przegrani, [w:] J. Czapiński, T. Panek (red.), Diagnoza społeczna 2015. Warunki i jakość życia Polaków. Raport, Rada Monitoringu Społecznego, Warszawa 2015, s. 418.

$152 \mathrm{G}$. Mitchell, Indicators as tools to guide progress on the sustainable development pathway, [w:] R.J. Lawrence (red.), Sustaining Human Settlement. A Challenge for the New Millennium, Urban International Press, North Shields 2000, s. 55-104.

153 Za: M. Dębek, B. Janda-Dębek, Jakość życia w przestrzeniach zurbanizowanych - definicje, podsumowanie wyników badań oraz problemy metodologiczne, „Czasopismo Psychologiczne”, nr 2/2013, s. 254. 
Jak komentują te badania Michał Dębek i Bożena Janda-Dębek, nie wiadomo jednak, czy taka hierarchia wartości rzeczywiście wpływa na jakość życia w stopniu zidentyfikowanym przez respondentów. Kolejną niewiadomą jest to, na ile istotny był tu kontekst kulturowy badanej próby, skoro badania prowadzone były wśród Holendrów ${ }^{154}$. Najbardziej zawiłe metodyki obliczania jakości życia uwzględniają tysiące zmiennych, tak typu obiektywnego, jak subiektywnego. W rzeczywistości analizy te mogą być wówczas opracowywane jedynie przez rozbudowane zespoły badawcze, nieuchronnie wystawione na ryzyko błędów pomiaru, wpływających następnie na wartość całej klasyfikacji. W wyniku tego

rozbudowa systemu mierników analitycznych ma swoje złe strony; w powodzi szczegółów można zgubić obraz całości. Trudne jest bowiem, jeżeli nie wręcz niemożliwe, wyrobienie sobie ogólniejszego poglądu na temat poziomu życia na podstawie zestawienia dziesiątek a nawet setek różnych mierników, z których każdy istotny jest dla oceny dobrobytu społecznego, ale dotyczy tylko jednego i na ogół bardzo wąskiego poziomu życia ${ }^{155}$.

Badania takie mogą być jednak dobrym punktem wyjściowym do analizy czynnikowej o właściwościach redukcyjnych. Jest to istotne w świetle wyborów metodycznych zastosowanych przeze mnie samego w dalszej części książki.

\subsubsection{Jakość życia w środowisku zurbanizowanym}

W związku z gwałtowną urbanizacją środowisko miejskie staje się coraz bardziej dominującym obszarem ludzkiej egzystencji. Podczas gdy po raz pierwszy w historii przewiduje się stopniowe kurczenie się światowej populacji wiejskiej, gwałtowny przyrost liczby ludności związany będzie w 95 procentach z miastami ${ }^{156}$. Z tego punktu widzenia niezwykłej wagi nabiera kwestia pomiaru jakości życia w środowisku zurbanizowanym. Robert W. Marans i Robert J. Stimson określają tym mianem

satysfakcję, którą jednostka uzyskuje z otoczenia ludzkiego, warunków psychicznych, warunków zależnych od skali i mogących wpływać na zachowanie indywidualnych osób, grup takich jak gospodarstwa domowe i jednostki ekonomiczne takie jak firmy ${ }^{157}$.

154 Ibidem.

155 J. Piasny, op. cit., s. 75.

156 M. Davis, Planeta slumsów, tłum. K. Bielińska, Instytut Wydawniczy Książka i Prasa, Warszawa 2009, s. 11-12.

157 R.W. Marans, R.J. Stimson, Introduction, [w:] eidem (red.), Investigating Quality of Urban Life. Theory, Methods and Empirical Research, Springer, Dordrecht-Heidelberg-London-New York 2011, s. 1. 
Autorzy ci proponują dla takich pomiarów stosowanie trzech rodzajów wskaźników: obiektywnych, subiektywnych oraz behawioralnych. W pierwszej grupie badacze ci wymieniają następujące mierniki: stopa zatrudnienia, poziom wykształcenia, dochód per capita, statystyki odnoszące się do poziomu przestępczości, przemocy domowej, śmiertelności, zachorowalność na choroby przewlekłe, jakość powietrza, gęstość zaludnienia, liczba pustostanów (housing vacancy rate), powierzchnia parków, liczba pojazdów transportu publicznego, odległość do przystanku transportu publicznego, dostępność sklepów spożywczych czy długość wykonywanych podróży. Do wskaźników subiektywnych należą zaś: satysfakcja z mieszkania i sąsiedztwa, cele podróży, opinie dotyczące przestępczości, jakości szkół, systemu opieki zdrowia, odczucia w kwestii gospodarki odpadami, kongestii, przeludnienia, działalności władz lokalnych, satysfakcja z własnego zdrowia, rodziny, znajomych, pracy, ogólny poziom satysfakcji z życia. Ostatnią grupę, wskaźniki behawioralne, opisują za pomocą przykładów takich jak: poziom użytkowania transportu publicznego, uprawianie sportu, powierzchnia przeznaczona dla podróży pieszych i rowerowych, uczestnictwo w wydarzeniach kulturalnych i korzystanie z instytucji kultury, użytkowanie parków, użytkowanie zakładów opieki zdrowotnej, powierzchnia sąsiedztw, poziom zaangażowania w wolontariat, partycypacja obywatelska na poziomie lokalnym oraz mobilność mieszkaniowa ${ }^{158}$. Wskaźniki te są niekiedy agregatami mierników bardziej szczegółowych. Istotne jest przy tym, że obiektywne nie muszą odnosić się wyłącznie do danych infrastrukturalnych. Co więcej, jak podają ci autorzy, obok wskaźników fizycznych odnoszących się do takich elementów infrastruktury szarej, jak drogi czy gęstość zabudowy, oraz zielonej, jak parki i plaże, równie dobrze wskazać można obiektywne wskaźniki społeczne. Te ostatnie intuicyjnie należy kojarzyć raczej z grupą mierników subiektywnych. W gronie obiektywnych wskaźników społecznych wyróżnić dają się takie, jak poziom przestępczości czy zróżnicowania kulturowego ${ }^{159}$.

Pamiętać należy przy tym, że kategoria zróżnicowania, pozornie stosunkowo mało istotna w monokulturowym polskim kontekście, jest wrażliwa na własności lokalnych kontekstów społeczno-przestrzennych. Może odnosić się zarówno do tak kwestionowanych pod względem naukowej użyteczności wskaźników, jak Floridiański gay index i inne elementy teorii tego autora krytykowane już nawet przezeń samego ${ }^{160}$, jak i mierników mających wieloletnią tradycję, ugruntowaną w socjologii miasta. Takim indykatorem jest zwłaszcza zróżnicowanie rasowe,

158 Ibidem, s. 3.

${ }^{159}$ R. Stimson, R.W. Marans, Objective Measurements of Quality of Life Using Secondary Data Analysis, [w:] eidem (red.), op. cit., s. 34.

160 Ł. Drozda, Miejska wspólnota nie dla każdego, „Autoportret. Pismo o dobrej przestrzeni”, nr 4/2015, s. 94. 
szczególnie użyteczne w przypadku badań nad gentryfikacją w miastach wieloetnicznych. Jeden z autorów ukuł nawet definicję gentryfikacji jako sumy „wysiedleń, utraty dziedzictwa kulturowego, napływu bogatych i wybielania (whiteness)" poddanego temu procesowi sąsiedztwa ${ }^{161}$. Opracowanie użytecznych wskaźników zróżnicowania kulturowego w kontekście Polski wydaje się istotnym, acz trudnym wyzwaniem dla rodzimych studiów nad waloryzacją przestrzeni. Można sobie bowiem wyobrazić przezwyciężenie prób operacjonalizacji stosownych zmiennych, na przykład odsetka nieheteronormatywnych gospodarstw domowych czy stopnia uczestnictwa w praktykach religijnych Kościoła rzymskokatolickiego - w obu przypadkach mierzonych dla danego sąsiedztwa. Wyzwaniem może być jednak ich pomiar i uzyskanie miarodajnych wyników. Mniej istotne zdają się natomiast wskaźniki odnoszące się do zróżnicowania etnicznego. Pomimo ustabilizowania się i postępującej integracji w Polsce takich mniejszości narodowych, jak obecni od wczesnych lat 90. XX wieku Wietnamczycy i Czeczeni, ciągle stanowią one niewielki odsetek populacji. Sytuacji tej nie zmienia kryzys uchodźczy. Nie tylko zresztą ze względu na zachowawczą politykę migracyjną prawicowych rządów Platformy Obywatelskiej, Polskiego Stronnictwa Ludowego i Zjednoczonej Prawicy. Oddziałuje w tym kontekście też niechęć imigrantów do przybywania do Polski graniczącej bądź związanej wspólną polityką wizową ze znacznie bardziej zasobnymi finansowo i już zróżnicowanymi kulturowo państwami „starej” Uniii ${ }^{162}$. Badania zróżnicowania mogą odnosić się zatem właściwie wyłącznie do niewielkiego, lokalnego kontekstu takiego jak pojedyncze osiedla ${ }^{163}$. Podobne konstatacje dotyczą przedstawionego w tej rozprawie tureckiego studium przypadku. Skala homofobii w tutejszym kontekście właściwie uniemożliwia dokonywanie jakichkolwiek pomiarów odsetka mniejszości seksualnych w ogóle populacji.

Z punktu widzenia istotnej dla moich rozważań waloryzacji przestrzeni wytwarzanych społecznie ważne jest więc należyte zróżnicowanie mierników jakości życia, tak aby ukazywały one poszczególne wymiary funkcjonalności przestrzeni zurbanizowanej. Wydaje się, że umożliwi to równoczesne wykorzystanie indykatorów o charakterze „obiektywnym”, subiektywnym i behawioralnym. Przy doborze takich wskaźników należy jednak zwrócić uwagę na trafność ich zastosowania

161 P. Moskowitz, op. cit., ebook.

162 Dyskusyjna jest oczywiście kwestia bardzo licznej już mniejszości ukraińskiej, której populację szacuje się na około 1,5 mln osób. Odmienności kulturowe i etniczne tych imigrantów nie są jednak aż tak silnie zarysowane. Testem na trwałość ich diaspory będzie natomiast nadchodząca liberalizacja niemieckiego rynku pracy.

163 Przykład stanowi tutaj chętnie zasiedlane przez warszawską mniejszość wietnamską blokowisko osiedla Za Żelazną Bramą. Zob. S. Toruńczyk-Ruiz, Sq̨siedztwo i sq̨siedzi w opiniach Polaków i cudzoziemców, „Biuletyn Migracyjny”, nr 28/2011, https://sites.google.com/site/biulletynmigracyjny/archiwum-html/biuletyn-migracyjny-28/bm28art3, dostęp: 15.07.2016. 
w określonym kontekście geograficznym i społecznym. Szczególnie problematyczne są w tym zakresie wskaźniki zróżnicowania kulturowego.

\subsection{Spoleczne wytwarzanie przestrzeni miasta}

\subsubsection{Proces spolecznego wytwarzania przestrzeni}

Spośród licznych typologii przestrzeni często stosuje się intuicyjny podział na przestrzeń naturalną oraz przetworzoną przez człowieka. Symbolem tej pierwszej jest przyroda czy uchodzący za bliższy naturze krajobraz wiejski, jak określa tereny niezurbanizowane Christopher Alexander ${ }^{164}$. Alternatywą dlań jest środowisko zbudowane, którego emanację stanowi zwłaszcza miasto. Pragnienie kontaktu z naturą rozumianą jako przyroda jest jednak powszechne, o czym świadczy zjawisko suburbanizacji. Wśród źródeł motywacji „ucieczki z miasta” wyróżnić można między innymi chęć kontaktu z przyrodą - przez własny ogród czy spacery po „naturalnej” okolicy. Z biegiem czasu suburbanitów przybywa, wskutek czego ich okolica traci naturalne walory. Innymi słowy, następuje urbanizacja.

Powstaje wobec tego pytanie, czy w ogóle istnieje coś takiego jak naturalna przestrzeń? W hierarchii krajobrazów obok kulturowego (silnie przetworzonego przez człowieka, do tej kategorii zaliczyć należy środowisko zurbanizowane), wyróżnić można także naturalny (o ograniczonym wpływie człowieka) i pierwotny (pozbawiony jego wpływu). W rzeczywistości krajobrazy pierwotne już niemal nie istnieją. Przestrzenie kojarzone powszechnie z naturą stanowią pochodną zagospodarowania przez ludzi prowadzących świadomą gospodarkę rolną i leśną. Na przykład niemal wszystkie lasy w Polsce pełnią funkcję produkcyjną i wszystkie są objęte obowiązkiem szczegółowej inwentaryzacji. W naszej części Europy istnieje w tej chwili wyłącznie jeden nizinny las pierwotny, czyli taki, który nie został ukształtowany pod wpływem człowieka. Jest to Puszcza Białowieska. Jednakże polityczne targi i zakusy na produkcyjną sferę funkcjonowania tej przestrzeni leśnej pokazują, że również i ona kształtowana jest przez działania ludzi. Także przez zaniechanie i wyznaczenie ścisłych granic naturalności, związanych z zakresem form ochrony przyrody ${ }^{165}$.

W dobie nawigacji satelitarnej trudno mówić o występowaniu jakichkolwiek ziem nieznanych (łac. terrae incognitae) czy tym bardziej ziem niczyich (łac. terrae nullius). Druga z przywołanych kategorii, ochoczo stosowana w epoce odkryć geograficznych i następującego po niej kolonializmu, była tak naprawdę rasistow-

${ }^{164}$ Ch. Alexander et al., op. cit., s. 38.

165 P. Sztompka, Socjologia wizualna. Fotografia jako metoda badawcza, Wydawnictwo Naukowe PWN, Warszawa 2005, s. 35. 
skim wytłumaczeniem dla podporządkowywania sobie ziem zamieszkanych przez inne ludy niż biali chrześcijanie. Stąd też powstawały takie teorie, jak orientalizm, łączący w spójną całość przeciwieństwo świata okcydentalnego (zachodniego). Prowadził on do ujednolicających generalizacji kulturowych regionów tak zróżnicowanych, jak na przykład Afryka Równikowa i Indochiny. Innym jego następstwem była koncepcja swobodnego eksploatowania obcych kulturowo światów wraz z bezwzględnym wyzyskiem ich ludności i ziemi ${ }^{166}$. W tym sensie każda znana współcześnie przestrzeń stanowi skutek działań człowieka, którego wytworu stanowić nie mogą prawdopodobnie tylko ziemie niczyje. Jak wskazuje Anna Cymer, przykłady takich przestrzeni są jednak nieliczne. Typowe dla nich warunki do pewnego stopnia spełniają już tylko przestrzeń kosmiczna, części mórz i oceanów oraz uniemożliwiające egzystencję człowieka ziemie Arktyki i Antarktydy ${ }^{167}$. Postępujące globalne ocieplenie i inne skutki wpływu antropogenicznego sugerują jednak, że jedynym rodzajem przestrzeni niewytworzonej z udziałem człowieka jest prawdopodobnie ciągle przerastająca jego możliwości technologiczne przestrzeń kosmiczna. W zakres waloryzacji przestrzeni wytwarzanych społecznie można zatem włączyć niemal całą przestrzeń o materialnym wymiarze. Nie każda jednak przestrzeń jest związana przedmiotowo $\mathrm{z}$ oddolnym sposobem jej wytwarzania, a więc takim, który jest właściwy urbanistyce oddolnej.

Realnie powiązana z egzystencją człowieka i interesująca z punktu widzenia niniejszej pracy przestrzeń zamieszkana, ,nie jest tworem natury, lecz dziełem na wskroś ludzkim, przez ludzi wytworzonym w sposób uwarunkowany czynnikami przyrodniczymi, społecznymi i kulturowymi”"168. Tę myśl Bohdana Jałowieckiego uzupełnił Edward Soja. Zauważył on, iż „sama w sobie może być pierwotnie dana, ale organizacja i znaczenie przestrzeni stanowi produkt społecznych tłumaczeń, transformacji i doświadczeń” ${ }^{169}$. Stwierdzenie, że przestrzeń zamieszkana jest produktem procesu wytwórczego, stanowiącego wynik działalności ludzi, prowokuje postawienie pytania o sposoby jej wytwarzania. W opinii Jałowieckiego wyróżnić można „trzy główne paradygmaty wyjaśniania sposobu wytwarzania przestrzeni” ${ }^{170}$.

166 E.W. Said, Orientalizm, tłum. M. Wyrwas-Wiśniewska, Zysk i S-ka, Poznań 2005, passim; S. Lindqvist, Wytępić całe to bydło, tłum. M. Haykowska, W.A.B., Warszawa 2009, passim; J. Ziegler, Nienawiść do Zachodu, tłum. E. Cylwik, Instytut Wydawniczy Książka i Prasa, Warszawa 2010; M. Bobako, Islamofobia jako technologia władzy. Studium z antropologii politycznej, Universitas, Kraków 2017, s. 20.

167 A. Cymer, Terrae nulius - ziemie niczyje, [w:] B. Świątkowska (red.), My i oni. Przestrzenie wspólne / projektowanie wspólnoty, Fundacja Bęc Zmiana, Warszawa 2014, s. 375-380.

168 B. Jałowiecki, Społeczne wytwarzanie..., op. cit., s. 11.

169 E. Soja, Postmodern Geographies. The Reassertion of Space in Critical Social Theory, Verso, London-New York 1990, s. 79-80.

170 B. Jałowiecki, Społeczne wytwarzanie przestrzeni..., op. cit., s. 12. 
Pierwszy z nich - woluntarystyczno-kreacyjny - odnosi się do przestrzeni kształtowanej

przez architekta i urbanistę zgodnie z jego wiedzą i talentem, a architektura i urbanistyka jest [tutaj] zarazem nauką i sztuką wytwarzania przestrzeni [...] W skrajnym przypadku projekt przestrzenny staje się sui generis projektem społeczeństwa, kształtowania nowych zachowań, więzi społecznej itp. W tej sytuacji architekt i urbanista przyjmuje na siebie rolę demiurga starającego się zmienić niedoskonały świat ${ }^{171}$.

Tego rodzaju wytwarzanie „demiurgiczne” zakłada możliwość prowadzenia rzeczywistego procesu projektowego w przemyślany sposób. Za archetypiczny wręcz przykład w odniesieniu do tego podejścia uznać można projekty barona Georgesa Haussmanna, prefekta cesarskiego z okresu panowania Napoleona III i autora koncepcji przebudowy Paryża w II połowie XIX wieku ${ }^{172}$. Za inny i bardziej współczesny, Roberta Mosesa. Ten wpływowy urzędnik u szczytu kariery zajmował „W nowojorskim ratuszu jednocześnie aż 12 stanowisk kierowniczych, posiadając przy tym faktyczną władzę nad decyzjami dotyczącymi rozwoju miasta"173. Uczyniło to zeń prawdopodobnie najbardziej wpływowego urbanistę modernistycznego. Obaj planiści dokonywali głębokich zmian w istniejącej siatce urbanistycznej, radykalnie przekształcając oblicza swoich miast.

Do projektów „demiurgicznych” zaliczyć można też świadome strategie związane z mniej lub bardziej utopijnymi koncepcjami tworzenia nowych siedlisk ludzkich. Wymienić można wiele takich realizacji: od zaplanowanych stolic, takich jak Astana, Brasilia, Naypyidaw czy Waszyngton, przez mniejsze miasta różnych epok, włącznie z Czandigarh dokończonym po tragicznej śmierci Macieja Nowickiego przez Le Corbusiera czy rodzimym Zamościem, aż po niezrealizowane miasta-ogrody Ebenezera Howarda ${ }^{174}$ i plan Voisin Le Corbusiera ${ }^{175}$. Do tego dochodzą wielkie widowiska mające oblicze również architektoniczne. Ich emanację stanowi na przykład gorączkowa rozbudowa infrastruktury na Euro 2012 w Polsce, prowadzona tak, aby „nie trzeba było się wstydzić przed obcokrajowcami” ${ }^{176}$. Wreszcie zaś - strategie rewitalizacyjne. W tym ostatnim zakresie ikoną „demiurgicznego” wytwarzania przestrzeni jest baskijskie Bilbao. Przemiana tego miasta stanowi owoc prawdopodobnie najbardziej udanej i globalnie rozpoznawalnej rewitalizacji obszaru poprzemysłowego, który dawniej słynął raczej z gospodarczej degradacji

171 Ibidem, s. 12.

172 J. Rykwert, op. cit., s. 131-132.

173 M. Świderski, Paradoks Roberta Mosesa, „Rzut”, nr 6/2014, s. 14-15.

${ }^{174}$ E. Howard, Miasta-ogrody jutra, tłum. M. Trykozko, Centrum Architektury, Instytut Kultury Miejskiej, Warszawa-Gdańsk 2015, passim.

175 Le Corbusier, Plan Voisin, http://bit.ly/2Own8oQ, dostęp: 25.03.2019.

176 Ł. Drozda, Dwa tysiące. Instrukcja obsługi polskiej urbanizacji w XXI w., Fundacja Bęc Zmiana, Warszawa 2018, s. 217-218. 
i terroryzmu ETA. Dzisiaj jest to miejsce modne i znane z takich ikon, jak filia Muzeum Guggeinheima zaprojektowana przez Franka Gehry'ego czy terminal lotniczy autorstwa Santiago Calatravy. Są to symbole przemian stanowiących obiekt marzeń samorządów miejskich całego świata, znanych pod nazwą „efektu Bilbao" ${ }^{177}$. Lista ta wydaje się zresztą nie zamykać na wskazanych przykładach. Przy tej okazji warto też wspomnieć o swoistym akcie „demiurgicznym”, jakim była powojenna odbudowa Warszawy.

W obrębie drugiego podejścia wskazywanego przez Jałowieckiego - mechanistyczno-deterministycznego - wytwarzanie przestrzeni przebiega natomiast

poprzez identyfikację anonimowych sił zarazem przyrodniczych i społecznych, które działają niezależnie od woli jednostek zredukowanych do pojęcia homo oeconomicus, postrzegających przestrzeń na poziomie podspołecznym. Przykładem takiego sposobu wyjaśniania są koncepcje chicagowskiej szkoły ekologii ludzkiej ${ }^{178}$.

Ta klasyczna, pionierska w obrębie socjologii szkoła badała miasta, rozpatruje je jako wytwory „naturalnych” i „,bezosobowych” procesów. Procesy te związane są w jej ujęciu z liczbą ludności miast, gęstością ich zaludnienia oraz zróżnicowaniem społecznym mieszkańców i formami życia zbiorowego ${ }^{179}$. Wszystkie te elementy stanowią czynniki kształtujące ekologiczne strefy oddziaływania oraz stratyfikujące miasto wedle zuniwersalizowanego wzorca. Mimo ogromnych zasług szkoły chicagowskiej, zwłaszcza w badaniu segregacji społecznej miast, przedstawianie w ten sposób dynamiki rozwojowej środowisk zurbanizowanych nie sprawdziło się we wszystkich przypadkach, zwłaszcza w odniesieniu do policentrycznych miast obrastających dzielnicami nędzy (slumsami) ${ }^{180}$, będącymi również przedmiotem zainteresowania jednego ze studiów przypadku przyjętych w tej pracy.

177 „Efekt Bilbao” bywa też obiektem krytyki. Dejan Sudjic, porównujący widowiskową stararchitekturę Bilbao do propagandowej hitlerowskiej Alberta Speera, parafrazuje słynne Bauhausowe hasło: „[f]orma przestała podążać za funkcją; podąża teraz za wizerunkiem. [...] Każdy teraz chce mieć ikonę. Każdy chce architekta, który zapewni to, co Gehry zrobił dla Bilbao [...]. Czasami wydaje się, że na świecie pracuje 30 architektów, latający cyrk z wiecznym jet lagiem. [...] [Ich b]udynki się zauważa. Problem polega na tym, że skoro tyle współcześnie powstających gmachów jest zwyczajnie cudacznych, skąd klient ma wiedzieć, że jego wrak, meteoryt czy latający spodek okaże się ikoną, której pożąda, a nie kupą śmieci, czego się zresztą trochę obawia”. D. Sudjic, op. cit., s. 345, 363-364. Podobny krytycyzm też w innych publikacjach: J. McGuirk, op. cit., ebook; K. Nawratek, Miasto jako idea polityczna, Korporacja Ha!art, Kraków 2008, s. 58.

178 B. Jałowiecki, Społeczne wytwarzanie przestrzeni..., s. 12.

179 B. Jałowiecki, M.S. Szczepański, op. cit., s. 24.

180 N. AlSayyad, Urban Informality as a „New” Way of Life, [w:] A. Roy, N. AlSayyad (red.), Urban Informality. Transitional Perspectives from the Middle East, Latin America and South Asia, Lexington Books, Lanham-Oxford 2004, ebook. 
Trzecim podejściem wyróżnionym przez Jałowieckiego jest z kolei paradygmat dialektyczny. Opiera się on na założeniu,

że wytwarzanie przestrzeni jest pełnym konfliktów procesem społecznym, warunkowanym przez czynniki przyrodnicze, ekonomiczne, polityczne i kulturowe ${ }^{181}$.

Paradygmat dialektyczny zakłada, że społeczne wytwarzanie przestrzeni nie ma charakteru anonimowego. Możliwe jest zidentyfikowanie konkretnych aktorów tego procesu, kierujących się często sprzecznymi interesami. Konfliktowe ujęcie dialektyczne stanowi podstawę badań miejskich marksistów, czyli tak zwanych metromarksistów.

Z miejskim marksizmem i dialektycznym (konfliktowym) podejściem do procesu wytwarzania przestrzeni związana jest zwłaszcza postać Henriego Lefebvre’a, francuskiego filozofa i socjologa, znanego zwłaszcza jako autora koncepcji prawa do miasta ${ }^{182}$. Autor ten wywarł przemożny wpływ na wiele dyscyplin koncentrujących swoją uwagę na przestrzeni. Pojęciu jej wytwarzania poświęcił przede wszystkim znaną i wywierającą ogromny wpływ na późniejsze dokonania socjologii miasta, choć nieprzetłumaczoną nigdy na język polski książkę Production de l'espace (1974) ${ }^{183}$. Przestrzeń, pisał tam, jest produktem społecznych relacji składających się na wytwarzanie przestrzeni (spatialization). Przy tym jednak

nigdy nie jest [ona] produkowana ${ }^{184} \mathrm{w}$ takim sensie jak kilogram cukru czy fragment płótna. [...] Byłoby bardziej właściwe powiedzieć, że jest ona po pierwsze warunkiem wstępnym oraz wynikiem społecznej nadbudowy ${ }^{185}$.

Przestrzeń jest zatem dla cytowanego autora produktem, którego można używać i który można konsumować, a zarazem i środkiem produkcji, który

nie może być odseparowany zarówno od sił wytwórczych, włączając technologię i wiedzę, jak i kształtowanego przez nie społecznego podziału pracy czy też od państwa i społecznej nadbudowy ${ }^{186}$.

181 B. Jałowiecki, Społeczne wytwarzanie przestrzeni..., s. 12.

${ }^{182}$ H. Lefebvre, Prawo do miasta, tłum. E. Majewska, „Praktyka Teoretyczna”, nr 5/2012, s. 183-197. Autor ten był w opinii Marka Gottdienera „być może największym myślicielem marksistowskim od czasów Marksa i pewnie jednym z największych filozofów naszych czasów". Zob. M. Gottdiener, A Marx for Our Time: Henri Lefebvre and The Production of Space, „Sociological Theory”, vol. 11, nr 1/1993, s. 129.

183 Korzystam z tłumaczenia angielskiego: H. Lefebvre, The Production of Space...

${ }^{184}$ Podobnie jak większość polskich autorów konsekwentnie stosuję termin wytwarzanie przestrzeni. Warto jednak wspomnieć także o tym, że niektórzy wolą mówić o jej produkcji; zob. np. K. Kurnicki, Ideologie w mieście. O społecznej produkcji przestrzeni, Zakład Wydawniczy Nomos, Kraków 2018, passim.

185 H. Lefebvre, The Production of Space..., s. 85.

186 Ibidem. 
Zdaniem innego metromarksisty, Neila Smitha, Lefebvre koncentruje się tym samym nie tyle na procesie produkcji przestrzeni, ile raczej na reprodukcji społecznych stosunków produkcji ${ }^{187}$. Konstytuują one centralny dlań, chociaż ukryty, proces społeczeństwa kapitalistycznego, mający w tym ujęciu charakter przestrzenny ${ }^{188}$. Charakterystyczna dla ujęcia dialektycznego reprezentowanego przez ten nurt jest krytyka koncepcji „demiurgicznych”. Jak pisał sam Lefebvre,

[a]rchitekt, urbanista, socjolog, ekonomista, filozof czy polityk nie mogą na mocy jakiegoś dekretu wywoływać z nicości nowych form i stosunków międzyludzkich. Dla uściślenia, ani architekt, ani socjolog nie posiadają władzy dokonywania cudów. Ani jeden, ani drugi nie wytwarza stosunków społecznych. [...] Tylko życie społeczne (praxis) w swoim ogólnoświatowym sprawstwie posiada taką władzę ${ }^{189}$.

Dlatego też, zgodnie z marksistowskim ujęciem kwestii klasowej, w myśl tego autora wyłącznie

grupy, klasy lub frakcje klas społecznych [...] mogą przejąć inicjatywę i doprowadzić do pełnego rozwiązania problemów miejskich ${ }^{190}$.

Teoria Lefebvre'a, w znacznym stopniu niedookreślona, doczekała się uszczegółowienia i interpretacji ze strony wielu autorów. Warto przytoczyć jej rozwinięcie autorstwa Davida Harveya ${ }^{191}$, który konstruuje „siatkę” (grid) praktyk przestrzennych na bazie trzech typów przestrzeni wyróżnionych przez Lefebvre'a. W ramach tej ,siatki” Harvey wymienia metody wytwarzania przestrzeni związane z: (1) materialnymi praktykami przestrzennymi (material spatial practices) opartymi na doświadczeniu; (2) przestrzeniami reprezentowanymi (representation of space) opartymi na percepcji przestrzeni, czyli wrażenia na temat jej rzeczywistego,

187 Na wytwarzaniu samej przestrzeni w pewnym sensie bardziej skupia się urbanistyczna teoria placemaking. B.a., Placemaking. What if we built our cities around places?, Project for Public Spaces, New York 2018, passim.

188 N. Smith, Uneven Development. Nature, Capital, and the Production of Space, The University of Georgia Press, Athens 2008, s. 123. Jak zwraca uwagę Tim Unwin, w anglosaskiej literaturze zajmującej się tematyką wytwarzania przestrzeni istnieje pewna terminologiczna niezgodność w używaniu terminów takich jak wytwarzanie-produkcja (production), budowanie (construction) oraz tworzenie (creation) przestrzeni. Niektórzy z autorów wykazują w tej materii niekonsekwencję, używając tych terminów jako synonimów, chociaż mają one różne zakorzenienie. To wytwarzanie jest tym o wyraźnych konotacjach marksistowskich, starannie używanym przez samego Lefebvre'a. T. Unwin, A waste of space? Towards a critique of the social production of space, „Transactions of the Institute of British Geographers”, nr 1/2000, s. 19.

${ }^{189}$ H. Lefebvre, Prawo do miasta..., s. 187.

190 Ibidem, s. 191.

191 D. Harvey, The Condition of Postmodernity. An Enquiry into the Origins of Cultural Change, Blackwell, Oxford 1991, s. 220-221. 
fizycznego wymiaru; oraz (3) przestrzeniami reprezentacji (spaces of representation) opartymi na wyobrażeniach podmiotu w stosunku do tej przestrzeni. W odniesieniu do pierwszej ze wskazanych kategorii autor ten pisze o wytwarzaniu fizycznej infrastruktury (transportu i komunikacji, środowiska zbudowanego, systemu gospodarki odpadami) oraz terytorialnej organizacji infrastruktury społecznej (formalnej i nieformalnej). W wymiarze percepcji przestrzeni praktykami jej wytwarzania są dlań nowe systemy mapowania, wizualnej reprezentacji, komunikacji oraz architektoniczne „dyskursy” semiotyczne. W wymiarze wyobrażeń zaś - utopijne plany, wyobrażone krajobrazy, naukowe fikcje ontologiczne, mity przestrzeni i miejsc, poetyki przestrzeni.

Typologię Harveya można uzupełnić o determinanty procesu społecznego wytwarzania przestrzeni. Jałowiecki wyróżnia wśród jego ograniczeń przyrodę (środowisko naturalne); rozwój techniki i technologii (poziom rozwoju sił wytwórczych); stosunki panowania - podległości (w aspekcie ekonomicznym stosunki produkcji - własności, w aspekcie politycznym - władza, a w aspekcie ideologicznym - ideologia klasy dominującej); oraz systemy wartości i kategorie kultury funkcjonujące w danym społeczeństwie.

W skład tego modelu wchodzi też oczywiście dominująca ideologia, chociaż nie jest ona nigdy dominująca bez reszty, do końca. Pojawiają się bowiem stale kontrideologie, które mają także swój udział w społecznym wytwarzaniu przestrzenii ${ }^{192}$.

Reasumując, w opinii Bohdana Jałowieckiego i Marka S. Szczepańskiego,

[w]szelkie typy i rodzaje przestrzeni, a przestrzeni miejskiej w szczególności, są produktem (wytworem) materialnych sił sprawczych, pozostających w związku z innymi elementami materialnymi i ludźmi. W ten sposób wytworzone stosunki materialno-społeczne nadają przestrzeni określone formy, funkcje i znaczenie w danym okresie historycznym. Podstawowe stosunki produkcji znajdują swój wyraz lub obraz w danej strukturze społecznej, ekonomicznej, politycznej i ideologicznej, a przede wszystkim w postaci praktyk przestrzennych i społecznych. W trakcie tych praktyk ludzie w poszczególnych społeczeństwach wytwarzają swoją przestrzeń, naznaczają ją i przyswajają ${ }^{193}$.

Autorzy ci konstruują też użyteczną z punktu widzenia moich rozważań definicję, w myśl której

[t]ermin „społeczne wytwarzanie przestrzeni” odnosi się w istocie do procesu przeobrażeń świata fizycznego (przestrzeni fizycznej) w świat społeczny (przestrzeń społeczną). Uspołecznienie fizycznej przestrzeni to zamanifestowanie w niej obecności człowieka, jego codziennych i świątecznych zachowań, jego potęgi, mocy lub - przeciwnie - słabości

192 B. Jałowiecki, Społeczne wytwarzanie przestrzeni..., s. 39-43.

193 B. Jałowiecki, M.S. Szczepański, op. cit., s. 33. 
i upadku. Szczególnym rodzajem społecznego wytwarzania przestrzeni jest kreacja miasta i odpowiadających im form przestrzennych o charakterze urbanistyczno-architektonicznym. Chodzi tutaj o poszukiwanie przestrzennego wyrazu dla takiego typu społecznej organizacji, jaką jest miasto, a ściślej - zbiorowość miejska ${ }^{194}$.

Definicja ta przyświeca podjętej w tej książce tematyce waloryzacji przestrzeni wytwarzanych społecznie, prowadząc do formułowania wniosków na temat urbanistyki oddolnej jako rozwiązania stosowanego w ramach polityki miejskiej.

\subsubsection{Aktorzy wytwarzający przestrzeń}

Założenie o społecznym charakterze procesu wytwarzania przestrzeni implikuje kolejne pytanie o to, kto tę przestrzeń właściwie wytwarza. Paradygmat „demiurgiczny" zakłada tradycyjne rozumienie oparte na istnieniu władzy. Na przykład samorządu dążącego do rozbudowy infrastruktury czy wielkiego inwestora biznesowego. W podejściu charakterystycznym dla ekologii społecznej ważniejsze od identyfikacji podmiotu wytwórczego (funkcję tę pełnią całe grupy społeczne) jest wskazanie typów procesu wytwarzania. Wzorce gwałtownego i dynamicznego wzrostu miasta wywoływane są tutaj przez migracje, na bazie których opracowano wzorce zachowania takie jak inwazja, przetrwanie, asymilacja, adaptacja czy kooperacja ${ }^{195}$. Metromarksiści natomiast dostrzegają w mieście konflikt o podłożu ekonomicznym, związanym z klasową rywalizacją o przestrzeń (ziemię), mogącą stanowić podstawę do akumulacji kapitału. Społeczne wytwarzanie przestrzeni staje się rezultatem tego konfliktu. Sama

[p]rzestrzeń jest [dla nich] produktem społecznym, jest wytwarzana nie przez tajemnicze siły biologiczne czy podspołeczne, ale przez konkretnych ludzi działających w realnie, historycznie ukształtowanych strukturach społecznych. Każda przestrzeń jest korelatem klas, warstw i grup społecznych. Za każdą formą przestrzenną kryją się aktorzy, którzy ją wytworzyli zgodnie ze swoimi interesami i ideologią i których potrzeby ona zaspokaja ${ }^{196}$.

Koncepcja dialektyczna pozwala identyfikować poszczególnych aktorów, którzy są zresztą historycznie zmienni. Innych aktorów wyróżnić można w odniesieniu do Średniowiecza (konflikt związany z pańszczyzną czy eksploatacją mieszczan), innych dla Polski Ludowej (akumulacja kapitału przez nomenklaturę, kwestia chłoporobotników, suburbanizacja „prywaciarzy” i „badylarzy”) czy wreszcie specyficznych dla Polski po 1989 roku. Jałowiecki jako główne grupy aktorów wskazuje współcześnie: inwestorów - korporacje i władze polityczne różnych szczebli (1); regulatorów - władze polityczne razem z urbanistami (2); wykonawców -

\footnotetext{
194 Ibidem, s. 169.

195 N. AlSayyad, op. cit., ebook.

196 B. Jałowiecki, Społeczne wytwarzanie przestrzeni..., s. 44.
} 
deweloperzy i przedsiębiorstwa budowlane (3); recenzentów - przede wszystkim media (4); oraz kontestatorów - organizacje ekologiczne i stowarzyszenia NIMBY (5) ${ }^{197}$. Klasyfikacja ta ulegać może rozbudowie. Ważnymi wykonawcami i inwestorami zarazem pozostają aktorzy indywidualni budujący na własne potrzeby, a rolę stowarzyszeń NIMBY odgrywać mogą też zrzeszenia podmiotów biznesowych. Grupy nacisku lokować mogą się wedle jeszcze innego klucza, gdy uwzględnieni zostaną aktorzy nieformalni - włącznie z organizacjami przestępczymi. Yusnani Mohd Yusof i Marek Kozlowski wyróżniają takie grupy, jak deweloperzy, właściciele nieruchomości, inwestorzy krótko- i długoterminowi, doradcy rozwojowi, wykonawcy budowlani oraz sektor publiczny ${ }^{198}$. Jeszcze inni autorzy, w ślad za teorią aktora-sieci, podnoszą też znaczenie aktorów pozaludzkich, na przykład rzeczy, miejsc czy zwierząt. Mimo odmiennego statusu także takie podmioty mają bowiem wyraźną moc sprawczą w zakresie wytwarzania przestrzeni ${ }^{199}$.

Interesy aktorów są często sprzeczne, stąd i samo społeczne wytwarzanie przestrzeni jest procesem pełnym sprzeczności. Zgodnie z paradygmatem neomarksistowskim przestrzeń odzwierciedla stosunki panowania klasowego. W szczególności czyni to ta intensywnie zurbanizowana, jako przestrzeń o najwyższej wartości ekonomicznej ${ }^{200}$, a zarazem najbardziej zawiłej mozaice społecznej. David Harvey zauważa w tym kontekście, że miasto doby neoliberalizmu jest przede wszystkim

towarem zarezerwowanym dla tych, którzy posiadają pieniądze. [...] Postmodernistyczna skłonność do wspierania, zarówno w wyborach związanych z miejskim stylem życia, jak zwyczajach konsumenckich, czy formach kulturowych tworzenia się nisz rynkowych, oznacza współczesne doświadczenie życia miejskiego jako wolności rynkowego wyboru tylko o tyle, o ile posiada się pieniądze i umiejętność bronienia się przed prywatyzacją systemu redystrybucji bogactwa [...]. Rozpleniają się centra handlowe, multipleksy i hipermarkety (budowa każdego z nich stała się dużym biznesem), jak też fastfoody i rzemieślnicze targowiska, kultury butików. Ogólnie zachodzi proces, który Sharon Zukin figlarnie ujęła jako „pacyfikację przy użyciu cappuccino”201.

197 Ibidem, s. 304. „NIMBY (not in my backyard, pol. 'nie w moim sąsiedztwie') opisuje paradoks występujący, gdy obywatele zgłaszają żądanie większej liczby publicznej infrastruktury, ale odmawiają poparcia dla budowy takiej infrastruktury w pobliżu ich własnego domu”. R.J. Johnson, M.J. Scicchitano, Don't Call Me NIMBY. Public Attitudes Toward Solid Waste Facilities, „Environment and Behavior", nr 3/2012, s. 410.

198 Y.M. Yusof, M. Kozlowski, op. cit., s. 87. Zob. też C. Colomb, Staging the New Berlin. Place Marketing and the Politics of Urban Reinvention post-1989, Routledge, Abingdon 2012, s. 30.

199 B. Latour, Reassembling the Social. An Introduction to Actor-Network-Theory, Oxford University Press, New York 2005, s. 70-74; idem, Polityka natury. Nauki wkraczają do demokracji, tłum. A. Czarnacka, Wydawnictwo Krytyki Politycznej, Warszawa 2009, s. 121-129.

${ }^{200} \mathrm{Z}$ wyjątkiem być może jedynie terenów obfitych w złoża atrakcyjnych kopalin.

201 D. Harvey, Bunt miast. Prawo..., s. 35. Przywołany cytat Zukin stanowi potoczną definicję procesu gentryfikacji. Kawa cappuccino w świecie anglosaskim uchodzi za atrybut hipsterów na podobieństwo latte z sojowym mlekiem lub latte macchiato w Polsce. 
Tę konfliktową optykę wytwarzania przestrzeni aprobuje również Andy Merrifield. Pisze on o przechwytywaniu przez kapitalistów działań pozornie sprzecznych $\mathrm{z}$ ich interesami. To bowiem

zaradność burżuazji zawsze prowadzi do powstania rynku dla radykalnych idei, $[\ldots]$ nowoczesny kapitalizm tworzy specyficzne rynkowe nisze, plądruje te idee, doprowadza do ich utowarowienia, pobiera opłaty za ich czytanie, wyzyskuje mózgi, które wpadły na te pomysły, dokonuje ich reapropracji w celu wygenerowania jeszcze większego zysku i zakumulowania kapitału²02.

Być może zbiegiem okoliczności jest, że to paryska ulica St. Honore stała się patronką sieci kawiarń wypierających z centrum Warszawy tanie bary mleczne ${ }^{203}$. Trudno jednak inaczej postrzegać cenę designerskiego wydania radykalnie antykapitalistycznej książki Czytanie kapitału. Swego czasu sprzedawano ją w berlińskim muzeum sztuki nowoczesnej Hamburger Bahnhof za 49 euro ${ }^{204}$. Przedmiotem utowarowienia może stać się nie tylko mniej czy bardziej upolityczniony opór, ale i sama praktyka użytkowania przestrzeni publicznych. Odnalezienie kolejnych nisz rynkowych tego rodzaju staje się wyłącznie kwestią czasu. Do katalogu takich praktyk można z pewnością zaliczyć fenomen aplikacji Pokémon Go. Jest to wirtualna „gra miejska” łącząca doświadczanie fizycznej przestrzeni ze światem wirtualnym za pomocą smartfona ${ }^{205}$. Latem 2016 roku w ciągu paru godzin stała się ona najczęściej pobieranym oprogramowaniem telefonów komórkowych na świecie. Pod względem liczby użytkowników błyskawicznie prześcignęła między innymi Twittera ${ }^{206}$.

Zdaniem Merrifielda mówić można także o swoistej syntezie podejścia dialektycznego i „demiurgicznego” - pod nazwą „neohaussmanizacji”. Stanowi ona według tego autora nową formę miejskiego utwierdzania panowania klasowego i akumulacji kapitału. Podporządkowane interesom kapitalistów projekty przestrzenne charakterystyczne dla klasycznej „haussmanizacji” zastępowane są tutaj przez nowe formy panoptyczne właściwe dla późnego neoliberalizmu. Mogą mieć one charakter jednocześnie przestrzenny i cyfrowy, jak ma to miejsce w przypadku

202 A. Merrifield, Nowa kwestia miejska, tłum. P. Juskowiak, Wydawnictwo Naukowe PWN, Warszawa 2016, s. 174.

${ }^{203}$ To przy tej ulicy założono klub jakobinów w czasie Wielkiej Rewolucji Francuskiej. W przypadku baru chodzi o tak zwanego Karalucha obok kampusu Uniwersytetu Warszawskiego.

${ }^{204}$ L. Althusser, E. Balibar, R. Establet, P. Macherey, J. Rancière, Das Kapital lesen, Westfälisches Dampfboot, Münster 2015.

205 A. de Souza e Silva, Pokémon Go as an HRG: Mobility, sociability, and surveillance in hybrid spaces, „Mobile Media \& Communication”, nr 1/2017, s. 3-4.

${ }^{206}$ A. Ross, The Profit in the PokéStop, https:/www.jacobinmag.com/2016/07/pokemon-go-niantic-ingress-pokestops-profits/, dostęp: 3.08.2016. 
grodzonych osiedli mieszkaniowych, systemów monitoringu oraz miejskich baz danych typu big data. Jednocześnie technologiczny wymiar neohaussmanizacji ułatwia zdaniem tego autora klasowy opór. Wyrazem takiego działania jest dlań zwłaszcza internetowy, demaskatorski portal śledczy WikiLeaks. Funkcjonuje on wprawdzie w kontrolowanym przez sektor publiczny internecie, ale władze nie potrafią go opanować ${ }^{207}$.

Na podstawie identyfikacji konfliktu klasowego wokół miejskiej przestrzeni Merrifield podejmuje też krytykę modelu miast kreatywnych i inteligentnych. Kreatywność jest dlań związana nie z innowacyjnością, ale iluzorycznym językiem neoliberalizmu. Zwłaszcza z księgowością kreatywną i rozmaitymi sposobami prywatyzowania dóbr publicznych na użytek klasy wyższej. Ponadto stosuje on autorski podział miast na pasożytnicze i generatywne. Obiektem realnego kreowania wartości dodanej są dlań te drugie, jako odpowiedzialne za realną produkcję, najczęściej będące ośrodkami globalnego Południa. Najzamożniejsze miasta Północy w tym modelu jedynie przechwytują niewytworzone przez siebie nadwyżki. Metropolie pierwszego świata, pisze Merrifield,

kiedyś produkowały rzeczy, zapewniały rzeczywiste miejsca pracy i generowały bogactwo. Teraz jednak to $w$ tych ostatnich popijające cappuccino elity bezczynnie przesiadują w modnych barach i kawiarniach, sprawdzając na swych smartfonach kursy akcji, a ich designerskie sportowe ubrania produkowane są w najpodlejszych fabrykach odzieży w takich „generatywnych miastach” jak Dhaka czy Dżakarta ${ }^{208}$.

Jednocześnie autor ten zwraca uwagę, że „pasożytniczy urbanizm zagnieżdża się wszędzie”. Przenika zarówno globalne centrum, jak i jego peryferia, które także posiadają swoje elity żyjące w innej przestrzeni, bliższej na przykład oddalonemu o tysiące kilometrów Manhattanowi aniżeli odgrodzonej mentalnie, finansowo i często fizycznie, pobliskiej dzielnicy nędzy. Pasożytnicza urbanizacja jest niebezpieczna i zagrożona wybuchami społecznych napięć. Erupcjami tego rodzaju niezadowolenia mogą być mniej i bardziej poważnie zagrażające trwałości systemu władzy rewolucje, od krwawej, Wielkiej Rewolucji Francuskiej począwszy, na ruchu Oburzonych kończąc ${ }^{209}$.

${ }^{207}$ A. Merrifield, op. cit., s. 128-129.

208 Ibidem, s. 160-161.

${ }^{209}$ Dość powszechnie stosowanym określeniem miejskich protestów pierwszej połowy drugiej dekady XXI w. jest termin ruch Occupy. Wydaje się on umocowany ze względu na dominację kulturową języka angielskiego, ale jest dyskusyjny pod względem chronologii wydarzeń. Wcześniejsze względem demonstracji w Nowym Jorku i innych miastach Stanów Zjednoczonych były bowiem wystąpienia europejskie i arabskie. Za inicjatora protestów uznać można Stéphane'a Hessela, francuskiego dyplomatę, weterana i działacza społecznego, autora hasła „oburzajcie się” (fr. Indignez-vous!). S. Hessel, Czas oburzenia!, tłum. P. Witt, Oficyna Naukowa, Warszawa 2011. 
Wieloaspektowe ujęcie problematyki społecznego wytwarzania przestrzeni sugeruje moim zdaniem konieczność odwołania się do wszystkich trzech podejść, chociaż paradygmat dialektyczny wydaje się zawierać najwięcej niuansów i czerpać z dorobku obu pozostałych. W optykę konfliktu klasowego wpisuje on bowiem zarówno stosunki władzy, jak i procesy przestrzenne, na czele z konfliktową w swoim charakterze gentryfikacją. W różnych okresach kluczowe znaczenie mogą też zyskiwać poszczególne podejścia. Pamiętać należy ponadto, że miasto, w tym nawet jego najgęściej zabudowane centrum ${ }^{210}$, nigdy nie jest zakończonym procesem. „Na tym polega podstawowa różnica pomiędzy architekturą a urbanistyką - architektura dotyczy skończonych struktur (budynków), urbanistyka dotyczy bytów, które pojawiają się i znikają"211. Częścią urbanistyki we współczesnej przestrzeni zurbanizowanej jest natomiast urbanistyka oddolna, będąca przedmiotem mojego zainteresowania.

\subsubsection{Formalne i nieformalne sposoby wytwarzania przestrzeni}

Opisane przez Andy'ego Merrifielda miasta generatywne często postrzegane są jako peryferyjna, mniej znacząca alternatywa dla „zwykłej” urbanizacji. Podejście to wydaje się jednak nie pasować do rzeczywistości. Wedle Mike’a Davisa,

miasta przyszłości nie będą zbudowane ze szkła i stali - jak wyobrażały to sobie wcześniejsze pokolenia urbanistów - lecz z suszonej cegły, słomy, plastiku z odzysku, bloków cementu i drewnianych odpadów. Zamiast strzelać w niebo światłami, świat miast XXI w. tonie w nędzy - to świat zanieczyszczeń, ekskrementów i rozkładu. Miliard mieszkańców postmodernistycznych slumsów może z zazdrością patrzeć na ruiny domów z solidnej gliny w Çatal Höyük w Anatolii, wzniesionych 9 tys. lat temu, u zarania urbanizacji ${ }^{212}$.

\section{Myśl tę podziela Nezar AlSayyad, którego zdaniem}

fenomen wzrostu miast w trzecim świecie w ciągu ostatnich czterech dekad [XX w.] wskazuje, że przyszłość [...] należy do miast takich jak Kair, Rio de Janeiro, Stambuł czy Bombaj, oraz może być najlepiej badana w odniesieniu do nich ${ }^{213}$.

To do tej nazwy odwoływali się potem Oburzeni (hiszp. Indignados), okupujący miasta wcześniej niż członkowie ruchu Occupy. Co znaczące, to właśnie w Hiszpanii Oburzeni odnieśli też realny sukces polityczny w ramach autorskich struktur politycznych - partii Podemos. W Stanach Zjednoczonych reprezentantem politycznym Occupy okazał się radykalny kandydat na prezydenta, Bernie Sanders. Działał on jednak w obrębie „starej” Partii Demokratycznej. Finalnie w wyborach prezydenckich wspierał establishmentową konkurentkę, Hillary Clinton.

${ }^{210}$ A. Wallis, Informacja i gwar. 0 miejskim centrum, Państwowy Instytut Wydawniczy, Warszawa 1979, s. 150-151.

${ }^{211}$ K. Nawratek, Miasto jako idea..., s. 30.

${ }^{212}$ M. Davis, op. cit., s. 33.

${ }^{213}$ N. Alsayyad, op. cit., ebook. 
Współczesne wytwarzanie przestrzeni zurbanizowanej ma tym samym w znacznym stopniu charakter nieformalny. Z punktu widzenia niniejszych rozważań istotne jest więc dla mnie określenie różnic między formalnym i nieformalnym społecznym wytwarzaniem tej przestrzeni.

Tradycyjna urbanizacja miała bez wątpienia charakter formalny. Historyczne miasta rzadko były wielkimi organizmami, przez co łatwiej poddawały się kontroli formalnej władzy oraz przeważnie opierały się na czytelnym planie. Jakkolwiek dzielnice nędzy stały się ubocznym produktem rewolucji przemysłowejej ${ }^{214}$, zupełnie przeobrażającej oblicze miast na całym świecie, nowoczesność nie doprowadziła początkowo do mniejszej uniformizacji środowiska zurbanizowanego. W sferze mieszkalnictwa obserwować można było wówczas narodziny budownictwa patronalnego wspieranego przez przemysłowców. Zarówno tych zorientowanych filantropijnie, jak i na reprodukcję siły roboczejej ${ }^{215}$. Wraz z rozwojem państwa opiekuńczego zaczęło ono być zastępowane przez mieszkalnictwo publiczne, zwłaszcza komunalne. Nieco rzadziej rolę tę odgrywało mieszkalnictwo społeczne. Podejście formalne było charakterystyczne następnie dla większości osiedli modernistycznych. W różnym stopniu strategię tę stosowano w państwach kapitalistycznych, realnego socjalizmu, jak też eksperymentujących z modelem mieszanym państwach rozwijających się. Po pewnym czasie w pierwszej z wymienionych grup zaczęto dostrzegać ograniczenia tego modelu. Spektakularnym przykładem stało się wyburzenie osiedla Pruitt-Igoe w amerykańskim St. Louis w 1972 roku, określone przez Charlesa Jencksa mianem symbolicznego końca modernizmu w architekturze ${ }^{216}$.

Epoka budowy wielkich blokowisk trwała dłużej w przypadku państw autorytarnych, albowiem jak podaje Justin McGuirk, dyktatury w przeciwieństwie do demokratycznie wybranych władz mogą ,łatwiej [...] zarządzać funduszami, tłumić sprzeciw i obchodzić niewygodne prawa” związane z zagospodarowaniem przestrzennym $^{217}$. Równocześnie w realno-socjalistycznej Polsce ukończono jedno z największych blokowisk warszawskich, monumentalne osiedle Za Żelazną Bramą, a później inne inwestycje tego typu. Po 1989 roku w państwach przechodzących transformację do modelu gospodarki rynkowej nastąpił odwrót od przestrzeni kreowanej odgórnie przez państwo na rzecz jej prywatyzacji. W polskim przypadku kluczową rolę w dalszym ciągu odgrywało jednak budownictwo formalne. Sektor publiczny zastąpiły korporacje budowlane (deweloperzy) oraz instytucje

${ }^{214}$ F. Engels, Położenie klasy robotniczej w Anglii, tłum. A. Długosz, Książka i Wiedza, Warszawa 1952, passim.

${ }^{215}$ A. Andrzejewski, Polityka mieszkaniowa, Państwowe Wydawnictwo Ekonomiczne, Warszawa 1987 , s. 38-55.

${ }^{216}$ Ch. Jencks, Architektura postmodernistyczna, tłum. B. Gadomska, Arkady, Warszawa 1987, s. 9.

${ }^{217}$ J. McGuirk, op. cit., ebook. 
finansowe kredytujące kapitałochłonne budownictwo ${ }^{218}$. W państwach rozwiniętych formalny wymiar mają też przestrzenie publiczne. Szczególna rola modelu formalnego w najbardziej rozwiniętych państwach świata wynika z pozycji instytucji własności w ich systemach ekonomicznych. To zresztą, w myśl kontrowersyjnej opinii Hernanda de Sota, ma stanowić kluczową przewagę konkurencyjną globalnej Północy ${ }^{219}$.

Podsystem nieformalny ${ }^{220}$ opisywany bywa jako pasożytniczy. Taki punkt widzenia reprezentują często przedstawiciele władz publicznych i innych grup zainteresowanych rozszerzaniem wpływów podatkowych. W rzeczywistości jednak podsystemy formalny i nieformalny są względem siebie komplementarne i sprzężone. Pierwszy z nich, podaje Michel S. Laguerre, stanowi przeważnie wzorzec zachowania i wyznacza granice drugiego, ponieważ samodzielnie określa własny obszar. Jego odpowiednik nieformalny reguły te akceptuje lub odrzuca, adaptując się do zmieniających się realiów podsystemu formalnego. Nieformalność jest konstruktem społecznym, który ma stale zmieniającą się strukturę. Zmiany te zachodzą w zależności od rozmiarów nieformalnych instytucji (liczby zaangażowanych osób), częstotliwości (okresu, w trakcie którego funkcjonuje), lokalizacji (zajmowanej przestrzeni) oraz strukturalnej pozycji (w ramach formalnej organizacji albo społeczeństwa jako całości). Działania podsystemu nieformalnego odpowiadają na potrzeby niezaspokajane przez podsystem formalny. Tak rozumiany podsystem nieformalny z biegiem czasu może ulegać instytucjonalizacji do charakteru formalnego lub przeciwnie, wzmacniać się w momentach kryzysowych podsystemu formalnego ${ }^{221}$.

Emanacją podsystemu nieformalnego jest nieformalne miasto. Jak twierdzi Laguerre, jest ono

wszechobecne [...]. Można je odnaleźć w procesach charakterystycznych dla nieformalnego wytwarzania [informalization] przestrzeni zurbanizowanej, nieformalnej gospodarce, nieformalnych politykach systemów sądowych, systemach klik w nowoczesnych przedsiębiorstwach i nieformalnej komunikacji w ramach publicznej biurokracji. Jest też możliwe do odnalezienia w relacjach sąsiedzkich i rodzinnych. W tym sensie jest miastem tętniącym

218 Ł. Drozda, Własność w modelu neoliberalnym na przykładzie polskiej przestrzeni zurbanizowanej po 1989 r., „Studia Regionalne i Lokalne”, nr 4/2016, passim.

${ }^{219}$ H. de Soto, Tajemnica kapitału. Dlaczego kapitalizm tryumfuje na Zachodzie a zawodzi gdzie indziej, tłum. S. Czarnik, Fijor Publishing, Chicago-Warszawa 2002, passim.

${ }^{220}$ Anglojęzyczne określenie informality zdaje się nie mieć polskiego odpowiednika. W zależności od kontekstu stosuję określenia takie jak „nieformalne miasto”, „podsystem nieformalny”, „nieformalna urbanizacja” oraz „architektura i urbanistyka nieformalna”.

${ }^{221}$ M.S. Laguerre, The Informal City, St. Martin's Press, New York 1994, s. 5-17. 
życiem. Analiza jego właściwości, funkcjonowania i relacji względem systemu formalnego jest niezbędnym krokiem na drodze do zrozumienia procesu urbanizacji ${ }^{222}$.

Czy nieformalność jest zjawiskiem pozytywnym? Część autorów zwraca uwagę na nieuchronność stosowania metod właściwych dla miasta nieformalnego. Za pioniera nurtu zwolenników nieformalnej urbanistyki uznać należy brytyjskiego architekta Johna F.C. Turnera. Autor ten, opierając się na własnych badaniach prowadzonych w dzielnicach nędzy w Peru i Meksyku, stawiał opozycję między architekturą autonomiczną (wytwarzaną przez jej użytkowników, self-determined) oraz heteronomiczną (wytwarzaną zewnętrznie, other-determined). W jego opinii budownictwo autonomiczne wyróżnia większa efektywność ekonomiczna (jako nienastawione na sprzedaż), lepiej reaguje ono na lokalne potrzeby (wypełnia standardy projektowania partycypacyjnego), a także zapewnia komfort psychiczny swoim użytkownikom-twórcom (dumę z osiągnięć, dobre samopoczucie i pobudza ich kreatywność). Turner przyznawał się do inspiracji ideami anarchistycznymi Piotra Kropotkina i wyrażał przy tym lęk o wykorzystanie jego argumentacji na rzecz polityki „leseferystycznej”. Sprzeciwiał się zarówno centralnie administrowanemu systemowi zapewniania mieszkań, jak i oparciu mieszkalnictwa na instytucjach sektora finansowego. Przede wszystkim jego opór budziło wyburzanie slumsów, które uważał za niedopuszczalne marnotrawstwo w warunkach ograniczonych zasobów ${ }^{223}$.

Argumentacja ta cieszyła się dużą popularnością w latach 60. i 70. ubiegłego stulecia. Warto wskazać szczególnie na wystawę Architecture without Architects (Architektura bez architektów, kurator Bernard Rudolsfky) odbywającą się w podobnym czasie (1964 rok) w nowojorskim Museum of Modern Art. Prezentowała ona osiągnięcia architektury nieprofesjonalnej z poprzednich epok oraz kultur innych niż zachodnie. Wystawę tę razem $\mathrm{z}$ równoległą działalnością Jane Jacobs można według Jana van Ballegooijena i Roberta Rocca wpisać w kontekst szerszej krytyki dominującej podówczas architektury modernistycznej. W latach 60 . była ona bowiem postrzegana już często jako nadmiernie zuniformizowana oraz nieskuteczna w rozwiązywaniu problemów społecznych ${ }^{224}$. Kolejna fala popularności rozwiązań

222 Ibidem, s. 25.

223 J.F.C. Turner, Housing by People. Towards Autonomy in Building Environments, Pantheon Books, New York 1977, s. XIV, XXIII, 62, 65. O „epoce buldożerów”: I. Sagan, Miasto. Nowa kwestia i nowa polityka, Wydawnictwo Naukowe Scholar, Warszawa 2017, s. 101.

$224 \mathrm{~J}$. van Ballegooijen, R. Rocco, The Ideologies of Informality: informal urbanisation in the architectural and planning discourses, „Third World Quarterly”, vol. 34, nr 10/2013, s. 1800. Zob. też M. Tobolczyk, Architektura wspótczesna. Geneza i charakterystyka wiodq̨cych nurtów, Oficyna Wydawnicza Politechniki Warszawskiej, Warszawa 2017, s. 131-132. Jacobs stwierdziła nawet w jednym ze swoich wystąpień, że „[p]aradoksalnie nowe idee w urbanistyce mogły się [...] pojawić tylko tam, gdzie mniejszy był wpływ [oficjalnej] urbanistyki”. J. Jacobs, Czy wielkie plany rozwiążą problem 
nieformalnych nastąpiła ich zdaniem po okresie zastoju obejmującym dwie ostatnie dekady XX wieku. Dziać miało się to za sprawą autorów takich jak Rem Koolhaas $^{225}$, Justin McGuirk ${ }^{226}$ czy wenezuelskie biuro projektowe Urban Think-Tank ${ }^{227}$. Ostatnie lata stanowią okres wzmożonego zainteresowania inicjatywami nieformalnymi, zwłaszcza w odniesieniu do Ameryki Łacińskiej228 lub szerzej rozumianych państw rozwijających się 229 . Szczególnym odzwierciedleniem zainteresowania architekturą nieformalną było uhonorowanie w 2016 roku nagrodą Pritzkera Alejandra Araveny. Chilijczyk ten zaprojektował osiedle Quinta Monroy, składające się z domów komunalnych zbudowanych „do połowy”. Oferują one jedynie najbardziej niezbędną infrastrukturę, co wymusza inicjatywę użytkowników i znacząco obniża koszt inwestora ${ }^{230}$.

Rozwiązania nieformalne są jednak także poddawane krytyce. Turnerowi zarzucano związki z Bankiem Światowym i forsowanie poglądów przygotowujących grunt pod wycofywanie się sektora publicznego z działań interwencyjnych i wspierających ${ }^{231}$. Szczególnym zagrożeniem w opinii krytyków tego podejścia jest kwestia uwłaszczenia właścicieli nieformalnych siedlisk, mogąca stanowić pochodną podejścia autonomicznego. Zdaniem Alana Gilberta powodem przyznawania praw własności jest fakt, że to nie tylko popularny sposób zdobywania głosów ze strony nowo obdarowanych właścicieli, ale i samo uwłaszczenie ułatwia zaciąganie pożyczek pod zastaw nieruchomości. To dlatego jest ono tak popularne na politycznej prawicy. Pozwala bowiem stać się miejskiemu biedakowi „odpowiednim obywatelem"232. Zapewnianie mieszkań jest też droższe niż legalizowanie nieformalnego

odnowy? Przemówienie podczas konferencji „Dzielnice mieszkalne a odnowa miejska” w Hamburgu, 12-14 października 1981, [w:] S. Zipp, N. Storring (red.), Jane Jacobs. Wielkie małe plany: zbiór krótkich tekstów, tłum. M. Trykozko, Centrum Architektury, Warszawa 2017, ebook.

225 http://lagos.submarinechannel.com/, dostęp: 4.08.2016.

$226 \mathrm{~J}$. McGuirk, op. cit., passim.

${ }^{227}$ http://u-tt.com/, dostęp: 4.08.2016.

${ }^{228}$ F. Hernández, M. Millington, I. Borden (red.), Transculturation. Cities, Spaces and Architecture in Latin America, Rodopi, Amsterdam-New York 2005, passim; F. Hernández, P. Kellett, L.K. Allen (red.), Rethinking the Informal City. Critical Perspectives from Latin America, Berghahn Books, New York-Oxford 2010, passim; K. Kurowski, Samoorganizacja $w$ wielkomiejskim slumsie. Przykład Limy, Wydawnictwa Uniwersytetu Warszawskiego, Warszawa 2013, passim. Ameryka Łacińska była też tematem kilku wystaw w ramach Biennale Architektury w Wenecji.

${ }^{229}$ S. Attia, S. Shabka, Z. Shafik, A. Ibrahim (red.), Dynamics and Resilience of Informal Areas. International Perspectives, Springer, Dordrecht-Oxford 2016, passim.

${ }^{230}$ http://www.elementalchile.cl/en/projects/quinta-monroy/, dostęp: 4.08.2016.

${ }^{231}$ M. Davis, op. cit., s. 106-107.

232 Warto przypomnieć, że odwołujący się do retoryki wrażliwości społecznej rząd Jerzego Buzka (1997-2001) także roztaczał wizję powszechnego uwłaszczenia polskich lokatorów. Podobną obietnicę niesie też za sobą realizowany przez rządy Beaty Szydło (2015-2017) i Mateusza 
osadnictwa. Do tego druga ze wskazanych strategii pozwala generować dochód. Oprócz podatków od nieruchomości można pobrać opłatę administracyjną związaną z procedurą legalizacji nieformalnego zamieszkania ${ }^{233}$. Ponadto, dodaje Davis, uwłaszczenie w slumsach może prowadzić do zwiększenia nierówności społecznych przez wykreowanie nowego podziału między uwłaszczonymi i najemcami, „którzy stanowią faktyczną większość ubogich”234. Dla van Ballegooijena i Rocca dyskurs urbanistyki nieformalnej niesie za sobą tym samym ,wysokie ryzyko stania się neoliberalnym narzędziem odbierania instytucji państwa legitymacji i skutecznego wpływu na rozwój urbanizacji”. Natomiast „pseudodystopijna rzeczywistość trzecioświatowych metropolii stająca się utopijną projekcją przyszłości zachodnich metropolii" jest raczej zwykłym frazesem (cliché). Jest on w ich opinii pozbawiony głębszej refleksji nad problematyką mieszkaniowego ubóstwa ${ }^{235}$.

Istotnym kontrapunktem dla krytyki podejścia nieformalnego jest fakt, iż niekoniecznie model ten musi być związany ze skrajnym ubóstwem i niską jakością środowiska zurbanizowanego. W odniesieniu do niektórych dzielnic nędzy jakość życia rzeczywiście jest tak niska, że zwolennicy ich rewitalizacji nie proponują niczego oprócz wyburzania. Jak jednak wskazuje Kim Dovey,

[s]trategie błyskawicznej formalizacji przez wyburzanie i przebudowę są zarówno niepożądane jak i niewykonalne z wielu powodów - ekonomicznych, społecznych, środowiskowych i estetycznych ${ }^{236}$.

Slumsy powinny być zdaniem tej autorki ulepszane „na miejscu”. Ich relokalizacja nie ma sensu, ponieważ niszczy sieć stosunków ekonomicznych związanych z miejscem pracy. Sama akceptacja złych warunków egzystencji wynika często właśnie z lokalizacji umożliwiającej zarabianie na życie. Nieuprawnione jest też generalizowanie na temat wszystkich dzielnic nieformalnych. W języku polskim nie istnieje odpowiednik anglojęzycznego slumsu. Jedynymi synonimami stają się dlań przez to określenia takie jak dzielnica zdegradowana, biedy bądź nędzy. Poszczególne typy slumsów występujące na świecie posiadają jednak własne nazwy, które

Morawieckiego (2017- ) program Mieszkanie Plus, zakładający docelowe uwłaszczenie jego beneficjentów. Programy realizowane przez rządy Donalda Tuska i Ewy Kopacz (2007-2015) oparte były na wspieraniu kredytowania inwestycji deweloperskich. Wszystkie polskie programy mieszkaniowe wdrażane przez wspomniane, prawicowe rządy miały zatem na celu dochodzenie do pełnej własności prywatnej.

${ }^{233}$ A. Gilbert, Love in the Time of Enhanced Capital Flows: Reflections on the Links between Liberalization and Informality, [w:] A. Roy, N. AlSayyad (red.), op. cit., ebook.

${ }^{234}$ M. Davis, op. cit., s. 119.

235 J. van Ballegooijen, R. Rocco, op. cit., s. 1796, 1803.

${ }^{236}$ K. Dovey, Informalising architecture. The challenge of informal settlements, „Architectural Design", nr 6/2013, s. 84-86. 
niekoniecznie muszą symbolizować rażąco złe warunki skutkujące zagrożeniem epidemiologicznym i skrajnym wykluczeniem. Za oferujące stosunkowo wysoką jakość egzystencji uchodzą tureckie gecekondu ${ }^{237}$. Własną specyfikę posiadają latynoamerykańskie favele, conventillos i barriadas, indyjskie bustees, chawls i zapadtattis, kenijskie vijiji, marokańskie bidonvilles czy filipińskie barong-barong 238 . Jeszcze inną charakterystykę mają osiedla nieformalne w Europie Wschodniej i Południowej239 albo formalne francuskie slumsy-blokowiska: banlieue. Interesujące dla dalszego toku wywodu wydaje się zatem podejście mieszane, właściwe wspomnianym projektom Araveny. Wykorzystują one zarówno inicjatywę „nieformalną”, jak i częściowe finansowanie publiczne.

Warto też zwrócić uwagę na odmienną specyfikę nieformalnego, społecznego wytwarzania przestrzeni publicznych. Przestrzenie te co do zasady stoją w sprzeczności z regułami miasta neoliberalnego. Przestrzeń publiczna sprzyja swobodzie kształtowania zachowań zbiorowych. Prowadzi do rozmaitych interakcji, może też służyć do wytwarzania wspólnoty, włącznie z tą polityczną. Ciągle kluczowa wydaje się manifestacja aktu politycznego właśnie w przestrzeni publicznej, a nie wirtualnych sieciach ${ }^{240}$. Wspomnieć można w tym miejscu place we wszystkich rewoltach ostatnich lat posiadających miejskie oblicze. Majdan w Kijowie, Puerta del Sol w Madrycie, Syntagma w Atenach, Tahrir w Kairze, Taksim w Stambule, będący w rzeczywistości skwerem park Zuccotti w Nowym Jorku. A także wiele innych, mających już rangę globalnie rozpoznawalnych symboli. Przede wszystkim jednak przestrzenie publiczne nie sprzyjają akumulacji kapitału. Stanowią wyimek z przestrzeni stającej się przedmiotem obrotu i spekulacji nieruchomościami. Zarządcy współczesnych, zdepolityzowanych miast hołdują bardziej wytwarzaniu przestrzeni kolektywnych, a nie publicznych. Jak pisze Krzysztof Herman, służą one tymczasem do gromadzenia ludzi, ale już niekoniecznie do wywoływania interakcji między nimi ${ }^{241}$.

${ }^{237}$ B. Usta, Gecekondu, [w:] P. Derviş, B. Tanju, U. Tanyeli (red.), Becoming Instanbul. An Encyclopedia, SALT/Garanti Kültuir AŞ, İstanbul 2015, s. 124.

${ }^{238}$ A. Miastowska, Czym jest i gdzie powstaje dzielnica nędzy, [w:] J. Jankowska (red.), Ku Afryce. Poznawać. Działać. Dzielić się, Instytut Wydawniczy Książka i Prasa, Warszawa 2014, s. 22-23. W tym samym artykule znaleźć można też inne typologie slumsów.

239 S. Tsenkova, Informal settlements in post-communist cities: Diversity factors and patterns, „Urbani izziv”, nr 2/2010, s. 74.

${ }^{240}$ D. Harvey, Bunt miast. Prawo..., s. 213-214; K. Nawratek, Ideologie w przestrzeni. Próby demistyfikacji, Universitas, Kraków 2005, s. 156; J. Jones, Social media and social movements, „International Socialism", nr 130/2011, passim.

${ }^{241}$ K. Herman, Ogrody tymczasowe w przestrzeniach kolektywnych, Wydawnictwo Sztuka Ogrodu Sztuka Krajobrazu Beata J. Gawryszewska, Warszawa 2011, s. 42, 44-45. 
Tendencje takie odnaleźć można we wszystkich miastach stanowiących przedmiot moich badań w tej książce. Obok mającej już długą tradycję akumulacji opartej na spekulacji przestrzenią na Manhattanie ${ }^{242}$ czy ekspansji warszawskich centrów handlowych, przykładem skrajnym jest Park Gezi. To w rzeczywistości karłowaty $\mathrm{i}$, o ironio, w niewielkim stopniu zielony, ostatni fragment zielonej infrastruktury w ścisłym centrum Stambułu. Zgodnie z planami władz przekształcony miał być jednak w kolejne centrum handlowe, będące tym samym prywatną przestrzenią kolektywną. Opór mieszkańców względem kontrowersyjnej inwestycji stał się zarzewiem największego demokratycznego protestu w Turcji ostatnich lat i poważnym problemem politycznym dla rządu Recepa T. Erdoğana. Ten polityk, w specyficzny sposób łączący religijny konserwatyzm ze wsparciem dla neoliberalnego programu zarządzania miastem, był zresztą wcześniej burmistrzem Stambułu ${ }^{243}$.

Przestrzeń publiczna również może być wytwarzana heteronomicznie bądź autonomicznie czy też w sposób mieszany. Tego właśnie teoretycznie wymaga polskie ustawodawstwo, stawiające wymóg prowadzenia konsultacji społecznych w odniesieniu do planowania przestrzennego ${ }^{244}$. Konsultacje te nie zawsze spełniają jednak wymogi otwartego dialogu władz z mieszkańcami, którego celem jest „podjęcie przez władze optymalnych decyzji w sprawach publicznych”. Efektywne przeprowadzenie tego procesu możliwe jest dopiero przy poszanowaniu właściwych im zasad. Wśród nich wskazuje się na dobrą wiarę stron procesu, a także jego powszechność, przejrzystość, responsywność (prawo do merytorycznej odpowiedzi w rozsądnym terminie), koordynację między poszczególnymi organami administracji, przewidywalność oraz poszanowanie interesu publicznego i dobra ogólnego $^{245}$. Partycypacja związana z wytwarzaniem przestrzeni narażona jest jednak na te same ograniczenia, co szerzej rozumiany proces partycypacji. Jak pisała Sherry R. Arrenstein, chociaż teoretycznie powszechnie akceptowany, nie cieszy się on podobnym uznaniem, kiedy partycypacja staje się narzędziem reprezentacji interesów wykluczonych grup użytkowników przestrzeni. Albowiem

gdy ubodzy zaczynają definiować ją w kategoriach redystrybucji władzy, [...] konsensus w tej sprawie znika, pojawiają się podziały rasowe, etniczne, ideologiczne i polityczne ${ }^{246}$.

${ }^{242}$ R. Koolhaas, Deliryczny Nowy Jork. Retroaktywny manifest dla Manhattanu, tłum. D. Żukowski, Karakter, Kraków 2013, s. 93-124.

${ }^{243}$ D. Sudjic, Język miast, tłum. A. Sak, Karakter, Kraków 2017, ebook.

${ }^{244}$ L. Mergler, K. Pobłocki, M. Wudarski (red.), Anty-bezradnik przestrzenny - prawo do miasta w działaniu, Res Publica, Warszawa 2013, s. 176-239.

${ }^{245}$ O. Chrzanowski, E. Rościszewska, Kanon lokalnych konsultacji społecznych, Fundacja Inicjatyw Społeczno-Ekonomicznych, Warszawa 2015, s. 4-5.

${ }^{246}$ S.R. Arrenstein, Drabina partycypacji, [w:] J. Erbel, P. Sadura (red.), Partycypacja. Przewodnik Krytyki Politycznej, Wydawnictwo Krytyki Politycznej, Warszawa 2012, s. 12. 
Autorka ta podkreślała, że partycypacja może oznaczać zarówno realną władzę mieszkańców, jak i pusty rytuał. Na podstawie tego wyróżniła osiem poziomów „drabiny” partycypacji. Rozpoczynają je szczeble „niepartycypacyjne”: manipulacja (1) i terapia (2). Po nich następują działania pozorne: informowanie (3), konsultacje (4) i ugłaskiwanie (5). Następnie zwiększające obywatelską kontrolę lub bezpośrednio delegujące poziom decyzyjności na mieszkańców: partnerstwo (6), delegowanie (7) i kontrola obywatelska $(8)^{247}$.

Wskazane tutaj kategorie dotyczące obywatelskiej partycypacji cechuje duża subiektywność. Sprzyja to manipulacyjnemu wykorzystywaniu, zarówno przez polityków, jak i świat biznesu. Szeroki jest katalog praktyk wypaczających w tym zakresie idee uczestnictwa wszystkich interesariuszy w procesie decyzyjnym. Może wykorzystywać manipulowanie sondażami opinii (zastosowaną próbą albo nadinterpretacją wyników), doborem ekspertów czy stronniczą prezentacją problemu w przypadku metod deliberatywnych. Innym sposobem jest manipulacja granicami, tak zasad, jak i fizycznych granic projektu realizowanego w rzeczywistej przestrzeni. Ten ostatni problem odnieść można do kwestii zyskującego także w Polsce ogromną popularność mechanizmu budżetu partycypacyjnego ${ }^{248}$. Technika ta wywodzi się z „autonomicznych” realiów charakterystycznych dla latynoamerykańskiej alternatywy dla polityki neoliberalnej ${ }^{249}$. W polskim kontekście budzi jednak wątpliwości ze względu na zróżnicowaną siłę nacisku grup interesu promujących swoje obywatelskie pomysły wśród mieszkańców czy niejasności wokół procedury weryfikacji projektów przyjmowanych do głosowania. Rodzi to tym samym ryzyko podobnej pozorności i leseferystycznego uwikłania prowadzonej tą drogą partycypacji obywatelskiej, jakie zarzucano Turnerowi i jego koncepcji autonomii. Innymi słowy, tytułowego koszmaru partycypacji. Metody włączające w ograniczonym zakresie techniki partycypacyjne mogą mieć w niektórych przypadkach wyłącznie pozorowany charakter, co ma na celu swego rodzaju ugłaskiwanie strony społecznej. Wywołuje to jednak krytykę niektórych przykładów zastosowania cieszącej się coraz większym zainteresowaniem urbanistyki oddolnej.

\subsubsection{Metody spolecznego wytwarzania przestrzeni miasta}

Przestrzenie mogą być zatem wytwarzane społecznie różnymi sposobami. Na koniec pierwszego rozdziału proponuję wobec tego wyróżnienie trzech sposobów

${ }^{247}$ Ibidem, s. $15-17$.

248 A. Bluj, E. Stokłuska, Budżet partycypacyjny (obywatelski) krok po kroku. Poradnik dla praktyków, Fundacja Pracownia Badań i Innowacji Społecznych „Stocznia”, Warszawa 2015, passim.

${ }^{249}$ R. Górski, Bez państwa. Demokracja uczestniczq̨ca w działaniu, Korporacja Ha!art, Kraków 2007, s. 136-138. 
wytwarzania formalnego oraz dwóch dla nieformalnego. W pierwszej grupie należy wskazać na wytwarzanie odgórne (bez konsultacji z otoczeniem społecznym), konsultacyjne (zakładające ograniczony margines negocjacji co do kształtu przestrzeni) oraz partycypacyjne (zakładające daleko posunięty stopień decyzyjności strony społecznej). W odniesieniu do wytwarzania nieformalnego mówić należy o wytwarzaniu legalnym (w sposób zgodny z prawem, choćby przez zgłoszenie inicjatywy do stosownego organu) lub partyzanckim (metodą faktów dokonanych) (tabela 1).

Tab. 1. Metody społecznego wytwarzania przestrzeni miasta

\begin{tabular}{|l|l|}
\hline \multicolumn{1}{|c|}{ Metody formalne } & \multicolumn{1}{c|}{ Metody nieformalne } \\
\hline $\begin{array}{l}\text { 1. Odgórne } \\
\text { 2. Konsultacyjne } \\
\text { 3. Partycypacyjne }\end{array}$ & 1. Legalne \\
\hline
\end{tabular}

Źródło: opracowanie własne.

Przedstawiona typologia wytwarzania formalnego związana jest ze strukturą „drabiny partycypacji”. Ta zastosowana w odniesieniu do wytwarzania nieformalnego bazuje natomiast na typologii urbanistyki taktycznej (tactical urbanism). Mike Lydon i Anthony Garcia definiują tę ostatnią jako

nastawienie na budowanie sąsiedztw i aktywizmu [miejskiego] przy użyciu krótkoterminowych, niskokosztowych i prowadzonych w małej skali [scal-able] interwencji i polityk[, które są] [...] stosowane przez zróżnicowanych aktorów: wliczając władze, biznes i organizacje non-profit, grupy obywatelskie oraz pojedyncze jednostki ${ }^{250}$.

Taktyczna urbanistyka to zatem tak zwane hakowanie miasta mające na celu wykorzystanie dostępnych zasobów i uwolnienie potencjału społecznych interakcji w celu trwałego przekształcenia przestrzeni. Stąd, zdaniem przywołanych autorów, jej przykładami nie są działania prowadzące wyłącznie do zwykłej estetyzacji przestrzeni. Nawet jeżeli są to ,rozwiązania tymczasowe, [to mają] stanowić test dla trwałych efektów" - uzupełnia tę konstatację Paulo Silva ${ }^{251}$. Sami Lydon i Garcia dzielą urbanistykę taktyczną na zalegalizowaną (sanctioned) oraz niezalegalizowaną (unsanctioned) ${ }^{252}$.

${ }^{250}$ M. Lydon, A. Garcia, Tactical Urbanism. Short-term Action for Long-term Change, Island Press, Washington 2015, s. 2.

251 P. Silva, Tactical urbanism: Towards an evolutionary cities' approach?, „Environment and Planning B: Planning and Design”, vol. 43, nr 6/2016, s. 10.

${ }^{252}$ M. Lydon, A. Garcia, op. cit., s. 7-9, 73. 
Przestrzeń wytwarzana społecznie obejmuje wszystkie typy środowiska zurbanizowanego. W każdym przypadku aktorem wytwarzającym tę przestrzeń jest bowiem człowiek i wytworzone przezeń formy organizacji społecznej, takie jak państwo, przedsiębiorstwa czy organizacje oddolne. Z punktu widzenia niniejszych rozważań zastosowanie znalazła jednak uproszczona definicja przestrzeni wytwarzanej społecznie w mieście. Jest nią przestrzeń wytworzona w sposób nieformalny partyzancki (gecekondu w Stambule) oraz jednocześnie nieformalny legalny i formalny (konsultacyjny lub partycypacyjny), jak miało to miejsce w przypadku warszawskiego placu Grzybowskiego i nowojorskiego parku High Line. Rozumiana tak przestrzeń wytwarzana społecznie jest tym samym produktem różnego typu działań, które łącznie określam mianem urbanistyki oddolnej. Stanowi ona de facto przeciwieństwo opisanego wyżej wytwarzania odgórnego, obejmując cztery pozostałe ze wskazanych kategorii społecznego wytwarzania przestrzeni. Rzeczywistym przykładom stosowania urbanistyki oddolnej, w postaciach konsultacyjnej, partycypacyjnej, legalnej czy partyzanckiej, przyjrzymy się w dalszej części tej książki. 


\section{Metoda wieloczynnikowej waloryzacji przestrzeni}

\subsection{Zasady waloryzacji przestrzeni zurbanizowanej}

Wieloznaczność pojęcia przestrzeni oraz zróżnicowanie celów towarzyszących jej waloryzacji skutkuje brakiem powszechnie przyjętej metodyki tego zagadnienia. Istnieje wiele „metod i technik oceny, które stały się integralną częścią działań człowieka w przestrzeni” ${ }^{253}$. Metody te można dzielić na rozmaite sposoby: ze względu na towarzyszące im intencje (cel, kierunek oceny), pole (przedmiot, obiekt, zakres, zasięg), sposób dokonywanej oceny (kryterium, techniki) oraz sposób jej prezentacji (opisowa, graficzna, symboliczna). Przy zastosowaniu kryterium podziału opartego na przedmiocie waloryzacji, czyli rodzaju przestrzeni, Iwona Cieślak rozróżnia z kolei waloryzację przyrodniczą, fizjograficzną, krajobrazów kulturowych, socjologiczną miasta oraz inwestycyjną 254 .

Wieloaspektowość oceny jakości przestrzeni zurbanizowanej związana z jej możliwie zobiektywizowaną waloryzacją wymaga zastosowania elementów charakterystycznych dla większości, jeśli nie wszystkich z wymienionych wyżej podejść. Waloryzacja przestrzeni właściwej środowisku zurbanizowanemu przede wszystkim jest kojarzona z oceną zasobów kulturowych. Te ostatnie, jak piszą Jan Rylke i Anna Długozima, są ,zawarte w przestrzeni naszego środowiska [i] tworzą obszary składające się z miejsc zamieszkanych lub użytkowanych przez ludzi”255. Kulturę definiuje się jako ogół wartości, obrzędów i sposobów życia wyróżniających zbiorowości ludzkie oraz ich wytwory, składające się na cywilizacyjny dorobek, stanowiący przeciwieństwo porządku naturalnego ${ }^{256}$. Istotne z punktu

${ }^{253}$ K. Szuniewicz, Metodologia oceny i waloryzacji przestrzeni, [w:] I Cieślak (red.), Wspótczesna waloryzacja przestrzeni..., s. 31-32.

${ }^{254}$ I. Cieślak, Wybrane metody waloryzacji..., s. 42-82.

255 J. Rylke, A. Długozima, op. cit., s. 255.

${ }^{256}$ Z. Bauman, Socjologia, Wydawnictwo Zysk i S-ka, Warszawa 1996, s. 148-150; A. Giddens, op. cit., s. 724; A. Kłoskowska, Kultura masowa. Krytyka i obrona, Państwowe Wydawnictwo Naukowe, Warszawa 1990, s. 40. 
widzenia waloryzacji zasobów kulturowych czynniki przenikają zatem analizy charakterystyczne dla różnych podejść. O jakości przestrzeni zurbanizowanej świadczy, po pierwsze, jakość wyposażającej ją infrastruktury osadniczej - mieszkaniowej, społecznej, transportowej, technicznej i usługowej równocześnie. Po drugie, do tego dołączają elementy środowiskowe, w tym właściwości środowiska spolecznego, będące przedmiotem zainteresowania tak socjologii, jak psychologii czy urbanistyki. Do tego dochodzi jeszcze jakość infrastruktury zielonej, powietrza i klimatu akustycznego, będących w obszarze zainteresowania zarazem nauk przyrodniczych i technicznych. Waloryzacja skupia się też na walorach ekonomicznych przestrzeni czy wreszcie jej subiektywnym postrzeganiu opartym na percepcji przestrzeni przez jej użytkowników. Konkludując te spostrzeżenia, stwierdzić należy, że przedmiotem wieloczynnikowej waloryzacji powinna być ocena zarówno (1) materialnego, czyli fizycznego wymiaru przestrzeni, jak i dotyczących jej (2) subiektywnych wrażeń.

Kluczowe w przypadku takiej waloryzacji zdaje się określenie liczby stosowanych zmiennych. Rylke i Długozima proponują w tej kwestii wyróżnienie dwóch grup metodycznych, to jest waloryzacji (1) jedno- oraz (2) wieloczynnikowej ${ }^{257}$. Jednoczynnikowa wyróżnia się niskim kosztem wykonania oraz obiektywizmem. Lapidarny ładunek informacyjny uzyskanych przy jej zastosowaniu wyników umożliwia wyostrzenie ocen jakości przestrzeni. Wadą tego podejścia jest jego redukcjonistyczny charakter. Przestrzeń zamieszkaną nasyca wielość poziomów, znaczeń i przestrzennych wartości. Rzadko kiedy może być oceniana wyłącznie za pomocą jednego aspektu. To zerojedynkowe podejście może zostać $\mathrm{z}$ powodzeniem zastosowane $\mathrm{w}$ przypadku badania zasobów przyrodniczych takich jak bioindyktatory ${ }^{258}$. W odniesieniu do przestrzeni zurbanizowanej bardziej trafna wydaje się waloryzacja wieloczynnikowa. Obejmuje ona więcej aspektów, chociaż jest też bardziej kosztowna i narażona na większy subiektywizm. Ocena przestrzeni tak złożonej, związana z wieloaspektowym zjawiskiem jakości życia w środowisku zurbanizowanym, wymaga tym samym zastosowania możliwie dużej liczby jak najbardziej zróżnicowanych zmiennych. Ukazuje to odmienne cechy tej przestrzeni oraz pozwala jak najpełniej zidentyfikować największą liczbę wartości przestrzennych. Zarówno w odniesieniu do wymiaru materialnego, jak i tego postrzeganego bardziej subiektywnie.

257 J. Rylke, A. Długozima, op. cit., s. 264.

${ }^{258}$ Przykład stanowi metoda wskaźnika biomasy osobniczej chrząszczy z rodziny biegaczowatych (SBO). Waga tych zwierząt odławianych z określonego obszaru pozwala określać dojrzałość ekosystemu za pomocą tylko jednej cechy. J. Szyszko, Biegaczowate, [w:] J. Szyszko et. al., op. cit., s. 117-139. 
Na bazie wspomnianej w poprzednim rozdziale typologii Maransa i Stimsona wyróżnić należy trzy typy wskaźników możliwych do wykorzystania dla celów takiej waloryzacji. Są to wskaźniki (1) obiektywne, (2) subiektywne oraz (3) behawioralne. W przypadku pierwszej grupy najbardziej użyteczne są badania ilościowe, a w odniesieniu do drugiej - te o charakterze jakościowym. Wskaźniki typu behawioralnego korzystać mogą natomiast $\mathrm{z}$ obu tych typów badań. W zakresie źródeł użyteczne jest pozyskiwanie informacji na bazie danych pierwotnych jako czerpiących z analiz samego badacza lub danych wtórnych, z których część ma źródła urzędowe. Inne wymagają pozyskania ze źródeł niepublicznych, niekiedy komercyjnych. Te ostatnie są szczególnie cenne w przypadku mniej udoskonalonego systemu informacji i statystyki publicznej. Jak pokazują moje dalsze analizy, na przykład system amerykańskiej statystyki publicznej oferuje zdecydowanie szerszy zakres informacji o środowisku zurbanizowanym niż jego polski odpowiednik.

Dane te mogą być przetwarzane manualnie albo w sposób zautomatyzowany w różnym stopniu. Błędne wydaje się wyróżnianie wśród technik waloryzacji przestrzeni tych opisywanych niekiedy w literaturze jako oparte na systemie informacji geograficznej (GIS). Umożliwia on gromadzenie, przetwarzanie oraz wizualizację danych przestrzennych przy zastosowaniu technik informatycznych ${ }^{259}$. GIS odnosi się do tak zróżnicowanych danych jak otwarte publiczne geoportale czy zamknięte systemy komercyjne, zwłaszcza Google Maps. Są one, ze względu na swoją złożoność, raczej sposobami zbierania lub wizualizacji danych aniżeli osobną metodą waloryzacji przestrzeni. GIS nie tyle wprowadza nowe metody ocen, ile przekształca te już istniejące, bazujące na udoskonalonych technikach pomiaru i przetwarzania danych. Wśród technik przetwarzania towarzyszących waloryzacji wyodrębnić można zatem na przykład te niewykorzystujące pośrednictwa zaawansowanych urządzeń (wywiady, rysunki, zliczanie na kartce papieru, używanie stopera czy ręcznego licznika), te o ograniczonej automatyzacji (metody wizualne analizowane w sposób niezautomatyzowany) oraz o zaawansowanej automatyzacji (zautomatyzowane analizy przestrzenne).

Na podstawie powyższych obserwacji wyróżnić należy przede wszystkim typologię technik waloryzacji przestrzeni zurbanizowanej opartą na kryterium liczby stosowanych wskaźników (1) oraz przyjętego typu badań (2). Poszczególne metody czerpać mogą ze zróżnicowanych typów wskaźników oraz źródeł i technik przetwarzania danych (tabela 2).

${ }^{259}$ R. Szczepanek, Systemy informacji przestrzennej z Quantum GIS. Część I, Wydawnictwo Politechniki Krakowskiej, Kraków 2013, s. 6-7; H. Olenderek, Historia geomatyki..., [w:] W. Milewski (red.), Geomatyka w lasach państwowych. Część I. Podstawy, Centrum Informacyjne Lasów Państwowych, Warszawa 2010, s. 19-21. GIS określany jest też czasem jako system informacji przestrzennej (SIP). 
Tab. 2. Metody waloryzacji przestrzeni zurbanizowanej

\begin{tabular}{|c|l|l|l|l|}
\hline $\begin{array}{c}\text { Metody według } \\
\text { kryterium liczby } \\
\text { wskaźników }\end{array}$ & $\begin{array}{c}\text { Metody } \\
\text { według typu } \\
\text { badań }\end{array}$ & $\begin{array}{c}\text { Charakter } \\
\text { wskaźników }\end{array}$ & Źródła danych & $\begin{array}{c}\text { Techniki } \\
\text { przetwarzania } \\
\text { danych }\end{array}$ \\
\hline $\begin{array}{l}\text { 1. Jednoczynni- } \\
\text { kowa }\end{array}$ & $\begin{array}{l}\text { 1. Jakościowa } \\
\text { 2. Ilościowa }\end{array}$ & $\begin{array}{l}\text { 1. Obiektywny } \\
\text { 2. Subiektywny } \\
\text { 3. Behawioralny } \\
\text { kowa }\end{array}$ & $\begin{array}{l}\text { 1. Pierwotne } \\
\text { 2. Wtórne } \\
\text { urzędowe } \\
\text { 3. Wtórne } \\
\text { nieurzędowe }\end{array}$ & $\begin{array}{l}\text { 1. Manualne } \\
\text { 2. O ograniczonej } \\
\text { automatyzacji } \\
\text { 3. O zaawansowa- } \\
\text { nej automaty- } \\
\text { zacji }\end{array}$ \\
\hline
\end{tabular}

Źródło: opracowanie własne.

Oprócz przedstawionych klasyfikacji możliwe jest wyróżnienie technik prezentacji danych w podziale na opisowe (tekstowe i tabelaryczne) oraz wizualne (wykresowe, obrazowe, modelowe i kartograficzne). W odniesieniu do metod waloryzacji przestrzeni zurbanizowanej można przeważnie stosować wszystkie lub większość z zarysowanych technik prezentacji.

Najczęściej stosowanym sposobem [...] jest forma opisowo-kartograficzna, pozwalająca na syntetyczną prezentację elementów rzeczywistości poprzez ich cechy jakościowe. Do tej formy należy zaliczyć mapy, diagramy, kartogramy. Można spotkać również prezentacje w formie symboli, wzorów matematycznych i logicznych, modeli obrazowania, krzywych zależności lub dokumentacji fotograficzneje ${ }^{260}$.

Wieloczynnikowa waloryzacja przestrzeni wymaga też zakreślenia przestrzennych granic analizy (określenia jej pola podstawowego), dobranych na podstawie celu badania oraz możliwości technicznych, fizycznych bądź finansowych. Pola podstawowe mogą mieć granice związane $\mathrm{z}$ naturalnymi jednostkami przyrodniczymi (facjami, ekotopami i fizjotopami), granicami administracyjnymi (jednostek samorządu terytorialnego, urzędów statystycznych, podziałami geodezyjnymi) lub sztuczne granice wyznaczone metodą geometryczną. W przypadku pól opartych na jednostkach przyrodniczych wyniki waloryzacji są najbardziej obiektywne. Związanie granic z podziałami administracyjnymi zapewnia największą liczbę danych urzędowych, które stają się jednak problematyczne w przypadku zmiany tych granic. Z kolei wyznaczanie geometryczne ułatwia porównywanie pól.

Dobór pól podstawowych [...] znajduje odzwierciedlenie w ostatecznych wynikach badań. Wybór wielkości, kształtu oraz rozmieszczenia pól musi być poparty wnikliwą analizą zarówno przedmiotu waloryzacji, jej celu oraz obszaru, do którego się odnosi. Jest integralną

${ }^{260}$ K. Szuniewicz, op. cit., s. 36. 
częścią procesu wartościowania przestrzeni. Ich nieprawidłowe dopasowanie może doprowadzić do błędnego wnioskowania i konkluzji nieprzydatnych w realizacji zadań będących jej następstwem ${ }^{261}$.

W przypadku przestrzeni zurbanizowanej metoda geometryczna może odnosić się na przykład do granicy tak zwanego akceptowalnego dojścia pieszego. W opinii Jana Gehla wyznacza je obszar ekwidystansy 500 metrów. Podział geometryczny powinien być też do pewnego stopnia elastyczny, zwłaszcza w przypadku waloryzacji przestrzeni prowadzonej w środowisku intensywnie zurbanizowanym. Szczególnie istotne są przerywające przestrzenną ciągłość Lynchowskie krawędzie. Granica 500 metrów dostosowana musi być do konkretnych warunków. Może być bowiem złamana przez elementy takie jak duża droga, rzeka czy bariery charakterystyczne dla podziałów wynikających zarówno z ukształtowania terenu, jak i czynników kulturowych (religie, etniczności). O percepcji tego obszaru decyduje wreszcie i kwestia psychologiczna. Zdaniem Gehla jako krótsza jest odbierana droga „interesująca, bogata w doznania i komfortowa”262. W przypadku niektórych metod waloryzacji przestrzeni badanie powinno być powtarzane. Pole podstawowe uzupełnia wówczas możliwie upodobnione do niego pole kontrolne.

Dla zastosowanej w pracy metody WWP, wykorzystującej równocześnie badania ilościowe i jakościowe, największe znaczenie ma zatem jej zróżnicowanie. Kluczową wytyczną jest w tym zakresie sugestia dotycząca zapewnienia przez badacza możliwie daleko idącego pluralizmu stosowanych wskaźników, źródeł informacji oraz technik przetwarzania danych. Niemożliwe jest rozstrzygnięcie kwestii tego, które z analizowanych czynników są w jej przypadku najważniejsze. Albowiem to właśnie złożoność tej metody pozwala na formułowanie ocen w odniesieniu do różnorodnych i niekiedy trudnych do zhierarchizowania wymiarów przestrzeni zurbanizowanej.

\subsection{Struktura zastosowanej metody i jej techniki badawcze}

\subsubsection{Ogólna charakterystyka metody i źródel danych}

Dla potrzeb podjętych przeze mnie analiz niezbędne zdaje się zastosowanie złożonych badań wykorzystujących zróżnicowane techniki. Opierają się one tak na pierwotnych, jak wtórnych źródłach danych. Część z nich prowadziłem na bazie metod kameralnych, w analizach tych stosując szczegółową kwerendę polskiej i zagranicznej literatury przedmiotu. Badania literaturowe czerpały z dorobku

261 Ibidem, s. 40-41.

${ }^{262}$ J. Gehl, Miasta dla ludzi..., s. 127. 
literatury naukowej z zakresu szeroko rozumianych studiów miejskich. Miejsce szczególne należy przyznać w tym kontekście studiom poświęconym tematyce waloryzacji przestrzeni. Mniej złożone badania tego rodzaju były już prowadzone w niektórych polskich ośrodkach naukowych. Za najbardziej kompleksowe z powstałych $\mathrm{w}$ ten sposób opracowań można uznać wielokrotnie wykorzystywane przeze mnie publikacje badaczy z Uniwersytetu Warmińsko-Mazurskiego w Olsztynie oraz Szkoły Głównej Gospodarstwa Wiejskiego w Warszawie ${ }^{263}$. Pokrewne waloryzacji badania służą też opracowywaniu części diagnostycznych dokumentów planistycznych czy studiów wykonalności i opracowań ewaluacyjnych dla projektów z zakresu zagospodarowania przestrzeni ${ }^{264}$. Sam termin waloryzacja przestrzeni zdecydowanie chętniej stosują rodzimi autorzy. Odróżnia to ich od ujęcia anglojęzycznego, gdzie częściej spotykane są studia poświęcone ewaluacji krajobrazu (landscape evaluation) ${ }^{265}$. Badawczy problem wieloczynnikowej waloryzacji przestrzeni zurbanizowanych wytwarzanych społecznie jest jednak zagadnieniem stosunkowo nowym. Dotychczasowe opracowania rzadko kiedy krzyżowały ze sobą perspektywy charakterystyczne dla nauk społecznych i technicznych, tak jak ma to miejsce w tej książce, zazwyczaj skupiając się na ujęciu jednoczynnikowym. Ważną częścią bazy źródłowej okazały się dodatkowo opracowania właściwe poszczególnym technikom badawczym oraz teorii nauk o polityce publicznej, socjologii miasta, urbanistyki czy studiów nad jakością życia. Na stosowane przeze mnie podejście badawcze wpłynęła również wydatnie własna monografia poświęcona tematyce gentryfikacji ${ }^{266}$.

Badania literaturowe uzupełniły dane ilościowe i jakościowe o rozmaitym pochodzeniu. W tym zakresie użyteczne okazały się na przykład statystyczne dane urzędowe oraz różnorodne materiały wizualne. Niektóre informacje zaczerpnąłem ze źródeł powszechnie dostępnych, głównie internetowych baz danych polskich, amerykańskich i tureckich instytucji publicznych oraz publicznie dostępnych kont w sieciach społecznościowych. Szczególnie to ostatnie źródło dostarczyło dużej liczby informacji, w tym zapisu 44,5 tysiąca postów opublikowanych w serwisie

${ }^{263}$ Zwłaszcza publikacja I. Cieślak (red.), Wspótczesna waloryzacja przestrzeni...

${ }^{264}$ Zob. np. W. Wojtowicz, Jakie ulice najlepsze dla mieszkańców? ZDM porównał główne ulice Warszawy, http://urbnews.pl/ulice-najlepsze-dla-mieszkancow-zdm-porownal-glowne-ulice-warszawy/, dostęp: 27.12.2017.

265 Zob. np. M.R. Moss, W.G. Nickling, Landscape evaluation in environmental assessment and land use planning, „Environmental Management”, nr 1/1980, passim; A. Farina, Landscape Ecology in Action, Springer Science+Business Media, Dordrecht 2000, s. 109-192. Duży przegląd publikacji znaleźć można też w internetowym opracowaniu Review of Existing Methods of Landscape Assessment and Evaluation, www.macaulay.ac.uk/ccw/task-two/evaluate.html, dostęp: 1.11.2017.

${ }^{266}$ Ł. Drozda, Uszlachetniając przestrzeń. Jak działa gentryfikacja i jak się ją mierzy, Instytut Wydawniczy Książka i Prasa, Warszawa 2017. 
Instagram. Niespełna $900 \mathrm{z}$ nich poddałem następnie pogłębionej analizie jakościowej. Liczebność tych fotografii w odniesieniu do konkretnych studiów przypadku była bardzo różna, a charakterystyka przyjętej ostatecznie próby została bardziej szczegółowo wyjaśniona w dalszych częściach książki. Jednocześnie jestem zmuszony zaznaczyć w tym miejscu ograniczony charakter niektórych obserwacji prowadzonych w przypadku tureckiej części badania. Monitoring internetowej aktywności w przestrzeni zurbanizowanej bazował w tamtejszym kontekście wyłącznie na metodach jakościowych. Odróżniło go to od pozostałych studiów przypadku. Jeszcze bardziej ograniczony charakter miało badanie stambulskiego rynku nieruchomości. Pośrednim substytutem w tym zakresie okazały się związane z podobnym zakresem przedmiotowym badania stopnia zaawansowania gentryfikacji. Jeden z wymiarów tego zjawiska jest bowiem w istotnym stopniu determinowany przez właściwości rynkowego obrotu nieruchomościami. Podsumowując kwestię zarysowanych w tym miejscu ograniczeń, wskazać należy, że spośród siedmiu badawczych metod szczegółowych pięć zastosowałem w pełnym zakresie do trzech studiów przypadku. Pozostałe dwie w pełni zrealizowałem wyłącznie dla fragmentów poświęconych Warszawie i Nowemu Jorkowi. Bardziej rozwinięty charakter miały badania rynku nieruchomości w tych dwóch ostatnich miastach. W ich przypadku przyjęte próby odnosiły się do bardziej kompleksowej analizy statystycznej rynku. W kontekście amerykańskiego studium przypadku korzystałem z ogólnodostępnej, wielotysięcznej i bardzo szczegółowej bazy obejmującej wszystkie transakcje dokonywane w całym mieście.

Inne źródła stanowiły dane pozyskiwane w ramach zapytań w trybie dostępu do informacji publicznej lub pytań o mniej sformalizowanym charakterze. Część informacji pochodzi także ze źródeł komercyjnych. Kolejną grupą istotnych źródeł były te pochodzące z własnych badań terenowych prowadzonych w Polsce, Stanach Zjednoczonych i Turcji. Ich pierwsza część realizowana była w latach 2016-2017 w Warszawie. Późniejsze badania objęły dwie zagraniczne podróże studialne odbyte w sierpniu 2017 roku. Wyjazdy te umożliwiły przede wszystkim inwentaryzację urbanistyczną wybranych studiów przypadku oraz odbycie poświęconych im spacerów badawczych. Przy tej okazji powstały również zdjęcia służące późniejszym analizom prowadzonym już w formule kameralnej oraz badaniom ankietowym z udziałem studentów gospodarki przestrzennej w Szkole Głównej Gospodarstwa Wiejskiego w Warszawie. Podróże studialne umożliwiły ponadto pozyskanie szkiców (map poznawczych) obrazujących poziom percepcji i emocjonalnego nacechowania związków z badanymi przestrzeniami zurbanizowanymi ich mieszkańców i innych grup użytkowników tych przestrzeni.

Dzięki wyjazdom badawczym udało mi się przeprowadzić wywiady z użytkownikami każdego $\mathrm{z}$ analizowanych miejsc. W ramach tych rozmów odbyło się 
łącznie 91 wywiadów, z tego 30 w sierpniu 2016 roku w Warszawie. Rok później zarejestrowałem rozmowy z respondentami w Stambule (30) oraz Nowym Jorku $(31)^{267}$. Badaniom związanym $\mathrm{z}$ analizą pierwszego ze studiów przypadku towarzyszyła największa liczba odmów. Na rozmowę godził się w tym miejscu rzadziej niż co drugi z użytkowników przestrzeni zurbanizowanej, chociaż zarazem wszyscy ostateczni rozmówcy zgodzili się opracować swoje mapy poznawcze. Wszystkie rozmowy przeprowadziłem osobiście, z czego prawie każdą w języku polskim ${ }^{268}$. W czasie kolejnej części badań, prowadzonych już na obszarze sąsiedztwa Karanfilköy w Stambule, udało mi się pozyskać łącznie 25 map poznawczych. Pomimo niewielkiej liczby odmów w stosunku do wszystkich prób wywiadu, najmniejszej spośród analizowanych przypadków, wielu respondentów nie chciało uzupełniać wypowiedzi szkicowymi rysunkami. Część do współpracy w tym zakresie namówiła dopiero interwencja asystującej w badaniu tłumaczki. Prowokowało to pewne metodologiczne nieścisłości, mogące potencjalnie wpływać sugerująco na charakter powstających rysunków. Dokładność tłumaczenia jest z kolei jeszcze jednym potencjalnym zniekształceniem dotyczącym wyników tej części badań terenowych, jako jedynej nieprowadzonej w sposób w pełni bezpośredni. W parku High Line w Nowym Jorku, gdzie odbywała się ta najpóźniejsza część badań terenowych, udało się pozyskać 28 map poznawczych. Niemal wszystkie wywiady towarzyszące opracowaniu tych szkiców przeprowadzono w języku angielskim ${ }^{269}$. Wszystkie rozmowy w Stanach Zjednoczonych miały charakter bezpośredni między badaczem i ankietowanymi. Dzięki temu udało się uniknąć istotniejszych zniekształceń pomiaru i metodologicznych odstępstw mogących wynikać z pośrednictwa osoby trzeciej odpowiedzialnej za tłumaczenie. Odróżnia to te wywiady od badań prowadzonych wcześniej w Stambule. Większość rozmów została nagrana, aczkolwiek w kilku przypadkach, na wyraźną prośbę udzielających wywiadu, zapis rozmowy dokonywany był ręcznie ${ }^{270}$. Ważną część badań stanowiły też analizy wykorzystanych materiałów wizualnych, na podstawie których wykonałem badania wedle oceny piękna scenerii.

W sferze instrumentarium służących mi narzędzi badawczych podstawową rolę odgrywało zastosowanie odpowiedniego oprogramowania komputerowego.

${ }^{267}$ Lista rozmówców znajduje się w aneksie 1 zamieszczonym na końcu pracy. Rozmowy przeprowadzone w Warszawie określają liczby towarzyszące literze „A”, analogicznie w przypadku Nowego Jorku i Stambułu zastosowałem litery „B” i „C”.

${ }^{268}$ Z wyjątkiem jednego wywiadu z mieszkańcem Wielkiej Brytanii przeprowadzonego w jego języku ojczystym. Był to jednak mężczyzna mieszkający w przeszłości przez pewien okres w Warszawie. Jak stwierdził, bywał on w tamtym okresie w badanym miejscu prawie codziennie.

${ }^{269} \mathrm{Z}$ wyjątkiem dwóch rozmów z przypadkowymi respondentami pochodzenia polskiego.

${ }^{270}$ Sytuacja taka wystąpiła wielokrotnie w Warszawie, tylko jeden raz w Stambule i ani razu w Nowym Jorku. 
Większość obliczeń wykonałem za pomocą programu Microsoft Excel, a część z tych dotyczących monitoringu internetu z użyciem aplikacji Brand24. Opracowanie wszelkich analiz przestrzennych ułatwiło wykorzystanie QGIS lub innych dostępnych w sieci aplikacji przetwarzających dane przestrzenne. W tym zakresie przydatne były głównie rządowe geoportale oraz narzędzia firmy Google.

Reasumując, przeprowadzone przeze mnie badanie składa się z analiz obszarów pól podstawowych związanych z przyjętymi studiami przypadku. Pola te wyznaczałem w uzależnieniu od dostępnych danych i charakterystyki metod szczegółowych bądź związanych z nimi technik badawczych. W przypadku niektórych metod badanie uzupełniło wprowadzenie specjalnych pól kontrolnych. Służyły one weryfikacji lub porównaniu wyników dotyczących pola podstawowego. Odpowiedzią na złożoność przedmiotu badania - przestrzeni zurbanizowanej - było opracowanie metody wieloczynnikowej waloryzacji przestrzeni (WWP). Na metodę tę składa się siedem metod szczegółowych odnoszących się do dwóch głównych grup problemowych. Pierwszą stanowią „obiektywne” analizy cen rynku nieruchomości oraz należących do obu typów grup zmiennych o charakterze „obiektywnym” i subiektywnym, które służą klasyfikacji poziomu jakości życia oraz percepcji przestrzeni. Poszczególne metody szczegółowe wykorzystują zróżnicowane techniki badawcze. W przypadku niektórych metod zastosowanie znalazła więcej niż jedna taka technika.

Z metodologicznego punktu widzenia proponowaną przeze mnie metodę osadzić należy zatem w ramach paradygmatu metodologii mieszanej i podejścia właściwego studium przypadku. Metoda ta może zostać zastosowana nawet przez indywidualnego badacza. Cel jej opracowania stanowi próba połączenia większej liczby metod, które dalej nazywam metodami szczegółowymi. Tych ostatnich nie należy przy tym utożsamiać z tradycyjnie rozumianymi cechami zmiennymi, ponieważ niektóre metody szczegółowe bazują na większej liczbie takich zmiennych. Metody te umożliwiają również prowadzenie ocen o charakterze jednocześnie obiektywnym, subiektywnym i behawioralnym. Wykorzystują zróżnicowane źródła i techniki przetwarzania danych, a także badają równocześnie materialny wymiar przestrzeni i jej percepcję. Listę stosowanych metod szczegółowych uzupełnić należy jeszcze o przedmiot ich analiz oraz charakterystykę właściwych im wskaźników, co umożliwia lepsze zrozumienie charakterystyki poszczególnych etapów procesu badawczego (tabela 3).

Podstawowe przestrzenne pole stosowania metod szczegółowych wyznaczane jest metodą geometryczną na podstawie granicy akceptowalnego dojścia pieszego, z uwzględnieniem kluczowych krawędzi przestrzennych. Podejście to umożliwia wyznaczenie rzeczywistego obszaru funkcjonalnego analizowanej przestrzeni miejsca analizowanych przekształceń oraz obszaru, na który oddziałuje. Granice 
Tab. 3. Metody szczegółowe wieloczynnikowej waloryzacji przestrzeni (WWP)

\begin{tabular}{|l|l|l|}
\hline \multicolumn{1}{|c|}{ Przedmiot oceny } & \multicolumn{1}{|c|}{ Metoda szczególowa } & \multicolumn{1}{c|}{ Charakter wskaźnika } \\
\hline \multirow{2}{*}{$\begin{array}{l}\text { Materialny wymiar } \\
\text { przestrzeni }\end{array}$} & Badanie rynku nieruchomości & Obiektywny \\
\cline { 2 - 3 } & Ocena infrastruktury osadniczej & Obiektywny / behawioralny \\
\cline { 2 - 3 } & Gentryfikacja obszaru & Subiektywny / obiektywny \\
\hline Percepcja przestrzeni & Ocena estetyki przestrzeni & Subiektywny \\
\cline { 2 - 3 } & Mapowanie poznawcze & Subiektywny \\
\cline { 2 - 3 } & Ocena bezpieczeństwa & Obiektywny / subiektywny \\
\cline { 2 - 3 } & Monitoring internetu & Behawioralny \\
\hline
\end{tabular}

Źródło: opracowanie własne.

pola podstawowego mogą być jednak nie w pełni tożsame w odniesieniu do różnych metod szczegółowych. Jest to związane przede wszystkim z kwestią dostępności odpowiednich danych. Przyjrzyjmy się zatem poszczególnym metodom szczegółowym, przy okazji czego opisane zostaną również zastosowane techniki, metody analizy danych oraz sposób doboru prób ${ }^{271}$.

\subsubsection{Badanie rynku nieruchomości}

Przedmiot badania pierwszej z metod szczegółowych stanowi identyfikacja walorów ekonomicznych przestrzeni na podstawie analizy wartości rynkowej nieruchomości znajdujących się w polu podstawowym. Metoda ta oparta jest na wskaźniku obiektywnym - transakcjach zawieranych w świecie rzeczywistym. Wartość rynkowa nie ma charakteru obiektywnego. Jak podaje Elżbieta Mączyńska, cena nieruchomości jest bowiem wynikiem subiektywnych negocjacji kupca i sprzedawcy ${ }^{272}$. Wartość rynkowa i cena są równe wyłącznie w teoretycznych warunkach konkurencji doskonałej ${ }^{273}$. Jakkolwiek konkurencja tego rodzaju stanowi konstrukt nieodzwierciedlony empirycznie, osiągnięcie jej warunków w przypadku rynku nieruchomości jest już w praktyce nieosiągalne lub graniczące $\mathrm{z}$ chwilowym przypadkiem. Wynika to przede wszystkim z niewielkiej elastyczności rynku, zwłaszcza długotrwałego charakteru inwestycji na rynku nieruchomości, a także występują-

${ }^{271}$ Część użytecznych informacji metodologicznych zainteresowane osoby znajdą także w aneksach zamieszczonych na końcu książki.

272 E. Mączyńska, Wycena nieruchomości w celu ustanowienia zabezpieczenia hipotecznego, [w:] G. Główka (red.), Nieruchomość, kredyt, hipoteka, Poltext, Warszawa 2008, s. 161.

${ }^{273}$ E. Kucharska-Stasiak, op. cit., s. 174; E. Mączyńska, op. cit., s. 161. 
cych barier informacyjnych. Pełna znajomość wszystkich czynników wpływających na cenę i walory użytkowe nieruchomości jest praktycznie niemożliwa, zwłaszcza w odniesieniu do większej ich liczby. Zdaniem Ewy Kucharskiej-Stasiak na wartość nieruchomości wpływają jednocześnie czynniki fizyczne i środowiskowe, ekonomiczne, prawne, demograficzne, polityczne i socjalne, których rola jest zmienna w zależności od kontekstu ${ }^{274}$. Najważniejszymi czynnikami kształtującymi wycenę pozostają z kolei w opinii Diany Polkowskiej lokalizacja oraz samo sąsiedztwo tej lokalizacji, które wpływają nierzadko na ponad połowę wartości nieruchomości ${ }^{275}$. Pomimo tych zastrzeżeń bazujące na zasadach profesjonalnej wyceny nieruchomości badanie ich rynku wydaje się najbardziej zobiektywizowaną metodą szczegółową waloryzacji przestrzeni wytwarzanej społecznie.

W samej wycenie nieruchomości budowlanych wyróżnia się kilka podejść, które wykorzystują następujące techniki:

1) porównawcze - metody porównywania parami, korygowania ceny średniej oraz analizy statystycznej rynku - celem tych metod jest wycena opierająca się na analizie cen nieruchomości podobnych ${ }^{276}$;

2) dochodowe - inwestycyjna, zysków - metody wyceny na bazie potencjalnego dochodu uzyskiwanego z nieruchomości;

3) kosztowe - kosztów odtworzenia, zastąpienia i likwidacji - metody oparte na kosztach związanych z różnego rodzaju przekształceniami nieruchomości;

4) mieszane - wskaźników szacunkowych gruntów, pozostałościowa - metody łączące cechy trzech powyższych grup ${ }^{277}$.

W pracy wykorzystałem uproszczoną metodę analizy statystycznej rynku. Zasadniczym założeniem metod porównawczych jest zobiektywizowanie wyceny nieruchomości na podstawie znajomości lokalnego rynku nieruchomości. Jego analiza prowadzi do wyznaczenia wartości rynkowej na podstawie uśrednionych cen. Szczegóły zastosowanej w ramach WWP metodyki dobrałem do konkretnych studiów przypadku. Jako kluczowe traktowałem przyjęcie ujednoliconych zasad do wyceny nieruchomości z pola podstawowego i kontrolnego. Analizie poddałem zatem transakcje dokonywane przed przeprowadzoną interwencją i po niej, wskazując tym samym jej potencjalny wpływ na rynkową wartość nieruchomości.

${ }^{274}$ E. Kucharska-Stasiak, op. cit., s. 190-191.

275 D. Polkowska, Ekonomiczna wartość przestrzeni miejskiej, [w:] M. Madurowicz (red.), Wartościowanie wspótczesnej przestrzeni miejskiej, Wydawnictwo Wydziału Geografii i Studiów Regionalnych UW, Urząd m.st. Warszawy, Warszawa 2010, s. 196.

${ }^{276}$ Wyróżniających się np. podobnym metrażem, lokalizacją i parametrami technicznymi.

277 E. Mączyńska, op. cit., s. 165. Ze względu na małe znaczenie dla waloryzacji przestrzeni zurbanizowanej pomijam metody wyceny nieruchomości rolnych i leśnych. 
Generalna zasada metody porównawczej wyceny nieruchomości wskazuje na konieczność prowadzenia analizy w okresie nie dłuższym niż dwuletni. Ma to na celu wyeliminowanie jak największej liczby zmiennych niezależnych wpływających na wycenę. W ramach badania rynku nieruchomości dla metody WWP możliwe jest jednak stosowanie również dłuższych szeregów czasowych. Celem takiego działania jest wskazywanie trendów kształtowania się cen stanowiących rezultaty przekształceń badanych przestrzeni, pokazywanych w ujęciu rocznym.

\subsubsection{Analiza infrastruktury osadniczej}

Druga z proponowanych metod szczegółowych WWP odnosi się do oceny infrastruktury osadniczej. Jest to pojęcie stosowane nieco rzadziej od bardziej rozpowszechnionej koncepcji infrastruktury społecznej. Oba terminy cechują się równocześnie pewnymi podobieństwami i różnicami. Ten drugi wskazuje na stopień wyposażenia przestrzeni zurbanizowanej w tak zwane usługi podstawowe. Dotyczą one przede wszystkim zaspokajania potrzeb edukacyjnych, opiekuńczych, tych z zakresu ochrony zdrowia czy wyposażenia handlowego. Z kolei do infrastruktury osadniczej zalicza się także szerzej rozumiane usługi podstawowe, jakimi są urządzenia infrastruktury komunalnej (urządzenia technicznej obsługi, jak wodociągi i kanalizacja ${ }^{278}$. Koncepcja infrastruktury osadniczej zwraca zatem uwagę nie tylko na podstawowe aspekty wyposażenia przestrzeni zurbanizowanej, ale także i jej bardziej złożone wymiary. Waloryzacja tego aspektu materialnego wymiaru przestrzeni zurbanizowanej sugeruje konieczność analizy zarówno technicznego przygotowania infrastruktury, włącznie z jej badaniami ilościowymi, jak i jej badania jakościowego. Pozwala ono ocenić stopień dopasowania tej infrastruktury do potrzeb jej użytkowników. W pierwszym wymiarze przedmiotem oceny jest kwestia dostępności infrastruktury, odwołująca się do ocen o charakterze obiektywnym. W pozostałych stanowi go natomiast analiza zachowań komunikacyjnych i aktywności wykonywanych w przestrzeni publicznej przez użytkowników. Wskaźniki obrazujące jakość tego aspektu mają charakter behawioralny.

W wymiarze badania poziomu dostępności lokalnej infrastruktury osadniczej opisywana metoda szczegółowa koncentruje się na szeroko rozumianej inwentaryzacji danego obszaru. Ma to na celu zbadanie jakości infrastruktury i jej możliwości zaspokajania potrzeb lokalnej ludności. Kryterium dostępności usług podstawowych wynika z zasad wymiarowania przestrzeni zamieszkanej. Jak zauważa Jan M. Chmielewski, przy planowaniu budownictwa mieszkaniowego istotne są dwie skale. Są to (1) regulująca stosunki między ludźmi skala dystansów społecznych

${ }^{278}$ M. Cesarski, Od funkcjonalnego mieszkania ku zrównoważonej przestrzeni zamieszkiwania rola infrastruktury osadniczej, „Kwartalnik Kolegium Ekonomiczno-Społecznego Studia i Prace”, nr 2/2012, s. 136-137. 
oraz ta związana z (2) granicą akceptowanego dojścia pieszego. W ujęciu tego autora dystans pieszy pokonywany przez mieszkańców „bez wysiłku”, podobnie jak dla przywołanego już Jana Gehla, to odległość rzędu 500 metrów. Obok tej klasyfikacji Chmielewski podaje kolejne dystanse, takie jak bliskie dojście (80 metrów) oraz dojście akceptowalne (1000 metrów $)^{279}$. Na bazie tych wartości opracowana została przezeń dokładna skala wymiarowania przestrzeni grupowych (osiedlowych). Obejmuje ona pożądane odległości od miejsca zamieszkania dla przedszkola (250-350 metrów), żłobka (500-600 metrów), przychodni zdrowia i apteki (500-1000 metrów), ośrodka osiedlowego (700-800 metrów), szkoły podstawowej (500-600 metrów), sklepu spożywczego (250-300 metrów) oraz klubu osiedlowego (250-600 metrów) $)^{280}$.

Dokładne odzwierciedlenie dystansów w skali tego rodzaju jest niemożliwe, stąd jest to raczej typ idealny projektowania przestrzeni zamieszkanej. W historii podejmowano już jednak próby tego typu opracowań, chociaż dokładne zwymiarowanie przestrzeni zamieszkanej w ten sposób jest niezwykle trudne. Barierami w tym zakresie są na przykład ukształtowanie terenu, dostępność dla osób z niepełnosprawnościami ${ }^{281}$ i rozmiar nieruchomości służącej inwestycji przy budowie nowego osiedla. Inne przeszkody stanowią ograniczenia zagospodarowania terenu już istniejącego siedliska czy wreszcie kapitałochłonność infrastruktury społecznej. Najbardziej popularnym przykładem próby wcielenia tych założeń w życie była koncepcja jednostki sąsiedzkiej. Zdaniem Aleksandra Wallisa opisać można ją jako osiedle tworzone

w oparciu o wspólne terytorium, na którym lokalizowano centrum usługowe, ośrodek rekreacyjny, przedszkole i szkołę [...][, mające] prowadzić do powstania nowej wspólnoty miejskiej. Koncepcja urbanistyczna [była] nastawiona tutaj w maksymalnym stopniu na sprzyjanie kontaktom wewnątrz osiedla oraz na podkreślanie jego odrębności ${ }^{282}$.

279 Zwraca uwagę niespójność terminologiczna między Gehlem i Chmielewskim. W tej pracy jako dojście „akceptowalne” przyjmuję granicę 500 metrów, zgodnie z definicją tego pierwszego.

${ }^{280}$ J.M. Chmielewski, Teoria urbanistyki w projektowaniu..., s. 103. Wśród potencjalnych zastrzeżeń do tej koncepcji należy zgłosić brak precyzyjnego wymiarowania odległości do urzędu pocztowego i administracji osiedlowej. Przez cytowanego autora wskazane są one wśród ,innych usług wymagających indywidualnego programu”.

${ }^{281}$ Tematyką dostępności architektoniczno-urbanistycznej dla osób z niepełnosprawnościami zajmuje się projektowanie uniwersalne (universal design). Kładzie ono nacisk na takie projektowanie przestrzeni zurbanizowanej, które uwzględnia „potrzeby wszystkich ludzi - użytkowników otoczenia, niezależnie od ich możliwości fizycznych i psychicznych”. Zob. E. Kuryłowicz, Uwarunkowania architektoniczne kształtowania otoczenia wybudowanego przyjaznego dla osób niepełnosprawnych, [w:] A. Jędrzejczak-Sprycha (red.), Projektowanie uniwersalne. Sztokholm miasto dla wszystkich, Stowarzyszenie Przyjaciół Integracji, Warszawa 2005, s. 13.

282 A. Wallis, Socjologia wielkiego miasta, Państwowe Wydawnictwo Naukowe, Warszawa 1967, s. $133-134$. 
W opinii przywołanego autora rozwiązanie to dobrze sprzyjało najmłodszym mieszkańcom, więcej problemów wprowadzając do świata dorosłych. Mimo wszystko było jednak prawdopodobnie najlepszym ze znanych sposobów organizacji ekologicznych stosunków w mieście. Jakkolwiek przedmiotem analiz niniejszej książki nie są osiedla powstałe według koncepcji jednostki sąsiedzkiej, w badaniu jakości przestrzeni zurbanizowanej własności te są bardzo użyteczne jako wytyczne dla modelowych rozwiązań.

Drugim z istotnych wymiarów waloryzacji infrastruktury osadniczej jest badanie jej wartości użytkowej. Odnosi się ona do innego aspektu niż wartość wymienna analizowana na podstawie badania rynku nieruchomości. Sposób użytkowania umożliwia opracowanie wskaźnika jakości przestrzeni zurbanizowanej typu behawioralnego. W tym zakresie przede wszystkim badać można zachowania w przestrzeni publicznej. Wśród odwołujących się do tej kategorii aktywności pozadomowych Gehl wyróżnia trzy typy. Po pierwsze, są to odbywające się w każdych warunkach a ktywności konieczne, na przykład dojście do autobusu. Po drugie, mające miejsce jedynie w sprzyjających warunkach zewnętrznych aktywności opcjonalne, takie jak przechadzka dla zaczerpnięcia świeżego powietrza. Po trzecie, a ktywności społeczne, zależne od obecności innych ludzi w publicznej przestrzeni, na przykład zabawa dzieci. Zdaniem przywołanego autora wraz z poprawą jakości przestrzeni pozadomowej wzrasta liczba czynności opcjonalnych, pociągając za sobą także wzrost liczebny czynności społecznych ${ }^{283}$. Ważnym wskaźnikiem w badaniach aktywności pozadomowych jest też poziom intensywności ruchu pieszego. Ma on „szczególne znaczenie dla oceny wycinków przestrzeni miejskiej [...]. Uważa się go za podstawowy czynnik witalności śródmieść i poszczególnych dzielnic"284.

Badanie aktywności w przestrzeni publicznej korzysta z metod ilościowych i jakościowych. W aspekcie ilościowym uwagę zwraca liczba użytkowników, ich charakterystyka metrykalna oraz natężenie wykonywanych czynności. Dla waloryzacji przestrzeni istotna jest nie tylko liczba jej użytkowników, ale też odsetek tych, którzy decydują się podjąć działanie świadczące o wykorzystywaniu tej przestrzeni w określony sposób. W przypadku przestrzeni tranzytowej liczba osób w niej obecnych będzie miała inne znaczenie niż w odniesieniu do ślepego zaułka. Ważne będzie natomiast to, ile osób zdecyduje się w obu tych miejscach usiąść, aby móc odpocząć lub wejść w interakcję z innym użytkownikiem. Obserwacja pod względem charakterystyki metrykalnej ma charakter szacunkowy. Nie jest bowiem możliwe dokładne określenie wieku ani charakteru relacji użytkowników.

${ }^{283}$ J. Gehl, Życie między budynkami..., s. 9-14; J. Gehl, Miasta dla ludzi..., s. 20-22.

${ }^{284}$ I. Cieślak, Waloryzacja przestrzeni miejskiej - ocena jakości użytkowej przestrzeni komunikacyjnej [w:] eadem (red.), Wspótczesna waloryzacja przestrzeni..., s. 177. 
Z tego też względu obok łatwo identyfikowalnej płci przyjmuje się dla innych cech kategorie ogólne takie jak młodzież, osoby dorosłe czy seniorzy. Dla waloryzacji przestrzeni ważne jest też zwrócenie uwagi na dokładny kontekst podejmowanych działań, na czele z ich formalnym bądź nieformalnym charakterem. W odniesieniu do przywołanej wcześniej sytuacji (siedzenia) ważne jest zdiagnozowanie tego, czy ma ono charakter użytkowania formalnego (na przykład ławka, krzesło) czy nieformalnego (ziemia, trawnik, schody) ${ }^{285}$. Badanie tego rodzaju pozwala ocenić jakość przestrzeni pod kątem takich czynników, jak potencjalna uniformizacja i opresyjność (zakaz deptania trawników) czy otwarcie na spontaniczne sposoby użytkowania (możliwość swobodnego piknikowania na trawniku).

Obserwacje aktywności w przestrzeni publicznej mają też charakter jakościowy. Określa to sytuacja właściwa dla konkretnych miejsc, co może ograniczać porównywalność pozyskanych tą drogą danych. Przykład takiej informacji to jakościowy szacunek popularności przestrzeni wśród osób nieheteronormatywnych, widoczny w przypadku miast zachodnich (Nowy Jork), ale już nie w przypadku tych o przewadze ludności muzułmańskiej (Stambuł). Popularność tę trudno ująć za pomocą dokładnych danych liczbowych. Przykładem bardziej uniwersalnym jest z kolei badanie uwzględniające liczbę i charakterystykę odwiedzających dane miejsce psów. Występowanie tych zwierząt (w uzależnieniu od liczby i rasy) może charakteryzować do pewnego stopnia wybrane przestrzenie i stopień ich gentryfikacji. Sylvie Tissot wskazuje w tym kontekście na popularność pewnych ras w rejonach o większej zamożności. Widać to zwłaszcza na przykładzie „rodzinnych” ras $\mathrm{z}$ rodziny retrieverów $\mathrm{w}$ zestawieniu $\mathrm{z}$ rasami agresywnymi reprezentatywnymi dla uboższych sąsiedztw ${ }^{286}$.

Istotnym czynnikiem badań jakości przestrzeni publicznej jest ponadto wpływ czasu. Obok zróżnicowanych poziomów postrzegania przestrzeni, w samym tylko jej materialnym wymiarze jest ona inaczej użytkowana w rytmie doby, dni tygodnia, dni specjalnych (świąt państwowych i religijnych oraz innych dni zwiększających użytkowanie związanych z konkretnymi wydarzeniami w przestrzeni publicznej: festiwalami, widowiskami, pogrzebami itp.) oraz pór roku. Z tego względu zaleca się dokonywanie pomiarów o zróżnicowanych porach dnia; przy dobrej pogodzie (zachmurzenie, opady i wiatr ograniczają użytkowanie przestrzeni w inny sposób niż za pomocą działań koniecznych, do pewnego stopnia powoduje to też upał);

285 J. Gehl, B. Svarre, How To Study Public Life?, Island Press, Washington 2013, s. 7.

${ }^{286}$ S. Tissot, Good Neighbors: Gentrifying Diversity in Boston's South End, Verso, London-New York 2015, ebook. Już sama obecność psów w przestrzeni publicznej jest cennym wskaźnikiem charakteryzującym ich właścicieli. Pies jest przykładem zwierzęcia niedostosowanego do modelu życia prekariatu, w przeciwieństwie do kota, którego nie trzeba wyprowadzać na spacer i można na dłużej zostawić w domu. Lepiej przez to pasuje do gospodarstw domowych prowadzonych przez osoby o nieregularnym czasie pracy. 
w różnych dniach tygodnia sprzyjających odmiennym typom użytkowania; a także ich powtarzanie. Wszystko to zapewnia możliwość późniejszego uśrednienia wyników pomiarów ${ }^{287}$. Wskazane czynniki wymuszają również zróżnicowane tempo poruszania się oraz motywują do różnej długości przebywania w poszczególnych miejscach. Szybciej chodzi się na przykład przy niskiej temperaturze powietrza. Często związane jest to dodatkowo z grupą wiekową i zawodową. Inne tempo poruszania się mają przecież seniorka, grupa osób poruszających się w towarzystwie małych dzieci albo policjant patrolujący okolicę 288 .

W opinii Gehla i Birgitte Svarre ${ }^{289}$ w gronie technik pomiarowych wyróżnić można następujące rozwiązania, korzystające ze zróżnicowanych sposobów pozyskiwania i prezentacji danych:

1) zliczanie - określa dokładną liczbę użytkowników przestrzeni - może mieć charakter manualny bądź być wykonywane urządzeniami pomiarowymi o różnym stopniu automatyzacji;

2) mapowanie - pokazuje rozkład czynności oraz ewentualnie ich natężenie w poszczególnych fragmentach przestrzeni, szkicowane manualnie albo automatycznie;

3) wyznaczanie tras (tracing) - podobne do techniki mapowania, ukazuje graficznie trasy najczęściej wybierane przez użytkowników przestrzeni;

4) śledzenie (tracking) - w odróżnieniu od techniki wyznaczania tras skupione na dokładniejszej obserwacji zachowania konkretnych użytkowników przestrzeni;

5) tropienie śladów (looking for traces) - analiza pod kątem śladów tras utrwalonych w przestrzeni (przedeptów na terenach nieprzeznaczonych do komunikacji czy śladów na śniegu), która na inny sposób pokazuje najczęściej wybierane trasy piesze;

6) fotografowanie i filmowanie - utrwalanie obrazów związanych z przestrzenią poszerzające obserwacje wykonywane na bieżąco oraz ułatwiające ich wizualizację;

7) korzystanie z dziennika badawczego - notowanie i szkicowanie informacji przez badacza;

8) testowanie piesze - wykonywanie przez obserwatora autorskich testów zapoznających go z przestrzenią 290 .

${ }^{287}$ D. Sauter, M. Wedderburn, Measuring Walking. Towards Internationally Standarised Monitoring Methods of Walking and Public Space, referat wygłoszony podczas konferencji „On Survey Methods in Transport”, Annecy (Francja), 25-31 maja 2008 r., http://bit.ly/2Wpdg2H, dostęp: 25.03.2019.

288 J. Gehl, B. Svarre, op. cit., s. 18-19.

289 Ibidem, s. 22-35.

${ }^{290}$ W odniesieniu do pierwszych pięciu kategorii podobną, acz uproszczoną typologię opisuje Cieślak wyróżniająca wśród „metod ewaluacji” przestrzeni publicznych: mapowanie behawio- 
W badaniu stanowiącym element niniejszej pracy wykorzystałem cztery ostatnie spośród wskazanych wyżej technik. Są one najbardziej użyteczne w badaniach jakościowych wykonywanych przez badacza samodzielnie. Pozostałe, na czele ze zliczaniem użytkowników przestrzeni, lepiej sprawdzają się w przypadku długotrwałych obserwacji wykonywanych przez zorganizowane zespoły. Ważnym czynnikiem jest też kształt i charakter badanej przestrzeni, warunkujący sensowność wykorzystania poszczególnych technik pomiarowych. Techniką praktyczną i łatwą w zastosowaniu, nawet przy braku zaplecza w postaci większego zespołu, jest z pewnością śledzenie pozwalające sprawdzać prędkość poruszania się pieszych. Rozwiązanie to sprawdza się w odniesieniu do przestrzeni liniowych, takich jak analizowany w tej pracy High Line Park. Inne badane studia przypadku mają jednak charakter punktowy lub obszarowy. Uniemożliwiło to tym samym zastosowanie podobnych pomiarów dla celów tej książki.

Kolejnym wskaźnikiem behawioralnym służącym waloryzacji wartości użytkowej przestrzeni jest określenie jej uwarunkowań komunikacyjnych. Poruszanie się pieszo jest najbardziej podstawowym typem zachowania komunikacyjnego, a zarazem kategorią użytkowania przestrzeni publicznej. Co jednak istotne, uwarunkowania komunikacyjne mają też szerszy kontekst i związane są z większym obszarem niż granice pola podstawowego. Innymi słowy, odnoszą się do sposobów poruszania się po badanym obszarze (mała skala komunikacji) oraz wydostania się z tego obszaru (duża skala komunikacji). Pierwsza skala odnosi się do badań aktywności w przestrzeni publicznej, a druga do zaawansowanych badań ruchu. Te ostatnie często przyjmują postać złożonych metodologicznie i cyklicznych w swoim charakterze analiz. Zaawansowane badania ruchu sprawdzają szczegółowo odbywane przez mieszkańców miasta podróże, rozumiane jako zmiany miejsca pobytu dokonywane przy użyciu jednego bądź kilku środków transportu, mające określony cel i trasę ${ }^{291}$. W badaniach ruchu wyróżnia się podróże piesze oraz niepiesze, czyli te wykorzystujące przynajmniej jeden środek transportu. Dzięki wyróżnieniu rodzajów podróży niepieszych możliwe jest też stworzenie podziału zadań przewozowych. Wyróżnia on takie metody przemieszczania się, jak podróż pojazdami transportu publicznego (z możliwością wskazania ich dalszych rodzajów), samochodami osobowymi (niekiedy z wyodrębnieniem taksówek), rowerami

ralne, metody zliczania oraz techniki śledzenia i tropienia śladów. Zob. I. Cieślak, Wybrane metody waloryzacji..., s. 67-70. Przegląd technik komputerowych w publikacji D. Bauer, N. Brändle, S. Seer, M. Ray, K. Kitazawa, Measurement of Pedestrian Movements: A Comparative Study on Various Existing Systems, [w:] H. Timmermans (red.), Pedestrian Behavior. Models, Data Collection and Applications, Emerald, Bingley 2009, passim. Zob. też D. Ley, R. Cybriwsky, Urban Graffiti as territorial Markers, „Annals of the Association of American Geographers”, nr 4/1974, passim.

${ }^{291}$ Na przykład dłuższą niż 100 metrów. 
czy jeszcze innymi środkami transportu. Dobór tych ostatnich uzależnia się od lokalnego kontekstu. Dla niektórych przestrzeni w badanym w tej pracy Stambule użyteczne byłoby na przykład analizowanie ruchu promów na Bosforze oraz podziemnych kolejek linowych tünel, które mają w tej aglomeracji istotne znaczenie transportowe. Badania ruchu ze względu na swoją złożoność pozwalają niekiedy pozyskać w tym zakresie niezwykle dokładne dane. Wykorzystane przeze mnie badanie warszawskie z 2015 roku czerpie z analiz dotyczących 36,5 tysiąca indywidualnych podróży odbywanych na terenie stolicy. Wskazuje także kilkaset rejonów początku i końca podróży, które są zbliżone do przyjętych tu pól podstawowego i kontrolnego. Względy finansowe i organizacyjne tak zaawansowanego projektu skłaniają do korzystania w tym zakresie z danych zastanych.

Badanie uwarunkowań komunikacyjnych ma duże znaczenie dla waloryzacji przestrzeni i jest wskaźnikiem ponadprzeciętnie „obiektywnym”. W porównaniu do wielu nieprecyzyjnych kategorii urbanistycznych układ komunikacyjny jest stosunkowo łatwo mierzalny. Sposoby poruszania się istotnie wpływają na jakość życia w środowisku zurbanizowanym, a także na inne czynniki je kształtujące. Szczególnie wskaźnik podziału zadań przewozowych odgrywa rolę agregatu dla większej liczby danych. Istotne jest tu zwrócenie uwagi na udziały ruchu pieszego i samochodów prywatnych, mogące świadczyć o takich kwestiach, jak poziom usług transportu publicznego, stopień segregacji społecznej czy skala dekoncentracji przestrzennej miasta. Jak pokazują badania przestrzeni zamieszkanej, zwiększenie skali ruchu pieszego poprawia jakość powietrza, korzystnie wpływa na aktywność fizyczną mieszkańców, zwiększa bezpieczeństwo komunikacyjne, a nawet zwiększa poziom ogólnej konsumpcji. Ten ostatni mechanizm stanowi pochodną wzrostu obrotów punktów handlowych położonych przy ulicach przyjaznych pieszym $^{292}$. W konsekwencji tego jako miasto dobre do życia coraz częściej określa się takie, które sprzyja właśnie ruchowi pieszemu (walkable) ${ }^{293}$. Z kolei forsowanie ruchu samochodowego wpływa destrukcyjnie na zachowania społeczne. Kierowcy odbierają miasto w innej skali. Dostrzegają mniej szczegółów, mają mniejszą możliwość skorzystania z punktów usługowych i spontanicznego zachowania. Przypadkowe spotkania i interakcje częste w transporcie publicznym, na drodze rowerowej czy chodniku, w przypadku podróży samochodowych są już niemal niemożliwe. Pomiary prowadzone przez zespół Gehla wskazują, iż przy ulicach o większym natężeniu ruchu ludzie mniej chętnie ze sobą rozmawiają. Przy ciągach o jego szyb-

${ }^{292}$ M. Skrzypek, Atlas sytuacji pieszych, fundacja tu obok, Lublin 2016, s. 14-18.

293 Ł. Drozda, Dyktatura kierowców. Nieracjonalność systemu transportowego Warszawy, [w:] B. Świątkowska, K. Pobłocki (red.), Architektura niezrównoważona, Fundacja Bęc Zmiana, Warszawa 2016, s. 97; J. Speck, Walkable City. How Downtown Can Save America, One Step at a Time, North Point Press, New York 2013, ebook. 
szym tempie są zaś mało skłonni do tego, aby pozwalać samodzielnie poruszać się swoim dzieciom ${ }^{294}$.

Ocena infrastruktury osadniczej cechuje się różną trafnością w zależności od stopnia dokładności i liczby wykorzystanych źródeł. Kluczowe dla tej metody szczegółowej WWP jest prowadzenie analiz w odniesieniu do jej obiektywnej dostępności, a także behawioralnych analiz zachowania jej użytkowników.

\subsubsection{Gentryfikacja obszaru}

Przyjęcie wskaźnika oceny zaawansowania „uszlachetnienia” danej przestrzeni pozwala zwrócić uwagę na skutki procesu jej społecznego wytwarzania wywierane w odniesieniu do poszczególnych aktorów. Nawet jeżeli środowisko zurbanizowane cechuje się wysoką jakością, ważna jest kwestia tego, kto korzysta z finalnego kształtu miejsc wytworzonych w ramach tego procesu. Istotne jest zatem badanie użytkowników takiej przestrzeni nie pod kątem tradycyjnie rozumianego salda migracji, określającego ilościowy wymiar wzrostu lub regresu populacji ${ }^{295}$, lecz charakterystyki jakościowej. Z punktu widzenia waloryzacji przestrzeni interesującym pytaniem nie jest to, o ile zmieniła się liczba ludności pola podstawowego, ale to, jaki ta zmiana ma charakter i w jakim stopniu prowadzi do wypierania (displacement) dotychczasowej populacji. Gentryfikacja stanowi często pochodną procesu rewitalizacji. Ustawowa definicja klasyfikuje ten ostatni jako wielowymiarową interwencję społeczną, kładącą nacisk nie tylko na prowadzone przy tej okazji roboty budowlane, ale też społeczne i ekonomiczne zanurzenie tego procesu. Rewitalizacja kojarzona bywa jednak z interwencją w samo środowisko zbudowane. Sprzyja to inspirowaniu przez ten mechanizm polityki miejskiej nie rozwiązań sprzyjających zrównoważonemu osadnictwu, lecz praktyk wywołujących segregację przestrzenną ${ }^{296}$. Skłania to wręcz do utożsamiania rewitalizacji z dokonującą się w rzeczywistości „dewitalizacją” życia społecznego w sąsiedztwach doświadczających tego typu programów regeneracji ${ }^{297}$.

Gentryfikacja jest określeniem sekwencyjnego procesu przemiany przestrzeni zurbanizowanej. Odnosi się do obszarów zdegradowanych, które odzyskują status atrakcyjnych przestrzeni ${ }^{298}$. Spośród różnych modeli stadialnych tego procesu

${ }^{294}$ J. Gehl, Życie między budynkami..., s. 172-173.

295 B. Hamm, op. cit., s. 108.

296 Ł. Drozda, Pułapka gentryfikacji? Związki...

${ }^{297}$ N. Smith, Gentrification and Uneven Development, „Economic Geography”, vol. 58, nr 2/1982, s. $139-140$.

298 „Autorką pojęcia gentryfikacja jest brytyjska socjolożka, Ruth Glass, która w publikacji z 1964 roku zauważyła, że dochodziło ówcześnie do klasowej »sukcesji» w Londynie, powodującej wypieranie dotychczasowych mieszkańców z wybranych sąsiedztw [...] szczególnie widoczne 
najczęściej wyróżnia się jego dwie fazy podstawowe: gentryfikację marginalną oraz zaawansowaną. W pierwszym etapie dochodzi do wzrostu różnorodności populacji poddawanego temu procesowi obszaru. Pojawiają się wówczas tak zwani pionierzy gentryfikacji, wśród których wyróżnia się przede wszystkim takie grupy, jak artyści i pracownicy sektora kultury, turyści oraz studenci. Od rdzennej ludności odróżniają ich większe zasoby kapitału kulturowego w jego trzech formach - ucieleśnionej (obycie w świecie i znajomość norm kulturowych), instytucjonalnej (wykształcenie poparte dyplomem) oraz uprzedmiotowionej (posiadane przedmioty). Gentryfierzy marginalni pozwalają uatrakcyjnić wizerunek przestrzeni, nadać mu intrygującą, kontrkulturową aurę. Pomagają też skojarzyć jej powszechny wizerunek z kreatywnością, czyli jednym z kluczowych terminów neoliberalnego dyskursu o przestrzeni ${ }^{299}$.

W ślad za gentryfikacyjnymi pionierami pojawiają się osoby dysponujące już najbardziej tradycyjną formą kapitału - kapitałem ekonomicznym. Są to gentryfierzy zaawansowani, korzystający z dobrodziejstw wcześniej „uszlachetnionej” już przestrzeni. O jej atrakcyjności świadczy nie tylko jej atrakcyjny wizerunek, ale i dobra lokalizacja oraz wyposażenie w wysokiej jakości infrastrukturę osadniczą. Przejmowana przez nich przestrzeń obok budzącej pozytywne skojarzenia reinwestycji przechodzi także proces unifikacji i komercjalizacji. Symbolizują ją estetyzacja przestrzeni, zmiana profilu dostępnych lokalnie usług oraz wypieranie dotychczasowej ludności. To ostatnie zjawisko pokazuje niekiedy brutalne oblicze, tak jak w przypadku polskiej „dzikiej reprywatyzacji”300. Wiąże się ona z wszelkimi możliwymi formami „oczyszczania” atrakcyjnych nieruchomości z ich dotychczasowych lokatorów, jeśli tylko nie gwarantują właścicielom budynków maksymalnego zysku. Innym razem wysiedlenia mają przyczyny bardziej pośrednie jako związane z rosnącymi kosztami życia w sąsiedztwach, na których obszarze dotychczasowe usługi zastępują na przykład drogie kawiarnie sieciowe. Kulminacją tego zjawiska jest możliwość wystąpienia dodatkowej fazy określanej jako supergentryfikacja. Odnosi się ona do sytuacji, w której przekształcone jeszcze wcześniej w za-

w dzielnicach Hampstead i Chelsea”. Termin gentry to anglojęzyczne określenie szlachty. Ł. Drozda, Uszlachetniajq̨c przestrzeń. Jak..., s. 40; R. Glass, Aspects of Change, [w:] J. Brown-Saracino (red.), The Gentrification Debates, Routledge, New York 2010, passim.

299 O. Mould, Against Creativity, Verso, London-New York 2018, passim.

${ }^{300}$ W latach 2016-2018 ukazała się cała grupa publikacji na ten temat. Zob. np. P. Ciszewski, R. Nowak, Wszystkich nas nie spalicie, Trzecia Strona, Warszawa 2016, passim; I. Szpala, M. Zubik, Święte prawo. Historie ludzi i kamienic z reprywatyzacją w tle, Wydawnictwo Agora, Warszawa 2017, passim. Szerszy przegląd zob. Ł. Drozda, "Wild reprivatization”: property restitution on the example of post-communist Warsaw, „dérive”, vol. 72, nr 3/2018, passim. 
awansowanym stopniu sąsiedztwo zostaje zdominowane przez jeszcze bogatszych gentryfierów, którzy wypierają tych już i tak zamożnych ${ }^{301}$.

Gentryfikacja ma tym samym kilka wymiarów mogących zaistnieć równolegle lub w odosobnieniu. Z tego względu wyróżnić należy (1) gentryfikację społeczną, związaną z wymianą ludności i służącej jej infrastruktury osadniczej, (2) gentryfikację ekonomiczną, której następstwem jest wzrost wartości rynkowej nieruchomości, oraz (3) gentryfikację przestrzenną, prowadzącą przede wszystkim do poprawy stanu lokalnego środowiska zbudowanego. $\mathrm{O}$ zaawansowaniu gentryfikacji świadczy stopień przekształceń przestrzeni zurbanizowanej w odniesieniu do każdego z przywołanych tu wymiarów (tabela 4).

Nasilenie gentryfikacji społecznej, jako związane z wypieraniem dotychczasowej populacji i relokowaniem nierozwiązanych problemów poza „uszlachetniony” obszar, ocenia się na ogół wyjątkowo negatywnie. Z tego punktu widzenia występowanie gentryfikacji i pomiar stopnia jej zaawansowania stanowią wskaźnik użyteczny dla metody WWP. Trudne w operacjonalizacji i złożone zjawisko mierzone jest w sposób subiektywny, zwłaszcza za względu na niedostępność wielu danych potrzebnych dla oszacowania skali ,uszlachetniania” przestrzeni. Co jednak istotne, analiza gentryfikacji ekonomicznej opiera się de facto na badaniu rynku nieruchomości. Pokazuje to też częściowo obiektywne zakorzenienie wskaźnika właściwego dla tej metody szczegółowej. Wskaźniki cząstkowe gentryfikacji przestrzeni zurbanizowanej znajdujące zastosowanie w jej waloryzacji wskazują między innymi na odmienność „uszlachetniania” przestrzeni w przypadku obszarów o różnym stopniu intensywności urbanizacji.

\subsubsection{Ocena estetyki przestrzeni}

Uproszczona, jakościowa ocena estetyki przestrzeni (brzydka - ładna) należy do podstawowego wymiaru jej waloryzacji. Jest to też jedna z najbardziej uznaniowych w operacjonalizacji metod szczegółowych WWP. Oceny estetyczne mają wszakże dalece subiektywny charakter. Niezależnie od wątpliwości w stosunku do możliwości waloryzowania przestrzeni ze względu na jej piękno podejmuje się mimo wszystko w tym zakresie pewne próby badawcze $e^{302}$.

Najbardziej znaną z polskich metod waloryzacji estetycznej jest koncepcja krzywej wrażeń autorstwa Kazimierza Wejcherta. Zakłada ona możliwość oceny

301 Ł. Drozda, Uszlachetniając przestrzeń. Jak..., s. 39-78. Zob. też Ł. Drozda, The gentrification approach as an analytical tool in assessing the effects of participatory urban policy, „Urban Development Issues", nr 4/2018, passim.

302 E.L. Shafer, R.O. Brush, How To Measure Preferences for Photographs of Natural Landscapes, „Landscape Planning”, nr 4/1977, s. 255-256. 


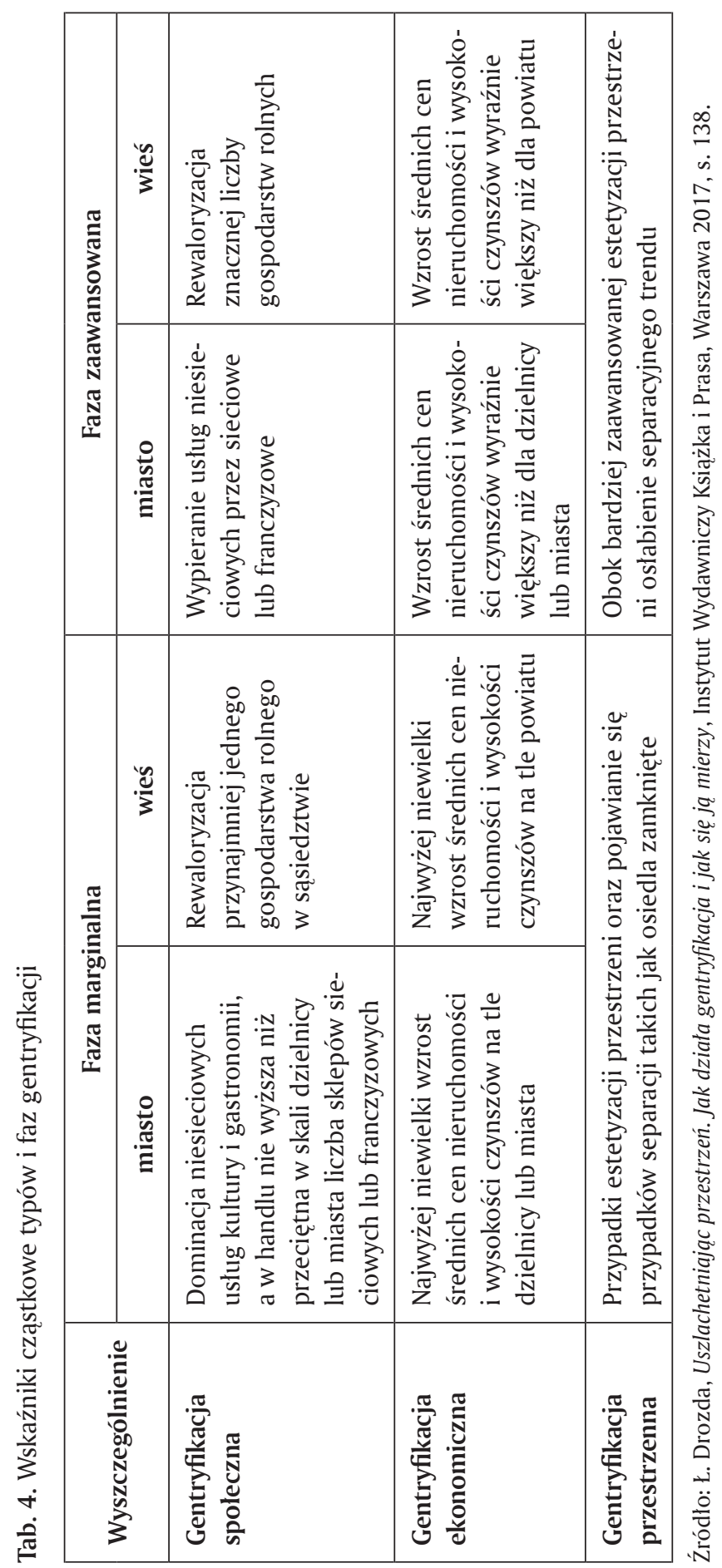


wrażeń emocjonalnych związanych z wartościowaniem przestrzeni poprzez analizę jej sekwencji. Jak podaje ten autor,

[p]omimo subiektywnych doznań i oceny układów przestrzennych przez różnych obserwatorów można przyjąć, że istnieje wyraźna grupa reagująca na widziane obrazy podobnie, przeciętnie, a wykres odchyleń od reakcji przeciętnej będzie zbliżony do „krzywej rozkładu normalnego"303.

Krzywa ta umożliwia ocenę elementów liniowych, takich jak miejskie ulice. Zgodnie z uwagami Wejcherta jego technika nie sprawdza się w środowisku monotonnym, składającym się z jednolitych wnętrz urbanistycznych pozbawionych większych otwarć. Jako przykład wnętrza czytelnego autor ten wymienia układ ulicy Krakowskie Przedmieście w Warszawie. Jej wnętrza

są bardzo czytelne, sprzężone za pomocą przestrzeni i dominant kolejnych odcinków tego ciągu: plac Zamkowy - wnętrze przed kościołem Karmelitów - małe wnętrze pożyteczne przed [Pałacem Prezydenckim] - wnętrze u wylotu ulicy Królewskiej - rozszerzenie ulicy przed Pałacem Staszica z centralnie ustawionym pomnikiem Kopernika i wysokościowym akcentem wież Kościoła Św. Krzyża. Te wyodrębniające się wyraźnie odcinki ulicy można nazwać odcinkami wrażeń, z których każdy ma swoją dominantę i odmienny od sąsiadujących odcinków nastrój. W strukturze miast, wydzielające się odcinki wrażeń stanowią o jej bogactwie, walorach indywidualnych przestrzeni, [ich] zapamiętywalności ${ }^{304}$.

Ważnym aspektem, jaki powinien towarzyszyć stosowaniu krzywej wrażeń, jest zwrócenie uwagi na czasoprzestrzenne ujęcie właściwe tej koncepcji. Na percepcję kolejnych elementów w istotny sposób wpływa zwłaszcza tempo ich odbioru. Venturiańska „architektura samochodowa” ${ }^{305}$ będzie odbierana w odmienny sposób w przypadku szybkiej jazdy autem. Pozwala ona bowiem swobodnie oglądać sekwencje akcentów dostosowanych do prędkości poruszania się samochodu. W przypadku podróży pieszych widok takich ciągnących się kilometrami parkingów i małej liczby architektonicznych detali jest zaś skrajnie monotonny. Dlatego też zastosowana w takim kontekście krzywa nie wykaże zróżnicowania przestrzeni. Podobnie wyglada to w przypadku podróżowania innymi środkami transportu, zwłaszcza podziemnym metrem ${ }^{306}$. Tworzenie odpowiednich sekwencji czasowych układu urbanistycznego było zresztą przez Kevina Lyncha porównywane do

${ }^{303}$ K. Wejchert, op. cit., s. 171.

${ }^{304}$ Ibidem, s. 174-176.

305 R. Venturi, D. Scott-Brown, S. Izenour, op. cit., passim.

306 J. Hidenobu, Tokyo. A Spatial Anthropology, University of California Press, Berkeley-London 1995, s. 9. 
fragmentów utworu muzycznego. Autor ten uważał je za jedno z podstawowych narzędzi projektowania urbanistycznego ${ }^{307}$.

Inną stosowaną metodą waloryzacji estetyki przestrzeni jest wywodząca się z leśnictwa ocena piękna scenerii (SBE, scenic beauty estimation) ${ }^{308}$. Dostosowana później także do potrzeb analizy różnych form krajobrazu kulturowego ${ }^{309}$ metoda ta pozwala w znormalizowany sposób dokonywać pomiarów opinii dotyczących nawet złożonych krajobrazów. Jak podają Jan Rylke i Magdalena Gąsowska, SBE obejmuje (1) przeprowadzenie podziału krajobrazu na jednostki podlegające ocenie; (2) wykonanie w każdej z nich 10-25 przezroczy reprezentatywnych dla jej wyglądu; (3) pokazanie slajdów i poddanie ich ocenie obserwatorów; oraz (4) obliczenie ich ocen ${ }^{310}$. Pozwala to na uzyskanie wiarygodnych opinii nawet w warunkach znacznej homogeniczności próby właściwej wysokiemu poziomowi jej selekcji. Jak pokazały testy przeprowadzone przez różnych autorów, możliwe jest mimo wszystko uzyskanie wiarygodnych wyników nawet w sytuacji, gdy respondenci nie znają całego kontekstu przestrzennego ${ }^{311}$. Czyni to SBE metodą bardziej uniwersalną w zastosowaniu od wspomnianej wcześniej krzywej wrażeń.

$Z$ drugiej strony, wadą tego rozwiązania jest potencjalne niedoszacowanie innych zmysłów wpływających na percepcję przestrzeni: dźwięku czy zapachu. Podstawową jego zaletą jest jednak możliwość dokonywania analizy obszaru o bardziej zróżnicowanym układzie przestrzennym niż liniowy. We wspomnianym i najczęściej stosowanym wariancie SBE polega na podziale ocenianego krajobrazu na części, co umożliwia na przykład oddzielenie od siebie poszczególnych wnętrz urbanistycznych. Krzysztof Herman zastosował natomiast zmodyfikowany wariant SBE. Rozwiązanie to nie wymaga już podobnego zhierarchizowania części

307 K. Lynch, op. cit., s. 125.

308 T.C. Daniel, R.S. Boster, Measuring Landscape Esthetics: The Scenic Beauty Estimation Method, USDA Forest Service, U.S. Department of Agriculture 1976, passim. Rzadziej używana jest nazwa metody piękna scenerii krajobrazu (PSK). Zob. I. Dymitryszyn, A. Schwerk, Piękno scenerii krajobrazu - turystyka a różnorodność gatunkowa biegaczowatych - przykład badań z Puszczy Piskiej i Drawieńskiego Parku Narodowego, „Studia i Materiały Centrum Edukacji Przyrodniczo-Leśnej”, z. 4/2009, passim.

309 Seung-Bin Im, Visual Preferences in Enclosed Urban Spaces. An Exploration of a Scientific Approach to Environmental Design, „Environment and Behavior”, vol. 16, nr 2/1984, passim.

$310 \mathrm{~J}$. Rylke, M. Gąsowska, Wartości krajobrazu wiejskiego i przemysłowego dla rozwoju rekreacji na przykładzie wsi warmińskich i Kanału Elbląskiego, „Nauka. Przyroda. Technologie”, t. 3, z. 1/2009, s. 7-8.

311 Seung-Bin Im, op. cit., s. 256-259. Herman zauważa z kolei, że znajomość lokalnego kontekstu przestrzennego stanowi jedyną zauważalną, istotną zmienną wpływającą na sposoby formułowania przez respondentów ich ocen jakości przestrzeni. Czynniki takie jak płeć, poziom wykształcenia czy wykonywany zawód zdają się nie wywierać podobnego wpływu. Zob. K. Herman, op. cit., s. 113-115. 
składowych i służy jedynie ocenie poszczególnych ilustracji badanej przestrzeni. Autor ten sprawdzał, w jaki sposób na jej percepcję wpływa wprowadzanie do niej nowych elementów modyfikujących jej wygląd ${ }^{312}$. Do podobnych zasad, jak te zastosowane w przypadku opisywanej metody, przychyla się też Piotr Sztompka. Jego zdaniem „,[w]iększą intersubiektywność interpretacji można uzyskać [...] "testując" ją na większym gronie odbiorców [...] [oraz] za pomocą większej liczby zdjęć"313. Zbliżoną opinię wyraził Paweł Rygiel. Wedle niego postrzeganie widzialnego otoczenia przez różne osoby jest podobne, co zarówno wynika $\mathrm{z}$ anatomicznych i fizjologicznych cech narządu ludzkiego wzroku, jak i jest warunkowane cywilizacyjnie i społecznie ${ }^{314}$. Jeszcze innym przykładem zastosowania fotografii dla celów waloryzacji przestrzeni i próby jej grupowej oceny jest badanie gustu architektonicznego autorstwa Błażeja Prośniewskiego. W ujęciu tego autora „najwłaściwsze zdaje się być użycie fotografii jako głównego narzędzia podczas badania gustu architektonicznego"315. Kolejne podejście to visitor employed photography, bardziej elastyczne od SBE i wykorzystujące fotografie wykonywane przez samych respondentów $w^{316}$.

Wskazane podejścia nie wyczerpują katalogu metod waloryzacji estetyki przestrzeni. Do podejść pozwalających identyfikować wartości estetyczne zaliczyć można też metodę wartościowania krajobrazu za pomocą kryterium linii prostej Janusza Janeckiego (wysoka ocena przestrzeni zbliżonych do krajobrazu naturalnego kategoryzowanych na podstawie „wysycenia linii prostych”); metodę DCP w badaniu ciągłości przestrzennych (przestrzeń o wysokiej wartości jest relatywnie jednorodna); metodę JARK-WAK Janusza Bogdanowskiego, oceniającą stan zachowania układu, kompozycji i zabudowy tradycyjnej ${ }^{317}$; czy niektóre techniki zaczerpnięte $\mathrm{z}$ badań marketingowych. Te ostatnie zdają się szczególnie przydatne przy ocenie potencjału przestrzeni dla celów turystyki ${ }^{318}$. W przeciwieństwie do SBE, krzywej wrażeń czy visitor employed photography rozwiązania te wskazują jednak

${ }^{312} \mathrm{~W}$ tym przypadku niewielkie urządzenia zielonej infrastruktury i meble miejskie. K. Herman, op. cit., s. 116-120.

313 P. Sztompka, op. cit., s. 95.

${ }^{314}$ P. Rygiel, Odporność wizualna krajobrazu - zastosowanie w planowaniu przestrzennym, „Czasopismo Techniczne. Architektura", z. 5-A/2007, s. 257.

315 Posługuje się on kategorią wywiadu fotograficznego, uzupełniając techniki ilościowe tymi o charakterze jakościowym. Zob. B. Prośniewski, Gust nasz pospolity, Fundacja Bęc Zmiana, Fundacja im. Stefana Kuryłowicza, Warszawa 2014, ebook.

316 G.J. Cherem, B.L. Driver, Visitor Employed Photography: A Technique to Measure Common Perceptions of Natural Environments, ,Journal of Leisure Research”, nr 1/1983, passim.

${ }^{317}$ I. Cieślak, Wybrane metody waloryzacji..., s. 59-67.

318 E.M. Cichy-Pazder, Atrakcyjność miasta metropolitarnego. Wyznaczniki percepcyjne i behawioralne, [w:] M. Madurowicz (red.), Percepcja wspótczesnej przestrzeni..., s. 133-142. 
apriorycznie na pewne cechy przestrzeni o wysokiej jakości. Uniemożliwia to formułowanie ocen dążących do obiektywizmu.

Ocena estetyki jest przykładem wskaźnika dalece subiektywnego, ale mimo wszystko wnosi istotny wkład w triangulację metodyki zastosowanej na użytek mojego badania. Ze względu na to wykorzystałem zmodyfikowaną wersję omawianej wyżej metody SBE. W przeciwieństwie do najbardziej rozpowszechnionego wariantu jej użycia nie wyróżniłem poszczególnych wnętrz urbanistycznych dla badanych przykładów. Wynika to z faktu, że większość analizowanych kontekstów przestrzennych nie wykazała pod tym względem dużej złożoności. Celem nadrzędnym było też porównanie pola podstawowego z przykładami wybranymi jako pola kontrolne. Istotna była zatem różnica, a nie dokładna wartość bezwzględna ocen formułowanych przez respondentów. Zamiast dzielić wszystkie przypadki na poszczególne jednostki, waloryzowane były przestrzenie relatywnie amorficzne. Większa dokładność dotyczyła wyboru takiej samej lub zbliżonej liczby ich zobrazowań. Fotografie przedstawiające poszczególne wycinki przestrzeni dobrałem dla uwypuklenia charakterystycznych i reprezentatywnych dystynkcji między polami podstawowym i kontrolnym. Zwracały w tym aspekcie uwagę na przykład różnice w typach zabudowy, skali i sposobach użytkowania pieszego czy charakterze występującego lokalnie ruchu ulicznego. Przemieszane ze sobą fotografie (łącznie 141 dla siedmiu miejsc) przedstawiłem paraeksperckiej grupie respondentów. Składała się ona ze studentów kierunku gospodarka przestrzenna, w ramach którego kształci się między innymi przyszłych urbanistów ${ }^{319}$. Podobnie jak we wspomnianym badaniu Hermana jako skalę ocen zastosowałem tradycyjną, pięciopunktową skalę Likerta ${ }^{320}$. Oceny dokonywane w ten sposób przez studentów wykazały dużą zbieżność i sugerują możliwość określenia uśrednionej, zbiorowej klasyfikacji (tabela 5).

Odchylenie standardowe ocen formułowanych w odniesieniu do poszczególnych zdjęć rzadko przekraczało więcej niż 1 stopień, co sugeruje możliwość uśredniania sposobów wartościowania przestrzeni przez respondentów. Zgodność opinii studentów pozwoliła na ich uśrednienie oraz sformułowanie w ten sposób zbiorowej waloryzacji estetycznej przestrzeni.

319 Badanie przeprowadzono w październiku 2017 roku z udziałem 72 studentów III i IV roku inżynierskich studiów stacjonarnych na kierunku gospodarka przestrzenna w Szkole Głównej Gospodarstwa Wiejskiego w Warszawie. Realizowany w tej uczelni kurs wprowadza także wiele istotnych z punktu widzenia przedmiotu kompetencji związanych z architekturą krajobrazu. Dziękuję za pomoc w przeprowadzeniu badania Beacie Gawryszewskiej i Kindze Niedziółce-Rybak.

${ }^{320}$ W większości badań SBE stosowana jest bardziej złożona skala dziesięciopunktowa. 
Tab. 5. Zróżnicowanie ocen w ramach zmodyfikowanej metody oceny piękna scenerii (SBE)

\begin{tabular}{|c|c|c|c|c|c|c|c|}
\hline \multirow[b]{2}{*}{ 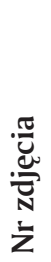 } & \multicolumn{7}{|c|}{ Miejsce } \\
\hline & $\frac{\bar{z}}{\frac{\pi}{2}}$ & 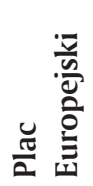 & 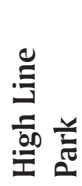 & 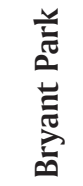 & 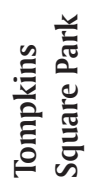 & $\frac{\overline{\frac{\pi}{Z}}}{\frac{\bar{z}}{z}}$ & 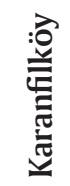 \\
\hline 1 & 0,77 & 0,70 & 0,93 & 0,80 & 0,84 & 0,89 & 0,69 \\
\hline 2 & 0,85 & 0,65 & 1,01 & 0,83 & 0,79 & 0,77 & 1,02 \\
\hline 3 & 0,73 & 0,67 & 1,03 & 0,85 & 0,89 & 0,79 & 0,72 \\
\hline 4 & 0,87 & 0,74 & 1,01 & 0,92 & 0,81 & 0,66 & 0,99 \\
\hline 5 & 1,11 & 0,93 & 0,83 & 0,79 & 0,71 & 0,75 & 1,10 \\
\hline 6 & 0,74 & 0,71 & 1,08 & 1,26 & 0,77 & 0,97 & 0,69 \\
\hline 7 & 0,94 & 1,12 & 1,11 & 1,17 & 0,79 & 0,81 & 1,03 \\
\hline 8 & 0,96 & 1,03 & 0,79 & 0,96 & 0,89 & 0,87 & 0,70 \\
\hline 9 & 0,67 & 0,82 & 0,71 & 0,91 & 0,83 & 0,96 & 0,89 \\
\hline 10 & 0,70 & 0,88 & 0,80 & 0,95 & 0,93 & 0,92 & 0,92 \\
\hline 11 & 0,81 & 1,00 & 1,01 & 1,02 & 0,82 & 0,80 & 0,93 \\
\hline 12 & 0,89 & 0,69 & 0,92 & 0,78 & 0,93 & 0,77 & 1,00 \\
\hline 13 & 0,95 & 1,07 & 0,95 & 0,69 & 0,61 & 0,92 & 0,74 \\
\hline 14 & 0,75 & 0,79 & 0,94 & 0,82 & 0,94 & 1,00 & 0,98 \\
\hline 15 & 0,77 & 0,87 & 0,76 & 0,85 & 0,95 & 0,61 & 0,92 \\
\hline 16 & 0,96 & 0,55 & 1,01 & 0,99 & 0,79 & & \\
\hline 17 & 1,07 & 0,75 & 0,84 & 0,70 & 0,84 & & \\
\hline 18 & 0,92 & 0,84 & 0,83 & 0,77 & 0,86 & & \\
\hline 19 & 0,77 & 0,93 & 0,81 & 0,74 & 0,79 & & \\
\hline 20 & 0,69 & 0,92 & 0,80 & 0,94 & 0,93 & & \\
\hline 21 & 0,75 & 0,98 & 0,97 & & & & \\
\hline 22 & 0,96 & 0,89 & 0,89 & & & & \\
\hline 23 & 0,72 & 0,93 & 0,97 & & & & \\
\hline 24 & & & 0,97 & & & & \\
\hline 25 & & & 1,09 & & & & \\
\hline
\end{tabular}

Źródło: opracowanie własne. 


\subsubsection{Mapowanie poznawcze}

Jak zauważa Luc Pauwels, w społecznych badaniach wizualnych dominują fotografie jako najwygodniejsze w przygotowaniu obrazy analizowanych przestrzeni. Cennych informacji dostarczają jednak także inne źródła. Autor ten wymienia w tym miejscu malarstwo i kreskówki, w przypadku których istotna jest nie tylko treść, ale i sposób prezentacji. Pauwels wyróżnia ogółem dwa rodzaje obrazów: mimesis (wierna reprodukcja lub przekaz) oraz ekspresję (kreacja lub konstruowanie pewnej wizji przedstawienia).

Oba te aspekty - na różne sposoby - odgrywają swoje role w każdym obrazie czy reprezentacji oraz w szerszym kontekście ich użycia [...]. Rzekome przeciwieństwo mimetyzmu i ekspresji jest mylące oraz niekonstruktywne ${ }^{321}$.

Omówiona już metoda szczegółowa oceny estetyki przestrzeni, mająca na celu relatywną obiektywizację subiektywnego wartościowania przestrzeni, jest w tym wymiarze metodą mimetyczną. Metody służące opisowi percepcji przestrzeni są natomiast oparte na ekspresji. Ich celem nie jest przedstawienie respondentom możliwie zobiektywizowanego materiału do rzetelnej oceny za pomocą metod ilościowych, ale odwrotnie, uzyskanie od nich obrazu skrajnie subiektywnego. Następnie zaś „odczytanie” na podstawie tego obrazu wartości przypisywanych przestrzeni. Innymi słowy, ocena estetyki odnosi się do Lefebvriańskiej przestrzeni reprezentowanej, natomiast metoda percepcji jest właściwa dla zidentyfikowanej przez tego autora przestrzeni reprezentacji. Tej ostatniej nie można przedstawić za kogoś. Stąd też obraz percepcji, i tak do pewnego stopnia zniekształcony przez sposób przedstawienia, zaprezentowany może zostać wyłącznie przez sam podmiot percepcji - osobę spostrzegającą przestrzeń. Z tego względu wśród technik stosowanych w badaniu percepcji przestrzeni wyróżnić należy formy opisowe i wizualne, możliwe do pozyskania w formie mówionej (wywiady), tekstowej bądź graficznej.

Forma graficzna odnosić może się do fotografii, ale są to zdjęcia wykonywane nie przez badacza wedle jego własnej wizji, lecz podmiot percepcji lub zgodnie z jego wytycznymi. Technikę tę określa się mianem wywiadu fotograficznego, którego celem nie jest uzyskanie „wirtualnego inwentarza obiektów, ludzi i artefaktów", ale odczytanie jego kontekstu społecznego i osobistego. Jak podaje Marisol Clark-Ibáñez, zdjęcia stanowiące podstawę wywiadu fotograficznego

${ }^{321}$ L. Pauwels, Zwrot wizualny $w$ badaniach $i$ komunikacji wiedzy. Kluczowe problemy rozwijania kompetencji wizualnej w naukach społecznych, [w:] M. Frąckowiak, K. Olechnicki (red.), Badania wizualne $w$ działaniu. Antologia tekstów, tłum. M. Rosińska, Fundacja Bęc Zmiana, Warszawa 2011, s. 25-26. 
funkcjonują [...] jako medium komunikacji pomiędzy badaczem a uczestnikiem badania. Fotografie nie muszą [nawet] reprezentować empirycznej prawdy lub „rzeczywistości”322.

Autorka ta podaje przykład respondentki, autorki zdjęcia drzewa wykonanego za pomocą aparatu fotograficznego otrzymanego od badaczki. Zdjęcie to, w zamierzeniu mające ukazywać życie codzienne badanej (meksykańskiej dziewczynki przebywającej nielegalnie na terenie USA), miało rozbudowaną, ale i ukrytą wartość poznawczą. Dzięki metodzie wywiadu, łączącej analizę wykonanych przez respondentkę zdjęć z późniejszą rozmową z badaczką, możliwe stało się odkrycie warunków życia dziewczynki. Oznaczały one izolację w wielogodzinnym osamotnieniu, w zamkniętym domu, w sytuacji surowego zakazu wyjścia na zewnątrz. Złamanie tej reguły groziłoby bowiem kontaktem z patrolem straży granicznej, mogącej deportować małoletnią imigrantkę i jej rodzinę.

Inna metoda badania percepcji przestrzeni stosowana $\mathrm{w}$ odniesieniu do formy graficznej wykorzystuje technikę kartograficzną i opiera się na tworzeniu map poznawczych, inaczej określanych mianem mentalnych bądź kognitywnych. Szkicowane są one samodzielnie przez podmiot percepcji - w pełni abstrakcyjnie (na białej kartce) bądź przez sugestie nanoszone na przygotowanym uprzednio podkładzie. W pierwszym przypadku mapy prowadzą do zniekształceń przestrzeni. Pomijają pewne elementy, subiektywizują realne dystanse między elementami, modyfikują ich proporcje, a nawet pojawiają się na nich elementy nieistniejące w rzeczywistości. Wszystkie te informacje stanowią jednak cenne źródła informacji, ponieważ to właśnie obraz zniekształceń, a nie rzeczywistości, opisuje sposób postrzegania przestrzeni przez jej odbiorcę. Rzeczywistość jest bowiem, jak wskazują Peter Gould i Roudney White, odbierana za pomocą „filtrowania wrażeń”. Percepcja ma charakter fragmentaryczny, a przestrzeń postrzegana jest przez tak wybrany wycinek, który jest w stanie ogarnąć ludzki aparat poznawczy ${ }^{323}$.

W ujęciu Marcjanny Nóżki wśród map poznawczych możliwe jest wyróżnienie ich kilku typów. Do najczęściej spotykanych należą schematyczne mapy szkicowe (rysowanie fragmentów rozpoznanej przestrzeni) i mapy ewaluatywne (identyfikacja lubianych, nielubianych i „znaczących” miejsc). Spotykane są też techniki bazujące na wykorzystaniu materiału wizualnego (identyfikacja fragmentów przestrzeni z użyciem zdjęć lub slajdów wybranych miejsc), techniki oparte na określaniu odległości między wyróżnionymi punktami w przestrzeni, gotowych map terenu czy mobilne metody wizualne uwzględniające rejestrację obrazu i dźwięku ${ }^{324}$.

${ }^{322}$ M. Clark-Ibáñez, Kadrowanie świata społecznego przy użyciu wywiadu fotograficznego, [w:] M. Frąckowiak, K. Olechnicki (red.), op. cit., s. 47, 51.

323 P. Gould, R. White, Mental Maps, Routledge, London 2002, s. 29.

${ }^{324}$ M. Nóżka, op. cit., s. 246. 
Donald Appleyard dzieli z kolei mapy mentalne na sekwencyjne (sequential) - skoncentrowane na odtwarzaniu przez badanych kształtu dróg, oraz przestrzenne (spatial) - gdzie wyróżniane są indywidualne budynki, krajobrazy lub całe dystrykty. Mapy mentalne inaczej tworzone są przez różne grupy badanych. Osoby lepiej wykształcone konstruują je bardziej zgodnie $\mathrm{z}$ obrazem rzeczywistym analizowanej przestrzeni. Osoby krótko mieszkające w badanym miejscu (i inne gorzej znające przestrzeń) oraz najmłodsi respondenci325 ${ }^{32}$ czéściej sięgają po rozwiązania sekwencyjne. To za ich pomocą są bowiem w stanie lepiej odtwarzać swoje stałe trasy. Wśród zidentyfikowanych przez Appleyarda zmiennych istotny wpływ miały również czytelność i charakter kompozycji urbanistycznej, wykonywany zawód czy sposób przemieszczania się po mieście. Występowały też różnice zależne od płci przy relatywnie gorszej orientacji przestrzennej kobiet. W opinii przywołanego badacza nie musi to jednak wynikać z uwarunkowania genetycznego, ile raczej społecznego. Oddziałuje tu prawdopodobnie izolacja przestrzenna gospodyń domowych jako mniej mobilnych od aktywnych zawodowo partnerów płci męskiej. Poza tym zauważył on, że kobiety w mniejszym stopniu niż mężczyźni przekładają w sposób świadomy pozyskane przez siebie informacje na mapę poznawczą ${ }^{326}$.

Subiektywne mapy poznawcze, pisze Appleyard, mogą

dostarczać bogatych źródeł informacji na temat miejskiej percepcji, szczególnie w korelacji z terenowymi badaniami wizualnego, funkcjonalnego i społecznego charakteru miasta. Mapy obrazują przestrzenne relacje, które są bardzo trudne do zwerbalizowania ${ }^{327}$.

Planiści przestrzeni w celu strukturyzowania przestrzeni zwykle stosują metody analizujące ją w wielkiej skali. Jednakże to identyfikowane w ramach badań percepcji metody strukturalizowania przestrzeni przez „zwykłych ludzi z poziomu ziemi są być może bardziej właściwe i do tego bardziej interesujące" ${ }^{328}$. Do map

325 Jak zauważa Kowalczyk, strukturyzując przestrzeń, dzieci zwracają uwagę na inne elementy i nadają im inną rangę. Rzadko wskazują lokalizacje urzędów, ale obok miejsc zabaw czy zamieszkania kolegów i krewnych potrafią namierzyć umiejscowienie szkoły, kościoła, boiska lub najbliższego sklepu. Tworzone przez nie mapy poznawcze są inne, ale nie mniej dokładne względem tych tworzonych przez dorosłych, skutkiem czego stanowią równie cenne źródło badawcze. Inna jest głównie skala. Przestrzeń oswojona przez dzieci odnosi się do płaszczyzny okręgu o promilu o długości 200-250 metrów. Podobne wyniki uzyskiwano w tym zakresie w badaniach prowadzonych zarówno w Polsce, jak i w Wielkiej Brytanii. Zob. A. Kowalczyk, Percepcja środowiska miejskiego przez dzieci (na przykładzie Warszawy), [w:] B. Jałowiecki, H. Libura (red.), op. cit., s. 260-265.

326 D. Appleyard, Styles and Methods of Structuring a City, „Enviroment and Behavior”, nr 2/1970, s. 103-114.

327 Ibidem, s. 116.

328 Ibidem. 
mentalnych odwoływali się też inni autorzy, z Kevinem Lynchem na czele. Jego koncepcja obrazu miasta bazowała przecież na mapach tworzonych przez mieszkańców Bostonu, Jersey City i Los Angeles ${ }^{329}$. Podobnie czynił Edward Tolman badający mapy poznawcze przestrzeni tworzone nie tylko przez ludzi, ale i szczury. W tym ostatnim przypadku miały one jednak oczywiście postać wyobrażeniową ${ }^{330}$. Za syntetyczny dla wskazanych technik uznać można fotospacer zastosowany przez Nóżkę, polegający na korekcji stworzonej w warunkach laboratoryjnych mapy mentalnej za pomocą spaceru śladami narysowanej wcześniej trasy w towarzystwie badacza. W czasie fotospaceru, obok przeprowadzenia wywiadu terenowego, podmiot percepcji proszony jest o uzupełnienie materiału o własnoręcznie wykonane zdjęcia ${ }^{331}$. W ten sposób ekspresyjny obraz przestrzeni nabiera jeszcze większej kompletności.

W tej pracy wykorzystałem mapy poznawcze szkicowane przez zróżnicowaną grupę respondentów (dzieci, młodzież, dorosłych, seniorów i tak zwane osoby „niepożądane” - na przykład bezrobotnych mężczyzn spożywających alkohol). Zapewniło to stosowną reprezentatywność zebranej próby i zmniejszyło oddziaływanie potencjalnych zniekształceń wyników. Wpływ na nie wywierać mogłoby na przykład nieuświadomione forsowanie przez badacza jego własnego gustu i spostrzeżeń odnośnie do przestrzeni zurbanizowanej. Respondenci wskazywali zaś na identyfikowane przez nich elementy przestrzeni z uwzględnieniem jej atutów i wad, co w myśl koncepcji Tomasza Nawrockiego opisać można jako mapy oceniające ${ }^{332}$. Mapy wykonywane były przy wsparciu techniki wywiadu częściowo ustrukturyzowanego w warunkach terenowych. Respondenci opracowywali je bezpośrednio w analizowanym miejscu, co niewątpliwie wpływało na kształt szkiców ich autorstwa. Obrazy te przyjmowały postać rysunków tworzonych z użyciem trzech kolorów. Zielony oznaczał identyfikowane przez nich elementy pozytywne, czarny - neutralne, a czerwony - negatywne. Warto również nadmienić, że w niektórych przypadkach autorzy szkiców decydowali się na wylistowanie cech przestrzeni w formie słownej (aneks 3). Jakkolwiek zatem we własnym badaniu przyjąłem metodę charakterystyczną dla jej pierwotnego zastosowania właściwego urbanistyce i psychologii środowiskowej, pokazuje to użyteczność humanistycznie zorientowanej metody mapowania pola politycznego. Zgodnie z ujęciem zaproponowanym

${ }^{329}$ K. Lynch, op. cit., s. 17.

330 E.C. Tolman, Cognitive maps in rats and men, „The Psychological Review”, nr 4/1948, s. $189-208$.

331 M. Nóżka, op. cit., s. 30.

332 T. Nawrocki, Wykorzystanie map mentalnych $w$ badaniach przestrzeni publicznych. Przykład Gliwic, [w:] B. Komar, J. Biedrońska, A. Szewczenko (red.), Badania interdyscyplinarne w architekturze, t. 2, Wydawnictwo Politechniki Śląskiej, Gliwice 2015, s. 8-9. 
przez Frederica Jamesona, a stosowanym już także przez polskich badaczy, mapa poznawcza może być bowiem konstruowana także na poziomie tekstu ${ }^{333}$.

\subsubsection{Ocena bezpieczeństwa}

Niezwykle ważnym kontekstem badania percepcji przestrzeni jest też ocena jej bezpieczeństwa.

Bezpieczeństwo jest jedną z najważniejszych wartości dla $[\ldots]$ jednostek [...] [oraz ma c)harakter egzystencjalny i obejmuje zaspokojenie takich potrzeb jak: istnienie, przetrwanie, całość, niezależność, tożsamość, spokój, posiadanie, pewność funkcjonowania i rozwoju.

Postrzeganie bezpieczeństwa zaś

ma charakter obiektywny lub subiektywny, ze względu na ścisły związek między bezpieczeństwem a stanem percepcji społecznej334.

Bezpieczeństwo, chociaż odnosi się do wskaźników obiektywnych, takich jak policyjne statystyki określające poziom przestępczości (a także poziom jej wykrywalności), związane jest też z czynnikami subiektywnymi. Szczególnie istotne jest wzmacnianie przekazu przez media, które w dobie silnej konkurencji o odbiorców chętnie uciekają się do manipulowania sensacyjnymi informacjami.

Tabloidy oraz sensacyjne programy telewizyjne budują wiedzę potoczną na temat zjawiska przestępczości, często dezinformując bądź mitologizując pewne wymiary zjawiska i radykalizując społeczne postawy w kwestii zwalczania zagrożenia ${ }^{335}$.

W taki kontekst można wpisać zwłaszcza współczesny lęk przed terroryzmem. Skutecznie podsyca on rasizm i islamofobię dzięki działalności propagandowej tak zwanego Państwa Islamskiego ${ }^{336}$ czy innych grup ekstremistycznych oddziałujących na psychikę mieszkańców i użytkowników przestrzeni zurbanizowanej. Współczesne miasto, jak pisze Stephen Graham, staje się zatem scenerią „zmilitaryzowanej urbanistyki”337.

333 F. Jameson, Mapowanie poznawcze, tłum. B. Kuźniarz, „Krytyka Polityczna”, nr 16-17/2018, passim; W. Marzec, Rebelia i reakcja. Rewolucja 1905 roku i plebejskie doświadczenie polityczne, Wydawnictwo Uniwersytetu Łódzkiego, Universitas, Łódź-Kraków 2016, s. 148-152; J. Kusiak, op. cit., s. 32-38.

334 J. Zając, Bezpieczeństwo państwa, [w:] K.A. Wojtaszczyk, A. Materska-Sosnowska (red.), Bezpieczeństwo państwa. Wybrane problemy, Oficyna Wydawnicza Aspra-JR, Warszawa 2009, s. 17.

335 J. Gądecki, Za murami Osiedla..., s. 113.

336 O. Hanne, T. Flichy de la Neuville, Państwo Islamskie. Geneza nowego kalifatu, tłum. J. Danecki, Wydawnictwo Akademickie Dialog, Warszawa 2015, passim.

337 S. Graham, Cities Under w Siege..., passim. Zob. też: D. Simpson, V. Jensen, A. Rubing (red.), The City Between Freedom and Security. Contested Public Spaces In the 21st Century, Birkhauser, Basel 
Poczucie bezpieczeństwa stanowi główną po potrzebach fizjologicznych podstawę ludzkich wymagań, niezwykle istotną nawet przy uwzględnieniu potencjalnej krytyki ich najczęściej stosowanej hierarchii ${ }^{338}$. Wiąże się z obiektywnymi i subiektywnymi przesłankami. Wpływa na postawy społeczne w zakresie użytkowania przestrzeni oraz wydatnie warunkuje jej percepcję. Dowodzi tego powszechność gettoizacji przestrzeni miejskiej. Zjawisko to kojarzy się przede wszystkim z regionami o dużym poziomie zróżnicowania społecznego - okupowanymi terytoriami Palestyny, peryferyjnymi państwami Ameryki Łacińskiej i Republiką Południowej Afryki czy „północnymi” Stanami Zjednoczonymi. Grodzone osiedla to najbardziej wyrazista emanacja tego procesu, niezwykle reprezentatywna również dla polskiej urbanizacji po 1989 roku. Obok istotnego dla ich popularności komponentu społecznego prestiżu grodzone osiedla są też zdaniem Edwarda J. Blakely'ego i Mary G. Snyder „enklawami strachu” (enclaves of fear). Często realizują je nie deweloperzy, ale „mieszkańcy istniejących sąsiedztw, którzy instalują bramy i barykady, starając się obronić swój sposób życia”339. To samo zjawisko widoczne jest w Polsce na przykładzie grodzenia osiedli powstałych w okresie dwudziestolecia międzywojennego i Polski Ludowej. Można je określić mianem „wtórnie grodzonych”.

Poczucie bezpieczeństwa wpływa na postrzeganie jakości środowiska zurbanizowanego oraz „złych” i „,dobrych” dzielnic. Oddziałuje też na kluczowy dla akumulacji kapitału społecznego poziom zaufania do innych ludzi czy istotne dla definiowania tożsamości przywiązanie do miejsca ${ }^{340}$. Istotnie oddziałuje tym samym na ekonomiczną waloryzację przestrzeni, jak też materialne praktyki przestrzenne. Z nakreślonego przeglądu głównych obiektywnych i subiektywnych przesłanek poczucia bezpieczeństwa w przestrzeniach wytwarzanych w ramach urbanistyki oddolnej wynika, że w ramach metody WWP badanie tej kwestii powinno odwoływać się do zróżnicowanych technik. Zastosowanie znalazły zatem wywiady, identyfikacja struktury przestrzennej środowiska zurbanizowanego, ale i analiza statystyk policyjnych. To ostatnie, metodologiczne zakotwiczenie lokuje omawianą metodę w gronie rozwiązań opierających się na wskaźnikach „obiektywnych”. Ze względu na potoczne wyobrażenia dotyczące tej tematyki percepcja bezpieczeństwa odwołuje się jednak też do wskaźników subiektywnych.

2016, passim; S. Graham, Vertical The City from Satellites to Bunkers, Verso, London-New York 2016, passim.

338 A. Maslow, Motywacja i osobowość, tłum. P. Sawicka, Wydawnictwo Naukowe PWN, Warszawa 2009, s. 65-68.

339 E.J. Blakely, M.G. Snyder, Fortress America. Gated Communities in the United States, Brooking Institution Press, Washington 1997, s. 99. Zob. też S. Bagaeen, O. Uduku, Gated Histories: An Introduction to Themes and Concepts, [w:] eidem (red.), Gated Communities. Social Sustainability in Contemporary and Historical Gated Developments, Earthscan, London-Washington 2010, s. 2.

${ }^{340}$ M. Lewicka, op. cit., s. 130-131. 


\subsubsection{Monitoring internetu}

Monitoring internetu pozwala łączyć ilościowe i jakościowe analizy przestrzeni na podstawie konstruowanych na różne sposoby wskaźników behawioralnych. Ma to w dodatku miejsce przy nietypowej w odniesieniu do tego typu indykatorów metodzie desk research. Monitoring internetu zakorzeniony jest głównie w badaniach marketingowych. Funkcjonuje w ich ramach jako narzędzie zarządzania wizerunkiem stosowane podczas kampanii reklamowych, działaniach na rzecz stabilności ocen marki oraz przy inicjatywach przeciwdziałających potencjalnym kryzysom komunikacyjnym. Dzisiejsze zaawansowane technologicznie narzędzia umożliwiają nie tylko analizy tekstowe znane już od czasów prostych badań wycinków prasowych, ale nawet analizy treści wizualnych. Wyszukiwarki internetowe operują bowiem nie tylko za pomocą treści tekstowych, lecz także obrazów, a dostępne są nawet złożone narzędzia analizy audycji radiowych i telewizyjnych ${ }^{341}$. Znaczenie monitoringu wzrasta w związku z rozwojem technologicznym oraz upowszechnianiem się modelu Web 2.0. Treści pojawiające się w sieci w niewielkim już stopniu tworzone są przez dysponujących fachową wiedzą webmasterów. Coraz częściej odpowiedzialni są za nie zwykli internauci, którzy w rozmaity sposób reagują i powielają internetowe treści dzięki ich komentowaniu, udostępnianiu i przesyłaniu $^{342}$. Na przykład w czerwcu 2013 roku, po zaledwie trzech latach działania tej aplikacji i przy mniejszym niż obecne nasyceniu wyposażenia populacji w smartfony, w serwisie Instagram opublikowanych było już prawie 16 miliardów zdjęćc $c^{33}$. Od tego czasu liczba ta wzrasta w tempie wykładniczym.

Drugim źródłem zakorzenienia monitoringu internetu są analizy dyskursu prowadzone przez badaczy z obszaru nauk społecznych ${ }^{344}$. Technika ta jest przydatna w przypadku ograniczonych możliwości prowadzenia analiz diachronicznych wedle innych sposobów. Umożliwia przede wszystkim analizowanie mało responsywnych publikatorów, dopuszczających najwyżej telefony lub listy do redakcji, niekoniecznie zresztą autentyczne, względnie także niektórych otwartych for i komentarzy internetowych. Badania dyskursu z tego względu pozwalają naświetlić kontekst i wskazać treści tworzone przez uprzywilejowanych aktorów dysponują-

${ }^{341}$ Np. PRESS-SERVICE Monitoring Mediów, http://psmm.pl/, dostęp: 10.07.2017.

342 M. Czaplicka, Zarzq̨dzanie kryzysem w social media, Helion, Gliwice 2014, s. 10; M. Sadowski, Rewolucja social media, Helion, Gliwice 2013, s. 33-60.

${ }^{343}$ N. Hochman, L. Manovich, Zooming into an Instagram City: Reading the local through social media, „First Monday”, nr 6/2013, http://bit.ly/2v4SCY5, dostęp: 10.07.2017.

${ }^{344}$ Zob. np. Ł. Drozda, Lewactwo. Historia dyskursu o polskiej lewicy radykalnej, Instytut Wydawniczy Książka i Prasa, Warszawa 2015, passim. Szeroki przegląd badań internetu w naukach społecznych zob. D. Jemielniak, Socjologia internetu, Wydawnictwo Naukowe Scholar, Warszawa 2019, passim. 
cych dostępem do mediów. Nie umożliwiają jednak opracowywania analiz behawioralnych o synchronicznym charakterze, niedostępnych również w przypadku większości GIS ${ }^{345}$. W odróżnieniu od tych metod treści zamieszczane przez indywidualnych użytkowników sieci społecznościowych pozwalają nie tylko analizować zachowania w czasie. Obok służących do pozyskiwania danych na ten temat informacji kluczowy jest mechanizm geolokalizacji. Agata Malesińska podaje w tym kontekście przykład podejścia infomediologicznego. Dzięki analizie lokalizacji wpisów na Twitterze możliwe jest ono opisanie dotykających populację chorób, ich objawów, podejmowanych metod leczenia, a nawet wskazywanie zasięgu epidemii $^{346}$. Raz Schwartz i Nadav Hochman zwracają natomiast uwagę, że używanie społecznościowych mediów lokacyjnych (locative media) umożliwia umiejscawianie aktywności użytkowników poszczególnych przestrzeni, co pośrednio ocenia ich atrakcyjność. Badanie treści wizualnych pokazuje, co jest waloryzowane i w jaki sposób na bazie analizy fotografowanych miejsc, zjawisk i osób. Informacje o czasie wykonania zdjęcia pozwalają opisać częstotliwość użytkowania określonej przestrzeni. Analizy wskazują również ścieżki poruszania się czy czynności wykonywane w danej przestrzeni. Na przykład jedzenie jest pośrednią oznaką tego, że jest ona postrzegana pozytywnie, ponieważ zapewnia stosowny komfort dla wykonywania tej czynności ${ }^{347}$.

Monitoring internetu przyjęty w ramach WWP koncentruje się na treściach udostępnianych w mediach społecznościowych. Sieci tego rodzaju odgrywają coraz bardziej dominującą rolę wśród ogółu treści publikowanych w internecie, a zarazem zapewniają ich stosunkową unifikację, użyteczną z punktu widzenia badaczy. W opinii Schwartza i Hochmana

szybko rosnąca liczba osób logujących się i dzielących się swoimi codziennymi aktywnościami zapewnia coraz większej liczbie przedsiębiorstw, urbanistów i badaczy dostęp do bardzo złożonych danych na temat miejskich aktywności, które nie były nigdy wcześniej możliwe do analizowania ${ }^{348}$.

Treści udostępniane za ich pomocą odnoszą się do relatywnie jednolitych szablonów powiązanych z profilami użytkowników, w każdym przypadku przybiera-

345 V. Frias-Martinez, V. Soto, H. Hohwald, E. Frias-Martinez, Characterizing Urban Landscapes using Geolocated Tweets, International Conference on Social Computing and 2012 ASE/IEEE International Conference on Privacy, Security, Risk and Trust, https://ieeexplore.ieee.org/document/6406289, dostęp: 18.04.2019, s. 239.

346 A. Malesińska, Twitter jako źródło wiedzy o stanie zdrowia polskiego społeczeństwa - ujęcie infodemiologiczne, „Kultura Popularna”, nr 3/2016, passim.

${ }^{347}$ R. Schwartz, N. Hochman, The Social Media Life of Public Spaces: Reading Places Through the Lens of Geo-Tagged Data, [w:] R. Wilken, G. Goggin (red.), Locative Media, Routledge, New York 2014, passim.

348 Ibidem, s. 15-16. 
jących zbliżony układ informacji. Najbardziej użyteczne pod kątem rozwiniętych analiz są takie serwisy, jak tekstowy Twitter, wymuszający wręcz syntetyzację komunikatów tekstowych do 280 znaków, oraz wizualny Instagram. Ten ostatni umożliwia publikowanie zdjęć wyłącznie za pomocą aplikacji na smartfony. Początkowo wszystkie treści dostosowywano tutaj do identycznych wymiarów fotografii. Obecnie możliwe jest już dodawanie obrazków również w innych rozmiarach czy nawet krótkich filmów. Dopuszczalny zakres personalizacji treści dodawanych na Instagramie jest jednak w dalszym ciągu ograniczony ${ }^{349}$. Zamknięty jest zwłaszcza katalog możliwych do wykorzystania automatycznych filtrów, które umożliwiają szybką obróbkę grafiki i udoskonalenie estetyczne amatorskich fotografii. Jak pokazują przeprowadzone na dużej próbie badania Hochmana i Lva Manovicha, techniki wykonywania zdjęć zamieszczanych na Instagramie są podobne właściwie na całym świecie, włącznie z popularnością filtrów stosowanych równie chętnie w odmiennych kontekstach geograficznych i kulturowych. Pozwala to zatem na komparatystykę o ponadnarodowym charakterze (rycina 1 ).

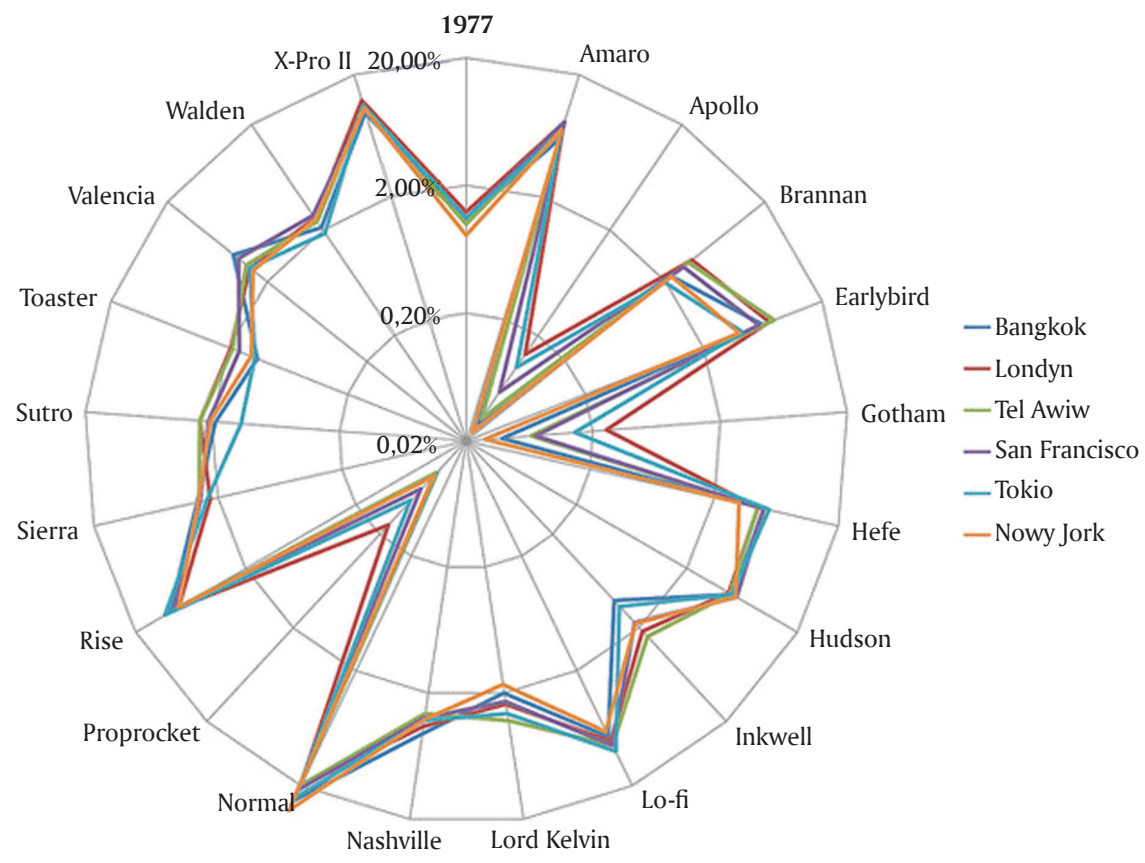

Ryc. 1. Częstotliwość używania filtrów aplikacji Instagram w różnych miastach

Źródło: N. Hochman, L. Manovich, Zooming into an Instagram City: Reading the local through social media, „First Monday”, nr 6/2013, http://bit.ly/2v4SCY5, dostęp: 10.07.2017.

${ }^{349}$ M. Zappavigna, Social media photography: construing subjectivity in Instagram images, „Visual Communication”, vol. 15, nr 3/2016, s. 275. 
Datująca się od początków 2001 roku eksplozja popularności „komunikacji bezprzewodowej, [...] poskutkowała nagłym i bezprecedensowym przyrostem wolumenu informacji udostępnianej przez ludzi cyfrowo" 350 . Metoda szczegółowa waloryzacji przestrzeni oparta na monitoringu internetu ma jednak w dalszym ciągu pewne ograniczenia. Są one związane na przykład z mniejszą popularnością wykonywania zdjęć w mniej atrakcyjnych miejscach. Wszakże

użytkownicy nie relacjonują swoich wizyt w supermarkecie albo dojazdu do pracy. Zamiast tego dzielą się obrazami jako częścią strategicznych dystynkcji: fotografują siebie z przyjaciółmi, w ładnych ubraniach, ważnych dla nich miejscach. Słowem, używają Instagrama dla zaznaczenia pozycji w społecznej strukturze miasta ${ }^{351}$.

Ważna zdaje się przez to triangulacja pozwalająca na różnicowanie metod i technik badawczych, na co pozwala wieloczynnikowy charakter WWP. Jak piszą bowiem Schwartz i Hochman,

używanie tego rodzaju danych nie zaprzecza konieczności wykonywania dodatkowych, bardziej tradycyjnych badań takich jak obserwacje, ankiety i wywiady. Jedynie łączenie mieszanki metod jakościowych i ilościowych umożliwia zwiększanie rozumienia przestrzeni publicznej i naszych wysiłków dla uczynienia jej bardziej przyjazną dla integracji społecznej i czerpania przyjemności z doświadczania życia w środowisku intensywnej urbanizacji ${ }^{352}$.

Z drugiej strony sam fakt wybierania miejsc jako tematów służących społecznościowej komunikacji świadczyć może na rzecz ich pozytywnej oceny w oczach użytkowników, a mniej wyrazistej względem miejsc nieobecnych na tych samych platformach. Unaoczniają to schematy pokazujące najczęstsze geolokalizacje zdjęć zamieszczanych w serwisie Flickr (kolor czarny i czerwony). W czytelny sposób pozwalają one identyfikować główne obszary funkcjonalne i reprezentacyjne Warszawy czy zatokę Bosfor stanowiącą najwyżej waloryzowany element krajobrazu kulturowego Stambułu (ryciny 2 i 3).

Analiza lokalizacji zdjęć udostępnianych w mediach społecznościowych pozwala też podjąć dyskusję z teorią Marca Augé. Pokazują one bowiem nowe sposoby użytkowania tradycyjnie tranzytowych ,nie-miejsc”, co obrazuje behawioralny wskaźnik bazujący na analizie treści publikowanych w sieci ${ }^{353}$. Warto przywołać w tym miejscu konstatację Waldemara Kuligowskiego i Agaty Stanisz, stwierdzających

350 A. Malesińska, op. cit., s. 121.

351 J.D. Boy, J. Uitermark, How to Study the City on Instagram, „PLoS ONE”, vol. 11, nr 6/2016, s. $2,14$.

352 R. Schwartz, N. Hochman, op. cit., s. 17.

353 R. Wilken, Mobilizing Place: Mobile Media, Peripatetics, and the Renegotiation of Urban Places, „Journal of Urban Technology”, vol. 15, nr 3/2008, s. 45. 


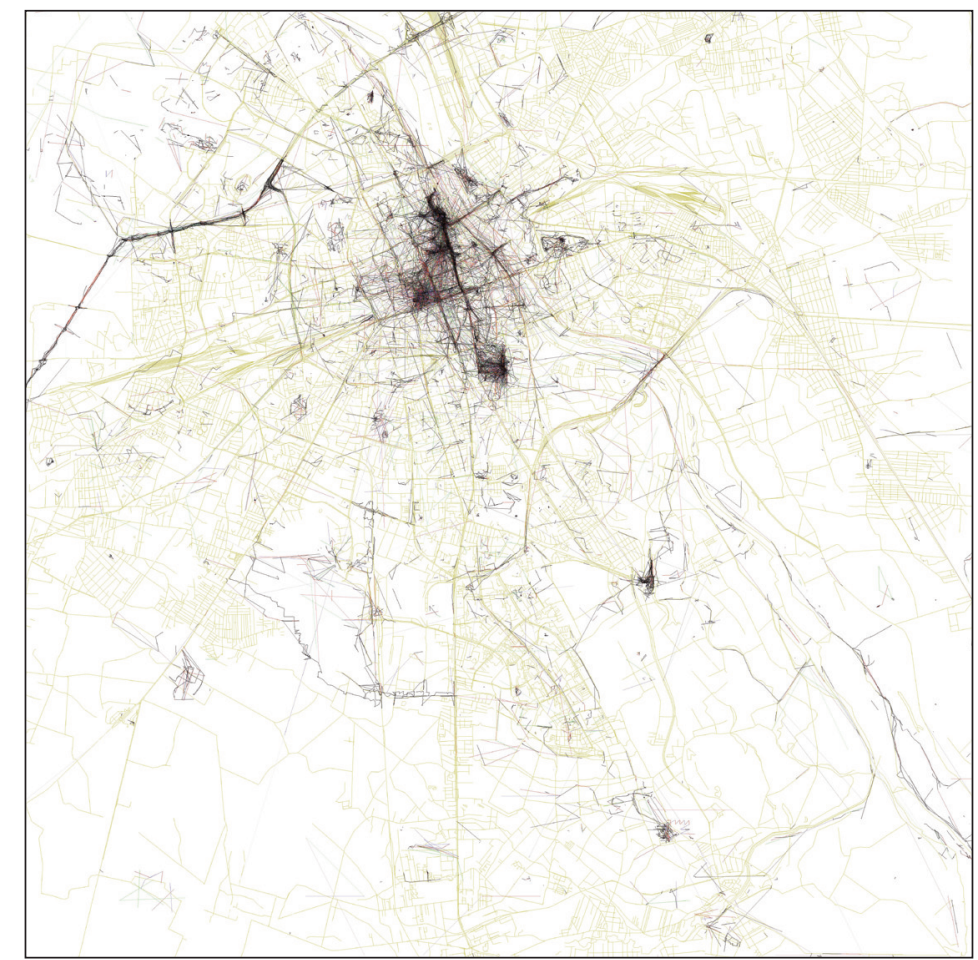

Ryc. 2. Miejsca wykonywania największej liczby zdjęć w serwisie Flickr - przykład Warszawy Źródło: E. Fischer, The Geotaggers' World Atlas \#66: Warsaw, http://bit.ly/2sIpLYE, dostęp: 10.07.2017.

na podstawie badań parkingów dla samochodów ciężarowych, że nie w każdym przypadku tego typu obiekty ,uniemożliwiają nawiązanie relacji z tym co lokalne czy podejmowanie aktywności posiadających jakieś znaczenie społeczne" 354 . Nawet przywołana wcześniej opinia Johna D. Boya i Justusa Uitermarka może nie być słuszna. Być może to właśnie wizyta w zwykłym sklepie stanie się tematem fotograficznej opowieści opublikowanej $w$ internecie? Zdecydowanie poważniejszym ograniczeniem zdaje się dostęp do technologii chętniej używanych przez przedstawicieli młodszych generacji i mniej wykluczonych cyfrowo społeczności. Wykluczenie to szybko maleje jednak nie tylko w państwach rozwiniętych, ale i nawet na peryferiach światowego kapitalizmu. Usługi telekomunikacyjne w Azji i Afryce upowszechniają się szybciej niż dostęp do podstawowej infrastruktury komunalnej ${ }^{355}$. W wymiarze pokoleniowym rośnie odsetek ludności nieznającej

${ }^{354}$ W. Kuligowski, A. Stanisz, Ruchome modernizacje. Między Autostrada Wolności a „stara dwójkq", Instytut Wydawniczy Książka i Prasa, Warszawa 2017, s. 138.

355 Posiadanie smartfona kojarzy się z bogactwem już tylko stereotypowo. Urządzenia tego typu $\mathrm{w}$ formach abonamentowych dostępne są w bardzo niskich cenach. Swoją popularność 


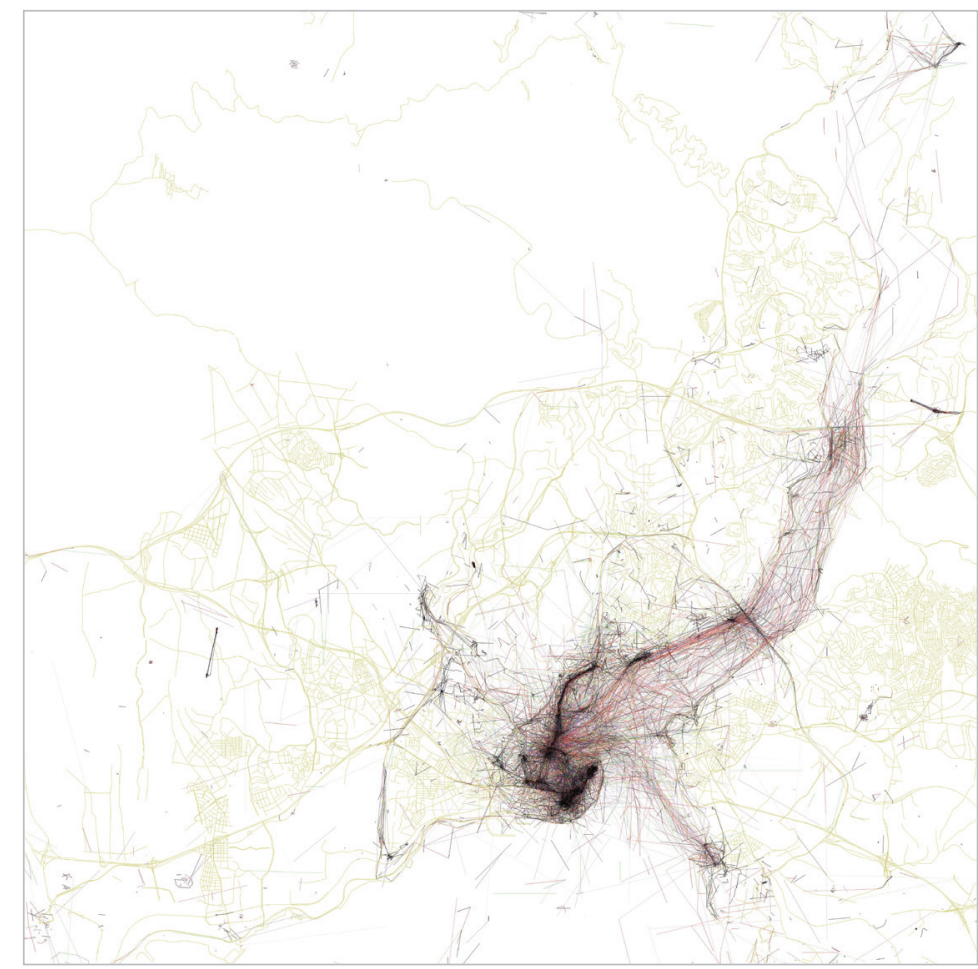

Ryc. 3. Miejsca wykonywania największej liczby zdjęć w serwisie Flickr - przykład Stambułu Źródło: E. Fischer, The Geotaggers' World Atlas \#37: Istanbul, http://bit.ly/2u5QGBy, dostęp: 10.07.2017.

świata sprzed epoki jego cyfryzacji. Gwałtownie wzrasta też nasycenie smartfonami, o czym świadczy na przykład odsetek ruchu w sieci generowanego przez urządzenia mobilne. W 2017 roku miały one odpowiadać za aż trzy czwarte globalnej aktywności internautów ${ }^{356}$. Z kolei wedle rodzimej statystyki publicznej na koniec

zaznaczyły przy okazji kryzysu uchodźczego. Wiele osób uciekających przed wojną dysponuje takimi właśnie telefonami komórkowymi. Zapewniają im one możliwość kontaktu z bliskimi, ale też orientacji w przestrzeni dzięki dostępowi do internetu czy nadajnikowi GPS. Ich zakup jest również racjonalny w sytuacji konieczności szybkiego upłynnienia posiadanych oszczędności. K. Kondova, The smartphone as a lifeline: the impact of digital communication technologies and services on refugees' experiences during their flight, Erasmus School of History, Culture and Communication, Erasmus University, Rotterdam 2016, passim; M. Gillespie, L. Ampofo, M. Cheesman, B. Faith, E. Iliadou, A. Issa, S. Osseiran, D. Skleparis, Mapping Refugee Media Journeys. Smartphones and Social Media Networks, The Open University, France Médias Monde, 2016, passim.

${ }^{356}$ Najbardziej zasobne ludnościowo i intensywnie rozwijające się gospodarczo państwa nie odbiegają od tego globalnego trendu. W Chinach urządzenia mobilne odpowiadać mają za 76 procent ruchu, a w Indiach za 73 procent. B.a., 2017: 75\% ruchu w Sieci wygenerujq̨ urzq̨dzenia mobilne, http://bit.ly/2u1adDx, dostęp: 10.07.2017. 
2016 roku liczba abonentów i użytkowników telefonii mobilnej w Polsce niemal półtora raza przekroczyła wielkość całej populacji państwa (54,7 miliona ${ }^{357}$. Jedyną obiektywną przeszkodą do pokonania wydaje się w tym zakresie zatem dostępność danych zamieszczanych w mediach społecznościowych. Chroniący swoją prywatność użytkownicy często ograniczają dostęp do własnych profili. Zjawisko to stosunkowo rzadko spotykane jest jednak w przypadku Twittera i Instagrama. Czyni to treści obecne w tych sieciach wyjątkowo atrakcyjnymi dla potrzeb prowadzonych analiz.

Prostsza jest analiza pierwszego z tych narzędzi. Dzięki wyborowi stosownych słów kluczowych, hashtagów oraz geolokalizacji twittów pozwala ono na sprawdzenie rodzajów ich sentymentu ${ }^{358}$. Lapidarna struktura nie dłuższych niż 280 znaków wpisów pozwala na łatwą identyfikację wszelkich pozytywnych, negatywnych i neutralnych wzmianek na temat badanej przestrzeni. Bardziej złożone jest badanie wizualne zdjęć publikowanych w drugim z przywołanych źródeł. W tym wypadku sprawdzanie sentymentu nie ma większego sensu, ponieważ treści nieatrakcyjne wizualnie i świadczące o szpetocie są udostępniane na Instagramie niezwykle rzadko. Dla potrzeb waloryzacji cenna może być jednak analiza elementów, jakie są uwzględnione w treści zdjęcia, oraz tych, których na nich brakuje. O pozytywnej waloryzacji świadczy ukazywanie rozległych kadrów przestrzeni, zaprojektowanych dla niej detali urbanistycznych, jej graficznych odwzorowań czy zdjęć ludzi pozwalających skojarzyć miejsce wykonania fotografii z konkretnymi miejscami. Nie czynią tego natomiast tak zwane selfie, czyli wykonywane smartfonami zdjęcia autoportretowe. Nie pokazują one żadnych elementów otoczenia, przez co możliwe byłoby zrobienie ich we właściwie dowolnym miejscu. Podobną właściwość mają zdjęcia detali niewynikających ze sposobu zaplanowanego zagospodarowania przestrzeni, mogące dokumentować jej estetyczne i funkcjonalne słabości. Niezależne od kontekstu są też przeważnie zdjęcia zwierząt będących oddzielnymi tematami fotograficznymi. Ich obecność może jednak ilustrować określone cechy przestrzeni, takie jak stopień cechującej ją swobody użytkowania. Nieobecność psów na zdjęciach świadczy przypuszczalnie o takich obostrzeniach jak zakaz wstępu dla zwierząt domowych. Warto pamiętać, że niektóre zdjęcia mogą przedstawiać na raz kilka typów z zarysowanej tu typologii fotografii (tabela 6).

Innym przedmiotem potencjalnych analiz, obok przeglądu treści komunikatów tekstowych i wizualnych, jest określenie charakterystyki ich nadawców. W sieciach

357 Informacja o sytuacji społeczno-gospodarczej kraju w 2016 roku, Główny Urząd Statystyczny, Warszawa 2017, s. 71.

358 K. Tomanek, Analiza sentymentu - metoda analizy danych jakościowych. Przykład zastosowania oraz ewaluacja słownika RID i metody klasyfikacji Bayesa $w$ analizie danych jakościowych, „Przegląd Socjologii Jakościowej”, t. 10, nr 2/2014, passim. 
Tab. 6. Zdjęcia publikowane w mediach społecznościowych a percepcja przestrzeni

\begin{tabular}{|l|c|}
\hline \multicolumn{1}{|c|}{ Typ zdjęcia w odniesieniu do przestrzeni } & Czy ilustruje pozytywną percepcję? \\
\cline { 1 - 1 } Ogólne ujęcie przestrzeni & \\
\cline { 1 - 1 } Detal urbanistyczny & \\
\cline { 1 - 1 } Ludzie w określonym kontekście & \\
\cline { 1 - 1 } Odwzorowanie graficzne & \\
\cline { 1 - 1 } Detal nieurbanistyczny & \\
\cline { 1 - 1 } Ludzie w nieokreślonym kontekście & \\
\cline { 1 - 1 } Zwierzęta & \\
\hline Inne & \\
\hline
\end{tabular}

Źródło: opracowanie własne.

społecznościowych publikują zarówno indywidualni użytkownicy, jak i konta oficjalnych instytucji czy tak zwani liderzy opinii. Do grona takowych liderów zaliczyć można wszelkie osoby, które

dodają firmie czy produktowi wiarygodności. Ich zasięg, reputacja oraz treści, które tworzą, są sposobem na zaangażowanie użytkownika i przyciągnięcie jego uwagi [...] w miejscach, w których na co dzień przebywają w siecis ${ }^{359}$.

Liderami opinii mogą być osoby rozpoznawalne poza internetem, jak też te, których pozycja wynika z samej obecności w sieci, na przykład śledzenia ich konta przez wielu użytkowników Twittera i Instagrama. Jako umowną granicę pozwalającą oddzielić nie zawsze łatwych w identyfikacji liderów opinii traktować można zapewne granicę 5 tysięcy śledzących ich stale użytkowników ${ }^{360}$. Rząd tej wielkości wskazuje na status publiczny przy praktycznie niemożliwej do osiągnięcia tak wielkiej ogólnej liczbie internetowych „znajomych”. Pokazuje zarazem potencjał komercyjnego zastosowania internetowego profilu. Obok struktury zaangażowania opisującej stopień zainteresowania daną przestrzenią poszczególnych instytucji, przedsiębiorstw i liderów opinii, cennych informacji dostarcza także ogólna liczba zainteresowanych nią użytkowników oraz częstotliwość ich zaangażowania. Większa liczba postów jednego użytkownika wskazuje na lokalizację jego biznesu w pobliżu lub incydentalną obecność podczas wydarzenia niezwiązanego z codziennym

${ }^{359}$ B. Stawarz, Content marketing po polsku. Jak przyciqgnq̨ć klientów, Wydawnictwo Naukowe PWN, Warszawa 2015, ebook.

360 Jest to maksymalna liczba internetowych „znajomych”, jakich można mieć w ramach konta prywatnego użytkownika na Facebooku. 
kształtem takiej przestrzeni. Kluczową statystyką nie jest natomiast liczba wzmianek lub ich łączny zasięg określany na bazie liczby odbiorców. Te kluczowe z marketingowego punktu widzenia parametry świadczą co prawda o zainteresowaniu daną przestrzenią, ale niekoniecznie o jej pozytywnej recepcji. Poza tym nawet najlepiej oceniana przestrzeń nie dorówna jej gorzej ocenianej odpowiedniczce, jeżeli wystąpi między nimi skrajna dysproporcja pod względem ich areału.

Podobnie jak w przypadku innych metod waloryzacji przestrzeni zwracających uwagę na ich cechy estetyczne, także w przypadku monitoringu internetu ważny jest okres prowadzenia obserwacji. Szereg czasowy nie powinien być przesadnie krótki, albowiem wykrzywiłoby to pomiar oraz uzależniło go od warunków atmosferycznych. Specyficzny charakter mają też obserwacje z dni specjalnych. Uroczysta oprawa może stać się tematem fotografii częściej niż zaprojektowane elementy otoczenia, co prowadziłoby do niekoniecznie słusznych wniosków na temat ich społecznego odbioru. Ważne jest też odpowiednie dobranie pól kontrolnych. Znalezienie podobnych przestrzeni, najlepiej w zbliżonym miejscu, pozwala uniknąć zniekształceń obserwacji wynikających z lokalnej specyfiki geograficznej i kulturowej, które wpływają na sposoby użytkowania przestrzeni publicznej. Obserwacje prowadzone dla celów analizy podjętych w rozprawie studiów przypadku wykonano z tego względu za pomocą narzędzia komercyjnego monitoringu internetowego - Brand24. Umożliwiło to agregację informacji statystycznych oraz pobranie największej możliwej liczby wzmianek zamieszczanych równocześnie w mediach społecznościowych ${ }^{361}$.

361 Dziękuję firmie Brand24 i Mikołajowi Winkielowi za udostępnienie tego narzędzia monitoringu internetu na użytek niniejszego badania. 
CZĘŚĆ II

Między oddolnością i dewitalizacją studia przypadku 



\section{Sztuka publiczna. Plac Grzybowski}

\subsection{Interwencja artystyczna jako impuls działań spolecznych}

Plac Grzybowski w Warszawie powstał na rozstaju dwóch istotnych dawniej tras komunikacyjnych, ulic Twardej i Bagno. Od początku istnienia stanowi wierną egzemplifikację historycznej i urbanistycznej złożoności śródmieścia polskiej stolicy. Na przestrzeni dziejów pełnił liczne funkcje. Począwszy od tych administracyjnych, związanych z istniejącym tutaj ratuszem jurydyki ${ }^{1}$ Grzybów, po późniejsze więzie$n^{2} e^{2}$ czy handel. Początkowo odbywał się on w tym miejscu pod postacią regularnego targowiska, a następnie - zagłębia sklepów rzemieślniczych. Plac jest istotny również z punktu widzenia tradycji polskiego ruchu robotniczego. Dla upamiętnienia zorganizowanej w tej okolicy słynnej demonstracji Polskiej Partii Socjalistycznej z 1904 roku przebiegała tędy trasa wielu pochodów pierwszomajowych. Jest to też miejsce ważne dla żydowskiej tożsamości, ze względu na zlokalizowanie tej przestrzeni publicznej na dawnym obszarze zamieszkania przedstawicieli tej właśnie mniejszości etnicznej. Aktualnie w lokalnej strukturze przestrzennej najbardziej rozpoznawalnym elementem jest zbudowany pod koniec XIX wieku neorenesansowy kościół Wszystkich Świętych. W czasie II wojny światowej plac był też razem ze znajdującą się przy nim katolicką parafią włączony początkowo w granice getta. Parafia ta skupiała w tym czasie mieszkających w jego granicach żydowskich chrześcijan.

Okolica przekształcała się w okresie powojennym, stając się paradoksalnie, mimo lokalizacji w ścisłym centrum miasta, stosunkowo peryferyjnie położoną przestrzenią publiczną. Do dzisiaj znajduje się na uboczu dominującego wyraźnie w kompozycji warszawskiego Śródmieścia placu Defilad i reszty otoczenia Pałacu

\footnotetext{
${ }^{1}$ Jurydyka to odrębna własność szlachecka bądź kościelna, która nie podlegała miejskiemu prawu.

${ }^{2}$ W XIX-wiecznej Warszawie w użyciu znajdował się nawet związek frazeologiczny „iść na Grzybów”. Oznaczał on konieczność odbycia kary w więzieniu.
} 


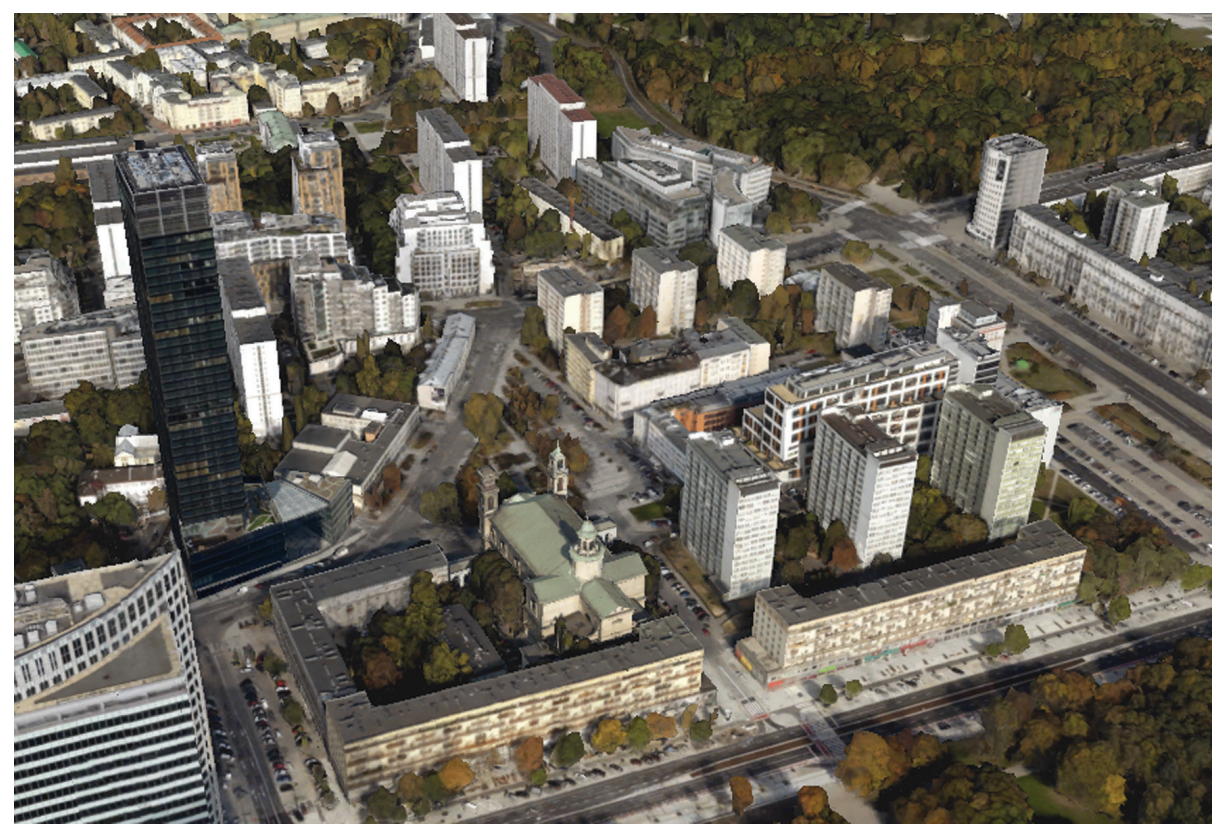

Ryc. 4. Plac Grzybowski w Warszawie (wizualizacja otoczenia) Źródło: Google Earth, dostęp: 1.10.2017.

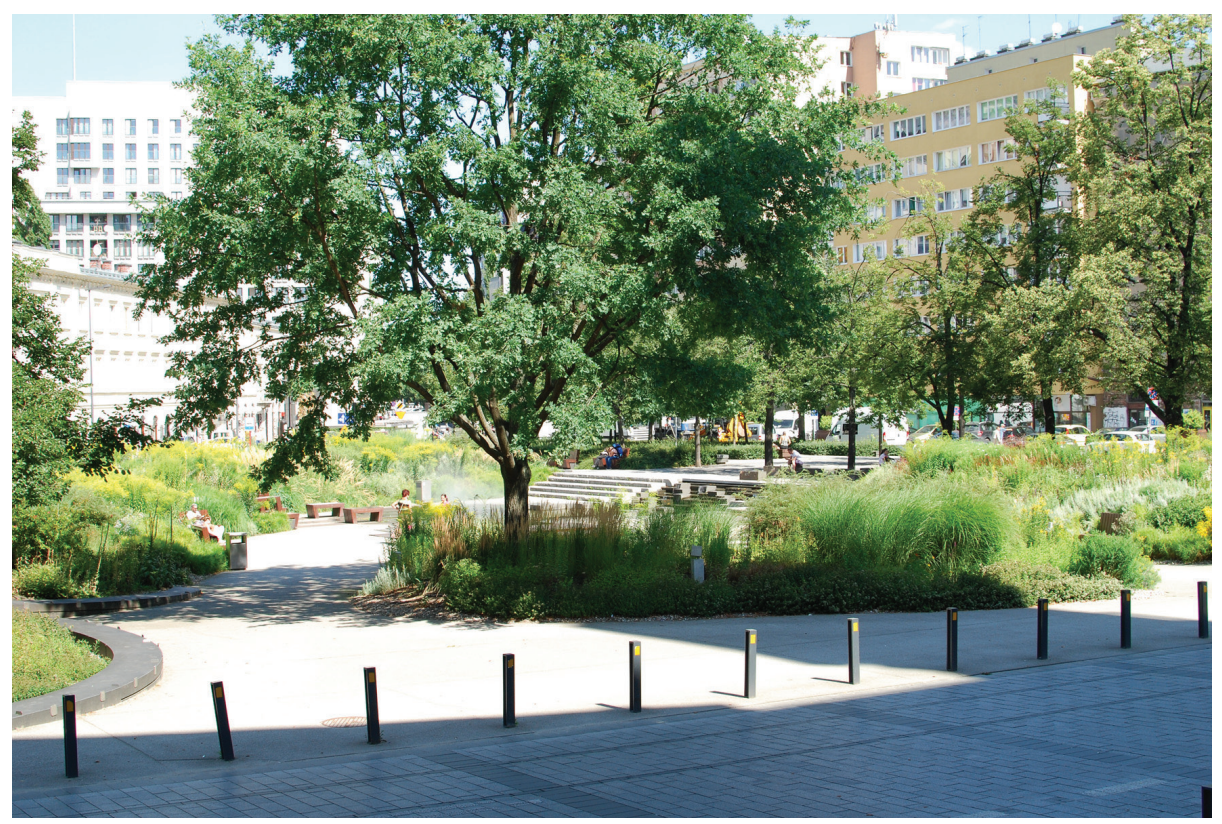

Ryc. 5. Plac Grzybowski w Warszawie (2017)

Fot. Łukasz Drozda 
Kultury i Nauki. Możliwe jest przy tym do zidentyfikowania założenie osiowe, które wyróżnia do pewnego stopnia tutejszy kościół. Jest to skutek odpowiedniego usytuowania znacznie większego odeń pobliskiego Pałacu, który sam w sobie jest głównym symbolem współczesnego miasta ${ }^{3}$. Plac Grzybowski stał się jednak zaniedbaną i zdominowaną przez urządzoną w niewielkim stopniu zieleń częścią sieci pomniejszych placów centralnej Warszawy, podobnie jak pobliskie place Dąbrowskiego i Powstańców Warszawy. Na początku XXI wieku w podziemiach cieszącej się sławą „ratującej Żydów” świątyni działalność prowadziła księgarnia znana ze sprzedaży antysemickich publikacji. Wśród wysuwanych propozycji zagospodarowania placu proponowano rozwiązania tak radykalne i martyrologiczne, jak zlokalizowanie w tym miejscu pomnika ofiar Rzezi Wołyńskiej. Projekt postulowanego monumentu składał się z przerażającej wizji drzewa, z którego gałęzi wyłaniać miały się ciała powieszonych na nim dzieci.

Odzwierciedleniem kłopotliwej i nieprzyjaznej tożsamości był nieład lokalnej struktury urbanistycznej. Jakkolwiek rejon ten przed wojną był

jednym z najintensywniej zabudowanych w mieście[, jego o]becna zabudowa, która powstała w większości po wojnie, stanowi charakterystyczny dla centrum Warszawy konglomerat. Wolno stojące bloki mieszkalne sąsiadują z fragmentami dawnej pierzejowej zabudowy, która zachowała się częściowo przy ulicach Próżnej, Zielnej i Twardej, a także wzniesionymi po 1990 roku budynkami biurowymi i usługowymi, które zostały zrealizowane wewnątrz kwartałów i przy ulicy Grzybowskiej. [...] Ta część śródmieścia jest także obszarem ekspansji zabudowy wysokiej, która zaczęła powstawać w ostatnich latach w centrum Warszawy. [...] Mimo postępującego procesu zabudowy, na terenach wokół placu [...] wciąż znajdują się wolne tereny inwestycyjne [...]. Struktura urbanistyczna obszaru jest równie niespójna jak jego zabudowa ${ }^{4}$.

W tak zdegradowanej przestrzeni działalność podjęła Joanna Rajkowska, artystka znana w Warszawie głównie z wcześniejszej instalacji umieszczonej przy innym śródmiejskim placu - rondzie de Gaulla. Praca z 2001 roku pod tytułem Pozdrowienie $z$ alej Jerozolimskich polegała na ustawieniu w tym miejscu

${ }^{3}$ Wedle badań ankietowych Michała Murawskiego PKiN jako symbol miasta jest wskazywany około dziesięć razy częściej niż Zamek Królewski i pięć razy częściej niż Syrenka. Niezależnie od wielu dyskusji na temat przekształcenia czy wyburzenia monumentalnego, socrealistycznego gmachu jako symbolu totalitarnego okresu w polskiej historii, cieszy się on sympatią większości warszawiaków. Z kolei zdaniem urbanistów wszelkie próby zakłócenia jego dominacji w strukturze przestrzennej w rzeczywistości tylko dodatkowo podkreślają jego wielkość i usytuowanie. Zob. M. Murawski, Kompleks gmachu. Życie społeczne stalinowskiego wieżowca w kapitalistycznej Warszawie, Muzeum Warszawy, Warszawa 2015, s. 244-245, 338-339.

${ }^{4}$ K. Domaradzki, Przestrzeń Warszawy. Tożsamość miasta a urbanistyka, Muzeum Powstania Warszawskiego, Warszawa 2016, s. 166-167. 
sztucznej palmy w rzeczywistej skali. Miało to przypominać o żydowskiej tożsamości Śródmieścia. Związana ona jest z współcześnie niezrozumiałą na ogół nazwą jednej z jego centralnych arterii, która upamiętnia osadę znajdującą się na wysokości dzisiejszej ulicy Towarowej. Planowana prowokacja artystyczna z biegiem czasu stała się lubianym przez mieszkańców symbolem tej okolicy, kojarzonym bardziej abstrakcyjnie niż w pierwotnych założeniach autorki. Jak podaje Joanna Erbel, instalacja „nawiązująca do etnicznej tradycji Warszawy była obiektem, który przeciwstawiał się obowiązującej logice miasta. Była wizualnym skandalem podważającym zastany porządek. Nie mieściła się w neoliberalnym podziale widzialności”’ Głośna praca stała się zaczątkiem nurtu tak zwanej sztuki publicznej, starającej się za pomocą interwencji artystycznych przekształcać przestrzeń miejską z przełomu XX i XXI wieku. Ta ostatnia w epoce transformacyjnych zmian uchodziła za mało atrakcyjną dla potrzeb spędzania wolnego czasu „przestrzeń transferu”, właściwą epoce „betonowej przestrzeni”. W coraz większym stopniu symbolizowało ją dyscyplinowanie jej użytkowników pod postacią rozmaitych narzędzi inwigilacji pojawiających się w przestrzeni zurbanizowanej, jak kamery nadzoru i grodzone osiedla mieszkaniowe ${ }^{6}$.

Kilka lat po powstaniu „palmy” w warszawskiej przestrzeni pojawiać zaczęły się kolejne instalacje tego rodzaju. Ich przykład stanowi pomnik praskiego alkoholika, Pana Gumy (2009), wykonany przez Pawła Althamera wspólnie z tamtejszymi dziećmi. Podobnie oddziaływały inicjatywy podkreślające kulturotwórczy aspekt zamykanego wtedy wieloetnicznego targowiska na Stadionie Dziesięciolecia. W ramach tej fali zdarzeń kolejną instalację przygotowała sama Rajkowska, wybierająca tym razem na obszar swoich działań właśnie plac Grzybowski. Zdegradowana wizualnie przestrzeń „krzyżujących się narracji i pamięci” stała się scenerią, w której artystka usadowila w 2006 roku

staw ozdobiony krzewami, nenufarami, otoczony trawą [o nazwie] Dotleniacz [...]. Z dna stawu wydobywały się bąbelki tlenu odświeżające powietrze i uprzyjemniające wspólne bycie w tej przestrzeni. Bez wskazywania czegokolwiek lub kogokolwiek, przypominania o istniejących napięciach, bez konfrontacji ${ }^{7}$.

${ }^{5} \mathrm{~J}$. Erbel, 0 tym, co się stało, że sztuka w przestrzeni publicznej stała się kluczowym obszarem walki o lepsze życie w mieście, a potem przestała nim być, [w:] J. Dominiczak, K. Wielebska, A. Szynwelska (red.), Sztuka i przestrzeń publiczna: Pierwsze sympozjum Galerii Zewnętrznej Miasta Gdańska, Centrum Sztuki Współczesnej Łaźnia, Gdańsk 2012, s. 124.

${ }^{6}$ Ibidem, s. 121-124.

${ }^{7}$ M. Raczyńska, Czasem nic się nie dzieje, czasem coś się wydarza, [w:] Zespół Krytyki Politycznej (red.), Rajkowska. Przewodnik Krytyki Politycznej, Wydawnictwo Krytyki Politycznej, Warszawa 2010, s. 215. 
Instalacja kwestionowała dominujące w dyskusji o zagospodarowaniu tutejszej przestrzeni narracje martyrologiczne. Miejsce zaprojektowano jako miejsce niezobowiązującego wypoczynku, czyli ogród, inny od tradycyjnego parku czy placu. Wyposażono go w plastikowe meble miejskie, kolorowe materace i powierzchnie zachęcające do położenia się z własnym kocem. Można tym samym uznać to miejsce za przykład „wernakularnej demokracji”, której zaprojektowanie informuje o „oddolnym, demokratycznym zagospodarowywaniu przez samych mieszkańców,

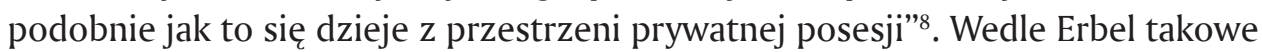

pokojowe współbycie razem było możliwe nie tylko dzięki samej obecności wody i zieleni, której mieszkańcy zdawali się tak bardzo potrzebować, ale przede wszystkim dzięki specyficznej formie „Dotleniacza”, który łatwo dostosowywał się do różnych form cielesnego użytkowania przestrzeni, jakie narzucali mu użytkownicy?

Celem działania Rajkowskiej było utworzenie społecznego i przestrzennego zwornika dla zaniedbanego obszaru, mającego stać się miejscem spotkań integrujących lokalną społeczność. Autorka określała zastany plac mianem „chorego” miejsca. Jak deklarowała przy opisie projektu, pracując nad nim myślała o

wycieczkach izraelskich, które idą przez plac Grzybowski, zupełnie nie wiedząc, gdzie są ani czym w istocie jest prowadząca do placu ulica Próżna. O tym, jak ci Izraelczycy pompują swoje poczucie wspólnoty traumą i cudza winą. Myślę o polskich starszych paniach, które patrzą na to wszystko podejrzliwe, o psach, co srają, gdzie popadnie i nikt po nich nie sprząta. O utrzymującym się wokół kościoła Wszystkich Świętych antysemickim smrodku z księgarni Patriotycznej. Przypominają mi się fałszywi Żydzi z pejsami tańczący na festiwalu Singera i „koszerne” paszteciki wieprzowe sprzedawane w budce obok. Widzę biznesmenów idących przez ten plac do pracy w korporacjach i Deutsche Bank, który obsługuje tam swoich klientów. Figura papieża błogosławi to wszystko ze schodów kościoła, a harcerze składają kwiaty pod jednym z głazów upamiętniających kolejne polskie nieszczęścia. Dotleniacz miał być rodzajem oazy radykalnie zmieniającej nasze postrzeganie tego miejsca, bo inaczej się patrzy na Próżną zza geranium i chmury tlenu. Miał być miejscem wyjętym z kontekstu, a zarazem ulokowanym w jego najściślejszym centrum, trochę jak oko cyklonu. W tej oazie wszystkie relacje miały być ustanawiane na nowo ${ }^{10}$.

${ }^{8}$ B.J. Gawryszewska, Zielona zmiana w krajobrazie miasta. Wernakularne ogrody miejskie jako konsekwencja przemian wizerunku, funkcji i znaczenia zieleni w przestrzeni publicznej, „Societas/Communitas", nr 2/2018, s. 138.

9 J. Erbel, Jak działa sztuka w przestrzeni publicznej?, [w:] J. Baranowska, P. Sztarbowski (red.), Liberated Energy, Instytut Teatralny im. Zbigniewa Raszewskiego, Warszawa 2011, s. 140.

${ }^{10} \mathrm{~J}$. Rajkowska, Sztuka publicznej możliwości, rozmawia A. Żmijewski, [w:] Zespół Krytyki Politycznej (red.), Rajkowska. Przewodnik Krytyki..., s. 238-239. 
Wedle deklaracji autorki, celem jej interwencji nie miało przy tym być nadanie okolicy ostatecznego kształtu, ale „uruchomienie relacji i oddanie ludziom władzy" nad ich otoczeniem w przestrzeni zurbanizowanej ${ }^{11}$. W tym aspekcie Dotleniacz okazał się sukcesem. Nie tylko zdobył medialny rozgłos, ale też wzbudził zainteresowanie mieszkańców przekształconą tymczasowo przestrzenią. Uwolnił tym samym ich polityczny potencjał pod kątem walki o kształt przestrzeni stanowiącej rezultat procesu jej społecznego wytwarzania. W 2007 roku instalacja została ostatecznie zdemontowana, ale w tym samym czasie rozgorzała dyskusja nad przyszłym kształtem tego miejsca po jego zapowiedzianej rewitalizacji. Pomimo poparcia lokalnej społeczności, domagającej się pozostawienia stawu po remoncie towarzyszącym odnowie skweru, tej wizji przeciwstawiali się urzędnicy i prawicowi politycy. Szczególnie krytycznie usposobiony był naczelnik miejskiego wydziału estetyki przestrzeni publicznej. Forsował on pomnik upamiętniający Polaków pomagających Żydom podczas okupacji. Ten ostatni powstanie zresztą nieco na uboczu placu, w sąsiedztwie kościoła. Jako zaś „kretyńską” oraz lansowaną przez dziennikarzy „Gazety Wyborczej” instalację tę oceniali radni Prawa i Sprawiedliwości. W ich opinii celem istnienia Dotleniacza było „to, by uniemożliwić uhonorowanie bohaterskich Polaków"12.

Ostatecznie zrealizowany projekt stanowi zachowawczy kompromis między dążeniami zwolenników powstałego w ramach strategii urbanistyki taktycznej stawu a forsującymi sformalizowany wymiar tej przestrzeni urzędnikami. W latach 2009-2011 przeprowadzona została kompleksowa modernizacja placu. W jej wyniku przeorganizowano lokalny ruch samochodowy, a na miejscu zniszczonego zieleńca urządzono zaprojektowany skwer. W jego centralnej części znalazło się oczko wodne z niewielkim elementem kaskadowym. Wyposażono je też w zmgławiacze, będące czytelnym nawiązaniem do podobnego elementu z instalacji Rajkowskiej. Przywołane przekształcenia poprzedziły cykl inwestycji prywatnych następujących w bezpośrednim otoczeniu placu. Nową i konkurencyjną wobec kościoła Wszystkich Świętych subdominantą wysokościową dla okolicy stał się apartamentowiec Cosmopolitan, zaprojektowany przez światowej sławy architekta Helmuta Jahna (2013). Równolegle znaczne zmiany zaszły na wychodzącej z placu ulicy Próżnej. Krótka uliczka stanowiła przez wiele lat jedną z nielicznych w najbliższej okolicy zachowanych pozostałości przedwojennej zabudowy. Stała się przy okazji nieformalnym pomnikiem dojmującego wpływu, jaki wywarł na Warszawę drugi ogólnoświatowy konflikt zbrojny. Pieczołowicie odrestaurowane kamienice krótko po renowacji placu przekształciły się w luksusowe biurowce. Na ich parterach miejsce znalazły natomiast restauracje przeznaczone dla zamożnych klientów.

${ }^{11}$ J. Rajkowska, Wzlot z kulq u nogi, rozmawia K. Pawełek, „Obieg”, nr 1-2/2010, s. 56.

${ }^{12} \mathrm{~J}$. Fusiecki, PiS naucza i demaskuje, http://bit.ly/2usFFcj, dostęp: 26.03.2019. 
Gentryfikacja centralnego punktu Grzybowa jest więc już widoczna gołym okiem. Wątpliwości dotyczą nie tego, czy w ogóle występuje, ale faktycznego związku z nią oraz siły tej relacji w odniesieniu do przemian zainicjowanych przez projekt Rajkowskiej. W jakim stopniu ukierunkowany na upodmiotowienie lokalnej społeczności pomysł zainspirował ściśle neoliberalne „uszlachetnienie” tej przestrzeni, a w jakim działanie to wynikało z szerszych przekształceń warszawskiego Śródmieścia? Jakie były następstwa interwencji artystycznej dla tej przestrzeni zurbanizowanej? W kolejnych podpunktach przyjrzę się temu właśnie zagadnieniu.

\subsection{Właściwości rynku nieruchomości}

Informacje na temat sprzedaży nieruchomości gromadzone są w Polsce w ramach publicznego Rejestru Cen i Wartości Nieruchomości (RCiWN). Za jego prowadzenie w przypadku stolicy odpowiada jednostka o nazwie Biuro Geodezji i Katastru Urzędu miasta stołecznego Warszawy. Część zawartych w tym zestawieniu informacji ma charakter powszechnie dostępny i jest możliwa do sprawdzenia w internecie, w tym te dotyczące adresu budynku i parametrów użytkowych lokalu będącego przedmiotem obrotu. Udostępnia się je w ramach miejskiego GIS. Dane szczegółowe, w tym dotyczące dokładnej ceny transakcyjnej, udostępniane są natomiast odpłatnie. Pomimo posiadania stosownych danych lokalna administracja nie prowadzi dostępnych jawnie przekrojowych analiz rynku nieruchomości. Z tego względu opracowują je wyłącznie komercyjne podmioty działające na rynku nieruchomości. Dane dotyczące rynku nieruchomości zbiera też na podstawie informacji pozyskiwanych od poszczególnych jednostek samorządu terytorialnego Główny Urząd Statystyczny ${ }^{13}$. Z tego powodu na użytek badania rynku nieruchomości w pobliżu placu Grzybowskiego wykorzystałem informacje pochodzące z dwóch wskazanych wyżej źródeł statystki publicznej. Pozyskałem zatem odpłatnie dane od warszawskiego samorządu oraz nieodpłatne zestawienie informacji o cenach średnich nieruchomości mieszkalnych na rynku wtórnym, przygotowane przez urząd statystyczny.

Jako pole podstawowe określiłem w przypadku badania rynku nieruchomości bezpośrednie otoczenie placu Grzybowskiego. Wyznaczyłem je za pomocą wyraźnych krawędzi przestrzennych, jakimi są w tym przypadku większe ciągi uliczne. Ze względu na dostępność i porównywalność danych wyodrębniłem z tego obszaru transakcje dokonywane na wolnym rynku, dotyczące nieruchomości mieszkalnych zlokalizowanych w trzech socmodernistycznych blokach przy ulicy Bagno, pod

${ }^{13}$ Szczegółowe dane udostępnia w tym zakresie na żądanie jego wojewódzki oddział w Lublinie. 
numerami 3, 5 i 7. Umożliwiło to znalezienie nieruchomości położonych w bezpośrednim sąsiedztwie placu jako oddalonych od jego krawędzi o nie więcej niż 100 metrów. Wszystkie wykazywały też wiele cech podobieństwa pod kątem metrażu i pozostałych parametrów technicznych, a także roku budowy, pełnego udziału we własności i wtórnego charakteru obrotu. Ze względu na koszt pozyskania, dostępność i kontekst czasowy przemian związanych z przekształceniami placu Grzybowskiego, analizie poddałem transakcje prowadzone w 2006, 2009 oraz 2012 roku, czyli przed interwencją przestrzenną Rajkowskiej (2006), w trakcie debaty publicznej dotyczącej rewitalizacji tego miejsca (2009), a także okresu po zakończeniu przebudowy (2012).

Tab. 7. Kształtowanie się transakcyjnych cen nieruchomości w złotych $w$ okolicy placu Grzybowskiego i Warszawie ogółem (2006-2012)

\begin{tabular}{|l|c|c|c|}
\hline \multicolumn{1}{|c|}{ Lokalizacja } & $\mathbf{2 0 0 6}$ & $\mathbf{2 0 0 9}$ & $\mathbf{2 0 1 2}$ \\
\hline $\begin{array}{l}\text { Okolica placu } \\
\text { Grzybowskiego }\end{array}$ & 7501 & 9886 & 9451 \\
\hline Warszawa ogółem & 5709 & 8140 & 8067 \\
\hline
\end{tabular}

Źródło: opracowanie własne na podstawie Rejestru Cen i Wartości Nieruchomości Urzędu m.st. Warszawy.

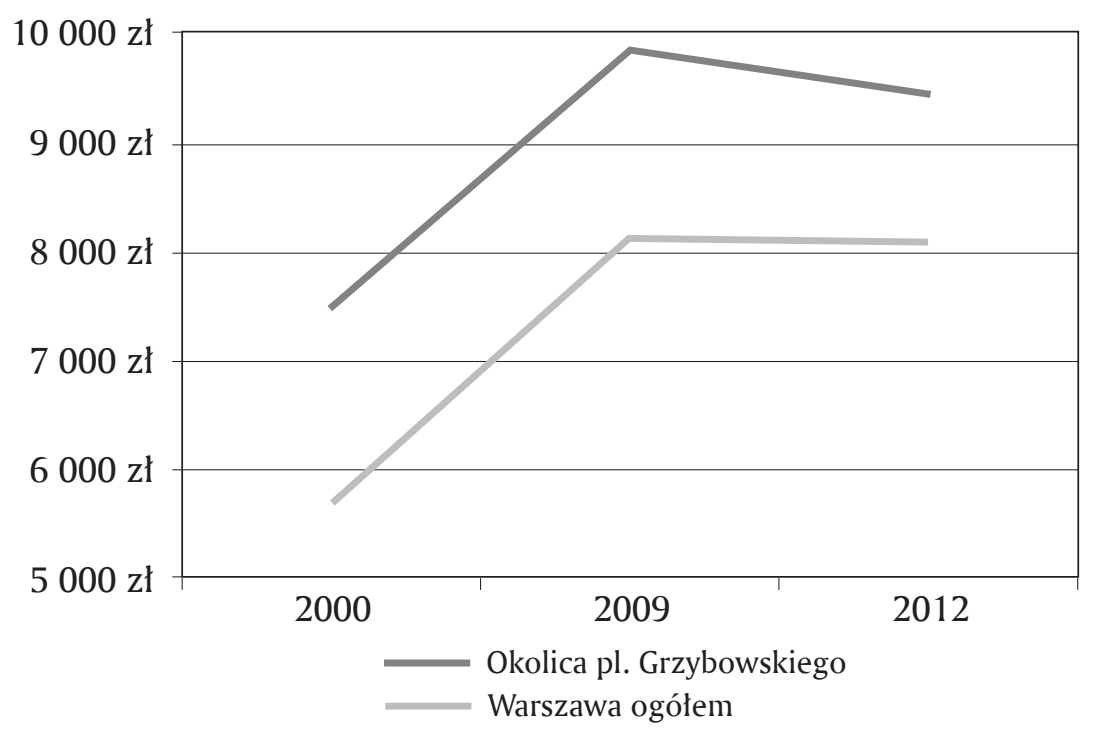

Wyk. 1. Trend transakcyjnych cen nieruchomości w okolicy placu Grzybowskiego i Warszawie ogółem (2006-2012)

Źródło: opracowanie własne na podstawie Rejestru Cen i Wartości Nieruchomości Urzędu m.st. Warszawy. 
Na podstawie powyższych kryteriów czasowych, przestrzennych i jakościowych wyznaczyłem grupę 37 transakcji reprezentatywnych dla pola podstawowego. Odpowiednio 11, 18 i 8 dla kolejnych ze wskazanych lat. Polem kontrolnym dla analizy były z kolei dane agregowane przez statystykę publiczną odnośnie do wszystkich 20069 transakcji dotyczących nieruchomości mieszkalnych, jakie przeprowadzono w Warszawie w tych samych latach.

Ceny transakcyjne na placu Grzybowskim w okresie poddanym analizie odzwierciedlały ogólne tendencje właściwe dla całego rynku nieruchomości w Warszawie (tabela 7 i wykres 1 ). W późniejszym okresie traciły one nawet na wartości rynkowej w jeszcze większym stopniu niż w przypadku przeciętnych nieruchomości w całym mieście. Powyższa obserwacja nie uprawnia do wyprowadzenia wniosków na temat gentryfikacji ekonomicznej związanej z artystyczną interwencją przestrzenną w odniesieniu do instalacji Dotleniacz. W analizowanym okresie nie został też jeszcze zaobserwowany wpływ następującej po nim odgórnie zaplanowanej rewitalizacji samego placu.

\subsection{Ocena funkcji z zakresu infrastruktury osadniczej}

Okolica placu Grzybowskiego jest przykładem przestrzeni zurbanizowanej, na której rozwój wpływa przede wszystkim atrakcyjne położenie w Warszawie. Plac ten mieści się w bezpośrednim sąsiedztwie centrum całej aglomeracji. Położenie wpływa między innymi na możliwość korzystania z bogatej szaty usługowej w obszarze śródmiejskim. Warunkuje to usytuowanie zarówno instytucji publicznych, jak i licznych punktów handlowych. Do zalet tego miejsca zaliczyć można również płaskie ukształtowanie terenu oraz jego dostosowanie do potrzeb osób z niepełnosprawnościami. Osiągnięto je dzięki zastosowaniu takich elementów jak pochylnie lub brak podwyższonych progów w ciągach pieszych.

Plac jest dobrze wyposażony w usługi transportu publicznego. Zaledwie 200 metrów dzieli go od zejścia do najbliższej stacji metra, która stanowi główny węzeł przesiadkowy i punkt skrzyżowania obu linii tej podziemnej kolejki. Niewiele dalej jest do przystanków autobusowych i tramwajowych. To właśnie transport publiczny stanowi niezwykle skuteczny element wyposażenia infrastrukturalnego dla otoczenia placu. Wskazuje na to zwłaszcza jego znaczny udział w podziale zadań przewozowych wśród podróży wykonywanych przez osoby udające się w ten rejon Warszawy. Tylko 16 procent z nich używa w tym celu samochodu osobowego, a aż 78 procent - transportu publicznego. Z tego aż 32 procent podróży obsługuje metro. Sytuacja, gdy ten środek transportu razem z autobusami i tramwajami jest wybierany pięć razy częściej niż auta, jest rzadko spotykana w aglomeracji, 
w której samochody odpowiadają za 44 procent wszystkich podróży niepieszych. W przypadku tej kategorii podróży realizowanych do miejsca pracy auta wybierane są nieco częściej - w co czwartym przypadku. Jednak aż dwa razy więcej z przyjeżdżających tu służbowo osób deklaruje możliwość skorzystania z własnego samochodu. Wskazuje to na dobrowolność tego typu zachowania komunikacyjnego, wynikającą $\mathrm{z}$ atrakcyjności takiego wyboru ${ }^{14}$. Jednocześnie, jak wykazała analiza map poznawczych i towarzyszących im wywiadów przeprowadzonych $\mathrm{w}$ ramach badań terenowych, nawet po uspokojeniu ruchu w otoczeniu placu odczuwalna jest uciążliwa dla użytkowników pieszych obecność samochodów. Ciągle jest ona postrzegana przez nich jako jeden z największych problemów tej przestrzeni zurbanizowanej.

W zakresie aktywności wykonywanych na placu przez jego użytkowników spotkać można wszystkie grupy czynności identyfikowane w ramach opisanej uprzednio typologii Jana Gehla. Wśród czynności koniecznych jest to do pewnego stopnia przestrzeń tranzytowa. Część osób przemyka tylko przez plac bez dłuższego zatrzymania. Znaczna część pojawiających się w tym miejscu ludzi decyduje się jednak na różnego typu czynności opcjonalne i społeczne. Obserwacje ilościowe prowadzone w tym miejscu wykazały, że w zależności od dnia i godziny między 40 a 80 procent obecnych tu osób rozmawia z innymi ludźmi. Na porównywanym z nim pobliskim placu Dąbrowskiego na takie zachowania w niektórych godzinach decyduje się co dziesiąty z jego użytkowników ${ }^{15}$. Użytkowanie placu Grzybowskiego charakteryzuje się jednak jeszcze większym zróżnicowaniem. Świadczy o tym fakt, iż odwiedzający traktują to miejsce jako przestrzeń atrakcyjną dla spędzania wolnego czasu. Chętnie wykonują w związku z tym pamiątkowe fotografie, odbywają spotkania towarzyskie lub służbowe, prowadzą rozmowy telefoniczne, spożywają posiłki czy opalają się w ciepłe i słoneczne dni. Wysoką ocenę jakości przestrzeni poświadcza nie tylko to, że przestrzeń placu stała się punktem atrakcyjnym dla wycieczek turystów z zagranicy. Pod tym względem decydującą rolę odgrywa z pewnością historyczne dziedzictwo miejsca. Nie jest ono związane z działaniami, których wpływ stanowi przedmiot zainteresowania w tej pracy. W czasie obserwacji terenowych prowadzonych na placu był on jednak traktowany także jako plener dla fotograficznych sesji ślubnych czy scen kręconych na powietrzu przez ekipy

${ }^{14}$ Obliczenia własne na podstawie Warszawskiego Badania Ruchu 2015. Jako otoczenie placu Grzybowskiego wybrano przyjęte przez autorów WBR rejony komunikacyjne nr 31 i 32. Obejmują one przestrzeń pomiędzy aleją Jana Pawła II oraz ulicami Grzybowską, Marszałkowską i Świętokrzyską. W ramach WBR zidentyfikowano łącznie 96 podróży spełniających te kryteria.

${ }^{15}$ Obliczenia na podstawie obserwacji własnych prowadzonych od 10 lipca do 25 sierpnia 2016 roku. 
filmowe na użytek seriali telewizyjnych. Pokazuje to, jak pozytywna jest również ogólnospołeczna recepcja tej przestrzeni publicznej.

Jak ukazuje analiza lokalnej infrastruktury osadniczej, plac Grzybowski jest pod tym względem bardzo dobrze wyposażonym miejscem. Do jego szczególnych zalet zaliczyć można wyjątkowo korzystne powiązania komunikacyjne oraz różnorodność podejmowanych przez jego użytkowników aktywności opcjonalnych i społecznych.

\subsection{Zaawansowanie gentryfikacji obszaru}

Okolica placu Grzybowskiego w okresie poprzedzającym interwencję artystyczną Joanny Rajkowskiej była typowym obszarem zdegradowanym. To właśnie w takim miejscu rozpocząć może się gentryfikacyjna transformacja przestrzeni. Zaniedbany był wtedy jednak nie tylko ów plac, ale również jego najbliższe otoczenie. Szczególnie zdewastowana była ulica Próżna odchodząca od placu w kierunku wschodnim. Ten ostatni fragment zachowanej, oryginalnej, przedwojennej zabudowy składał się ze zrujnowanych i opuszczonych kamienic. Instalacja Dotleniacz czy powstała rok później kawiarnia Cafe Próżna z pewnością wpisują się w trend gentryfikacji marginalnej. Inicjowana ona jest często przez działania artystów i niszowych instytucji kultury. Dopiero ich śladem podąża zaangażowanie reinwestycji z udziałem większego kapitału finansowego.

Uruchomienie dyskusji wokół zagospodarowania placu Grzybowskiego bez wątpienia wsparło przemianę sfery usługowej w jego otoczeniu. Gentryfikacja społeczna tego miejsca widoczna jest zwłaszcza pod względem nie tyle wymiany mieszkańców, ile działających w tym miejscu punktów handlowych i gastronomicznych. Badanie terenowe nie wykazało wysokiego stopnia wypierania okolicznej ludności. Wśród mieszkańców korzystających chętnie z tutejszego skweru wyraźną grupę stanowią seniorzy zamieszkujący na przykład okoliczne bloki zlokalizowane przy ulicy Bagno czy większe osiedle Za Żelazną Bramą. Niekiedy są oni lokatorami w tym miejscu nieprzerwanie już od kilkudziesięciu lat (A13, A27) ${ }^{16}$. Gentryfikacja społeczna nie ma zatem charakteru całościowego, jako że nie występuje jednocześnie w każdym z jej trzech wymiarów. Przemianie ulega jednak struktura usługowa, która przyciąga zwłaszcza nowe restauracje przeznaczone dla lepiej uposażonych klientów. W bezpośrednim sąsiedztwie przebudowanego skweru działalność prowadziły do niedawna takie mało reprezentacyjne punkty usługowe jak pralnia czy obecne na Grzybowie od dekad zakłady rzemieślnicze. Coraz wyraźniej obecność zaznaczają jednak zupełnie inne podmioty gospodarcze, wypierające tradycyjnych

16 Oznaczenia respondentów w aneksach. 
ajentów. Za symbol gentryfikacji na skalę warszawską można uznać na przykład obecność kawiarni Charlotte Menora. Jest ona w tym zakresie lokalnym odpowiednikiem symbolu o skali globalnej - kawiarni Starbucks. Lokal ten w swojej pierwszej lokalizacji zasłynął między innymi dzięki sprzedaży ekstremalnie drogiej bułki tartej. W potocznym mniemaniu stała się ona wręcz czołowym artefaktem oderwanej od rzeczywistości klasy wyższej i pejoratywnie postrzeganych hipsterów ${ }^{17}$. Charlotte Menora deklaratywnie jest lokalem gastronomicznym powiązanym z lokalnym dziedzictwem kulturowym i żydowską tradycją tej części miasta. W rzeczywistości jednak to raczej jeden z czterech bliźniaczo podobnych lokali sieciowych. Funkcjonują one także we Wrocławiu i Krakowie, oferując przetworzone na zglobalizowaną i skomercjalizowaną modłę wyobrażenie na temat francuskiej kuchni. Co istotne, działalność kawiarni umożliwiło dopiero unieważnienie konkursu na zagospodarowanie jednego z lokali. Pierwotnie zwyciężyła w nim koncepcja utworzenia centrum społecznego prowadzonego przez lewicującą organizację pozarządową i Wydawnictwo Krytyki Politycznej. Także po przeciwnej stronie placu w wyniku nagłego odkrycia „zagrożenia budowlanego” jeden z deweloperów przyspieszył zamknięcie innej instytucji kultury, Teatru Żydowskiego. Usprawniło to kolejną budowę w tej okolicy. Obecność tego i innych drogich lokali gastronomicznych, pojawianie się franczyzowych sklepów sieciowych i rewaloryzacja zrujnowanych kamienic na luksusowe biurowce świadczą niezbicie o występowaniu gentryfikacji społecznej zaniedbanego dawniej sąsiedztwa. Nie uruchomiła ona jednak jak na razie procesu wypierania ludności.

Podobnie fragmentaryczny charakter ma tutejsza gentryfikacja ekonomiczna. Wpływ na rynek nieruchomości w okolicy nie miał jak do tej pory kompleksowego charakteru. Ceny istniejących już wcześniej lokali nie rosły w szybszym tempie niż średnia ogólnowarszawska. Oferta wzbogacona została jednak o różnego typu nieruchomości luksusowe, zarówno mieszkalne, jak i biurowe. Elewacje pieczołowicie odrestaurowanych kamienic przy ulicy Próżnej skrywają teraz przede wszystkim wysokiej klasy biura. Od strony południowo-zachodniej placu powstał jeden z najbardziej luksusowych apartamentowców w mieście, jakim jest 160-metrowy drapacz chmur. Kolejne inwestycje o podobnej skali planowane są w związku z wyburzeniem wspomnianego Teatru Żydowskiego.

Zdecydowanie najwyraźniejszy przebieg ma gentryfikacja przestrzenna. Jej emanację stanowi przebudowa samego placu i utworzenie w jego obrębie reprezentacyjnego skweru. Po pewnym czasie podobne przekształcenia, wykraczające poza ramy standardowej estetyzacji, dotknęły również szerszego otoczenia placu,

17 Ł. Drozda, Dwa tysiq̨ce. Instrukcja obsługi polskiej urbanizacji w XXI w., Fundacja Bęc Zmiana, Warszawa 2018, s. 119-120. 
zwłaszcza ulicy Próżnej. Uświadomić je sobie pozwala kontrast między ostatnią z niewyremontowanych jeszcze kamienic a pozostałą częścią tej ulicy (rycina 6). Podobnie jak dla społecznego i ekonomicznego wymiaru gentryfikacji, również w tym przypadku główną wątpliwość stanowi skala wpływu wynikająca z przemian placu Grzybowskiego. Nie wiadomo, czy i na ile istotniejszą rolę odegrała w tym kontekście większa liczba uwarunkowań związanych na przykład z lokalizacją w ścisłym centrum miasta. Podobne przekształcenia dotykają przecież i innych części stołecznego Śródmieścia.

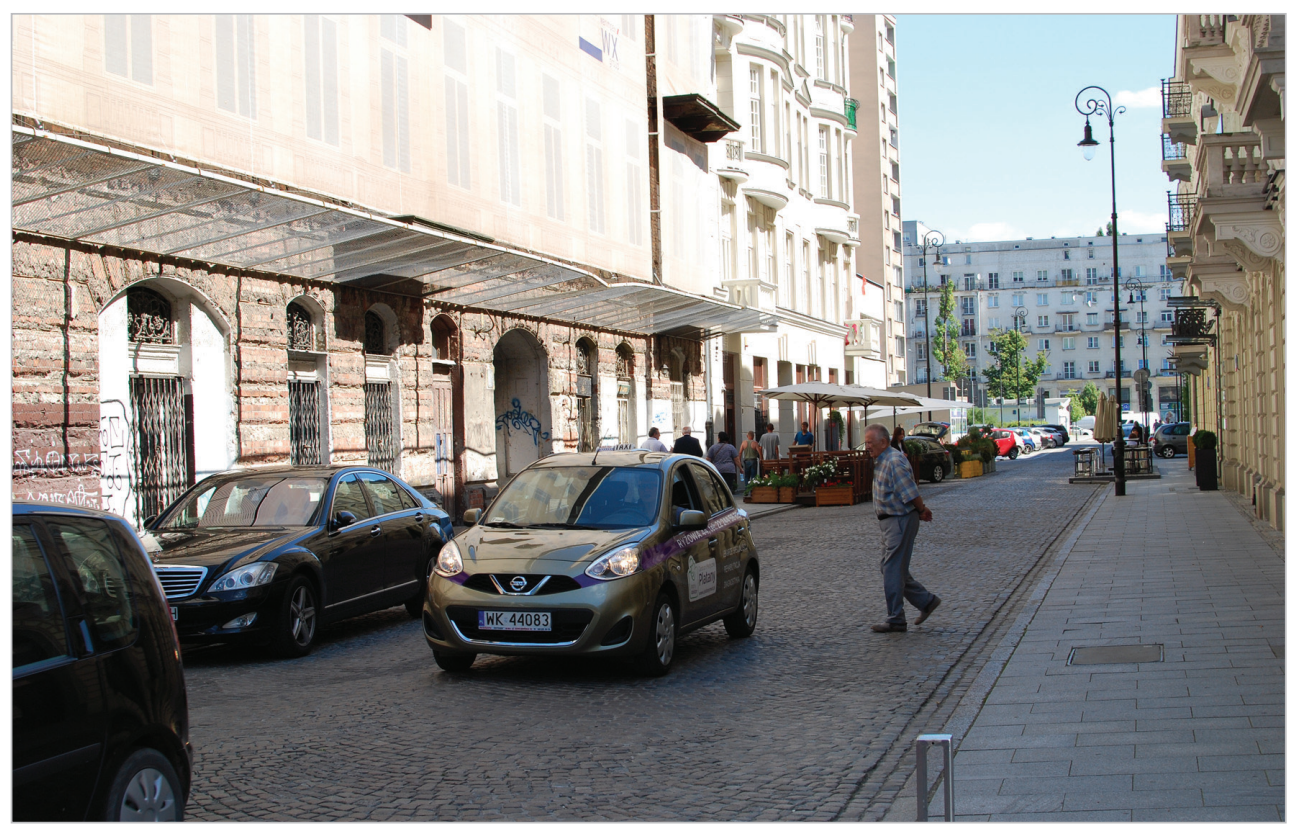

Ryc. 6. Ulica Próżna w Warszawie (2017)

Fot. Łukasz Drozda.

Wpływ artystycznej interwencji wydaje się najsilniej oddziaływać z tego względu właśnie na estetyzację środowiska zbudowanego, która stanowi podstawę gentryfikacji przestrzennej. O jej związkach z projektem Rajkowskiej świadczy rola urządzeń wodnych zastosowanych w konstrukcji skweru w ramach finalnie zrealizowanego projektu. Pod tym względem trudno znaleźć podobny do placu Grzybowskiego skwer znajdujący się w zarządzie publicznym w całej dzielnicy. Gentryfikacja ekonomiczna i społeczna mają jednak w przypadku opisywanej okolicy charakter fragmentaryczny i niejednoznaczny. 


\subsection{Wartości estetyczne przestrzeni}

Badanie społecznej oceny estetyki przestrzeni zurbanizowanej w przypadku placu Grzybowskiego oparte zostało na jego porównawczej waloryzacji względem placu Europejskiego (aneksy 4.1 i 4.2). Oba te miejsca położone są na obszarze śródmiejskim Warszawy. Są przy tym stosunkowo podobnej wielkości skwerami pieszymi, a ich obecny kształt ocenić należy jako pochodną kompleksowej modernizacji i planowanego sposobu zagospodarowania. Oba miejsca różnią się jednak genezą powstania i strukturą własności. Plac Grzybowski to przykład przestrzeni w pełni publicznej, otwartego placu miejskiego. Na jego obecny sposób zagospodarowania wpłynęła interwencja aktora społecznego przyjmująca postać instalacji artystycznej i późniejsza debata dotycząca kształtu rewitalizowanego miejsca. Plac Europejski, chociaż również pozbawiony barier przestrzennych, jest przestrzenią komercyjną udostępnioną powszechnie tylko na pozorne podobieństwo przestrzeni publicznej. Kształt tego miejsca stanowi wynik działań właściciela terenu - dewelopera i inwestora pobliskich biurowców. Pole podstawowe waloryzacji odnosi się tym samym do miejsca związanego z działaniami z zakresu urbanistyki oddolnej. Nie można jednak takiej charakterystyki odnieść do jego pola kontrolnego.

W celu przedstawienia respondentom reprezentatywnego obrazu obu tych przykładów przestrzeni zurbanizowanej przygotowałem prezentację składającą się z 23 fotografii, które przemieszałem ze zdjęciami ilustrującymi pozostałe studia przypadków. Cztery przedstawiają elementy reprezentatywne dla kategorii detalu urbanistycznego (meble miejskie, fontanny na obu placach, tablice informacyjne, pomniki). Pięć pokazuje zachowania użytkowników we wskazanych tu miejscach. 14 kadrów reprezentuje zaś ogólny kontekst przestrzenny bez koncentracji na sposobach jego użytkowania. Ostatnia grupa zdjęć ukazała zatem rezultat projektowania urbanistycznego i powiązania przestrzenne obu placów z ich otoczeniem za pomocą bardziej obszernych ujęć.

Analiza wyników ocen formułowanych przez respondentów poddanych badaniu za pomocą metody SBE pokazuje, że plac Europejski oceniany jest jako miejsce o nieznacznie większej estetyce przestrzeni (3,73 pkt) niż plac Grzybowski (3,61 pkt). Rozbieżność ta jest jednak niewielka. Co więcej, w przypadku obu analizowanych miejsc wiele podobieństw wykazywały zbliżone tematycznie fragmenty przestrzeni zurbanizowanej. Szczególnie wysoko oceniane były na przykład urządzenia błękitnej infrastruktury, czyli będące przestrzennymi zwornikami obu placów elementy wodne, w obu przypadkach pozbawione barier dostępności. Oceny negatywne formułowano natomiast w stosunku do wysokiej zabudowy dominującej nad otoczeniem obu placów. Respondenci nie wskazali tym samym szczególnych zalet pola podstawowego w stosunku do pola kontrolnego. Ocenili je nieco bardziej negatywnie, aczkolwiek w niewielkim stopniu. 


\subsection{Sposoby mapowania poznawczego}

Na podstawie analizy szkiców wykonanych przez respondentów (aneks 3.1) plac Grzybowski określić można jako przestrzeń czytelną dla jego użytkowników. Dotyczy to zwłaszcza stanowiącego część centralną skweru, będącego zarazem obiektem interwencji Rajkowskiej i późniejszej, odgórnej inwestycji miejskiej. Zdecydowana większość szkiców wplata przynajmniej niektóre elementy odwzorowania planimetrycznego. Służą one do zakreślenia na przykład wyraźnych granic skweru, nawet gdy całe zobrazowania mają charakter perspektywiczny. Kiedy takiego określenia nie uzyskiwał skwer, wyraźnie określona w charakterystycznie „mapowy” sposób zostawała przynajmniej powierzchnia wodna. Elementy wykorzystujące wodę są tymczasem zwornikiem skweru i jego najbardziej charakterystycznym fragmentem, akcentowanym także z urbanistycznego punktu widzenia.

Bardziej swobodny charakter, obrazujący plac Grzybowski jako delikatnie przenikający przez jego otoczenie, ma tylko pięć z 30 pozyskanych szkiców (A5, A9, A18, A26, A27). Nawet w tej grupie znalazły się jednak zobrazowania takie jak przejawiający wiele cech profesjonalnych rysunek autorstwa kandydatki na studia architektoniczne (A26) ${ }^{18}$. W tym przypadku wynikało to ze świadomie zastosowanej przez respondentkę techniki, a nie z nieidentyfikowania przez nią elementów struktury przestrzennej miejsca. W pełni kartograficzne lub pokrewne im techniki mapowania wykorzystali wszyscy respondenci płci męskiej. Podobne typy zobrazowań wyraźnie przeważały również wśród udzielających wywiadu kobiet (12 z 17). Równie częstymi użytkownikami miejsca są mieszkańcy najbliższej okolicy (13), co mieszkańcy innych części miasta (12), rzadziej obecni byli natomiast przyjezdni (5). Techniki planimetryczne przeważają wśród każdej z tych grup respondentów. Do pewnego stopnia szkice autorstwa tubylców są nawet nieco mniej dokładne pod kątem odzwierciedlania rzeczywistego charakteru placu. Ujawnia to ich większe nacechowanie emocjonalne.

Plac Grzybowski budzi zdecydowanie ciepłe odczucia u swoich użytkowników. W większości przypadków przy jego rysowaniu respondenci używali wyłącznie barwy określającej pozytywne elementy tej przestrzeni. Całkiem często udzielającym wywiadu zdarzało się wskazywać elementy negatywne (19 z 30), przeważnie dotyczyły one jednak obiektów zewnętrznych w stosunku do skweru i najczęściej nie wynikały z jego zaprojektowania. Zdarzają się opinie kwestionujące zastosowane rozwiązania projektowe. Na przykład mieszkającego w okolicy emeryta (A13)

${ }^{18}$ W czasie przeprowadzania rozmowy osoba ta ćwiczyła zresztą umiejętności tworzenia rysunku architektonicznego. Na placu regularnie odbywają się też zajęcia plenerowe w ramach kursów dla kandydatów na tego typu kierunki, które przygotowują do egzaminów wstępnych na studia. 
denerwuje nadmierne wykorzystanie elementów kamiennych w posadzce i wyposażeniu skweru. Samo miejsce budzi jednak przy tym jego sympatię. Jak zauważył, „bardzo [lubię tu być], jak ja tu z 50 lat jestem, to trudno nie lubić”. Przebywanie w tym miejscu stanowi dlań lubiany, codzienny rytuał: „No to tradycja jest już taka, że prawie codziennie muszę być tak, że gazetka, kawka, przyzwyczajenie takie”. Najczęściej jako wadę wskazywano uciążliwość zbyt dużego ruchu samochodowego (A16, A23, A28, A29) - i to pomimo reorganizacji i uspokojenia ruchu związanego z przebudową placu i sąsiedniej ulicy Próżnej. Wyraźnie stanowisko to przedstawia głos prawniczki będącej na urlopie macierzyńskim (A28). Jak opisuje,

konstrukcja tego placu w ogóle mi nie przeszkadza, nie wzbudza żadnych moich emocji, oprócz tych samochodów. Gdyby zlikwidować tę drogę i ten parking $[\ldots]$ to plac byłby większy, można byłoby go jeszcze bardziej zagospodarować i pewnie jeszcze więcej osób mogłoby z niego skorzystać. Samochody są tutaj przeogromną wadą. Nawet ta ulica nie jest uciążliwa, ale te samochody, które tutaj jeżdżą, lub stoją tutaj pod nosami ludzi, którzy piją kawę czy coś jedzą, to jest po prostu do likwidacji [...]. Tak by było fajniej.

Część osób zwróciła uwagę na szpecący okolicę kikut po drzewie złamanym przez wichurę krótko przed badaniami terenowymi (później drzewo zostało wycięte). Czynił tak na przykład mieszkający w innej dzielnicy finansista (A20), którego zdaniem „szkoda, że za mało drzew jest, to drzewo niestety jest już [...] nie żyje”.

Sprzeczne opinie wzbudza kościół, będący tradycyjną dominantą wysokościową placu, a także przyjmujący tę rolę nowy element z jego otoczenia. Chodzi o agresywny pod względem skali apartamentowiec Cosmopolitan. Zdecydowanie sprzeciwił się mu zamieszkały w innej dzielnicy muzyk (A10), ale poparli go z kolei przyjezdna nauczycielka akademicka (A16) i zagraniczny doradca biznesowy (A11). Co jednak warte podkreślenia, ten ostatni związany jest $\mathrm{z}$ branżą nieruchomości. $\mathrm{Z}$ innymi respondentami dzielił jednak często spotykaną niechęć do zaniedbanych oraz socmodernistycznych budowli w okolicy. Cosmopolitan to dla niego „wielki kontrast z tym placem, ale naprawdę dobra rzecz. [Bloki to natomiast] gówno, gówno, gówno", które należałoby wyburzyć. Podobnie jak szpetny w jego opinii gmach Teatru Żydowskiego, rzeczywiście zresztą wyburzany, aby „przywrócić miejscu utraconą chwałę". Podobnie oceniła ten typ zabudowy pracująca w sąsiedztwie kobieta zatrudniona w korporacji (A18). Dla niej ,jest to fajne, że są wieżowce”. Entuzjazm wyrażali też studenci. Jak komentował mieszkający w innej dzielnicy (A25): „A i co tu jest jeszcze brzydkie, to jest ten blok pomalowany - że się tak wyrażę - na oczojebny żółty”. Inny, mieszkający z kolei w najbliższej okolicy (A4), także dostrzegał kontrast peerelowskich bloków ze współczesnymi drapaczami chmur. Jak powiedział, „te wieżowce mi się podobają, nadają takiego fajnego tempa miastu, city". Wśród negatywnych elementów otoczenia uwagę zwrócił nato- 
miast na zaniedbane centrum usługowe, zdominowane jego zdaniem przez tanie bary gastronomiczne sprzedające kebap. Ośrodek tych usług mieści się jednak nie na placu, ale przy wyraźnie gorszej jego zdaniem pobliskiej przestrzeni negatywowej utworzonej na niezagospodarowanym obszarze obok ulicy Marszałkowskiej.

Wielu użytkowników placu podkreślało, że Grzybowski to wzorcowy przykład przestrzeni zurbanizowanej. Dla przywołanego wcześniej studenta (A25) ,jakby wszystkie place w Warszawie tak wyglądały, to byłoby super”. Zdanie to podzielał mieszkający w innej dzielnicy ekonomista (A14): „Myślę, że tak i to takie miejsce jest wyróżniające się odnośnie tej przestrzeni miejskiej, o której się dużo mówi, żeby ją jakoś zagospodarowywać". Wedle mieszkającej tuż obok emerytki (A22) Grzybowski jest zaś „bardzo zaprojektowany, sprawdza się ten Dotleniacz, te babcie, staruszki tu przychodzą, to jest bomba". Na podstawie dodatkowego pytania o ocenę zaprojektowania placu niemal wszyscy respondenci określali swój stosunek do niego jako pozytywny. Często dodatkowo podkreślali własne entuzjastyczne nastawienie. Ostatnia z przywołanych wypowiedzi świadczy o skojarzeniu aktualnego kształtu placu z artystyczną interwencją z przeszłości, jakkolwiek obecnie istniejąca konstrukcja tylko nawiązuje do rzeczywistego Dotleniacza. W świadomości tej mieszkanki pozwoliło to nawet wytworzyć przekonanie o specjalnych właściwościach aktualnie obowiązującego rozwiązania, gdzie ,jest inne powietrze, ono biega po tej wodzie, ja to czuję". Istnienie instalacji artystycznej kojarzyło jednak tak naprawdę tylko 5 z 30 respondentów. W gronie tym znaleźli się zarówno pobliscy mieszkańcy, jak i emeryt deklarujący pamięć o akcji i podpisywanie petycji w obronie Dotleniacza (A13) czy mieszkanki innych dzielnic (A3, A23), bywające na miejscu tylko okazjonalnie. Tylko te dwie osoby określiły jednak umiejscowienie projektu Rajkowskiej jako kluczowego elementu w historii tego miejsca.

Najczęściej wskazywanym aktorem tutejszego społecznego wytwarzania przestrzeni byli Żydzi. Wpływ ten identyfikowano z różnymi elementami. Od historycznych uwarunkowań ze szczególną rolą getta (A14, A16, A20, A25), przez związaną z tym faktem współczesną politykę kulturalną (A4, A7, A16, A25, A28), aż po teorie spiskowe (A22). Szczególnie ciekawa jest właśnie ta ostatnia wypowiedź. Nie zawiera ona w sobie zabarwienia antysemickiego, lecz raczej szacunek i uznanie dla żydowskiej gospodarności. Jak oceniła jej autorka,

wiadomo, że to dzięki Żydom. Oni bardzo o to dbają, chcą zaznaczyć, że to jest to miejsce o nich. Wczoraj myli te ławki [mowa o służbach oczyszczających miasto - Ł.D.]. Tu nie ma menelstwa. Trzeba to zaznaczyć! Tu przychodzę trzy i pół miesiąca, nie zastałam jeszcze [...] niemyjących się osób (A22).

Opinia ta wydaje się zarazem mało wiarygodna, zważywszy na odnotowaną przy okazji badań obecność na miejscu osób bezdomnych, żebraków czy nagabujących przechodniów przedstawicieli sekt religijnych. 


\subsection{Poziom i poczucie bezpieczeństwa}

Analizę towarzyszącą ocenie poziomu bezpieczeństwa w okolicy placu Grzybowskiego oparłem na dwóch grupach źródeł. Po pierwsze, odzwierciedlają one pomiary subiektywnych odczuć wynikających z percepcji tej przestrzeni zurbanizowanej u jej użytkowników. Po drugie, użyteczne były mające bardziej obiektywny charakter dane ilościowe pozyskiwane ze statystyk policyjnych. Informacje z zakresu pierwszej $z$ tych grup opracowałem $w$ ramach 30 wywiadów przeprowadzonych $\mathrm{z}$ respondentami, w trakcie których pytani byli oni o własne poczucie bezpieczeństwa w trakcie przebywania na placu Grzybowskim. W celu zestawienia tych informacji z danymi o charakterze urzędowym wystąpiłem w trybie dostępu do informacji publicznej z wnioskiem do Komendy Stołecznej Policji. Pozwoliło to na dostęp do danych pochodzących z Krajowego Systemu Informacyjnego Policji (KSIP) ${ }^{19}$. W ramach tego systemu liczba przestępstw agregowana jest w ujęciu miesięcznym w odniesieniu do poszczególnych ulic i placów. Oznacza to niestety niewielką dokładność w przypadku dłuższych, liniowych ciągów komunikacyjnych. Krótka uliczka zawierająca raptem kilka numerów jest opisywana w tym kontekście dokładnie tak samo jak parokilometrowa arteria. System pozwala wskazać na liczebność naruszeń prawa podzielonych wedle kilku kategorii ${ }^{20}$.

Ze względu na dostępność danych, charakter analizowanej przestrzeni oraz możliwości porównywania pozyskanych informacji wykonałem analizę liczby przestępstw popełnianych w polu podstawowym oraz kontrolnym. Polem podstawowym jest w tym przypadku najbliższa okolica placu Grzybowskiego, a jako pole kontrolne zdefiniowałem plac Dąbrowskiego. Oba te miejsca są do siebie stosunkowo podobne pod względem rozmiarów oraz usytuowania, a także leżą w tej samej części dzielnicy Śródmieście. Jak wykazały pomiary wykonane za pomocą GIS, plac Dąbrowskiego jest od Grzybowskiego nieco mniejszy (1,1 wobec 1,5 hektara). W obu przypadkach zbliżona do siebie jest jednak powierzchnia skwerów pieszych (0,5 hektara). Skwery te ulokowane są w punktach centralnych obu miejsc.

Place stanowią przykłady podstawowych przestrzeni publicznych w najbliższej okolicy. Spełniają funkcje użytecznej dla mieszkańców zielonej infrastruktury, a upodabnia je występowanie elementów wodnych, chociaż ten na placu Grzybowskim jest bardziej złożony od fontanny na placu Dąbrowskiego. Oba koncentrują

19 Te i następne dane na podstawie odpowiedzi Gabinetu Komendanta Stołecznej Policji nr G-2047/1580/17 z 3 kwietnia 2017 roku. Zgodnie z ówczesnymi możliwościami systemu opracowano dane z okresu od początku stycznia 2013 roku do końca lutego 2017 roku.

${ }^{20}$ Wyróżnia w tym zakresie przestępstwa ogółem, te o charakterze kryminalnym, przestępczość rozbójniczą, przestępstwa z włamaniem, kradzieże samochodów i cudzych rzeczy, bójki i pobicia, uszkodzenia mienia oraz uszczerbki na zdrowiu. 
różne typy usług. Tych o charakterze gastronomicznym więcej jest przy Grzybowskim. Nie są to jednak lokale czynne do godzin późnonocnych czy organizujące hałaśliwe imprezy, jakie mogłyby wpływać na odmienność sposobów użytkowania tych przestrzeni związaną ze wzrostem przestępczości. Zarazem, co jest bardzo użyteczne z punktu widzenia badań tej problematyki, oba miejsca nie są specjalnie powiązane przestrzennie. Dystans w linii prostej jest krótki i liczy kilkaset metrów, skutkiem czego mieści się w granicach akceptowalnego dojścia pieszego. Rozdzielają go jednak dwie linie zwartej zabudowy, a także mająca charakter nieprzekraczalnej bariery szeroka ulica Marszałkowska (łącznie sześć pasów na dwóch jezdniach rozdzielonych torowiskiem tramwajowym). Dzięki temu oba te miejsca traktować należy jako w pełni rozłączne. Różnicę stanowi też poziom ich zainwestowania. W przypadku Grzybowskiego mowa o zaprojektowanej bardziej współcześnie i lepiej zadbanej, reprezentacyjnej przestrzeni publicznej. Skwer na placu Dąbrowskiego ma natomiast przestarzały charakter. Większość pieszych jedynie przecina go w trakcie drogi między ulicą Marszałkowską i Traktem Królewskim, nie traktując tego miejsca jako punktu docelowego.

Chcąc zapewnić możliwie daleko idącą reprezentatywność danych, w przypadku obu badanych miejsc zebrałem informacje dotyczące samych placów i ich bezpośredniego otoczenia. Posłużyło do tego uwzględnienie informacji dotyczących trzech reprezentatywnych ulic z okolicy każdego z placów. Wszystkie łączą się bezpośrednio z tymi miejscami oraz mają zbliżoną łączną długość. Ze względu na zakres powiązań z placami i adekwatność danych do analizy trafiły ciągi możliwie krótkie, których długość sprawdziłem przy użyciu GIS. W efekcie okolicę pola podstawowego - placu Grzybowskiego - zdefiniowałem jako powierzchnię placu wraz z ulicami Mariańską, Bagno i Próżną. Łączna długość tych trzech ciągów wynosi około 430 metrów. Z kolei związane z placem Dąbrowskiego pole kontrolne objęło powierzchnię placu, a także obszar ulic Rysiej, Szkolnej i Kredytowej, czyli łącznie około 360 metrów. Dodatkowym polem kontrolnym została natomiast dłuższa i niepowiązana bezpośrednio z tymi placami ulica Mazowiecka. Znajduje się ona w tej samej części Warszawy, a zarazem nieco bliżej placu Dąbrowskiego. Słynie jako jedno z największych zagłębi klubowo-rozrywkowych stołecznego Śródmieścia. Zwiększa to też natężenie wielu typów przestępczości, charakterystyczne dla obszarów koncentrujących większą liczbę punktów nocnej rozrywki i intensywniejszego spożycia alkoholu. Rysują się w ten sposób trzy obszary stanowiące podstawę finalnej analizy poziomu bezpieczeństwa (tabela 8).

W świetle powyższych danych plac Grzybowski nie wyróżnia się specjalnie negatywnie w stosunku do innych miejsc w jego najbliższej okolicy. Łączna liczba przestępstw ogółem, tych o charakterze kryminalnym, a także rozbojów i włamań bądź brak występowania w obu miejscach kradzieży samochodów, dowodzą 


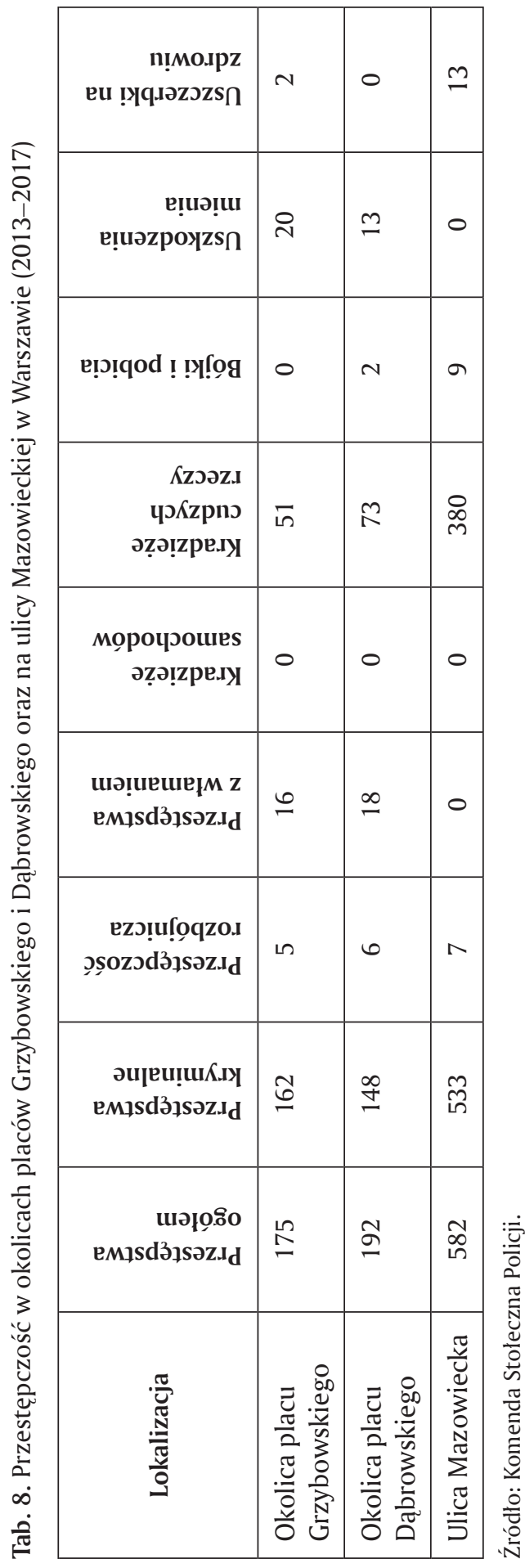


podobieństw między tymi miejscami. Jednocześnie wyraźnie kontrastują ze znacznie wyższym poziomem przestępczości na ulicy Mazowieckiej. Nie tylko częściej rejestruje się tam bójki, pobicia i uszczerbki na zdrowiu, ale przede wszystkim zdecydowanie częściej dochodzi w tym miejscu do kradzieży cudzych rzeczy. Spotyka je się aż niemal osiem razy częściej. Właśnie większą bliskością tej ulicy wobec placu Dąbrowskiego tłumaczyć można zapewne nieco wyższą liczbę kradzieży odnotowywanych w porównaniu z placem Grzybowskim.

W ujęciu danych urzędowych jest to więc „zwykły” poziom przestępczości. Pole podstawowe nie odbiega pod tym względem od swojego otoczenia. Podobną refleksję ujawniają rozmowy z niemal wszystkimi respondentami. 29 z 30 spośród nich stwierdziło, że czuje się na placu Grzybowskim bezpiecznie. Jak jednak podkreślił zamieszkały w jego najbliższej okolicy młody architekt (A6), „Warszawa jest ogólnie w ogóle coraz bardziej miastem bezpiecznym. W ogóle Śródmieście, centrum, łącznie z tym, że tak samo jeszcze jak okolice Hal Mirowskich. To są naprawdę fajne miejsca, w których życie jeszcze jest i kwitnie sobie, tak że jak najbardziej bezpiecznie”. Badani identyfikowali między innymi jako sprzyjające bezpieczeństwu elementy zaprojektowania placu (A9), a także chwalili obecność straży miejskiej (A13).

Niektórzy respondenci narzekali jednak na poziom bezpieczeństwa w nocy albo też wykazywali pewne obawy wobec tego, jak wyglądać może plac po zmroku, nawet jeśli na nim wtedy nie bywają (A1, A15, A16, A17, A21, A23, A30). Jednocześnie podkreślali, że jest to nie tyle właściwość samego placu Grzybowskiego, ile ogólnie współczesności. W wypowiedziach tego rodzaju dostrzegać można pokłosie takich zjawisk, jak poczucie zagrożenia związane ze współczesnym terroryzmem czy uprzedzeniami wobec imigrantów i uchodźców. W taki sposób sprawę ujęła na przykład mieszkająca tuż obok emerytka:

Ja czuję się bezpiecznie. To jeszcze wieczorem późno nie wychodzę sama, zresztą to takie są przypadki, ale to nie tylko na placu Grzybowskim, bo i w innych dzielnicach. W tych miejscach odbywają się niektóre takie zabawy, że naprawdę godne podziwiania, bo nigdy nie było tego w Warszawie, co teraz się dzieje. Zresztą nie tylko u nas w Warszawie, bo i w innych państwach też, bo u nas jest jeszcze względnie (A15).

Jednocześnie jednak niektórzy wywiadowani byli zdania przeciwnego. Inna seniorka zamieszkała w okolicy (A22), w odpowiedzi na pytanie o poczucie bezpieczeństwa, celowy nacisk położyła na kwestię tego, że nie odczuwa dyskomfortu $\mathrm{w}$ badanym miejscu nawet $\mathrm{w}$ nocy, chociaż jest to teoretycznie najmniej przyjazny temu moment. „Bardzo, właśnie bardzo, tak [czuję się tutaj bezpiecznie]. Nie uwierzy Pan, ale nawet o północy tu z [psem] przychodzę. Fajni ludzie wieczorem sobie siedzą. Bardzo bezpiecznie”. Mówiąc o czasie przed zmrokiem, poczucie 
dyskomfortu w zakresie bezpieczeństwa zaznaczyła tylko jedna respondentka. Co jednak istotne, była to osoba przyjezdna, studentka pochodząca z mniejszego miasta (A29), niebezpieczeństwo identyfikująca głównie ze złym klimatem akustycznym. Jak to ujęła:

Nie do końca [czuję się tu bezpiecznie]. Po pierwsze, tu jest bardzo głośno, a ja nie lubię hałasu i nie czuję się bezpiecznie w miejscach, w których jest głośno. Po drugie, jakoś tak porównując, no ja nie byłam w wielu miejscach w Warszawie. Ale to, co jest bliżej, to jest park Saski? To tam jest jakoś ciszej i jest tam więcej starszych osób, to może dzięki nim czuję się bezpieczniej.

Była to jedyna tak stanowczo krytyczna wypowiedź.

\subsection{Wyniki monitoringu internetu}

Monitoring źródeł internetowych służący analizie sposobów wartościowania przestrzeni placu Grzybowskiego przez jego użytkowników wykonałem na podstawie analizy treści publikowanych w serwisie Instagram w czerwcu 2017 roku. Okres ten wybrałem ze względu na dostępność narzędzi pomiarowych, a także charakter użytkowania przestrzeni zurbanizowanej w trakcie tej pory roku - przełomu wiosny i lata. Ma ono wówczas większą częstotliwość ze względu na dobrą pogodę, a zarazem jest pozbawione dni specjalnych związanych ze świętami o charakterze narodowym i religijnym. Mogłyby one tymczasem potencjalnie sprzyjać niestandardowemu i ponadprzeciętnemu wykorzystywaniu przestrzeni publicznej.

Podobnie jak w przypadku oceny estetycznej przestrzeni prowadzonej wedle metody SBE jako pole kontrolne dla monitoringu internetowych treści określiłem plac Europejski. Zarówno pole podstawowe, jak i kontrolne wyznaczyłem za pomocą automatycznego pomiaru prowadzonego z wykorzystaniem narzędzia Brand24. Pomocne były dla tego celu wszystkie wskazania dla lokalizacji i hashtagów związanych z obiema przestrzeniami ${ }^{21}$. W przypadku placu Grzybowskiego pozyskałem tą drogą 296 wpisów, a 163 odnośnie do placu Europejskiego. W stosunku do każdego z nich wylosowałem następnie, przy wyłączeniu postów zamieszczanych przez autorów udostępniających więcej niż dwa posty, grupę 100 wpisów poddanych szczegółowej jakościowej analizie treści (tabela 9) ${ }^{22}$.

W obu przypadkach przestrzeń zurbanizowana była oceniana przez swoich odbiorców pozytywnie. Elementy zaprojektowane albo aktywności ludzi ściśle

21 Wykorzystałem analizę postów zawierających w swojej treści i oznaczeniach lokalizacji zapytania takie, jak pisane razem i rozłącznie „plac grzybowski” oraz „plac europejski”.

${ }^{22}$ Dane nie sumują się do jedności w związku z możliwością występowania kilku tematów równorzędnych w ramach jednej fotografii. 
Tab. 9. Waloryzacja percepcji przestrzeni na podstawie wpisów w serwisie Instagram - place Grzybowski i Europejski w Warszawie (czerwiec 2016)

\begin{tabular}{|c|c|c|}
\hline Wyszczególnienie & Plac Grzybowski & Plac Europejski \\
\hline \multicolumn{3}{|c|}{ Elementy obrazujące pozytywną percepcję przestrzeni (proc.) } \\
\hline Ogólne ujęcie przestrzeni & 57 & 52 \\
\hline Detal urbanistyczny & 10 & 26 \\
\hline Ludzie w określonym kontekście & 15 & 27 \\
\hline Odwzorowanie graficzne & 0 & 0 \\
\hline \multicolumn{3}{|c|}{ Elementy niezależne od pozytywnej percepcji przestrzeni (proc.) } \\
\hline Detal nieurbanistyczny & 9 & 3 \\
\hline Ludzie w nieokreślonym kontekście & 3 & 1 \\
\hline Zwierzęta & 1 & 3 \\
\hline Inne & 12 & 9 \\
\hline Ilustracje przestrzeni ogólem & 82 & 90 \\
\hline
\end{tabular}

Źródło: opracowanie własne.

umiejscowione w ramach badanych przestrzeni dotyczyły 8 lub 9 na każde 10 przypadków zdjęć. Mająca prawdziwie publiczny i nielimitowany charakter przestrzeń pola podstawowego sprzyja przy tym bardziej zróżnicowanym sposobom użytkowania. Jakkolwiek liczba fotografii uwzględniających tutejsze detale urbanistyczne była mniejsza niż w przypadku pola kontrolnego, niemal za każdym razem fotografowane były w przypadku placu Grzybowskiego jego inne elementy. W przypadku placu Europejskiego zaprojektowane odgórnie detale stanowiły temat aż przeszło jednej czwartej fotografii. Co warte podkreślenia, we wszystkich przypadkach ujęcia takich elementów szczegółowych jako dominujących charakter całego zdjęcia głównym tematem fotografii był mebel miejski złożony z dużego napisu „Kocham Warszawę". Użytkowanie placu Europejskiego, powstałego wszakże jako przestrzeń parapubliczna, stanowiąca uzupełnienie w pełni komercyjnego kompleksu biurowego, jest tym samym znacznie bardziej sformalizowane. Czynności wykonywane przez ludzi w tej przestrzeni odpowiadają założeniom czynionym przez projektantów tego miejsca.

Na poziomie analizy użytkowników najczęściej zamieszczających wpisy na temat obu opisywanych placów mówić można o nieco większym zainteresowaniu placem Grzybowskim. Był on tematem wpisów 319 użytkowników wobec 140 osób i instytucji zainteresowanych drugim z opisywanych miejsc. W pierwszym 
przypadku wpisy cieszyły się też większym średnim zasięgiem. Docierały do około 5105 użytkowników wobec $695 \mathrm{w}$ drugim przypadku. Z kolei przyjęcie mediany jako miernika przeciętnego zainteresowania odbiorców wskazuje na niemal identyczne zainteresowanie - 228 wobec 229 użytkowników.

Wyniki zastosowanego monitoringu internetu pokazują, że pole podstawowe i kontrolne cieszą się podobnym zainteresowaniem ze strony zarówno twórców ich zobrazowań, jak i odbiorców tych treści. Użytkowanie placu Europejskiego ma jednak bardziej sformalizowany charakter. Obie przestrzenie postrzegane są bowiem jako zadbane i odbierane przez swoich odbiorców przeważnie pozytywnie.

\subsection{Podsumowanie}

Rozważania na temat waloryzacji wytwarzanej w toku urbanistyki oddolnej przestrzeni placu Grzybowskiego nie dają podstaw, aby stwierdzić, że rozpoczęła się na tym obszarze gentryfikacja ekonomiczna. Taki obraz jest stosunkowo wyraźny, jeżeli wziąć pod uwagę tylko tendencje występujące na lokalnym rynku nieruchomości. Plac ten wykazuje się też wysoką jakością infrastruktury osadniczej. Częściowo czerpie korzyści z uwarunkowań zewnętrznych, zwłaszcza dogodnych powiązań komunikacyjnych, jest jednak też przykładem dobrze funkcjonującej przestrzeni zurbanizowanej. Taką konstatację można sformułować także wówczas, gdy skupić się tylko na autonomicznych cechach tego miejsca. Przestrzeń ta sprzyja na przykład zróżnicowanym czynnościom wykonywanym przez jej użytkowników. Aktywności te wykraczają ponad poziom ich obowiązkowego zakresu, czyli opisywanych przez Gehla czynności koniecznych. Analiza percepcji miejsca u osób użytkujących otoczenie placu Grzybowskiego pozwoliła skonstruować jego obraz jako atrakcyjnego do przebywania. Chwalą go w tym względzie osoby o różnym poziomie znajomości lokalnego kontekstu i różnym poziomie przywiązania do tego miejsca. Często czynią to w oderwaniu od znajomości historii placu lub przy pomijaniu tej jego części, która realnie wpłynęła na obecny sposób zagospodarowania tej przestrzeni. Nad niedawne wydarzenia przedkładają niekiedy bardziej mgliste zdarzenia z odleglejszych dziejów.

Równocześnie jednak w okolicy tej tempa nabiera gentryfikacja w wymiarze społecznym. Ciągle jest ona jednak ograniczona. Nie towarzyszy jej zmasowane wypieranie ludności ani nie odnotowane zostały szokujące zmiany w dostępności cenowej tutejszych mieszkań. Konsekwencje społeczne jak na razie dotknęły raczej dogęszczania nowej zabudowy i wymiany dostępnych usług. Istotna jest natomiast gentryfikacja przestrzenna. Modernizacja w ramach konsultacyjnego wytwarzania przestrzeni jako następstwa Dotleniacza zainspirowała taką właśnie odmianę „uszlachetniania”. Trudno wskazać inny przykład podobnej zmiany miejsca w War- 
szawie w odniesieniu do jakiegokolwiek skweru, który nie stanowiłby fragmentu większego założenia urbanistycznego. Tego typu miejsca skojarzyć można wprawdzie z dużymi inwestycjami wokół Traktu Królewskiego czy bulwarów wiślanych, ale już nie w przypadku porównywalnych z Grzybowskim pozostałych ze śródmiejskich placów, a przynajmniej tych w zarządzie publicznym. Nie sposób przy tym tej przestrzeni zaklasyfikować jako bardziej bezpiecznej. Także i mniej doinwestowane place $\mathrm{w}$ centrum miasta wykazują w tym względzie podobną charakterystykę. Plac Grzybowski jest w stosunku do nich miejscem niewyróżniającym się. W zakresie oceny piękna scenerii jest on waloryzowany podobnie jak lokalizacje, których przekształcenie miało czysto komercyjny charakter, bez żadnego związku z zaangażowaniem strony społecznej. Analiza behawioralna oparta na monitoringu internetowych śladów aktywności użytkowników tego placu pokazuje, że jest on oceniany jako równie estetyczne miejsce co jego skomercjalizowany odpowiednik. Brak niektórych walorów charakterystycznych dla przestrzeni publicznej w przypadku pola kontrolnego nie spowodował, aby stało się ono gorzej oceniane przez odbiorców. Spontaniczność i mniejsze zdyscyplinowanie formalne właściwe użytkowaniu przestrzeni publicznej nie zostają w tym przypadku docenione tak, jak mogliby się spodziewać entuzjaści egalitarnej przestrzeni zurbanizowanej. 


\section{Zielona gentryfikacja. High Line Park}

\subsection{Zielony aktywizm w bogatej metropolii}

Drugie badane studium przypadku ulokowane jest we wschodniej części dzielnicy Manhattan w Nowym Jorku, dokładnie na obszarze między ulicami 14. i Horatio. Na początku XX wieku kojarzony był on przede wszystkim z działalnością przemysłową. To właśnie temu okolica zawdzięcza swoją nazwę - Meatpacking District (dystrykt przetwórstwa mięsnego). Historycznie rzecz biorąc, cieszyła się ona przeważnie złą sławą. Powszechną niechęć wzbudzał zwłaszcza intensywny ruch kołowy związany z ulokowanymi w tym miejscu zakładami produkcyjnymi. Dla niektórych ulic ukuto nawet $\mathrm{z}$ tego względu przydomek Alei śmierci (Death Avenue), wskazujący na charakterystyczne dla tego sąsiedztwa liczne wypadki komunikacyjne. Po fali protestów zaczęto rozważać inwestycję mającą odciążyć układ transportowy, polegającą na budowie nadziemnej kolei przemysłowej. Projekt przeciągał się w czasie, najpierw z powodu kosztów I wojny światowej, a potem przez wybuch wielkiego kryzysu. Ostatecznie ukończono go w 1934 roku. Powstała w ten sposób infrastruktura znajdowała się w użyciu jednak stosunkowo krótko. Już w latach 60. XX wieku zaczęto ograniczać jej użytkowanie i wyburzono pierwsze fragmenty, a w 1980 roku z linii skorzystał ostatni pociąg. Jeszcze w tej samej dekadzie pierwszej próby jej rewitalizacji podjął się snujący rozwinięte plany inwestycyjne przedsiębiorca i aktywista miejski, Peter Obletz. Jednak już w 1987 roku jego porozumienie z miastem zostało unieważnione. Linia kolejowa położona w sercu centralnej, nowojorskiej dzielnicy, przecinająca powierzchnię takich sąsiedztw ${ }^{23}$, jak Chelsea i Greenwich Village, zaczęła w związku z tym niszczeć

${ }^{23}$ Struktura terytorialna miasta Nowy Jork, które jest tylko częścią większej aglomeracji i stanu o tej samej nazwie, składa się w pierwszej kolejności z pięciu dzielnic (boroughs): Manhattanu, Brooklynu, Queens, Bronxu oraz Staten Island. W ramach tych części wyróżnia się mniejsze sąsiedztwa (neighborhoods), o często umownych granicach w przeciwieństwie do administracyjnego podziału na rady osiedlowe (community boards), które składają się przeważnie z kilku sąsiedztw. 


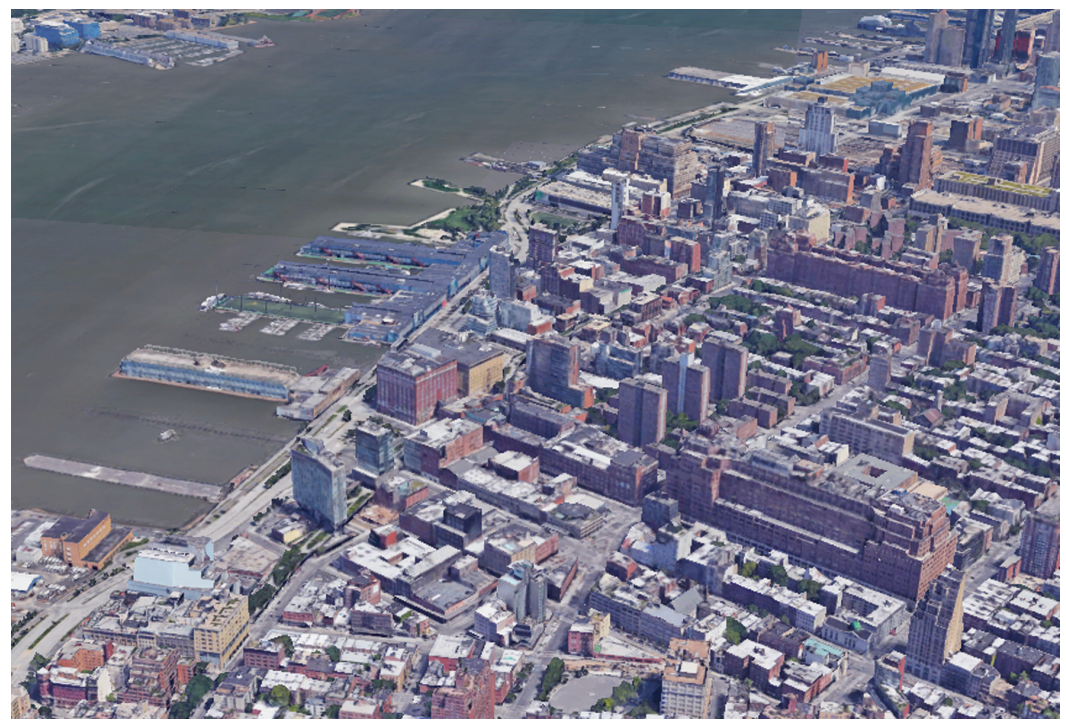

Ryc. 7. High Line Park w Nowym Jorku (wizualizacja otoczenia) Źródło: Google Earth, dostęp: 1.10.2017.

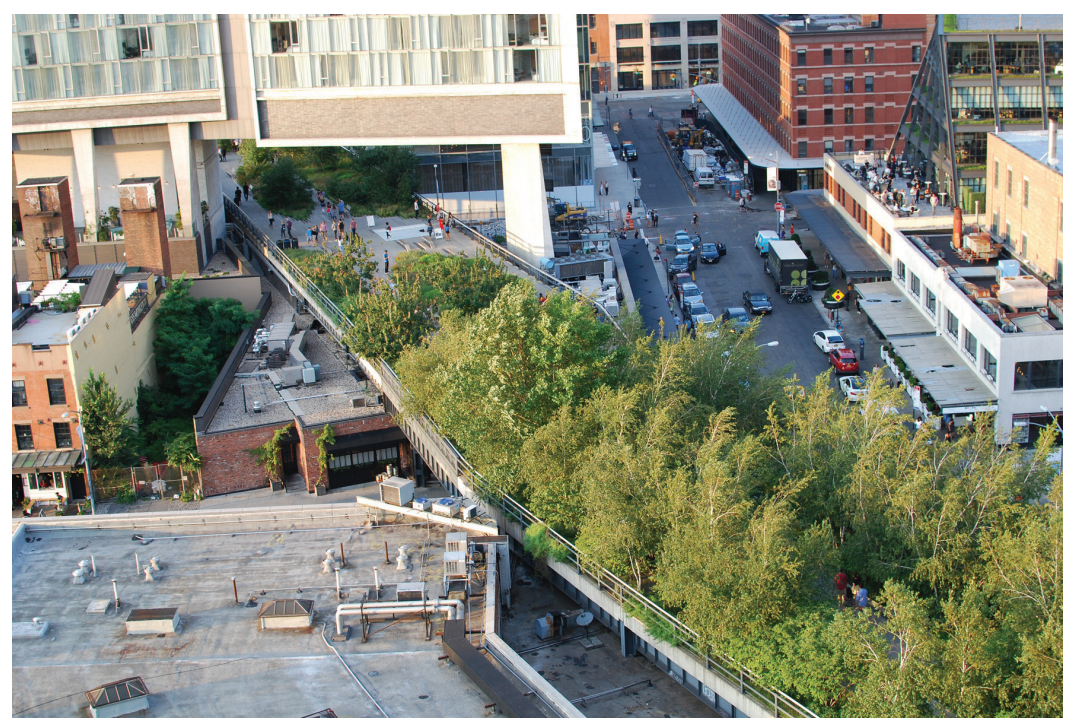

Ryc. 8. High Line Park w Nowym Jorku (2017)

Fot. Łukasz Drozda.

Odpowiednikiem sąsiedztwa w przypadku polskich miast są do pewnego stopnia osiedla. Termin ten nie wydaje się jednak dobrze określać fragmentów przestrzeni zurbanizowanej o płynnych granicach i kwartałowej zabudowie. Rodzime osiedla kojarzy się najczęściej z zaplanowaną funkcjonalnie strukturą relatywnie amorficznego blokowiska. 
i zarastać bujną roślinnością. Stopniowo wtapiała się w krajobraz okolicy poddanej nabierającej tempa deindustrializacji. W latach 90. rozpoczęto wyburzanie kolejnych fragmentów tej infrastruktury. Jej pozostawione estakady stanowiły ogranicznik w zagospodarowaniu okolicznych nieruchomości, które zyskiwały w owym czasie na wartości w zawrotnym tempie ${ }^{24}$.

W 1999 roku sprawą zamkniętej i zapomnianej linii, określanej teraz jako High Line, zainteresowali się dwaj aktywiści miejscy - Joshua David i Robert Hammond. Byli to w gruncie rzeczy gentryfierzy marginalni tej okolicy, w której zamieszkali odpowiednio w 1986 i 1993 roku jako przedstawiciele wolnych zawodów niezwiązanych z historią tego miejsca. David był dziennikarzem-freelancerem, Hammond - konsultantem w korporacji Ernst\&Young. Mężczyźni ci utworzyli następnie stowarzyszenie Friends of the High Line (FHL, Przyjaciele High Line), którego celem było uratowanie przed wyburzeniem niszczejącej liniii ${ }^{25}$. Ich rozrastająca się organizacja rozpoczęła systematyczny lobbing na rzecz ponownego zagospodarowania pozostałości trasy kolejowej, przekonując do tej koncepcji kolejne grupy lokalnych interesariuszy. Pozyskaniu poparcia mieszkańców posłużyło wprowadzenie metod oddolnego projektowania i rozmaite pomysły aktywizacji lokalnej społeczności ${ }^{26}$. Większy opór stawiali natomiast początkowo niechętni tej inicjatywie przedsiębiorcy i przedstawiciele władz miejskich. Te ostatnie w okresie rządów republikańskiego burmistrza miasta Rudolpha Giulianiego (1994-2001) wybitnie niechętnie patrzyły na tego rodzaju inicjatywy. Hamowały one bowiem potencjał popieranej przezeń możliwej komercjalizacji przestrzeni zurbanizowanej.

Przedstawiciele FHL rozważali w tym okresie różne możliwe scenariusze rewaloryzacji pod względem ich wykonalności oraz korzyści, jakie mogłyby przynieść okolicy. Sceptycznie odnosili się zwłaszcza do pomysłu wyburzenia całości wiaduktów, co przyniosłoby pozorne korzyści właścicielom nieruchomości znajdujących się pod nimi dzięki uwolnieniu gruntów pod nową zabudowę. Jeszcze inny pomysł zakładał przywrócenie funkcji transportowej. Stary wiadukt okazał się jednak przesadnie wąski dla ruchu pasażerskiego i wymogów technicznych nowojorskiego metra, jak i zbyt krótki jako racjonalnie zaplanowany ciąg rowerowy. Analizy FHL wykazały z kolei, że najbardziej pożądanym sposobem zagospodarowania byłby ciąg pieszy integrujący funkcje parkowe, wzorowany na paryskim Promenade

${ }^{24}$ J. David, Reclaiming the High Line, Design Trust for Public Space, New York 2002, s. 44-55.

25 J. David, R. Hammond, High Line. The Inside Story of New York City's Park in the Sky, Farrar, Straus and Giroux, New York 2011, s. 3-5.

${ }^{26}$ A.B. Alvarez, M.W. Wright, New York City's High Line: Participatory Planning or Gentrification?, Working Paper, The Pennsylvania State University, https://www.semanticscholar.org/paper/NewYork-City-s-High-Line-Participatory-Planning-Alvarez-Wright/1b0bfc1d332f5c0bd59a5d4389512fa ae56db990\# paperDetail, dostęp: 1.12.2017. 
Plantée. Krytycyzm pomysłodawców rewaloryzacji linii budziły przy tym pomysły jej szerszej komercjalizacji, jak choćby utworzenia popieranego przez niektórych pasażu handlowego ${ }^{27}$.

Pomysł na rewaloryzację linii zaczął zyskiwać coraz większe poparcie. FHL korzystało na przykład z atmosfery przyjaznej projektom odnowy przestrzeni publicznej, jaka zapanowała w Nowym Jorku po zamachach z 11 września 2001 roku. Do zwolenników inicjatywy zaliczać zaczęli się wówczas nowy burmistrz Michael Bloomberg (2002-2013) i prominentni urzędnicy z jego administracji. Przyjaźniejsze nastawienie deklarowali ponadto liczni przedsiębiorcy i celebryci, na czele z hollywoodzkimi aktorami Kevinem Baconem i Edwardem Nortonem. Wsparcie elit pozwoliło pozyskać finansowanie społecznościowe w wysokości kilkudziesięciu milionów dolarów. Uzupełniało to obfite środki przyznane na budowę parku przez sektor publiczny, zarówno władze samorządowe, jak i państwowe. Dzięki temu aktywiści FHL zdołali przeforsować pomysł kompleksowej renowacji starej linii. Zachowane zostały wszystkie istniejące odcinki, włącznie z otwartą najpóźniej częścią północną. Jej teren władze początkowo planowały wykorzystać dla potrzeb budowy stadionu dla klubu futbolu amerykańskiego i organizacji Igrzysk Olimpijskich planowanych na 2012 rok $^{28}$. Cały, liczący 2,3 kilometra długości obiekt przygotowano w trzech etapach inwestycyjnych realizowanych w latach 2006-2014 oraz udostępniono do zwiedzania pod nazwą High Line Park. Później uzupełniono go o jeszcze jedną krótką część w jego północnym fragmencie.

Powstała w ten sposób przestrzeń nie jest typowym publicznym parkiem, ale przykładem prywatnej przestrzeni publicznej, czyli tak zwanego POPS (privately owned public space ${ }^{29}$. Chociaż teoretycznie pozostaje związana z funkcją zielonej infrastruktury oraz plenerowej galerii sztuki, w rzeczywistości utrzymywana jest na zasadach komercyjnych. Istotne są zwłaszcza dotacje od sektora prywatnego, z których obficie korzysta FHL. Organizacja ta pełni aktualnie funkcję administratora parku i jest w dalszym ciągu kierowana przez jednego z jej założycieli, Hammonda. Na ironię zakrawa fakt, iż początkowy etap inwestycji oddano do użytku w okresie pierwszej fali globalnego kryzysu gospodarczego z 2009 roku, podobnie jak pierwszą część niegdysiejszej linii kolejowej z końca lat 20. poprzedniego stulecia. Wśród sponsorów współczesnej realizacji znalazł się nawet niesławny z powodu doktryny too big to fail bank inwestycyjny Goldman Sachs.

Przeprowadzona sprawnie inwestycja doprowadziła do utworzenia wzorcowej przestrzeni zielonej. W międzynarodowym konkursie na projekt zagospodarowa-

\footnotetext{
${ }^{27}$ J. David, Reclaiming the High Line..., s. 74-79.

${ }^{28}$ Ostatecznie ich gospodarzem był Londyn.

${ }^{29}$ L. Polyák, Pakiet praw i obowiązków, „Autoportret. Pismo o dobrej przestrzeni”, nr 3/2017,
} s. 10 . 
nia przyszłego parku wśród przegranych ofert znalazły się projekty takich sław, jak Zaha Hadid czy pracownia Skidmore, Owing and Merrill. Finalnie wyłoniono zwycięską propozycję konsorcjum biura Diller Scofidio + Renfro, architekta krajobrazu Jamesa Cornera i projektanta zieleni Pieta Oudolfa. Zakładała ona utworzenie parku imitującego bogactwo przyrodnicze, które stało się częścią obiektu w okresie jego nieużytkowania. Służyła w ten sposób jego „postindustrialnej malowniczości” (industrial picturesque), jak tego typu atrakcyjną urbanistycznie surowość określa Kevin Loughran. Nawiązuje on w tym kontekście do estetyki właściwej wysoko cenionym współcześnie mieszkaniom w loftach ${ }^{30}$. Jak podają Wiesława i Wojciech Gadomscy, „swingujący” kształt dawnej linii kolejowej pozwolił utworzyć ciąg pieszy o wysokiej atrakcyjności. Korzysta on ze zróżnicowania wnętrz krajobrazowych, wielości ciekawych widoków charakterystycznych dla dynamicznego środowiska zurbanizowanego Manhattanu czy różnorodnych otwarć widokowych.

High Line wyraźnie katalizuje zmiany w otaczającej przestrzeni sąsiedzkiej. Zjawisko rewitalizacji opuszczonych, poprzemysłowych obiektów osiągnęło nową skalę w obliczu realizacji projektu. Budynki bezpośrednio sąsiadujące z estakadą torowiska znacznie podniosły swoją atrakcyjność i wartość rynkową, szczególnie dotyczy to apartamentów z oknami wychodzącymi na park. Nieliczne, wolne działki graniczące z High Line zostały zabudowane pojawiła się nowa, ciekawa architektura czytelnie odnosząca się do postindustrialnego dziedzictwa ${ }^{31}$.

Jak stwierdza w innym opracowaniu ta sama autorka, przyjęta przez autorów zwycięskiego projektu strategia ,agritektury” w synergiczny sposób

łącz[y] element[y] antropogeniczn[e] ze światem przyrody. Rośliny w sposób bardzo naturalny przenikają się z elementami nawierzchni i trudno w sposób jednoznaczny określić, który z tych elementów jest w tym założeniu ważniejszy. Dodatkowo nie ma między nimi wyraźnej granicy - „grzebieniaste” elementy nawierzchni w sposób bardzo miękki łączą się z zieleniąㄹ.

Z kolei jeszcze niedawno „marginalizowany fragment poprzemysłowej dzielnicy staje się żywą, atrakcyjną przestrzenią miejską"33. High Line to z takiego punktu

${ }^{30}$ K. Loughran, Imbricated Spaces: The High Line, Urban Parks, and the Cultural Meaning of City and Nature, „Sociological Theory”, vol. 34, nr 4/2016, s. 311-320.

31 W. Gadomska, W. Gadomski, Park High Line - przestrzeń publiczna jako rezultat rewitalizacji postindustrialnego dziedzictwa zachodniego Manhattanu, „Przestrzeń i Forma”, nr 21/2014, s. 76, 78.

32 W. Gadomska, Humanizacja postindustrialnej przestrzeni miejskiej - przykład nowojorskiego parku High Line jako udanej rewitalizacji dawnej linii kolejowej, „Humanistyka i Przyrodoznawstwo”, nr 20/2014, s. 537.

33 Ibidem, s. 545. Podobny opis zob. H. Foster, The Art-Architecture Complex, Verso, LondonNew York 2013, ebook. 
widzenia spektakularny sukces, wysoko oceniany przez wielu krytyków architektu$\mathrm{ry}^{34} \mathrm{i}$ intensywnie przez nich nagradzany. Jak zauważa jednak Alexander J. Reichl, wyróżnienia tego typu dotyczą niemal wyłącznie fizycznych walorów środowiska zbudowanego. Wzbogaciły je w ostatnich latach również projekty takich starchitektów, jak wspomniana Hadid, Renzo Piano i Frank Gehry. Podobnej wagi przy nagradzaniu nie przywiązuje się jednak do wywoływanych przez inwestycję skutków społecznych ${ }^{35}$. Aktualnie park odwiedzany jest przez około 5 milionów osób rocznie, wśród których aż połowę stanowią przyjezdni. Świadczy to o turystycznej popularności miejsca niekoniecznie jednak wykorzystywanego przez miejscową ludnośćc ${ }^{36}$.

Idealizowany przez niektórych entuzjastów projekt zaczął z czasem budzić znaczne kontrowersje. Inicjatorzy jego powstania oficjalnie zapewniali o poparciu dla interesów lokalnej społeczności. W rzeczywistości jednak konieczność pozyskania ogromnego finansowania powodowała, że właściwą grupą docelową nie byli lokalni mieszkańcy, niedysponujący odpowiednim kapitałem, lecz inwestorzy z zewnątrz, zwłaszcza deweloperzy ${ }^{37}$. Dzięki temu część dawnych sojuszników FHL zaczęła odwracać się od uczestnictwa w tej organizacji oraz krytykować model funkcjonowania parku dopuszczający jedynie wybrane sposoby użytkowania. Niemożliwe jest tutaj na przykład palenie papierosów, jeżdżenie rowerem, grillowanie czy wyprowadzanie psów. Przykład transformacji High Line pokazał, że komercyjny model organizacji infrastruktury zielonej może na przykład ograniczać jej dostępność dla wyłącznie bogatszych mieszkańców sąsiedztw, a także inspirować ich postępującą „zieloną gentryfikację”. Pomimo że teoretycznie wyłączono część potencjalnych terenów inwestycyjnych znajdujących się pod wiaduktami, wywołało to raczej proces bazujący na tej właśnie spekulacji poprzez podniesienie wartości gruntów sąsiednich ${ }^{38}$. Od 2011 roku pracownicy FHL zaczęli prowadzić wysłuchania lokatorów z okolicy. Wykazały one, że trzymają się oni z dala od parku ze względu na brak poczucia, aby powstał on dla ich potrzeb, a także wrażenie, iż nie spotykają $w$ nim ludzi podobnych do siebie. Niechęć wzbudzał u nich również program wydarzeń organizowanych w parku ${ }^{39}$.

${ }^{34}$ N. Millington, From urban scar to 'park in the sky': terrain vague, urban design, and the remaking of New York City's High Line Park, „Environment and Planning A”, vol. 47, nr 11/2015, s. 2324.

35 A.J. Reichl, The High Line and the ideal of democratic public space, „Urban Geography”, vol. 37, nr 6/2016, s. 15-16.

${ }^{36} \mathrm{~J}$. Haffner, The dangers of eco-gentrification: what's the best way to make a city greener?, http:// bit.ly/2CGtA7V, dostęp: 25.03.2019.

37 O nowojorskich wpływach tak zwanego sektora FIRE, obejmującego przedsiębiorstwa finansowe, ubezpieczeniowe i działające na rynku nieruchomości zob. R. Fitch, The Assasination of New York, Verso, London-New York 1993, passim.

${ }^{38}$ S. Lang, J. Rothenberg, Neoliberal urbanism, public space, and the greening of the growth machine: New York City's High Line park, „Environment and Planning A”, nr 1-19/2016, s. 5, 11, 13-15.

${ }^{39}$ L. Bliss, The High Line's Next Balancing Act, http://bit.ly/2Wp4bHi, dostęp: 25.03.2019. 
W opinii Nate'a Millingtona towarzysząca tej inicjatywie retoryka zrównoważonego rozwoju wsparła raczej model agresywnej, neoliberalnej reurbanizacji ${ }^{40}$. Nie ma ona tymczasem wiele wspólnego z bardziej demokratycznym dawnym miejskim nieużytkiem ${ }^{41}$. High Line jest obecnie najdroższym w utrzymaniu parkiem w całym Nowym Jorku, ze zdecydowanie największym poziomem zatrudnienia. W 2010 roku pracowało tutaj aż 12,5 osoby w przeliczeniu na akr powierzchni, czyli zdecydowanie więcej w porównaniu do na przykład Hudson River Park $(0,03)$ czy Central Parku $(0,4)^{42}$. W opinii Leona Morenasa inwestycja ta stanowi przykład szerszej strategii działań prowadzonych przez administrację Bloomberga. Służyła ona jego zdaniem dofinansowaniu przede wszystkim tej części zielonej infrastruktury miejskiej, która jest bardziej modna dzięki unikaniu plebejskich aktywności, jak na przykład wspomniane już grillowanie, albo też zdyscyplinowana przez intensywne patrolowanie powierzchni liniowego parku przez licznych strażników. Ma to jakoby prowadzić do osiągnięcia „dźwigniowego” efektu takich inwestycjii3. Pierwsze odcinki High Line o łącznej powierzchni 1,2 hektara patrolowało nawet dwunastu strażników. Tymczasem blisko siedmiokrotnie większe parki w innych dzielnicach korzystały z dwa razy mniejszej liczebnie ochrony. Na dodatek, kontynuuje Morenas, prywatyzacja parków oznacza zachowanie całości zysków w bardziej opłacalnych jednostkach, bez możliwości ich dystrybucji. Zarządca High Line, Hammond, zarabiał w 2009 roku ponad 75 tysięcy dolarów. To więcej niż ówczesny komisarz wszystkich parków publicznych. Nie przeszkadzał temu fakt, iż ten ostatni odpowiadał za łącznie dziesięć tysięcy razy większy areał powierzchni zielonych ${ }^{44}$.

${ }^{40}$ N. Millington, op. cit., passim.

${ }^{41}$ B.J. Gawryszewska, M. Łepkowski, A. Wilczyńska, City wastelands: Creating places of vernacular democracy, [w:] C. Certomà, S. Noori, M. Martin Sondermann (red.), Urban Gardening and the Struggle for Social and Spatial Justice, Manchester University Press, Manchester 2019, s. 56.

42 D.J. Patrick, The matter of displacement: a queer urban ecology of New York City's High Line, „Social \& Cultural Geography”, vol. 15, nr 8/2014, s. 927-928.

43 Wartość zielonej infrastruktury trudno przeliczyć na pieniądze, aczkolwiek podejmowane są takie próby. Potencjalne korzyści związane mogą być z oddziaływaniem na takie czynniki, jak wzrost wartości nieruchomości, stymulacja rozwoju turystyki, poprawa wartości użytkowej, ograniczenie kosztów obsługi systemu opieki zdrowotnej, poprawa spójności społecznej, redukcja kosztów związanych z gospodarką wodą deszczową oraz usuwania zanieczyszczeń powietrza. Wyliczono na przykład zysk związany z użytkowaniem w 2006 roku parków w Bostonie jako miejsc generalnego wypoczynku, uprawiania sportu oraz przestrzeni wydarzeń publicznych. Oszacowano go na kwotę około 354 milionów dolarów. Zob. P. Wernik, B. Welle, Measuring the Economic Value of a City Park System, The Trust for Public Land, Washington-San Francisco 2009, s. $1-15$.

${ }^{44}$ L. Morenas, A Critique of the High Line: Landscape Urbanism and the Global South, [w:] A. Duany, E. Talen (red.), Landscape Urbanism and its Discontents. Dissimulating the Sustainable City, New Society Publishers, Gabriola Island 2013, s. 193-194. 
Jak zatem ocenić jakość tego typu środowiska zurbanizowanego? Na ile efektowną oraz użyteczną przestrzenią publiczną jest High Line Park oraz w jaki sposób wpływa on na przekształcenia swojego najbliższego otoczenia? Dla oceny tego studium przypadku „zielonego” aktywizmu przeprowadziłem analizę według metody WWP.

\subsection{Właściwości rynku nieruchomości}

W przypadku analizy wpływu rewitalizacji High Line Park na rynek okolicznych nieruchomości możliwe jest zastosowanie szerokiego zakresu danych ze względu na ich łatwą dostępność. W porównaniu do informacji analizowanych w Warszawie nowojorski odpowiednik rejestru cen i wartości nieruchomości przekazuje więcej informacji o dokonywanych transakcjach, a na dodatek dane te publikowane są bezpośrednio $\mathrm{w}$ internecie i dostępne nieodpłatnie. W celu badania rynku nieruchomości wykorzystałem zatem dane udostępniane przez Departament Finansów Miasta Nowy Jork (New York City Department of Finance), przedstawiający listę wszystkich transakcji dokonywanych od 2003 do 2016 roku$^{45}$. Wśród jawnych informacji znajdują się w przypadku tego rejestru te dotyczące między innymi wysokości ceny transakcyjnej, typu nieruchomości, a także jej położenia możliwego do zlokalizowania na podstawie na przykład okręgu podatkowego (tax block). Ta ostatnia informacja jest w tym kontekście szczególnie użyteczna. W przypadku ściśle ortogonalnej siatki ulicznej Manhattanu okręgi dotyczą przeważnie jednego lub kilku kwartałów zwartej zabudowy zlokalizowanych między najbliższymi ulicami. Numerację poszczególnych okręgów sprawdzić można na przykład za pomocą miejskiego albo komercyjnego GIS.

Jako pole podstawowe badania określiłem w tym kontekście wszystkie okręgi podatkowe znajdujące się w odległości nie dalszej niż dwie przecznice od High Line, co pozwoliło wytyczyć obszar bezpośredniego oddziaływania parku ${ }^{46}$. W rzeczywistości rejon ten jest prawdopodobnie większy, ale w ten sposób wyznaczony został fragment dzielnicy, z którym zakres powiązań ma najbardziej intensywny charakter. Odległość drogi od sklasyfikowanych w ten sposób punktów w stosunku do parku nie przekracza jednego kilometra, a w większości wypadków możliwe jest też dojście piesze w granicach 600-700 metrów. To tylko nieco więcej niż zakłada wyznaczana przez urbanistów akceptowalna granica dojścia pieszego. Przyjęcie takich granic wykorzystuje też łatwe do zidentyfikowania krawędzie przestrzenne.

45 Stan na 1 lipca 2017 roku; http://www1.nyc.gov/site/finance/taxes/property-annualized-sales-update.page, dostęp: 1.07.2017.

${ }^{46}$ Pole podstawowe objęło w związku z tym okręgi o numerach 626-629, 654, 668-679, 688705, 712-729, 731 i 738-757. 
Od strony zachodniej jest to wybrzeże rzeki Hudson będące granicą wodną Nowego Jorku i New Jersey. Od pozostałych stron krawędź stanowią większe ulice: Jane na południu, Ósma Aleja od wschodu oraz 34. Ulica od północy. Polem porównawczym dla pola podstawowego stał się cały obszar dzielnicy Manhattan.

Udostępniany przez nowojorską administrację publiczną rejestr nie przekazuje danych o metrażu prywatnych nieruchomości mieszkalnych, dlatego też wykorzystałem ceny transakcyjne bez uwzględnienia powierzchni lokali. Ze względu na reprezentatywność dla komercyjnego rynku mieszkalnego oraz liczbę możliwych do odnotowania transakcji, w celu wyznaczenia nieruchomości o podobnych właściwościach podstawą analizy zostały transakcje dotyczące apartamentów we wspólnotach mieszkaniowych ( $\operatorname{condos}^{47}$ ) w budynkach $\mathrm{z}$ windą. Ze względu na zupełnie niereprezentatywny charakter jako nieodzwierciedlające wartości rynkowej z analizy zostały wyłączone te transakcje, których wartość wynosiła poniżej 20 tysięcy dolarów. W badaniu rynku nieruchomości sprawdzane były ceny z lat 2003-2015. Jakkolwiek w ramach wyceny nieruchomości przy użyciu metody porównawczej analizuje się zwykle transakcje zawierane w okresie nie dłuższym niż dwa lata, celem analizy w niniejszej pracy było prześledzenie trendów z dłuższego okresu. Związane były one bowiem potencjalnie $\mathrm{z}$ inwestycją realizowaną etapowo, a wcześniej zapowiadaną z paroletnim wyprzedzeniem. O ile pierwsze działania aktywistów na rzecz rewitalizacji High Line podjęte zostały jeszcze w 1999 roku, to już w 2002 poparcie dla inicjatywy zaczęły otwarcie deklarować władze miasta. $Z$ tego też względu dolną granicę analizowanego okresu przyjąłem na podstawie kryterium dostępności danych, a nie momentu, w którym ujawnienie przyszłych planów inwestycyjnych zaczęło wpływać na kształtowanie się tendencji na rynku nieruchomości. Na podstawie zakreślonych wyżej wymogów czasowych, przestrzennych i jakościowych wyodrębniłem grupę 2219 transakcji dla pola podstawowego (okolicy High Line) oraz 84340 z pola kontrolnego (całej dzielnicy Manhattan) (tabela 10 i wykres 2).

W latach 2003-2015 ceny transakcyjne w okolicy High Line odnotowały znaczący wzrost (o 135 procent), ale zarazem mniejszy niż w przypadku całej dzielnicy (155 procent). W pobliżu parku ceny te rosły jednak systematycznie zwłaszcza od 2006 roku, czyli od rozpoczęcia robót budowlanych powiązanych z rewitalizacją. Zwiększały się następnie nieprzerwanie aż do wybuchu globalnego kryzysu, a nawet nieco dłużej, przekraczając w tym czasie ogólny poziom cen średnich na Manhattanie. W dłuższej perspektywie ukończenie tej inwestycji nie wydaje się

47 Tego typu forma własności jest najbardziej upowszechniona na analizowanym obszarze, a także bardzo popularna w całych USA. W lokalach tego typu mieszka średnio co piąty Amerykanin. Zob. W. Graham, Miasta wyśnione. Siedem wizji urbanistycznych, które kształtują nasz świat, tłum. A. Sak, Karakter, Kraków 2016, s. 205-206. 


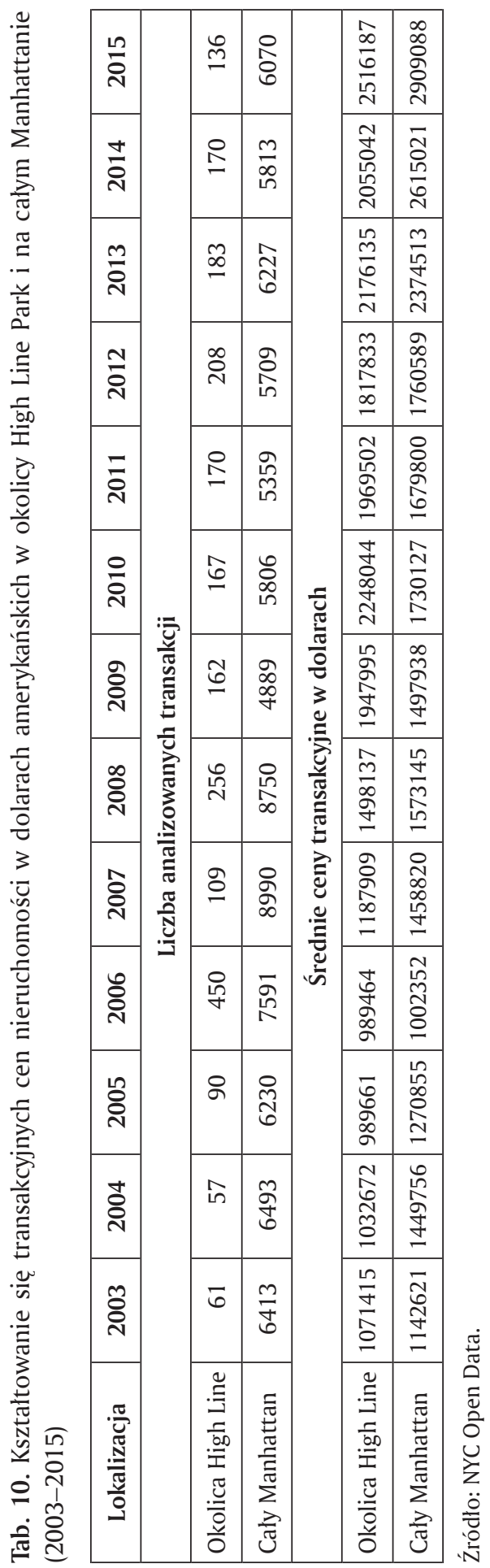




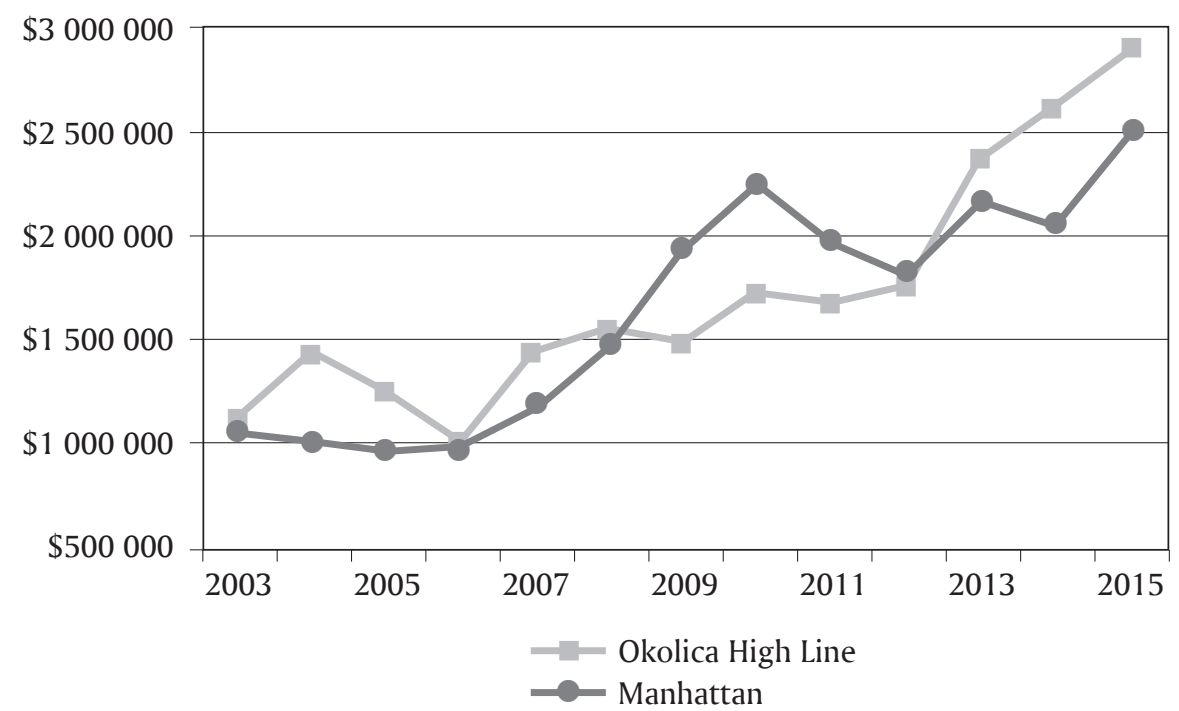

Wyk. 2. Trend cen transakcyjnych nieruchomości w okolicy High Line Park i na całym Manhattanie (2003-2015)

Źródło: NYC Open Data.

jednak ilustrować większego wpływu na wzrost wartości tutejszych nieruchomości aniżeli ogólne zjawiska gospodarcze odczuwalne w większej skali właściwej całej dzielnicy. Co jednak zwraca uwagę, rynek w okolicy High Line był nieco bardziej stabilny niż w przypadku całego pola kontrolnego, gdy wziąć pod uwagę wpływ globalnego kryzysu silnie oddziałującego na rynek nieruchomości w Nowym Jorku (wykres 3). Przyjmując rok 2008 jako bazowy ${ }^{48}$, zauważyć można, że liczba transakcji w okolicy High Line zmalała w mniejszym stopniu niż w przypadku całej dzielnicy. Na dodatek wyhamowanie wzrostu cen widoczne było w przypadku dzielnicy już w 2008 roku, a w okolicy High Line zbliżona tendencja ujawniła się dopiero trzy lata później (wykres 2).

Bezpośredni wpływ pojawienia się parku High Line na gentryfikację ekonomiczną jego okolicy miał prawdopodobnie charakter tymczasowy. O ile przeprowadzenie opisywanej inwestycji nastąpiło w okresie, kiedy tutejsze nieruchomości zyskiwały na wartości, na dłuższą metę wzrost ten następował równolegle do analogicznych zjawisk widocznych na znacznie większym obszarze całego pola kontrolnego.

${ }^{48}$ Rok później liczba takich transakcji na całym Manhattanie spadła łącznie o ponad 44 procent, a w okolicy High Line - o prawie 37 procent. 


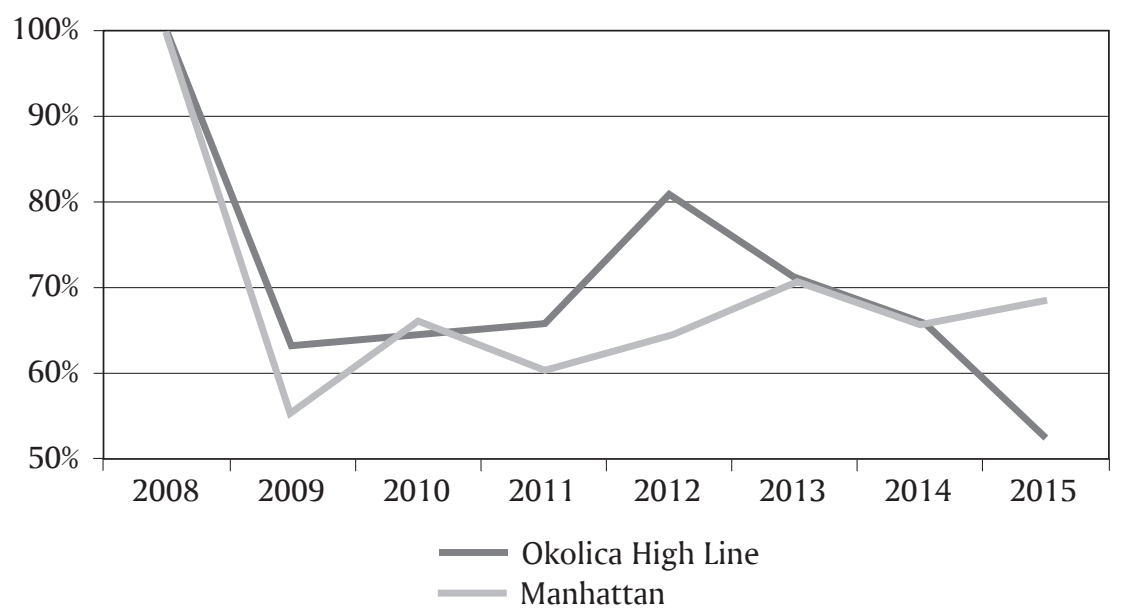

Wyk. 3. Liczba transakcji zawieranych na rynku nieruchomości w okolicy High Line Park i na Manhattanie po wybuchu globalnego kryzysu $(2008-2015,2008$ rok $=100)$

Źródło: NYC Open Data.

\subsection{Ocena funkcji z zakresu infrastruktury osadniczej}

Okolica High Line korzysta $\mathrm{z}$ wielu zalet właściwych obszarowi śródmiejskiemu wielkiego ośrodka metropolitarnego. Liniowy park jest miejscem dostępnym dla swojego otoczenia dzięki relatywnie dużej liczbie wejść lokowanych przy mniej i bardziej istotnych ulicach, jakie przecinają jego trasę. W pięciu miejscach dostać można się do niego za pomocą windy lub rampy dostępnej również dla osób z niepełnosprawnościami warunkującymi ograniczenia w zakresie mobilności. Cała powierzchnia nadziemnego parku umożliwia poruszanie się przy użyciu wózka inwalidzkiego, brakuje jednak w nim elementów wyposażenia dla osób niewidomych. Podobnie korzystnie park wypada pod względem możliwości skorzystania z transportu publicznego. W kilku miejscach przystanki autobusów oddalone są od jego wejść o raptem kilkadziesiąt metrów. Główne wejście od strony północnej znajduje się też bardzo blisko stacji metra 34. Ulica - Hudson Yards. Ta ostatnia na tle większości przestarzałej infrastruktury podziemnej kolejki zdecydowanie pozytywnie wyróżnia się pod względem dostępności dla użytkowników z dysfunkcjami narządu ruchu.

Wśród aktywności wykonywanych w parku przez jego użytkowników zaobserwować można wszystkie rodzaje zachowania z typologii Gehla. High Line wypełnia funkcję rekreacyjną i sprzyja różnego typu czynnościom opcjonalnym. Obok spacerowiczów i turystów spotkać można tutaj, szczególnie w godzinach porannych, 
wiele osób uprawiających różnego typu sporty, zwłaszcza bieganie. W tej wąskiej przestrzeni zaobserwować można ponadto wiele interakcji między zwiedzającymi. Dla ich potrzeb zaprojektowano na przykład kilka poszerzonych przestrzeni wspólnych, jak na przykład niewielki placyk i amfiteatr na wysokości skrzyżowania Dziesiątej Alei i 17. Ulicy. Także zarządca parku organizuje cały program wydarzeń kulturalnych. Obejmuje on nie tylko standardowe wydarzenia, takie jak oprowadzanie z przewodnikiem, ale również lekcje jogi i tai-chi, spektakle teatralne czy plenerowe wystawy wykorzystujące powierzchnię parkowego wiaduktu. W środkowej części działa do tego specjalna strefa, obejmująca między innymi punkty drobnej gastronomii. Wszystko to świadczy o wielofunkcyjnym, hybrydowym charakterze tego miejsca ${ }^{49}$. Oprócz tego liniowy charakter parku nadaje mu funkcję komunikacyjną związaną z czynnościami koniecznymi. Dwuipółkilometrowa trasa umożliwia przejście znacznej części zachodniego Manhattanu bez konieczności zatrzymywania się przez pieszego na światłach lub współdzielenia przestrzeni z samochodami.

Użytkowanie High Line ma jednak zarazem liczne ograniczenia. Regulamin parku wymusza je przeważnie ze względu na rozmaite uwarunkowania przestrzenne, które mogłyby zaostrzać konflikty między odmiennymi grupami użytkowników. Z tego punktu widzenia zrozumiały jest zakaz używania na tym wąskim ciągu pieszym rowerów, deskorolek i skuterów. Inne wymogi tłumaczyć można dbałością o staranne utrzymanie terenów zieleni. Reguły korzystania z High Line zakazują jednak wprost „napraszania się” innym ludziom (solicitation) oraz wymagają zdobywania wielorakich pozwoleń. Takimi regulacjami obarczone jest na przykład wykonywanie fotografii z użyciem statywu czy nawet organizowanie zgromadzeń liczących więcej niż 20 uczestników. Jest to zaskakujące ze względu na zaprojektowanie na trasie parku miejsc umożliwiających wspólne przebywanie nawet większych grup. High Line jest też całkowicie niedostępny dla osób spacerujących z psami. Wstęp możliwy jest wyłącznie dla tych asystujących. Użytkowanie parku ma zatem też momentami represyjne zabarwienie. Wynika to z liczby ograniczeń skrajnie formalizujących tę przestrzeń. Formalizacja ta jest w tym parku dalej posunięta niż w podobnych miejscach w tym mieście, zwłaszcza w porównaniu do tych w zarządzie publicznym.

Intensywne użytkowanie parku i masowa obecność turystów sprawiają, że częstotliwość użytkowania tej przestrzeni niekoniecznie dowodzi jej wysokiej witalności. Jest to przecież często odarte z cech jakiejkolwiek spontaniczności. High Line to przykład pieczołowicie zaprojektowanej przestrzeni użytku zbiorowego, ale liczba ograniczeń podaje w wątpliwość możliwość określenia tej przestrzeni

49 M. Gyurkovich, Komercja i kultura czyli dwa oblicza struktur hybrydowych we współczesnych metropoliach, [w:] idem (red.), Hybrid Urban Structures, Wydawnictwo Politechniki Krakowskiej, Kraków 2016, s. 27. 
jako publicznej. Podobnie jak wiele innych przestrzeni zielonych na Manhattanie, liniowy park pozostaje $\mathrm{z}$ tego względu daleki od w pełni demokratycznego i egalitarnego charakteru.

\subsection{Zaawansowanie gentryfikacji obszaru}

High Line stanowi reprezentatywny przykład zaawansowanej gentryfikacji przestrzeni zurbanizowanej. Uwagi o wpływie tego parku na „uszlachetnianie” przestrzeni w jego okolicy omawiane są już nie tylko przez badaczy z zakresu studiów miejskich, ale nawet i media głównego nurtu. W 2015 roku, gdy otwierano ostatni z odcinków liniowego parku, w felietonie opublikowanym na łamach „New York Timesa” pod wymownym tytułem „Disney World nad Hudson” Jeremiah Moss określił to miejsce jako obszar dalekiego zaawansowania tego procesu. „High Line stał się [wówczas dla niego] zatkanym przez turystów katalizatorem jednego z najbardziej gwałtownych procesów gentryfikacji w historii tego miasta"50.

Rejon parku pod wieloma względami stanowi przykład modelowej przestrzeni sprzyjającej gentryfikacyjnym przemianom. Nieczynny wiadukt to zobrazowanie przestrzeni zdegradowanej w sensie dosłownym, porzuconej i niszczejącej infrastruktury transportowej. W dodatku w okolicy pojawili się już kilka dekad temu typowi gentryfierzy marginalni. Wśród pionierów „uszlachetniania” obecnych od dłuższego czasu w przecinanym przez High Line sąsiedztwie Chelsea wskazać można artystów i pracowników instytucji kultury. Po szeroko zakrojonej deindustrializacji okolica ta zaczęła być kojarzona na przykład z masowo otwierającymi się w tym miejscu galeriami sztuki. Przenosiły się one tutaj przeważnie z sąsiedztwa SoHo położonego w zachodniej części Manhattanu. Harvey Molotch i Mark Treskon zobrazowali nawet tę funkcjonalną zmianę z wykorzystaniem danych ilościowych. W latach 1990-2007 w Chelsea łączna liczba działających galerii sztuki powiększyła się o 287. W analogicznym okresie w SoHo zmniejszyła się zaś aż o $171^{51}$ (tabela 11 ).

Obok artystów wskazać można na inne tradycyjne grupy gentryfierskie. Na przykład społeczność osób nieheteronormatywnych, spotykanych zresztą i wśród respondentów z badań terenowych. Jej reprezentantami byli nawet sami inicjatorzy

50 J. Moss, Disney World on the Hudson, „New York Times”, 22 sierpnia 2017, s. A25. Moss jest też autorem książki pod wymownym tytułem „Przemijający Nowy Jork. Jak wielkie miasto utraciło swoją duszę”. Zob. J. Moss, Vanishing New York: How a Great City Lost Its Soul, Dey Street Books, New York 2017.

${ }^{51}$ H. Molotch, M. Treskon, Changing Art: SoHo, Chelsea and the Dynamic Geography of Galleries in New York City, „International Journal of Urban and Regional Research”, vol. 33.2, nr 6/2009, s. 519-524. 
Tab. 11. Liczba galerii w sąsiedztwach Chelsea i SoHo w Nowym Jorku (1990-2007)

\begin{tabular}{|l|c|c|c|c|c|}
\hline \multicolumn{1}{|c|}{ Sąsiedztwo } & 1990 & 1995 & 2000 & 2005 & 2007 \\
\hline Chelsea & 16 & 12 & 144 & 257 & 303 \\
\hline SoHo & 275 & 286 & 192 & 133 & 104 \\
\hline
\end{tabular}

Źródło: H. Molotch, M. Treskon, Changing Art: SoHo, Chelsea and the Dynamic Geography of Galleries in New York City, „International Journal of Urban and Regional Research”, vol. 33.2, nr 6/2009, s. 524.

regeneracji parku. Pełniący do dzisiaj funkcję kierowniczą w organizacji zarządzającej tym miejscem Robert Hammond świadomie powołuje się zresztą na ten fakt ${ }^{52}$. Historia powstania organizacji jednoczącej aktywistów działających na rzecz rewitalizacji High Line zdominowana jest właśnie przez przedstawicieli mniejszości seksualnych i reprezentantów świata sztuki. To właściciele galerii byli od początku zagorzałymi sojusznikami i donatorami FHL. Szczególnie aktywna na tym polu była zwłaszcza projektantka mody, Diane von Furstenberg. Posiada ona własną galerię w odległości raptem 40 metrów od jednego z wejść do południowej części parku.

Owocem podniesienia się prestiżu sąsiedztwa, w którym funkcjonuje High Line, było też wybudowanie nowej siedziby muzeum amerykańskiej sztuki współczesnej. Prestiżowe Whitney Museum of American Art działa w bezpośrednim sąsiedztwie głównego wejścia do parku od południowej strony. Chociaż obecna wystawa stała przywołanej placówki prezentuje program kuratorski bez wątpienia radykalny, wyraziście lewicowy i skoncentrowany również na dorobku mniej uprzywilejowanych warstw społeczeństwa, bilet jednorazowego wstępu kosztuje 25 dolarów. Jest to tyle samo, ile na przykład w nowojorskim oddziale sieci Guggenheima, będącej symbolem komercjalizacji i globalizacji w świecie sztuki. W budynku muzeum działalność prowadzi też bardzo droga restauracja. Whitney Museum stanowi w tym kontekście jeden $\mathrm{z}$ widocznych gołym okiem elementów procesu przemiany lokalnej szaty usługowej. W całym Meatpacking District obok galerii przybyło zwłaszcza rozmaitych restauracji i kawiarni odpowiadających potrzebom niemal wyłącznie zamożnej grupy klientów. Zapewne tylko to ratuje rentowność ostatnich $\mathrm{z}$ działających $\mathrm{w}$ tym miejscu przedsiębiorstw związanych z przetwórstwem mięsnym. Nawet jednak w tych miejscach, gdzie są one jeszcze obecne, sąsiadują już przez ulicę z modnymi lokalami gastronomicznymi. Zjawisko to zaobserwować można wyraźnie na przykład na zachodnim skraju 12. Ulicy (rycina 9). Po stronie północnej (na zdjęciu po lewej) widoczne są już kawiarnie, a na południowej - ostatnie magazyny.

${ }^{52}$ D.J. Patrick, op. cit., s. 929. 


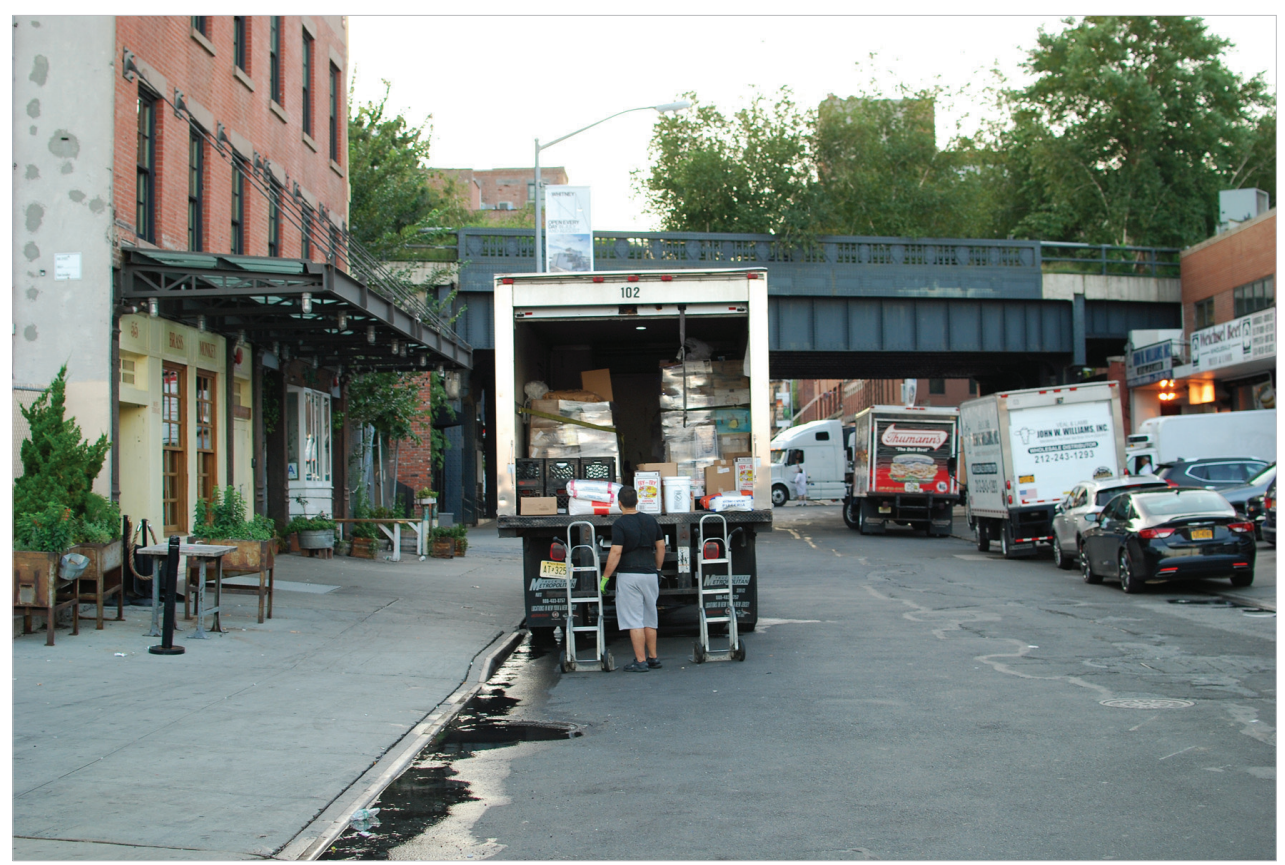

Ryc. 9. Zachodnia część 12. Ulicy na Manhattanie (2017)

Fot. Łukasz Drozda.

Nie tylko okoliczności powstania, ale również dalsze etapy funkcjonowania liniowego parku okazały się charakterystyczne dla typowego przebiegu gentryfikacji przestrzeni zurbanizowanej. Jak pokazują obserwacje funkcjonującego już parku, stał się on miejscem zdominowanym przez inną grupę użytkowników niż większość nowojorskich urządzeń infrastruktury zielonej. Potwierdzają to moje badania terenowe: wśród użytkowników parku przeważały osoby przyjezdne (19 z 31 przypadków). Grono to zresztą mogłoby się dodatkowo powiększyć o mieszkających w mieście czasowo studentów i imigrantów zarobkowych. Nadreprezentowani są także przedstawiciele zawodów umysłowych. Wśród 31 respondentów znaleźli się tylko jeden bezrobotny (B14) i czworo ludzi wykonujących zawody fizyczne. W dwóch przypadkach były to jednak osoby na tyle zamożne, że stać je było na międzykontynentalną wyprawę turystyczną do Nowego Jorku z Japonii i Wielkiej Brytanii (B5, B20). W trzecim była to tancerka i instruktorka fitness (B12), której profesja też nie jest charakterystyczna dla klasy robotniczej. Z kolei w czwartym - latynoska opiekunka (B11). We własnym państwie zdobyła ona znacznie wyższe wykształcenie nauczycielki, co w grupie zawodów fizycznych lokuje ją jedynie ze względu na imigrację ekonomiczną. O zaawansowaniu gentryfikacji świadczy też fakt, że znacznie częściej od takich osób spotykani są w parku 
nie tylko pracownicy instytucji kultury i kupcy dzieł artystycznych, ale również osoby zatrudnione w sektorze finansowym.

Obserwacje autorskie potwierdziły też inną konstatację pochodzącą z zastanych źródeł ilościowych (tabela 12). Jest nią związana z High Line nieformalna segregacja rasowa. Struktura użytkowników tego parku jest wyraźnie zdominowana przez białą część ludności w znacznie większym stopniu od innych miejsc tego typu na Manhattanie. W wieloetnicznym Nowym Jorku, podobnie jak i w reszcie Stanów Zjednoczonych, podziały ekonomiczne zbiegają się z podziałami rasowymi. Biała część populacji jest zatem najlepiej sytuowana, a za najuboższą uważa się Afroamerykanów ${ }^{53}$. Charakteru High Line jako parku zdominowanego przez uprzywilejowane warstwy dowodzi fakt, iż aż 83 procent zwiedzających go stanowią osoby białe (nie wliczając nawet Latynosów). Jednocześnie raptem 6,9 procent to Afroamerykanie i Latynosi. Odsetki te inaczej lokują się tymczasem nie tylko w innych nowojorskich parkach, ale i wśród mieszkańców sąsiedztwa. Biali stanowią tylko 64,4 procent tutejszej populacji, a czarni i Latynosi - łącznie 22,3 procent. Innymi słowy, mniejszości te korzystają z parku cztery razy rzadziej niż zamieszkują jego otoczenie, a biali są w nim dodatkowo nadreprezentowani. Kontrast ten jest jeszcze bardziej wymowny przy porównaniu z wartościami średnimi dla Manhattanu i Nowego Jorku jako całości. Konstatacje te potwierdziły także wyniki badań terenowych. Wśród 31 respondentów znalazła się tylko jedna Afroamerykanka. Tak marginalnej reprezentacji tej grupy rasowej nie sposób tłumaczyć ani wysokim odsetkiem odmów jej przedstawicieli, ani też jakimkolwiek celowym pomijaniem tych rozmówców. Po prostu są w tym miejscu niezwykle rzadko obecni.

Paradoksalnie, jak pokazało badanie cen nieruchomości, mniej oczywiste jest natomiast natężenie gentryfikacji typu ekonomicznego. Pomimo że analiza cen nie dostarczyła jednoznacznych dowodów, do bardziej kategorycznych wniosków prowadzi badanie terenowe. $\mathrm{O}$ ile od południa High Line zamyka siedziba muzeum sztuki współczesnej i zagłębie modnych kawiarni, o tyle od strony północnej na obszarze Hudson Yards powstał ogromny kompleks biurowy. Jest on też powiązany $\mathrm{z}$ tak ważnymi publicznymi inwestycjami infrastrukturalnymi, jak wybudowanie nowej stacji metra, która wyróżnia się na tle ogółu niedofinansowanej infrastruktury transportowej w Nowym Jorku. W okolicy High Line powstaje ponadto znaczna liczba innych biur i apartamentów. Inwestycje te związane są z jednymi z najdroższych segmentów rynku nieruchomości, a liczba prowadzonych w okolicy parku budów przewyższa średnią dla całej dzielnicy. Warto przy tym pamiętać, że i tak słynie ona z wielkiej aktywności przedsiębiorców budowlanych i wysokiej intensywności

53 Ł. Drozda, Uszlachetniając przestrzeń. Jak działa gentryfikacja i jak się ją mierzy, Instytut Wydawniczy Książka i Prasa, Warszawa 2017, s. 116-117. 
Tab. 12. Struktura rasowa zwiedzających parki i mieszkańców ich otoczenia w procentach (2010-2014)

\begin{tabular}{|l|c|c|c|c|}
\hline \multicolumn{1}{|c|}{$\begin{array}{c}\text { Nazwa parku* } \\
\text { okolicy*** }\end{array}$} & Biali & Czarni & Azjaci & Latynosi \\
\hline Nowy Jork (ogółem) & 33,3 & 22,8 & 12,6 & 28,6 \\
\hline Manhattan (ogółem) & 48,0 & 12,9 & 11,2 & 25,4 \\
\hline High Line & 83,0 & 4,0 & 10,0 & 2,9 \\
\hline Okolica & 64,4 & 6,0 & 10,4 & 16,3 \\
\hline Tompkins Square & 61,4 & 10,4 & 9,9 & 18,3 \\
\hline Okolica & 54,4 & 6,6 & 14,1 & 22,0 \\
\hline Union Square & 56,2 & 14,5 & 14,1 & 15,2 \\
\hline Okolica & 75,3 & 2,9 & 12,4 & 7,0 \\
\hline Washington Square & 70,5 & 7,6 & 16,4 & 5,5 \\
\hline Okolica & 80,3 & 2,1 & 7,9 & 6,8 \\
\hline Central & 59,8 & 15,8 & 11,3 & 13,2 \\
\hline Okolica**** & $10,0 / 88,1 / 72,3$ & $62,6 / 1,0 / 5,6$ & $2,5 / 4,7 / 7,8$ & $22,1 / 4,5 / 11,9$ \\
\hline
\end{tabular}

* Stan na 2014 rok. *** Stan na 2010 rok. ***** W przypadku Central analizowane są trzy różne sąsiedztwa o odmiennej charakterystyce rasowej, kolejno: Harlem, Upper East Side i Upper West Side. Źródło: A.J. Reichl, The High Line and the ideal of democratic public space, „Urban Geography”, vol. 37, nr 6/2016, s. $8-11$.

urbanizacji. Z drugiej strony, jeszcze przed otwarciem ostatniej części High Line inicjatorzy jego powstania zwracali uwagę na ożywienie inwestycyjne w najbliższym sąsiedztwie parku. Pojawiały się tutaj luksusowe budynki, takie jak apartamentowce czy filie cenionych muzeów sztuki. Na ogół projektowali je najbardziej popularni i prestiżowi architekci na świecie. Nierzadko byli to laureaci Nagrody Pritzkera, skoro w gronie tym są Frank Gehry, Jean Nouvel, Renzo Piano, Robert A.M. Stern i biuro Polshek Partnership ${ }^{54}$. Przegrana w konkursie architektonicznym na koncepcję High Line pracownia Zahy Hadid realizuje kolejny projekt w bezpośrednim sąsiedztwie centralnej części wiaduktu zawierającego ten liniowy park.

Jakkolwiek High Line nie zainicjował tego zmasowanego ruchu inwestycyjnego, szybko stał się narzędziem wspierającym realizację interesów wielkich deweloperów budowlanych. Spacer po wiadukcie umożliwia oglądanie wielu reklam zamieszczanych w taki sposób, aby były dobrze widoczne właśnie dla osób

54 J. David, R. Hammond, op. cit., s. 222. 
zwiedzających park. Wyrażenie „High Line” trafiło do nazw wielu prowadzonych w okolicy inwestycji. Jak pokazują ich anonse, promuje się przede wszystkim w tych przypadkach walory związane z prestiżem właściwym atrakcyjnej lokalizacji czy brakiem uciążliwości komunalnych lokatorów ${ }^{55}$. Dostęp do jednego z biur sprzedaży takich nieruchomości położonego na wysokości 16 . Ulicy możliwy jest nawet bezpośrednio z poziomu konstrukcji, na której umieszczony jest park (rycina 10). Gentryfikacja ekonomiczna w otoczeniu High Line jest bardzo zaawansowana, nawet jeśli nie wydaje się to oczywiste na podstawie analizy cen transakcyjnych na rynku nieruchomości. Co więcej, skala inwestycji wielkiego kapitału w tym otoczeniu nasuwa skojarzenia z etapem najdalej posuniętego „uszlachetniania”, czyli supergentryfikacją.

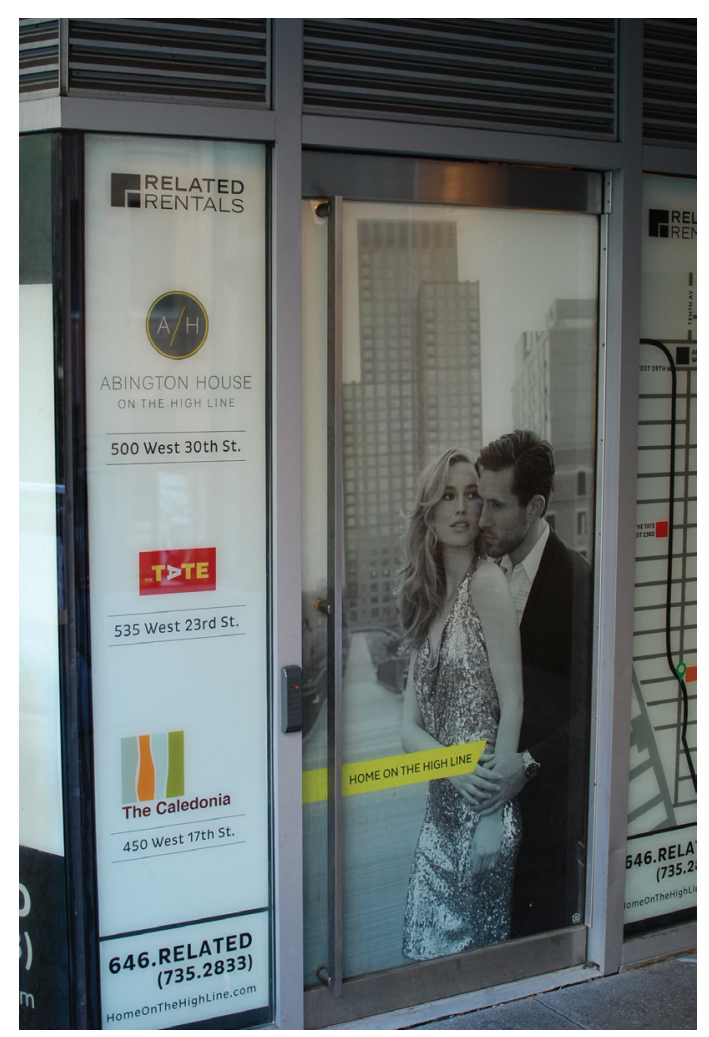

Ryc. 10. Biuro sprzedaży nieruchomości dostępne bezpośrednio z poziomu parku High Line (2017)

Fot. Łukasz Drozda.

55 Instrumentem polityki mieszkaniowej w Nowym Jorku jest między innymi wymóg oddawania części mieszkań w zabudowie typu wielorodzinnego na użytek mieszkalnictwa o regulowanych czynszach (affordable). 
Wyraźne jest za to znaczne zaawansowanie gentryfikacji w wymiarze przestrzennym. O jej postępach świadczą jednocześnie ożywiony ruch inwestycyjny i charakter oddawanych do użytku nieruchomości, jak i sama interwencja urbanistyczna związana z rewaloryzacją niegdysiejszej nadziemnej linii kolejowej. Estetyzacja tej przestrzeni zurbanizowanej ma charakter kompleksowy i całościowy. Zmienia się wizerunek całego sąsiedztwa, a nie tylko jego wybranych części. Nie jest też możliwe w tej chwili dostrzeżenie większych, zamkniętych enklaw będących potencjalnymi gettami bogactwa w sąsiedztwie High Line. Marginalny etap gentryfikacji zawansowanej kojarzyć należy wobec tego ze znacznie wcześniejszymi realizacjami niż rewitalizacja pokolejowej infrastruktury.

Okolica tego nowojorskiego parku znajduje się zatem na etapie bardzo zaawansowanego stadium „uszlachetniania” przestrzeni. Jest to przykład gentryfikacji rozwiniętej w jej wszystkich trzech wymiarach: społecznym, ekonomicznym i przestrzennym. Zwłaszcza w kontekście drugiego z nich transformacja ta nabiera własności tak zwanej supergentryfikacji.

\subsection{Wartości estetyczne przestrzeni}

Oceny estetyki przestrzeni High Line dokonałem w porównaniu do dwóch innych przestrzeni zielonych, czyli parków Bryant i Tompkins Square (aneksy 4.3, 4.4 i 4.5). Wszystkie trzy położone są w dolnej części Manhattanu, aczkolwiek w jego fragmentach o nieco odmiennej charakterystyce. Pole podstawowe badania (High Line) przecina zachodni obszar dzielnicy, na który składają się głównie stosunkowo zamożne sąsiedztwa. Nie mają one przy tym charakteru centralnego, chociaż należy zaliczyć je do ścisłego obszaru śródmiejskiego. Bryant znajduje się z kolei w jednym z centrów funkcjonalnych miasta w bardzo bliskiej odległości od placu Times, jednego z najbardziej uczęszczanych w Nowym Jorku. Tompkins to natomiast mniej zadbany park we wschodniej i mniej zamożnej części Manhattanu. Dwie pierwsze przestrzenie znajdują się w zarządzie prywatnym organizowanym przez powołane do tego celu organizacje non-profit. Prowadzą one rozwiniętą działalność komercyjną na rzecz utrzymania tych parków. Tompkins jest za to mniej od nich doinwestowanym i rzadziej uczęszczanym parkiem w zarządzie publicznym.

Ze względu na odmienną wielkość ocenianych parków w celu przedstawienia ich reprezentatywnego obszaru zestawiłem ze sobą nieco większą liczbę fotografii High Line (25) niż dla dwóch pozostałych miejsc (po 20). Trzy zdjęcia ukazują detale urbanistyczne takie jak meble miejskie, bliskie kadry zieleni urządzonej czy fotografie tablic informacyjnych. Również trzy poświęcone zostały przedstawieniu użytkowników każdego z ocenianych miejsc. 14 do 19 pozostałych zdjęć stanowi natomiast ujęcia reprezentatywne dla szerszego kontekstu przestrzennego. 
Fotografie przedstawiłem później respondentom jako przemieszane z kadrami reprezentatywnymi dla pozostałych badanych przestrzeni zurbanizowanych z Warszawy i Stambułu.

Analiza fotografii będących przedmiotem badania wskazuje, że najwyżej ocenianym przez studentów gospodarki przestrzennej miejscem jest w tym zestawie park Bryant (3,58 pkt). Bardzo zbliżony charakter mają natomiast uśrednione oceny High Line (3,28 pkt) i Tompkins Square (3,23 pkt). We wszystkich trzech przypadkach najniżej waloryzowane przez odbiorców były zdjęcia tablic informacyjnych, niezależnie zresztą od techniki ich wykonania. Podobnie negatywny odbiór dotyczył zarówno kolorowych informatorów wykonanych z plastiku, jak i bardziej efektownych elementów z kortenu. Ten ostatni uznawany jest obecnie za jeden z najbardziej modnych materiałów architektonicznych. Najpozytywniejsze noty uzyskały zdjęcia przedstawiające niektóre fragmenty zieleni urządzonej oraz tradycyjne elementy małej architektury, takie jak klasycystyczna fontanna w parku Bryant czy podobna altanka w Tompkins Square. W przypadku High Line żaden z elementów nie uzyskał za to zbliżonej do nich oceny. Zdjęcie ocenione najlepiej odnosi się do kadru, za którego główny temat uznać należy szersze ujęcie krajobrazowe - panoramę z widokiem na rzekę Hudson. Jest ona tymczasem elementem zewnętrznym w stosunku do samego parku.

Powyższe obserwacje prowadzą do zaskakującej konstatacji. High Line wydaje się stanowić większą atrakcję w porównaniu do zastosowanych w badaniu pól kontrolnych, jest wszak celem masowej, silnie umiędzynarodowionej turystyki, a także przestrzenią przygotowaną podług najnowszych trendów projektowania urbanistycznego. Piękno tutejszej scenerii nie wydaje się jednak oceniane wyżej niż w odniesieniu do dwóch z rzadziej uczęszczanych i bardziej tradycjonalistycznych przestrzeni zielonych określających pole kontrolne.

\subsection{Sposoby mapowania poznawczego}

Analiza szkiców wykonanych przez respondentów (aneks 3.2) pokazuje, że High Line jest przestrzenią bardzo czytelną dla użytkowników. Chociaż zaledwie pięcioro $\mathrm{z}$ nich wykonało dokładniejsze odwzorowania typu planimetrycznego dla całego parku (B1, B4, B7, B27, B30), w sposób bliski rzeczywistości „mapowało” go jeszcze więcej osób. Niekiedy wprost deklarowały one, że ograniczają zakres przestrzenny ilustracji głównie ze względu na rozległość liniowego parku (prawie dwa i pół kilometra) wobec niewielkiego rozmiaru oferowanej im kartki papieru. Nawet osoby przebywające w High Line po raz pierwszy potrafiły precyzyjnie oddawać jego kształt (B4, B15, B27, B30), wiążąc go niekiedy z otoczeniem w postaci regularnej siatki ulicznej Manhattanu (B6). Zgodnie z generalną prawidłowością 
wykonywania map poznawczych, wyraźnie bardziej kartograficzny charakter miały opracowania wykonywane przez mężczyzn. W 8 na 11 przypadków opracowywali oni albo „czyste” mapy, albo też łączyli techniki zobrazowań perspektywicznych z tymi właściwymi mapom. Uwagę zwraca jednak liczba rysunków autorstwa kobiet, spośród których blisko połowa (7 z 17) szkiców zawierała wiele kluczowych elementów dla map. Zrozumiałość struktury przestrzennej poświadcza też, że zaledwie cztery rysunki opracowali mieszkańcy najbliższego sąsiedztwa (B1, B2, B3, $\mathrm{B} 14)$. Tylko jeden respondent $\mathrm{z}$ tego grona (B1) zdecydował się na opracowanie rzeczywistej mapy. Tym samym to nie nadreprezentacja lokalnej ludności decydowała prawdopodobnie o wrażeniu dużej czytelności przestrzeni dla jej użytkowników.

Aż 17 z 28 szkiców wykonały natomiast osoby mieszkające poza Nowym Jorkiem, na dodatek przeważnie za granicą. Najczęściej reprezentowaną grupą wśród respondentów były osoby przebywające w High Line po raz pierwszy (13 z 31), rzadziej natomiast - bywalcy regularni, obecni w tym miejscu częściej niż raz w tygodniu ( 9 z 31). Potwierdza to obserwacje innych badaczy, wskazujących na dominację wśród użytkowników parku osób z zewnątrz. High Line jest zatem rzeczywiście dużą atrakcją turystyczną. Sprzyja to opisywaniu go w wielu źródłach, a historyczny kontekst miejsca nakreślają też dostępne w parku tablice informacyjne. Wskutek tego nawet w tak luźno związanej z miejscem grupie użytkowników przeszło dwie trzecie ( 21 z 31) wykazuje przynajmniej pobieżną znajomość historii tego miejsca.

High Line jest miejscem lubianym przez swoich użytkowników. Sympatię lub otwarte uwielbienie dla parku zadeklarowali wszyscy wywiadowani. Ten pozytywny stosunek łączy, co istotne, nie tylko najbardziej zamożnych użytkowników parku. Wśród jego entuzjastów wskazać można różne typy zawodów umysłowych, długoletnich aktywistów, jak na przykład fotograf poświęcający parkowi istotną część swojego życia zawodowego (B1), i zwykłych turystów. Możliwość zwiedzania jednego z najdroższych miast na świecie świadczy zresztą wymownie o ich dobrej sytuacji materialnej. Pracownicy fizyczni (B5, B12, B19) czy jedyny ankietowany bezrobotny (B14) nie wskazali na swoich mapach żadnych cech negatywnych. Symptomatyczna była wypowiedź zwłaszcza tego ostatniego. Ów modelowy gentryfier pierwotny, zamieszkujący tę okolicę na wiele lat przed jej rewitalizacją, osoba homoseksualna, krytycznie odnosił się do ludzi nierespektujących sztywnych reguł obowiązujących na terenie parku. Proces gentryfikacji, którego sam do pewnego stopnia czuł się ofiarą, traktował zarazem jako konieczność. Jak skomentował,

wszyscy mówią, że Manhattan traci swoją kulturę. Ale to jest XXI wiek! Jest czysto, jest miło, jest tak jak powinno być. Wszystko się zmienia, możesz tego nie przyjmować albo to zaakceptować. Ja to akceptuję. 
Negatywne elementy otoczenia na szkicach wskazywał niespełna co trzeci z respondentów (9 na 28). Zdecydowanie bardziej krytyczni okazywali się przy tym mężczyźni (7 z 11), osoby uczące się ( 3 z 3) i młodsze ( 4 z 6) oraz w niewielkim stopniu reprezentanci zawodów umysłowych $(6$ z 21). Negatywne elementy rozpoznały natomiast tylko dwie z 17 kobiet. Znaczna część wad wynikała przy tym z czynników innych niż te właściwe parkowi. Wskazywano w tym charakterze na przykład hałas związany z sąsiednimi budowami. Jak opisywał to mieszkający w innej części miasta finansista (B23), „tutaj masz wiele miejsc w budowie, jak to w Nowym Jorku. Cały czas się buduje, ciągle odbudowuje... Zawsze hałas, kurz, ciągłe prace budowlane". Inną z dostrzeganych wad jest z kolei irytująco wysoka zdaniem niektórych liczba odwiedzających park turystów. W opinii nowojorczyka $\mathrm{z}$ innej dzielnicy (B21)

jest tu bardzo tłoczno. To bardzo wąskie miejsce, z masą ludzi, którzy tędy przechodzą. Lubię w tym miejscu to, że możesz zaznać spokoju, przeczytać książkę i posłuchać muzyki, ale czasem ktoś w kółko chodzi i wtedy jest trochę zbyt gorączkowa atmosfera.

Szczególną uwagę na ten element zwracali wszyscy użytkownicy bliżej związani z parkiem, mieszkańcy zarówno jego bezpośredniego otoczenia, jak i pozostałych części miasta. W stosunku do obfitującego w negatywne czynniki otoczenia High Line zdaje się oazą. Jak zauważyła jedna z mieszkanek innej części Manhattanu (B11),

wszystko [w tym parku] jest pozytywne, ale zarazem wszystko wokół się buduje... I hałas. Czasem jak idziesz chodnikiem, to nie jest bezpiecznie ze względu na te wszystkie budowy, ale kiedy jesteś tutaj na górze, to już jest OK.

W porównaniu do uwag krytycznych poświęconych zewnętrzu parku, zaledwie dwoje respondentów wskazało na negatywne elementy samego High Line. Zwrócili oni uwagę na brak toalet (B23) i ograniczenia w użytkowaniu związane z zamykaniem parku w godzinach nocnych (B4). Ich odosobnione opinie, na dodatek odwiedzających park po raz pierwszy zachodnioeuropejskich turystów, nie są jednak reprezentatywne dla ogółu użytkowników. Jednoznaczną sympatię wobec miejsca deklarują również wszyscy respondenci zamieszkujący jego najbliższą okolicę. W grupie tej znalazł się nawet jedyny okoliczny mieszkaniec deklarujący brak znajomości lokalnej historii (B13).

\subsection{Poziom i poczucie bezpieczeństwa}

Waloryzacja przestrzeni wytwarzanej społecznie w odniesieniu do High Line, podobnie jak i w poprzednio omawianym studium przypadku, korzystać może pod 
względem oceny poziomu bezpieczeństwa z danych zarówno urzędowych o charakterze ilościowym, jak i jakościowych źródeł opartych na badaniach terenowych. W przypadku pierwszej grupy analiz, tak samo jak w przypadku badania rynku nieruchomości, źródła informacji do desk research są jednak w Nowym Jorku bardziej rozbudowane niż te dostępne dla Warszawy. W internecie zamieszczana jest na przykład kompletna lista wszystkich interwencji tutejszej policji z wielu ostatnich lat, począwszy od 2006 roku $^{56}$. Dostępne publicznie i nieodpłatnie dane obejmują wiele szczegółowych elementów, włącznie z określeniem typu przestępstwa, charakteru interwencji czy nawet danych geolokalizacyjnych ${ }^{57}$. W konsekwencji możliwe jest zarówno wyróżnianie przestępstw pod kątem miejsc interwencji wskazywanych w zestawieniu tabelarycznym, jak i tworzenie złożonych zobrazowań graficznych poziomu przestępczości dla różnych części miasta.

Na użytek niniejszej pracy wykorzystałem obie te techniki analizy. Dla określenia poziomu przestępczości w okolicy High Line wyznaczyłem pole podstawowe badania - park i jego najbliższą okolicę - oraz kilka pól kontrolnych. Pod tym kątem wyróżnić udało się inne przestrzenie zielone znajdujące się na południowym i środkowym Manhattanie. Są to znajdujący się w zarządzie prywatnym Bryant oraz administrowane w pełni publicznie Washington Square i Tompkins Square. Z tak zakreślonej analizy porównawczej zniknął najbardziej popularny i największy z parków w Nowym Jorku - Central. Jest on nieporównanie większy obszarowo, a przy okazji trudniejszy w nadzorze. Ma też zupełnie inną strukturę przestrzenną, która siłą rzeczy wymaga odmiennych technik ochrony. Na dodatek Central przecina różne typy sąsiedztw wykazujące się różnym poziomem zamożności. Wszystko to mnoży w jego przypadku wpływ zróżnicowanych czynników zewnętrznych mogących wpływać na poziom bezpieczeństwa w obrębie tego parku.

W pierwszej kolejności zbadałem zatem interwencje policyjne odnoszące się do poszczególnych parków, określonych w zestawieniu tabelarycznym jako dokładne miejsce tych interwencji. Dodatkowo wykonałem bardziej złożoną analizę przestrzenną, w ramach której wytyczyłem obszar szerszego otoczenia, funkcjonalnie powiązanego z tymi parkami. Na podstawie GIS określiłem dokładną ekwidystansę wyznaczającą krańce takich pól powierzchni w odniesieniu do każdego z parków, będącą promieniem 400 metrów. Odległość tę zdefiniowała granica akceptowalnego dojścia pieszego (500 metrów). Jakkolwiek zatem granicę tę kreśli się przeważnie nieco szerzej, poprawka skracająca ów dystans wynika w tym

56 NYPD Complaint Data Historic, https://data.cityofnewyork.us/Public-Safety/NYPD-Complaint-Data-Historic/qgea-i56i/data\# column-menu, dostęp: 1.09.2017.

${ }^{57}$ Niektóre typy przestępstw są opisane mniej dokładnie, a ich opisy nie zawierają danych geolokalizacyjnych. Uzasadnia się to bezpieczeństwem ofiar. Dotyczy to na przykład interwencji w sprawie gwałtów. 
przypadku z faktu, iż w środowisku intensywnie zurbanizowanym rzadko możliwe jest dokonywanie takich pomiarów w linii prostej. Przyjęte stumetrowe ograniczenie, jak pokazały pomiary testowe z wykorzystaniem GIS, wydaje się jednak wystarczające ze względu na idealną regularność ortogonalnej siatki ulicznej tej części Manhattanu.

Analiza danych ilościowych pod względem konkretnego miejsca interwencji pozwala określić High Line jako miejsce niezwykle bezpieczne. Dopiero od 2014 roku, a więc już po otwarciu drugiego odcinka liniowego parku, interwencje policyjne zaczęły być klasyfikowane pod kątem lokalizacji w odniesieniu nie tylko do adresów ulicznych, ale również i tutejszych parków. W latach 2014-2016 takich interwencji w High Line było łącznie raptem 11, w dodatku najczęściej nie dotyczyły poważnych przestępstw. W porównaniu do pozostałych $\mathrm{z}$ analizowanych parków High Line wydawał się więc ponadprzeciętnie bezpiecznym miejscem. W sprawdzanym okresie w Washington Square policja interweniowała łącznie 100 razy, w Tompkins Square - 72, a nawet w Bryant takowych interwencji było aż 70 . Dwa pierwsze parki, jako mniej doinwestowane i znajdujące się w zarządzie publicznym, teoretycznie bardziej sprzyjać mogłyby przestępczości pospolitej. Symptomatyczna w aspekcie celów analizy jest jednak dysproporcja między High Line i ostatnim ze wskazanych tu trzech parków. W obu przypadkach mowa bowiem o intensywnie nadzorowanych i skomercjalizowanych przestrzeniach administrowanych przez podmioty prywatne. Pomimo tego High Line zdaje się bardziej bezpiecznym miejscem od Bryant.

Podobny obraz ujawnia opracowanie dotyczące szerszego kontekstu przestrzennego, wykonane na podstawie analiz rozleglejszego otoczenia parków przy wsparciu GIS (tabela 13). Otoczenie to znacznie różni się pod względem obszarowym. Szczególnie w przypadku High Line, długiego na ponad dwa kilometry, acz stosunkowo przy tym niewielkiego. Przyjęcie jako miary jego okolicy dokładnej ekwidystansy spowodowało zakreślenie pola o powierzchni aż 62,8 hektara. Jest to tym samym obszar trzy do czterech razy większy niż w przypadku pól kontrolnych. Stanowi też około połowy powierzchni nieporównywalnie większego parku Central. $Z$ tego względu jako miarę przyjąłem nie wartości bezwzględne, ale przeliczenie metrów kwadratowych przypadających na poszczególne typy przestępstw. W przygotowanym przeze mnie zestawieniu zwraca uwagę kilka rodzajów przestępstw miarodajnych dla kształtowania się poczucia bezpieczeństwa u użytkowników przestrzeni zurbanizowanej. Wyróżniłem zarazem takie, do których możliwe było pozyskanie dokładnych danych lokacyjnych. W tym zakresie wskazuję więc na morderstwa, włamania, napaście z kradzieżą oraz przestępstwa narkotykowe.

Na podstawie takiej analizy skonstatować można, że okolica High Line pozytywnie wyróżnia się pod kątem bezpieczeństwa w stosunku do przyjętych pól 
Tab. 13. Poziom przestępczości w otoczeniu parków High Line, Bryant, Tompkins Square i Washington Square w Nowym Jorku (2006-2016)

\begin{tabular}{|c|c|c|c|c|c|}
\hline \multirow[t]{2}{*}{ Nazwa parku } & \multirow{2}{*}{$\begin{array}{c}\text { Powierzchnia } \\
\text { okolicy parku } \\
\text { ogólem [ha] }\end{array}$} & Morderstwa & Włamania & $\begin{array}{c}\text { Napaście } \\
\text { z kradzieżą }\end{array}$ & $\begin{array}{l}\text { Przestępstwa } \\
\text { narkotykowe }\end{array}$ \\
\hline & & \multicolumn{4}{|c|}{ [liczba $\mathrm{m}^{2}$ przypadających na 1 przestępstwo] } \\
\hline High Line & 62,8 & 125563 & 3004 & 3412 & 887 \\
\hline Bryant & 15,3 & 0 & 971 & 2020 & 2842 \\
\hline $\begin{array}{l}\text { Tompkins } \\
\text { Square }\end{array}$ & 18,9 & 0 & 762 & 1086 & 464 \\
\hline $\begin{array}{l}\text { Washington } \\
\text { Square }\end{array}$ & 19,6 & 0 & 2113 & 2284 & 162 \\
\hline
\end{tabular}

Źródło: NYC Open Data.

kontrolnych. Wyraźnie rzadziej dochodziło tutaj do włamań czy napaści z kradzieżą. Jedynie pod względem liczby odnotowanych przestępstw narkotykowych były one częściej spotykane niż w otoczeniu parku Bryant. W stosunku do Washington Square notowano je jednak aż przeszło pięć razy rzadziej. Co ciekawe, było to jedyne miejsce, w którym w badanym okresie odnotowano jakiekolwiek morderstwo. Odnośnie do tej obserwacji warto jednak pamiętać o dużej rozległości pola podstawowego w stosunku do tych kontrolnych.

W trakcie wywiadów z użytkownikami parku uzyskałem zbliżone opinie, dodatkowo uwiarygadniające wnioski z badań ilościowych. W podobny sposób deklarowali oni wyraźne wysokie poczucie bezpieczeństwa podczas przebywania w High Line. Zdecydowanie określiło odczucia w ten sposób aż 30 spośród 31 wszystkich respondentów. Jedyny głos przeciwny dotyczył ogólnego braku poczucia bezpieczeństwa w miejscach zdominowanych przez turystykę (B30). Inni wywiadowani albo jasno podkreślali brak wątpliwości w tej kwestii, albo też wręcz porównywali poziom bezpieczeństwa do innych miejsc lub negatywnie postrzeganej przeszłości. Jak określił to żartobliwie brazylijski turysta (B20), „w porównaniu do Sao Paulo wszystko jest bezpieczne", a z kolei zdaniem bezrobotnego od dawna zamieszkałego w tej okolicy (B14) sytuacja zdążyła się tu poprawić w ciągu minionych lat. Na pytanie, czy czuje się bezpiecznie, odpowiadał wręcz: „Absolutnie. [...] [Przed laty] było tutaj niebezpiecznie, brudno, to miejsce było opuszczone. Ludzie uprawiali seks na ulicy". Niektórzy uczestnicy badania terenowego w pozytywnym kontekście podkreślali też obecność gęstej sieci kamer monitoringu przemysłowego i innych technik nadzoru, jakie są wykorzystywane dla celów utrzymania porządku w parku. Wspominał o tym na przykład związany zawodowo z High Line fotograf 
(B1), który stwierdził, że „w większości sytuacji czuję się [tutaj] bezpiecznie. Czasem jesteś sam w tym pięknym parku, no czuję się bezpiecznie, ale to jest coś dziwnego, że wiesz, nikt nie będzie wiedział, jak coś się wydarzy. Ale z drugiej strony wszędzie są kamery". Dla turystki z Korei Południowej (B28) pozytywny wpływ na poczucie bezpieczeństwa miał z kolei fakt, iż widziała w parku „trochę ochrony".

Uogólniając powyższe obserwacje uzyskane na podstawie dwóch źródeł danych i trzech technik badawczych, park High Line wydaje się miejscem o wysokim poziomie bezpieczeństwa. Wynika to zarówno z analizy porównawczej źródeł urzędowych o oficjalnym charakterze, jak i zbadania subiektywnej z założenia percepcji przestrzeni u użytkowników tego miejsca.

\subsection{Wyniki monitoringu internetu}

Podobnie jak w przypadku placu Grzybowskiego, dla potrzeb monitoringu internetowej aktywności w przestrzeni wokół High Line poddanym badaniu materiałem były wzmianki ukazujące się w czerwcu 2017 roku. Tak samo jak w Warszawie, ze względu na warunki pogodowe jest to w Nowym Jorku okres sprzyjający zwiększonemu użytkowaniu przestrzeni publicznej, a zarazem pozbawiony dni specjalnych. Przeprowadzony monitoring objął analizę treści zdjęć publikowanych w serwisie Instagram na temat pięciu parków położonych na Manhattanie. Różnią się one pod względem wielkości, sposobu zagospodarowania czy zarządu i statusu własnościowego. W tutejszej strukturze przestrzennej wyodrębniane są odmiennej wielkości skwery, jak i nieporównywalnie większy od pozostałych przestrzeni zielonych Central Park czy też sam High Line. Ten ostatni wyróżnia się nietypowym, linearnym ukształtowaniem. Wyraźne różnice dotyczą też wymiarów i skali doinwestowania poszczególnych parków. High Line znajduje się w zarządzie niepublicznym, podobnie jak mniejszy i bardziej zwarty odeń Bryant (3,8 ha). Z kolei park Zuccotti to w rzeczywistości niewielki $(0,3$ ha), publicznie dostępny skwer, należący jednak w pełni do prywatnego właściciela, firmy deweloperskiej Brookfield Office Properties. Trzy wymienione parki wykazują zatem tylko część właściwości tradycyjnych, zielonych przestrzeni publicznych. Tak naprawdę reprezentują typ opisywanego wcześniej POPS. Z pozoru powszechnie dostępny Zuccotti szczególną sławę zyskał jako miejsce obozowiska ruchu Occupy Wall Street w 2011 roku, siłowo usuniętego $\mathrm{z}$ czasem $\mathrm{z}$ powierzchni tej prywatnej $\mathrm{w}$ istocie działki. $\mathrm{W}$ przeciwieństwie do pozostałych dwóch parków tylko w wypadku High Line powstanie przestrzeni zainicjowały działania oddolnego ruchu aktywistów miejskich. Z kolei Tompkins Square oraz Central Park są większymi powierzchniowo (odpowiednio: 4,2 i 341 hektarów) przestrzeniami znajdującymi się w pełnym zarządzie publicznym. Także 
Tompkins Square ma jednak w historii epizod podobny do Zuccotti. Związany był on z brutalną, policyjną pacyfikacją zamieszek trwających tutaj w 1988 roku i następnych latach.

W celu analizy pola podstawowego oraz czterech wskazanych wyżej i odnoszących się do niego pól kontrolnych wyselekcjonowałem grupę fotografii zamieszczonych w serwisie Instagram: 3263 dotyczące High Line, 6294 na temat Bryant, 50 o Zuccotti, 143 o Tompkins Square oraz 34130 o Central. Zdjęcia wybrane na podstawie analizy hashtagów i geolokalizacji nie objęły w rzeczywistości wszystkich wpisów na temat wskazanych przestrzeni. Wynika to z konieczności zastosowania automatycznych ustawień filtrujących, pozwalających odsiewać wzmianki dotyczące motoryzacji i sportu związane $\mathrm{z}$ anglojęzycznym wyrażeniem high line, mogące określać na przykład właściwości silnika samochodowego. Podobne problemy przyniosła nazwa central park (park centralny). Spotyka się ją w wielu innych miejscach na świecie, jak na przykład często obecnym w mediach społecznościowych przypadku indonezyjskiej Dżakarty. W odniesieniu do parków High Line, Bryant oraz Central wylosowana została spośród powyższych ilustracji grupa 100 wpisów dla każdego z tych przypadków. Dla Zuccotti i Tompkins analizowano natomiast wszystkie wpisy spełniające kryterium związku z badanymi przestrzeniami, których liczba była tym samym mniejsza niż $100^{58}$. Opublikowane materiały pozyskałem za pomocą narzędzia Brand24. Wyniki szczegółowej, jakościowej analizy treści objęły zatem łącznie 425 wybranych w ten sposób zdjęć (tabela 14).

Analiza fotografii zamieszczanych na Instagramie pokazuje, że opisywane przestrzenie zielone na Manhattanie są w różny sposób oceniane i wykorzystywane przez użytkowników. Pod względem liczby ilustracji przestrzeni zurbanizowanej znaczne podobieństwa wykazują wszystkie trzy parki znajdujące się w zarządzie prywatnym. Jakkolwiek High Line jako obiekt urbanistyczny wzbudzał zainteresowanie najczęściej, albowiem w przypadku aż 9 na 10 zdjęć uwieczniano elementy zagospodarowania tej przestrzeni, jego przewaga nad Bryant i Zuccotti jest w tym przypadku nieznaczna. Co więcej, porównanie z zaprojektowanym w pełni odgórnie i komercyjnie Zuccotti pokazuje, że większego zainteresowania nie wzbudzają nawet liczne detale urbanistyczne urozmaicające przestrzeń liniowego parku. Pod względem liczby fotografii wykonywanych ludziom nie widać z kolei

58 Ze względu na reprezentatywność danych z analizy treści wyłączyłem znaczną część postów zamieszczanych z najbardziej aktywnych kont odnośnie do Tompkins Square, zwłaszcza internetowej telewizji muzycznej cbhoodtv oraz aktywisty LGBT o pseudonimie brooklyngringo. Ukazywały one plenerowy koncert punkowy i uczestników demonstracji tego środowiska odbywające się w opisywanym parku. Wskazane zdjęcia ilustrowały nietypowe i przeważające liczebnie na Instagramie sposoby użytkowania badanej przestrzeni publicznej. W drugim z przywołanych przypadków zamieszczono aż 39 postów z tego samego konta. 
Tab. 14. Waloryzacja percepcji przestrzeni na podstawie wpisów w serwisie Instagram - parki High Line, Bryant, Zuccotti, Tompkins Square i Central w Nowym Jorku (czerwiec 2016)

\begin{tabular}{|l|c|c|c|c|c|c|}
\hline \multicolumn{1}{|c|}{ Wyszczególnienie } & High Line & Bryant & Zuccotti & $\begin{array}{c}\text { Tompkins } \\
\text { Square }\end{array}$ & Central \\
\hline \multicolumn{7}{|c|}{ Elementy obrazujące pozytywną percepcję przestrzeni (proc.) } \\
\hline Ogólne ujęcie przestrzeni & 48 & 40 & 41 & 13 & 37 \\
\hline Detal urbanistyczny & 16 & 5 & 24 & 10 & 4 \\
\hline $\begin{array}{l}\text { Ludzie w określonym } \\
\text { kontekście }\end{array}$ & 28 & 39 & 29 & 24 & 28 \\
\hline Odwzorowanie graficzne & 1 & 0 & 0 & 2 & 1 \\
\hline \multicolumn{7}{|c|}{ Elementy niezależne od pozytywnej percepcji przestrzeni (proc.) } \\
\hline Detal nieurbanistyczny & 4 & 11 & 9 & 10 & 0 \\
\hline $\begin{array}{l}\text { Ludzie w nieokreślonym } \\
\text { kontekście }\end{array}$ & 1 & 6 & 3 & 9 & 5 \\
\hline Zwierzęta & 0 & 0 & 0 & 16 & 8 \\
\hline Inne & 7 & 5 & 6 & 22 & 20 \\
\hline $\begin{array}{l}\text { Ilustracje przestrzeni } \\
\text { ogólem }\end{array}$ & 89 & 82 & 85 & 48 & 68 \\
\hline
\end{tabular}

Źródło: opracowanie własne.

większych różnic między wszystkimi pięcioma parkami, także tymi w zarządzie publicznym. W przypadku tych ostatnich mniej doceniany zdaje się jednak sposób ich urządzenia. Dla ponad połowy zdjęć Tompkins Square lokalny kontekst przestrzenny był co najwyżej pobocznym tematem fotografii. Zdjęcia publicznych parków pokazują z kolei bardziej swobodny sposób ich użytkowania. Na przykład większą reprezentację zwierząt nieobecnych we wszystkich trzech znajdujących się w zarządzie prywatnym przestrzeniach zielonych.

Także analiza zasięgu treści zamieszczanych przez poszczególnych użytkowników publikujących na Instagramie posty odnoszące się do High Line nie pozwoliła udowodnić większej popularności tego miejsca w stosunku do innych przestrzeni zielonych na Manhattanie. Biorąc pod uwagę tysiąc najbardziej aktywnych użytkowników, wskazanych przez szacunki narzędzia pomiarowego Brand24, w przypadku High Line zdjęcia cieszyły się tylko pozornie większym średnim zasięgiem. Docierały bowiem do 13,4 tysiąca wobec 3 tysięcy odbiorców zdjęć prezentujących Bryant. Przy wzięciu pod uwagę jako miernika takiego przeciętnego zasięgu nie średniej, lecz mediany, zasięg dotyczący postów o drugim z przywołanych parków 
był nawet większy: 404 wobec 384 odbiorców. Tym samym nie jest uzasadnione stwierdzenie, jakoby publikacje dotyczące High Line wzbudzały więcej reakcji odbiorców.

Analiza treści sugeruje, że oddolny wpływ obywatelskiej organizacji na społeczne wytwarzanie przestrzeni w przypadku High Line nie skutkował innym sposobem zainteresowania i użytkowania, niż miało to miejsce w przypadku pozostałych miejsc równie doinwestowanych, ale organizowanych w sposób w pełni odgórny. Zdecydowanie większe znaczenie zdaje się mieć skala doinwestowania właściwa dla miejsc znajdujących się w zarządzie prywatnym, a nie partycypacyjne zakorzenienie ich powstawania. Jednocześnie jednak te sprywatyzowane w różnym stopniu parki wydają się mniej egalitarne i demokratyczne w charakterze funkcjonowania niż dopuszczające więcej sposobów użytkowania obiekty w pełni publiczne.

\subsection{Podsumowanie}

Powstanie parku High Line, podobnie jak przekształcenie analizowanego uprzednio placu Grzybowskiego, nie wywołało oczywistych symptomów gentryfikacji w odniesieniu do komercyjnego rynku nieruchomości. Nie przekreśla tego faktu nawet to, iż istotny wydaje się korzystny wpływ wywierany przez tę przestrzeń zieloną na ten rynek tak dotkliwie doświadczony skutkami globalnego kryzysu z 2008 roku. Wysoką jakość użytkową wykazuje tutejsza infrastruktura osadnicza. Korzystnie ocenić można powiązania parku z jego otoczeniem albo poziom jego skomunikowania za pomocą transportu zbiorowego. Zalety miejsca ukazuje rozliczność czynności wykonywanych w tej przestrzeni przez osoby, które je odwiedzają. Mapowanie poznawcze pozwala ocenić High Line jako lokalizację miłą do przebywania. Negatywne czynniki kojarzone są raczej z otoczeniem w postaci rozpędzonej, wielkiej metropolii niż wadami samego parku, nawet jeśli irytująca bywa dla niektórych liczba obecnych w nim ludzi, zwłaszcza turystów z całego świata. Tubylcy są w tym przypadku mniejszościową grupą użytkowników, ale niezależnie od poziomu znajomości kontekstu historycznego darzą oni to miejsce bardzo dużą sympatią. Nie zmienia tego nawet liczba zakazów i ograniczeń warunkująca niewielką swobodę korzystania z tej przestrzeni. High Line wydaje się również bardzo bezpieczny. Lepiej wypada w tym zakresie od pozostałych parków w mieście, zwłaszcza tych utrzymywanych w zarządzie publicznym. W okolicy zrewaloryzowanej linii dawnej kolei notowanych jest mniej przestępstw niż w innych miejscach tego typu na Manhattanie. Poświadczają tę prawidłowość w równym stopniu dane urzędowe i potoczne wyobrażenia użytkowników tej przestrzeni. 
Podobnie jak w otoczeniu warszawskiego skweru, także i to urządzenie zielonej infrastruktury okazuje się sprzyjać jednak wielu innym wymiarom gentryfikacji. High Line nie tylko doprowadził już do oczywistego „uszlachetnienia” przestrzennego zdegradowanej dawniej okolicy. Dzisiaj jest ona już niemal w całości pozbawiona swojego industrialnego dziedzictwa. Park ten zmodyfikował też tę przestrzeń społecznie, sprowadzając do okolicy kolejną grupę marginalnych gentryfierów. Ich role odegrali tłumnie gromadzący się w tym miejscu turyści. Śladem tych ostatnich podążyła silniejsza komercjalizacja całego sąsiedztwa, nawet jeśli zaczątków tego procesu doszukiwać można się jeszcze wcześniej. Nie w przypadku wszystkich pionierów gentryfikacji winą za ich obecność obarczać można inicjatorów powstania znanego parku. Już wcześniej masowo otwierano w tej części miasta galerie sztuki, ale to High Line przyciągnęło instytucje jeszcze większe i zasobniejsze finansowo, takie jak Whitney Museum. Istnienie parku wspiera też w ukryty i niekoniecznie intencjonalny sposób segregację rasową. Biała część ludności jest dodatkowo nadreprezentowana w stosunku do ogółu lokalnej populacji. Skala inwestycji wielkiego kapitału i klarujący się obraz gentryfikacyjnego zaawansowania nasuwa wręcz skojarzenia z najdalej posuniętym etapem „uszlachetniania”, czyli supergentryfikacją. Do zaskakujących wniosków prowadzi też ocena estetyki liniowego parku. High Line bywa oceniany gorzej niż podobnie zadbane miejsce o bardziej tradycjonalistycznej formie i bardzo podobnie do nawet wyraźnie zaniedbanego parku o równie klasycznym obliczu. Monitoring aktywności $\mathrm{w}$ internecie sugeruje natomiast, że większe znaczenie niż społeczne zakorzenienie historii tego miejsca ma fakt poziomu doinwestowania tej przestrzeni. High Line wcale nie cieszy się większym uznaniem odbiorców, nawet jeśli odwiedza go najwięcej turystów. Popularność tego miejsca wynika także z jego ponad dwukilometrowej rozciągłości czy sprytnie wykorzystywanych technik marketingu terytorialnego. Rzeczywisty kształt tego obiektu pozwala wyjaśnić jedynie część jego wizerunkowego sukcesu. 


\section{Miasto nieformalne. Karanfilköy}

\subsection{Spontaniczna urbanizacja w modelu gecekondu}

Żywiołowy i chaotyczny charakter wpisany jest w funkcjonowanie Stambułu właściwie od jego zarania. Ta obecnie około 15-milionowa aglomeracja skupia 19 procent populacji całej Turcji, a o intensywności tempa jej urbanizacji wymownie świadczy skala i gwałtowność wzrostu liczby ludności. Od 2000 roku zwiększyła się aż o 4 miliony mieszkańców ${ }^{59}$. Większa i bardziej zamożna część metropolii lokuje się w jej europejskiej części, natomiast fragment położony po azjatyckiej stronie cieśniny Bosfor charakteryzuje zdecydowanie szybsze tempo urbanizacji. Na dobrą sprawę Stambuł jest dzięki temu jedynym położonym przynajmniej po części w Europie megamiastem. Pod względem struktury przestrzennej bardziej przypomina jednak arabskie odpowiedniki. Nawet w obrębie obszaru śródmiejskiego siatka ulic jest nieregularna. Ciagi te wytyczano dopiero na podstawie istniejącej wcześniej zabudowy, którą z biegiem lat jedynie dogęszczano. W przestrzeni zurbanizowanej widoczne są jednakże i wpływy zachodnie, co świadczy o integracji różnych kultur urbanistycznych charakterystycznej dla pogranicza dwu kontynentów.

Ta dychotomia staje się niekiedy polem walki konkurencyjnych i upolitycznionych tożsamości. Do konfliktów społecznych zogniskowanych wokół procesu społecznego wytwarzania przestrzeni zaliczyć można zwłaszcza głośną sprawę protestów, jakie wybuchły w 2013 roku. Wywołującą je iskrą okazało się ujawnienie planów związanych z likwidacją parku Gezi w sąsiedztwie Taksimu, najważniejszego placu miasta. Ten stosunkowo niewielki obiekt parkowy jest jedną z ostatnich przestrzeni z zakresu zielonej infrastruktury funkcjonujących w stambulskim śródmieściu, na dodatek symbolem zwesternizowanego stylu planistycznego z okresu

${ }^{59}$ Dane tureckiego urzędu statystycznego za rok 2016; http://www.turkstat.gov.tr/PrelstatistikTablo.do?istab_id=1590, dostęp: 14.07.2017. 
rządów kemalistowskich republikanów. Dzisiejsze islamistyczne władze kierowane przez byłego burmistrza miasta, a obecnie prezydenta państwa Recepa Tayyipa Erdoğana, jako wrogie obozowi politycznemu kemalistów, zamierzały zamienić ten park w centrum handlowe w zrekonstruowanych koszarach sułtańskiej artylerii. Pomysł wywołał wielodniowe protesty antyrządowe, $\mathrm{z}$ czasem rozprzestrzeniające się na inne miasta w całym państwie. Był to jeden z największych demokratycznych zrywów w historii Turcji. Połączył on tak zróżnicowane grupy, jak głównonurtowa kemalistowska socjaldemokracja, kurdyjska mniejszość, kibice zwaśnionych klubów piłkarskich czy lokalny ruch LGBT ${ }^{60}$. Konflikty sekularnej i islamistycznej kultury dotyczą także wielu innych aspektów użytkowania przestrzeni publicznej, związanych na przykład ze statusem kobiet ${ }^{61}$.

Podobnie jak w przypadku innych ośrodków o największym zaludnieniu na świecie, również za rozrost Stambułu odpowiadają zwłaszcza dzielnice biedy. Powstanie pierwszych z nich w ich zbliżonej do współczesnej odmiany datuje się po II wojnie światowej. Przekształceniom ulegać zaczęła wówczas turecka gospodarka, odchodząca od modelu opartego na rolnictwie. To z kolei wywołało zmasowane migracje do miast. Nie były one w stanie sprostać napływowi ludności ze względu na zbyt ubogie zasoby mieszkaniowe. Przybysze z prowincji zaczęli zatem masowo budować osiedla nieformalne, czyli tak zwane gecekondu ('zbudowane w ciągu nocy') $)^{62}$. Tryb ich powstawania wynikał z faktu, że zgodnie z prawem ochronie podlegały przez wiele lat nawet samowole pozbawione stosownego tytułu własnościowego wobec zagospodarowywanego na ich rzecz gruntu. Warunkiem koniecznym do spełnienia było tylko ukończenie ich konstrukcji w ciągu doby. Budynki te rozrastały się następnie w górę, korzystając z niewielkiej szczelności systemu zagospodarowania przestrzennego i lokalnej tradycji wąskiej, wielokondygnacyjnej zabudowy. Lokuje ona warstwowo mieszkania kolejnych generacji wielopokoleniowych rodzin.

Tego typu nieformalne osadnictwo stanowiło przez kilka dekad główny instrument tureckiej polityki przestrzennej. Budynki legalizowane były dzięki falom abolicji stosowanych wobec mieszkańców tego typu osiedli. Rozwiązanie to generowało wprawdzie wysokie koszty związane z zarządzaniem zabudowywanymi bez-

${ }^{60} \mathrm{~S}$. Tekinalp, Rationalization of contradictory cognitive dichotomies versus democracy demands: Istanbul Gezi Park protests, „Rationality and Society”, vol. 28, nr 1/2016, s. 84.

61 B. Gökarıksel, The intimate politics of secularism and the headscarf: the mall, the neighborhood, and the public square in Istanbul, „Gender, Place \& Culture: A Journal of Feminist Geography”, nr $1 / 2012$, passim.

${ }^{62}$ Jest to określenie zarówno całego slumsu, jak i pojedynczego budynku. S. Alkan, Globalization, Locality and the Struggle over a Living Space. The case of Karanfilköy, [w:] F. Eckardt, K. Wildner (red.), Public Istanbul Spaces and Spheres of the Urban, Transcript Verlag, Bielefeld 2008, s. 56. 
planowo terenami, wymagającymi na przykład uzbrojenia terenu, ale jednocześnie było wygodne z punktu widzenia polityków. Nieformalne osadnictwo zdejmowało z nich odpowiedzialność za budownictwo mieszkaniowe, a zarazem pozwalało pozyskać poparcie wyborców wdzięcznych za otrzymane prawa własnościowe do zasiedzianych przez siebie gruntów. Tuna Kuyucu i Özlem Ünsal określają to jako „populistyczny” model urbanizacji, który miał ich zdaniem zaniknąć w związku z rozwojem neoliberalnego rynku mieszkaniowego. Rynek taki umożliwia osiąganie większej stopy zwrotu z inwestycji w nieruchomości. Przyciąga dzięki temu nowych i coraz bardziej bezwzględnych w charakterze działań aktorów procesu społecznego wytwarzania przestrzeni. Są to zwłaszcza wielkie korporacje deweloperskie i współpracujące z nimi ściśle agencje publiczne. Za początek tak zarysowanego nowego modelu tureckiej polityki mieszkaniowej autorzy ci uważają okres następujący po załamaniu gospodarczym Turcji z początku XXI wieku. Kluczowe jest w ich opinii zwłaszcza nowe prawo z 2004 roku, wprowadzone przez rząd islamistycznej i wolnorynkowej Partii Sprawiedliwości i Rozwoju (AKP). Ustawa ta po raz pierwszy otwarcie kryminalizowała budowanie gecekondu, obarczając tego rodzaju skłoting sankcją pięciu lat pozbawienia wolności ${ }^{63}$. Pierwsze symptomy tego rodzaju represyjnej transformacji polityki mieszkaniowej dostrzegalne były jednak już nawet wcześniej.

Zdaniem Aylin Brigitte Yildirim wyróżnić można ogółem cztery główne fazy kształtowania się osiedli w modelu gecekondu. Pierwsza z nich to gecekondu zamrożone (frozen gecekondu), które pierwszy raz obserwowano w latach 50. i 60. XX wieku. Kształtujące się w ten sposób sąsiedztwa składały się właściwie wyłącznie z wolnostojących, niewielkich domków z małymi ogródkami. Od lat 70. ubiegłego stulecia swoją obecność zaznaczać zaczęła faza post-gecekondu. Wówczas, w ramach tak zwanego modelu yap-sat ('wybuduj i sprzedaj'), osiedla tego rodzaju były po raz pierwszy poddawane procesom reurbanizacji. Niewielkie budynki podwyższano o kolejne piętra, tworząc całe kwartały przeciętnie pięciokondygnacyjnej zabudowy. W jej ramach pojedyncze lokale przekazywano dotychczasowym użytkownikom gruntu. W kolejnym etapie, apartmankondu, zabudowa ulegała większej intensyfikacji do postaci powstających w przeważnie nieprzepisowy sposób pierwszych bloków. Ostatni etap reurbanizacji stanowi stadium tak zwanego varoş. Sąsiedztwa tego rodzaju zamieniają się wówczas ostatecznie w monotonne blokowiska, przeważnie składające się z zabudowy o niskiej jakości, na dodatek niezbyt odpornej na trzęsienia ziemi. Warto nadmienić, że określenie varoş ma w języku tureckim wyjątkowo pogardliwe konotacje i jego stosowanie jest krytykowane nawet przez osoby niechętne wszelkim gecekondu. Etap

${ }^{63}$ T. Kuyucu, Ö. Ünsal, 'Urban Transformation' as State-led Property Transfer: An Analysis of Two Cases of Urban Renewal in Istanbul, „Urban Studies”, nr 7/2010, s. 1483-1484. 
varoş zdaniem przywołanej autorki rozwijał się zwłaszcza od lat 90. XX wieku' ${ }^{64}$. Niekiedy projekty zakrojonej podobnie „odgórnej” reurbanizacji przeprowadzają też instytucje publiczne ${ }^{65}$.

Jakość środowiska mieszkaniowego w tureckich osiedlach nieformalnych jest stosunkowo wysoka w porównaniu do innych miejsc tego rodzaju. Często nie przypominają one w ogóle południowoamerykańskich i wschodnioazjatyckich odpowiedników. W tradycyjnym sąsiedztwie typu gecekondu gęstość zaludnienia wynosi około 100-250 osób na hektar. W kolejnych stadiach stopniowo wzrasta, ale jeszcze w drugiej fazie nie przekracza raczej poziomu 250-500 osób na analogicznym obszarze $^{66}$. Urbanizacja gecekondu przebiega zazwyczaj wedle dość regularnego wzorca. Prowadzi do powstawania ubogich, negatywnie postrzeganych i przez to stygmatyzowanych w publicznym dyskursie sąsiedztw ${ }^{67}$. Co jednak istotne, ten pesymistyczny scenariusz osadniczy nie spełnia się we wszystkich przypadkach, a niekiedy wywołuje odwrotne przemiany i powolną gentryfikację. Stanowi to wariant niewątpliwie korzystny z punktu widzenia części mieszkańców, a kształtowane w ten sposób sąsiedztwa rozwijają się do postaci bardzo odległej od stereotypowo rozumianego slumsu. Największymi beneficjentami opisywanego modelu okazują się ci mieszkańcy, którzy zdołali zasiedlić gecekondu w ich początkowej fazie, a tym samym pozyskać najatrakcyjniejsze grunty. To właśnie oni byli w stanie zyskownie odsprzedać potem nieruchomości nabyte wcześniej w drodze nieomal bezkosztowego zasiedzenia ${ }^{68}$.

${ }^{64}$ A.B. Yildirim, In_formal_Istanbul. Potential of the Gecekondu and Alternatives to Redevelopment in the Case of Karanfilköy, 2009 ISA-RC21 Sao Paulo Conference Inequality, Inclusion and the Sense of Belonging, www.fflch.usp.br/centrodametropole/ISA2009/assets/papers/01-A-8.pdf, dostęp: 14.07.2017, s. 5-6.

65 B. Uzun, M. Çete, H.M Palancioglu, Legalizing and upgrading illegal settlements in Turkey, „Habitat International”, nr 34/2010, passim.

${ }^{66}$ N. Billig, Everyday Life and Sharing of Open Space in Istanbul's Informal Settlements, [w:] A. Madanipour, S. Knierbein, A. Degros (red.), Public Space and the challenges of Urban Transformation in Europe, Routledge, London 2013, s. 156.

${ }^{67}$ A.B. Candan, B. Kolluoğlu, Emerging Spaces of Neoliberalism: A Gated Town and a Public Housing Project in Istanbul, „New Perspectives on Turkey”, nr 39/2008, s. 7.

${ }^{68}$ Obraz pełnej transformacji gecekondu stanowi na przykład akcja przedostatniej powieści Orhana Pamuka. Ukazuje ona losy rodziny Karataşów przechodzącej pełną drogę tego rodzaju przemian. Początkowo dwaj nestorzy rodu dokonują wspólnie nielegalnego zasiedzenia gruntu. Następnie jeden z nich rozwija działalność gospodarczą. Po czasie dokonuje zyskownej odsprzedaży nieruchomości i otrzymuje w nowym bloku wybudowanym na miejscu dawnego domu apartament o poprawionym standardzie. O. Pamuk, Dziwna myśl w mej głowie, tłum. P. Kawulok, Wydawnictwo Literackie, Kraków 2015, passim. 


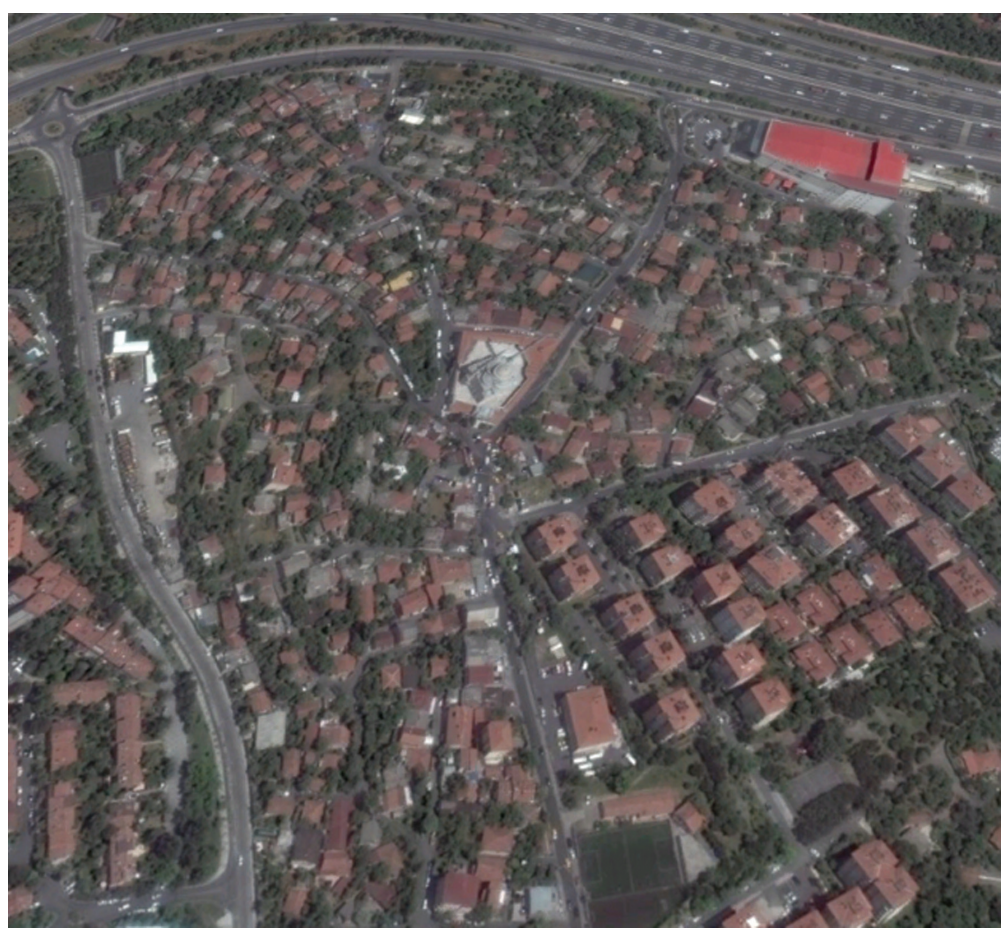

Ryc. 11. Karanfilköy w Stambule (2017, zdjęcie satelitarne otoczenia) Źródło: Google Earth, dostęp: 1.10.2017.

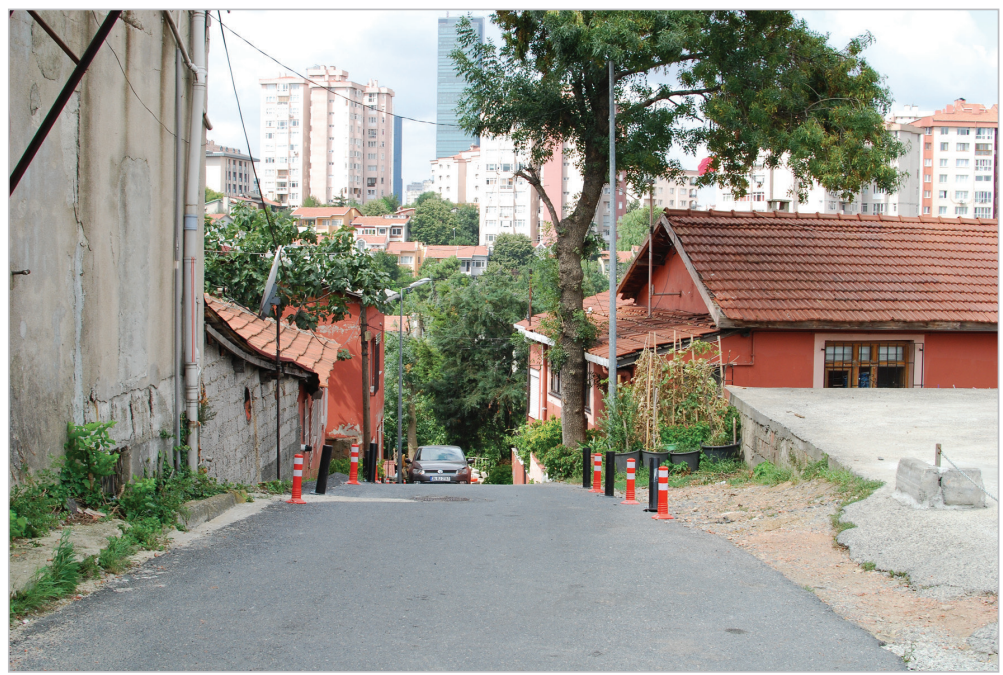

Ryc. 12. Karanfilköy w Stambule (2017)

Fot. Łukasz Drozda. 
Przykładem nietypowego z tego punktu widzenia stambulskiego sąsiedztwa jest Karanfilköy (Wioska goździków), stanowiące część kwartału Akatlar, położonego w dzielnicy Beşiktaş w europejskiej części miasta ${ }^{69}$. Zlokalizowane jest ono na południe od międzynarodowej trasy szybkiego ruchu E80, łączącej się z ważnym węzłem komunikacyjnym, jakim jest most nad Bosforem imienia Mehmeda Zdobywcy. Karanfilköy to kameralne sąsiedztwo, którego rozwój osadniczy zatrzymał się na pierwszym etapie - „zamrożenia”. Okolica ta w dalszym ciągu składa się z kameralnej zabudowy o zróżnicowanym stanie technicznym. Niekiedy upodabnia to ją do sąsiedztwa willowego, co zapewnia systematyczna aktywność inwestycyjna mieszkańców. Odróżnia to ich od stereotypowo postrzeganych mieszkańców gecekondu pod względem poziomu zamożności ${ }^{70}$. Widoczny jest też kontrast między Karanfilköy i położonymi obok sąsiedztwami, które powstały w podobnym okresie, ale zostały później odcięte po wybudowaniu wspomnianej trasy. Współcześnie cechuje je większa koncentracja gęstej zabudowy. Zachowania przestrzenne mieszkańców kilku okolicznych sąsiedztw zbadał wcześniej architekt krajobrazu Noah Billig. Określił on Karanfilköy mianem okolicy mogącej stanowić pozytywną „inspirację dla innych sąsiedztw i miast"71.

Oferujące dobre warunki środowiskowe sąsiedztwo stanowi przy tym teren inwestycyjny wartościowy z punktu widzenia wielkich przedsiębiorstw działających na stambulskim rynku nieruchomości. Ta niezagospodarowana za pomocą intensywnej zabudowy przestrzeń zurbanizowana, podobnie jak wiele innych gecekondu w całej Turcji, znajduje się w atrakcyjnej lokalizacji i „strategicznym punkcie nieopodal takich miejsc, jak centra finansowe, lotniska i galerie handlowe"72, w tym przypadku również kampus Uniwersytetu Bosforskiego. Nastawione na współpracę z korporacjami deweloperskimi władze lokalne w 1996 roku podniosły wobec tego limit wysokości dopuszczalnej tu zabudowy z 6,5 do 15,5 metra. Próbowały w ten sposób przyczynić się do powstania wielkoskalowego projektu deweloperskiego o nazwie Akatlar-Alkent. W tym samym roku odbyły się w związku z tym pierwsze przymusowe wyburzenia, w czasie których usunięto aż 53 budynki. W pacyfikacji sąsiedztwa udział wzięło cztery tysiące policjantów i pół tysiąca strażników miejskich, korzystających z pomocy między innymi wozu opancerzonego. O sile

${ }^{69}$ W Stambule wyróżniać można trójszczeblową strukturę. Dzieli się ona na główne dzielnice (ilçe), kwartały (mahalle) oraz sąsiedztwa (semt). Polskojęzyczne osiedle jest stosunkowo najbliższe ostatniej z przywołanych jednostek osadniczych. Zarazem kojarzy się jednak z innym typem zabudowy niż nieregularne stambulskie sąsiedztwa.

${ }^{70}$ H. Isanovic, Should the Informal become Formal: The Case of Karanfilkoy in Istanbul, Turkey, „International Journal of Arts \& Sciences”, nr 5/2014, s. 632.

${ }^{71}$ N. Billig, op. cit., s. 168.

${ }^{72}$ S. Alkan, op. cit., s. 66. 
nacisku na lokalną społeczność wymownie świadczy, że jeszcze dwa lata wcześniej, podczas kampanii wyborczej, burmistrz dzielnicy zapowiadał respektowanie przez władze prawa do istnienia wszystkich ówczesnych gecekondu. Ta obietnica wyborcza została jednak szybko złamana ${ }^{73}$.

Rozpoczęte zostały w związku z tym roboty rozbiórkowe. Przy okazji zainicjowano brutalną i zmasowaną akcję pacyfikacyjną oraz kampanię medialną przeciw stygmatyzowanym na wiele sposobów varoşlu, jak pogardliwie określa się mieszkańców takich gecekondu. Lokalna społeczność zdołała jednak stawić skuteczny opór tym działaniom i ocalić pozostałą część sąsiedztwa. Na bazie organizacji kulturowo-oświatowej AKDER mieszkańcy potrafili zintegrować swoją społeczność, a także przeprowadzić udaną kampanię społeczną z udziałem lokalnych naukowców. Nietypowym przykładem świadczącym o poziomie integracji tej społeczności jest fakt, że Karanfilköy, będące pierwotnie osiedlem nędzy zakładanym przez przedstawicieli ludności napływowej, od 1996 roku jest zamknięte na imigrację osadników spoza grona dotychczasowych mieszkańców ${ }^{74}$. Wszystko to pokazuje, jak wysokie są posiadane przez tubylców zasoby kapitału społecznego i jak duże jest zdyscyplinowanie sąsiedzkiej społeczności.

W przeciwieństwie do dwóch poprzednich studiów przypadku omawianych w pracy Karanfilköy stanowi przykład przestrzeni wytworzonej społecznie w sposób w pełni oddolny. Jego mieszkańcy prowadzili swoje działania nie tylko bez inspiracji zewnętrznych aktorów i przy braku wsparcia lokalnych władz, ale wręcz przeciw ich twardemu stanowisku. Działo się to na dodatek przy braku środków finansowych choćby zbliżonych do innych, analizowanych w tej pracy przypadków. W jaki zatem sposób tego rodzaju oddolność wpływa na efektywność funkcjonowania przestrzeni zurbanizowanej i poziom jakości życia w kształtującym się tak środowisku? Metoda WWP ma w tym przypadku ocenić relacje mierzalnych w różnym stopniu nakładów i efektów gecekondu jako przykładu urbanistyki oddolnej.

\subsection{Właściwości rynku nieruchomości - powód zaniechania badań}

Ze względu na charakter prowadzonej w sąsiedztwie Karanfilköy polityki mieszkaniowej, uniemożliwiającej migracje z zewnątrz, a także zawiły charakter statusu własnościowego tutejszych nieruchomości, nie zastosowałem badania ich rynku jako metody waloryzacji przestrzeni. Swoboda migracji i wolny rynek nieruchomości mieszkaniowych dotyczą wyłącznie części sąsiedztwa znajdującej się poza

${ }^{73}$ Ibidem, s. 66-67.

${ }^{74}$ A.B. Yildirim, op. cit., s. 11. Chodzi oczywiście o stałych, legalnych lokatorów. Na terenie sąsiedztwa zamieszkują także inni lokatorzy długoterminowi, napływający tu nawet w późniejszym okresie, tacy jak na przykład afgańscy zbieracze złomu. 
obszarem domków typu gecekondu. Czynniki te nie są zaś związane z działaniami lokalnych aktorów społecznych. Lokuje to tę część sąsiedztwa poza tym obszarem badawczym przyjętym w mojej pracy.

\subsection{Ocena funkcji z zakresu infrastruktury osadniczej}

Ze względu na duże zagęszczenie zabudowy i spontaniczny charakter rozplanowania przestrzennego całej okolicy granice Karanfilköy są nieostre i dyskusyjne nawet dla mieszkańców sąsiedztwa. Niektóre osoby pochodzące z zamożniejszej części okolicy wręcz kwestionują używanie tej samej nazwy w odniesieniu do ich własnych adresów. Utożsamiają to określenie wyłącznie z ubogą zabudową gecekondu ${ }^{75}$. Oczywista jest właściwie wyłącznie granica północna, którą wyznacza trasa szybkiego ruchu. Podobnie wyraźnych krawędzi przestrzennych nie sposób zidentyfikować jednak w odniesieniu do pozostałych stron osiedla. Płynne granice definiować można w związku z tym głównie w zestawieniu z typami otaczającej gecekondu bardziej uporządkowanej i wyższej zabudowy, na zasadzie ich wizualnego odróżnienia.

Na podstawie tak zarysowanych wymiarów Karanfilköy sprawia wrażenie sąsiedztwa dostosowanego do ludzkiej skali urbanistycznej. Nieregularne ukształtowanie siatki ulicznej powoduje niestety, że określenie rozmiarów osiedla jest jeszcze trudniejsze. Nieco tę kwestię upraszczając, jego wymiary można określić jako zbliżone do powierzchni o średnicy około jednego kilometra, jeśli liczyć długość tras pieszych prowadzących z obu krańców tego obszaru. Wyraźną dominantą wysokościową i przestrzenną jest położony na wzgórzu meczet. Na południe od niego rozpościera się główny ośrodek usługowy. Obiekty te znajdują się mniej więcej pośrodku powierzchni Karanfilköy. Tym samym odległość od centrum sąsiedztwa rzadko kiedy przekracza 500 metrów, co określa się jako granicę akceptowalnego dojścia pieszego. Percepcja tej odległości może być większa ze względu na ukształtowanie terenu. Na przykład różnica poziomu między południową i północną częścią wynosi kilkadziesiąt metrów. Należy jednak zaznaczyć, że podobnie ukształtowana jest większość terenów górzystego Stambułu. Kilkunastomilionowa i chaotycznie zabudowana metropolia przeważnie wymusza też pokonywanie znacznie większych odległości, co w dobrym świetle stawia wymiary kameralnego pod tym względem Karanfilköy.

Pomimo korzystnego zwymiarowania niewątpliwą wadą sąsiedztwa jest stopień wyposażenia go w niektóre usługi podstawowe typu publicznego. Stanowi

${ }^{75}$ Uczynił tak jeden z potencjalnych respondentów. Mężczyzna w średnim wieku z oburzeniem stwierdził, że nie będzie rozmawiał na temat Karanfilköy ze względu na to, że mieszka w dobrym bloku, a nie ubogim gecekondu. 
to charakterystyczną cechę wielu osiedli ludzkich powstających w bezplanowy sposób. Brakuje zwłaszcza usług oświaty, o czym świadczy zjawisko masowego dowożenia dzieci i młodzieży do szkół przez często spotykane w tej okolicy minibusy. Biorąc pod uwagę zwymiarowanie jednostki sąsiedzkiej, występują jednak tutaj przynajmniej ekwiwalenty niemal wszystkich pozostałych usług postulowanych w ramach tej koncepcji. W odległym w granicy akceptowalnego dojścia ośrodku osiedlowym wokół meczetu znaleźć można zarówno aptekę, jak i spełniające funkcję klubu dla mieszkańców bezpośrednie otoczenie meczetu. Na jego zadbanym dziedzińcu znajduje się między innymi dostępna również dla kobiet kawiarnia z krytymi dachem stolikami w ogródku. Innymi miejscami spotkań są natomiast bary znajdujące się w tej samej okolicy. Pozytywnie zdają się kształtować także odległości oddzielające mieszkańców od sklepów spożywczych. Obok tych funkcjonujących wokół meczetu można znaleźć niewielkie punkty handlowe w bardziej peryferyjnych częściach sąsiedztwa. Między innymi we wschodniej - na rogu ulic Fenerli Hristo i Kaçar - czy północnej i południowej - przy głównej ulicy Zeytinoğlu. Do tego mieszkańcy mogą też korzystać z punktów usługowych poza granicami samego osiedla, w tym dużego centrum handlowego.

Pod względem uwarunkowań komunikacyjnych mieszkańcy powszechnie zachwalają korzystne położenie sąsiedztwa. W odległości nieco ponad kilometra od jego południowej granicy znajduje się stacja oddanej do użytku w ostatnich latach szóstej linii stambulskiego metra ${ }^{76}$. Przez główną ulicę sąsiedztwa przejeżdżają ponadto dwie linie autobusowe, kursujące do przystani promowych Kabataş i Beşiktaş. Są to ważne węzły przesiadkowe, które umożliwiają dalsze podróże po niemal całej metropolii. Od strony północnej sąsiedztwo graniczy z trasą ekspresową będącą dla samochodów kluczową arterią o ogólnokrajowym znaczeniu. Jak na standardy jednego z najbardziej zatłoczonych miast na świecie, wyposażenie transportowe Karanfilköy zdaje się w tym kontekście co najmniej zadowalające. Co więcej, stopień zakorkowania głównej ulicy osiedla jest niewielki nawet w godzinach szczytu komunikacyjnego. To zaleta tej okolicy w stosunku do reszty metropolii.

Mniej korzystna jest sytuacja pieszych. Obok górzystego ukształtowania terenu znać o sobie daje skrajne podporządkowanie innych uczestników ruchu wobec samochodów. Zajmują one zdecydowanie przeważającą część wszelkich przestrzeni publicznych. Chociaż brak chodników i wszędobylskość aut może być w tym aspekcie szokująca dla przybysza z zagranicy, jak na warunki stambulskie nawet ta zdominowana przez ruch samochodowy okolica wydaje się jednak miejscem

${ }^{76}$ Od 2013 roku liczba linii metra powiększyła się z dwóch do sześciu (stan na 2017 rok), a docelowo planowanych jest ich osiem. Podziemna kolej o bardzo dużej przepustowości stanowi jeden z największych projektów infrastrukturalnych realizowanych we współczesnej Turcji. 
cichym i spokojnym. Wyraźnie podkreślają to niemal wszyscy napotykani respondenci. Wskazują zwłaszcza na odczuwalną obecność zieleni. W okolicy brakuje wprawdzie większych urządzeń z zakresu zielonej infrastruktury, ale „zamrożone” gecekondu obfituje w niewielkie, przydomowe ogródki. W ciągu ostatnich lat oddano też do użytku kilka skwerów wyposażonych w nowoczesne place zabaw.

Pod względem sposobów użytkowania okolicy przeważa jednak wykonywanie czynności koniecznych. Spędzaniu wolnego czasu i wypoczynkowi sprzyja szczególnie istnienie kilku punktów gastronomicznych. Poza tym większość interakcji między mieszkańcami wynika z okazji towarzyszących załatwianiu innych spraw, zwłaszcza zakupów czy wspólnego oczekiwania na autobus. Przy poszukiwaniu potencjalnych respondentów nie udawało się napotykać takich osób na zaplanowanych przestrzeniach publicznych. Nawet nieliczne osoby przesiadujące na ławkach nie spędzały tam czasu w celu zwykłego odpoczynku, lecz było to związane z oczekiwaniem na coś lub kogoś. Czynności społeczne związane ze spotkaniami towarzyskimi obserwowane były wyłącznie w punktach gastronomicznych bądź przestrzeniach prywatnych i półprywatnych. Spotkania towarzyskie, najczęściej kobiece, widoczne były na gankach i w ogródkach gecekondu lub we wspólnych przestrzeniach grodzonych osiedli. W takich też warunkach przeprowadzono kilka rozmów z mieszkańcami.

Podsumowując te obserwacje, Karanfilköy ocenić można jako miejsce o relatywnie korzystnej strukturze urbanistycznej - i to pomimo chaotycznego sposobu powstawania sąsiedztwa. Atut stanowi również dobrze ukształtowane wyposażenie w usługi podstawowe, z zastrzeżeniem braku organizacji zaplecza oświatowego. Dysfunkcje sposobu organizacji przestrzeni publicznych współgrają jednak w tej okolicy z ograniczonymi przejawami życia społecznego. Poza obszarami o prywatnym, półprywatnym lub skomercjalizowanym charakterze właściwie nie ma ono szansy zaistnieć, co sprzyja poczuciu izolacji między mieszkańcami i przybyszami z zewnątrz, jakie zaobserwowane zostało podczas przeprowadzania wywiadów. Wrażenia dotyczące tej kwestii opisane są w dalszej części pracy.

\subsection{Zaawansowanie gentryfikacji obszaru}

Zjawisko gentryfikacji zobrazowane może być właściwie za pomocą całego cyklu reurbanizacji sąsiedztw typu gecekondu. Na początkowym etapie swojego istnienia cechują się one słabą jakością środowiska zbudowanego, a poziom zamożności ich mieszkańców lokuje się wtedy na bardzo niskim poziomie. Siłą rzeczy czyni je to reprezentatywnymi przykładami dla przestrzeni zdegradowanej, czyli warunku wstępnego rozpoczęcia cyklu gentryfikacyjnego. Atrakcyjna lokalizacja stanowi do pewnego stopnia immanentną cechę każdego slumsu. Osiedla tego typu lokali- 
zowane są bowiem w celu zapewnienia dostępu do pracy osobom niebędącym w stanie uczestniczyć aktywnie w rynku nieruchomości. Swoboda decyzji migracyjnych jest w ich przypadku ograniczona zarówno możliwością wyboru miejsca pracy, jak i jedynego poziomu jakości środowiska bytowania, na jaki są sobie w stanie pozwolić. Po pewnym czasie, na fali zjawiska renty gruntowej, zdegradowane sąsiedztwa okazują się jednak atrakcyjne dla lokowania w ich obszarze coraz bardziej zaawansowanych reinwestycji. Następuje zatem stopniowa reurbanizacja prowadząca do uniformizacji takiej przestrzeni zurbanizowanej ${ }^{j 7}$. Powoli poprawia się jakość zabudowy, zmienia struktura dostępnych usług, dochodzi też do przynajmniej częściowej wymiany ludności. Karanfilköy stanowi pod tym względem specyficzny przykład. „Zamrożenie” gecekondu zatrzymuje działalność tego cyklu, a zarazem uwydatnia kontrasty między częściami dotkniętymi gentryfikacją i tymi, gdzie „uszlachetnianie” przestrzeni zostało powstrzymane.

Gentryfikacja w okolicy Karanfilköy jest widoczna gołym okiem, ale dotyczy tylko części sąsiedztwa. Jej przykładem jest część przebudowana do modelu bloków $\mathrm{z}$ dominującą funkcją grodzonych osiedli. O jej obecności świadczy niezbicie wymiana części populacji. Jak pokazują wywiady z mieszkańcami, wyraźnie identyfikują oni nie tylko oczywiste granice między dwoma typami zabudowy, ale i rozłączność obu lokalnych społeczności. Tej związanej ze starym gecekondu i drugiej, zamieszkującej zamożniejsze blokowisko. Jakkolwiek wśród tej ostatniej grupy zdarza się spotykać także potomków założycieli nieformalnego osiedla, którzy przeprowadzili się z czasem do nowych, „formalnych” budynków, stanowią oni w nich mniejszość. Przeważa ludność napływowa, słabiej znająca historię sąsiedztwa, rzadziej wykonująca zawody wymagające pracy fizycznej. Nawet wywiadowana mieszkanka bloku, lepiej zakorzeniona od większości sąsiadów w okolicy dzięki swojemu pochodzeniu (C13), także przedstawia już inny typ socjoekonomiczny. Jest on właściwy profesji wykonywanej przez osobę ze społecznego awansu, pracowała bowiem jako operatorka kamery zatrudniona w tureckiej telewizji. Ta część mieszkańców reprezentuje wobec tego grupę gentryfierów zaawansowanych. W starszej części zabudowy przeważają natomiast reprezentanci innych grup zawodowych oraz osoby o inaczej ukształtowanych, bardziej konserwatywnych przekonaniach. Pomimo bliskości stambulskich uczelni okolica nie jest zalewana przez szukających taniego kwaterunku studentów, enklawy pracowników sektora kultury czy właściwie niewidywanych w tej okolicy turystów. A mowa przecież o mieście wyraźnie związanym z sektorem gospodarki nastawionym na ich potrzeby. Gentryfierzy pierwotni nie zaznaczyli tym samym wyraźnej obecności w tym sąsiedztwie.

77 Ł. Drozda, W stronę urbanistyki (nie-okcydentalnej). Generatywny wymiar urbanizacji globalnego Południa, [w:] J. Osiński, M. Dobrzycka (red.), Postęp i regres. Ekonomiczno-społeczne uwarunkowania ewolucji cywilizacji, Oficyna Wydawnicza SGH, Warszawa 2017, s. 13. 
Gentryfikacja społeczna w jego starszej części nie jest zatem widoczna. Nie zostało tam uruchomione wypieranie miejscowej ludności, a szata usługowa zachowuje lokalny charakter. W okolicy nie widać placówek sieciowych i franczyzowych, które obecne są w okolicznych sąsiedztwach. Na przykład w dawno zamienionym na zamożniejsze blokowisko bardziej południowym dystrykcie Akatlar rzadko spotykane są już niewielkie sklepy osiedlowe, które ciągle stanowią podstawę aprowizacji mieszkańców Karanfilköy. Zamiast małych sklepików na odcinku ulicy Zeytinoğlu w Akatlar co chwila widoczne są charakterystyczne dyskonty sieci Şok. W północnej części gecekondu ważną rolę odgrywa nowoczesne centrum handlowe i konferencyjne pod nazwą Mustafa Kemal Kültüir Merkez Akatlar. Do złudzenia przypomina ono shopping malls spotykane na całym świecie. Jego główny punkt stanowi drogi hipermarket Carrefour Gourmet, przeznaczony dla klientów z tak zwanego segmentu premium. W podziemiach znaleźć można stylizowaną na włoską pizzerię restaurację Pomodoro. Bardzo odróżnia się ona od obecnych w Karanfilköy klasycznych barów sprzedających po niższych cenach pilaw, döner kebap, zupę z soczewicy i inne dania kuchni tureckiej. Centrum handlowe znajduje się jednak na obrzeżu sąsiedztwa, a nie w jego centralnej części, jak wiele powstających globalnie placówek tego typu. Przylega zamiast tego do i tak stanowiącej nieprzekraczalną barierę przestrzenną trasy ekspresowej. Jest tym samym wobec gecekondu elementem w gruncie rzeczy zupełnie zewnętrznym.

Podobnie jak w wielu innych miejscach Stambułu, będącego miastem wyraźnie nastawionym na turystykę, także i w Karanfilköy pojawiły się już pierwsze oferty wynajmu krótkoterminowego. Oferowane są w aplikacji Airbnb, którą uważa się za ważny akcelerator gentryfikacji ${ }^{78}$. Dostępne lokalnie oferty są jednak bardzo tanie. W Karanfilköy nie można odnająć większego apartamentu wyremontowanego dla potrzeb turystów, jaki bez trudu znaleźć da się w okolicznych sąsiedztwach. Dostępne są jedynie pojedyncze pokoje lub łóżka. Ich koszt jest bardzo mały i wynosi około 40 lir wobec cen w sąsiednich blokach zaczynających się przeważnie od $200 \operatorname{lir}^{79}$. Trudno zatem uznać to za przejaw choćby marginalnej fazy gentryfikacji ekonomicznej. O ile ceny nieruchomości w nowych blokach mogą być wysokie i nadawać okolicy status drogiego i prestiżowego adresu, to w ramach gecekondu nie funkcjonuje typowy rynek nieruchomości. Blokuje to spekulację właściwą ekonomicznemu wymiarowi „uszlachetniania” przestrzeni zurbanizowanej.

${ }^{78}$ Ł. Drozda, Economic or Social Capital? Uberisation as an Exemplification of the Rent Gap Theory on the Example of Poland, „Warsaw Forum of Economic Sociology”, nr 2/2017, s. 77-80.

${ }^{79}$ Stan na wrzesień 2017 roku, przy niemal równym kursie złotego polskiego i liry tureckiej. W obliczeniach siły nabywczej tureckiego społeczeństwa należy zwrócić uwagę na wyraźną inflację. W 2017 roku ceny przyjmowały mniej więcej 1,5 wysokości swojego poziomu z 2010 roku. Zob. Turkish Statistical Institute, Producer Price Index of Agricultural Products and Monthly Change (\%), http://www.turkstat.gov.tr/PrelstatistikTablo.do?istab_id=2113, dostęp: 15.09.2017. 
W zakresie gentryfikacji przestrzennej widać symptomy poprawy jakości przestrzeni. Już Hatidza Isanovic w swoim badaniu Karanfilköy sprzed kilku lat obserwowała pewne typy inwestycji dokonywanych przez mieszkańców, poprawiające jakość zabudowy. Równocześnie badaczka ta dostrzegła przykłady skrajnie zaniedbanej zabudowy substandardowej ${ }^{80}$. Moje własne badania terenowe poświadczają aktualność tych obserwacji (rycina 13). W Karanfilköy ciągle widoczne są jeszcze archaiczne konstrukcje, skrajnie różne na przykład od znacznie zamożniejszych fragmentów bardziej południowego Akatlar, takie jak te powstałe przy ulicach Kismet, Cebeci czy İşçiler. Tam również dominuje zabudowa jednorodzinna, ale działki są bardziej uporządkowane. Zamykają je ogrodzenia o lepszej jakości wykończenia, podczas gdy w gecekondu wiele działek pozostaje w pełni otwartych. Podobnie podniesiony jest standard domów, wyraźnie na dodatek wyższych. Bardziej zadbane są też ulice, gdy tymczasem w starszej części na bocznych uliczkach brakuje jakichkolwiek chodników (rycina 14). Trudno mówić wobec tego o występowaniu gentryfikacji przestrzennej na choćby wstępnym etapie. Obserwowalne są jedynie pewne symptomy tego zjawiska.

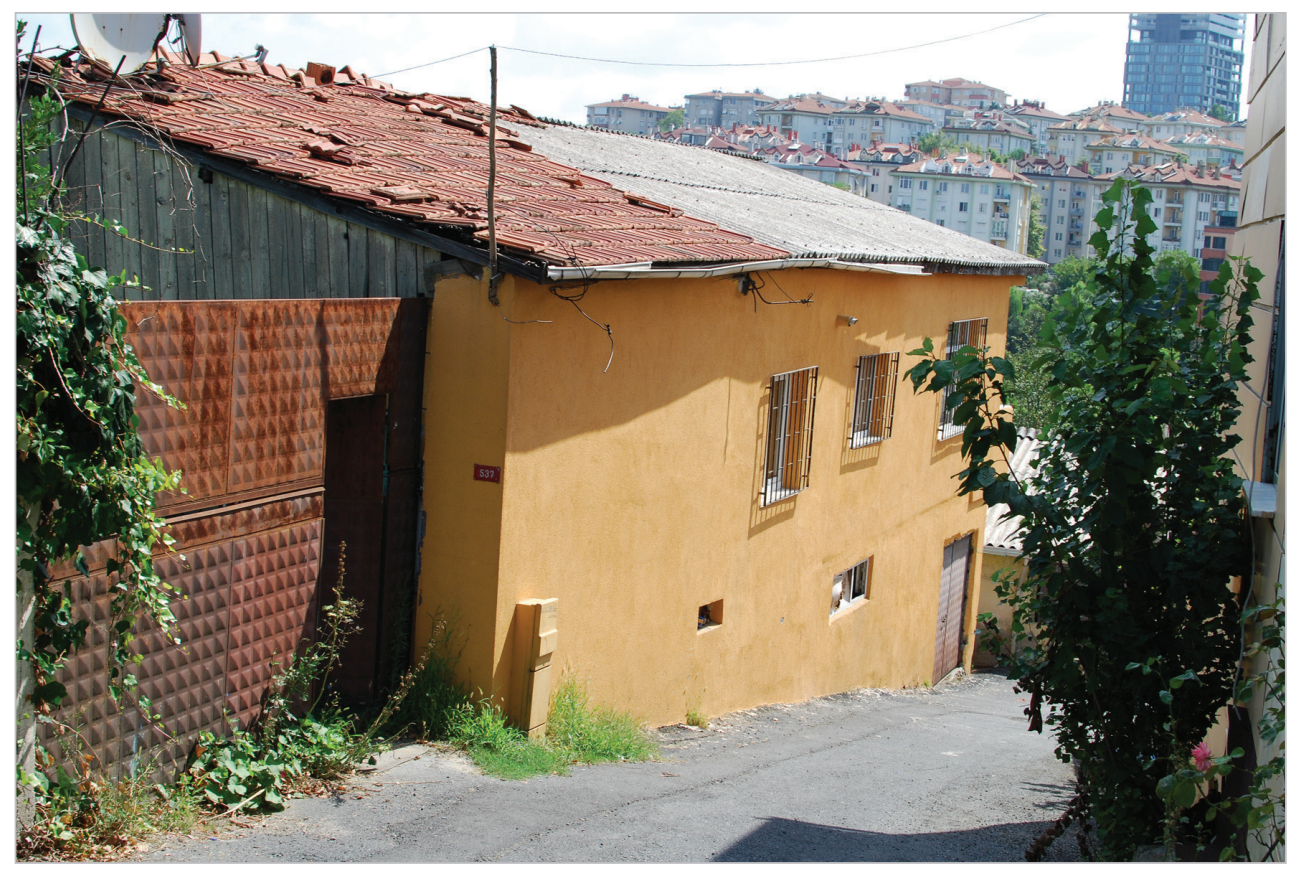

Ryc. 13. Przykład zaniedbanej zabudowy gecekondu w Karanfilköy (2017)

Fot. Łukasz Drozda.

${ }^{80}$ H. Isanovic, op. cit., s. 639-640. 


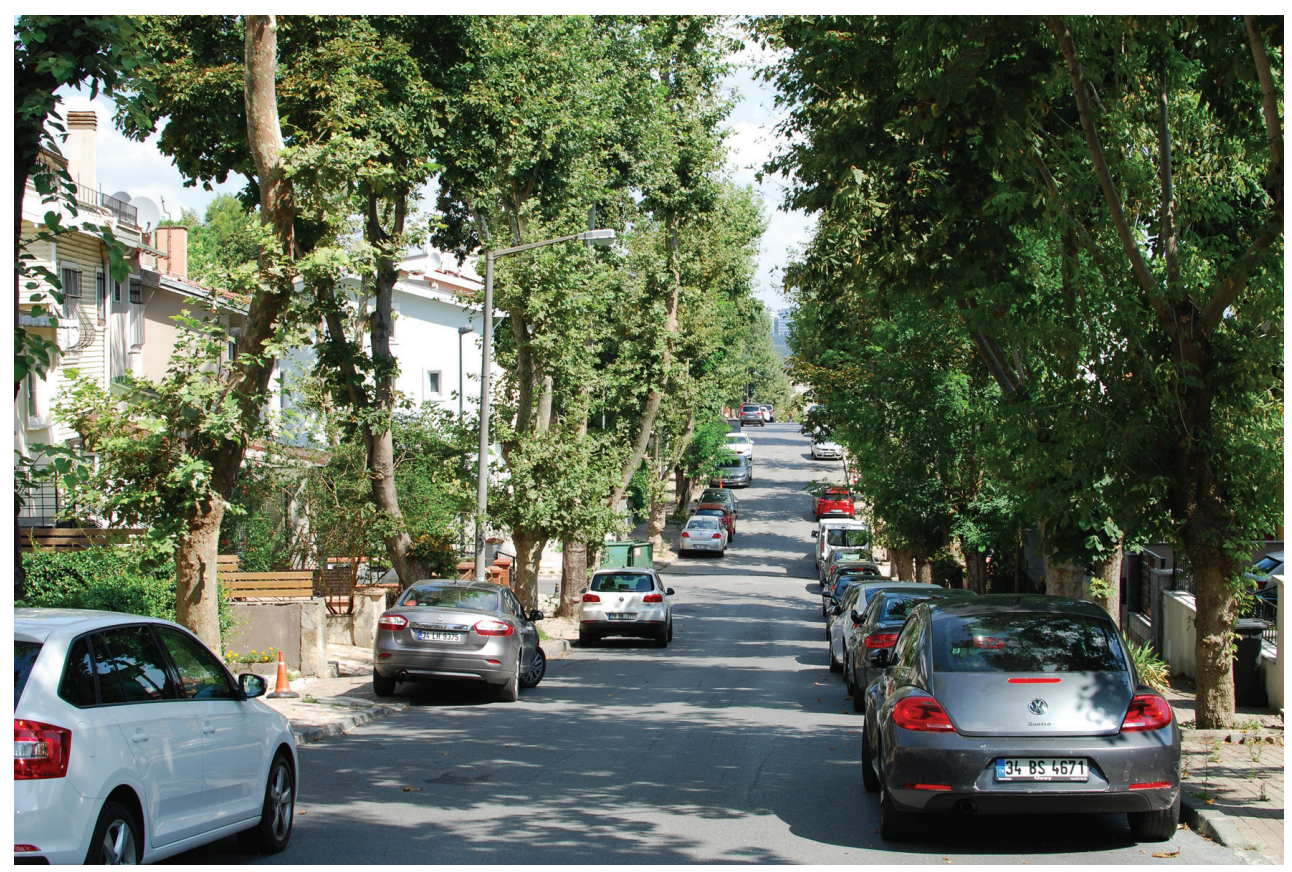

Ryc. 14. Przykład zabudowy willowej w Akatlar (2017) Fot. Łukasz Drozda.

Ogólnie rzecz biorąc, objawów gentryfikacji w Karanfilköy nie daje się zatem zaobserwować w zasadzie w żadnej z trzech typowych odmian tego procesu urbanizacyjnej transformacji.

\subsection{Wartości estetyczne przestrzeni}

Badanie społecznej percepcji estetyki miejsca na przykładzie Karanfilköy wykonałem za pomocą porównania kontrastujących wycinków tutejszej przestrzeni zurbanizowanej (aneksy 4.6 i 4.7). Pole podstawowe przyjęło postać tej części sąsiedztwa, która zagospodarowana jest przez tradycyjną zabudowę gecekondu. Pole kontrolne objęło natomiast nowszą i bardziej sformalizowaną zabudowę położonego w granicach Akatlar blokowiska oraz sąsiadującej z nim okolicy willowej. W celu zestawienia reprezentatywnej grupy ilustracji tej przestrzeni użyłem łącznie 15 zdjęć dla obu powyższych obszarów. Trzy z nich przedstawiają ujęcia tych fragmentów przestrzeni, w których dominującym elementem kadrów są samochody, wszędobylskie w tej okolicy, jak i innych częściach Stambułu. Dwie fotografie ukazują odmienne typy zabudowy obu obszarów - jednorodzinnej pola podstawowego i wielorodzinnej dla kontrolnego. 10 zdjęć pokazuje obrazy szerszego 
kontekstu przestrzennego. Są to różne fragmenty przestrzeni publicznej, większe panoramy widokowe czy ujęcia ulic różnego rzędu i wielkości.

Analiza piękna scenerii pola podstawowego i kontrolnego nie wykazała większych rozbieżności w zakresie ocen formułowanych w stosunku do obu tych zróżnicowanych przecież obszarów. Gecekondu oceniono niemal identycznie (2,67 pkt) jak bardziej uporządkowaną część okolicy (2,69 pkt). Respondenci najniżej ocenili oba typy zabudowy reprezentatywne dla tych przestrzeni. Nisko waloryzowano nie tylko mniej zadbane przykłady budynków jednorodzinnych z gecekondu, ale i niektóre wysokie bloki, jeżeli tylko przykłady te przedstawiano w oderwaniu od kontekstu ich większego otoczenia. Najbardziej pozytywny odbiór odnosił się natomiast do przykładów zabudowy willowej. Jedno z ujęć właściwych dla bogatszej części sąsiedztwa oceniono wyraźnie wyżej niż resztę fotografii. W pozostałych przypadkach wysokie oceny zyskiwały zarówno fragmenty sformalizowanej części sąsiedztwa, jak i estetyczne części utrzymanej w lepszym stanie zabudowy klasycznego gecekondu. Jak wykazuje porównawcza analiza SBE, większy zakres formalizacji przestrzeni nie wydaje się wpływać zatem na poprawę jej generalnego odbioru. W oczach respondentów nie stanowi ona przestrzeni zurbanizowanej o jakkolwiek wyższym poziomie estetycznym.

\subsection{Sposoby mapowania poznawczego}

Generalną konstatacją towarzyszącą analizie map poznawczych pozyskanych w Stambule (aneks 3.3) jest wrażenie niewielkiego poziomu ustrukturyzowania wiedzy o badanej przestrzeni u jej mieszkańców. Pomimo przewagi respondentów zamieszkujących lokalnie (16 z 25 autorów map) oraz odwiedzających je częściej niż raz w tygodniu (22 z 25), zaledwie jedna ilustracja przedstawiała wiernie charakter sąsiedztwa. Tylko dwóch respondentów sporządziło mapy stanowiące planimetryczne odwzorowanie okolicy (C3 i C25). Żaden natomiast nie opracował jej szkicu perspektywicznego, stanowiącego rysunkowe zobrazowanie życia ulicznego. Większość map poznawczych odnotowywała jedynie pojedyncze punkty orientacyjne. Były one w dodatku nierzadko zupełnie wyabstrahowane z kontekstu przestrzennego i wzajemnych powiązań z innymi częściami. Potencjalne wątpliwości sugerowałyby uwikłanie tego wyniku w charakterystykę osadzoną w ramach różnic kulturowych i właściwych im odmiennych sposobów strukturyzowania przestrzeni. Wbrew takim obawom zdarzały się różnego typu ilustracje obrazujące na zasadzie planimetrii i wzajemnych relacji elementów przestrzennych. Odnosiły się one jednak głównie do najbliższej okolicy domu własnego (C14, C26), miejsca zamieszkania krewnych (C19) czy też miejsca pracy (C10) albo bardziej abstrakcyjnego kontekstu usytuowania całego sąsiedztwa w stosunku do szerszej okolicy. 
Dotyczyło to na przykład nielubianych przez respondentów „wrogich” sąsiedztw, takich jak zamieszkałe przez często lewicową bądź alewicką ludność Armutlu (C4, C14, C15).

Najlepiej identyfikującymi otoczenie respondentami nie były ani osoby najdłużej mieszkające w okolicy, ani też te najlepiej wykształcone. Najdokładniejsze odwzorowania wykonali bowiem śmieciarz (zamieszkujący w odległej części miasta) i robotnik budowlany (mieszkaniec od wielu lat). Wśród analiz bliższej okolicy te autorstwa lokalnej gospodyni domowej i przyjezdnego licealisty pojawiającego się w Karanfilköy raz na pół roku były zaś podobnie dokładne co opracowania pracującego tutaj informatyka i zamieszkałego lokalnie pracownika korporacji transnarodowej. Pewne różnice, w zakresie mniejszej abstrakcyjności bądź wskazywania powiązań między elementami umiejscawianymi na mapie, cechowały obrazy wykonywane przez mężczyzn. I tak nie oznaczało to jednak dużej dokładności takich zobrazowań.

Ów ogólnie niski poziom znajomości struktury przestrzennej jest zaskakujący, wziąwszy pod uwagę jej relatywne uporządkowanie, zwłaszcza jak na wysoce chaotyczne standardy organizacji układu osadniczego Stambułu. Zlokalizować można bowiem na przykład powszechnie kojarzony i tradycyjnie usytuowany na wzgórzu punkt orientacyjny, którego funkcję pełni meczet mający dla Karanfilköy charakter centrotwórczy. Jest on zdecydowaną dominantą przestrzenną i wysokościową w swoim otoczeniu. W strukturze komunikacyjnej wyraźnie dominuje ulica Zeytinoğlu. Przecina ona sąsiedztwo wzdłuż w jego środkowej części, stanowiąc również kręgosłup komunikacyjny i trasę przelotową, zarówno w odniesieniu do ruchu samochodów prywatnych, jak i dwóch funkcjonujących lokalnie linii autobusowych. Wyraźne jest również lokalne centrum usługowe na nieformalnym placu obok meczetu, podobnie jest z krawędziami przestrzennymi całego sąsiedztwa. Zwłaszcza od północy Karanfilköy domyka nieprzekraczalna bariera w postaci trasy ekspresowej, przy której znajduje się też drugi najlepiej kojarzony przez użytkowników tego obszaru punkt, jakim jest miejscowe centrum handlowe. Wyraźne rozróżnienie i identyfikowane społecznie różnice towarzyszą też granicy między tradycyjnym gecekondu a zabudowującym dawną południową część sąsiedztwa grodzonym osiedlem złożonym z bloków o standardzie wyższym w stosunku do „slumsów”. Pomimo to większość tych elementów nie jest zauważana lub uważana za istotne przez bywalców i mieszkańców Karanfilköy. Nawet te najbardziej charakterystyczne obiekty jak meczet i centrum handlowe pojawiły się w tylko około jednej trzeciej szkiców (odpowiednio dziewięciu i ośmiu przypadkach).

Formułowane przez respondentów oceny przestrzeni mają wyrazisty charakter. Jedynie w czterech przypadkach zdecydowali się oni jakkolwiek zastosować oznaczenia elementów neutralnych. Większość zwracała uwagę głównie na pozy- 
tywne aspekty przestrzeni, ale nieco ponad połowa szkiców (13) zawierała też uwagi negatywne. Wśród powtarzających się, nielubianych elementów otoczenia można wyróżnić centrum handlowe (jeszcze częściej oceniane jednak jako element pozytywny) czy pobliskie sąsiedztwa i obce okolice, zwłaszcza wspomniane Armutlu. Trudno jednak powiedzieć, aby świadczyło to o patologicznym zamknięciu się lokalnej społeczności. Zwłaszcza że niechęć do tego sąsiedztwa deklarowały także osoby słabiej powiązane z Karanfilköy. Byli to dla przykładu kierowca autobusu mieszkający w odległej części miasta (C4) czy zbieracz złomu, imigrant ekonomiczny z Afganistanu (C23). Chociaż ten ostatni mieszka w tej okolicy od raptem sześciu lat, swoją niechęć wyraził najostrzejszymi słowami: „nienawidzę Armutlu”.

Jeszcze innym obiektem niechęci bywa samo gecekondu. Przeciwstawiają się mu zarówno niektórzy mieszkańcy bloków, jak i lokatorzy „slumsu”. W opinii zamożnego małżeństwa zamieszkującego na grodzonym osiedlu mieszkańcy gecekondu to

ludzie, którzy tu przyjeżdżali nie mieli na to pozwoleń, przyjechali i zbudowali swoje domy bez pozwolenia, bezprawnie. Jacy ludzie tam mieszkają? Jakie rodzaje prac wykonują. My naprawdę nie wiemy. To nas czyni niepewnymi w stosunku do nich (C14).

Jak uzupełniła wypowiedź swojego męża zgadzająca się z nim żona, nie oznacza to jednak, że należy tych ludzi dyskryminować. Służy temu na przykład określenie varoşlu, przesadnie stygmatyzujące i dyskryminujące. Podobny sceptycyzm względem slumsów zachowała też ich sąsiadka, zamożna trenerka fitnessu (C12). Negatywnie na gecekondu patrzą jednak nawet ich niektórzy długoletni lokatorzy, jak emerytowany robotnik, który sprowadził się w to miejsce w 1976 roku (C3). Postrzega on reurbanizację sąsiedztwa w kategoriach dziejowej konieczności. Nie lubi gecekondu, chce zmian i powstawania luksusowych budynków, ponieważ „nikt nie lubi pozostawać w gecekondu”. Jednocześnie jednak nie oznacza to dla niego wyparcia własnej tożsamości i zaakceptowania krzywdzącej etykiety demonizującej „slumsy”. Jak mówi,

nie akceptuję słowa varoş, ponieważ bogaci ludzie używają tego przeciwko nam. A my tymczasem mamy tutaj wykształconych ludzi z doktoratami, którzy mieszkają w tych domkach. Bogaci używają tego wyrazu, żeby obrażać nim biednych. Dlatego go nie używamy. My po prostu mieszkamy w gecekondu. My wszyscy jesteśmy tacy sami, jesteśmy obywatelami Turcji (C3).

Sąsiedztwo budzi też na ogół pozytywne opinie ankietowanych, chociaż zdarzają się zwolennicy przeciwnych opinii. Na przykład zamieszkały w odległej części miasta kierowca autobusu (C28) ceni lokalne środowisko zbudowane i zieleń, ale niechęcią darzy przedstawicieli lokalnej społeczności. Z kolei prowadzący 
jeden z punktów handlowych przedsiębiorcy przyznają się do niechęci wynikającej z braku pogłębionych relacji z mieszkańcami (C6) bądź dosłownie artykułowanej nienawiści do Karanfilköy (C5). Zniechęcało ich to do tworzenia mapy poznawczej w obawie przed reakcjami klientów. Uwagę zwracał jednak fakt, że osoby najlepiej osadzone w lokalnej sieci społecznej, a więc mieszkające lokalnie i wykazujące się dobrą wiedzą na temat historii sąsiedztwa (C3, C7, C8, C13, C15, C16, C18, C22, C26, C29 i C30), bez wyjątków je lubią. Potrafiący docenić społeczną i zaangażowaną historię miejsca respondenci są więc mu najbardziej przychylni.

\subsection{Poziom i poczucie bezpieczeństwa}

W porównaniu do poprzednich studiów przypadku pozyskiwanie danych służących opisowi poziomu bezpieczeństwa w przestrzeni zurbanizowanej w Turcji jest znacznie utrudnione. $\mathrm{O}$ ile możliwe jest przeprowadzanie wywiadów ulicznych obrazujących subiektywne postrzeganie tej kwestii przez użytkowników przestrzeni, zdecydowanie trudniej pozyskać wiarygodne dane typu urzędowego. Turcja współcześnie jest tylko nominalnie państwem demokratycznym. Pomimo odbywających się regularnie wyborów powszechnych, naruszenia ładu prawnego dotyczą już nawet najbardziej elementarnych kwestii ustrojowych ${ }^{81}$. Turecka policja jest znana ze skorumpowania i nieprzestrzegania praw człowieka. Nie jest więc wiarygodnym źródłem informacji w zakresie bezpieczeństwa. Dane w odniesieniu do tej kwestii w Karanfilköy pozyskałem zatem wyłącznie ze źródeł o charakterze pierwotnym.

Rozmowy z użytkownikami przestrzeni zurbanizowanej w gecekondu pokazały, że sąsiedztwo to postrzegane jest jako bezpieczne. Opinię taką wyraziło wszystkich 30 rozmówców. Niektórzy podkreślali jedynie, że nie jest tutaj tak bezpiecznie jak w ich własnej okolicy. Opinię taką wygłaszali na przykład licealiści - młody mężczyzna zatrudniony w lokalnym barze (C9) czy jego rówieśnik odwiedzający członków swojej rodziny (C19). Co istotne, tę samą opinię podkreślały także osoby przyjezdne, niełączące odpowiedzi na to pytanie z podobnym ładunkiem emocjonalnym. W opinii kierowcy autobusu mieszkającego w odległej części Stambułu (C4) Karanfilköy wyróżnia się pod względem poziomu bezpieczeństwa, ponieważ

${ }^{81}$ Władze Turcji prowadzą szczególnie represyjną i antydemokratyczną politykę po tak zwanym zamachu stanu z lipca 2016 roku. Wedle jednej z hipotez rzeczywistymi inicjatorami tego wydarzenia byli przedstawiciele obozu rządzącego, wykorzystujący je jako pretekst do rozliczenia z przeciwnikami politycznymi. W ramach ekspresowych śledztw i procesów uwięziono tysiące osób. Jeszcze więcej zwolniono z pracy, zwłaszcza w szkolnictwie wyższym, gdzie zatrudnienie utraciło około 8 tysięcy ludzi. Spośród 269 dziennikarzy uwięzionych na całym świecie w 2016 roku aż 140 pracuje w Turcji. R. Greenslade, Record number of journalists in jail globally after Turkey Crackdown, http://bit.ly/2U3QeSB, dostęp: 22.03.2019. 
w „porównaniu do innych sąsiedztw jest tutaj bezpiecznie”. Zdanie to podzielił zatrudniony na miejscu sklepikarz, pochodzący jednak z innego z pobliskich sąsiedztw. Jak ocenił, ,tutaj jest bezpiecznie dla każdego. [...] Także w nocy, w razie czego każdy ci wtedy pomoże" (C8). Nawet deklaracji otwartej niechęci do sąsiedztwa towarzyszyło uznanie faktu wysokiego poziomu bezpieczeństwa w badanej okolicy. Prowadząca tu biznes przedsiębiorczyni stwierdziła: „Czuję się bezpiecznie, ale nie lubię tego miejsca” (C5). Handlowczyni, która mieszka w bogatszej części okolicy, jaką jest blokowisko powstałe na skutek reurbanizacji części sąsiedztwa, zapytana o swoje poczucie bezpieczeństwa zwróciła uwagę, że czuje się pod tym względem komfortowo. Sprzeciwiła się nawet możliwemu jej zdaniem stereotypowemu stygmatyzowaniu okolicy ze względu na niższy poziom zamożności starej części gecekondu. Jak zaznaczyła, „tutaj jest trochę slumsów, które mogą być postrzegane jako miejsce zamieszkane przez złych ludzi, chociaż tak naprawdę są oni dobrzy. To miejsce jest w porządku” (C16).

Opinie osób przyjezdnych, a także mieszkańców różnych części Karanfilköy były w tej kwestii bardzo zgodne. Wysokie poczucie bezpieczeństwa deklarowali zarówno mieszkańcy starszej części gecekondu, na ogół średnio sytuowani, jak i bardziej majętne osoby z grodzonych bloków. Tego typu osiedla korzystają w wielu przypadkach także z usług prywatnych agencji ochrony, systemów monitoringu przemysłowego oraz innych zabezpieczeń rozpoznawanych i wskazywanych w trakcie rozmów przez obie określone tak grupy mieszkających. W porównaniu do innych części miasta w starszych fragmentach sąsiedztwa uwagę zwraca zwłaszcza liczba otwartych przestrzeni. Większość przydomowych ogródków ciągle pozbawiona jest wyraźnych barier przestrzennych. Niekiedy nie są one nawet w ogóle ogrodzone. Dzięki temu na przykład rozmowa C26 odbyła się głęboko we wnętrzu ogrodu domostwa należącego do jednej z mieszkanek tej okolicy.

Na negatywny odbiór poziomu bezpieczeństwa bardziej może wpływać raczej generalna sytuacja polityczna. Powszechny także w Polsce lęk i ksenofobia związana z kryzysem uchodźczym w tym państwie występują ze zwielokrotnioną siłą. Jest to o tyle zrozumiałe, że do Turcji rzeczywiście trafiła ogromna liczebnie fala uciekinierów z ogarniętej wojną domową Syrii. Pracownica banku zamieszkała w jednym z zamożniejszych bloków przyznała, że wprowadziła się do niego dopiero niedawno. Jak zadeklarowała: „Zdecydowałam się przeprowadzić tutaj ze względu na wychowanie dzieci w bloku, który jest bezpieczny. [...] Przeprowadziłam się z miejsca, gdzie jest dużo syryjskich uchodźców i nie chciałam mieszkać tam z dziećmi” (C17).

Na mieszkańców i ich relacje z osobami z zewnątrz oddziałuje też autorytarna polityka wewnętrzna islamistycznego rządu. Widoczne to było zwłaszcza w odmowach niektórych mieszkańców wobec próśb o przeprowadzanie wywiadu. Jeden 
z nich, pracownik wyjątkowo silnie dotkniętego represjami sektora akademickiego, odmówił jakiegokolwiek wypowiadania się. Co więcej, sugerował konieczność posiadania przeze mnie zezwolenia na prowadzenie badań, które mogłoby jego zdaniem być wydane przez policję lub lokalne władze. Inni potencjalni respondenci z kolei krytykowali fakt rozmawiania z obcokrajowcem postrzeganym jako przedstawiciel świata Zachodu i wrogiej tureckim interesom Unii Europejskiej. Przyznać należy jednak, że ogólna liczba odmów wywiadów była niewielka. Konserwatywne i zaludnione w znacznym stopniu przez zwolenników rządzącej partii AKP sąsiedztwo zamieszkuje również wiele osób deklarujących wolę pomocy i budowania pomostów z zaczepiającym ich cudzoziemcem. Także trójka respondentów pochodzenia nietureckiego, a więc dwójka zbieraczy złomu z Afganistanu (C23, C24) i pochodząca z Azerbejdżanu cukierniczka (C21), jednoznacznie pozytywnie oceniała poziom bezpieczeństwa w tej okolicy. Ostatnia ze wskazanych osób deklarowała wolę przeprowadzenia się do Karanfilköy na stałe po sprzedaży swojego domu w innym tureckim mieście.

\subsection{Wyniki monitoringu internetu}

Obserwacje prowadzone w ramach monitoringu internetu dotyczącego Karanfilköy mają z konieczności bardziej ograniczony charakter niż w przypadku obu poprzednich studiów przypadku. Liczba wzmianek na temat tego stambulskiego sąsiedztwa zamieszczanych na Instagramie jest zdecydowanie mniejsza niż w przypadku placu Grzybowskiego i parku High Line. Analiza ilościowa tych treści dotyczyłaby znacznie mniejszej próby. Zarazem odnosiłaby się jednak nie do generalnych rodzajów zachowania przeciętnych użytkowników przestrzeni, lecz indywidualnego stylu komunikacji głównie kilku najbardziej aktywnych użytkowników. W związku $\mathrm{z}$ tym wydaje się, że istnieją merytoryczne przesłanki do ograniczenia badań do analizy jakościowej.

Analizy testowe różnych hashtagów i geolokalizacji pozwoliły zdiagnozować zaskakujące i znaczne różnice warunkowane prawdopodobnie kulturowo, które wpływają na sposoby, w jaki używany jest w Turcji Instagram. Nie oznacza to, że mieszkańcy tego państwa mniej chętnie wykorzystują tę sieć, ale czynią to w zupełnie odmienny sposób. W Polsce i Stanach Zjednoczonych opcja geolokalizacji służy najczęściej prezentowaniu zdjęć, które są przydatne z punktu widzenia urbanistycznej waloryzacji jako rzeczywiste zobrazowania przestrzeni zamieszkanej. U Turków najczęściej spotykanym nawykiem jest jednak wykorzystywanie tego mechanizmu dla zamieszczania zdjęć wychwalających lokalne drużyny sportowe. Są to zwykle treści powiązane z futbolem - dotyczy to przy tym jednocześnie kobiet i mężczyzn. Sam hashtag gecekondu niezwykle często kojarzony jest na 
przykład z jednym z drugoligowych klubów piłkarskich z Ankary. Jeszcze innym zjawiskiem jest traktowanie sieci tego typu jako platform umożliwiających omijanie restrykcji związanych z dostępem do internetu. Tak jak i w wielu innych państwach muzułmańskich, oficjalnie blokowana jest tu możliwość odwiedzania stron pornograficznych. Instagram bywa zatem używany jako miejsce gromadzące linki do takich zakazanych prawnie treści.

Na bazie analizy postów zamieszczanych w tym serwisie, będących wzmiankami dotyczącymi Karanfilköy, tutejszego meczetu i głównej ulicy sąsiedztwa, możliwe było znalezienie pewnej grupy ilustracji pokazujących sposoby internetowej prezentacji tej okolicy. Przeważnie są to jednak zdjęcia niezwiązane z przestrzenią zurbanizowaną. Nie więcej niż jedna dziesiąta z nich obrazuje szersze kadry pokazujące wyraźnie zabudowę sąsiedztwa. Zdjęcia te rzadko kiedy ukazują zatem samo Karanfilköy, a częściej skupiają się na ciekawych zjawiskach atmosferycznych (opady śniegu, ulewny deszcz, silny wiatr) czy świetlnych (zachód słońca). Wiele fotografii pokazuje elementy zupełnie niepowiązane z szerszym kontekstem przestrzennym. Obok tych przedstawiających ludzi znaleźć można inne, ilustrujące zwierzęta, samochody czy różnego typu reklamy mniej lub bardziej związane z sąsiedztwem. W tym ostatnim gronie znalazły się wzmianki dotyczące tematów tak różnorodnych, jak nieruchomości i lokalne punkty usługowe, aż po erotyczną bieliznę w sprzedaży wysyłkowej. Jedynym bardziej regularnie fotografowanym obiektem jest lokalny meczet, a zaledwie kilka razy sfotografowano szerszą panoramę lokalnego krajobrazu. Jest to o tyle zaskakujące, że to teren górzysty, ułatwiający pokazywanie tego rodzaju szerokich kadrów. Ze względu na mniejszą próbę wobec tych z Warszawy i Nowego Jorku przegląd dotyczył ilustracji z okresu dziewięć razy dłuższego niż w pozostałych studiach przypadków - od stycznia do września 2017 roku. Najciekawsze z punktu widzenia waloryzacji przestrzeni zdjęcie opublikowano jednak poza tym czasem, w październiku 2015 roku. Przedstawia ono makietę osiedla wykonaną przez studenta architektury z lokalnej uczelni technicznej. Była to właściwie jedyna tak dokładna ilustracja odnaleziona w sieci, której autor podjął głębszą refleksję nad ogólnym charakterem sąsiedztwa.

Niewielu jest też użytkowników regularnie zamieszczających zobrazowania tego rejonu dzielnicy Beşiktaş. W analizowanym okresie większą liczbę fotografii na temat toczącego się w okolicy życia rodzinnego i towarzyskiego zamieściły na łamach Instagrama właściwie tylko dwie jego użytkowniczki. Co więcej, niektóre hashtagi i określenia geolokalizacji, które mogłyby teoretycznie opisywać Karanfilköy, w rzeczywistości wskazują na inne miejsca. Wynika to z błędnego określenia geolokalizacji. Niektóre posty pokazują na przykład zamieszczane w sieci przez mieszkańców sąsiedztwa zdjęcia z wakacji czy wypadów do innych części Stambułu. Uwagę zwraca jednak brak jakichkolwiek fotografii Karanfilköy związanych 
z ulicą Zeytinoğlu. Chociaż stanowi ona kręgosłup transportowy i zwornik przestrzenny całego sąsiedztwa, a przy niej zlokalizowana jest przeważająca liczba miejsc spotkań jego mieszkańców, ilustracje tej drogi powiązane są z jej dalszymi częściami. Te ostatnie przecinają tymczasem już inne, pobliskie sąsiedztwa.

Wszystkie typy obserwacji w ramach metody WWP sugerują, że Karanfilköy traktowane jest jako przestrzeń neutralna. Podobnie jak w przypadku wielu innych, miejskich sypialni o ograniczonej dynamice życia społecznego, użytkownicy tej przestrzeni zurbanizowanej bardzo rzadko dzielą się ze światem ilustracjami potrafiącymi ukazać charakter i specyfikę tego miejsca.

\subsection{Podsumowanie}

Waloryzacja stambulskiego gecekondu na podstawie metody WWP pozwoliła ujawnić złożony obraz tego charakterystycznego typu przestrzeni zurbanizowanej. Wyraźnie odróżnia się on od dwóch pierwszych analizowanych w książce studiów przypadku, gdzie wytwarzanie przestrzeni w wyniku grupy posunięć aktorów nieformalnych nie było aż tak odległe od formalnego sposobu jej kształtowania. Pomimo zupełnie bezplanowej genezy jest to przykład całkiem korzystnie zwymiarowanej przestrzeni zamieszkanej, dzięki czemu wyodrębnił się tutaj lokalny ośrodek usługowy. Sąsiedztwa nie dotknął transportowy paraliż, jakiego można byłoby się spodziewać w odniesieniu do osiedla nieformalnego. Sporo jest też zieleni, szczególnie jak na standardy tej tureckiej metropolii. Karanfilköy jest powszechnie lubiane, a najbardziej lubią je zazwyczaj ci użytkownicy, którzy też najlepiej je znają. Dość silna jest lokalna społeczność, chociaż zarazem niekiedy stosunkowo zamknięta względem rozmaitych grup z zewnątrz. Wysoki jest przy tym poziom tutejszego bezpieczeństwa. Doceniają ten fakt, oprócz samych mieszkańców, również osoby z zewnątrz czy nawet te wyraźnie niechętne sąsiedztwu. Negatywny wpływ odgrywają w tym zakresie głównie uwarunkowania wyższego rzędu, właściwe dla państwa zarządzanego przez coraz bardziej represyjną dyktaturę.

Monitoring sieci wykazuje neutralne traktowanie tej przestrzeni przez jej użytkowników. Rzadko staje się ona tematem przejawów wyraźnego zaangażowania stambulskich internautów. Zupełnie nieczytelna jest lokalna struktura przestrzenna, a większość spośród nawet jej regularnych użytkowników ma problemy z dokładnym opisaniem którychkolwiek ze składających się na nią elementów. Brakuje też usług i przestrzeni publicznych dla wykonywania czynności innych niż te najbardziej podstawowe i niedobrowolne. Pomimo zaobserwowania kilku dysfunkcji, a także ciążącego na gecekondu stygmatyzującego je stereotypu, jest to przykład urbanistyki oddolnej funkcjonującej całkiem sprawnie w analizowanych aspektach. Analiza porównawcza pokazuje, że miejsce to nie jest gorzej postrzegane 
niż znacznie bardziej sformalizowane pobliskie sąsiedztwa. Skutecznie opiera się też negatywnym przejawom „uszlachetniania” przestrzeni, które dotykają na ogół nowych osiedli forsowanych przez deweloperów i sprzyjających im polityków. W starszej części okolicy nie dochodzi do większej wymiany ludności, a lokalne usługi zachowują pierwotny i nieusieciowiony charakter. Dzięki temu znaczenie placówek handlu i gastronomii odnosi się do funkcji bardzo ważnej, ale rzadko kiedy dostrzegalnej w wyraźny sposób. Pozostają one bowiem zwornikami całej społeczności, stanowiącymi miejsca spotkań jej członków. Nie są widoczne symptomy spekulacji nieruchomościami lub manipulowania czynszami. W zasadzie nie jest zatem możliwe zaobserwowanie w tej okolicy negatywnych wymiarów gentryfikacji. 


\section{Bilans oddolności - zakończenie}

\section{Urbanistyka oddolna w społecznym wytwarzaniu przestrzeni - wnioski}

Omówione w drugiej części tej książki studia przypadków dotyczą społecznie wytworzonych przestrzeni zurbanizowanych powstałych w myśl schematu określanego przeze mnie mianem urbanistyki oddolnej. W wypadku trzech przywołanych miejsc zaangażowanie aktorów społecznych następowało na zróżnicowanym poziomie. Odcisnęło jednak piętno na ostatecznie powstałych kontekstach przestrzennych. Przykład pierwszy, Plac Grzybowski, to egzemplifikacja przekształceń środowiska zurbanizowanego zainicjowanych przez interwencję artystyczną. Poprzedziła ona zdecydowanie bardziej złożone, późniejsze działania autorstwa tak władz samorządowych, jak komercyjnych inwestorów. Procesy te wpisują się równocześnie w dwa odmienne wymiary wytwarzania przestrzeni oparte na metodach formalnych. Na etapie wstępnym, czyli przygotowania instalacji Joanny Rajkowskiej i jej wpływu na otoczenie, związanego z podejmowanymi w tym miejscu działaniami mieszkańców, było to działanie zakorzenione wyraźnie partycypacyjnie. Odnosiło się też jednak do legalnych działań z obszaru metod nieformalnych. Późniejsze decyzje władz dzielnicowych respektowały wolę strony społecznej w sposób co najwyżej ograniczony. Tylko pobieżnie angażowały bowiem końcowych użytkowników tej przestrzeni w sposób, który jest charakterystyczny dla konsultacyjnego wytwarzania przestrzeni. Podobną drogą powstawał także nowojorski park High Line. Działania strony społecznej zachodziły jednak w tym przypadku w większej zgodności z finalnie obranym sposobem rewaloryzacji wiaduktu zamkniętej linii kolejowej. Przekształcenie to przyjęło charakter partycypacyjny w jego pełnym rozumieniu. To nie lokalne władze przetworzyły na własny sposób koncepcję wypracowaną przez miejskich aktywistów. Przeciwnie, to politycy ulegli sile perswazji strony społecznej i wcielili w życie założenia ich koncepcji. Karanfilköy w Stambule to natomiast przykład wytwarzania przestrzeni z wykorzystaniem metod nieformalnych. Krzyżowały się w tym kontekście oparte na skłotingu działania 
o charakterze w pełni partyzanckim z różnymi sposobami ich późniejszej legalizacji. Relacja władz z aktorem społecznym nastąpiła tutaj dopiero na finalnym etapie i była w gruncie rzeczy zdecydowanie bardziej powierzchowna.

Wieloczynnikowa waloryzacja umożliwiła identyfikację różnych wartości przestrzennych w zakresie przywołanych tu przykładów przestrzeni zurbanizowanej. Doprowadziła do tego celu zarówno na poziomie jej rzeczywistego sposobu użytkowania, jak i wyobrażonych sposobów percepcji tych miejsc. Umożliwiło to posłużenie się rozmaitymi „obiektywnymi”, subiektywnymi i behawioralnymi wskaźnikami jakości środowiska zurbanizowanego. Jego przykłady odwołują się do zróżnicowanych kontekstów kulturowych oraz różnych części odmiennych obszarów metropolitarnych. Cechują się w ten sposób różnymi własnościami w zakresie prestiżu czy walorów funkcjonalnych.

Plac Grzybowski w Warszawie to miejsce o wysokiej jakości użytkowej. Jest chętnie wykorzystywany jako przestrzeń publiczna i rekreacyjna zarówno przez mieszkańców najbliższej okolicy, jak i osoby przyjezdne. Stopień gentryfikacji tego obszaru jest jeszcze umiarkowany. Zauważalne są już jednak w tym zakresie negatywne zjawiska, takie jak nabierająca tempa gentryfikacja społeczna. Pod innymi względami jest to miejsce niewyróżniające się specjalnie na tle podobnych placów w tej samej okolicy. Plac Grzybowski nie ma nad nimi szczególnie istotnych przewag konkurencyjnych. Podobnie wygląda ukazany w badaniach obraz nowojorskiego parku High Line. Ta przestrzeń jest także bardzo chętnie i różnorodnie użytkowana, budzi pozytywne uczucia wśród swoich odbiorców i oceniana jest jako miejsce szczególnie wartościowe. Jeszcze silniejsza niż w przykładzie warszawskim zdaje się jednak lokalnie występująca gentryfikacja. Dla tego procesu park wytworzony w ramach mechanizmu urbanistyki oddolnej stał się dodatkowym akceleratorem, równocześnie w wymiarze społecznym, ekonomicznym i przestrzennym. Także w tym przypadku odnotować można, że inne miejsca na Manhattanie pozbawione zbliżonego pod względem skali wpływu aktorów społecznych są równie dobrze funkcjonującymi przestrzeniami publicznymi. Z kolei sąsiedztwo Karanfilköy odróżnia się w kwestii swojej genezy. Ma ona oblicze bardziej nieformalne niż w obu pozostałych badanych przypadkach. Pomimo to jest to okolica lubiana przez użytkowników i zdaje się wykazywać wysoką jakością życia w środowisku zurbanizowanym. Bardzo skutecznie opiera się gentryfikacji, która w pozostałych miejscach analizowanych w pracy jest z różnym natężeniem wywoływana właśnie przez podejmowane przez aktorów społecznych oddolne interwencje. Negatywną stroną gecekondu okazuje się wyposażenie w niektóre usługi podstawowe. Okolica ta wcale jednak nie wypada pod tym względem gorzej niż wiele przestrzeni wytwarzanych w sposób formalny. Wspomnieć można tu na przykład współczesne blokowiska deweloperskie, które także pozbawione są dostępu do newralgicznych dla społeczności lokalnych usług oświatowych. 
Przywołane wyżej przypadki przedstawiają tylko część szerokiego spektrum wytworów urbanistyki oddolnej. Społeczne wytwarzanie przestrzeni przebiega na wielu poziomach, prowadząc do niekiedy sprzecznych rezultatów i powstawania odmiennych typów przestrzeni zurbanizowanej. Nawet traktowane zbiorczo metody formalne i nieformalne bardzo różnią się od siebie. Pomimo świadomości, że wykorzystany w pracy dobór przykładów nie ma charakteru w pełni reprezentatywnego, na kanwie opisanych przypadków możliwe jest wskazanie niektórych właściwości miejsc powstałych w wyniku działań z zakresu urbanistyki oddolnej. Przemawia za tym wyselekcjonowanie studiów przypadku o dużym zróżnicowaniu w zakresie właściwych im kontekstów geograficznych, społecznych, ekonomicznych i historycznych. Ich analiza pozwala wyprowadzić również pewne wnioski dotyczące refleksji nad współczesną, polską polityką miejską.

Zauważyć należy przede wszystkim, że urbanistyka oddolna niekoniecznie wywołuje gentryfikację, chociaż często nie jest w stanie powstrzymać zwłaszcza negatywnych aspektów tego procesu. Siła społecznego zaangażowania jako sposobu uwrażliwienia na ujemne skutki przestrzennych przekształceń okazuje się zatem tylko pozorna. Również pod kątem walorów użytkowych miejsca doświadczające takich działań nie zawsze są tak funkcjonalne, jak chcieliby sądzić zwolennicy partycypacyjnych metod projektowania, organizowania i zarządzania przestrzenią zurbanizowaną. Silny wpływ wywierają również bieżące mody. Niekiedy miejsca powstałe $w$ ramach procedur urbanistyki oddolnej nie są lepiej oceniane przez odbiorców. Dzieje się tak nawet wówczas, gdy z pewnych względów są przez nich najczęściej wybierane, użytkowane, jak również opisywane przez ekspertów.

Także kapitał społeczny nie jest przypisany jednolicie miejscom będącym wynikiem działania aktorów społecznych, a do tego cechujących się wysokim stopniem rozwoju gospodarczego czy uporządkowaniem struktury urbanistycznej. Przestrzeń zdegradowana przymusza mieszkańców do organizowania wzajemnej samopomocy i zacieśniania sąsiedzkich więzi. Ich lojalność względem siebie bywa warunkiem koniecznym dla możliwości przetrwania niektórych z gorzej sytuowanych społeczności. Prawidłowości te często są jednak ignorowane przez zwolenników administracyjnego uzdrawiania takich miejsc na siłę. Dzieje się tak dlatego, że nie potrafią oni zdiagnozować rzeczywistej sytuacji ze względu na tendencyjne dobieranie wskaźników lub twarde przesądy i osobiste uprzedzenia. Ich przykładem jest „globalny materializm”, czyli opisana przez Kacpra Pobłockiego skłonność do utożsamiania wyobrażonego „barbarzyństwa” - rozumianego jako sprzeciw wobec okcydentalnie zorientowanego materializmu - z bezrefleksyjnym zacofaniem, a nie dobrowolnym wyborem alternatywnej trajektorii życia i rozwoju. Pokutuje tutaj wizja, którą, odwołując się do tej koncepcji, opisałbym jako teleologiczną i ewolucyjną. Zakłada ona, „że rozwijać można się na jeden sposób, że każdy 
rozwój dąży do jakiegoś celu oraz że polega na przechodzeniu przez poszczególne etapy lub fazy" . Na przykład fetyszyzowana niekiedy przedsiębiorczość mierzona za pomocą liczby obecnych na danym obszarze podmiotów gospodarczych ukazuje niekiedy raczej wysoki poziom samozatrudnienia. Zamiast głębokiej witalności przestrzeni dowodzić może to równie dobrze wymuszonej prekaryzacji dotykającej ludności badanego terytorium. Nie tylko nie rozwiązuje to problemów społecznych, ale często nasila ryzyko wystąpienia rozmaitych zagrożeń właściwych niespójnemu modelowi ekonomicznego wzrostu² ${ }^{2}$.

Prawidłowości te nie są dostrzegane nie tylko przez wyalienowanych ze społeczeństwa miejskich włodarzy. Nawet niektórzy kierujący się najszlachetniejszymi intencjami miejscy aktywiści mogą okazać się w ten sposób nieświadomie adwokatami procesów negatywnie przekształcających przestrzeń zurbanizowaną. Lub też takich procesów, w których rachunek korzyści i strat jest bardziej niejasny. Uratowanie przed destrukcją zabytku inżynieryjnego, tradycyjnej kamienicy albo powstrzymanie ryzykownej inwestycji potrafi uruchomić inne, niezaplanowane działania. Te ostatnie mogą być negatywne w swoich następstwach. Na przykład High Line to z jednej strony park konserwujący z sukcesem architektoniczne i urbanistyczne dziedzictwo zachodniego Manhattanu oraz rozwiązanie inspirujące architektów krajobrazu na całym świecie. Z drugiej strony jest to jednak enklawa „białego” bogactwa. W dodatku coraz wyraźniej otaczana ze wszystkich stron luksusowymi biurowcami i rezydencjami ze stali, betonu i szkła. Całe sąsiedztwo Meatpacking District staje się w ten sposób - i to niekoniecznie powoli - dostępne właściwie tylko dla najzamożniejszych ludzi. Przemawia to za zasadnością stwierdzenia, że urbanistyka oddolna nie tylko nie zawsze powstrzymuje tego rodzaju gettoizację, ale czasem może sama wprost napędzać procesy elitaryzacji niektórych wycinków przestrzeni zurbanizowanej.

Użytkownicy tej przestrzeni głosują natomiast niekiedy nogami w sposób zupełnie odmienny od tego, jak oczekiwaliby nawet najbardziej uwrażliwieni społecznie aktywiści miejscy. Przykład w tym zakresie stanowią wielkie centra handlowe, niezwykle popularne w Polsce po 1989 roku. Placówki tego typu niekorzystnie oddziałują na różne aspekty przestrzeni zurbanizowanej i jej mieszkańców. Rujnują przede wszystkim drobny handel przyuliczny, co z kolei zmienia sposób i skalę użytkowania wielu przestrzeni publicznych. Czasami zmniejszają nawet poziom

${ }^{1}$ K. Pobłocki, Kapitalizm. Historia krótkiego trwania, Fundacja Bęc Zmiana, Warszawa 2017, s. 61, 430. Podobny schemat znajduje też zastosowanie w niektórych analizach polskiej transformacji po upadku realnego socjalizmu. Zob. np. S. Gökarıksel, Neither teleologies nor "feeble cries": revolutionary politics and neoliberalism in time and space, „Dialectical Anthropology”, nr 1/2018, s. 89.

${ }^{2}$ G. Standing, Prekariat. Nowa niebezpieczna klasa, tłum. K. Czarnecki, P. Kaczmarski, M. Karolak, Wydawnictwo Naukowe PWN, Warszawa 2014, s. 303-304. 
bezpieczeństwa na opustoszałych w związku z tym tradycyjnych ciągach. Prowadzi to do kumulowania negatywnych oddziaływań środowiskowych, tworzenia się wysp ciepła czy gromadzenia w jednym miejscu zbyt intensywnego ruchu samochodowego. Napędza to też proces bezrefleksyjnego nieraz i nadmiernego konsumpcjonizmu. Wielu pracowników shopping malls to pozbawiony jakichkolwiek praw i osłon socjalnych prekariat zatrudniony na podstawie niskopłatnych umów śmieciowych ${ }^{3}$. Niewłaściwe wydaje się nawet ocenianie ich jako miejsc ułatwiających życie osobom niedysponującym dostatecznym czasem na załatwienie swoich spraw. Większość tych czynności można przecież wykonać już za pośrednictwem internetu, który na dodatek ułatwia porównywanie konkurencyjnych ofert i tą drogą dokonywanie racjonalnych wyborów konsumenckich. Niezależnie od tego centra handlowe są jednak lubiane przez klientów. Niechętne im koncepcje teoretyków społecznych nie zmieniają faktu, że stają się one elementem wspólnego wypoczynku i chętnie wybieranymi przestrzeniami spędzania wolnego czasu, ,przejmują[c] rolę miejskiego centrum" ${ }^{4}$. Aprioryczna negacja tego faktu nie sprawi automatycznie, że urbanistyka oddolna stanie się dla nich konkurencyjnym rozwiązaniem. Warto zwrócić uwagę na ten aspekt tym bardziej, że tocząca się w Polsce głośna debata nad kwestią ograniczeń handlu w niedziele skupia się głównie na ekonomistycznym redukcjonizmie i motywowanej religijnie aksjologii. Ignoruje natomiast wątki typowe dla bardziej wyważonej dyskusji z zakresu polityki miejskiej.

Wnioskiem głównym w stosunku do polskiej polityki miejskiej z prowadzonych w tej pracy rozważań jest zatem konstatacja, iż formalizacja procesu społecznego wytwarzania przestrzeni rozumianego jako taki, który kładzie znaczny nacisk na partycypację społeczną, niekoniecznie wywołuje korzyści odczuwalne dla użytkowników przestrzeni zurbanizowanej. Często wykrzywia raczej jej pierwotną ideę oraz prowadzi do umocnienia się najbardziej uprzywilejowanych grup. Partycypacja w zakresie społecznego wytwarzania przestrzeni może jej nawet czasem szkodzić. Zgodzić można się z pesymistyczną refleksją Aleksandry Wasilkowskiej, wedle której pozbawiony regulacji

żywioł oddolnych inicjatyw może [...] doprowadzić do destrukcyjnych efektów ubocznych. Zawłaszczanie przestrzeni przez określone grupy interesów może prowadzić do destabilizującej miasto homogenizacji, gentryfikacji, grodzenia osiedli czy atrofii przestrzeni publicznej5.

3 P. Fleming, The Human Capital Hoax: Work, Debt and Insecurity in the Era of Uberisation, „Organization Studies”, nr 5/2017, s. 12.

${ }_{4}^{4}$ M. Smagacz-Poziemska, Czy miasto jest niepotrzebne? (Nowe) przestrzenie życiowe młodych mieszkańców, Wydawnictwo Naukowe Scholar, Warszawa 2015, s. 72-73.

${ }^{5}$ A. Wasilkowska, Warszawa jako struktura emergentna: Em_Wwa 1.0 / Warsaw as Emergent Structure: Em_Wwa 1.0, [w:] A. Wasilkowska, A. Nowak (red.), Warszawa jako struktura emergentna: Em_ Wwa 1.0 / Warsaw as Emergent Structure: Em_Wwa 1.0, Fundacja Bęc Zmiana, Warszawa 2014, ebook. 
Opisany przez Markusa Miessena koszmar partycypacji nie jest tym samym tylko konstruktem teoretycznym, lecz realnym zagrożeniem dla przestrzeni zurbanizowanej i polityki miejskiej. Zdaniem tego autora techniki społecznego zaangażowania zyskują poparcie jako pozwalające „przykryć” niedoskonałości polityki publicznej.

Partycypacja stała się skrajnie popularna wśród polityków pragnących się upewnić, że zamiast tworzyć krytyczne treści, mogą posłużyć się narzędziem, które samo w sobie odbierane jest jako krytyczne podejście ${ }^{6}$.

Partycypacja, wskazuje tu Miessen, staje się - świadomie lub nie - celem dla partycypacji samej w sobie. Nie jest natomiast narzędziem poprawy jakości życia w środowisku zurbanizowanym. W najlepszym przypadku przypomina jedynie zachowawcze planowanie o charakterze śledzącym, które nie antycypuje skutecznych rozwiązań strategicznych prowadzących do kształtowania harmonijnego osadnictwa ${ }^{7}$.

Partycypacja obywatelska jako mechanizm społecznego wytwarzania przestrzeni może tym samym także w Polsce prowadzić do sprzeczności wobec wizji zrównoważonego rozwoju snutej przez wielu miejskich aktywistów, jak i przedstawicieli władz publicznych. Dzieje się tak nawet wówczas, kiedy sprzyjają one pełnej transparentności i starają się jak najlepiej reagować na potrzeby zgłaszane przez mieszkańców za pomocą animowanych przez tych ostatnich ruchów miejskich. Negatywne skutki nie wynikają jednak tylko z fasadowości partycypacji. Powierzchowność tę kojarzy się przecież z pozorowaniem oddawania realnej władzy w ręce mieszkańców przez przywódców niechcących pozbyć się w rzeczywistości swoich wpływów politycznych. Nie chodzi też o pozorność możliwości samorządowców w tym zakresie jako podporządkowanych wpływom podmiotów znacznie od nich silniejszych. W tej grupie wskazać można byłoby wszakże choćby i autorytarne państwo z poziomu centralnego, które niechętnie deleguje zadania na niższy szczebel, bądź potężnych inwestorów na rynku nieruchomości. Tymczasem zdają się oni dzielić cenną z punktu widzenia renty gruntowej przestrzeń miejską na podobieństwo białych kolonizatorów zdobywających niczyj ich zdaniem, a przez to nieomal „orientalny”, zurbanizowany świat ${ }^{8}$. Partycypacja w niektórych

${ }^{6}$ M. Miessen, Koszmar partycypacji, tłum. M. Choptiany, Fundacja Bęc Zmiana, Warszawa 2013, s. 73.

7 J.M. Chmielewski, Teoria i praktyka planowania przestrzennego. Urbanistyka Europy, Oficyna Wydawnicza Politechniki Warszawskiej, Warszawa 2016, s. 181-185.

${ }^{8} \mathrm{~Np}$. Neil Smith opisuje tego typu porównania wyobrażenia o pionierskiej gentryfikacji z rzekomą odwagą i szlachetnością „odkrywców” Ameryki. Zob. idem, The New Urban Frontier. Gentrification and the revanchist city, Routledge, London 1996, s. 9-27. 
aspektach społecznego wytwarzania przestrzeni okazuje się mało skuteczna właśnie dlatego, że nie prowadzi do rozwiązywania realnie istniejących problemów. Jak komentuje tę kwestię Krzysztof Nawratek, „projektowanie partycypacyjne jest zbyt fragmentaryczne, by stanowić jakąkolwiek przeciwwagę dla rynkowych spekulacji”". Urbanistyka oddolna w wielu przypadkach nie radzi sobie z niektórymi zagrożeniami towarzyszącymi procesowi urbanizacji. Zupełnie nieskuteczna okazuje się w starciu z gentryfikacją miejskiej przestrzeni segregującą współczesne metropolie w niejednokrotnie bardzo brutalny sposób. Również z punktu widzenia rodzimej polityki miejskiej takie rozwiązania raczej nie mają szans rozwiązać jej kluczowych problemów. Miękkie, taktyczne w swoim charakterze działania urbanistyki oddolnej nie rozwiążą na przykład kwestii tak zwanej dzikiej reprywatyzacji, będącej najbrutalniejszą formą „uszlachetniania” przestrzeni zurbanizowanej. Tego typu zjawiska wymagają zapewne działań zdecydowanie formalnych, połączonych z wolą polityczną najbardziej wpływowych aktorów procesu społecznego wytwarzania przestrzeni, nie zaś luźnych zrzeszeń o oddolnym charakterze.

Powyższe rozważania pod znakiem zapytania stawiają kwestię trafności współcześnie prowadzonej polityki miejskiej w wariancie, który jest przyjazny szeroko rozumianemu aktywizowaniu społeczności lokalnych i wdrażaniu daleko posuniętych form partycypacyjnych. Odwołując się raz jeszcze do uwag, które formułowałem we wprowadzeniu, zwracam uwagę na znaczenie kategorii zaniechania jako metody formułowania polityk publicznych. Brak reakcji i rozwiązania problemu z perspektywy polityki publicznej tworzy tak zwane koszty zaniechania. Chociaż rzadko kiedy zwraca się uwagę na tę kwestię, stanowią one niezwykle ważną część racjonalnego bilansu efektów działań publicznych. Pozornie kojarzy się je najczęściej wyłącznie z obciążeniami i brakiem wypracowanego zysku ekonomicznego. W rzeczywistości zysk ten opiera się jednak na utraconych dodatkowych kosztach, jakie należałoby ponieść w przypadku braku wdrożenia zapobiegającej im polityki. Ich finansowe oszacowanie może być niekiedy nawet całkiem dokładne, możliwe jest także wskazanie innych metod obliczania takich korzyści ${ }^{10}$. Ujęcie tego typu jest w pewnym stopniu redukcjonistyczne, nie zwraca bowiem uwagi na fakt, iż zaniechanie nie w każdym przypadku ma czysto pasywny charakter. Może nawet wynikać z ideologicznego uwikłania.

Także i w tym przypadku użyteczny jest polski przykład „odzyskiwania” nieruchomości przez „prawowitych właścicieli”, uniemożliwiający planowanie strate-

9 K. Nawratek, Tarcza wielu możliwości, rozmawia D. Leśniak-Rychlak, „Autoportret. Pismo o dobrej przestrzeni”, nr 1/2017, s. 20.

${ }^{10}$ D.L. Weimer, A.R. Vining, Assessing the Costs and Benefits of Social Policies, [w:] eidem (red.), Investing in the Disadvantaged Assessing the Benefits and Costs of Social Policies, Georgetown University Press, Washington 2009, s. 9-14. 
giczne rozwoju przestrzeni zurbanizowanej. Jak pisze zajmująca się tym zjawiskiem aktywistka miejska i prawniczka Beata Siemieniako, u jego przyczyn leżą bowiem nie tylko kolesiostwo i anormalne w swoim charakterze nieprawidłowości, zakłócające działalność potencjalnie wydajnego systemu. Powodem jest także neoliberalna wizja polityczna ${ }^{11}$. Joanna Kusiak sugeruje wręcz, że teoria przestrzennego chaosu może być „salonowym” wariantem teorii spiskowej. „To, co jawi się nam jako chaos, jest w rzeczywistości bardzo dobrze zorganizowane. Nie można tu oczywiście mówić o sprawczości uproszczonego typu, zredukowanej [...] do działania konkretnej grupy społecznej"12. Sugerowanie tego rodzaju przyczynowego rozmycia pozwala jednakże zaciemnić kontekst zgodnie z partykularnymi interesami określonych aktorów procesu wytwarzania przestrzeni.

Przez politykę publiczną rozumie się zazwyczaj działania publiczne o charakterze technokratycznym, merytorycznym, możliwe do odseparowania od wpływów ideologicznych. Krzysztof Jasiecki pisze zatem o „merytokracji” jako ustroju, „W którym rządy sprawują (lub powinni sprawować) ludzie najlepiej do tego przygotowani - kompetentni i profesjonalni”" ${ }^{33}$. Emanacją tego modelu jest polityka publiczna różniąca się od walki politycznej jako potocznie rozumianego „politykowania”. Dezideologizacja polityki publicznej wydaje się jednak głęboko iluzoryczna, jeśli wziąć pod uwagę, iż także na wymiar policy oddziałują określone systemy wartości i przekonań interesariuszy tejże polityki ${ }^{14}$. Jak pisze Marshall Berman, same kryteria sukcesu i porażki są dalece relatywne i uzależnione od indywidualnych preferencji i interesów. Autor ten przekonuje, że „optymalne sukcesy dla niektórych mogą oznaczać destrukcję życia publicznego dla nas wszystkich”"15. Coś, co dla jednych będzie miejską odnową, dla innych staje się opisywanym przez tego filozofa miastobójstwem (urbicide), unicestwieniem miejskiego życia społecznego. Sposób dysponowania ograniczonymi zasobami, podejmowania poszczególnych decyzji i konkretnego ukierunkowania działań w zakresie polityki miejskiej nie powinien mieć zatem charakteru uniwersalnego.

Ideologia na poziomie zarządzania przestrzenią zurbanizowaną na lokalnym szczeblu czasem dotyka sfery czysto symbolicznej. Przykładem w zakresie polskiej

11 B. Siemieniako, Reprywatyzując Polskę. Historia wielkiego przekrętu, Wydawnictwo Krytyki Politycznej, Warszawa 2017, ebook.

12 J. Kusiak, Chaos Warszawa. Porządki przestrzenne polskiego kapitalizmu, Fundacja Bęc Zmiana, Warszawa 2018, s. 217.

${ }^{13}$ K. Jasiecki, Zasady merytokratyczne w polityce państwa - wzloty i upadki, „Studia z Polityki Publicznej”, nr 3/2016, s. 10.

${ }^{14}$ R. Szarfenberg, Polityka publiczna - zagadnienia i nurty teoretyczne, „Studia z Polityki Publicznej”, nr 1/2016, s. 57.

${ }^{15}$ M. Berman, Take It to the Streets: Conflict and Community in Public Space, [w:] idem, Modernism in the Streets. A Life and Times in Essays, oprac. D. Marcus, S. Sclan, Verso, London 2017, ebook. 
polityki miejskiej są tutaj tarcia wokół lokalizacji pomnika mającego godnie upamiętnić w Warszawie ofiary katastrofy smoleńskiej. Innymi razy chodzi o względy bardziej merytoryczne. Odnieść się można tu choćby i do oczekiwań względem wysoce kapitałochłonnej i związanej z zaspokojeniem najbardziej elementarnych potrzeb socjalnych polityki mieszkaniowej. Ucieczka od ideologii wydaje się zatem absolutnie niemożliwa. Ideologiczne zacietrzewienie może też wynikać z zewnętrznej krytyki polityki publicznej. Z zarzutem o sprzyjanie poglądom skrajnie lewicowym spotykają się współcześnie w Polsce bardzo często zwolennicy koncepcji zrównoważonego rozwoju. Na odcinku urbanistyki sympatyzują oni zwłaszcza z ideą gruntownego zreformowania polityki transportowej ${ }^{16}$. Krytyka „lewaków na rowerach" jest jednak o tyle zaskakująca, że ich wizja stanowi w rzeczywistości powrót do tradycjonalistycznej koncepcji urbanizacji. To burzyciele konserwatywnych wartości w dziedzinie projektowania, zwłaszcza zaś urbaniści modernistyczni, kojarzeni z ideologiami centrowymi lub lewicowymi, byli głównymi architektami obecnego modelu transportowego. Obrazowo określił to sam Le Corbusier. Jak pisał ów „papież modernizmu”, przyznający się przy tym do interesowania swoimi koncepcjami między innymi komunistów, to „[s]amochód musi uratować wielkie miasto". W celu realizacji swej wizji sławny architekt spotykał się z przedstawicielami francuskich koncernów motoryzacyjnych. Zupełnie otwarcie deklarował rozmowy z firmami Peugeot, Citroën i Vosin. Na cześć tej ostatniej nazwał nawet swój słynny plan urbanistyczny. Ciekawe zresztą jest, że sam autor Jednostki marsylskiej własne koncepcje starał się przedstawiać jako merytokratyczne. Pragnął bowiem „pozostać na płaszczyźnie technicznej”, ponieważ jak deklarował, „nikt nie namówi mnie do uprawiania polityki" ${ }^{17}$.

Popularny swego czasu w środowisku rodzimych ruchów miejskich stał się również koncept „miastopoglądu”. Pod hasłem tym kryje się zdaniem zwolenników tego rozwiązania unikające ideologicznego zacietrzewienia skupienie się na najważniejszych problemach wszystkich mieszkańców miast. W jaki sposób jednak zoperacjonalizować ten „pogląd” i jak określić hierarchię problemów w oderwaniu od politycznych idei? Co jest ważniejsze - redukcja poziomu zakorkowania, emisji smogu czy handlu roszczeniami w związku z „dziką reprywatyzacją”? Są to kluczowe i trudne do rozwiązania dylematy, $\mathrm{z}$ jakimi zmierzyć muszą się bezkrytyczni apologeci ,miastopoglądowej” urbanistyki oddolnej ${ }^{18}$. Podobne wątpliwości

${ }^{16}$ Podobne zjawisko w Stanach Zjednoczonych zob. M. Davis, City of Quartz: Excavating the Future in Los Angeles, Vintage Books, New York 1992, s. 122-123.

17 Le Corbusier, Urbanistyka, tłum. T. Swoboda, Centrum Architektury, Warszawa 2015, s. 297, 321.

${ }^{18}$ Część polskich aktywistów miejskich przeciwstawia się jednak takiej optyce, traktując jako zbiór doktrynalnych założeń np. Tezy o mieście Kongresu Ruchów Miejskich (op. cit.). Dziękuję za tę uwagę Hannie Gill-Piątek. 
dotyczą nawet głównego dokumentu programowego polskiej polityki miejskiej. Jak pisze na jego temat Rafał Matyja,

analiza politycznych aspektów omawianych problemów jest tym, czego autorzy [tego dokumentu] skrupulatnie unikali. Nie [mowa] przy tym o polityce rozumianej jako rywalizacja między partiami, ale przede wszystkim jako przemyślane i spójne działania rządu, uwzględniające fakt rywalizacji różnych podmiotów o wpływ na sprawy publiczne i o zasoby pozostające w dyspozycji instytucji publicznych ${ }^{19}$.

Ten sam autor dodaje też, że

[z]achowania administracji, podobnie jak dokumenty strategiczne, nigdy nie są politycznie neutralne. Przeciwnie - w demokracji to element realizacji zamierzeń rządu mającego "polityczną« właśnie legitymację do rządzenia lub pewnej szerszej wizji ustrojowej państwa ${ }^{20}$.

Równie krytyczni zdają się anglosascy badacze polityki mieszkaniowej David Madden i Peter Marcuse. Ich zdaniem

termin „polityka mieszkaniowa” [housing policy] już od swego zarania dowodzi własnej mityczności. To określenie samo w sobie sugeruje istnienie zgodnych wysiłków sektora publicznego dla rozwiązania problemu mieszkaniowego. Historyczna analiza działań publicznych i bezczynności dotykającej mieszkalnictwa niczego takiego jednak nie ujawnia. Polityka mieszkaniowa jest ideologicznym artefaktem, nie realną kategorią. Jest to sztucznie wyraźny obraz tego, co państwo rzeczywiście robi w gąszczu nieskoordynowanych i czasami sprzecznych wysiłków ${ }^{21}$.

Nie jest to zresztą zjawisko nowe, wziąwszy pod uwagę, że

polityka mieszkaniowa była konsekwentnie planowana w reakcji na potrzeby przemysłu budownictwa mieszkaniowego i politycznych potrzeb tych, którzy rządzą państwem² ${ }^{22}$

Już w dobie XIX-wiecznych osiedli patronalnych, znacznie wyprzedzających neoliberalną politykę społeczną $\mathrm{w}$ tak zwanym modelu workfare ${ }^{23}$, celem funk-

19 R. Matyja, Krajowa Polityka Miejska okiem politologa, „Zarządzanie Publiczne”, nr 3/2015, s. $57-58$.

${ }^{20}$ Ibidem.

21 D. Madden, P. Marcuse, In Defense of Housing. The Politics of Crisis, Verso, London 2016, ebook. Podobnie politykę mieszkaniową ocenia też Alexander Vasudevan. Według niego „mieszkalnictwo nie jest już postrzegane jako podstawowa potrzeba społeczna, ale instrument wytwarzania zysków przekształcający dzisiejsze miasta w obszary intensywnych wysiedleń i nierówności, wyzysku oraz ubóstwa”. Zob. idem, The Autonomous City. A History of Urban Squatting, Verso, London 2017, ebook.

${ }^{22}$ Ibidem.

23 „Polityka workfare nie ma na celu redukcji ubóstwa, lecz próbuje jedynie zmniejszyć widzialność biedy w obywatelskim krajobrazie”. Zob. L. Wacquant, Punishing the Poor. 
cjonowania społecznie zorientowanego mieszkalnictwa było przede wszystkim umożliwienie nie tyle samego egzystowania, ile wprost reprodukcji siły roboczej. Cel ten zresztą nie uległ zmianie do dzisiaj, skoro praktycznym celem polityki mieszkaniowej pozostaje $\mathrm{w}$ dalszym ciągu działanie służące utrzymaniu wzrostu gospodarczego.

Prowadzi to do wniosku być może najbardziej istotnego z punktu widzenia refleksji nad polityką miejską. Jest nim konstatacja, że roszcząca pretensje do lokowania się ponad ideologicznymi podziałami urbanistyka oddolna będzie mogła stać się efektywnym narzędziem polityki publicznej dopiero wówczas, gdy zostanie użyta przy zachowaniu świadomości towarzyszących jej politycznych uwikłań. Dopiero wtedy jasne stanie się bowiem, że dotycząca jej „ideologiczność jest tak powszechna, że stała się przezroczysta" ${ }^{24}$. Polska polityka miejska, by znowu sięgnąć do rozważań ze wstępu do tej pracy, nie może być zatem Mannowską nie-polityką.

Sformułowane wyżej uwagi pozwalają odnieść się do postawionych na wstępie pytań badawczych. Cel pracy przewidywał zbadanie następstw interwencji przestrzennych podejmowanych przez aktorów społecznych w różnych kontekstach kulturowych i geograficznych. W świetle powyższych konstatacji nie sposób nie uciec się do stwierdzenia, że oddolna forma prowadzenia działań nie zawsze wydaje się bardziej trafna od nawet bardzo mało responsywnych programów polityki publicznej. Omawiane studia przypadku dostarczyły przykładów, w których dysfunkcje społecznie zorientowanych metod wytwarzania przestrzeni prowadzą do nowych wad środowiska zurbanizowanego. Możliwym następstwem jest też występowanie zjawisk problemowych nieobecnych wcześniej w tym środowisku.

Jak się wobec tego wydaje, uczestnictwo pozostałych interesariuszy w zarządzaniu miastem jest konieczne. Jednakże nie w każdym kontekście i nie w każdej formie działania są to mechanizmy skuteczniejsze w rozwiązywaniu problemów społecznych od odgórnie prowadzonych polityk. Odpowiedź na kolejne z postawionych na wstępie pytań położyć musi nacisk na wskazanie większego niuansowania partycypacji społecznej w tym zakresie. Pytanie o wpływ urbanistyki oddolnej skłania do odróżnienia skutków takich działań w uzależnieniu od odmiennych grup ich odbiorców. Z perspektywy mieszkańców są to rozwiązania pożądane tylko wówczas, gdy pozostaną pod ich pełną kontrolą oraz nie będą miały na celu dokonania radykalnych zmian w charakterze modyfikowanego otoczenia. Partycypacja wydaje się dla nich bardziej korzystna wtedy, gdy prowadzi do obrony ich

The Neoliberal Government of Social Insecurity, Duke University Press, Durham-London 2009, s. 59. Podkreślenie w oryginale.

${ }^{24}$ K. Nawratek, Dziury w całym. Wstęp do miejskich rewolucji, Wydawnictwo Krytyki Politycznej, Warszawa 2012, s. 23. 
interesów, ale nie wyraża ambicji przekształcania środowiska zurbanizowanego i kompleksowej zmiany jego oblicza. W takim przypadku beneficjentami społecznego wytwarzania przestrzeni okażą się zupełnie inni interesariusze niż lokalna społeczność rozumiana jako całość. Być może będą to jej najzamożniejsi i najbardziej przedsiębiorczy członkowie. W innym przypadku zaś - wprost zewnętrzni inwestorzy z branży nieruchomości i różnego typu usług lokowanych w miejscu przekształconym na gentryfikacyjną modłę.

Postawione we wprowadzeniu do książki pytanie trzecie dotyczy wpływu partycypacji na lokalny rynek nieruchomości. W tym kontekście trudno udzielić jednoznacznej odpowiedzi. Omawiane przykłady przestrzeni wytworzonych społecznie oddziałują na tę kwestię w sposób zróżnicowany, a w niektórych przypadkach ich wpływ ujawnia dopiero zastosowanie bardziej złożonych mierników. Nie udowodniłem na przykład tego, że proces oddolnych przekształceń jest w stanie doprowadzić do zupełnego zmodyfikowania określonych sąsiedztw. Nie zaprezentowałem przecież przykładów całkowitego wyparcia ich dotychczasowej ludności albo też zupełnego zamknięcia się rynku nieruchomości dla tych osób, które wcześniej mogły na nim inwestować. Partycypacja społeczna może jednak w niektórych przypadkach doprowadzić do gwałtownego wzrostu cen budynków, mieszkań i punktów handlowych, a jej wpływ na gentryfikację struktury dostępnych lokalnie usług bywa jeszcze szybszy i bardziej jaskrawy. Uprawomocnione zdaje się tym samym stwierdzenie, że urbanistyka oddolna w zakresie wpływu na lokalny rynek nieruchomości najszybciej i najmocniej oddziałuje na lokale usługowe.

Odpowiedzi na pytanie czwarte, o poziom mierzalności efektów obywatelskich działań w kształtowaniu przestrzeni miejskiej, towarzyszyło wypracowanie złożonej metodyki wieloczynnikowej waloryzacji przestrzeni w postaci autorskiej metody WWP. Nie pozwoliło to na danie zerojedynkowych replik, jednoznacznie oceniających efekty zmian przestrzennych inspirowanych przez aktorów społecznych. Z pewnością udało się jednak wskazać namacalne skutki działań w odniesieniu do poszczególnych czynników. Zatem pozwoliło to dowieść, że pomiary skutków interwencji z zakresu urbanistyki oddolnej są możliwe.

Ostatnie z pytań postawionych w tej pracy zdaje się mieć do pewnego stopnia charakter uznaniowy. Odpowiedź na nie jest wyraźnie związana z osobistym stosunkiem do znacznie wykraczającej poza obszar zainteresowań studiów miejskich refleksji nad skutecznością wszelkich metod partycypacyjnych. Zawarte w książce przemyślenia skłaniają jednak także do paru pesymistycznych konstatacji w odniesieniu do zagadnienia skuteczności działań opartych na partycypacji społecznej w Polsce po 1989 roku. Analizowany przykład pokazał, że władze publiczne udział aktora społecznego często akceptują pozornie i w ograniczonym charakterze. W myśl przyjętej przeze mnie terminologii nie wykracza on $\mathrm{z}$ reguły dalece poza 
konsultacyjny, to jest bardzo powierzchowny charakter uczestnictwa w wytwarzaniu przestrzeni. Udało mi się też znaleźć przykłady uprawomocniające twierdzenie, że w wielu wymiarach partycypacja nie zwiększa efektywności funkcjonowania przestrzeni zurbanizowanej. Przeanalizowanie kilku newralgicznych zmiennych określających jakość życia w środowisku zurbanizowanym bądź jego społeczną percepcję pozwoliło dostrzec miejsca, gdzie osiągnięte zostały zbliżone rezultaty bez udziału oddolnych aktorów. Prowadził do tego albo brak partycypacyjnych działań ze strony sektora publicznego, albo też działalność o charakterze czysto komercyjnym.

Interwencja przestrzenna podmiotu społecznego rzeczywiście zdaje się wywierać znaczny wpływ na przestrzeń zurbanizowaną w takich jej wymiarach, jak poziom jakości życia i waloryzacja kapitałowa nieruchomości. W tym ostatnim przypadku poczynić należy jednak zastrzeżenie, że wpływ ten niekiedy ma charakter ukryty i wyraźny staje się dopiero po zastosowaniu mierników o bardziej pośrednim charakterze. Zgodnie ze wstępnymi przewidywaniami udało się udowodnić, że wpływ ten niekoniecznie ma charakter pozytywny i nie w każdym wymiarze poprawia poziom jakości życia mieszkańców. W innych zaś przypadkach z jej wyższego poziomu korzystają inni użytkownicy niż poprzedni mieszkańcy. Udokumentowanie związków między działaniem aktorów społecznych a ich wpływem na występowanie gentryfikacji potwierdza założenie, iż skutkiem takich interwencji może być zwiększanie się segregacji przestrzennej. Blokowanie tego typu negatywnych przekształceń udało się osiągnąć wyłącznie w trzecim z omawianych w pracy przypadków, czyli stambulskim gecekondu. Dwa pierwsze były natomiast nieformalnymi akceleratorami „uszlachetniania” ich okolicy.

Analiza partycypacji społecznej jako metody społecznego wytwarzania przestrzeni pokazuje, że jest to zjawisko niejednoznaczne i prowadzące niekiedy również do negatywnych przekształceń. Urbanistyka oddolna nie powinna być zatem traktowana jako narzędzie o charakterze uniwersalnym, możliwe do implementowania w każdym przypadku. Z jednej strony bezkrytyczny sposób adaptacji na użytek polskiej polityki miejskiej będzie niestety musiał wywołać liczne, niepożądane skutki. Z całą pewnością będą one odczuwalne dla większości użytkowników przestrzeni zurbanizowanej. Z drugiej strony urbanistyki oddolnej nie należy też jako idei zupełnie odrzucać. Analiza studium przypadku nieformalnego wytwarzania przestrzeni pokazała, że efekty tego typu „mrówczej” rewitalizacji ${ }^{25}$ mogą być o wiele lepsze od tych animowanych przez średnioklasowe ruchy miejskie z globalnej Północy. Tego typu oddolne działania są zresztą już spotykane także w rodzimej przestrzeni zurbanizowanej, by przywołać transformację niektórych socmodernistycznych czy socrealistycznych

${ }^{25}$ Dziękuję za sugestię tego określenia Waldemarowi Siemińskiemu. 
blokowisk ${ }^{26}$. Te ostatnie, wbrew niektórym pesymistycznym przewidywaniom, często okazują się całkiem udanym środowiskiem mieszkaniowym. Funkcjonują o wiele sprawniej niż kojarzone jako stygmatyzujące getta biedy blokowiska w rodzaju amerykańskich osiedli socjalnych i francuskich HLM.

„Mrówcza” rewitalizacja pozwala rozumieć koncepcję regeneracji przestrzeni zurbanizowanej w ramach teorii nielinearnych polityki publicznej, takich jak na przykład model ograniczonej racjonalności (bounded-rationality model) ${ }^{27}$. Mają one mniej redukcjonistyczny charakter od konkurencyjnego względem nich podejścia linearnego. W myśl tego ostatniego cały proces decydowania publicznego można precyzyjnie zaplanować wraz z uzyskaniem bardzo przewidywalnego rezultatu podjętych czynności. Perspektywa ta była najpewniej właściwa w przeszłości, gdy złożoność problemów publicznych zdawała się mniejsza niż obecnie. Polityka publiczna nie miała wtedy tak responsywnego charakteru i nie angażowała tak wielu różnych grup interesariuszy ${ }^{28}$. Dzięki temu jej efekty zdaniem Roberta Geyera i Samira Rihaniego wydawały się bardziej przewidywalne ${ }^{29}$. Późniejsze względem tego ujęcia teorie nielinearne sugerują, że problemów publicznych nie można jednak redukować do ich poszczególnych części. Komponenty te mają zróżnicowaną dynamikę, tak jak na przykład w odniesieniu do różnych i nie zawsze równolegle występujących wymiarów gentryfikacji. Jak komentuje to Andrzej Zybała, odrzucenie takiego sposobu myślenia było

związane z postępującym zjawiskiem komplikowania się zagadnień, które stawały się przedmiotem działań publicznych. Rządzący musieli rozwiązywać coraz trudniejsze problemy, które nie dawały się tak łatwo objąć zracjonalizowanymi metodami rozwiązywania [...]. Naukowcy zaczęli postrzegać proces powstawania polityk jako mniej racjonalny, często pełen nieoczekiwanych zwrotów, stopniowy (inkrementalny), wypełniony pewną dramaturgią sporu, rywalizacji o wpływy. Uznali, że działania publiczne są często wyrywkowe i niekom-

${ }^{26}$ Ł. Drozda, Urbanistyka socmodernistyczna na przykładzie polskich blokowisk z lat 70. i 80. XX wieku, „Studia Miejskie”, nr 26/2017, s. 121; J. Gądecki, I love NH. Gentryfikacja starej części Nowej Huty?, Wydawnictwo Instytutu Filozofii i Socjologii PAN, Warszawa 2012, passim. O dorobku socrealistycznej urbanistyki zob. też S. Kotkin, Magnetic Mountain. Stalinism as a Civilization, University of California Press, Berkley 1997, s. 18-19.

27 B.D. Jones, Bounded Rationality and Public Policy: Herbert A. Simon and the Decisional Foundation of Collective Choice, „Policy Sciences”, nr 3/2002, passim; P. Cairney, T. Heikkila, M. Wood, Making Policy in a Complex World, Cambridge University Press, Cambridge 2019, s. 9-12.

${ }^{28}$ A. Zybała, Polityka publiczna wobec teorii i jej praktyki w Polsce, „Wrocławskie Studia Politologiczne”, nr 18/2015, s. 29-30; J.R. Wedel, C. Shore, G. Feldman, S. Lathrop, Toward an Anthropology of Public Policy, „The Annals of the American Academy of Political and Social Science”, nr 30/2015, s. 39.

${ }^{29}$ R. Geyer, S. Rihani, Complexity and Public Policy: A new approach to twenty-first century politics, policy and society, Routledge, London 2010, s. 13. 
pletne, a ich ostateczny rezultat długo pozostaje niewiadomy, a przynajmniej trudny do przewidzenia $^{30}$.

Praktyka polityki miejskiej w Polsce sprawia tymczasem wrażenie nie związanej ze skrupulatnie zaplanowanym procesem, tylko raczej wypadkowej splotu przypadkowych okoliczności, osób i idei. Przez teoretyków polityki publicznej określane jest to mianem tak zwanego modelu kosza na śmieci (garbage can model) ${ }^{31}$. Krytykowana przez wielu teoretyków, zwłaszcza tych o orientacji konserwatywnej ${ }^{32}$, generalna słabość instytucji publicznych III RP dowodzi zresztą, że jest to o wiele szerszy problem systemowy. Dotyka to prawdopodobnie całej polityki publicznej w dzisiejszej Polsce, a nie tylko jej kluczowego z punktu widzenia moich rozważań wycinka miejskiego. Uwagi te zdają się odnosić także do urbanistyki oddolnej. Trudno uciec od konstatacji, że stosowanie tego sposobu kształtowania środowiska bytowania człowieka nie może być bezrefleksyjne. Zwłaszcza zaś nie tak uniwersalne, jak mogliby oczekiwać niektórzy apologeci tej metody wytwarzania przestrzeni.

\section{Perspektywy dla dalszych badań}

Książka ta napisana została w perspektywie charakterystycznej dla nauk o polityce publicznej, części składowej nowej dyscypliny akademickiej o nazwie nauki o polityce i administracji. W związku z tym koncentrowałem się, po pierwsze, na opisie instrumentu tej polityki - urbanistyki oddolnej. Po drugie - na deskrypcji celu tej polityki związanego z wypracowywaniem takiego modelu społecznego wytwarzania przestrzeni, który przyczynia się do powstania możliwie najbardziej udanego z punktu widzenia jej użytkowników kształtu przestrzeni zurbanizowanej. Założony cel pracy skonfrontowałem z rezultatami interwencji podjętych przez organizacje społeczne. Właśnie temu posłużyło przeprowadzenie waloryzacji metodą WWP. Czwartą z kluczowych płaszczyzn w perspektywie nauk o polityce publicznej jest natomiast analiza aktorów opisywanej polityki. W tym wypadku byli nimi rozmaici interesariusze procesu społecznego wytwarzania przestrzeni.

${ }^{30}$ A. Zybała, Jeszcze raz o politykach publicznych we Wrocławiu, „Miscellanea Anthropologica et Sociologica”, nr 3/2014, s. 160-161.

${ }^{31}$ J. Pierre, B.G. Peters, Governing Complex Societies. Trajectories and Scenarios, Palgrave Macmillan, London 2005, s. 52.

32 R. Matyja, Wyjście awaryjne. O zmianie wyobraźni politycznej, Karakter, Kraków 2018, passim; J. Staniszkis, Samoograniczająca się rewolucja, Europejskie Centrum Solidarności, Gdańsk 2010, s. 9-16; eadem, 0 władzy i bezsilności, Wydawnictwo Literackie, Kraków 2006, s. 25-34; W. Kieżun, Patologia transformacji, Poltext, Warszawa 2012, passim. 
Tego typu ujęcie badawcze, właściwe refleksji polityko-publicznej, wydaje się ciekawe również z punktu widzenia szerzej rozumianych studiów miejskich. Interdyscyplinarność obu tych podejść i wspólne zainteresowanie tematyką urbanistyczną przemawia za tym, aby badania w perspektywie polityki publicznej włączyć do studiów miejskich jako kolejne z uprawnionych w tym zakresie podejść naukowych. Na równi z takimi jak te typowe dla socjologii miasta, psychologii środowiskowej, geografii, ekonomii czy innych dyscyplin kojarzonych już do tej pory ze studiami miejskimi. Perspektywa polityki publicznej jest w Polsce szczególnie ciekawa ze względu na dopiero początkowy etap wypracowywania zasad rodzimej polityki miejskiej. Nowatorski charakter i oczywiste dlań ryzyko popełniania błędów charakterystycznych dla pionierskich działań skłaniają do przeprowadzania tego typu analiz. Mogą one niezwykle przydać się w ewaluacji zróżnicowanych działań z obszaru wytwarzania przestrzeni.

Zaproponowane podejście oparte na zastosowaniu metody WWP skłania do dalszego testowania metodyki przyjętej w tej pracy. Wieloczynnikowy charakter umożliwia modyfikowanie i doskonalenie przyjętych tu zmiennych, metod i właściwych im technik. Niekiedy wynikać to może z woli lepszego dopasowania założeń analitycznych do szczególnej specyfiki badanego kontekstu przestrzennego. Obiecującym kierunkiem zdają się być badania efektów popularnych współcześnie programów rewitalizacji. Wszechstronna analiza tak zróżnicowanych aspektów przestrzeni zurbanizowanej zwraca uwagę na przykład na poziom jej zgentryfikowania, walory funkcjonalne czy poziom satysfakcji użytkowników. Te i inne informacje uzyskiwane dzięki WWP powinny okazać się szczególnie pomocne dla ewaluatorów wszelkiego typu polityk miejskich. Szczególnie zaś dla tych osób, które sprawdzają rzeczywistą skuteczność programów nakierowanych na regenerację przestrzeni zdegradowanej. Zaprezentowane w pracy podejście badawcze zdaje się być też pod wieloma względami bardziej obiecujące niż ograniczająca w gruncie rzeczy perspektywa prostego rankingowania. Przedstawianie uproszczonych schematów jest $\mathrm{z}$ pewnością obrazowe i wygodne z punktu widzenia kładącego nacisk na pomiary konkurencyjności, a jest to podejście współcześnie bardzo popularne. Wizja taka przedstawia jednak ledwie fragmentaryczny i uproszczony obraz. Jest on atrakcyjny w ujęciu popularno-publicystycznym, ale bezużyteczny dla celów merytorycznej ewaluacji działań podmiotów publicznych i pozostałych interesariuszy procesu społecznego wytwarzania przestrzeni.

Rolą dalszych badań będzie wobec tego konstruktywna krytyka prowadząca do wyklarowania się jeszcze bardziej spójnych zasad wieloczynnikowej waloryzacji przestrzeni zurbanizowanej. Interesujące powinno być w tym kontekście zastosowanie jej w odniesieniu do innych typów osadniczych, równie jednak istotnych choćby ze względu na stosunkowo mało miejski charakter polskiego osadnictwa. 
Ciekawym testem dla przedstawionej w niniejszym opracowaniu metody WWP mogłoby się okazać zastosowanie jej w odniesieniu do innych perspektyw badawczych z obszaru studiów miejskich. Z ujęcia tego skorzystać będą mogli reprezentanci urbanistyki, ruralistyki, socjologii, ekonomii czy politologii, albo też innych nauk społecznych i technicznych, koncentrujących swą uwagę na przestrzeni funkcjonowania człowieka. Tak rozumiana wielotorowość to nieuchronna pochodna naturalnej złożoności procesu powstawania i ciągłego przekształcania tej przestrzeni. 


\section{Podziękowania}

Obrona pracy doktorskiej - jeśli wierzyć starszym i bardziej doświadczonym koleżankom i kolegom - jest najważniejszym momentem w życiu naukowca. Przedstawienie książki opartej na treści własnego doktoratu to wobec tego chwila łączącą w sobie ekscytację, dumę, ale i lęk poprzedzający oczekiwanie na zewnętrzne oceny.

Chciałbym więc przy tej okazji podziękować wszystkim, którzy wpłynęli na kształtowanie się moich przekonań na temat tego, jak w należyty sposób prowadzić badania naukowe. Wyraźne piętno odcisnęło w tym zakresie bardzo wielu ludzi. Wykładowczynie i wykładowcy, których spotkałem na swojej drodze w trakcie studiów na Uniwersytecie Warszawskim, w Szkole Głównej Gospodarstwa Wiejskiego i Szkole Głównej Handlowej. Następnie koleżanki i koledzy z różnych etapów edukacji. W końcu zaś także wiele innych inspirujących mnie na różne sposoby osób, które także wpływały na to, w jaki sposób postrzegam przedmioty i podmioty swoich dociekań. Spotykałem je nie tylko w murach Akademii, ale także zupełnie niespodziewanych sytuacjach życiowych.

Szczególne podziękowania chciałbym złożyć w tym miejscu promotorowi doktoratu - Maciejowi Cesarskiemu. Był on świetnym mentorem, umiejętnie wyważającym życzliwość i cierpliwość w stosunku do swojego doktoranta. Zapewniał duży zakres swobody i akceptował cierpliwie pojawiające się między nami różnice zdań. Nasza współpraca zaczęła się zresztą jeszcze w trakcie obrony pracy magisterskiej. Maciej nagrał się na moją skrzynkę głosową z informacją, że chętnie przyjmie mnie jako doktoranta pod swoje skrzydła. Wydarzyło sie to dokładnie wówczas, gdy broniłem pracy magisterskiej, która po czasie miała stać się moją pierwszą książką.

Podziękowania kieruję również w stronę osób recenzujących tę pracę. W pierwszej kolejności do Jacka Gądeckiego. To jego książka o grodzonych osiedlach wydana dekadę temu była dla mnie bezpośrednim impulsem do samodzielnego poświęcenia się studiom miejskim. Po latach został życzliwym recenzentem mojego doktoratu. Wiele sformułowanych przezeń uwag znalazło odzwierciedlenie w niniejszym wydaniu książkowym. Podobny dług wdzięczności i inspiracji zaciągam 
u Beaty Gawryszewskiej i Katarzyny Kajdanek, odpowiedzialnych za recenzje wydawnicze Urbanistyki oddolnej. Są one autorkami krytycznych refleksji uwrażliwiających tę książkę na konteksty istotne dla dwóch „skrzydeł” urban studies powiązanych z socjologią i architekturą krajobrazu.

Praca ta nie powstałaby też, gdyby nie pomoc osób, które zgodziły się konsultować moje pomysły na jeszcze wcześniejszych etapach. Zwłaszcza Magdy Andrejczuk, Sylwii Timoszuk i Krzysztofa Hermana. Nieoceniona okazała się zarówno życzliwość Mikołaja Winkiela, dzięki któremu mogłem skorzystać z danych firmy Brand24, jak i wsparcie rzeczoznawcy zapewnione przez Pawła Nowakowskiego. Z kolei Saygun Gökarıksel i Tilbe Akan pomogli przeprowadzić badania terenowe w Stambule, a Małgorzata Szymaniak - poradzić sobie z oddalonymi geograficznie zasobami bibliotecznymi w Wiedniu. W Polsce szczególnej pomocy udzielili mi Kinga Rybak-Niedziółka oraz kilka grup studentów gospodarki przestrzennej z SGGW. Na bieżąco wiele wątpliwości omawiałem ze wspomnianą Magdą Andrejczuk, Karolem Janosiem i Michałem Budzińskim, moimi przyjaciółmi z roku na studiach doktoranckich. Głęboko wdzięczny jestem wszystkim przełożonym, w tym bezpośredniemu szefowi - Tomaszowi Kaźmierczakowi. To oni, podobnie jak pracownice administracyjne z SGH i UW, najpierw umożliwili mi skorzystanie z grantu badawczego pozwalającego odbyć podróże do Nowego Jorku i Stambułu, a potem opublikowanie niniejszej książki. Gdyby nie Pracownia Badań i Innowacji Społecznych „Stocznia” oraz Polsko-Amerykańska Fundacja Wolności, których stypendystą miałem przyjemność być jako doktorant, opisywane na kartach tej publikacji badania być może nigdy by nie powstały. Nie wydarzyłoby się to, bo nie mógłbym w pełni zawodowo poświęcić się pracy naukowej, albo przynajmniej nie miałbym w tym takiej swobody. Wydaje mi się to szczególnie istotne w trudnych czasach wszędobylskiej ekonomizacji i parametryzacji nauki, wyjątkowo bolesnej dla jej społecznego odłamu. Wdzięczność deklaruję również wobec Wydawnictw Uniwersytetu Warszawskiego, które wyraziły zaufanie i zainteresowanie opublikowaniem książki.

Paroletni projekt tego rodzaju wykracza oczywiście poza krąg życia zawodowego. Za cierpliwość dziękuję zatem najważniejszym osobom ze sfery prywatnej. Rodzinie, licznym przyjaciołom, a przede wszystkim najdzielniejszym i najważniejszym kobietom mojego życia: Żonie Aleksandrze, Mamie Ładzie, oraz najważniejszej praktyczce warszawskiej urbanistyki - Lucynie. Część z podziękowaniami wydaje mi się zbyt krótka, abym zdołał umieścić w niej wszystkie istotne dla mnie osoby.

Niezależnie od szerokiego obozu przyjaciół i współpracowników, którzy gwarantowali wsparcie emocjonalne i pozwolili podnieść wartość tej publikacji, pełną odpowiedzialność za jej treść ponoszę osobiście i samodzielnie. Gdyby nie moje otoczenie, nie miałbym jednak odwagi podzielić się ze światem rezultatem własnych dociekań. Dziękuję więc wszystkim, którzy tej odwagi dodawali mi w ostatnich kilku latach. 


\section{Aneksy}

\section{Kwestionariusz wywiadu częściowo ustrukturyzowanego}

Wprowadzenie do wywiadu

Przedstawienie się.

Wyjaśnienie celu rozmowy - badanie naukowe dotyczące określonego miejsca

- placu, parku lub osiedla.

Zapytanie o zgodę na udzielenie i nagranie wypowiedzi.

Udzielenie gwarancji zachowania anonimowości.

\section{Pytania badawcze}

1. Jak często bywa Pan/i w miejscu badania?

2. Gdzie Pan/i mieszka?

3. Co spowodowało, że zdecydował/a się Pan/i pojawić w tym miejscu akurat w tej chwili, a nie w innej części miasta?

4. Czy lubi Pan/i to miejsce?

5. Czy czuje się Pan/i tutaj bezpiecznie?

6. Czy zna Pan/i historię tego miejsca?

\section{Wykonanie mapy poznawczej}

Czy może Pan/i wykonać nieskomplikowany i szkicowy w swojej formie rysunek (mapę) przedstawiający miejsce badania i jego najbliższe otoczenie?

Podziękowanie za rozmowę i zebranie ewentualnych uwag dodatkowych 


\section{Lista rozmówców podczas badań terenowych}

\begin{tabular}{|c|c|c|c|c|c|}
\hline $\begin{array}{c}\text { Kod } \\
\text { rozmowy }\end{array}$ & Zajęcie/zawód & Pleć & Wiek & $\begin{array}{c}\text { Miejsce } \\
\text { zamieszkania }\end{array}$ & $\begin{array}{c}\text { Częstotliwość } \\
\text { wizyt* }\end{array}$ \\
\hline A1 & Emerytka & K & ponad 80 & Najbliższa okolica & Regularnie \\
\hline $\mathrm{A} 2$ & Biegła rewidentka & K & 33 & Inna część miasta & Okazjonalnie \\
\hline A3 & Nauczycielka & K & ponad 60 & Inna część miasta & Okazjonalnie \\
\hline A4 & Student & M & 20 & Najbliższa okolica & Regularnie \\
\hline A5 & Pracownica biurowa & $\mathrm{K}$ & 47 & Inna część miasta & Regularnie \\
\hline A6 & Architekt & $\mathrm{M}$ & 32 & Najbliższa okolica & Regularnie \\
\hline A7 & Menedżer & $\mathrm{M}$ & 31 & Inna część miasta & Regularnie \\
\hline A8 & Uczennica & $\mathrm{K}$ & 17 & Poza miastem & Regularnie \\
\hline A9 & Studentka architektury & $\mathrm{K}$ & 21 & Poza miastem & Okazjonalnie \\
\hline A10 & Muzyk & $\mathrm{M}$ & 49 & Inna część miasta & Regularnie \\
\hline A11 & $\begin{array}{l}\text { Pracownik branży } \\
\text { nieruchomości i doradca } \\
\text { biznesowy }\end{array}$ & $\mathrm{M}$ & 43 & Poza miastem & Regularnie \\
\hline A12 & Ilustratorka & $\mathrm{K}$ & 30 & Najbliższa okolica & Regularnie \\
\hline A13 & Emeryt & M & 68 & Najbliższa okolica & Regularnie \\
\hline A14 & Ekonomista & M & 42 & Inna część miasta & Regularnie \\
\hline A15 & Emerytka & $\mathrm{K}$ & 92 & Najbliższa okolica & Regularnie \\
\hline A16 & $\begin{array}{l}\text { Nauczycielka akademic- } \\
\text { ka i reżyserka filmów } \\
\text { animowanych }\end{array}$ & K & 44 & Poza miastem & Okazjonalnie \\
\hline A17 & Kierowca & $\mathrm{M}$ & 40 & Inna część miasta & Regularnie \\
\hline A18 & Marketerka w korporacji & K & 32 & Inna część miasta & Regularnie \\
\hline A19 & $\begin{array}{l}\text { Chemiczka na urlopie } \\
\text { macierzyńskim }\end{array}$ & $\mathrm{K}$ & 29 & Najbliższa okolica & Regularnie \\
\hline A20 & Finansista & $\mathrm{M}$ & 43 & Inna część miasta & Okazjonalnie \\
\hline A21 & Taksówkarz & $\mathrm{M}$ & 35 & Inna część miasta & Regularnie \\
\hline A22 & Emerytka & $\mathrm{K}$ & 65 & Najbliższa okolica & Regularnie \\
\hline A23 & $\begin{array}{l}\text { Szefowa działu sprzeda- } \\
\text { ży w firmie logistycznej }\end{array}$ & K & 42 & Inna część miasta & Okazjonalnie \\
\hline
\end{tabular}




\begin{tabular}{|c|c|c|c|c|c|}
\hline $\begin{array}{c}\text { Kod } \\
\text { rozmowy }\end{array}$ & Zajęcie/zawód & Pleć & Wiek & $\begin{array}{c}\text { Miejsce } \\
\text { zamieszkania }\end{array}$ & $\begin{array}{c}\text { Częstotliwość } \\
\text { wizyt }^{\text {* }}\end{array}$ \\
\hline A24 & $\begin{array}{l}\text { Technik-handlowiec } \\
\text { spożywczy }\end{array}$ & M & 40 & Najbliższa okolica & Okazjonalnie \\
\hline A25 & Student & M & 21 & Inna część miasta & Okazjonalnie \\
\hline A26 & $\begin{array}{l}\text { Kandydatka na studia } \\
\text { architektoniczne }\end{array}$ & K & 21 & Poza miastem & Okazjonalnie \\
\hline A27 & Emerytka & K & 75 & Najbliższa okolica & Regularnie \\
\hline A28 & $\begin{array}{l}\text { Prawniczka na urlopie } \\
\text { macierzyńskim }\end{array}$ & K & 30 & Najbliższa okolica & Regularnie \\
\hline A29 & Studentka & K & 19 & Poza miastem & Okazjonalnie \\
\hline A30 & $\begin{array}{l}\text { Pracownik administra- } \\
\text { cyjny }\end{array}$ & M & 43 & Najbliższa okolica & Okazjonalnie \\
\hline B1 & Fotograf & M & 64 & Najbliższa okolica & Regularnie \\
\hline B2 & Agentka nieruchomości & K & 62 & Najbliższa okolica & Regularnie \\
\hline B3 & Pisarka & K & 70 & Najbliższa okolica & Regularnie \\
\hline B4 & Menedżer & M & 44 & Poza miastem & Pierwszy raz \\
\hline B5 & Pielęgniarka & K & 53 & Poza miastem & Okazjonalnie \\
\hline B6 & Inżynierka & K & 55 & Poza miastem & Pierwszy raz \\
\hline B7 & Nauczyciel & M & 27 & Inna część miasta & Regularnie \\
\hline B8 & Student & M & 21 & Poza miastem & Pierwszy raz \\
\hline B9 & Finansistka & K & 31 & Inna część miasta & Okazjonalnie \\
\hline B10 & $\begin{array}{l}\text { Pracownica galerii } \\
\text { sztuki }\end{array}$ & K & 25 & Poza miastem & Okazjonalnie \\
\hline B11 & $\begin{array}{l}\text { Opiekunka (nauczycielka } \\
\text { z zawodu) }\end{array}$ & K & 52 & Inna część miasta & Regularnie \\
\hline B12 & $\begin{array}{l}\text { Tancerka i instruktorka } \\
\text { fitness }\end{array}$ & K & 24 & Inna część miasta & Okazjonalnie \\
\hline B13 & Artysta & M & 38 & Najbliższa okolica & Regularnie \\
\hline B14 & Bezrobotny & M & 57 & Najbliższa okolica & Regularnie \\
\hline B15 & $\begin{array}{l}\text { Pracownica korporacji } \\
\text { farmaceutycznej }\end{array}$ & K & 37 & Poza miastem & Pierwszy raz \\
\hline B16 & $\begin{array}{l}\text { Nauczycielka francu- } \\
\text { skiego w nauczaniu } \\
\text { początkowym }\end{array}$ & K & 46 & Poza miastem & Pierwszy raz \\
\hline
\end{tabular}




\begin{tabular}{|c|c|c|c|c|c|}
\hline $\begin{array}{c}\text { Kod } \\
\text { rozmowy }\end{array}$ & Zajęcie/zawód & Pleć & Wiek & $\begin{array}{c}\text { Miejsce } \\
\text { zamieszkania }\end{array}$ & $\begin{array}{c}\text { Częstotliwość } \\
\text { wizyt }^{*}\end{array}$ \\
\hline B17 & Lekarka i doktorantka & K & 36 & Poza miastem & Okazjonalnie \\
\hline B18 & Pracownica działu kadr & K & 27 & Poza miastem & Pierwszy raz \\
\hline B19 & $\begin{array}{l}\text { Pracownica w sektorze } \\
\text { usług opiekuńczych }\end{array}$ & K & 39 & Poza miastem & Pierwszy raz \\
\hline B20 & Bankier & M & 30 & Poza miastem & Okazjonalnie \\
\hline B21 & Student i sprzedawca & M & 22 & Inna część miasta & Okazjonalnie \\
\hline B22 & Menedżerka & K & 45 & Poza miastem & Okazjonalnie \\
\hline B23 & Finansista & M & 40 & Inna część miasta & Okazjonalnie \\
\hline B24 & Student & M & 21 & Poza miastem & Pierwszy raz \\
\hline B25 & Mikrobiolożka & K & 30 & Poza miastem & Pierwszy raz \\
\hline B26 & Dziennikarz & M & 35 & Poza miastem & Pierwszy raz \\
\hline B27 & Uczeń & M & 18 & Poza miastem & Okazjonalnie \\
\hline B28 & Lekarka & K & 30 & Poza miastem & Pierwszy raz \\
\hline B29 & Programistka & K & 35 & Inna część miasta & Regularnie \\
\hline B30 & Badaczka w korporacji & K & 32 & Poza miastem & Pierwszy raz \\
\hline B31 & $\begin{array}{l}\text { Przedsiębiorca w branży } \\
\text { handlowej }\end{array}$ & M & 25 & Poza miastem & Pierwszy raz \\
\hline $\mathrm{C} 1$ & Serwisant autobusów & M & 58 & Inna część miasta & Regularnie \\
\hline $\mathrm{C} 2$ & Elektryk & M & 37 & Inna część miasta & Okazjonalnie \\
\hline $\mathrm{C} 3$ & $\begin{array}{l}\text { Emerytowany robotnik } \\
\text { budowlany }\end{array}$ & M & 53 & Najbliższa okolica & Regularnie \\
\hline $\mathrm{C} 4$ & Kierowca autobusu & M & 61 & Inna część miasta & Regularnie \\
\hline $\mathrm{C} 5$ & Farmaceutka & K & 60 & Inna część miasta & Regularnie \\
\hline C6 & $\begin{array}{l}\text { Technik pracujący } \\
\text { w aptece }\end{array}$ & M & 48 & Inna część miasta & Regularnie \\
\hline $\mathrm{C} 7$ & Sklepikarz & M & 66 & Inna część miasta & Regularnie \\
\hline $\mathrm{C} 8$ & $\begin{array}{l}\text { Emerytowana gospodyni } \\
\text { domowa }\end{array}$ & K & 90 & Najbliższa okolica & Regularnie \\
\hline C9 & Uczeń i pracownik baru & M & 20 & Inna część miasta & Regularnie \\
\hline $\mathrm{C} 10$ & Webdeveloper & M & 26 & Inna część miasta & Regularnie \\
\hline
\end{tabular}




\begin{tabular}{|c|c|c|c|c|c|}
\hline $\begin{array}{c}\text { Kod } \\
\text { rozmowy }\end{array}$ & Zajęcie/zawód & Płeć & Wiek & $\begin{array}{c}\text { Miejsce } \\
\text { zamieszkania }\end{array}$ & $\begin{array}{c}\text { Częstotliwość } \\
\text { wizyt }^{*}\end{array}$ \\
\hline C11 & Informatyk & M & 30 & Inna część miasta & Regularnie \\
\hline C12 & Trenerka fitness & K & 32 & Najbliższa okolica & Regularnie \\
\hline C13 & $\begin{array}{l}\text { Emerytowana filmow- } \\
\text { czyni }\end{array}$ & K & 52 & Najbliższa okolica & Regularnie \\
\hline C14 & $\begin{array}{l}\text { Małżeństwo pracowni- } \\
\text { ków korporacji z wy- } \\
\text { kształceniem technicz- } \\
\text { nym }\end{array}$ & $\begin{array}{l}\mathrm{K} / \\
\mathrm{M}\end{array}$ & $36 / 38$ & Najbliższa okolica & Regularnie \\
\hline C15 & Sklepikarz & M & 47 & Najbliższa okolica & Regularnie \\
\hline C16 & Handlowczyni & K & 52 & Najbliższa okolica & Regularnie \\
\hline C17 & Pracownica banku & K & 38 & Najbliższa okolica & Regularnie \\
\hline C18 & $\begin{array}{l}\text { Nauczycielka nauczania } \\
\text { początkowego }\end{array}$ & K & 40 & Najbliższa okolica & Regularnie \\
\hline C19 & Licealista & M & 19 & Inna część miasta & Okazjonalnie \\
\hline $\mathrm{C} 20$ & Kosmetolożka & K & 19 & Najbliższa okolica & Regularnie \\
\hline $\mathrm{C} 21$ & Cukierniczka & K & 40 & Poza miastem & Pierwszy raz \\
\hline $\mathrm{C} 22$ & Sklepikarz & M & 23 & Najbliższa okolica & Regularnie \\
\hline $\mathrm{C} 23$ & Zbieracz złomu & M & 24 & Najbliższa okolica & Regularnie \\
\hline $\mathrm{C} 24$ & Zbieracz złomu & M & 22 & Najbliższa okolica & Regularnie \\
\hline $\mathrm{C} 25$ & Śmieciarz & M & 27 & Inna część miasta & Regularnie \\
\hline $\mathrm{C} 26$ & Gospodyni domowa & K & 36 & Najbliższa okolica & Regularnie \\
\hline $\mathrm{C} 27$ & Gospodyni domowa & K & 45 & Inna część miasta & Pierwszy raz \\
\hline $\mathrm{C} 28$ & Kierowca autobusu & M & 54 & Inna część miasta & Regularnie \\
\hline $\mathrm{C} 29$ & $\begin{array}{l}\text { Urzędniczka administra- } \\
\text { cji samorządowej }\end{array}$ & K & 53 & Najbliższa okolica & Regularnie \\
\hline C30 & Kierowca autobusu & M & 36 & Najbliższa okolica & Regularnie \\
\hline
\end{tabular}

Źródło: opracowanie własne.

* Regularnie - raz w tygodniu lub częściej, okazjonalnie - rzadziej niż raz w tygodniu. 
3. Mapy poznawcze autorstwa respondentów zebrane podczas badań terenowych

\subsection{Plac Grzybowski}

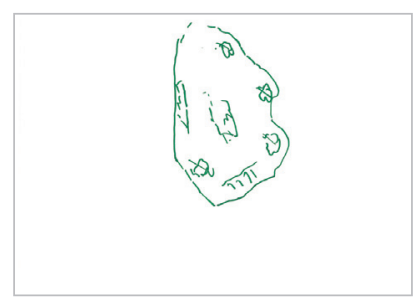

A1

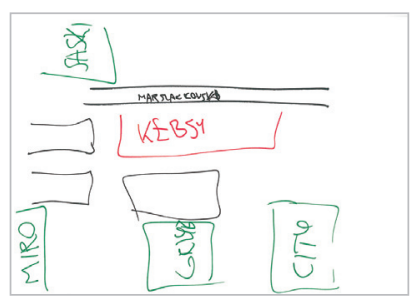

A4

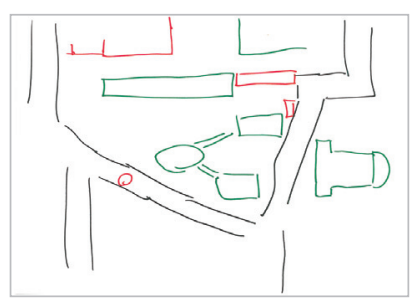

A7

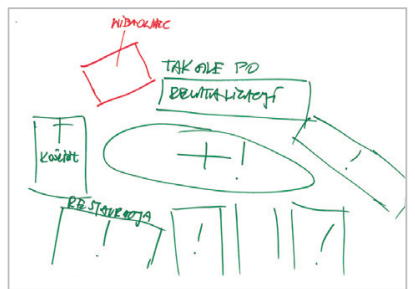

A10

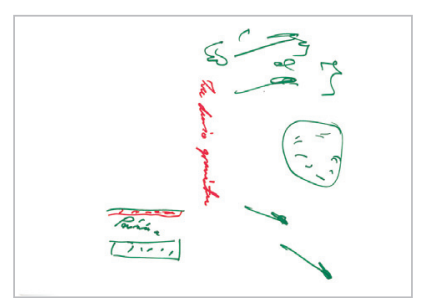

A13

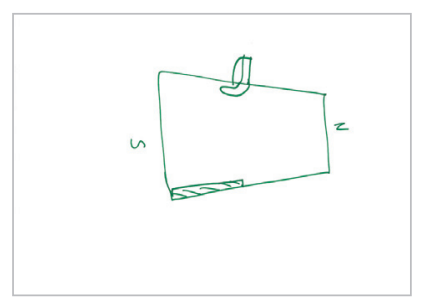

A2

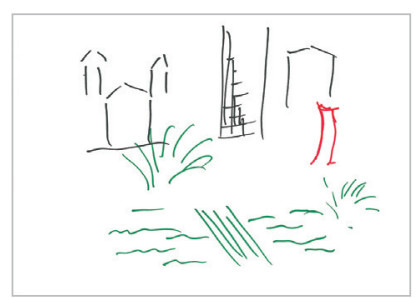

A5

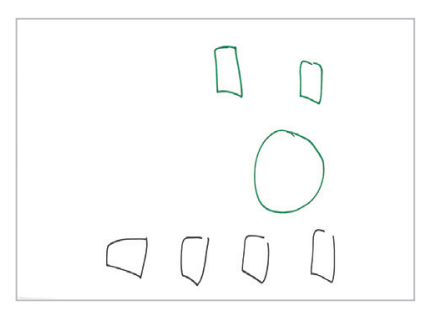

A8

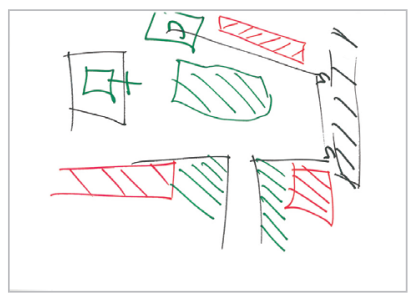

A11

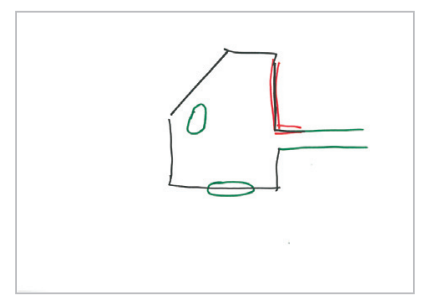

A14

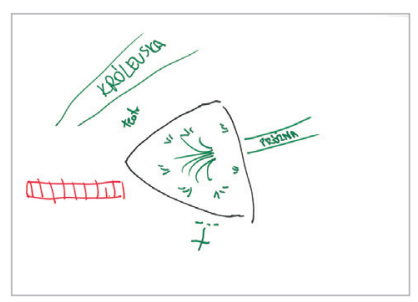

A3

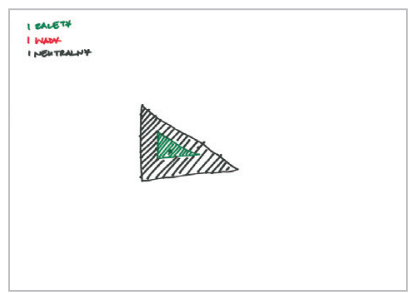

A6

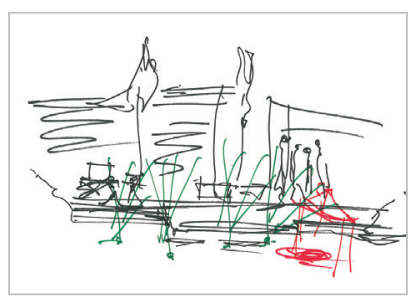

A9

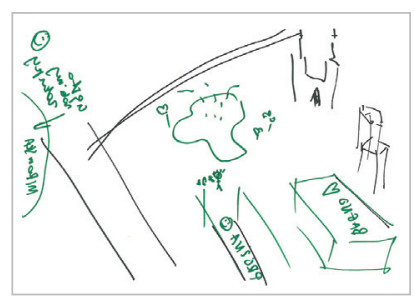

A12

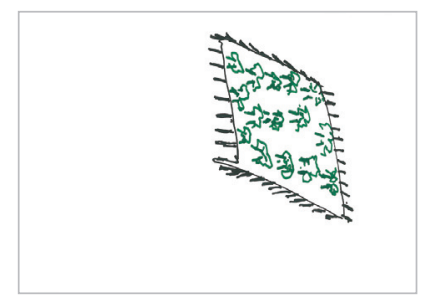

A15 


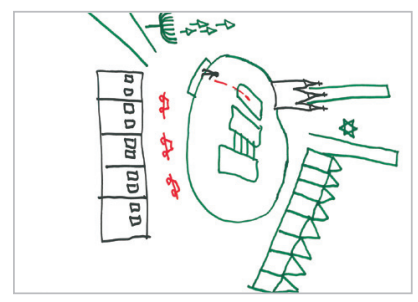

A16

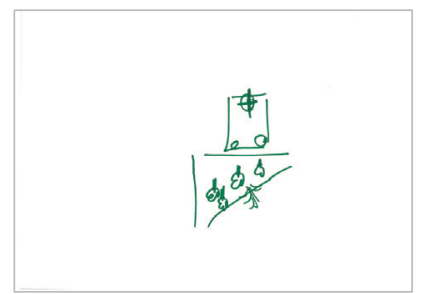

A19

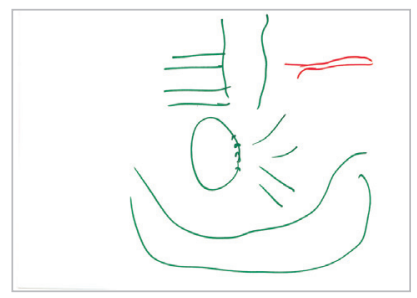

A22

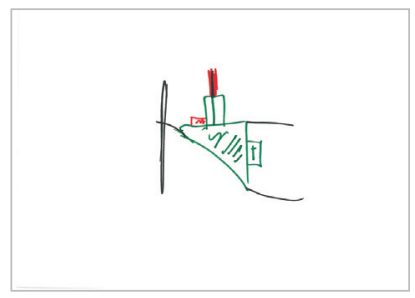

A25

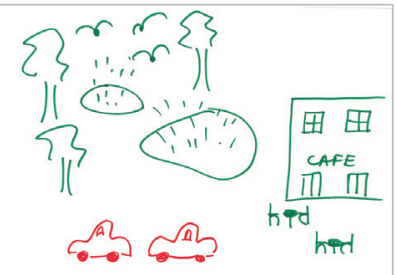

A28

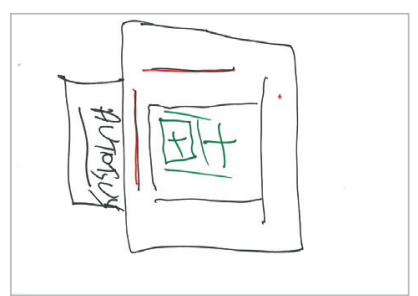

A17

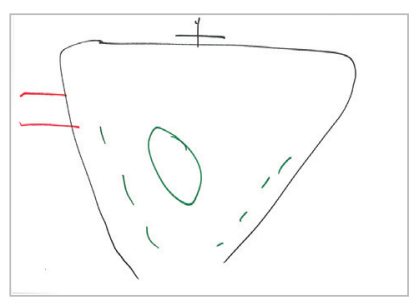

A20

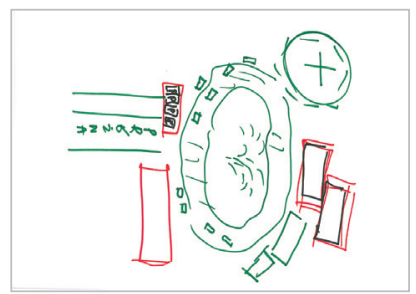

A23

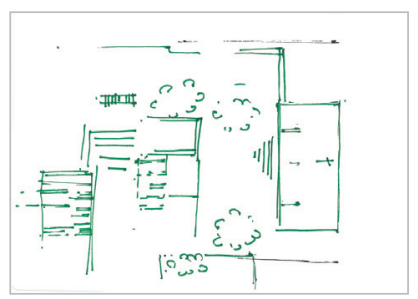

A26

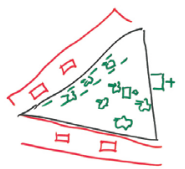

A29

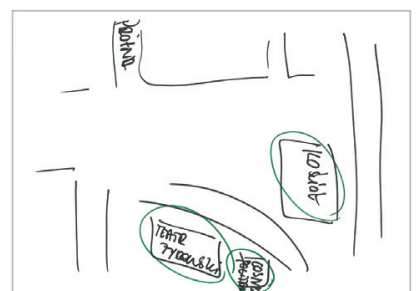

A18

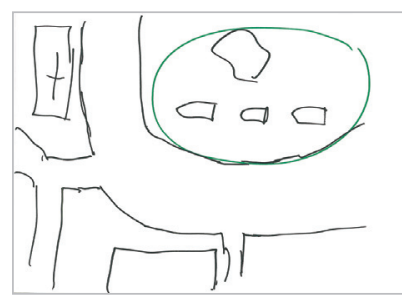

A21

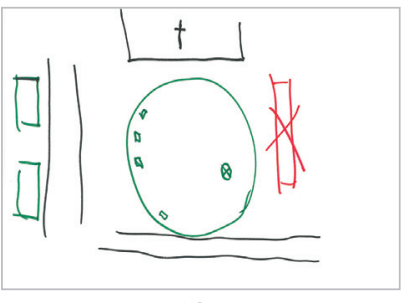

A24

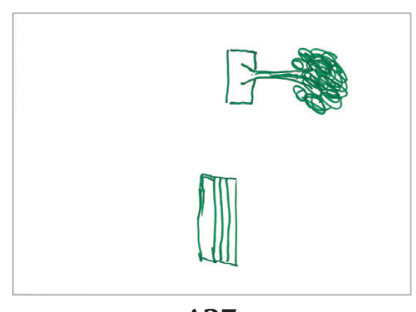

A27

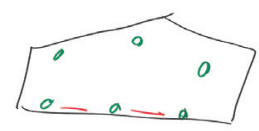

A30

Źródło: opracowanie własne. 
Aneksy

\subsection{Park High Line}

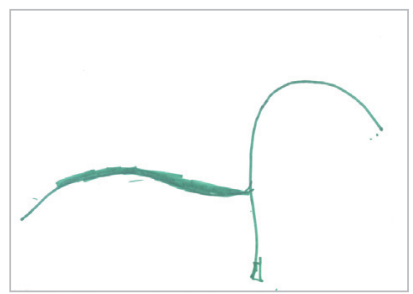

B1

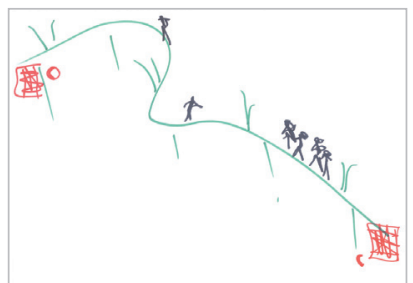

B4

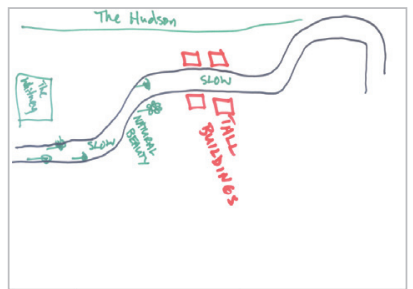

B7

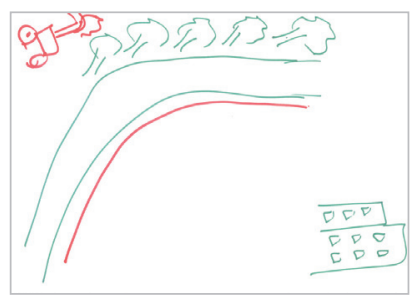

B11

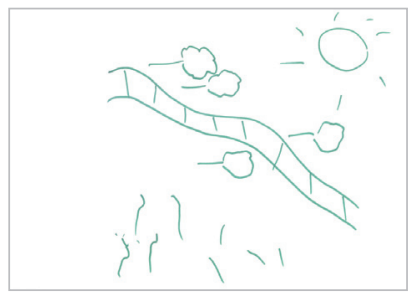

B15

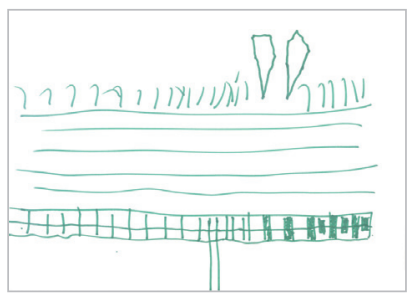

B2

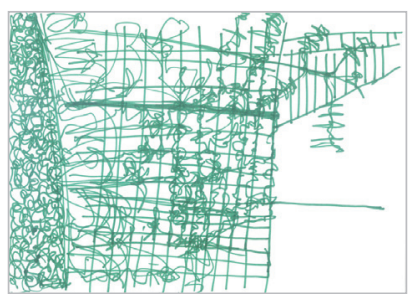

B5

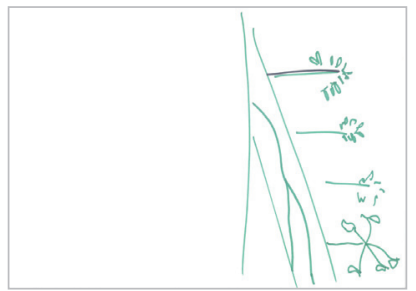

B9

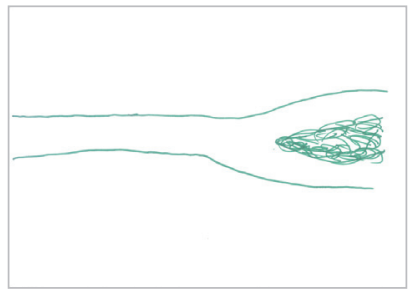

B12

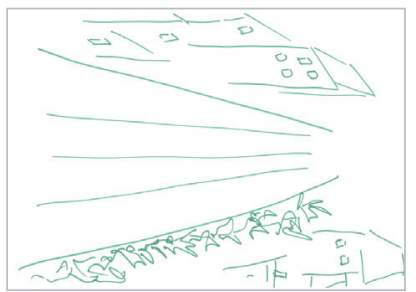

B16

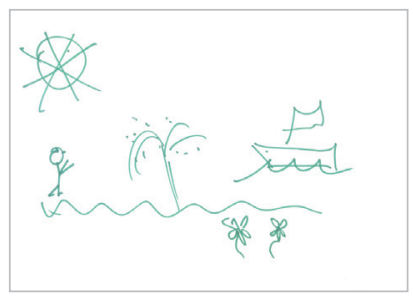

B3

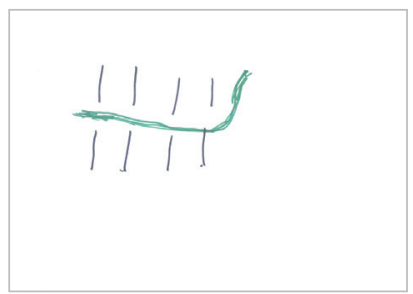

B6

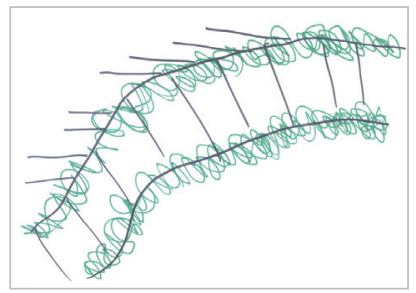

B10

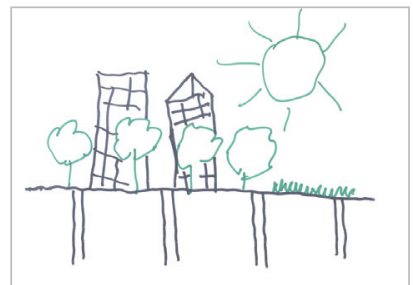

B14

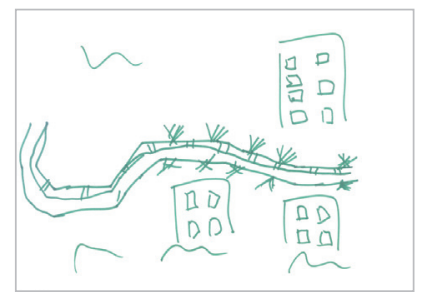

B17 


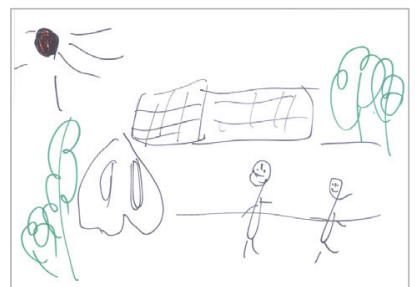

B19

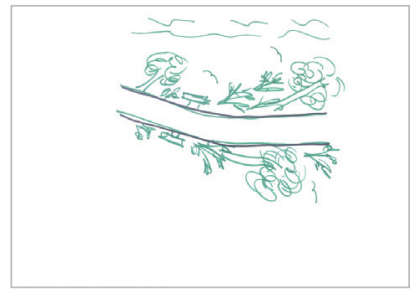

B22

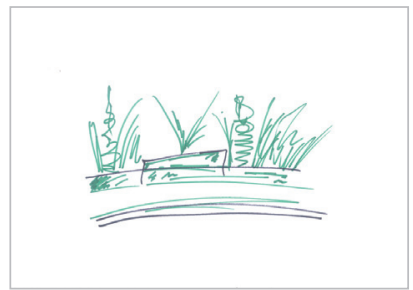

B25

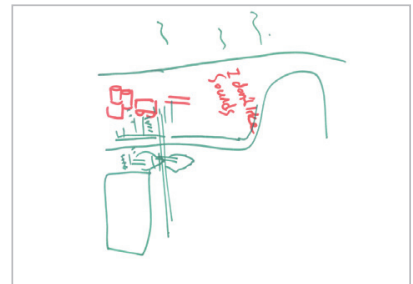

B28

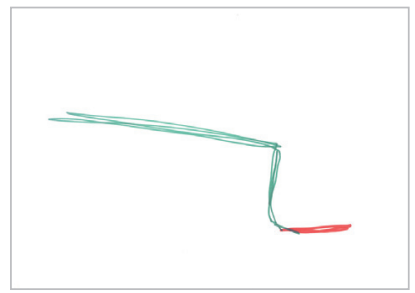

B31

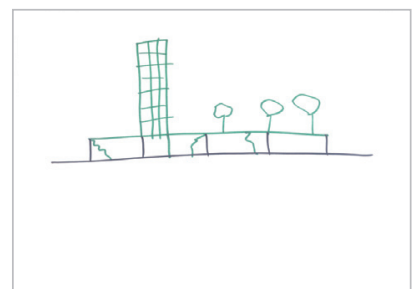

B20

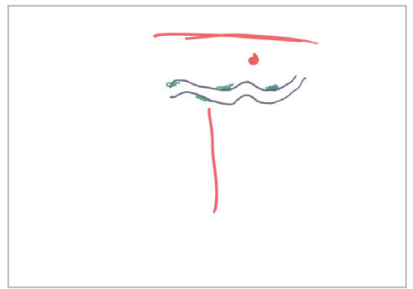

B23

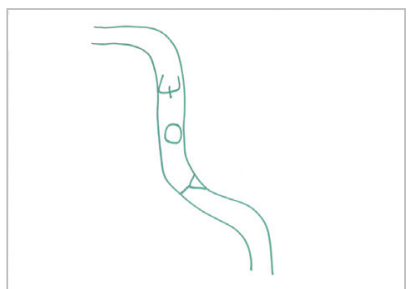

B26

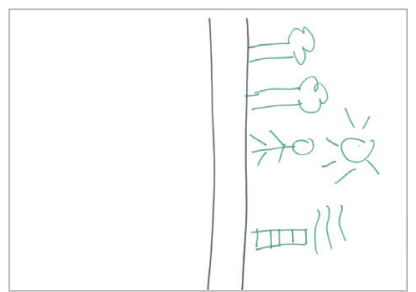

B29

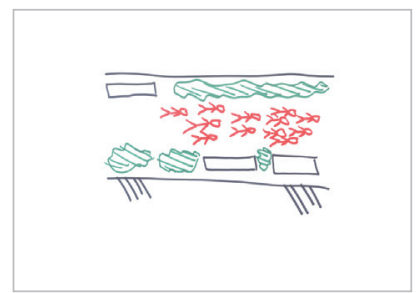

B21

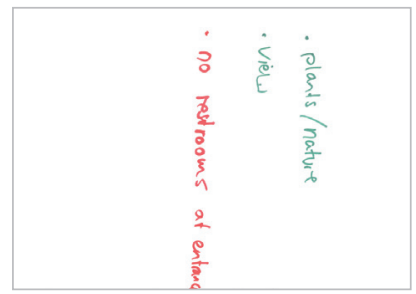

B24

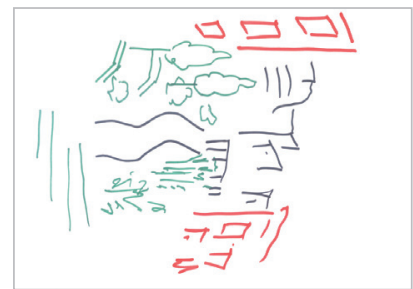

B27

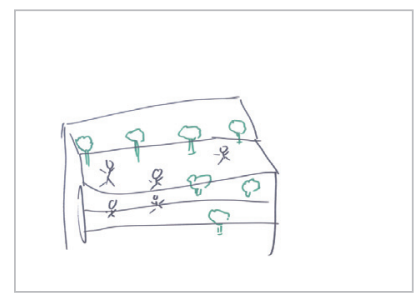

B30

Źródło: opracowanie własne. 
Aneksy

\subsection{Sąsiedztwo Karanfilköy}

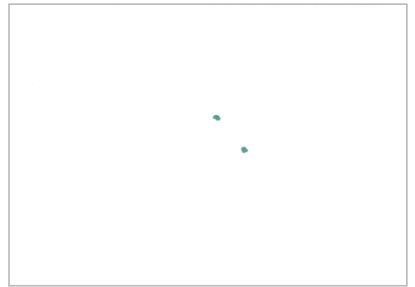

C1

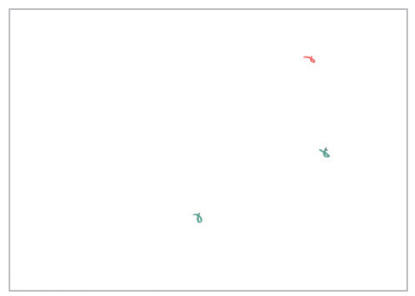

C4

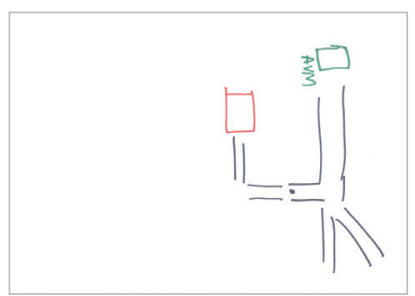

C10

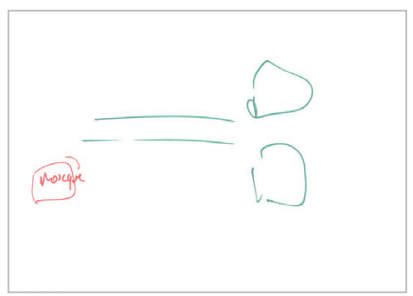

C14

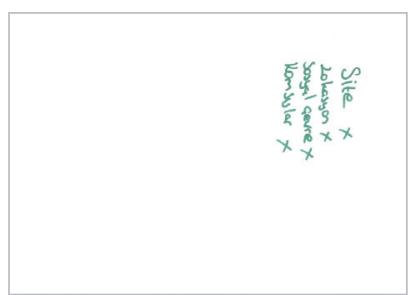

C17

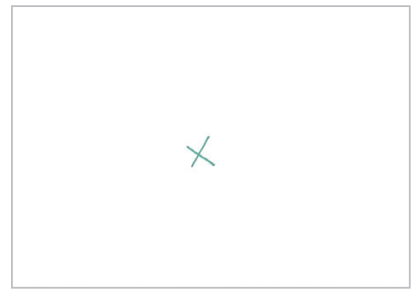

C2

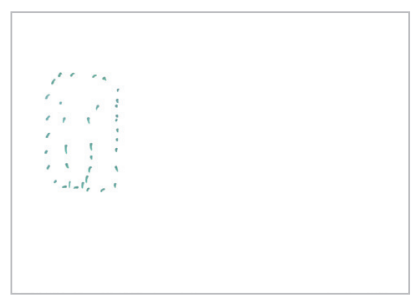

C7

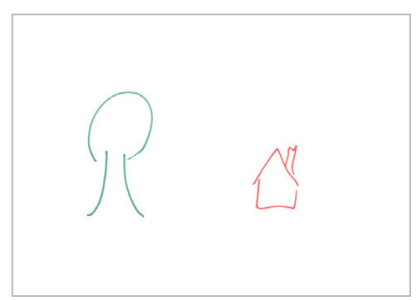

C11

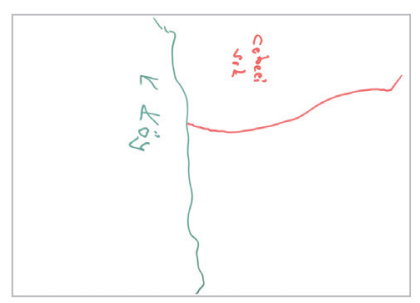

C15

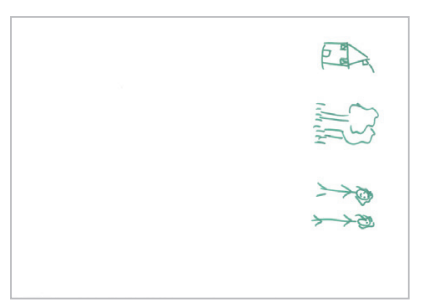

C18

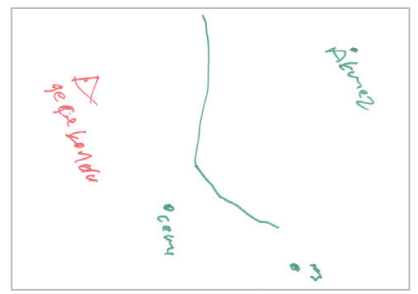

C3

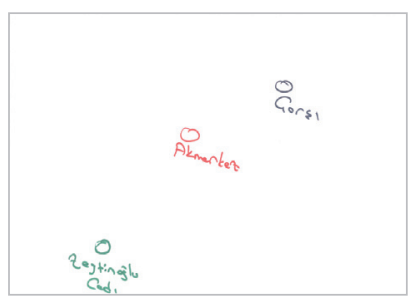

C9

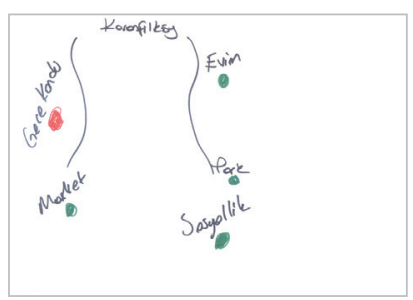

C12

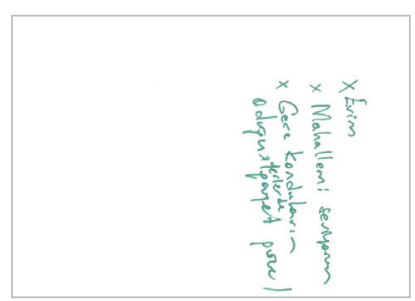

C16

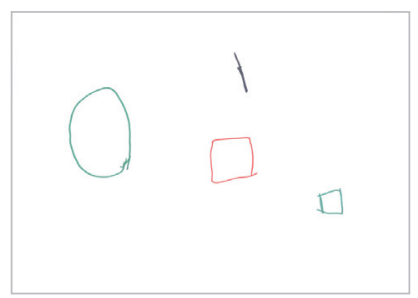

C19 


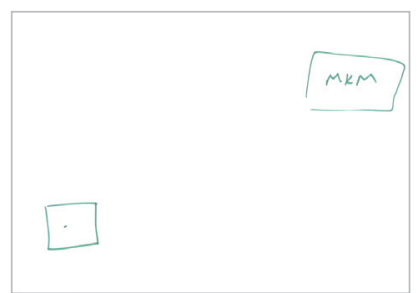

C20

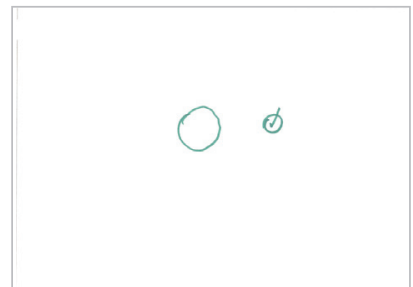

C23

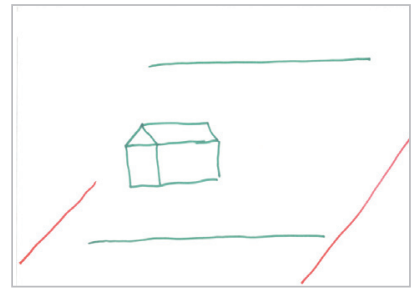

C26

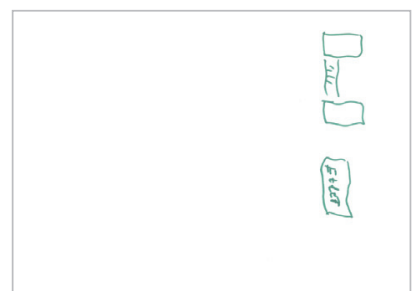

C21

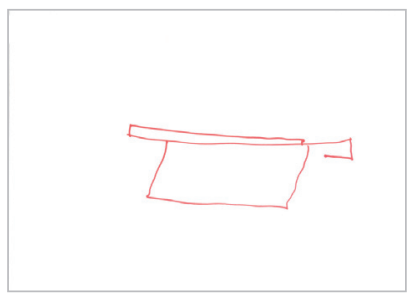

C24

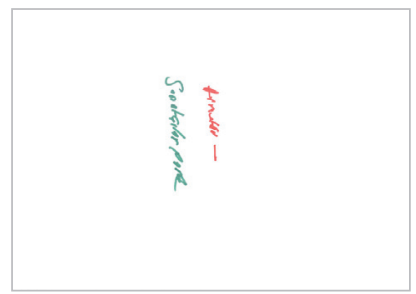

C28

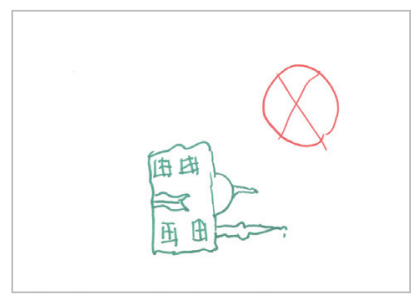

C22

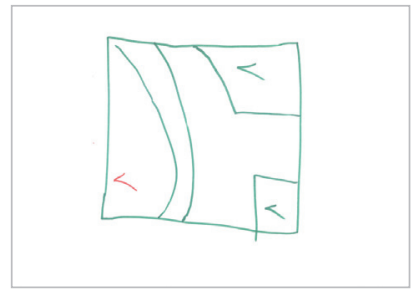

C25

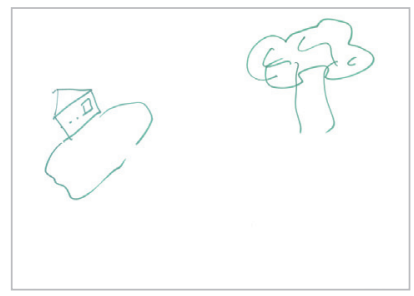

C29

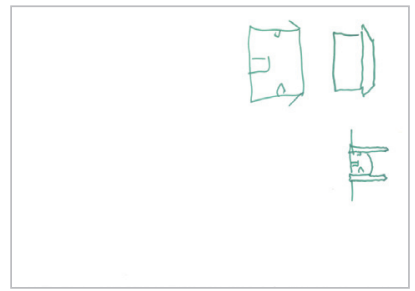

C30

Źródło: opracowanie własne. 


\section{Zdjęcia stanowiące podstawę analiz SBE i ich średnie oceny}

\subsection{Plac Grzybowski}

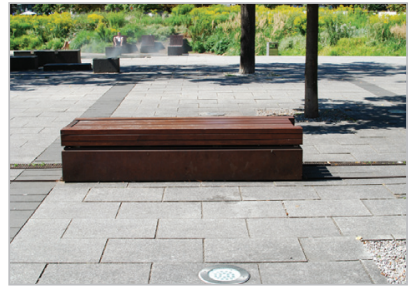

4,40

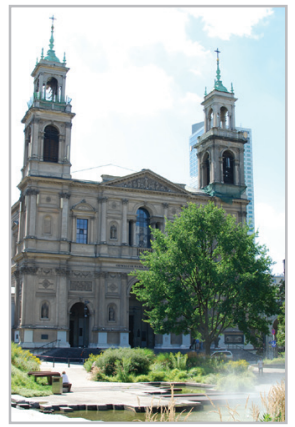

4,22

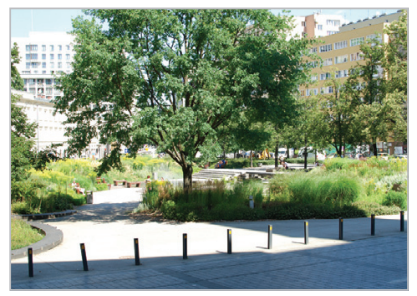

3,90

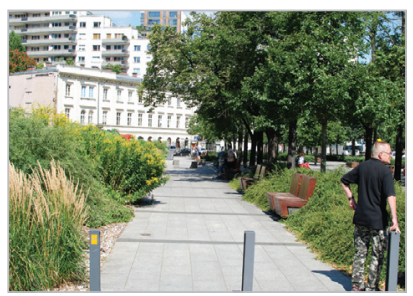

3,69

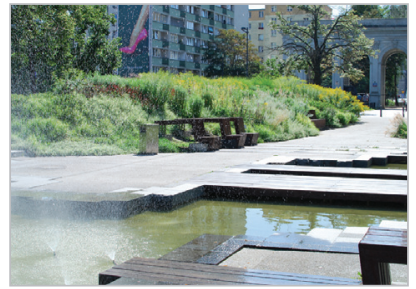

4,36

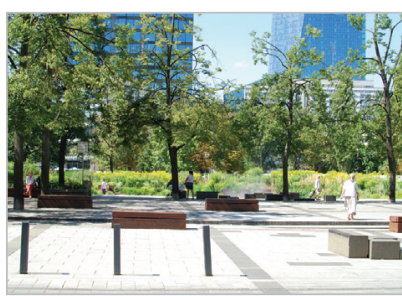

4,18

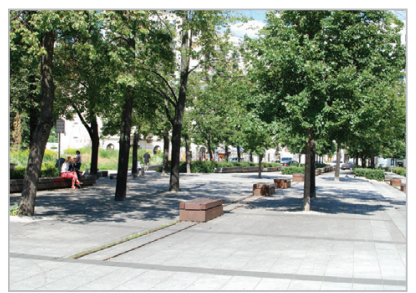

3,86

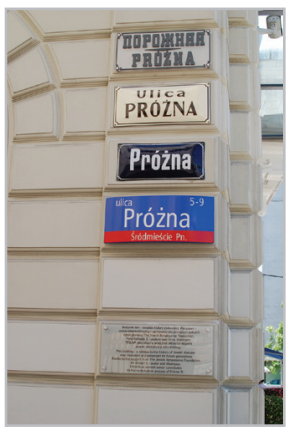

3,69

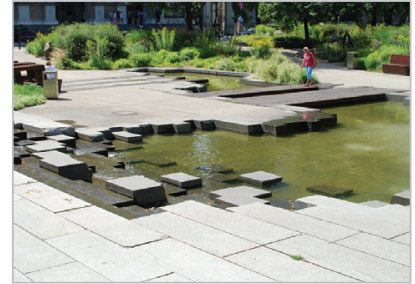

4,31

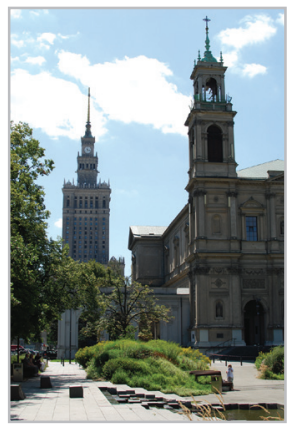

3,96

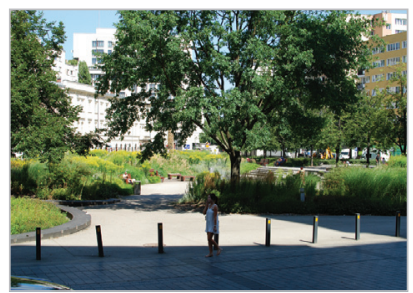

3,82

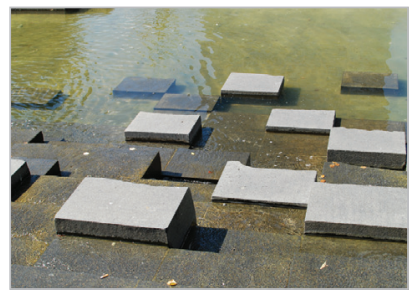

3,68 

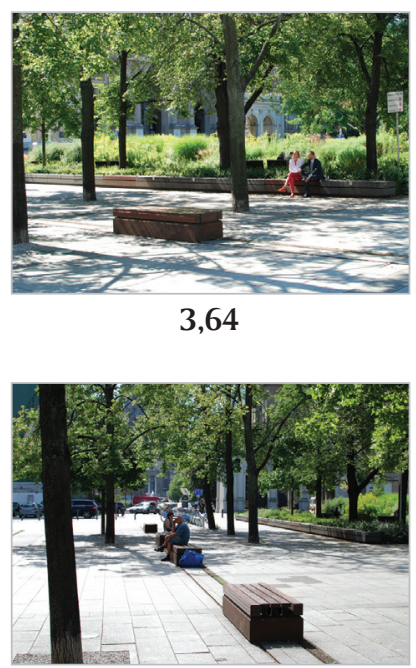

3,53

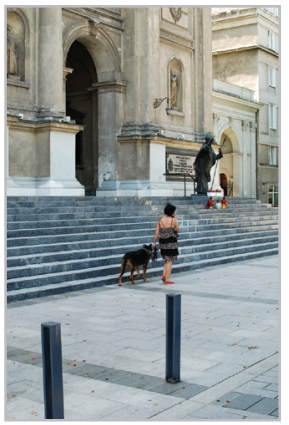

3,18

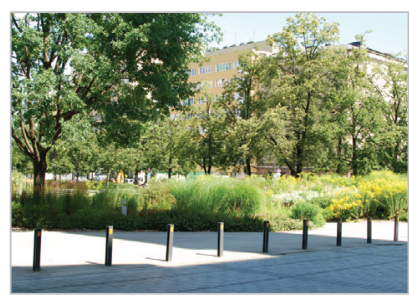

3,63

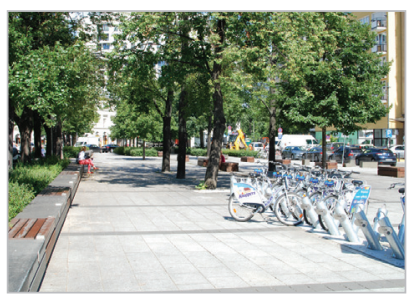

3,44

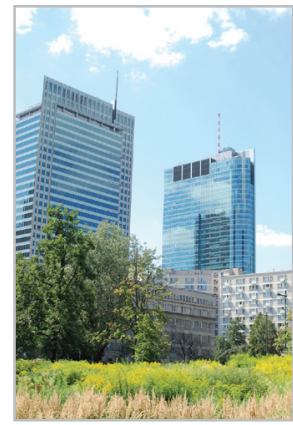

2,97

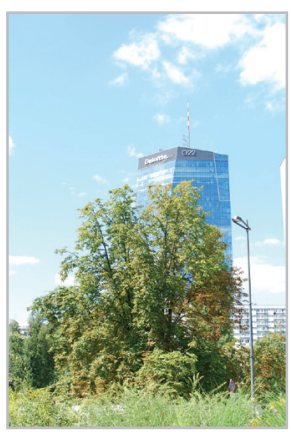

2,36

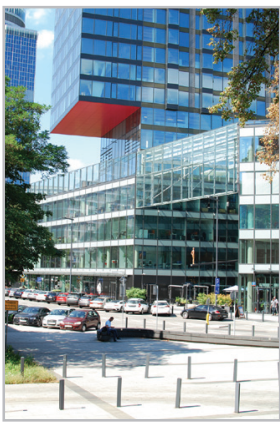

3,57

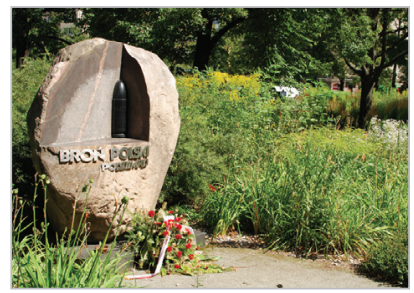

3,31

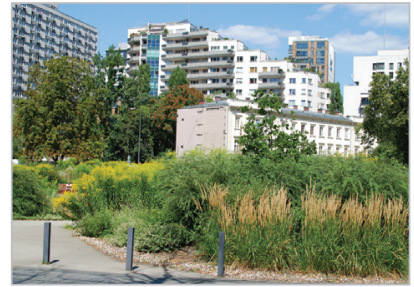

2,86

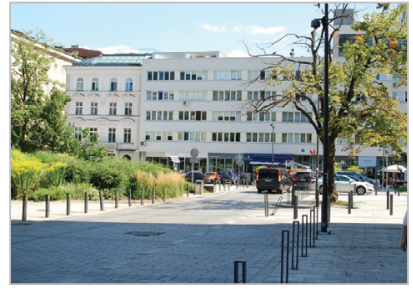

2,57

Źródło: opracowanie własne. 


\subsection{Plac Europejski}

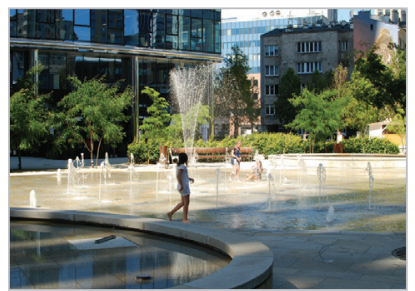

4,60

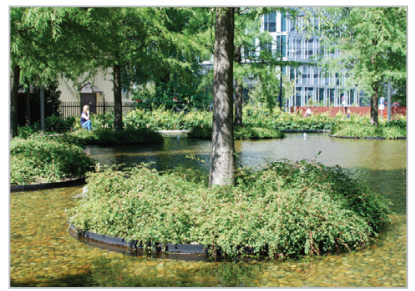

4,49

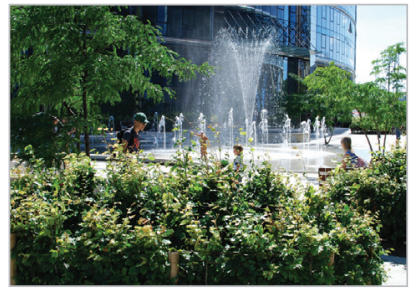

4,21

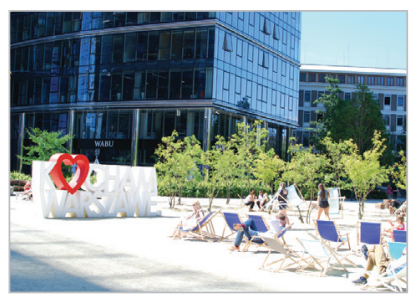

3,85

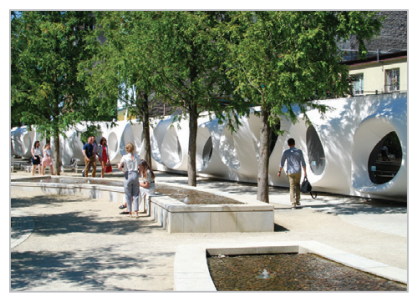

3,71

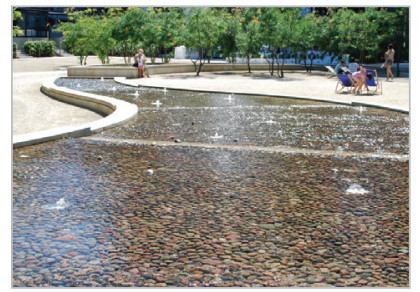

4,51

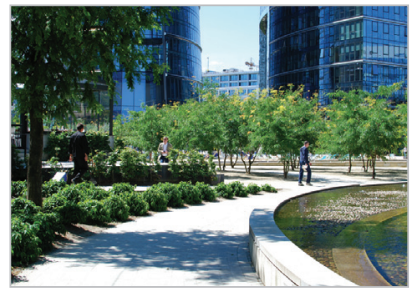

4,29

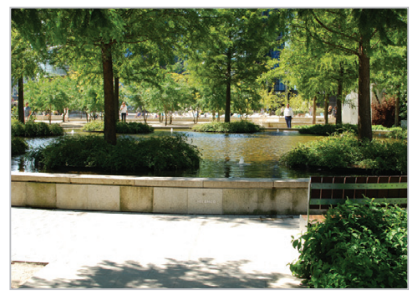

4,14

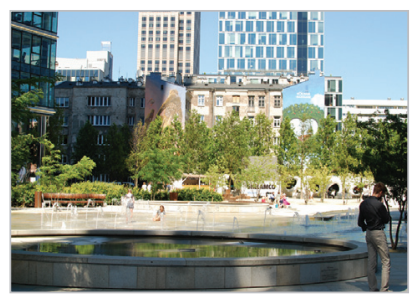

3,82

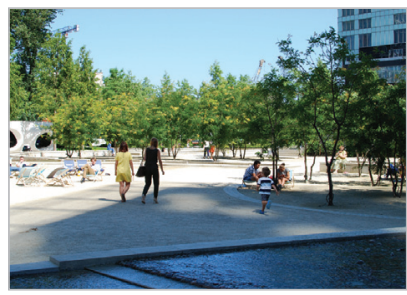

3,57

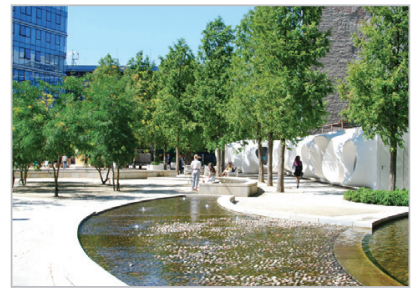

4,49

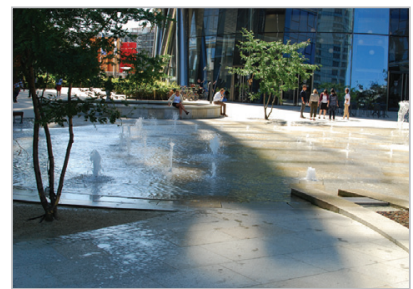

4,22

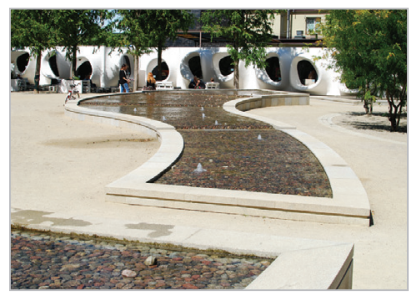

3,94

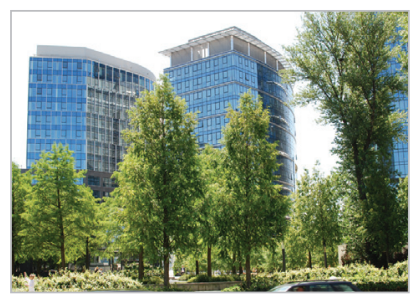

3,72

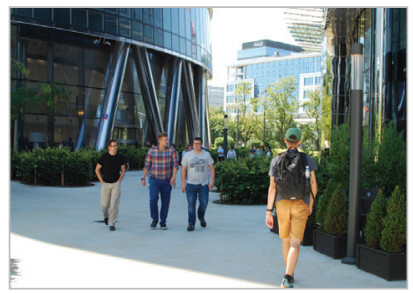

3,44 


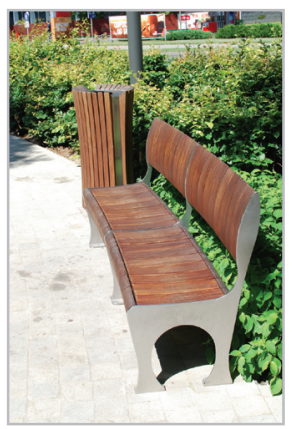

3,39

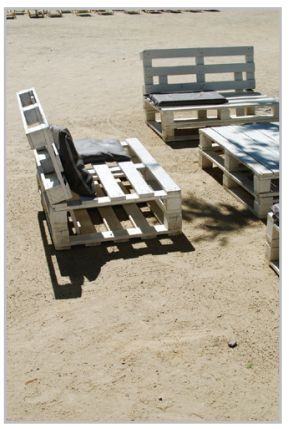

3,19

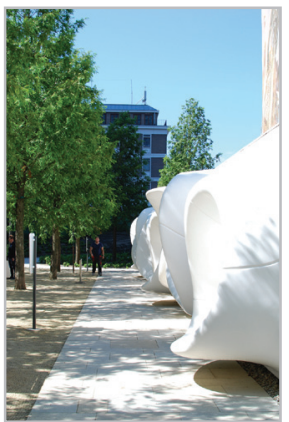

2,78

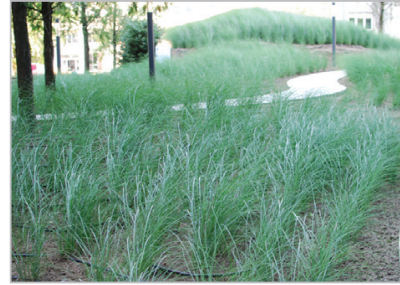

3,38

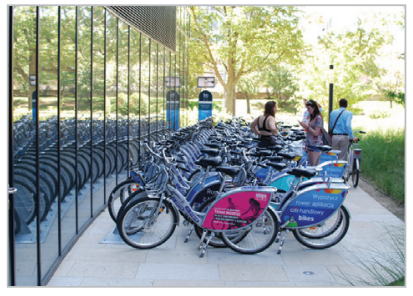

3,07

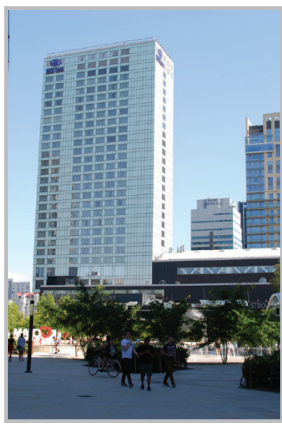

2,49

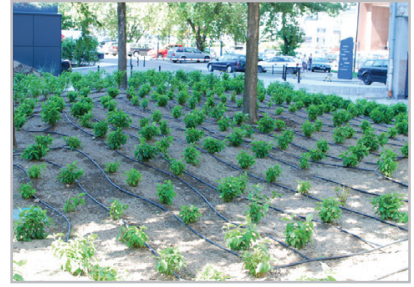

3,33

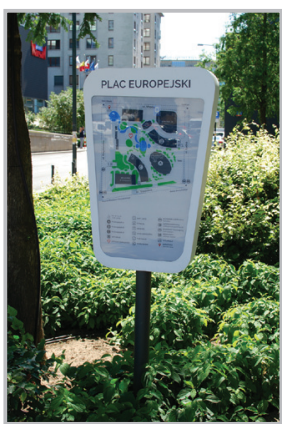

3,07

Źródło: opracowanie własne. 


\subsection{Park High Line}

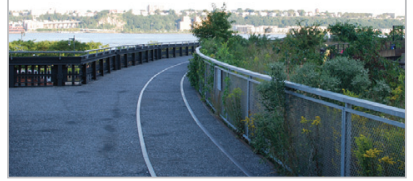

4,14

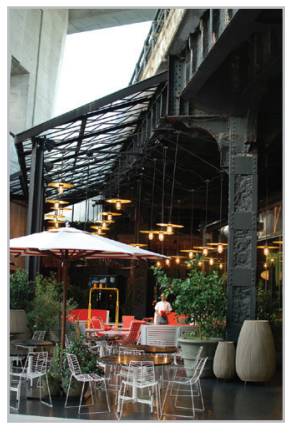

4,00

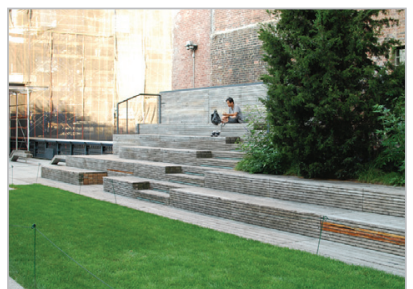

3,83

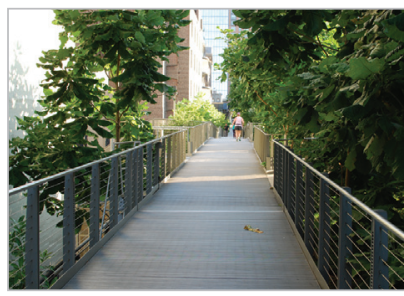

3,65

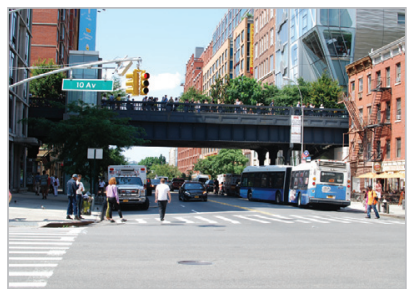

3,43

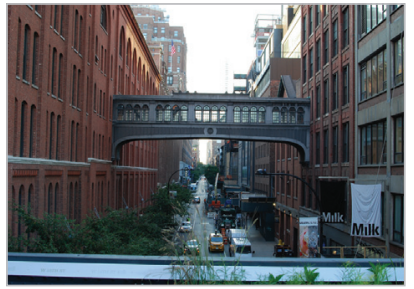

4,11

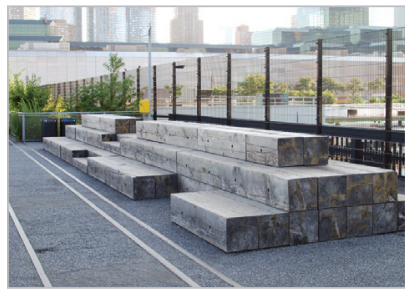

3,93

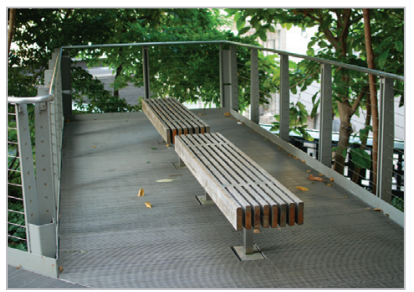

3,76

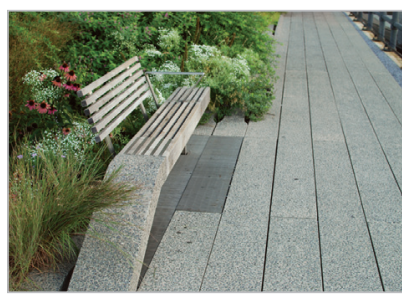

3,60

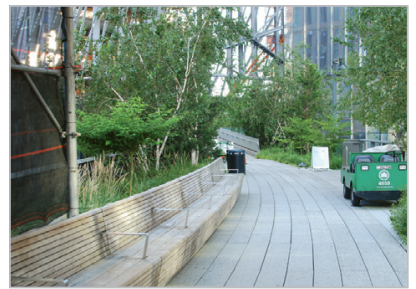

3,40

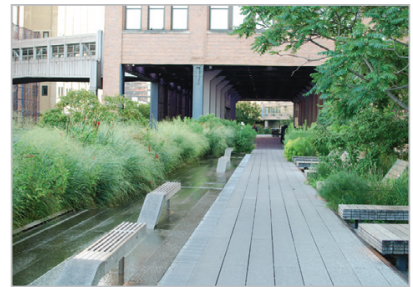

4,07

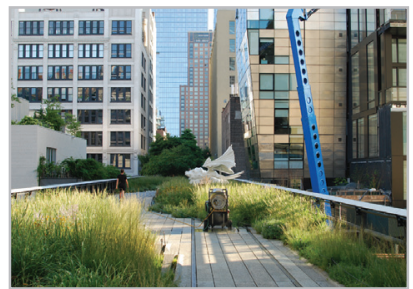

3,89

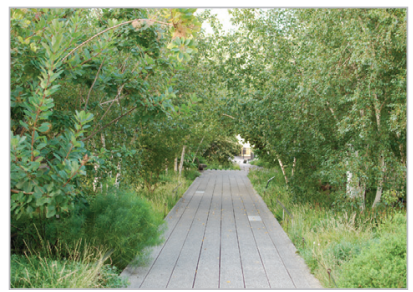

3,68

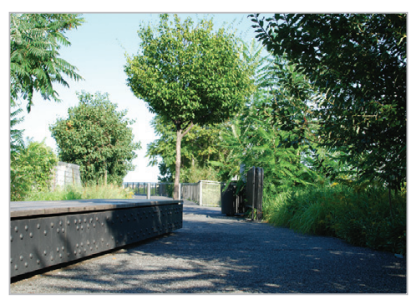

3,43

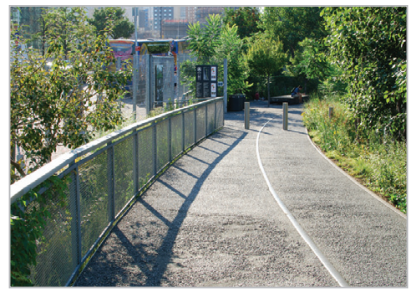

3,25 


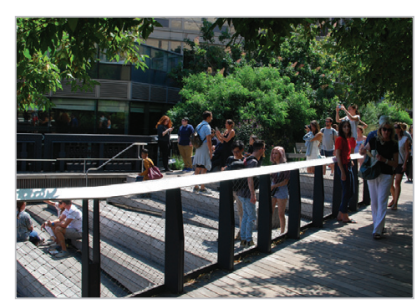

3,14
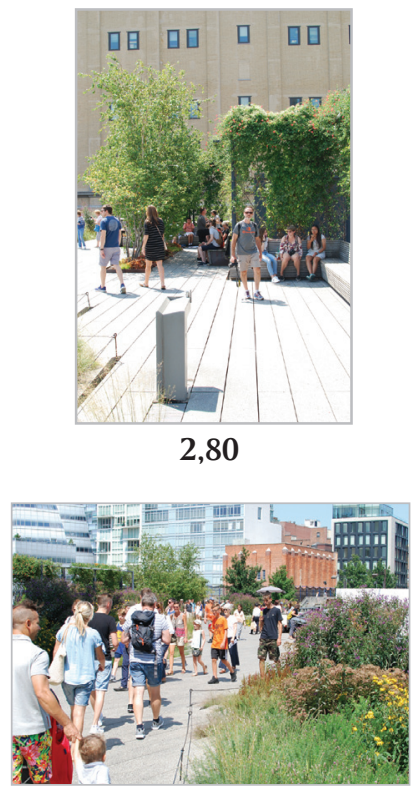

2,43

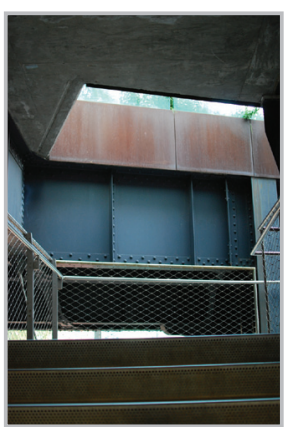

1,85

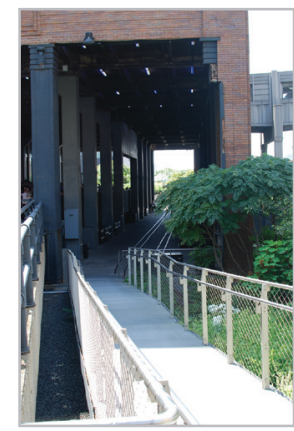

3,03

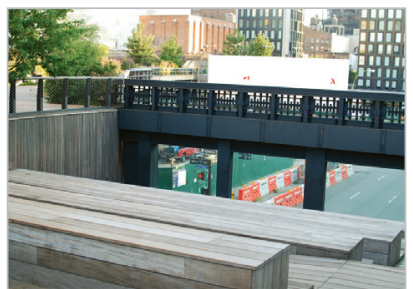

2,67

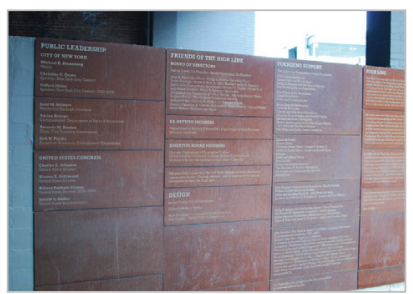

2,31

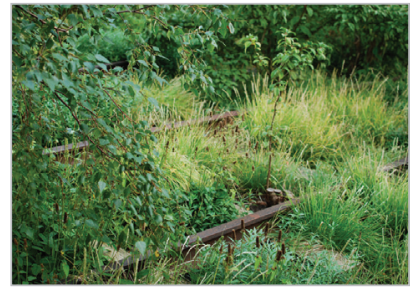

2,93

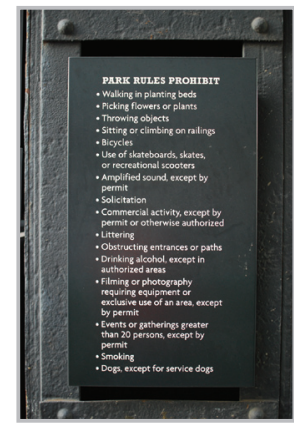

2,47

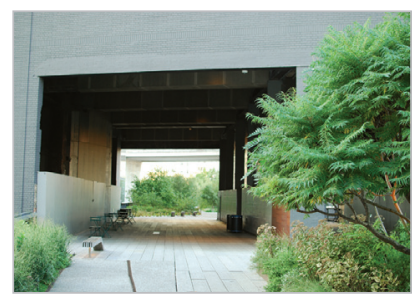

2,29

Źródło: opracowanie własne. 


\subsection{Park Bryant}

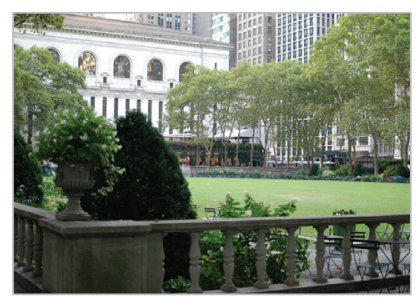

4,36

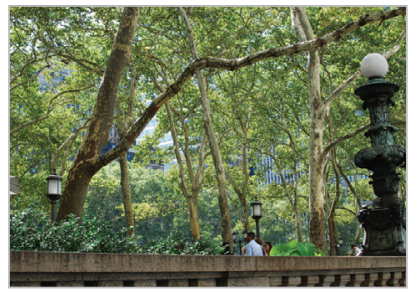

4,19

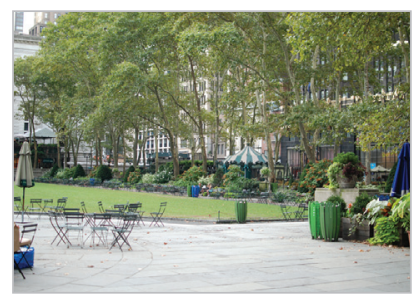

3,81

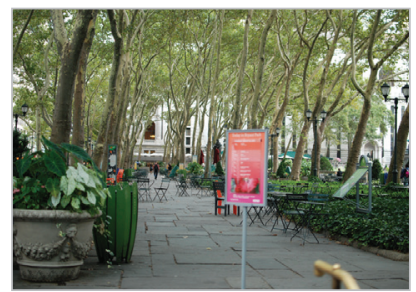

3,65

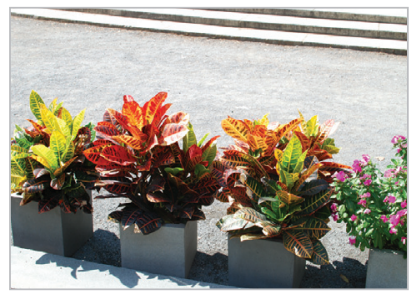

3,44

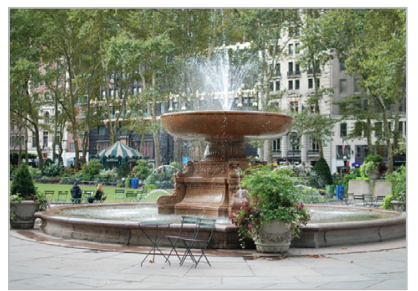

4,34

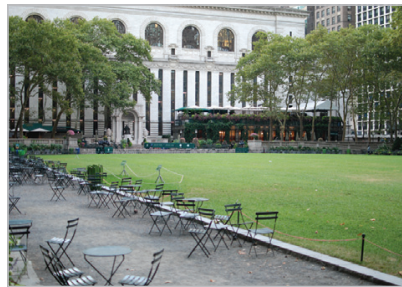

3,90

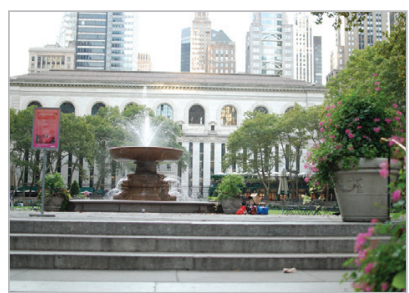

3,76

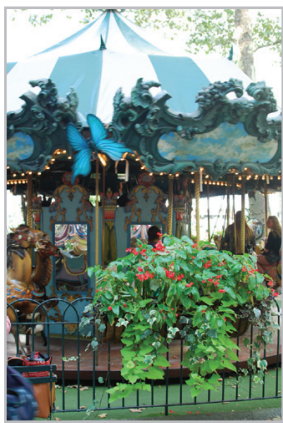

3,60

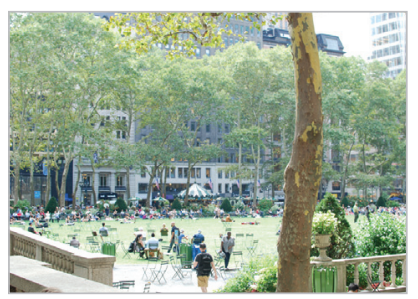

3,39

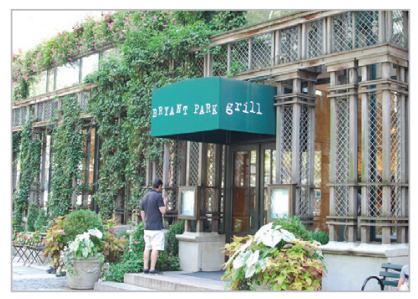

4,25

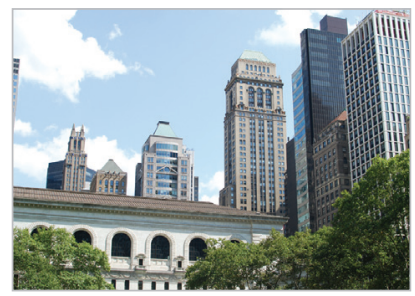

3,88

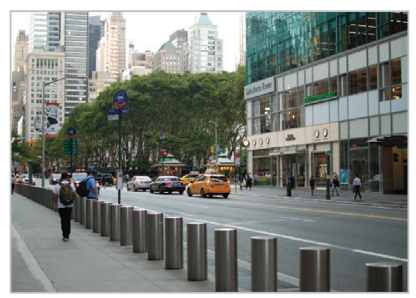

3,68

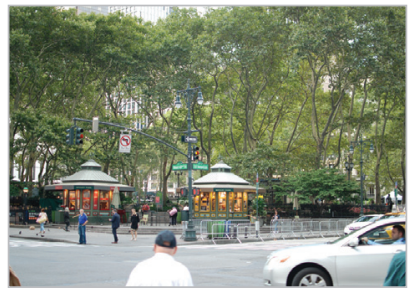

3,57

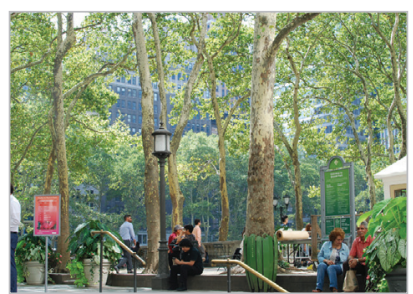

3,35 


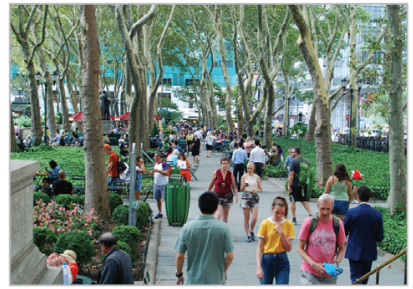

3,19

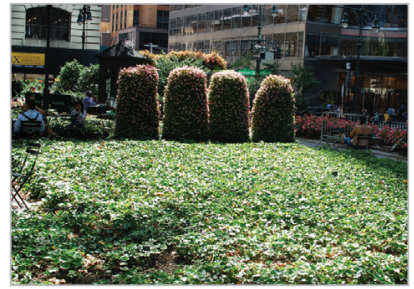

3,17

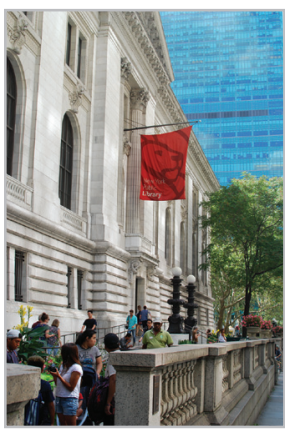

2,99

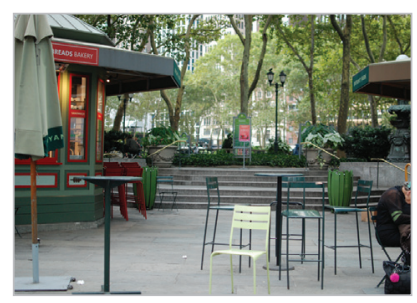

2,86

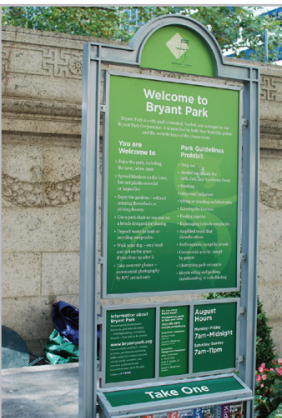

2,29

Źródło: opracowanie własne. 


\subsection{Park Tompkins Square}

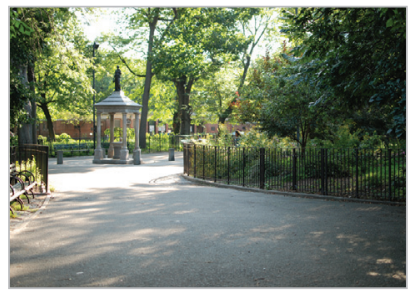

4,24

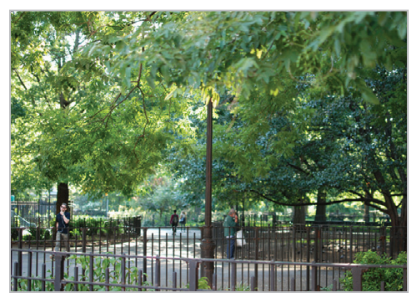

4,01

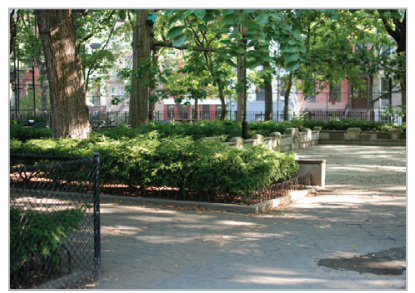

3,51

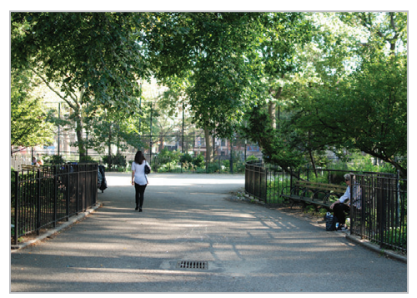

3,33

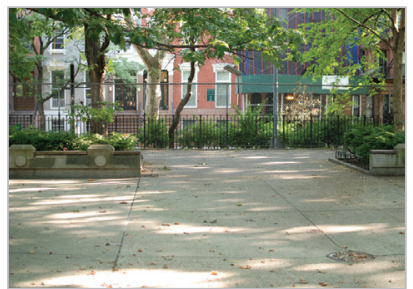

2,99

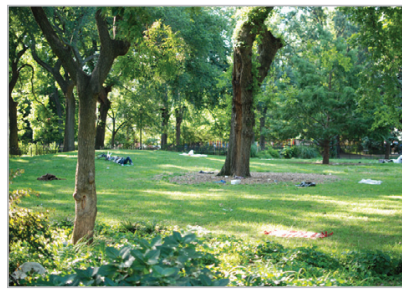

4,18

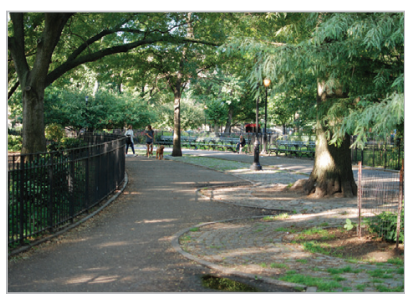

3,92

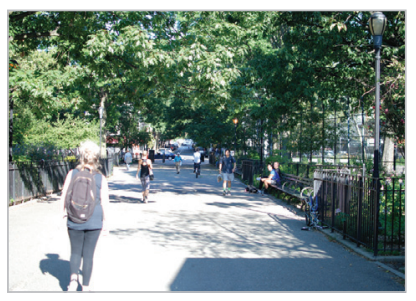

3,46

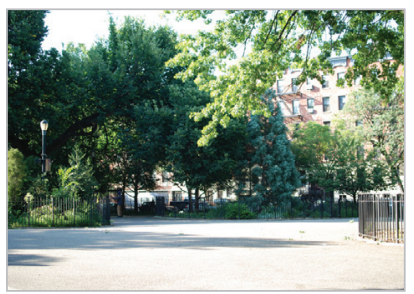

3,33

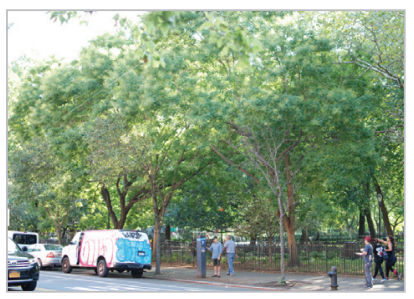

2,86

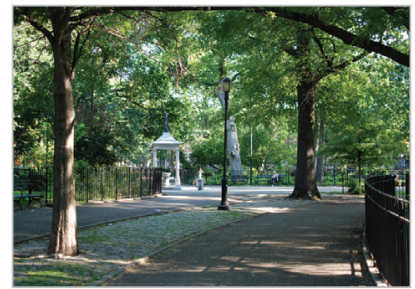

4,08

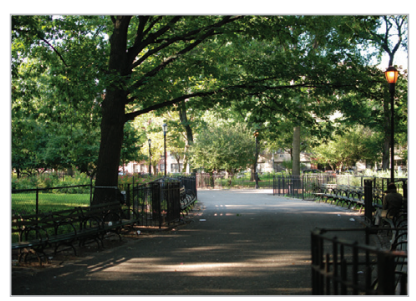

3,58

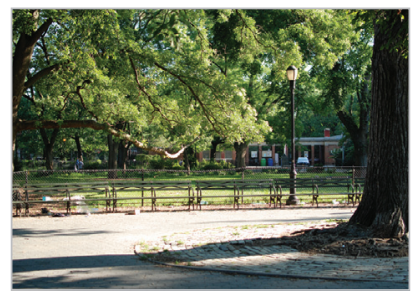

3,37

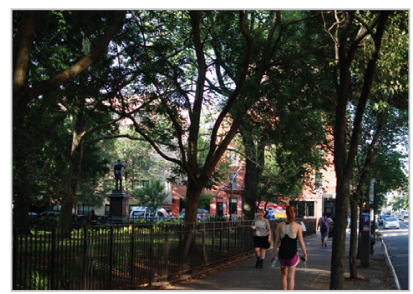

3,17

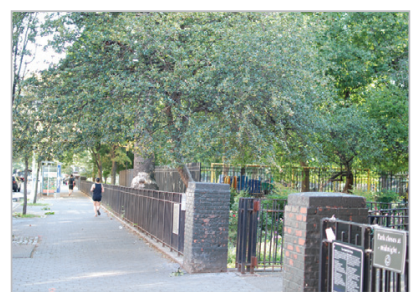

2,85 


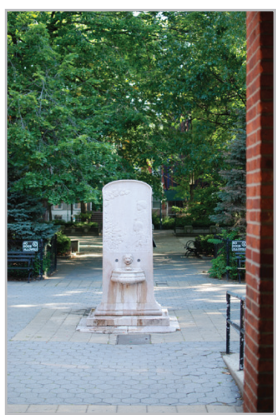

2,75

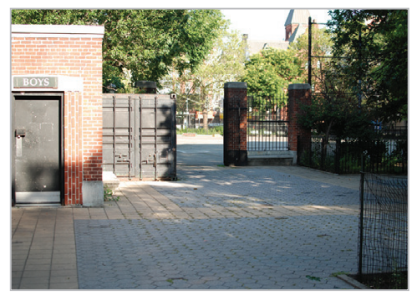

2,17

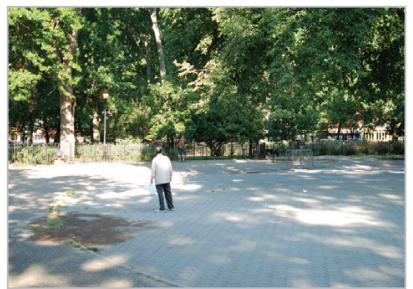

2,68

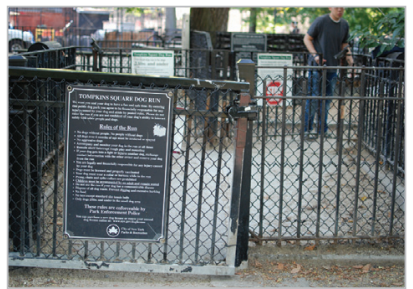

1,78

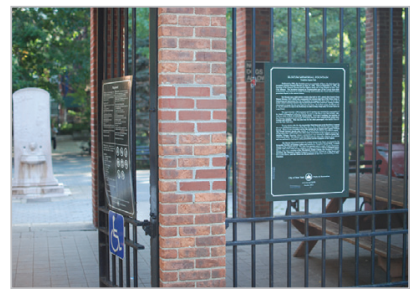

2,48

Źródło: opracowanie własne. 


\subsection{Sąsiedztwo Karanfilköy}

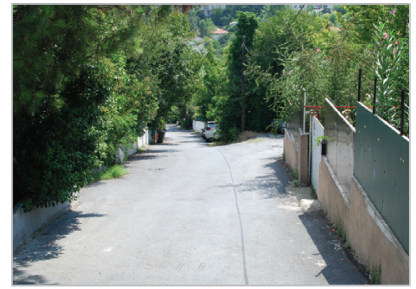

3,66

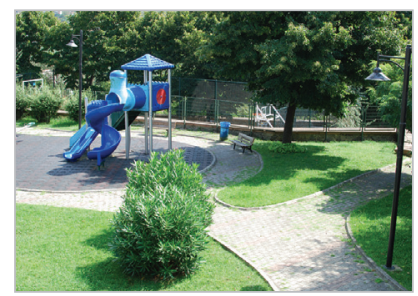

3,25

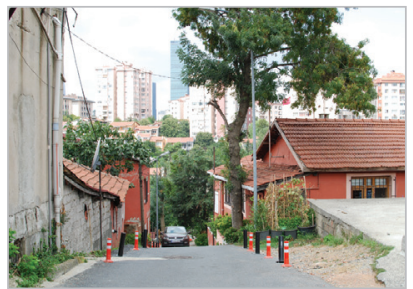

2,75

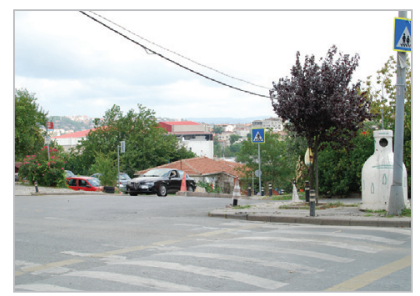

2,45

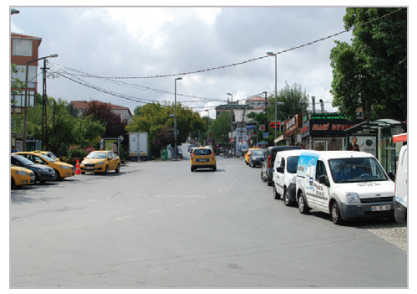

1,88

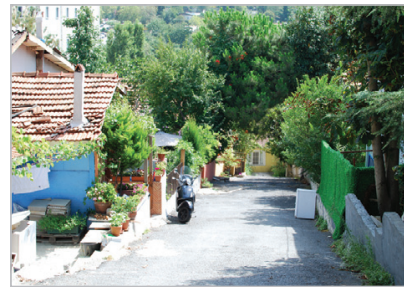

3,64

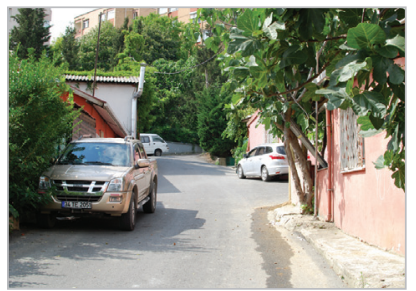

3,07

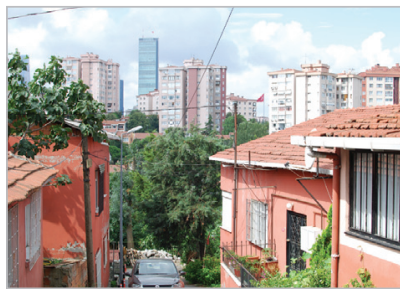

2,72

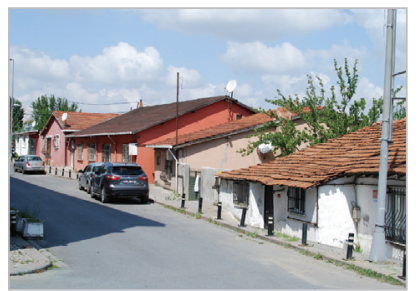

2,33

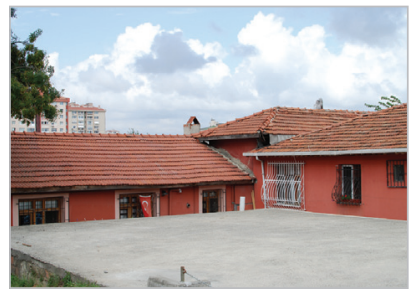

1,82

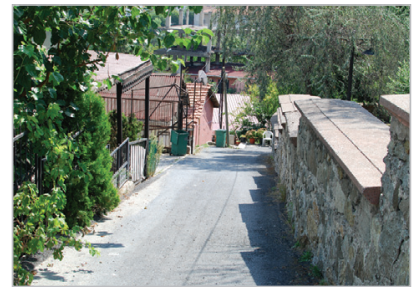

3,36

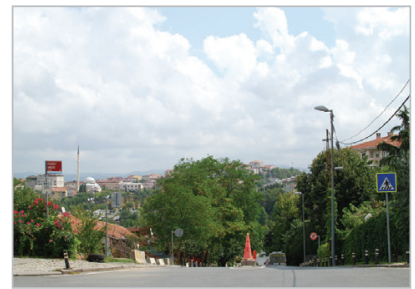

2,83

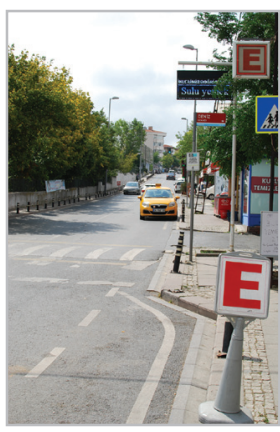

2,53

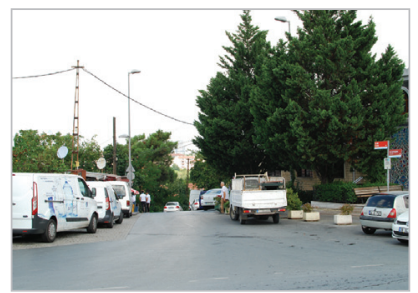

2,10

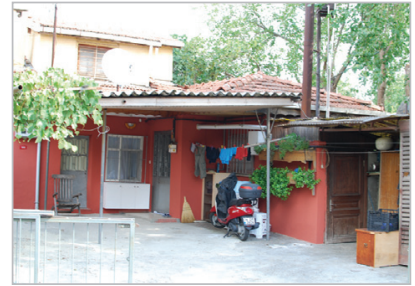

1,60

Źródło: opracowanie własne. 


\subsection{Najbliższe otoczenie sąsiedztwa Karanfilköy}

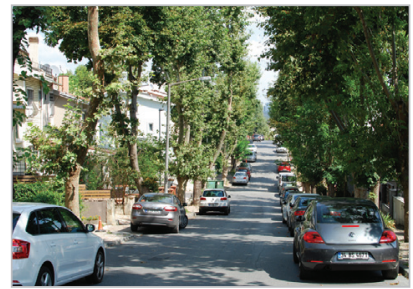

4,14

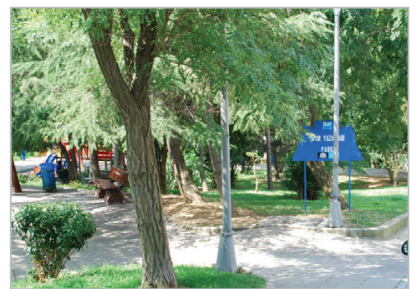

3,26

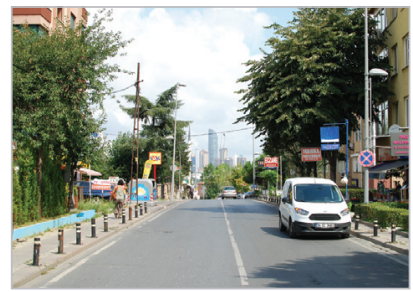

2,97

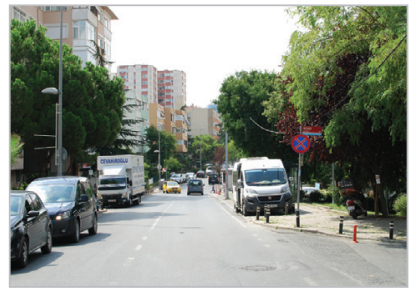

2,33

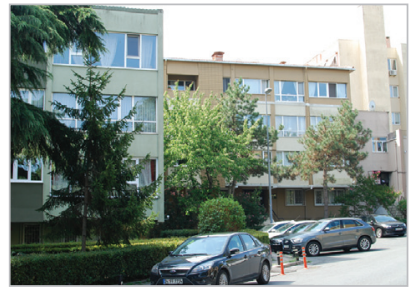

2,17

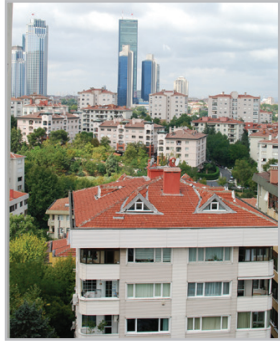

3,30

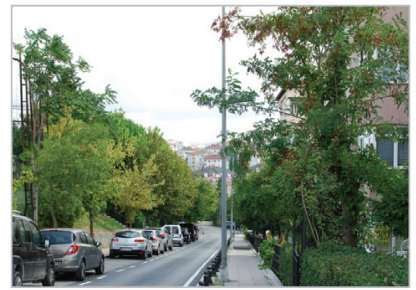

3,01

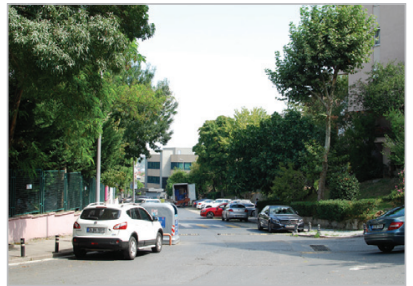

$$
2,64
$$

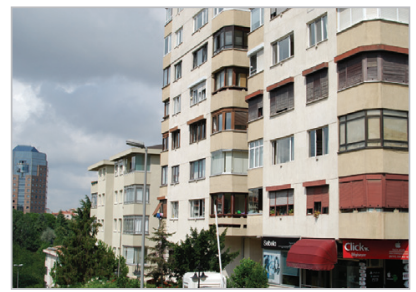

2,28

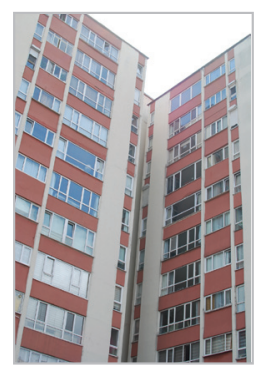

1,65

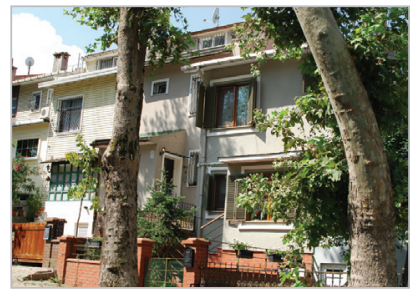

3,28

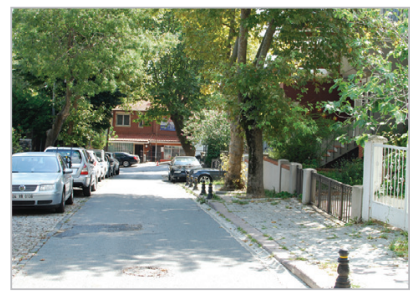

3,00

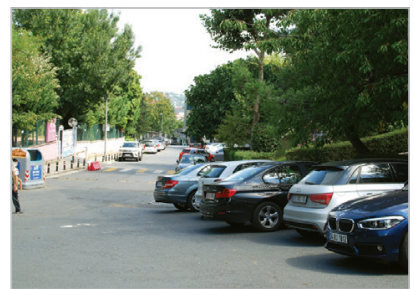

2,58

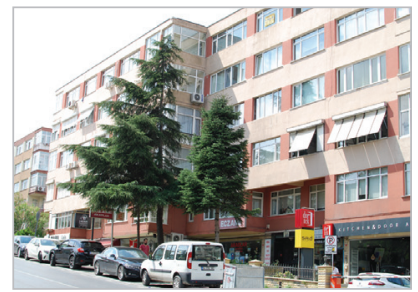

2,21

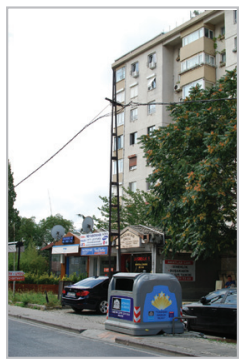

1,54

Źródło: opracowanie własne. 


\section{Spis tabel, wykresów i rycin}

\section{Tabele}

Tab. 1. Metody społecznego wytwarzania przestrzeni miasta . . . . . . . . . . 83

Tab. 2. Metody waloryzacji przestrzeni zurbanizowanej $\ldots \ldots \ldots \ldots \ldots \ldots \ldots \ldots$

Tab. 3. Metody szczegółowe wieloczynnikowej waloryzacji przestrzeni (WWP) . . . . 94

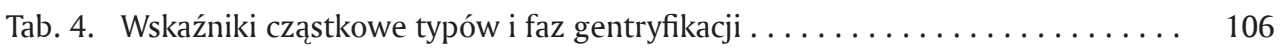

Tab. 5. Zróżnicowanie ocen w ramach zmodyfikowanej metody oceny piękna scenerii

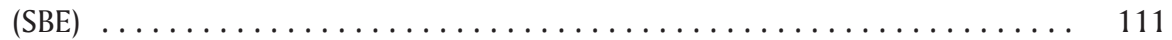

Tab. 6. Zdjęcia publikowane w mediach społecznościowych a percepcja przestrzeni . . 125

Tab. 7. Kształtowanie się transakcyjnych cen nieruchomości w złotych w okolicy placu Grzybowskiego i Warszawie ogółem $(2006-2012) \ldots \ldots \ldots \ldots \ldots \ldots \ldots$

Tab. 8. Przestępczość w okolicach placów Grzybowskiego i Dąbrowskiego oraz na ulicy

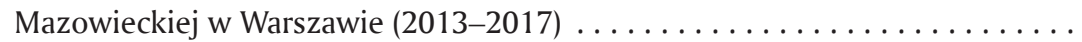

Tab. 9. Waloryzacja percepcji przestrzeni na podstawie wpisów w serwisie Instagram place Grzybowski i Europejski w Warszawie (czerwiec 2016) . . . . . . . . . . . .

Tab. 10. Kształtowanie się transakcyjnych cen nieruchomości w dolarach amerykańskich w okolicy High Line Park i na całym Manhattanie (2003-2015). . . . . . . . . 163

Tab. 11. Liczba galerii w sąsiedztwach Chelsea i SoHo w Nowym Jorku (1990-2007) . . 168

Tab. 12. Struktura rasowa zwiedzających parki i mieszkańców ich otoczenia w procentach

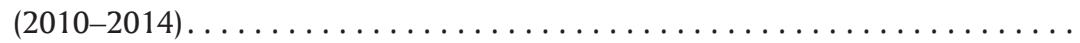

Tab. 13. Poziom przestępczości w otoczeniu parków High Line, Bryant, Tompkins Square i Washington Square w Nowym Jorku (2006-2016). . . . . . . . . . . . . .

Tab. 14. Waloryzacja percepcji przestrzeni na podstawie wpisów w serwisie Instagram - parki High Line, Bryant, Zuccotti, Tompkins Square i Central w Nowym Jorku

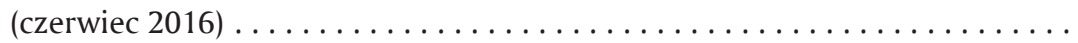

\section{Wykresy}

Wyk. 1. Trend transakcyjnych cen nieruchomości w okolicy placu Grzybowskiego

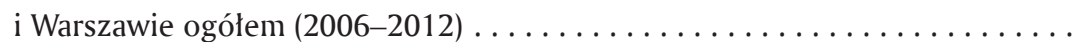

Wyk. 2. Trend cen transakcyjnych nieruchomości w okolicy High Line Park i na całym

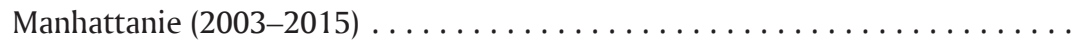

Wyk. 3. Liczba transakcji zawieranych na rynku nieruchomości w okolicy High Line Park i na Manhattanie po wybuchu globalnego kryzysu $(2008-2015,2008$ rok $=100)$ 


\section{Ryciny}

Ryc. 1. Częstotliwość używania filtrów aplikacji Instagram w różnych miastach . . . . 120

Ryc. 2. Miejsca wykonywania największej liczby zdjęć w serwisie Flickr - przykład

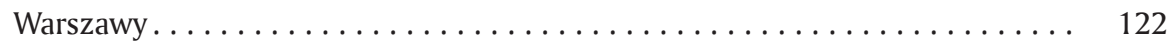

Ryc. 3. Miejsca wykonywania największej liczby zdjęć w serwisie Flickr - przykład

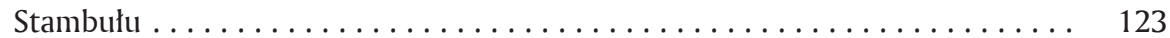

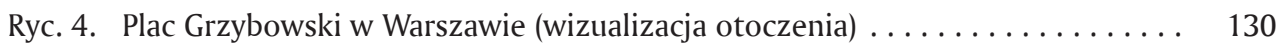

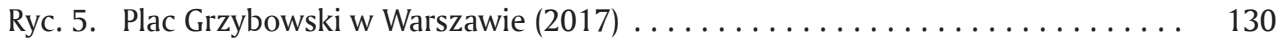

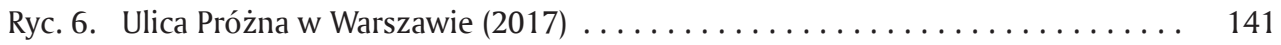

Ryc. 7. High Line Park w Nowym Jorku (wizualizacja otoczenia) . . . . . . . . . . 155

Ryc. 8. High Line Park w Nowym Jorku (2017). . . . . . . . . . . . . . . . . . . . . 155

Ryc. 9. Zachodnia część 12. Ulicy na Manhattanie (2017) . . . . . . . . . . . . . . 169

Ryc. 10. Biuro sprzedaży nieruchomości dostępne bezpośrednio z poziomu parku High

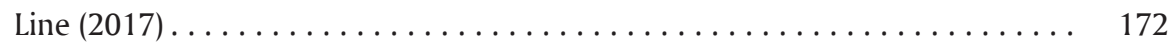

Ryc. 11. Karanfilköy w Stambule (2017, zdjęcie satelitarne otoczenia) . . . . . . . . . . 189

Ryc. 12. Karanfilköy w Stambule $(2017) \ldots \ldots \ldots \ldots$. . . . . . . . . . . . . . . . . . 189

Ryc. 13. Przykład zaniedbanej zabudowy gecekondu w Karanfilköy (2017) . . . . . . . . . 197

Ryc. 14. Przykład zabudowy willowej w Akatlar (2017) . . . . . . . . . . . . . . . 198 


\section{Bibliografia}

\section{Książki i artykuly}

Alexander Ch., S. Ishikawa, M. Silverstein, M. Jacobson, I. Fiksdahl-King, S. Angel, Język wzorców. Miasta, budynki, konstrukcja, tłum. A. Kaczanowska, K. Maliszewska, M. Trzebiatowska, przekł. przejrzał i popr. oraz wstępem opatrzył J.K. Lenartowicz, Gdańskie Wydawnictwo Psychologiczne, Gdańsk 2008.

Alkan S., Globalization, Locality and the Struggle over a Living Space. The Case of Karanfilköy, [w:] F. Eckardt, K. Wildner (red.), Public Istanbul Spaces and Spheres of the Urban, Transcript Verlag, Bielefeld 2008.

Almirall E., J. Wareham, C. Ratti, P. Conesa, F. Bria, A. Gaviria, A. Edmondson, Smart Cities at the Crossroads: New Tensions in City Transformation, „California Management Review”, nr 59/2016.

AlSayyad N., Urban Informality as a „New” Way of Life, [w:] A. Roy, N. AlSayyad (red.), Urban Informality. Transitional Perspectives from the Middle East, Latin America and South Asia, Lexington Books, Lanham-Oxford 2004.

Althusser L., E. Balibar, R. Establet, P. Macherey, J. Rancière, Das Kapital lesen, Westfälisches Dampfboot, Münster 2015.

Alvarez A.B., M.W. Wright, New York City's High Line: Participatory Planning or Gentrification?, Working Paper, The Pennsylvania State University, https:/www.semanticscholar.org/paper/ New-York-City-s-High-Line-Participatory-Planning-Alvarez-Wright/1b0bfc1d332f5c0bd59a5 d4389512faae56db990\# paperDetail, dostęp: 1.12.2017.

Andrzejewski A., Polityka mieszkaniowa, Państwowe Wydawnictwo Ekonomiczne, Warszawa 1987.

Anioł W., Kształtowanie przestrzeni miejskiej jako mikrokosmos polityki publicznej. Przypadek Warszawy, „Studia z Polityki Publicznej”, nr 2/2016.

Anioł W., Pułapka ekonomizmu. U źródeł dominacji neoliberalnej narracji modernizacyjnej w Polsce, „Przegląd Socjologiczny”, nr 2/2015.

Anty-bezradnik przestrzenny - prawo do miasta $w$ działaniu, L. Mergler, K. Pobłocki, M. Wudarski (red.), Res Publica, Warszawa 2013.

Appleyard D., Styles and Methods of Structuring a City, „Enviroment and Behavior”, nr 2/1970.

Arrenstein S.R., Drabina partycypacji, [w:] J. Erbel, P. Sadura (red.), Partycypacja. Przewodnik Krytyki Politycznej, Wydawnictwo Krytyki Politycznej, Warszawa 2012.

Atkinson R., G. Bridge, Introduction, [w:] eidem (red.), Gentrification in a Global Context, Routledge, London-New York 2005. 
Attia S., S. Shabka, Z. Shafik, A. Ibrahim (red.), Dynamics and Resilience of Informal Areas. International Perspectives, Springer, Dordrecht-Oxford 2016.

Augé M., Nie-miejsca. Wprowadzenie do antropologii hipernowoczesności, tłum. R. Chymkowski, Wydawnictwo Naukowe PWN, Warszawa 2012.

Bagaeen S., O. Uduku, Gated Histories: An Introduction to Themes and Concepts, [w:] eidem (red.), Gated Communities. Social Sustainability in Contemporary and Historical Gated Developments, Earthscan, London-Washington 2010.

Ballegooijen J. van, R. Rocco, The Ideologies of Informality: informal urbanisation in the architectural and planning discourses, „Third World Quarterly”, vol. 34, nr 10/2013.

Bauer D., N. Brändle, S. Seer, M. Ray, K. Kitazawa, Measurement of Pedestrian Movements: A Comparative Study on Various Existing Systems, [w:] H. Timmermans (red.), Pedestrian Behavior. Models, Data Collection and Applications, Emerald, Bingley 2009.

Bauman Z., Socjologia, Wydawnictwo Zysk i S-ka, Warszawa 1996.

Berman M., Take It to the Streets: Conflict and Community in Public Space, [w:] idem, Modernism in the Streets. A Life and Times in Essays, oprac. D. Marcus, S. Sclan, Verso, London 2017.

Beyme K. von, Wspótczesne teorie polityczne, tłum. J. Łoziński, Wydawnictwo Naukowe Scholar, Warszawa 2010.

Billig N., Everyday Life and Sharing of Open Space in Istanbul's Informal Settlements, [w:] A. Madanipour, S. Knierbein, A. Degros (red.), Public Space and the Challenges of Urban Transformation in Europe, Routledge, London 2013.

Blakely E.J., M.G. Snyder, Fortress America. Gated Communities in the United States, Brooking Institution Press, Washington 1997.

Bliss L., The High Line's Next Balancing Act, http://bit.ly/2Wp4bHi, dostęp: 25.03.2019.

Bluj A., E. Stokłuska, Budżet partycypacyjny (obywatelski) krok po kroku. Poradnik dla praktyków, Fundacja Pracownia Badań i Innowacji Społecznych „Stocznia”, Warszawa 2015.

Bobako M., Islamofobia jako technologia władzy. Studium z antropologii politycznej, Universitas, Kraków 2017.

Borys T., P. Rogala, Jakość życia na poziomie lokalnym - ujęcie wskaźnikowe, UNDP, Warszawa 2008. Bourdieu P., The forms of capital, [w:] J. Richardson (red.), Handbook of Theory and Research for the Sociology of Education, Greenwood, New York 1986.

Boy J.D., J. Uitermark, How to Study the City on Instagram, „PLoS ONE”, vol. 11, nr 6/2016.

Cairney P., T. Heikkila, M. Wood, Making Policy in a Complex World, Cambridge University Press, Cambridge 2019.

Campbell A., P.E. Converse, W.L. Rodgers, The Quality of American Life. Recent Pattern and Trends, McGraw-Hill, New York 1976.

Candan A.B., B. Kolluoğlu, Emerging Spaces of Neoliberalism: A Gated Town and a Public Housing Project in Istanbul, „New Perspectives on Turkey”, nr 39/2008.

Cesarski M., Polityka mieszkaniowa i osadnicza a wspótczesne problemy cywilizacji zachodniej, [w:] K. Żukrowska (red.), Nauki ekonomiczno-społeczne a rozwój, Oficyna Wydawnicza SGH, Warszawa 2008.

Cesarski M., Mieszkalnictwo społeczne a kryzysy gospodarcze XX i XXI w., [w:] J. Osiński (red.), Wymiary kryzysu - przyczyny, przejawy, prognozy i środki zaradcze, Oficyna Wydawnicza SGH, Warszawa 2009.

Cesarski M., Od funkcjonalnego mieszkania ku zrównoważonej przestrzeni zamieszkiwania - rola infrastruktury osadniczej, „Kwartalnik Kolegium Ekonomiczno-Społecznego Studia i Prace”, nr $2 / 2012$. 
Cesarski M., Polityka mieszkaniowa w Polsce a wyniki Narodowego Spisu Powszechnego z lat 2002 i 2011, [w:] P. Grata (red.), Od kwestii robotniczej do nowoczesnej kwestii socjalnej. Studia z polskiej polityki społecznej XX i XXI wieku, t. 3, Wydawnictwo Uniwersytetu Rzeszowskiego, Rzeszów 2015.

Cesarski M., Sytuacja mieszkaniowa w Polsce lat 2002-2014 - światowy kryzys, niewiadome i szanse zamieszkiwania, Oficyna Wydawnicza SGH, Warszawa 2016.

Cherem G.J., B.L. Driver, Visitor Employed Photography: A Technique to Measure Common Perceptions of Natural Environments, ,Journal of Leisure Research”, nr 1/1983.

Chmielewski J.M., Teoria i praktyka planowania przestrzennego. Urbanistyka Europy, Oficyna Wydawnicza Politechniki Warszawskiej, Warszawa 2016.

Chmielewski J.M., Teoria urbanistyki w projektowaniu i planowaniu miast, Oficyna Wydawnicza Politechniki Warszawskiej, Warszawa 2001.

Chrzanowski O., E. Rościszewska, Kanon lokalnych konsultacji społecznych, Fundacja Inicjatyw Społeczno-Ekonomicznych, Warszawa 2015.

Cichy-Pazder E.M., Atrakcyjność miasta metropolitarnego. Wyznaczniki percepcyjne i behawioralne, [w:] M. Madurowicz (red.), Percepcja wspótczesnej przestrzeni miejskiej, Wydział Geografii i Studiów Regionalnych UW, Warszawa 2007.

Cieślak I., Waloryzacja przestrzeni miejskiej - ocena jakości użytkowej przestrzeni komunikacyjnej, [w:] eadem (red.), Współczesna waloryzacja przestrzeni zurbanizowanej, Wydawnictwo Uniwersytetu Warmińsko-Mazurskiego w Olsztynie, Olsztyn 2012.

Cieślak I., Współczesne problemy oceny $i$ waloryzacji przestrzeni, [w:] eadem (red.), Wspótczesna waloryzacja przestrzeni zurbanizowanej, Wydawnictwo Uniwersytetu Warmińsko-Mazurskiego w Olsztynie, Olsztyn 2012.

Cieślak I., Wybrane metody waloryzacji przestrzeni zurbanizowanej, [w:] eadem (red.), Współczesna waloryzacja przestrzeni zurbanizowanej, Wydawnictwo Uniwersytetu Warmińsko-Mazurskiego w Olsztynie, Olsztyn 2012.

Ciszewski P., R. Nowak, Wszystkich nas nie spalicie, Trzecia Strona, Warszawa 2016.

Clark-Ibáñez M., Kadrowanie świata społecznego przy użyciu wywiadu fotograficznego, [w:] M. Frąckowiak, K. Olechnicki (red.), Badania wizualne $w$ działaniu. Antologia tekstów, tłum. M. Rosińska, Fundacja Bęc Zmiana, Warszawa 2011.

Colomb C., Staging the New Berlin. Place Marketing and the Politics of Urban Reinvention post-1989, Routledge, Abingdon 2012.

Le Corbusier, Plan Voisin, http://bit.ly/20wn8oQ, dostęp: 25.03.2019.

Le Corbusier, W stronę architektury, tłum. T. Swoboda, Centrum Architektury, Warszawa 2012.

Le Corbusier, Urbanistyka, tłum. T. Swoboda, Centrum Architektury, Warszawa 2015.

Creswell J.W., Ch.N. Poth, Qualitative Inquiry and Research Design: Choosing Among Five Approaches, Sage Publications, Thousand Oaks 2018.

Cymer A., Terrae nulius - ziemie niczyje, [w:] B. Świątkowska (red.), My i oni. Przestrzenie wspólne / projektowanie wspólnoty, Fundacja Bęc Zmiana, Warszawa 2014.

Czapiński J., Jakość życia w Polsce - wygrani i przegrani, [w:] J. Czapiński, T. Panek (red.), Diagnoza społeczna 2015. Warunki i jakość życia Polaków. Raport, Rada Monitoringu Społecznego, Warszawa 2015.

Czaplicka M., Zarządzanie kryzysem w social media, Helion, Gliwice 2014.

Czerwiński M., Życie po miejsku, Państwowy Instytut Wydawniczy, Warszawa 1974.

Daniel T.C., R.S. Boster, Measuring Landscape Esthetics: The Scenic Beauty Estimation Method, USDA Forest Service, U.S. Department of Agriculture 1976. 
David J., Reclaiming the High Line, Design Trust for Public Space, New York 2002.

David J., R. Hammond, High Line. The Inside Story of New York City's Park in the Sky, Farrar, Straus and Giroux, New York 2011.

Davis M., City of Quartz: Excavating the Future in Los Angeles, Vintage Books, New York 1992.

Davis M., Planeta slumsów, tłum. K. Bielińska, Instytut Wydawniczy Książka i Prasa, Warszawa 2009.

Desmond M., Evicted. Poverty and Profit in the American City, Crown Publishers, New York 2016.

Dębek M., B. Janda-Dębek, Jakość życia w przestrzeniach zurbanizowanych - definicje, podsumowanie wyników badań oraz problemy metodologiczne, „Czasopismo Psychologiczne”, nr 2/2013.

Domaradzki K., Przestrzeń Warszawy. Tożsamość miasta a urbanistyka, Muzeum Powstania Warszawskiego, Warszawa 2016.

Dovey K., Informalising architecture. The challenge of informal settlements, „Architectural Design”, nr 6/2013.

Dowbor L., Co to za gra? Nowe podejścia w ekonomii, Instytut Wydawniczy Książka i Prasa, Warszawa 2017.

Drozda Ł., Dwa tysiq̨ce. Instrukcja obsługi polskiej urbanizacji w XXI wieku, Fundacja Bęc Zmiana, Warszawa 2018.

Drozda Ł., Dyktatura kierowców. Nieracjonalność systemu transportowego Warszawy, [w:] B. Świątkowska, K. Pobłocki (red.), Architektura niezrównoważona, Fundacja Bęc Zmiana, Warszawa 2016.

Drozda Ł., Economic or Social Capital? Uberisation as an Exemplification of the Rent Gap Theory on the Example of Poland, „Warsaw Forum of Economic Sociology”, nr 2/2017.

Drozda $Ł .$, The gentrification approach as an analytical tool in assessing the effects of participatory urban policy, „Urban Development Issues”, nr 4/2018.

Drozda Ł., Koncepcja własności jako odpowiedzialności w planowaniu przestrzennym, [w:] J. Osiński, M. Pachocka, M. Ostrowska, M. Nawrot (red.), Rozwój we wspótczesnym świecie. Uwarunkowania, wyzwania, perspektywy, Oficyna Wydawnicza SGH, Warszawa 2016.

Drozda Ł., Lewactwo. Historia dyskursu o polskiej lewicy radykalnej, Instytut Wydawniczy Książka i Prasa, Warszawa 2015.

Drozda Ł., Miejska wspólnota nie dla każdego, „Autoportret. Pismo o dobrej przestrzeni”, nr 4/2015.

Drozda Ł., Pułapka gentryfikacji? Zwiq̨zki „uszlachetniania” przestrzeni z programami rewitalizacji polskich miast, „Studia Regionalne i Lokalne”, nr 4/2017.

Drozda Ł., Urbanistyka socmodernistyczna na przykładzie polskich blokowisk z lat 70. i 80. XX wieku, „Studia Miejskie”, nr 26/2017.

Drozda Ł., Uszlachetniając przestrzeń. Jak działa gentryfikacja i jak się jq̨ mierzy, Instytut Wydawniczy Książka i Prasa, Warszawa 2017.

Drozda Ł., W stronę urbanistyki (nie-okcydentalnej). Generatywny wymiar urbanizacji globalnego Południa, [w:] J. Osiński, M. Dobrzycka (red.), Postęp i regres. Ekonomiczno-społeczne uwarunkowania ewolucji cywilizacji, Oficyna Wydawnicza SGH, Warszawa 2017.

Drozda Ł., "Wild reprivatization": property restitution on the example of post-communist Warsaw, „dérive”, vol. 72, nr 3/2018.

Drozda Ł., Własność w modelu neoliberalnym na przykładzie polskiej przestrzeni zurbanizowanej po 1989 r., „Studia Regionalne i Lokalne”, nr 4/2016.

Drozda Ł., Zagospodarowanie przestrzeni i jego znaczenie dla polityki publicznej, [w:] J. Luszniewicz, K. Obłąkowska-Kubiak (red.), Polityka publiczna - doświadczenia i wyzwania, Oficyna Wydawnicza SGH, Warszawa 2018. 
Dudek A., Historia polityczna Polski 1989-2012, Znak, Kraków 2013.

Dymitryszyn I., A. Schwerk, Piękno scenerii krajobrazu - turystyka a różnorodność gatunkowa biegaczowatych - przykład badań z Puszczy Piskiej i Drawieńskiego Parku Narodowego, „Studia i Materiały Centrum Edukacji Przyrodniczo-Leśnej”, z. 4/2009.

Encyklopedia PWN, Wydawnictwo Naukowe PWN, http://encyklopedia.pwn.pl/haslo/waloryzacja;3993682.html, dostęp: 12.07.2016.

Engels F., Położenie klasy robotniczej w Anglii, tłum. A. Długosz, Książka i Wiedza, Warszawa 1952.

Erbel J., Jak działa sztuka w przestrzeni publicznej?, [w:] J. Baranowska, P. Sztarbowski (red.), Liberated Energy, Instytut Teatralny im. Zbigniewa Raszewskiego, Warszawa 2011.

Erbel J., 0 tym, co się stało, że sztuka w przestrzeni publicznej stała się kluczowym obszarem walki o lepsze życie w mieście, a potem przestała nim być, [w:] J. Dominiczak, K. Wielebska, A. Szynwelska (red.), Sztuka i przestrzeń publiczna: Pierwsze sympozjum Galerii Zewnętrznej Miasta Gdańska, Centrum Sztuki Współczesnej Łaźnia, Gdańsk 2012.

Farina A., Landscape Ecology in Action, Springer Science+Business Media, Dordrecht 2000.

Fitch R., The Assasination of New York, Verso, London-New York 1993.

Fleming P., The Human Capital Hoax: Work, Debt and Insecurity in the Era of Uberisation, „Organization Studies", nr 5/2017.

Florida R., Narodziny klasy kreatywnej oraz jej wpływ na przeobrażenia w charakterze pracy, wypoczynku, społeczeństwa i życia codziennego, tłum. T. Krzyżanowski, M. Penkala, Narodowe Centrum Kultury, Warszawa 2010.

Florida R., New Urban Crisis. How Our Cities Are Increasing Inequality, Deepening Segregation, and Failing the Middle Class - and What We Can Do About It, Basic Books, New York 2017.

Foster H., The Art-Architecture Complex, Verso, London-New York 2013.

Fraser M., A Question of Infinite Exlusivity, [w:] K. Nawratek B. Huggins, M. Oxley, A. Horton-Howe (red.), Radical Inclusivity. Architecture and Urbanism, dpr-barcelona, Barcelona 2015.

Frias-Martinez V., V. Soto, H. Hohwald, E. Frias-Martinez, Characterizing Urban Landscapes using Geolocated Tweets, International Conference on Social Computing and 2012 ASE/IEEE International Conference on Privacy, Security, Risk and Trusthttps:/ieeexplore.ieee.org/document/6406289, dostęp: 18.04.2019.

Fusiecki J., PiS naucza i demaskuje, http://bit.ly/2usFFcj, dostęp: 14.07.2017.

Gadomska W., Humanizacja postindustrialnej przestrzeni miejskiej - przykład nowojorskiego parku High Line jako udanej rewitalizacji dawnej linii kolejowej, „Humanistyka i Przyrodoznawstwo”, nr 20/2014.

Gadomska W., W. Gadomski, Park High Line - przestrzeń publiczna jako rezultat rewitalizacji postindustrialnego dziedzictwa zachodniego Manhattanu, „Przestrzeń i Forma”, nr 21/2014.

Gawryszewska B.J., Language of borders in the structure of everyday landscape, [w:] J. Plit, V. Andreychouk (red.), Methods of landscape research, Commision of Cultural Research of Polish Geographical Society, Sosnowiec 2008.

Gawryszewska B.J., Zielona zmiana w krajobrazie miasta. Wernakularne ogrody miejskie jako konsekwencja przemian wizerunku, funkcji i znaczenia zieleni w przestrzeni publicznej, „Societas/ Communitas", nr 2/2018.

Gawryszewska B.J., M. Łepkowski, A. Wilczyńska, City wastelands: Creating places of vernacular democracy, [w:] C. Certomà, S. Noori, M. Martin Sondermann (red.), Urban Gardening and the Struggle for Social and Spatial Justice, Manchester University Press, Manchester 2019. 
Gądecki J., I love NH. Gentryfikacja starej części Nowej Huty?, Wydawnictwo Instytutu Filozofii i Socjologii PAN, Warszawa 2012.

Gądecki J., Za murami. Osiedla grodzone w Polsce - analiza dyskursu, Wydawnictwo Uniwersytetu Wrocławskiego, Wrocław 2009.

Gądecki J., P. Kubicki, Polityki miejskie, „Politeja”, nr 1/2014.

Gehl J., Miasta dla ludzi, tłum. S. Nogalski, Wydawnictwo RAM, Kraków 2014.

Gehl J., Życie między budynkami. Użytkowanie przestrzeni publicznych, tłum. M.A. Urbańska, Wydawnictwo RAM, Kraków 2013.

Gehl J., B. Svarre, How To Study Public Life?, Island Press, Washington 2013.

Geyer R., S. Rihani, Complexity and Public Policy: A new approach to twenty-first century politics, policy and society, Routledge, London 2010.

Giddens A., Socjologia, tłum. A. Szulżycka, Wydawnictwo Naukowe PWN, Warszawa 2007.

Gilbert A., Love in the Time of Enhanced Capital Flows: Reflections on the Links between Liberalization and Informality, [w:] A. Roy, N. AlSayyad (red.), Urban Informality. Transitional Perspectives from the Middle East, Latin America and South Asia, Lexington Books, Lanham-Oxford 2004.

Gillespie M., L. Ampofo, M. Cheesman, B. Faith, E. Iliadou, A. Issa, S. Osseiran, D. Skleparis, Mapping Refugee Media Journeys. Smartphones and Social Media Networks, The Open University, France Médias Monde, 2016.

Glass R., Aspects of Change, [w:] J. Brown-Saracino (red.), The Gentrification Debates, Routledge, New York 2010.

Gottdiener M., A Marx for Our Time: Henri Lefebvre and The Production of Space, „Sociological Theory", vol. 11, nr 1/1993.

Gottdiener M., The Social Production of Urban Space, University of Texas Press, Austin 1997.

Gould P., R. White, Mental Maps, Routledge, London 2002.

Gökarıksel B., The intimate politics of secularism and the headscarf: the mall, the neighborhood, and the public square in Istanbul, „Gender, Place \& Culture: A Journal of Feminist Geography”, nr $1 / 2012$.

Gökarıksel S., Neither teleologies nor "feeble cries": revolutionary politics and neoliberalism in time and space, „Dialectical Anthropology”, nr 1/2018.

Górski R., Bez państwa. Demokracja uczestnicząca w działaniu, Korporacja Ha!art, Kraków 2007.

Graham S., Cities Under Siege. The New Military Urbanism, Verso, London-New York 2011.

Graham S., Vertical The City from Satellites to Bunkers, Verso, London-New York 2016.

Graham W., Miasta wyśnione. Siedem wizji urbanistycznych, które kształtują nasz świat, tłum. A. Sak, Karakter, Kraków 2016.

Greenslade R., Record number of journalists in jail globally after Turkey Crackdown, http://bit.ly/2U3QeSB, dostęp: 22.09.2017.

Gyurkovich M., Komercja i kultura czyli dwa oblicza struktur hybrydowych we wspótczesnych metropoliach, [w:] idem (red.), Hybrid Urban Structures, Wydawnictwo Politechniki Krakowskiej, Kraków 2016.

Gzell S., Wykłady o wspótczesnej urbanistyce, Oficyna Wydawnicza Politechniki Warszawskiej, Warszawa 2015.

Haffner J., The dangers of eco-gentrification: what's the best way to make a city greener?, http://bit. ly/2CGtA7V, dostęp: 25.03.2019.

Hall E.T., Ukryty wymiar, tłum. T. Hołówka, Państwowy Instytut Wydawniczy, Warszawa 1976.

Hamm B., Wprowadzenie do socjologii osadnictwa, tłum. A. Rosłan, Książka i Wiedza, Warszawa 1990. 
Hanne O., T. Flichy de la Neuville, Państwo Islamskie. Geneza nowego kalifatu, tłum. J. Danecki, Wydawnictwo Akademickie Dialog, Warszawa 2015.

Harvey D., Bunt miast. Prawo do miasta i miejska rewolucja, tłum. A. Kowalczyk et al., Fundacja Bęc Zmiana, Warszawa 2012.

Harvey D., The Condition of Postmodernity. An Enquiry into the Origins of Cultural Change, Blackwell, Oxford 1991.

Harvey D., The Enigma of Capital and the Crises of Capitalism, Oxford University Press, New York 2010.

Harvey D., From Managerialism to Entrepreneurialism: The Transformation in Urban Governance in Late Capitalism, „Geografiska Annaler”, vol. 71, nr 1/1989.

Harvey D., Przestrzenie globalnego kapitalizmu. W stronę teorii rozwoju nierównego geograficznie, tłum. J.P. Listwan, Instytut Wydawniczy Książka i Prasa, Warszawa 2016.

Harvey D., Przewodnik po Kapitale Karola Marksa, tłum. K. Szadkowski, Wydawnictwo Ekonomiczne Heterodox, Poznań 2017.

Harvey D., Social Justice and the City, The University of Georgia Press, Athens 2009.

Herman K., Ogrody tymczasowe w przestrzeniach kolektywnych, Wydawnictwo Sztuka Ogrodu Sztuka Krajobrazu Beata J. Gawryszewska, Warszawa 2011.

Hernández F., M. Millington, I. Borden (red.), Transculturation. Cities, Spaces and Architecture in Latin America, Rodopi, Amsterdam-New York 2005.

Hernández F., P. Kellett, L.K. Allen (red.), Rethinking the Informal City. Critical Perspectives from Latin America, Berghahn Books, New York-Oxford 2010.

Hessel S., Czas oburzenia!, tłum. P. Witt, Oficyna Naukowa, Warszawa 2011.

Hidenobu J., Tokyo. A Spatial Anthropology, University of California Press, Berkeley-London 1995.

Hochman N., L. Manovich, Zooming into an Instagram City: Reading the local through social media, „First Monday”, nr 6/2013, http://bit.ly/2v4SCY5, dostęp: 10.07.2017.

Hogwood B.W., L.A. Gunn, Policy Analysis for the Real World, Oxford University Press, Oxford 1984.

Howard E., Miasta-ogrody jutra, tłum. M. Trykozko, Centrum Architektury - Instytut Kultury Miejskiej, Warszawa-Gdańsk 2015.

Huntington S., Trzecia fala demokratyzacji, tłum. A. Dziurdzik, Wydawnictwo Naukowe PWN, Warszawa 1995.

Isanovic H., Should the Informal become Formal: The Case of Karanfilkoy in Istanbul, Turkey, „International Journal of Arts \& Sciences", nr 5/2014.

Izdebski H., Ideologia i zagospodarowanie przestrzeni. Doktrynalne prawno-polityczne uwarunkowania urbanistyki i architektury, Wolters Kluwer Polska, Warszawa 2013.

Jacobs J., Czy wielkie plany rozwiążą problem odnowy? Przemówienie podczas konferencji „Dzielnice mieszkalne a odnowa miejska" w Hamburgu, 12-14 października 1981, [w:] S. Zipp, N. Storring (red.), Jane Jacobs. Wielkie małe plany: zbiór krótkich tekstów, tłum. M. Trykozko, Centrum Architektury, Warszawa 2017.

Jacobs J., Śmierć i życie wielkich miast Ameryki, tłum. Ł. Mojsak, Centrum Architektury, Warszawa 2014.

Jałowiecki B., Fragmentacja i prywatyzacja przestrzeni, [w:] B. Jałowiecki, W. Łukowski (red.), Gettoizacja polskiej przestrzeni miejskiej, SWPS Academica, Wydawnictwo Naukowe Scholar, Warszawa 2007.

Jałowiecki B., Polityka miejska a prawo do miasta, „Zoon Politikon”, nr 4/2013.

Jałowiecki B., Społeczne wytwarzanie przestrzeni, Wydawnictwo Naukowe Scholar, Warszawa 2010. 
Jałowiecki B., Proces waloryzacji przestrzeni miejskiej, [w:] Z. Pióro (red.), Przestrzeń i społeczeństwo. Z badań ekologii społecznej, Książka i Wiedza, Warszawa 1982.

Jałowiecki B., M.S. Szczepański, Miasto i przestrzeń w perspektywie socjologicznej, Wydawnictwo Naukowe Scholar, Warszawa 2002.

Jameson F., Mapowanie poznawcze, tłum. B. Kuźniarz, „Krytyka Polityczna”, nr 16-17/2018.

Jasiecki K., Zasady merytokratyczne w polityce państwa - wzloty i upadki, „Studia z Polityki Publicznej”, nr 3/2016.

Jemielniak D., Socjologia internetu, Wydawnictwo Naukowe Scholar, Warszawa 2019.

Jencks Ch., Architektura postmodernistyczna, tłum. B. Gadomska, Arkady, Warszawa 1987.

John P., Local Governance in Western Europe, Sage Publications, London 2001.

Johnson R.J., M.J. Scicchitano, Don't Call Me NIMBY. Public Attitudes Toward Solid Waste Facilities, „Environment and Behavior”, nr 3/2012.

Jones B., Bounded Rationality and Public Policy: Herbert A. Simon and the Decisional Foundation of Collective Choice, „Policy Sciences”, nr 3/2002.

Jones J., Social media and social movements, „International Socialism”, nr 130/2011.

Kajdanek K., O potrzebie końca socjologii miasta, „Przestrzeń Społeczna”, nr 2/2012.

Kajdanek K., Suburbanizacja po polsku, Zakład Wydawniczy Nomos, Kraków 2012.

Kamp I. van, K. Leidelmeijer, G. Marsman, A. de Hollander, Urban environmental quality and human well-being. Towards a conceptual framework and demarcation of concepts; a literature study, „Landscape and Urban Planning”, nr 65/2003.

Kieżun W., Patologia transformacji, Poltext, Warszawa 2012.

Kingdon J.W., Agendas, Alternatives, and Public Policies, Longman, New York 2003.

Kłoskowska A., Kultura masowa. Krytyka i obrona, Państwowe Wydawnictwo Naukowe, Warszawa 1990.

Kmicic K., Struktura przestrzeni osiedli mieszkaniowych jako podstawa ksztattowania ich zagospodarowania przestrzennego - wybrane koncepcje podziału przestrzeni osiedlowych, [w:] B. Szulczewska, R. Giedych (red.), Przestrzeń przyrodnicza i społeczna osiedli mieszkaniowych w XX i XXI wieku, Wydawnictwo SGGW, Warszawa 2011.

Kondova K., The smartphone as a lifeline: the impact of digital communication technologies and services on refugees' experiences during their flight, Erasmus School of History, Culture and Communication, Erasmus University, Rotterdam 2016.

Koolhaas R., Deliryczny Nowy Jork. Retroaktywny manifest dla Manhattanu, tłum. D. Żukowski, Karakter, Kraków 2013.

Koolhaas R., Śmieciowa przestrzeń, tłum. M. Wawrzyńczak, Centrum Architektury, Warszawa 2017.

Koolhaas R., Wielka skala, czyli problem rozmiaru, [w:] Ch. Jencks, K. Kropf (red.), Teorie i manifesty architektury wspótczesnej, tłum. D. Szymczak, Grupa Sztuka Architektury, Warszawa 2013.

Kotkin S., Magnetic Mountain. Stalinism as a Civilization, University of California Press, Berkley 1997.

Kowalczyk A., Percepcja środowiska miejskiego przez dzieci (na przykładzie Warszawy), [w:] B. Jałowiecki, H. Libura (red.), Percepcja i waloryzacja środowiska naturalnego i antropogenicznego, Wydawnictwa Uniwersytetu Warszawskiego, Warszawa 1992.

Krier L., Architektura wspólnoty, tłum. P. Choynowski, słowo/obraz terytoria, Gdańsk 2011.

Kucharska-Stasiak E., Ekonomiczny wymiar nieruchomości, Wydawnictwo Naukowe PWN, Warszawa 2016. 
Kuligowski W., A. Stanisz, Ruchome modernizacje. Między Autostradq Wolności a „starq dwójkq̨”, Instytut Wydawniczy Książka i Prasa, Warszawa 2017.

Kurnicki K., Ideologie w mieście. O społecznej produkcji przestrzeni, Zakład Wydawniczy Nomos, Kraków 2018.

Kurowski K., Samoorganizacja w wielkomiejskim slumsie. Przykład Limy, Wydawnictwa Uniwersytetu Warszawskiego, Warszawa 2013.

Kuryłowicz E., Uwarunkowania architektoniczne kształtowania otoczenia wybudowanego przyjaznego dla osób niepełnosprawnych, [w:] A. Jędrzejczak-Sprycha (red.), Projektowanie uniwersalne. Sztokholm miasto dla wszystkich, Stowarzyszenie Przyjaciół Integracji, Warszawa 2005.

Kusiak J., Chaos Warszawa. Porządki przestrzenne polskiego kapitalizmu, Fundacja Bęc Zmiana, Warszawa 2018.

Kuyucu T., Ö. Ünsal, 'Urban Transformation' as State-led Property Transfer: An Analysis of Two Cases of Urban Renewal in Istanbul, „Urban Studies”, nr 7/2010.

Laguerre M.S., The Informal City, St. Martin's Press, New York 1994.

Lang S., J. Rothenberg, Neoliberal urbanism, public space, and the greening of the growth machine: New York City's High Line park, „Environment and Planning A”, nr 1-19/2016.

Lasswell H.D., The Policy Orientation, [w:] S. Braman (red.), Communication Researchers and Policy-making, The MIT Press, Cambridge 2003.

Lasswell H.D., A Pre-View of Policy Sciences, American Elsevier Publishing, Cambridge 1971.

Latour B., Polityka natury. Nauki wkraczaja do demokracji, tłum. A. Czarnacka, Wydawnictwo Krytyki Politycznej, Warszawa 2009.

Latour B., Reassembling the Social. An Introduction to Actor-Network-Theory, Oxford University Press, New York 2005.

Lefebvre H., Prawo do miasta, tłum. E. Majewska, „Praktyka Teoretyczna”, nr 5/2012.

Lefebvre H., The Production of Space, Blackwell, Oxford 1991.

Lewicka M., Psychologia miejsca, Wydawnictwo Naukowe Scholar, Warszawa 2012.

Lewicka M., A. Bańka, Psychologia środowiskowa, [w:] J. Strelau, D. Doliński (red.), Psychologia. Podręcznik akademicki, t. 2, Gdańskie Wydawnictwo Psychologiczne, Gdańsk 2008.

Lewicki J., Polityka miejska w polityce rozwoju państwa, [w:] D. Mikucka-Wójtowicz (red.), Przeszłość - Teraźniejszość - Przyszłość. Problemy badawcze politologów, Libron, Kraków 2010.

Ley D., R. Cybriwsky, Urban Graffiti as Territorial Markers, „Annals of the Association of American Geographers", nr 4/1974.

Lindqvist S., Wytępić całe to bydło, tłum. M. Haykowska, W.A.B., Warszawa 2009.

Loughran K., Imbricated Spaces: The High Line, Urban Parks, and the Cultural Meaning of City and Nature, „Sociological Theory”, vol. 34, nr 4/2016.

Lydon M., A. Garcia, Tactical Urbanism. Short-term Action for Long-term Change, Island Press, Washington 2015.

Lynch K., Obraz miasta, tłum. T. Jeleński, Archivolta Michał Stępień, Kraków 2011.

Madden D., P. Marcuse, In Defense of Housing. The Politics of Crisis, Verso, London 2016.

Malesińska A., Twitter jako źródło wiedzy o stanie zdrowia polskiego społeczeństwa - ujęcie infodemiologiczne, „Kultura Popularna”, nr 3/2016.

Malisz B., Gospodarka i polityka przestrzenna, [w:] J. Regulski (red.), Planowanie przestrzenne, Polskie Wydawnictwo Ekonomiczne, Warszawa 1985.

Marans R.W., R.J. Stimson, Introduction [w:] eidem (red.), Investigating Quality of Urban Life. Theory, Methods and Empirical Research, Springer, Dordrecht-Heidelberg-London-New York 2011. 
Marks K., Kapitat. Krytyka ekonomii politycznej, Proces wytwarzania kapitału, [w:] K. Marks, F. Engels, Dzieła, t. 23, Książka i Wiedza, Warszawa 1968.

Marzec W., Rebelia i reakcja. Rewolucja 1905 roku i plebejskie doświadczenie polityczne, Wydawnictwo Uniwersytetu Łódzkiego, Universitas, Łódź-Kraków 2016.

Maslow A., Motywacja i osobowość, tłum. P. Sawicka, Wydawnictwo Naukowe PWN, Warszawa 2009.

Matyja R., Krajowa Polityka Miejska okiem politologa, „Zarządzanie Publiczne”, nr 3/2015.

Matyja R., Wyjście awaryjne. O zmianie wyobraźni politycznej, Karakter, Kraków 2018.

Mączyńska E., Wycena nieruchomości w celu ustanowienia zabezpieczenia hipotecznego, [w:] G. Główka (red.), Nieruchomość kredyt hipoteka, Poltext, Warszawa 2008.

McGuirk J., Radykalne miasta. Przez Amerykę Łacińskq w poszukiwaniu nowej architektury, tłum. M. Wawrzyńczak, Fundacja Bęc Zmiana, Res Publica, Warszawa 2015.

McKenzie R.D., The Ecological Approach to the Study of the Human Community, [w:] R.E. Park, W. Burgess (red.), The City. Suggestions for Investigation of Human Behavior in the Urban Environment, The University of Chicago Press, Chicago-London 1984.

Merrifield A., Nowa kwestia miejska, tłum. P. Juskowiak, Wydawnictwo Naukowe PWN, Warszawa 2016.

Miastowska A., Czym jest i gdzie powstaje dzielnica nędzy, [w:] J. Jankowska (red.), Ku Afryce. Poznawać. Działać. Dzielić się, Instytut Wydawniczy Książka i Prasa, Warszawa 2014.

Miessen M., Koszmar partycypacji, tłum. M. Choptiany, Fundacja Bęc Zmiana, Warszawa 2013.

Millington N., From urban scar to 'park in the sky': terrain vague, urban design, and the remaking of New York City's High Line Park, „Environment and Planning A”, vol. 47, nr 11/2015.

Mitchell G., Indicators as tools to guide progress on the sustainable development pathway, [w:] R.J. Lawrence (red.), Sustaining Human Settlement. A Challenge for the New Millennium, Urban International Press, North Shields 2000.

Molotch H., M. Treskon, Changing Art: SoHo, Chelsea and the Dynamic Geography of Galleries in New York City, „International Journal of Urban and Regional Research”, vol. 33.2, nr 6/2009.

Montgomery Ch., Miasto szczęśliwe. Jak zmienić nasze życie, zmieniajq̨c nasze miasta, tłum. T. Tesznar, Wysoki Zamek, Kraków 2015.

Morenas L., A Critique of the High Line: Landscape Urbanism and the Global South, [w:] A. Duany, E. Talen (red.), Landscape Urbanism and its Discontents. Dissimulating the Sustainable City, New Society Publishers, Gabriola Island 2013.

Moskowitz P., How To Kill a City. Gentrification. Inequality, and the Fight for the Neighborhood, Nation Books, New York 2017.

Moss J., Disney World on the Hudson, „New York Times”, 22 sierpnia 2017.

Moss J., Vanishing New York: How a Great City Lost Its Soul, Dey Street Books, New York 2017.

Moss M.R., W.G. Nickling, Landscape evaluation in environmental assessment and land use planning, „Environmental Management”, nr 1/1980.

Mould O., Against Creativity, Verso, London-New York 2018.

Mularska-Kucharek M., Kapitał społeczny a jakość życia na przykładzie zbiorowości wielkomiejskiej, Wydawnictwo Uniwersytetu Łódzkiego, Łódź 2013.

Mumford L., The City in History. Its Origins, Its Transformations, and Its Prospects, Hartcour Brace Jovanovich, New York 1961.

Murawski M., Kompleks gmachu. Życie społeczne stalinowskiego wieżowca w kapitalistycznej Warszawie, Muzeum Warszawy, Warszawa 2015. 
Nawratek K., Dziury w całym. Wstęp do miejskich rewolucji, Wydawnictwo Krytyki Politycznej, Warszawa 2012.

Nawratek K., Ideologie w przestrzeni. Próby demistyfikacji, Universitas, Kraków 2005.

Nawratek K., Miasta - maszyny produkujące niezwykłość, „Znak”, nr 673/2011, http://www.miesiecznik.znak.com.pl/2754/miasta-maszyny-produkujace-niezwyklosc, dostęp: 2.05.2015.

Nawratek K., Miasto jako idea polityczna, Korporacja Ha!art, Kraków 2008.

Nawratek K., Tarcza wielu możliwości, rozmawia D. Leśniak-Rychlak, „Autoportret. Pismo o dobrej przestrzeni”, nr 1/2017.

Nawratek K., Total Urban Mobilisation. Ernst Jünger and the Post-Capitalist City, Palgrave Macmillan, Singapore 2019.

Nawrocki T., Wykorzystanie map mentalnych $w$ badaniach przestrzeni publicznych. Przykład Gliwic, [w:] B. Komar, J. Biedrońska, A. Szewczenko (red.), Badania interdyscyplinarne w architekturze, t. 2, Wydawnictwo Politechniki Śląskiej, Gliwice 2015.

Nejman R., M. Łepkowski, A. Wilczyńska, B.J. Gawryszewska, The right to wild. Green urban wasteland in the context of urban planning, „Urban Development Issues”, nr 3/2018.

Newman O., Creating Defensible Space, U.S. Department of Housing and Urban Development Office of Policy Development and Research, Washington 1996.

Norberg-Schulz Ch., Genius Loci. Towards a Phenomenology of Architecture, Rizzoli, New York 1979.

Nowak S., Metodologia badań społecznych, Wydawnictwo Naukowe PWN, Warszawa 2010.

Nóżka M., Społeczne zamykanie (się) przestrzeni. O wykluczeniu, waloryzacji miejsca zamieszkania i jego mentalnej reprezentacji, Wydawnictwo Naukowe Scholar, Warszawa 2016.

Offenhuber D., Technologie obywatelskie. Narzędzia czy terapia?, [w:] K. Piekarski (red.), Metody badania i odkrywania miasta oparte na danych, Medialab Katowice, Katowice 2015.

Olenderek H., Historia geomatyki..., [w:] W. Milewski (red.), Geomatyka w lasach państwowych. Część I. Podstawy, Centrum Informacyjne Lasów Państwowych, Warszawa 2010.

Oniszczuk J., Termin, rozumienie i ujęcia państwa, [w:] idem (red.), Współczesne państwo w teorii i praktyce, Oficyna Wydawnicza SGH, Warszawa 2011.

Pamuk O., Dziwna myśl w mej głowie, tłum. P. Kawulok, Wydawnictwo Literackie, Kraków 2015.

Patrick D.J., The matter of displacement: a queer urban ecology of New York City's High Line, „Social \& Cultural Geography", vol. 15, nr 8/2014.

Pauwels L., Zwrot wizualny w badaniach $i$ komunikacji wiedzy. Kluczowe problemy rozwijania kompetencji wizualnej w naukach społecznych, [w:] M. Frąckowiak, K. Olechnicki (red.), Badania wizualne w działaniu. Antologia tekstów, tłum. M. Rosińska, Fundacja Bęc Zmiana, Warszawa 2011.

Piasny J., Poziom i jakość życia ludności oraz źródta i mierniki ich określania, „Ruch Prawniczy, Ekonomiczny i Socjologiczny”, z. 2/1993.

Pierre J., B.G. Peters, Governing Complex Societies. Trajectories and Scenarios, Palgrave Macmillan, London 2005.

Piketty T., Kapitat w XXI wieku, tłum. A. Bilik, Wydawnictwo Krytyki Politycznej, Warszawa 2015.

Pióro Z., Główne nurty ekologii społecznej, [w:] idem (red.), Przestrzeń i społeczeństwo. Z badań ekologii społecznej, Książka i Wiedza, Warszawa 1982.

Pobłocki K., Kapitalizm. Historia krótkiego trwania, Fundacja Bęc Zmiana, Warszawa 2017.

Polanyi K., Wielka transformacja. Polityczne i ekonomiczne źródła naszych czasów, tłum. M. Zawadzka, Wydawnictwo Naukowe PWN, Warszawa 2010.

Polkowska D., Ekonomiczna wartość przestrzeni miejskiej, [w:] M. Madurowicz (red.), Wartościowanie wspótczesnej przestrzeni miejskiej, Wydawnictwo Wydziału Geografii i Studiów Regionalnych UW, Urząd m.st. Warszawy, Warszawa 2010. 
Polyák L., Pakiet praw i obowiqzzków, „Autoportret. Pismo o dobrej przestrzeni”, nr 3/2017.

Prawelska-Skrzypek G., Waloryzacja przestrzeni polskich miast w opinii ich mieszkańców, [w:] B. Jałowiecki, H. Libura (red.), Percepcja i waloryzacja środowiska naturalnego i antropogenicznego, Wydawnictwa Uniwersytetu Warszawskiego, Warszawa 1992.

Prośniewski B., Gust nasz pospolity, Fundacja Bęc Zmiana, Fundacja im. Stefana Kuryłowicza, Warszawa 2014.

Przestrzeń życia Polaków, J. Sepioł (red.), Stowarzyszenie Architektów Polskich, Warszawa 2014, http://www.sarp.org.pl/pliki/1908_53fdc64bb3140-pzp_spistresci_1.pdf, dostęp: 2.05.2015.

Przymeński A., Socjalny najem mieszkań jako instrument demarginalizacji mieszkaniowej w Polsce, „Problemy Polityki Społecznej. Studia i Dyskusje”, nr 1/2016.

Przymeński A., Zarządzanie socjalnq pomocą mieszkaniową, [w:] A. Przymeński, M. Oliwa-Ciesielska, Publiczna pomoc mieszkaniowa a demarginalizacja społeczna ludności ubogiej, Wydawnictwo Uniwersytetu Ekonomicznego w Poznaniu, Poznań 2014.

Raczyńska M., Czasem nic się nie dzieje, czasem coś się wydarza, [w:] Zespół Krytyki Politycznej (red.), Rajkowska. Przewodnik Krytyki Politycznej, Wydawnictwo Krytyki Politycznej, Warszawa 2010.

Rajkowska J., Sztuka publicznej możliwości, rozmawia A. Żmijewski, [w:] Zespół Krytyki Politycznej (red.), Rajkowska. Przewodnik Krytyki Politycznej, Wydawnictwo Krytyki Politycznej, Warszawa 2010.

Rajkowska J., Wzlot z kulq u nogi, rozmawia K. Pawełek, „Obieg”, nr 1-2/2010.

Raport o ekonomicznych stratach i społecznych kosztach niekontrolowanej urbanizacji w Polsce, IGCZ PAN, Fundacja Rozwoju Demokracji Lokalnej, Warszawa 2013.

Rasmussen S.E., Odczuwanie architektury, tłum. B. Gadomska, Wydawnictwo Murator, Warszawa 1999.

Reichl A.J., The High Line and the ideal of democratic public space, „Urban Geography”, vol. 37, nr 6/2016.

Review of Existing Methods of Landscape Assessment and Evaluation, www.macaulay.ac.uk/ccw/task-two/evaluate.html, dostęp: 1.11.2017.

Rist G., Urojenia ekonomii, tłum. Ś.F. Nowicki, Instytut Wydawniczy Książka i Prasa, Warszawa 2016.

Ross A., The Profit in the PokéStop, https://www.jacobinmag.com/2016/07/pokemon-go-niantic-ingress-pokestops-profits/, dostęp: 3.08.2016.

Rygiel P., Odporność wizualna krajobrazu - zastosowanie w planowaniu przestrzennym, „Czasopismo Techniczne. Architektura”, z. 5-A/2007.

Rykwert J., Pokusa miejsca. Przeszłość i przyszłość miast, tłum. T. Bieroń, Międzynarodowe Centrum Kultury, Kraków 2013.

Rylke J., A. Długozima, Ocena, wycena i kształtowanie zasobów kulturowych, [w:] J. Szyszko, B. Porter, J. Malczyk (red.), ABC gospodarki przestrzennej w aspekcie rozwoju regionalnego, Wydawnictwo SGGW, Warszawa 2009.

Rylke J., M. Gąsowska, Wartości krajobrazu wiejskiego i przemysłowego dla rozwoju rekreacji na przykładzie wsi warmińskich i Kanału Elblq̨skiego, „Nauka. Przyroda. Technologie”, t. 3, z. $1 / 2009$.

Sadowski M., Rewolucja social media, Helion, Gliwice 2013.

Sagan I., Miasto. Nowa kwestia i nowa polityka, Wydawnictwo Naukowe Scholar, Warszawa 2017. Said E.W., Orientalizm, tłum. M. Wyrwas-Wiśniewska, Wydawnictwo Zysk i S-ka, Poznań 2005. 
Samuelson P.A., W.H. Nordhaus, Ekonomia 1, tłum. H. Hagemejer, K. Hagemejer, J. Czekaj, Wydawnictwo Naukowe PWN, Warszawa 2000.

Sassen S., The Global City: Introducing a Concept, „Brown Journal of World Affairs”, nr 2/2005.

Sauter D., M. Wedderburn, Measuring Walking. Towards Internationally Standarised Monitoring Methods of Walking and Public Space, referat podczas konferencji „On Survey Methods in Transport”, Annecy (Francja), 25-31 maja 2008 r., http://bit.ly/2Wpdg2H, dostęp: 25.03.2019.

Schwartz R., N. Hochman, The Social Media Life of Public Spaces: Reading Places Through the Lens of Geo-Tagged Data, [w:] R. Wilken, G. Goggin (red.), Locative Media, Routledge, New York 2014.

Seung-Bin Im, Visual Preferences in Enclosed Urban Spaces. An Exploration of a Scientific Approach to Environmental Design, „Environment and Behavior”, vol. 16, nr 2/1984.

Shafer E.L., R.O. Brush, How To Measure Preferences for Photographs of Natural Landscapes, „Landscape Planning”, nr 4/1977.

Shaftoe H., Convivial Urban Spaces. Creating Effective Publice Spaces, Earthscan, London-Sterling 2008.

Siemieniako B., Reprywatyzując Polskę. Historia wielkiego przekrętu, Wydawnictwo Krytyki Politycznej, Warszawa 2017.

Sieverts T., Zwischenschadt: zwischen Ort und Welt Raum und Zeit Stadt und Land, Springer Fachmedien Wiesbaden, Wiesbaden 1998.

Silva P., Tactical urbanism: Towards an evolutionary cities' approach?, ,Environment and Planning B: Planning and Design", vol. 43, nr 6/2016.

Simpson D., V. Jensen, A. Rubing (red.), The City Between Freedom and Security. Contested Public Spaces In the 21st Century, Birkhauser, Basel 2016.

Skrzypek M., Atlas sytuacji pieszych, fundacja tu obok, Lublin 2016.

Smagacz-Poziemska M., Czy miasto jest niepotrzebne? (Nowe) przestrzenie życiowe młodych mieszkańców, Wydawnictwo Naukowe Scholar, Warszawa 2015.

Smith N., Gentrification and Uneven Development, „Economic Geography”, vol. 58, nr 2/1982.

Smith N., The New Urban Frontier. Gentrification and the revanchist city, Routledge, London 1996.

Smith N., Uneven Development. Nature, Capital, and the Production of Space, The University of Georgia Press, Athens 2008.

Soja E., Postmodern Geographies. The Reassertion of Space in Critical Social Theory, Verso, LondonNew York 1990.

Soto H. de, Tajemnica kapitału. Dlaczego kapitalizm tryumfuje na Zachodzie a zawodzi gdzie indziej, tłum. S. Czarnik, Fijor Publishing, Chicago-Warszawa 2002.

Souza e Silva A. de, Pokémon Go as an HRG: Mobility, sociability, and surveillance in hybrid spaces, „Mobile Media \& Communication”, nr 1/2017.

Sowell T., The housing boom and bust, Basics Books, New York 2009.

Speck J., Walkable City. How Downtown Can Save America, One Step at a Time, North Point Press, New York 2013.

Springer F., Zaczyn. O Zofii i Oskarze Hansenach, Karakter, Muzeum Sztuki Nowoczesnej w Warszawie, Kraków-Warszawa 2013.

Stake R.E., Jakościowe studium przypadku, [w:] N.K. Denzin, Y.S. Lincoln (red.), Metody badań jakościowych, t. 1, Wydawnictwo Naukowe PWN, Warszawa 2009.

Standing G., Prekariat. Nowa niebezpieczna klasa, tłum. K. Czarnecki, P. Kaczmarski, M. Karolak, Wydawnictwo Naukowe PWN, Warszawa 2014.

Staniszkis J., O władzy i bezsilności, Wydawnictwo Literackie, Kraków 2006.

Staniszkis J., Samoograniczająca się rewolucja, Europejskie Centrum Solidarności, Gdańsk 2010. 
Stawarz B., Content marketing po polsku. Jak przyciq̨nq̨ć klientów, Wydawnictwo Naukowe PWN, Warszawa 2015.

Stimson R., R.W. Marans, Objective Measurements of Quality of Life Using Secondary Data Analysis [w:] eidem (red.), Investigating Quality of Urban Life. Theory, Methods and Empirical Research, Springer, Dordrecht-Heidelberg-London-New York 2011.

Sudjic D., Kompleks gmachu. Architektura władzy, tłum. A. Rasmus-Zgorzelska, Centrum Architektury, Warszawa 2015.

Sudjic D., Język miast, tłum. A. Sak, Karakter, Kraków 2017.

Swianiewicz P., Nowe interpretacje teoretyczne polityki miejskiej, „Studia Regionalne i Lokalne”, nr $4 / 2005$.

Szafrańska E., J. Kaczmarek, Percepcja przestrzeni - pomiędzy prawdq a autentycznością, [w:] M. Madurowicz (red.), Percepcja wspótczesnej przestrzeni miejskiej, Wydział Geografii i Studiów Regionalnych UW, Warszawa 2007.

Szarfenberg R., Miejsce polityki społecznej w polityce publicznej-kontekst europejski, krajowy i lokalny, Mazowieckie Centrum Polityki Społecznej, Warszawa 2013.

Szarfenberg R., Polityka publiczna - zagadnienia i nurty teoretyczne, „Studia z Polityki Publicznej”, nr $1 / 2016$.

Szczepanek R., Systemy informacji przestrzennej z Quantum GIS. Część I, Wydawnictwo Politechniki Krakowskiej, Kraków 2013.

Szmidt B., Ład przestrzeni, Państwowy Instytut Wydawniczy, Warszawa 1981.

Szpala I., M. Zubik, Święte prawo. Historie ludzi i kamienic z reprywatyzacją $w$ tle, Wydawnictwo Agora, Warszawa 2017.

Sztompka P., Socjologia wizualna. Fotografia jako metoda badawcza, Wydawnictwo Naukowe PWN, Warszawa 2005.

Szuniewicz K., Metodologia oceny i waloryzacji przestrzeni, [w:] I. Cieślak (red.), Wspótczesna waloryzacja przestrzeni zurbanizowanej, Wydawnictwo Uniwersytetu Warmińsko-Mazurskiego w Olsztynie, Olsztyn 2012.

Szyszko J., Biegaczowate, [w:] J. Szyszko, J. Rylke, P. Jeżowski (red.), Ocena i wycena zasobów przyrodniczych, Wydawnictwo SGGW, Warszawa 2002.

Świderski M., Paradoks Roberta Mosesa, „Rzut”, nr 6/2014.

Tekinalp S., Rationalization of contradictory cognitive dichotomies versus democracy demands: Istanbul Gezi Park protests, „Rationality and Society”, vol. 28, nr 1/2016.

Thompson M., Between Boundaries: From Commoning and Guerrilla Gardening to Community Land Trust Development in Liverpool, „Antipode”, vol. 47, nr 4/2015.

Tissot S., Good Neighbors: Gentrifying Diversity in Boston's South End, Verso, London-New York 2015.

Tobolczyk M., Architektura wspótczesna. Geneza i charakterystyka wiodq̨cych nurtów, Oficyna Wydawnicza Politechniki Warszawskiej, Warszawa 2017.

Tolman E.C., Cognitive maps in rats and men, „The Psychological Review”, nr 4/1948.

Tomanek K., Analiza sentymentu - metoda analizy danych jakościowych. Przykład zastosowania oraz ewaluacja słownika RID i metody klasyfikacji Bayesa w analizie danych jakościowych, „Przegląd Socjologii Jakościowej”, t. 10, nr 2/2014.

Toruńczyk-Ruiz S., Sąsiedztwo i sq̨siedzi w opiniach Polaków i cudzoziemców, „Biuletyn Migracyjny”, nr 28/2011, https://sites.google.com/site/biulletynmigracyjny/archiwum-html/biuletyn-migracyjny-28/bm28art3, dostęp: 15.07.2016. 
Tsenkova S., Informal settlements in post-communist cities: Diversity factors and patterns, „Urbani izziv", nr 2/2010.

Tuan Y.-F., Przestrzeń i miejsce, tłum. A. Morawińska, Państwowy Instytut Wydawniczy, Warszawa 1987.

Turner J.F.C., Housing by People. Towards Autonomy in Building Environments, Pantheon Books, New York 1977.

Unwin T., A waste of space? Towards a critique of the social production of space, „Transactions of the Institute of British Geographers", nr 1/2000.

Usta B., Gecekondu, [w:] P. Derviş, B. Tanju, U. Tanyeli (red.), Becoming Instanbul. An Encyclopedia, SALT/Garanti Kültuir AŞ, İstanbul 2015.

Uzun B., M. Çete, H.M Palancioglu, Legalizing and upgrading illegal settlements in Turkey, „Habitat International”, nr 34/2010.

Vanolo A., Smartmentality. The Smart City as Disciplinary Strategy, „Urban Studies”, nr 5/2014.

Vasudevan A., The Autonomous City. A History of Urban Squatting, Verso, London 2017.

Venturi R., D. Scott-Brown, S. Izenour, Uczyć się do Las Vegas. Zapomniana symbolika formy architektonicznej, tłum. A. Porębska, Karakter, Kraków 2013.

Wacquant L., Punishing the Poor. The Neoliberal Government of Social Insecurity, Duke University Press, Durham-London 2009.

Wallis A., Informacja i gwar. O miejskim centrum, Państwowy Instytut Wydawniczy, Warszawa 1979.

Wallis A., Jakość życia - problemy i propozycje, „Ruch Prawniczy, Ekonomiczny i Socjologiczny”, z. $2 / 1976$.

Wallis A., Socjologia przestrzeni, oprac. E. Grabska-Wallis, M. Oficerska, Niezależna Oficyna Wydawnicza, Warszawa 1990.

Wallis A., Socjologia wielkiego miasta, Państwowe Wydawnictwo Naukowe, Warszawa 1967.

Wancke P., Nieruchomości. Leksykon pojęć i definicji, Wolters Kluwer Polska, Warszawa 2007.

Wasilkowska A., Warszawa jako struktura emergentna: Em_Wwa 1.0 / Warsaw as Emergent Structure: Em_Wwa 1.0, [w:] A. Wasilkowska, A. Nowak (red.), Warszawa jako struktura emergentna: Em_Wwa 1.0 / Warsaw as Emergent Structure: Em_Wwa 1.0, Fundacja Bęc Zmiana, Warszawa 2014.

Wedel J.R., C. Shore, G. Feldman, S. Lathrop, Toward an Anthropology of Public Policy, „The Annals of the American Academy of Political and Social Science”, nr 30/2015.

Weimer D.L., A.R. Vining, Assessing the Costs and Benefits of Social Policies, [w:] eidem (red.), Investing in the Disadvantaged Assessing the Benefits and Costs of Social Policies, Georgetown University Press, Washington 2009.

Wejchert K., Elementy kompozycji urbanistycznej, Warszawa, Arkady 1984.

Wernik P., B. Welle, Measuring the Economic Value of a City Park System, The Trust for Public Land, Washington-San Francisco 2009.

Whyte W.H., The Social Life of Small Urban Spaces, Project for Public Spaces, New York 2001.

Wicker A.M., Ecological Psychology. Historical Contexts, Current Conception, Prospective Directions, [w:] R.B. Bechtel, A. Churchman (red.), Handbook of Enviromental Psychology, John Wiley \& Sons, New York 2002.

Wilken R., Mobilizing Place: Mobile Media, Peripatetics, and the Renegotiation of Urban Places, "Journal of Urban Technology”, vol. 15, nr 3/2008.

Wirth L., Urbanism as a way of life, „The American Journal of Sociology”, nr 1/1938. 
Wojtowicz W., Jakie ulice najlepsze dla mieszkańców? ZDM porównat główne ulice Warszawy, http:// urbnews.pl/ulice-najlepsze-dla-mieszkancow-zdm-porownal-glowne-ulice-warszawy/, dostęp: 27.12.2017.

Woźnicki J., Nowa dyscyplina - „nauki o polityce publicznej” usytuowana w dziedzinie nauk społecznych, ,Nauka”, nr 1/2012.

Yildirim A.B., In_formal_Istanbul. Potential of the Gecekondu and Alternatives to Redevelopment in the Case of Karanfilköy, 2009 ISA-RC21 Sao Paulo Conference Inequality, Inclusion and the Sense of Belonging, www.fflch.usp.br/centrodametropole/ISA2009/assets/papers/01-A-8. pdf, dostęp: 14.07.2017.

Yusof Y.M., M. Kozlowski, Clients of Contemporary Urban Design. The Impact of Neoliberalism, [w:] K. Nawratek, B. Huggins, M. Oxley, A. Horton-Howe (red.), Radical Inclusivity. Architecture and Urbanism, dpr-barcelona, Barcelona 2015.

Zając J., Bezpieczeństwo państwa, [w:] K.A. Wojtaszczyk, A. Materska-Sosnowska (red.), Bezpieczeństwo państwa. Wybrane problemy, Oficyna Wydawnicza Aspra-JR, Warszawa 2009.

Zappavigna M., Social media photography: construing subjectivity in Instagram images, „Visual Communication", vol. 15, nr 3/2016.

Zborowski A., Wybrane aspekty badań poziomu i jakości życia $w$ dużym mieście, [w:] I. Jażdżewska (red.), Zróżnicowanie warunków życia ludności w mieście, Wydawnictwo Uniwersytetu Łódzkiego, Łódź 2004.

Ziegler J., Nienawiść do Zachodu, tłum. E. Cylwik, Instytut Wydawniczy Książka i Prasa, Warszawa 2010.

Znaniecki F., Socjologiczne podstawy ekologii ludzkiej, „Ruch Prawniczy, Ekonomiczny i Socjologiczny", z. 1/1938.

Zybała A., Jeszcze raz o politykach publicznych we Wroctawiu, „Miscellanea Anthropologica et Sociologica”, nr 3/2014.

Zybała A., Polityka publiczna wobec teorii i jej praktyki w Polsce, „Wrocławskie Studia Politologiczne", nr 18/2015.

Zybała A., Polityki publiczne. Doświadczenia w tworzeniu $i$ wykonywaniu programów publicznych w Polsce i innych krajach, Krajowa Szkoła Administracji Publicznej, Warszawa 2012.

B.a., 2017: 75\% ruchu $w$ Sieci wygeneruja urzq̨dzenia mobilne, http://bit.ly/2u1adDx, dostęp: 10.07.2017.

B.a., Droga Krajowej Polityki Miejskiej, „Miasta”, nr 1/2014.

B.a., Placemaking. What if we built our cities around places?, Project for Public Spaces, New York 2018. 


\section{Dokumenty urzędowe i strategiczne}

Bank Danych Lokalnych GUS, http://stat.gov.pl/bdl/, dostęp: 20.09.2015.

Deklaracja Słupska - nowa, progresywna polityka miejska, http://antymatrix.blog.polityka. pl/2015/03/18/konfederacja-slupska-deklaracja-nowej-progresywnej-polityki-miejskiej/, dostęp: 19.09.2015.

Europejska Rada Urbanistów, Nowa karta Ateńska. Wizja miast XXI wieku, Lizbona 2013, http:// www.zabytki-tonz.pl/pliki/karta\%20atenska\%202003_pl.pdf, dostęp: 19.09.2015.

Informacja o sytuacji społeczno-gospodarczej kraju w 2016 roku, Główny Urząd Statystyczny, Warszawa 2017.

Karta lipska na rzecz zrównoważonego rozwoju miast europejskich, Lipsk 2007, http://www.sarp. org.pl/pliki/karta_lipska_pl.pdf, dostęp: 19.09.2015.

Koncepcja Przestrzennego Zagospodarowania Kraju 2030, Kancelaria Prezesa Rady Ministrów, Warszawa 2011, http://rpo2020.lubuskie.pl/wp-content/uploads/2013/01/Koncepcja_Przestrzennego_Zagospodarowania_Kraju_203011.pdf, dostęp: 20.09.2015.

Kongres Ruchów Miejskich, Tezy o mieście, [w:] B. Świątkowska (red.), Coś, które nadchodzi. Architektura XXI wieku, Fundacja Bęc Zmiana, Warszawa 2011.

Krajowa Polityka Miejska 2023, dokument przyjęty uchwałą Rady Ministrów w dniu 20 października 2015 r., Ministerstwo Infrastruktury i Rozwoju, Warszawa 2015.

Krajowa Strategia Rozwoju Regionalnego 2010-2020: Regiony, miasta, obszary wiejskie, Ministerstwo Rozwoju Regionalnego, Warszawa 2010, http://www.malopolskie.pl/Pliki/2015/ KSRR_2020.pdf, dostęp: 20.09.2015.

NYPD Complaint Data Historic, https://data.cityofnewyork.us/Public-Safety/NYPD-ComplaintData-Historic/qgea-i56i/data\# column-menu, dostęp: 1.09.2017.

Odpowiedź Gabinetu Komendanta Stołecznej Policji nr G-2047/1580/17 z 3 kwietnia 2017 r.

Stowarzyszenie Architektów Polskich, Polska Polityka Architektoniczna, [w:] B. Świątkowska (red.), Coś, które nadchodzi. Architektura XXI wieku, Fundacja Bęc Zmiana, Warszawa 2011.

Turkish Statistical Institute, http://www.turkstat.gov.tr/PrelstatistikTablo.do?istab_id=1590, dostęp: 14.07.2017.

Turkish Statistical Institute, Producer Price Index of Agricultural Products and Monthly Change (\%), http://www.turkstat.gov.tr/PrelstatistikTablo.do?istab_id=2113, dostęp: 15.09.2017.

UNESCO, Rekomendacje UNESCO w sprawie historycznego krajobrazu miejskiego, http://www.unesco. pl/fileadmin/user_upload/pdf/Rekomendacje/rekomenkrajobraz.pdf, dostęp: 13.07.2016.

Ustawa z dnia 12 lipca 1984 r. o planowaniu przestrzennym, Dz. U. 1984 nr 35 poz. 185.

Ustawa z dnia 7 lipca 1994 r. o zagospodarowaniu przestrzennym, Dz. U. 1994 nr 89 poz. 415

Ustawa z dnia 27 marca 2003 r. o planowaniu i zagospodarowaniu przestrzennym, Dz. U. 2003 nr 80 poz. 717.

Ustawa z dnia 6 grudnia 2006 r. o zasadach prowadzenia polityki rozwoju, Dz. U. 2006 nr 227 poz. 1658.

Ustawa z dnia 9 października 2015 r. o rewitalizacji, Dz. U. 2015 poz. 1777.

Ustawa z dnia 5 lipca 2018 r. o ułatwieniach w przygotowaniu i realizacji inwestycji mieszkaniowych oraz inwestycji towarzyszących, Dz. U. 2018 poz. 1496.

World Urbanization Prospects. Highlights, United Nations, New York 2014. 


\section{Pozostała netografia}

Fischer E., The Geotaggers' World Atlas \#66: Warsaw, http://bit.ly/2sIpLYE, dostęp: 10.07.2017.

Fischer E., The Geotaggers' World Atlas \#37: Istanbul, http://bit.ly/2u5QGBy, dostęp: 10.07.2017. http://lagos.submarinechannel.com/, dostęp: 4.08.2016.

http://u-tt.com/, dostęp: 4.08.2016.

http://www.elementalchile.cl/en/projects/quinta-monroy/, dostęp: 4.08.2016.

http://www.uia.archi/en/ressources\#.Vf1CCd_tmko, dostęp: 19.09.2015.

http://www1.nyc.gov/site/finance/taxes/property-annualized-sales-update.page, dostęp: 1.07.2017. 


\section{Bottom-up urbanism: \\ The nightmare of participation and the production of space}

The so-called top-down approach, as it is now believed, is a rather non-effective way of implementing urban policy. Such paternalistic programs prove ineffective in responding to social needs, do not encourage social inclusion of economically excluded groups and are very capital-intensive. However, the opposite paradigm connected with the free market approach engendered similar criticism. By the same token, both policy types seem to be ineffective, especially after the global crisis of 2007-2008.

In order to solve such problems participatory techniques associated with the social production of urban space are recommended. This trend is also highly visible in Poland and manifests itself in the growing popularity of various forms of public consultations, participatory budgeting, the so-called tactical urbanism or even more advanced participatory techniques. Bottom-up urbanism (Polish urbanistyka oddolna) is also to be found here. It refers to organizing, adapting and designing urban areas through advanced social participation of local community representatives. This raises questions about what really motivates the use of participation techniques, how successful these solutions are and which users of urban areas are the real beneficiaries of these processes.

The book consists of two main parts. The first describes theoretical and methodological issues. Subsequently, the second one presents three case studies of urban transformations initiated by various grassroots actors. These are: Grzybowski Square in Warsaw, High Line Park in New York City, and Karanfilköy neighborhood in Istanbul. The first example illustrates the transformation of a specific inner city public area in Warsaw inspired by an artistic spatial intervention. The second presents altering usage patterns in case of the degraded space of a former industrial railway line in Manhattan that was transformed into a park as a result of an urban movement's actions. The third refers to the informal city form called 'gecekondu' - a slum housing estate of the Turkish type. 
One of the key conclusions resulting from this research is that bottom-up urbanism does not necessarily bring benefits to all of the users of urban areas. It often distorts its original idea and acts only on behalf of the most-privileged groups. In some cases, it rather evokes the so-called nightmare of participation, a phenomenon described by Markus Miessen. Such phenomena definitely require formal activities combined with the political will of the most influential actors in the process of the social production of space. It questions the accuracy of urban policy based on activation of local communities and the implementation of advanced participatory forms. Furthermore, sham meritocratic and evidence-oriented bottom-up urbanism is not free from ideological involvement with its constraints. It seems that in spite of its democratic character and flexibility that are the main advantages of such an approach, it is not possible to apply it in every possible urban context as a universally effective mechanism. 
